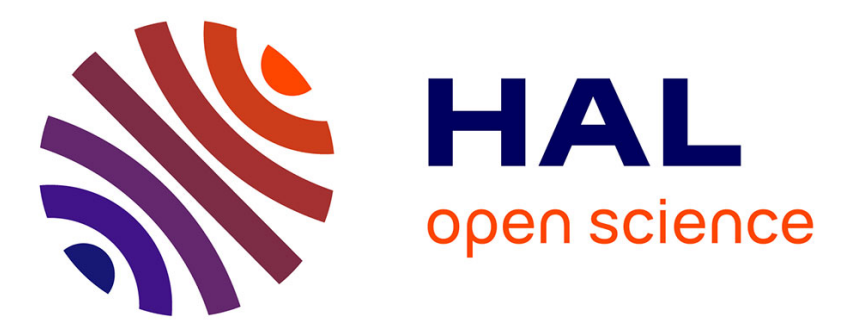

\title{
Colecciones, arqueólogos, instituciones y yacimientos en la España de los siglos XVIII al XX
}

\author{
Sergio España-Chamorro, Rebeca Arranz Santos, Alberto Romero
}

\section{To cite this version:}

Sergio España-Chamorro, Rebeca Arranz Santos, Alberto Romero (Dir.). Colecciones, arqueólogos, instituciones y yacimientos en la España de los siglos XVIII al XX. 2018. halshs-03548172

\section{HAL Id: halshs-03548172 \\ https://shs.hal.science/halshs-03548172}

Submitted on 9 Feb 2022

HAL is a multi-disciplinary open access archive for the deposit and dissemination of scientific research documents, whether they are published or not. The documents may come from teaching and research institutions in France or abroad, or from public or private research centers.
L'archive ouverte pluridisciplinaire HAL, est destinée au dépôt et à la diffusion de documents scientifiques de niveau recherche, publiés ou non, émanant des établissements d'enseignement et de recherche français ou étrangers, des laboratoires publics ou privés. 


\section{COLECCIONES, ARQUEÓLOGOS, INSTITUCIONES Y YACIMIENTOS EN LA ESPAÑA DE LOS SIGLOS XVIII AL XX}

Editores

Sergio España-Chamorro

Rebeca Arranz Santos

Alberto Romero Molero
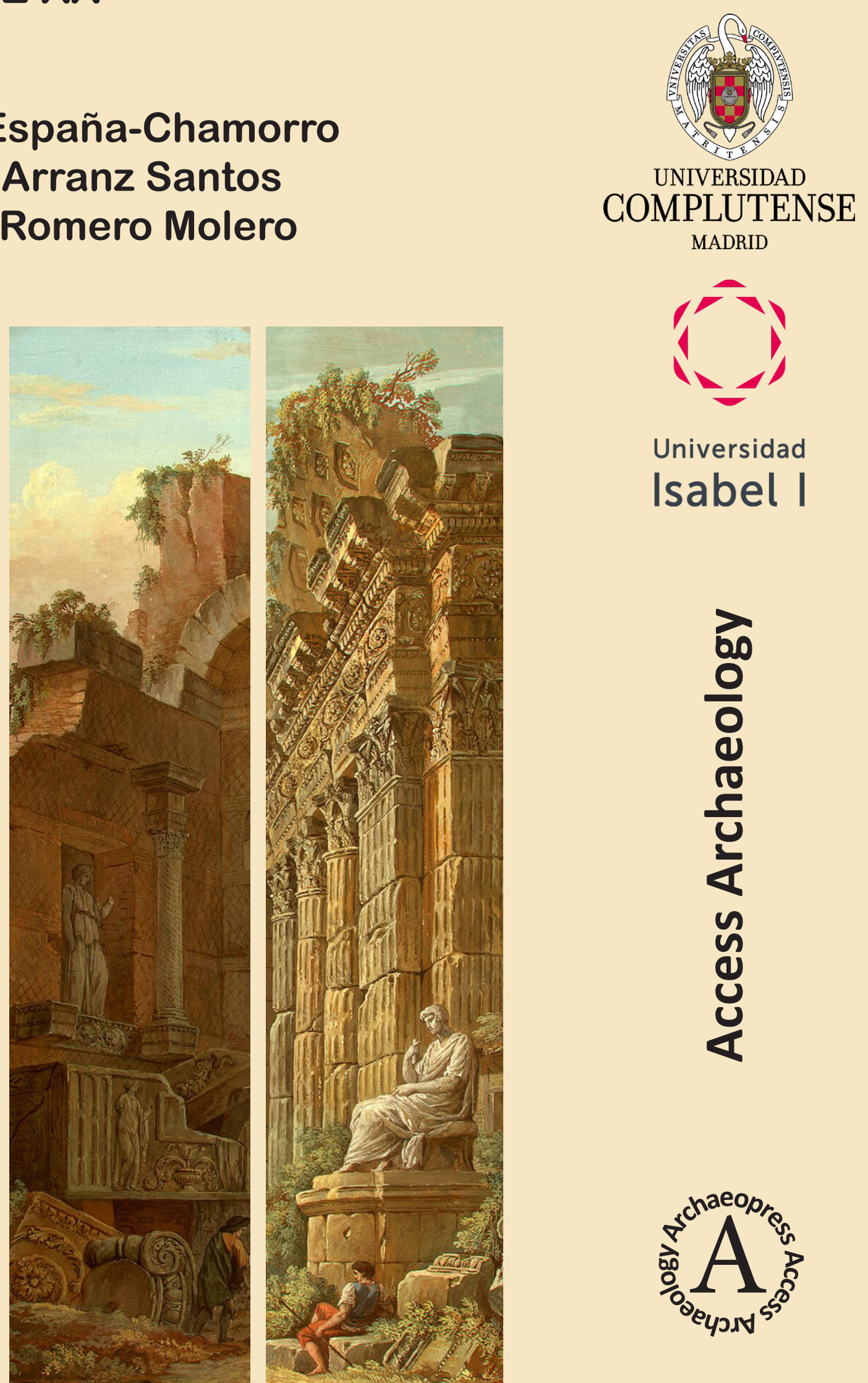


\section{COLECCIONES, ARQUEÓLOGOS, INSTITUCIONES Y YACIMIENTOS EN LA ESPAÑA DE LOS SIGLOS XVIII AL XX}

Editores

Sergio España-Chamorro

Rebeca Arranz Santos

Alberto Romero Molero
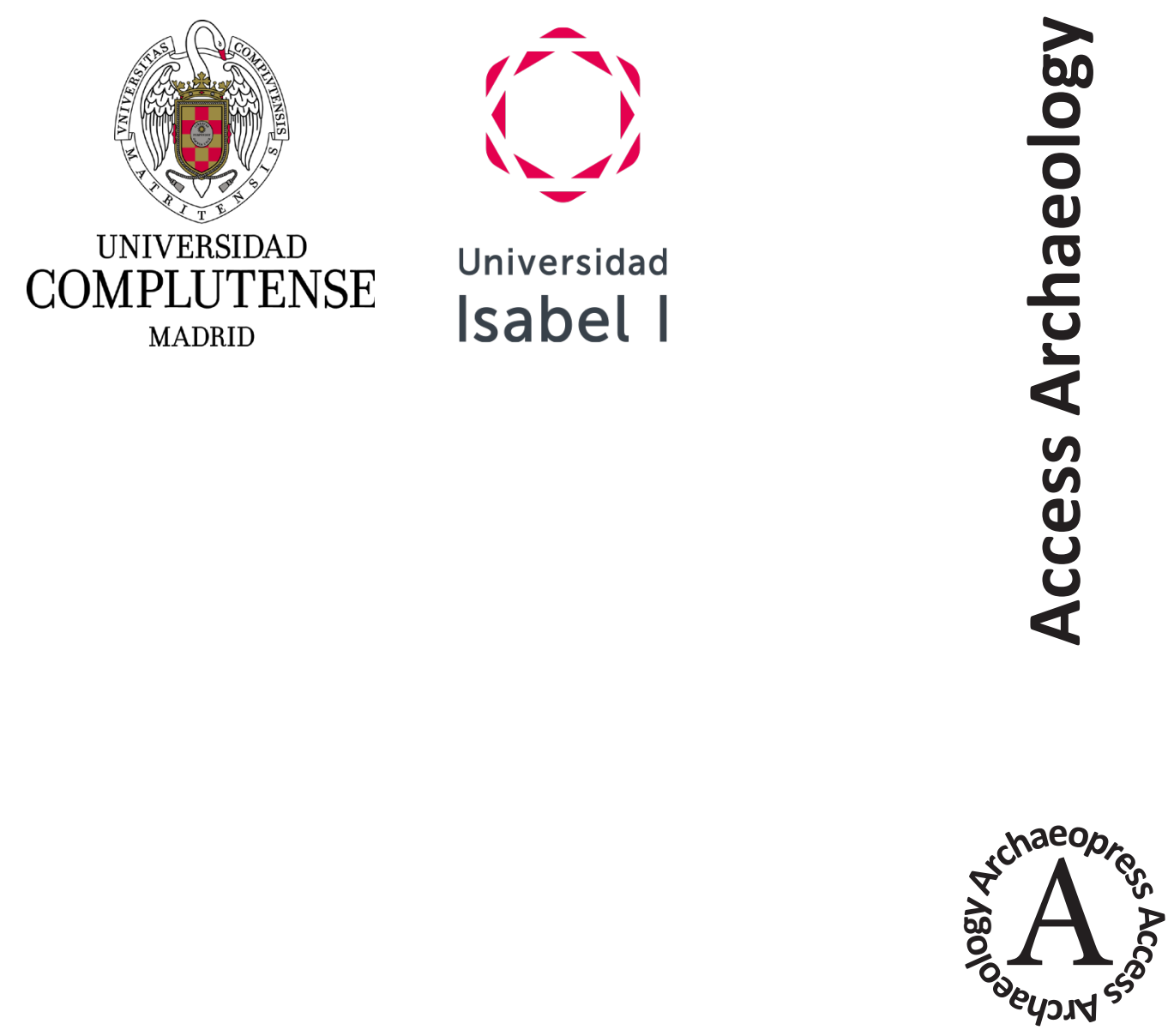


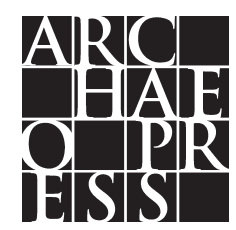

ARCHAEOPRESS PUBLISHING LTD

Summertown Pavilion

18-24 Middle Way

Summertown

Oxford OX2 7LG

www.archaeopress.com

ISBN 9781784918637

ISBN 9781784918644 (e-Pdf)

(C) Archaeopress and the individual authors 2018

All rights reserved. No part of this book may be reproduced or transmitted, in any form or by any means, electronic, mechanical, photocopying or otherwise, without the prior written permission of the copyright owners. 


\section{COLECCIONES, ARQUEÓLOGOS,}

\section{INSTITUCIONES Y YACIMIENTOS EN LA ESPAÑA DE LOS SIGLOS XVIII AL XX}

(Editores)

Sergio España-Chamorro

Rebeca Arranz Santos

Alberto Romero Molero 


\section{About Access Archaeology}

Access Archaeology offers a different publishing model for specialist academic material that might traditionally prove commercially unviable, perhaps due to its sheer extent or volume of colour content, or simply due to its relatively niche field of interest.

All Access Archaeology publications are available in open-access e-pdf format and in (on-demand) print format. The open-access model supports dissemination in areas of the world where budgets are more severely limited, and also allows individual academics from all over the world the chance to access the material privately, rather than relying solely on their university or public library. Print copies, nevertheless, remain available to individuals and institutions who need or prefer them.

The material is professionally refereed, but not peer reviewed. Copy-editing takes place prior to submission of the work for publication and is the responsibility of the author. Academics who are able to supply print-ready material are not charged any fee to publish (including making the material available in open-access). In some instances the material is type-set in-house and in these cases a small charge is passed on for layout work.

This model works for us as a publisher because we are able to publish specialist work with relatively little editorial investment. Our core effort goes into promoting the material, both in open-access and print, where Access Archaeology books get the same level of attention as our core peer-reviewed imprint by being included in marketing e-alerts, print catalogues, displays at academic conferences and more, supported by professional distribution worldwide.

Open-access allows for greater dissemination of the academic work than traditional print models, even lithographic printing, could ever hope to support. It is common for a new open-access e-pdf to be downloaded several hundred times in its first month since appearing on our website. Print sales of such specialist material would take years to match this figure, if indeed it ever would.

By printing 'on-demand', meanwhile, (or, as is generally the case, maintaining minimum stock quantities as small as two), we are able to ensure orders for print copies can be fulfilled without having to invest in great quantities of stock in advance. The quality of such printing has moved forward radically, even in the last few years, vastly increasing the fidelity of images (highly important in archaeology) and making colour printing more economical.

Access Archaeology is a vehicle that allows us to publish useful research, be it a PhD thesis, a catalogue of archaeological material or data, in a model that does not cost more than the income it generates.

This model may well evolve over time, but its ambition will always remain to publish archaeological material that would prove commercially unviable in traditional publishing models, without passing the expense on to the academic (author or reader).

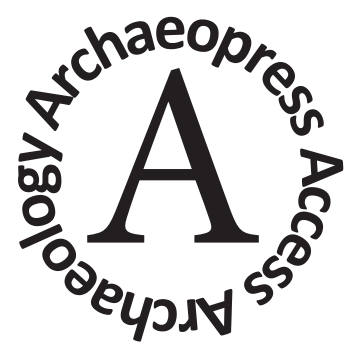




\section{Índice}

Prólogo

Jorge García Sánchez

La colección de antigüedades romanas de la Real Academia de la Historia: el proceso de formación.

Paloma Martín-Esperanza Montilla

Historia y Arqueología en el siglo XVIII en el Reino de Murcia: el descubrimiento de la antigüedad del Puerto de las Águilas.

Pedro Pérez Mulero

Del lugar donde fue Iliberri (Granada): historiografía de un debate.

Amparo Sánchez Moreno

Apuntes para una historiografía de la Arqueología en la ciudad de Guadix (Granada). Entre los mitos y la realidad.

Antonio López García y Antonio Reyes Martínez

La Arqueología en la prensa nacional: el caso de La llustración Española y Americana

Rebeca Arranz Santos

La formación arqueológica y en historia del arte del joven Manuel Gómez-Moreno Martínez (18701899)

Alfredo Mederos Martín

Ángel de los Ríos y los inicios de la Arqueología medieval en el norte de la Península Ibérica

Enrique Gutiérrez Cuenca

Pedro de Madrazo y la Arqueología española del siglo XIX

Alegra García García

Pioneros de la Arqueología alicantina. La necrópolis de l'Albufereta.

Enric Verdú Parra

De la exhumación de las estructuras a los estudios arquitectónicos. Nuevas aportaciones historiográficas a la edilicia de Carteia.

Alberto Romero Molero

La Rota protohistórica como ejemplo de la evolución del concepto de Tarteso 195

Álvaro Gómez Peña 
La Arqueología en Córdoba en la década de 1950. Un recorrido historiográfico a través de sus protagonistas..

Francisco José Rueda Olmo

El estudio de la cerámica numantina durante el primer tercio del siglo XX. .238 Álvaro Sánchez Climent 


\section{Índice de figuras y anexos}

Paloma Martín-Esperanza Montilla: La colección de antigüedades romanas de la Real Academia de la Historia: el proceso de formación

Pedro Pérez Mulero: Historia y arqueología en el siglo XVIII en el Reino de Murcia: el descubrimiento de la antigüedad del Puerto de las Águilas

Figura 1. Portada de la obra: Mussato Polihistor de Gálvez .14

Figura 2. Moneda en la que se interpretan los nombres antiguos de Eliochrota y Urce (Gálvez Borgoñoz 1991: 26)

Figura 3. Moneda que se interpreta como del rey Proco utilizada para dar cronología a la antigüedad de

Lorca (Gálvez Borgoñoz 1991: 31).... . .15

Figura 4. Portada de la obra: Antigüedad, y blasones de la ciudad de Lorca del Padre Morote............... 16

Figura 5. Detalle del mapa ptolemaico de Francesco di Nocola Berlinghieri, Florencia 1482 ....................18

Figura 6. 'Plano en que se muestra la situación del monte de las Aguilas, de su fuerte nombrado San Juan

Baptista y la batería de San Pedro... y proyecto de la nueva población que se manifiesta en este plano...' con el visto bueno del Conde de Aranda. Mateo Vodopich, Cartagena, 10-Sep.-1765. Archivo General de Simancas (Anónimo 2000: 130, n.228) .....

Figura 7. Plano con vista de la costa de Águilas. Firmado por Juan de Escofet en Lorca, 1 de septiembre de 1773. Archivo General de Simancas. Signatura: MPD, 23, 041.

Figura 8. Inscripción romana procedente de Águilas (Murcia), Lumiares, Barros Saguntinos, tav. IV, $\mathrm{n} \div 3$.

Figura 9. Vista de la nueva Población de las Águilas por el lado de Poniente atribuida a Gerónimo

Martínez de Lara. Biblioteca Nacional de España

Figura 10. Dibujo de la inscripción romana hallada en Águilas el 28 de febrero de 1788. Informe de Antonio Robles Vives al Conde de Floridablanca. Archivo Histórico Nacional, Madrid, Consejos 177501,007

Figura 11. P Fig. 11. Plano De las termas halladas en las Excavaciones de la nueva Población de las Águilas á 180 Varas de la Orilla del Mar. FR, Archivo Histórico Nacional, Diapositiva 74.

Figura 12. Moneda de Calagurris en Florez, 1757, tabla 12, nํ 10, según Robles 1788 dice que se parece a la de Águilas

Figura 13. Moneda de Acci en Florez 1757, tabla II, no 5, según Robles 1788 y Navarro 1789 es como la de Águilas.

Figura 14. Moneda de Cesar Augusta en Florez 1757, tabla 7, no 12, según Robles 1788 y Navarro 1789 es como la de Águilas

Figura 15. Moneda de Carthago nova en Florez 1757, tabla 16, no 9, según Robles 1788 y Navarro 1789

es la misma con poca diferencia a la de Águilas

Figura 16. Moneda posiblemente de Cartagena en Florez 1757, tabla 56, no 2, según Robles 1788 y

Navarro 1789 con alguna probabilidad es como la de Águilas

Figura 17. Moneda de Leptis en África en Florez 1757, tabla 58, no 7, según Robles 1788 y Navarro 1789 es como la de Águilas 
Figura 18. (Izquierda y central) monedas de Rosas en Florez 1757, tabla 65, no 8 y no 9, según Robles 1788 el anverso de ambas se parece a la de Águilas. Navarro 1789 dice que el anverso de la no 8 se parece a la de Águilas. Navarro también dice que el anverso de tal moneda es como la de Florez 1757, tabla 58, no 10 (Derecha), pero sin freno ni tan extendida la crin del caballo .32

Figura 19. (Izquierda) moneda en Florez 1757, tabla 56, no 13, según Robles 1788 se suele atribuir a Sanlúcar de Barrameda, es como la de Águilas. (Derecha) Moneda en Velázquez, 1752, tabla 17, no 1, según Navarro 1789 es como la de Águilas 32

Figura 20. Moneda en Florez 1757, tabla 67, no 8, según Robles 1788 se parece a la de Águilas, pero sin el ibis. Según Navarro 1789 se parece a la de Águilas

Figura 21. Monedas de Sacili en Florez 1757, tabla 39, no 7 y no 8, según Robles 1788 es como la de Águilas 33

Figura 22. Detalle del plano del Puerto de Águilas (no 25) (Ordovás 2005) ..................................................35

Tabla 1. Monedas romanas halladas en Águilas en el siglo XVIII ................................................................37

Tabla 2. Objetos arqueológicos procedentes del puerto de las Águilas documentados en el siglo XVIII....37

\section{Amparo Sánchez Moreno: Del lugar donde fue Iliberri (Granada): historiografía de un debate}

Figura 1. Mapa con la ubicación de Medina Elvira y el barrio del Albaicín en Granada

Figura 2. Dibujo de las lámparas de bronce de la Mezquita mayor de Medina Elvira realizados por M.

Gómez-Moreno (1888a: lám. VII)

Figura 3. Localización del barrio del Albaicín o Alcazaba Cadima sobre la Plataforma Vico (1595-1613: Plataforma por Ambrosio Vico Maestro Mayor de la insigne Iglesia de Granada, Salamanca. Mapa rectangular: 45 x 64 cm. Reproducción: Prieto, F., 1795. Número de control: IECA1988015125)........44

Figura 4. Alfabeto iliberritano y griego Iliberritano Antiguo creado por Flores (Sánchez López y Marín 2012: 32)

Figura 5. Dibujo del foro romano realizado por uno de los colaboradores de Flores en 1768 (Sotomayor 2008: 30)

Figura 6. Imagen exterior de la muralla zirí del siglo XI. En su interior se realizaron las primeras intervenciones arqueológicas en 1982 ...

Figura 7. Grabado de una falsificación de las excavaciones de Flores (Sánchez López y Marín 2012: 37 )...47

Figura 8. Portada del primer número de La Alhambra el 21 de abril de 1839 con un artículo de José de

Castro y Orozco titulado 'Fisonomía histórica de Granada'.

Figura 9. Dibujo de una de las urnas ibéricas realizado por M. Gómez-Moreno González (Moya 2004:

43).

Figura 10. Cuaderno de la Comisión de Monumentos en el que se registraba todo lo relativo a los hallazgos arqueológicos de Medina Elvira (Malpica 2013: 37) 51

Figura 11. Imagen con algunas de las piezas documentadas en Medina Elvira durante las excavaciones de 1875 (Malpica 2013: 44)

Figura 12. Plano topográfico de Sierra Elvira realizado por M. Gómez-Moreno González en 1875 (Moya 2004: 58)

Figura 13. Mapa con las excavaciones de Sierra Elvira realizado por los hermanos Oliver Hurtado (1875:

617-618) .53

Figura 14. Retrato de M. Gómez-Moreno González (Malpica 2013: 38) .......................................................53

Figura 15. Portada del Boletín del Centro Artístico de Granada ...............................................................54 
Figura 16. Copia de M. Gómez-Moreno González de un dibujo con los descubrimientos documentados en el siglo XVIII tras las excavaciones de Flores (Moya 2004: 57)

Antonio López García y Antonio Reyes Martínez: Apuntes para una historiografía de la arqueología en la ciudad de Guadix (Granada). Entre los mitos y la realidad

Figura 1. Crónica General de España de Ambrosio de Morales (1574) .......................................................61

Figura 2. Historia del Obispado de Guadix y Baza de Pedro Suárez (1696) ..................................................62

Figura 3. La España Sagrada de Enrique Flórez (1776) .........................................................................62

Figura 4. Sumario de las Antigüedades Romanas que hay en España de Ceán Bermúdez (1852) ...............63

Figura 5. Disertación sobre el dios Endovellico y noticia de otras deidades gentílicas de la España Antigua

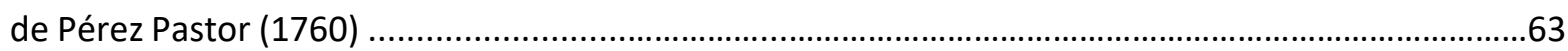

Figura 6. Colección de documentos para la historia monetaria de España de Barthe (1843) .....................64

Figura 7. Lápidas visigóticas de Guadix, Cabra, Vejer, Bailén y Madrid por Fita Colomé (1896) ..................65

Figura 8. Restos del Castillo de Luchena, reconocidos por Florez como 'Guadix El Viejo'.........................66

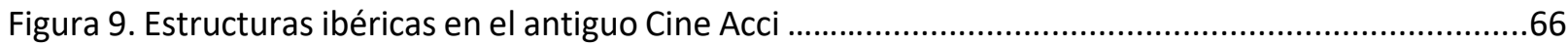

Figura 10. Estructuras del periodo ibérico pleno en la Calle Palacio de Guadix ......................................67

Figura 11. Acuñaciones monetarias accitanas de Augusto, Tiberio y Calígula .............................................68

Figura 12. Hipótesis topográfica planteada por Asenjo Sedano (2002) …................................................69

Figura 13. Restos reconstruidos del bajorrelieve del Caño de San Antón que se asemejan a la descripción

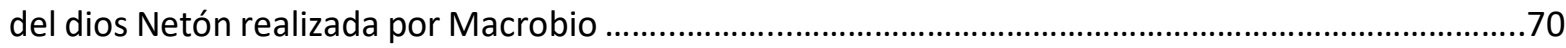

Figura 14. Pedestal de Isis en el Museo Arqueológico de Sevilla ..............................................................70

\section{Rebeca Arranz Santos: La arqueología en la prensa nacional: el caso de La llustración Española y Americana}

Figura 1. Encabezado del periódico The Illustrated London News ..........................................................78

Figura 2. Encabezado del Periódico L'Illustration ..........................................................................................79

Figura 3. Encabezado de La llustración española y Americana ....................................................................81

Figura 4. Punch, (noviembre, 6 de 1869): Don Layardos in Madrid. p. 179 .................................................86

Figura 5. La llustración Española y Americana, AÑO XXX-NÚM XXVII (julio, 22 de 1886): Museo de Boulaq, descubrimiento e inspección facultativa de la momia de Sesostris. p. 35 ..............................................87

Figura 6. La llustración Española y Americana, AÑO XXV-NÚM X (marzo, 15 de 1881): Estatua de Minerva, descubierta en Atenas. pp. 162-163 .....................................................................................................8

Figura 7. La Ilustración Española y Americana, AÑO XXVI-NÚM XV (abril, 22 de 1882): Roma antigua. Ruinas del Coliseo (Anfiteatro Flavio). pp. 250-251 ..............................................................................89

Figura 8. La llustración Española y Americana, AÑO XLI-NÚM XXXIII (agosto, 30 de 1897): Descubrimiento

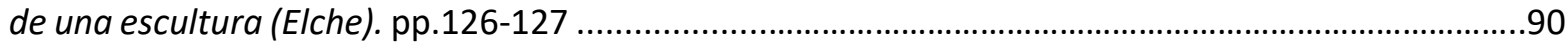

Figura 9. La llustración Española y Americana, AÑO XXXIV-NÚM XXXV (septiembre, 23 de 1890): Efectos del incendio en la arcada principal de la galería de entrada al salón de los emperadores y en el patio Ilamado de Doña Juana La Loca. p. 171

Figura 10. La Ilustración Española y Americana, AÑO XXXIV-NÚM XLVII (diciembre, 22 de 1890): Antigüedades aztecas 'Mictalacihuatl o diosa de la muerte'. p. 371.

Figura 11. La Ilustración Española y Americana, AÑO XV-NÚM.III (enero, 25 de 1871): Paris-Preparativos

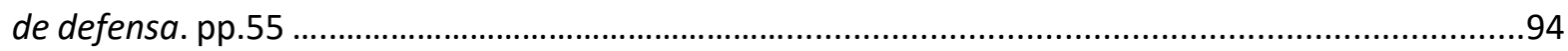


Figura 12. La llustración Española y Americana, AÑO LXIV-NÚM 43 (noviembre, 30 de 1920): La medicina en la antigüedad, por Doctor Albiñana, pp. 563-564.

Figura 13. La Ilustración Española y Americana, AÑO XXXV-NÚM XV (abril, 22 de 1891): Nuevos Descubrimientos de momias en Egipto. La extracción de sarcófagos del pozo de Deir-El-Bahuri. p. 243

Figura 14. La Ilustración Española y Americana, La llustración Española y Americana, AÑO XIX-NÚM XIV (abril, 15 de 1875): Restos del templo de Isis, en la isla de Phyle. p. 235

Figura 15. La llustración Española y Americana, AÑO LV-NÚM XIV (abril, 15 de 1911): Las ruinas de Itálica.

Noticias de algunas de las excavaciones en ellas practicadas, por Rodrigo Amador de los Ríos. pp. 218219... . .99

Anexo 1. Listado de noticias arqueológicas divididas según la temática. 101

Anexo 2. Gráfico de noticias arqueológicas en porcentaje según la temática ...........................................108

Anexo 3. Gráfico de noticias arqueológicas por año 108

\section{Alfredo Mederos Martín: La formación arqueológica y en historia del arte del joven Manuel Gómez- Moreno Martínez (1870-1899)}

Figura 1. Autorretrato de Manuel Gómez-Moreno González. 1877. Colección Particular .110

Figura 2. Plano del mosaico de Daragoleja (Granada) por Gómez-Moreno González. 1870. Museo Arqueológico de Granada (Moya, 2004: 40 fig.)

Figura 3. Plano de Sierra Elvira (Granada) por Gómez-Moreno González. 1875. Museo Arqueológico de Granada (Moya, 2004: 58 fig.)

Figura 4. Autorretrato de Manuel Gómez-Moreno González pintando. 1874. Museo de Bellas Artes de Granada 113

Figura 5. Retrato de Manuel Gómez-Moreno Martínez con 15 años por Gómez-Moreno González. 1885. Instituto Gómez-Moreno de la Fundación Rodríguez Acosta.. .114

Figura 6. Gómez-Moreno González y Gómez-Moreno Martínez en excursión con el Centro Artístico y Literario de Granada. 1877. Instituto Gómez-Moreno de la Fundación Rodríguez Acosta (Moya, 2004: 120 fig.)

Figura 7. Carta de Emil Hübner a Gómez-Moreno Martínez con transcripción de inscripción romana. 16-

5-1888. Instituto Gómez-Moreno de la Fundación Rodríguez Acosta (Moya, 2004: 124 fig.).

Figura 8. Guía de Granada por Gómez-Moreno González y Gómez-Moreno Martínez. 1892 ...................118

Figura 9. Juan Facundo Riaño. La llustración Española y Americana. 1892

Figura 10. Catálogo Monumental de España. Provincia de Ávila. Gómez-Moreno Martínez. 1900-01. Instituto del Patrimonio Cultural de España. Madrid

\section{Enrique Gutiérrez Cuenca: Ángel de los Ríos y los inicios de la arqueología medieval en el norte de la Península Ibérica}

Figura 1. Retrato de Ángel de los Ríos. Foto: (c) Biblioteca Menéndez Pelayo ........................................128

Figura 2. Localización de restos medievales estudiados por Ángel de los Ríos ......................................130

Figura 3. Vista exterior al N de Sn Román de Moroso, 1858. Archivo ......................................................131

Figura 4. Sepulcros de Villacantid. Archivo Ángel de los Ríos, Torre de Proaño .....................................133

Figura 5. Piedra con inscripción PELAIO, Archivo Ángel de los Ríos, Torre .................................................134

Figura 6. Hermita y cueva de Sn Vicente cerca de Cervera, Archivo Ángel ............................................134

Figura 7. Estelas de S. Cristóbal de Espinilla custodiadas en la capilla de la Torre de Proaño ....................135 
Figura 8. Calcos de estelas de S. Cristóbal de Espinilla, 1882. Archivo Ángel de los Ríos, Torre de Proaño 136

Figura 9. Segur de hierro de S. Cristóbal de Espinilla, 1892. Archivo Ángel de los Ríos, Torre de Proaño .137

Figura 10. Calco de estela de S. Cristóbal de Espinilla, 1892. Archivo Ángel de los Ríos, Torre de Proaño 138

Figura 11. Necrópolis de Quintanilla de Corvio en la actualidad .139

Figura 12. Estela de Quintanilla de Corvio. Foto: (C) Museo Arqueológico Nacional . 140

Figura 13. Sepulcros de Corbio. Archivo A. de los Ríos, Torre de Proaño. Copia Instituto Sautuola ...........141

Figura 14. Dibujo a lápiz de seis tumbas medievales. Dibujo: (C) RAH, CAT/9/7974/08(7) .142

\section{Alegra García García: Pedro de Madrazo y la arqueología española del siglo XIX}

\section{Enric Verdú Parra: Pioneros de la arqueología alicantina. la necrópolis de l'Albufereta}

Figura 1. La Alicante de los años 20-30 del siglo XX: 1. Fotografía aérea de la ciudad en 1932 (Martínez Morellá 1990: 647). 2. La calle Doctor Esquerdo en los años 30 (Moreno y Mateo 1991: vol. I, 117, no 8). 3. El mercado central alicantino en los años 20 (Moreno y Mateo 1991: vol. I, 135, no 3). 4 . El nuevo hospital en el barrio del Pla, años 30 (Moreno y Mateo 1991: vol. I, 231, no 41) ... .155

Figura 2. La vida cultural en el 'Ateneo': 1. Reunión amenizada con música de piano, años 20 (Moreno y Mateo 1991: vol. II, 146, no 16). 2. Miembros del 'Ateneo' en los años 20 (foto Alicante Vivo) ...........156

Figura 3. 'Construyendo' la Cultura Ibérica: 1. Esculturas ibéricas del Cerro de los Santos en Yecla (foto Archivo Tani Ripoll recogida en López 1999: 213). 2. Primeras excavaciones en la necrópolis de Cabecico del Tesoro (Verdolay), año 1935 (foto Archivo Gratiniano Nieto recogida en Quesada 2001: 65). 3. Trabajos de 1936 en el Tossal de Sant Miquel (Llíria) (foto Servicio de Investigación Prehistórica recogida en Bonet 1999: 119) 157

Figura 4. El Palacio Provincial de Alicante, años 50 (foto Colección Francisco Sánchez, Archivo Municipal de Alicante) 157

Figura 5. Localización de la necrópolis de l'Albufereta. .158

Figura 6. La transformación del paisaje desde inicios del siglo XX: 1. Panorámica de l'Albufereta desde el Tossal de Manises, año 1939 (foto Archivo Gráfico MARQ). 2. La carretera del Cabo Huertas, años 30 (foto Alicante Vivo). 3. L'Albufereta desde el Tossal de Manises durante los años 50 (foto Alicante Vivo). 4. Vista aérea de l'Albufereta en los años 40 (fototeca digital del Instituto Geográfico Nacional). 5. Imagen de la zona de playa con el Tossal de Manises al fondo (Lafuente 1934: lám. I). 6. Casetas de bañistas en los años 30 (foto Alicante Vivo). 7. La playa de l'Albufereta en el año 1942 (foto Alicante Vivo) 159

Figura 7. La imagen histórica de la huerta de Alicante y l'Albufereta: 1. Mapa manuscrito del siglo XVII (foto Archivo Municipal de Alicante). 2. Grabado publicado por Antonio José Cavanilles en 1797. 3. Plano de fines del siglo XVIII con indicación de los vestigios conocidos en el paraje de l'Albufereta realizado probablemente por Francisco Pérez Bayer (Verdú 2015, fig. 1.2). 4. Plano de Alicante e inmediaciones levantado en 1794 por Manuel Miralles (foto Alicante.es) 160

Figura 8. Plano del Tossal de Manises y zona de la playa con indicación del área excavada de la necrópolis de l'Albufereta (a partir de Lafuente 1934: lám. XXI). 161 
Figura 9. 1. José Lafuente durante las excavaciones en el Tossal de Manises, años 30. 2. Lafuente en el Museo Arqueológico Provincial (fotos Archivo Gráfico MARQ). 3. Portada de la memoria de excavaciones en l'Albufereta de 1934

Figura 10. Solveig Nordström en el antiguo Museo Arqueológico Provincial de Alicante (fotos Archivo Gráfico MARQ)

Figura 11. 1. José Belda arqueólogo (fotos Alicante Vivo). 2. Belda supervisando las excavaciones en I'Albufereta (foto Archivo Gráfico MARQ). 3. Junto a Rebollo en el improvisado taller de restauración del Palacio Provincial, años 50 (foto Archivo Gráfico MARQ) 164

Figura 12. 1. El primitivo Museo Arqueológico Provincial en los años 30. 2. El montaje de 1943 (fotos Colección Francisco Sánchez, Archivo Municipal de Alicante) 165

Figura 13. 1. Francisco Figueras en el Tossal de Manises. 2. Explicando las cisternas de Lucentum (fotos Archivo Gráfico MARQ). 3. Dos de sus principales obras arqueológicas: su ensayo de 1932 166

Figura 14. Fuentes de información y esquema de trabajo para el estudio de la necrópolis de l'Albufereta. . .169

Figura 15. Cuartillas manuscritas y mecanoescritas con descripciones de estructuras y objetos arqueológicos de la necrópolis de l'Albufereta (Biblioteca Gabriel Miró de Alicante), sobres y etiquetas identificativas (Museo Arqueológico de Alicante-MARQ) 170

Figura 16. Diversos borradores y bocetos finales de materiales de la necrópolis (fotos Archivo Gráfico MARQ)

Figura 17. 1. Cerámicas ibéricas (Lafuente 1959: lám. XI) y púnicas (Figueras 1956: láms. II, XXV y XXVII, y foto Archivo Gráfico MARQ) de la necrópolis de l'Albufereta. 2. 'Reconstrucción gráfica' de un 'braserillo' y dos broches de bronce (fotos Archivo Gráfico MARQ). 3. El 'grupo escultórico' de l'Albufereta (foto Archivo Gráfico MARQ) y reconstrucción de la policromía original (Figueras 1946: fig. 2)

Figura 18. Fotografías realizadas en el antiguo Museo Arqueológico Provincial de Alicante sobre varios montajes de materiales y vitrinas de la exposición, años 30 (fotos Archivo Gráfico MARQ) 173

Figura 19. 1. Croquis original de las excavaciones de l'Albufereta (foto Archivo Gráfico MARQ) y digitalización del documento (Verdú 2015: fig. 2.5). 2. Fotografía de diversos depósitos funerarios de la necrópolis (Lafuente 1957: lám. VII) y de una fosa con urna cineraria (Lafuente 1944: fig. 16), hoy identificada (foto Archivo Gráfico MARQ) 174

Figura 20. Selección de materiales cerámicos recuperados en la necrópolis de l'Albufereta (fotos Archivo Gráfico MARQ) 175

Figura 21. Otros objetos procedentes de l'Albufereta: reconstrucción de un monumento tipo 'pilarestela', pebetero en forma de cabeza femenina y propuesta de recreación de su policromía, esquema de colocación de las abrazaderas de yugo de bronce, collar de cuentas de pasta vítrea y colgante en forma de 'máscara demoníaca', monedas púnicas y restos de red de pesca carbonizada (fotos Archivo Gráfico MARQ) 176

Figura 22. Propuesta de cronología para las estructuras funerarias de la necrópolis de l'Albufereta (Verdú 2015: cuadros 5.1 y 5.2 ) 177

\section{Alberto Romero Molero: De la exhumación de las estructuras a los estudios arquitectónicos. Nuevas aportaciones historiográficas a la edilicia de Carteia}

Figura 1. Vista aérea de la ciudad de Carteia (San Roque, Cádiz). (C Paisajes Aéreos S.L. Foto J.C. Guzmán Espresati (2007) 182 
Figura 2. Visita de A. García y Bellido a Carteia durante los trabajos de D.E. Woods (1966). (C) Familia Collantes de Terán. Gentileza de Ma Belén Deamos ........................................................................183

Figura 3. Portada de Carteia I de F. Presedo et alii (1982) ........................................................................184

Figura 4. Portada de Sinus carteiensis: Colección de cartografía histórica. Tres siglos de imágenes de la Bahía de H. Jiménez Vialás (2012). ...................................................................................................185

Figura 5. West View of the Ruins of Carteia and its River, with a Prospect of the Rock of Gibraltar (1771).

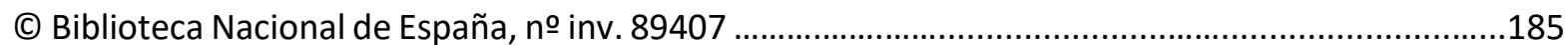

Figura 6. West View of the Ruins of Carteia and its River, with a Prospect of the Rock of Gibraltar (1771)

(detalle de las construcciones). (c) Biblioteca Nacional de España, no inv. 89407

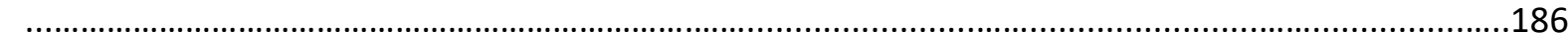

Figura 7. Vista del 'anfiteatro' de Carteia con sus 'almenillas'. Anónimo, siglo XVIII, colección particular .187

Figura 8. Vista de las excavaciones de Santa-Olalla en el teatro de Carteia. (C) Museo Arqueológico Nacional, Legado J. Martínez Santa-Olalla no inv. 1973-58-FF-10562(18) .......................................... 188

Figura 9. Sketch of Ground in the Vicinity of Gibraltar, the site of antient Carteia. (c) Gibraltar Garrison Library, The Gentleman's Magazine LXXXVI (1816) ...................................................................189

Figura 10. Plano de la ciudad de Carteia y área periurbana (1965). (C) Museo Arqueológico Nacional. Informe de M. Pellicer, $\mathrm{n}$ - inv. 1973-58-FF-10316(2) ......................................................................190

Figura 11. Trazado hipotético de la muralla romana de Carteia (2012). C Proyecto Carteia de la UAM .191

Álvaro Gómez Peña: La Rota protohistórica como ejemplo de la evolución del concepto de Tarteso

Figura 1. Ubicación geográfica de Rota (Cádiz, España) (elaboración propia) ........................................195

Figura 2. Estado actual de los corrales de pesca roteños (Arias 2005) ...................................................199

\section{Francisco José Rueda Olmo: La arqueología en Córdoba en la década de 1950. Un recorrido} historiográfico a través de sus protagonistas

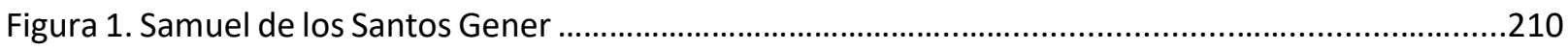

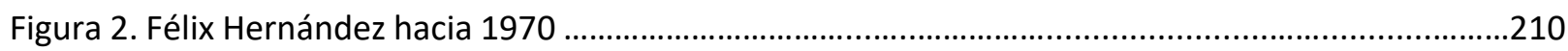

Tabla 1. Relación de catas practicadas por Antonio García y Bellido (Rueda 2015-2016: 156) ..............212

Figura 3. Reconstrucción del templo romano de la calle Claudio Marcelo según Antonio García y Bellido

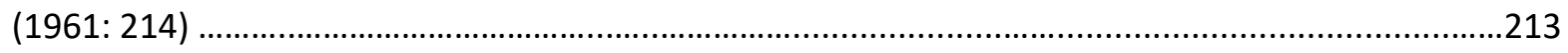

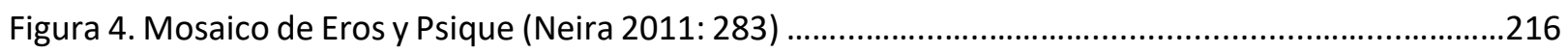

Figura 5. Mosaico de Polifemo y Galatea (Neira 2011: 284) .................................................................217

Figura 6. Relieve de la cara principal del sarcófago romano hallado en la zona del Brillante (Córdoba)

(García y Bellido 1958: 237)

Figura 7. Visita del alcalde de Córdoba, Antonio Cruz Conde (centro), a los Baños del Alcázar el 18 de

diciembre de 1961. A su derecha, Manuel Ocaña (Ocaña 1984: 141)

Figura 8. Grupo de estudiantes del Servicio Universitario de Trabajo en las excavaciones de los Baños del

Alcázar (Castejón 1961-1962: 241) ...........................................................................................221

Figura 9 y 10. Transformación de los jardines del Alcázar tras las labores de puesta en valor (Solano 2007)

Figura 11 y 12. El patio morisco antes y después de su restauración (Solano 2007) ...............................225

Figura 13 y 14. La torre de la Calahorra después de su restauración (Solano 2007) ..............................228 
Tabla 2. Proceso completo de restauración de las murallas de la Avenida del Corregido durante el mandato de Antonio Cruz Conde (tomada de Redondo 2013: 123 124).

Álvaro Sánchez Climent: El estudio de la cerámica numantina durante el primer tercio del siglo XX

Figura 1. Excavaciones practicadas en el cerro de La Muela (Garray, Soria) durante la Comisión de Excavaciones Arqueológicas (1906-1923). Fuente: www.numanciasoria.es .238

Figura 2. Motivos de caballo (y su evolución) en los vasos numantinos según Breuil y Cabré (1911: 255). A: estilización de los caballos de perfil. B: estilización de los caballos de frente

Figura 3. Prótomos de caballo y su estilización. Rioja de Pablo (1913: 213). A: caballos de perfil que darían lugar a espirales. B: caballos de frente que darían lugar a motivos triangulares 242

Figura 4. Algunas láminas presentes en la obra de Taracena (1924). A: lámina 1 de su clasificación tipológica. B: Motivos decorativos de un vaso con decoración polícroma. C: fotografía de un cuenco para rallar 



\section{Prólogo}

\section{Jorge García Sánchez}

\section{Universidad Complutense de Madrid}

En marzo de 2016 tuve la fortuna de organizar junto a Sergio España Chamorro y a Rebeca Arranz Santos (editores del volumen junto a Alberto Romero Molero) unas Jornadas científicas en la UCM que llevaron por título Colecciones, arqueólogos, instituciones y yacimientos en la España de los siglos XVIII al XX, cuyas actas prologo en estas páginas. Para los ponentes supuso una oportunidad de exponer, y ahora de publicar, el resultado de una serie de investigaciones que atañían a toda la geografía peninsular dentro del marco cronológico fijado, y en los aspectos delineados en el enunciado del encuentro; a mí, personalmente, a la vista de los trabajos presentados, me otorgó la posibilidad de realizar una reflexión acerca del punto en el que se hallaba la historiografía de la arqueología española superados los tres primeros lustros del siglo XXI.

Una reflexión, además, que me retrotraía a mi propia trayectoria profesional en esta especialidad, la historia de la arqueología, a la que cada vez se suman más adeptos. Mi acercamiento a ella se la debo a los deliciosos artículos que en los años 90' redactaba Ricardo Olmos con su prosa elegante para la Revista de Arqueología, en el apartado La arqueología soñada (aunque la sección Pioneros también mantenía esta orientación historiográfica). Cómo no convertirse en soñador leyendo sus análisis de la novela de corte arqueológico en los artículos "El Golpe en Vago" (abril de 1994), "Sónica la Cortesana" (junio de 1994) o "Una Mirada a la novela arqueológica de raíz decimonónica" (diciembre de 1992). Después -aunque la alusión sea meramente anecdótica- Olmos aceptó mi primer escrito historiográfico para la revista AEA y al cabo de los años terminó por ser mi superior en Roma, durante su dirección de la EEHAR (CSIC).

En esos años de La arqueología soñada aún desconocía que el punto de partida de la elaboración de nuestra historia de esta ciencia lo había marcado el Congreso Internacional sobre Historiografía de la Arqueología y de la Historia Antigua en España, organizado por el Departamento de Historia Antigua y Arqueología del CSIC en 1988, y en el que Olmos, de nuevo, estaba implicado. En la declaración de intenciones de esta reunión Javier Arce ya advertía de que su temática derivaba de una preocupación científica existente entre algunos miembros de dicho Departamento, y se nombraba especialmente la tesis doctoral que preparaba Gloria Mora, hoy profesora en la UAM, bajo el título Historia de la Arqueología en España, siglos XVIII y XIX (la cual salió a la luz en 1998 como Historias de Mármol. La Arqueología clásica española en el siglo XVIII). Es más, se aludía a que la investigación española jamás se había dedicado a estos estudios, y de hecho se echaban en falta nombres de autores de generaciones anteriores a los prologuistas Javier Arce y Ricardo Olmos. Se nombraba asimismo a la gigantesca figura de Arnaldo Momigliano, cuyos análisis de la historiografía de los estudios clásicos se remontaban a los años 50' y 60', sin que hubiesen tenido durante casi 40 años reflejo en nuestro país.

En ese congreso inicial predominaron los estudios puntuales, las comunicaciones basadas en biografías, en obras singulares de uno o varios autores, así como argumentos monográficos puntuales. Se había puesto la primera piedra, pero Olmos dogmatizaba que resultaba necesario proseguir con exámenes más genéricos, de profundizar en la teoría de encuadre de los estudios historiográficos o de abordar la arqueología desplegada durante el franquismo. Tampoco se habían cubierto aspectos como la revisión de las leyes relacionadas con el patrimonio cultural español, la didáctica de la disciplina, el papel de las instituciones oficiales, etc.

Repasando la producción bibliográfica inmediatamente posterior a 1988 no se puede menos que constatar el relevante papel jugado en la historiografía arqueológica patria por parte de los estudiosos procedentes del mundo del arte y de los responsables de instituciones museísticas. Una tendencia temprana estribó en 
la indagación del origen de las colecciones escultóricas clásicas en nuestros museos nacionales, lo cual significó un impulso de la investigación archivística de los contextos arqueológicos en que se rescataron las piezas, los perennes movimientos de las tallas en el mercado anticuario y su disposición en los ambientes palaciales reales y nobiliarios. En este sentido, los especialistas sí habían comenzado a abordar el análisis historiográfico previamente a 1988, como por ejemplo la obra de Elías Tormo sobre las Musas de la colección de la reina Cristina de Suecia (1936) o de su discípulo Xavier de Salas Bosch concerniente a la compra en España de dicha colección (1941). Así, los reales sitios, los mármoles del embajador José Nicolás de Azara, o los de la soberana apenas aludida, poblaron los textos de Miguel Ángel Elvira Barba mientras se superaba la frontera del siglo pasado, contemporáneamente a que José María Luzón promocionaba que se desentrañasen los fondos artísticos y arqueológicos del Museo del Prado y del Museo Arqueológico Nacional (recordaré el libro de referencia De Gabinete a Museo, de 1993). Luego llegarían, por cierto, las tesis doctorales dirigidas por el citado Luzón Nogué, entonces catedrático de Arqueología en la UCM, que consolidaron en Madrid las líneas de investigación enfocadas hacia el mundo del Grand Tour, del coleccionismo aristocrático, de las excavaciones borbónicas en Pompeya y Herculano, de los repertorios de vaciados escultóricos en yeso de la Real Academia de Bellas Artes de San Fernando y del rol de esta institución en el marco del anticuariado nacional, líneas en las que inserté mis investigaciones tanto predoctorales como posdoctorales. Acaecía una década después de que los historiadores de la Antigüedad y los arqueólogos se hubiesen puesto a la altura de los historiadores del arte mediante la defensa de sucesivas tesis de corte historiográfico en la UAM, enormemente activa en este proceso: la de Helena Gimeno, de 1992, relativa a la Historia de la investigación epigráfica en España en los siglos XVI y XVII, la de Gloria Mora de 1994, mencionada atrás, o la de Jorge Maier, que se aproximaba a la figura de Jorge Bonsor (1997).

Los lazos entre España e Italia, cultivados en los trabajos de la UCM, igualmente fueron objeto de una interesante colaboración entre la Universidad de Sevilla -con el profesor José Beltrán como principal exponente, ya responsable de la celebración de seminarios y congresos sobre la historiografía andaluza-, la sede romana del CSIC y distintas instituciones académicas italianas, garantes de una serie de iniciativas notables, como el Congreso Illuminismo e ilustración. Le antichità e i suoi protagonisti in Spagna e in Italia nel XVIII secolo (Roma, 2001), su continuación, el Congreso Internacional Arqueología, Coleccionismo y Antigüedad. España e Italia en el siglo XIX (Sevilla, 2004) o el Workshop Internacional Il collezionismo di antichità classiche e orientali nella formazione dei musei europei (Frascati, 2010). Las publicaciones resultantes ampliaron el espectro historiográfico hispano ahondando en esos vínculos entre la arqueología y los anticuarios de sendos países, en el comercio y el traslado de colecciones de antigüedades desde Roma y en los personajes españoles de la Italia del Settecento, artistas, viajeros, diplomáticos, hombres de religión, intelectuales, etc. que de un modo u otro contribuyeron al avance de esa arqueología aún acientífica y apegada al objeto artístico.

A la altura de 2016, las lagunas anunciadas en 1988, a casi 30 años de distancia, en gran medida se habían ido cubriendo. El elemento institucional y legislativo echado en falta por Ricardo Olmos se trató, precisamente, en el II Congreso Internacional publicado en 1997 con el subtítulo de La cristalización del Pasado: Génesis y desarrollo del Marco Institucional de la Arqueología en España, coeditado por Gloria Mora y Margarita Díaz-Andreu, el cual ya había sido precedido de la exposición de los comienzos del MAN De Gabinete a Museo. Tres siglos de Historia (1993); en 2001 esta vertiente prosiguió en las disertaciones del congreso Historiografía de la Arqueología Española. Las instituciones, llevadas a imprenta un año más tarde, en un volumen que esclarecía la arqueología efectuada por las distintas autonomías o la andadura de los organismos que históricamente habían asumido implicaciones arqueológicas, tales y como el Museo Arqueológico de Cataluña o los establecimientos fundados en Madrid a partir de la Ilustración, la Real Academia de la Historia, la Real Academia de Arqueología y Geografía, la Sociedad Numismática Matritense o la Escuela de Minas, entre otras. Una constante de este enfoque ha residido en el análisis de nuestra arqueología por reinados, hasta el punto de generar un auténtico debate acerca de las mayores o menores bondades de unos y otros monarcas en calidad de mecenas de las artes y de la cultura, y de patrocinadores de la arqueología. Por supuesto los escritos 
centrados en Carlos III han sido ingentes, y únicamente destacaré los estudios sobre él de Martín AlmagroGorbea y de Jorge Maier, contextualizados en la labor de la RAH, y los de María del Carmen Alonso en torno a la evolución de la metodología de excavación en Pompeya y Herculano en el periodo en que el Borbón todavía se sentaba en el trono napolitano.

La preocupación institucional no se podría haber llevado a cabo sin la consecuente formulación de índole teórica, eminentemente crítica, que explicase las manipulaciones a las que se han expuesto la arqueología y la historia en los periodos de avivado nacionalismo e imperialismo, así como en las dictaduras. Aquí merece nuestra atención la obra de Margarita Díaz Andreu, quien ya pronto introdujo estas pautas de reflexión, por ejemplo, acerca de la época del franquismo, en su visión de síntesis de la Arqueología en España de los siglos XIX y XX (1993-1994), junto a Gloria Mora en "Arqueología y Política" (Trabajos de Prehistoria, 1995), y especialmente, con un entramado geográficamente extenso, en A World History of 19th Century Archaeology. Nationalism, Colonialism and the past (2007). No puedo menos que apuntar numerosos textos basados en el pensamiento teórico de la historiografía arqueológica provienen del ámbito de la Prehistoria, con dos magníficos representantes en la UCM: Víctor Fernández Martínez, quién no sólo ha indagado en la arqueología española en África, sino en múltiples aspectos de la arqueología postcolonialista en ese continente, en Sudán, en Etiopía y otros lugares (recuérdese Una arqueología crítica, de 2006). Y Gonzalo Ruiz Zapatero, cuyas preocupaciones combinan matices de divulgación científica y popular, de la función social de la ciencia, de la arqueología, la historia- y la Prehistoria- sea en la educación que en la sociedad franquista, la percepción del mundo celta y su utilización mediática, etc.

Leo en la presentación que realiza Enrique Baquedano del volumen 150 años de historia de la arqueología: teoría y método de una disciplina (Madrid, 2017) que la historia de la arqueología "no es solamente esencial para comprender la evolución de los datos, de los análisis y de las ideas. Además, es extraordinariamente formativa, informativa y amena", y una línea más abajo añade los adjetivos "interesante" y "divertida". En efecto, la historiografía arqueológica es todo eso, además de necesaria y tremendamente vocacional. Véase que el libro que Baquedano introduce es de 2017. ¿Quizá empiezan a acumularse las publicaciones de esta rama sin mucho orden ni concierto, amenazando saturar el panorama académico de actas, catálogos de exposiciones, artículos y capítulos de libro donde cada autor cuenta su propia investigación historiográfica, incluso a nivel regional, o donde hasta un ínfimo erudito de aldea deviene un pionero imprescindible de la arqueología? Quizá, quizá. Pero recapacítese que lo que se estima el nacimiento de esta categoría de escritos -y bien hace en reivindicarlo Ruiz Zapatero en 150 años de historia....- con la obra de Glyn Daniel A Hundred Years of Archaeology (1950), y la "inmediata" The Origins and Growth of Archaeology (1967), sólo cuenta con 67 y 50 años de antigüedad, respectivamente. O que Conquête du passé, de Alain Schnapp, que valoro como un clásico de la materia, nos retrotrae solo a 1993. En los menos de 30 años que la historia de la arqueología española se lleva construyendo, por lo tanto, se han cumplido buena parte de las expectativas surgidas en esa reunión iniciática de finales de los 80 ', pero todavía nos hallamos en un estadio inaugural, de provisión de investigaciones, de desempolvar los manuscritos de sus estantes, de lo que dan buena fe libros como Colecciones, arqueólogos, instituciones y yacimientos en la España de los siglos XVIII al XX. Los trabajos que se suceden en él discurren por las líneas generales apuntadas antes y responden al propio llamamiento que realizamos en el título del Congreso: desde los análisis de los personajes, o de los grupos de individuos, precursores del avance de la ciencia arqueológica, hasta la observación de la evolución de las investigaciones en un yacimiento, área o región concretos, pasando por las transformaciones metodológicas y las aproximaciones teóricas de la disciplina. Los repertorios de antigüedades, las bibliotecas que archivan el saber, los epígrafes rescatados de la tierra, los museos que han custodiado las piezas, las academias, los problemas de identidad nacional, la arqueología hispana en el exterior... todos constituyen aspectos diferentes de nuestra historiografía y que tienen cabida en el volumen, manifestando la estupenda salud de la que goza esta rama de estudios. Acaso el próximo paso de nuestra especialidad sea el de difundirla en el extranjero, del mismo modo que nosotros no pecamos de ignorancia acerca de la arqueología mayormente- europea (otros lares nos quedan aún lejanos). 
Deseo, por último, agradecer a José María Luzón Nogué, a Alfredo Mederos Martín y a Gloria Mora Rodríguez su inestimable participación en nuestro Congreso del año pasado, como introductores a los argumentos a debatir en cada sesión; a los autores de los artículos, por compartir con nosotros sus experiencias, métodos e investigaciones, así como a los editores del libro, no sólo por su trabajo sino por recuperar y sacar a flote el proyecto de la publicación de la reunión. 


\title{
La colección de antigüedades romanas de la Real Academia de la Historia: el proceso de formación
}

\author{
Paloma Martín-Esperanza Montilla \\ Universidad Autónoma de Madrid
}

Desde su fundación en 1738, el objetivo de la Real Academia de la Historia ha sido, tal y como recogen sus estatutos, "purificar y limpiar la Historia de España de las fábulas que la deslucen e ilustrarla de las noticias que parezcan más provechosas" ${ }^{1}$. El inicio de sus actividades tuvo como tarea fundamental profundizar con sentido crítico en la Historia de España, para lo que realizó estudios sobre la Antigüedad que propiciaron las primeras excavaciones y documentaciones arqueológicas, así como la creación de un Gabinete de Antigüiedades (Almagro 2002: 47).

De esta forma, la Real Academia de la Historia canalizó las actividades históricas y anticuaristas de los siglos XVIII y XIX en España (Díaz-Andreu y Mora 1995: 27). Tras las Instrucciones del Marqués de la Ensenada, promulgadas como Real Orden el 8 de abril de 1872 (Tortosa y Mora 1996: 197), pasó a controlar cuantos hallazgos y excavaciones se hicieran en España en materia de antigüiedades, así como la publicación de obras al respecto (Díaz-Andreu y Mora op. cit., 27).

No es casual, por tanto, que el Gabinete de Antigüedades conserve una amplia colección de piezas muy variadas y de muy diversa procedencia que dan buena cuenta del papel jugado por esta institución en el cuidado del Patrimonio arqueológico. A día de hoy han sido estudiadas y publicadas prácticamente en su totalidad, a excepción de un importante número de antigüedades de época romana. Precisamente, el mayor número de piezas que conserva el Gabinete son hispanorromanas, por lo que el estudio y publicación de esta colección ha sido abordado en tres etapas: en un primer momento se catalogaron todas las piezas de Terra Sigillata, en un estudio publicado por J. Montesinos Martínez (Antigüedades romanas I 2004); posteriormente G. Rodríguez Marín y E. Alonso Cereza publicaron el volumen dedicado a Lucernas y Vidrios romanos (Antigüedades romanas II 2005), también alguna monografía sobre piezas importantes como el Disco de Teodosio, coincidiendo la última etapa con la actualidad, momento en el que yo misma estoy estudiando las piezas restantes de la colección romana, que se publicarán en fecha temprana en el volumen Antigüedades romanas III.

\section{Las antigüedades romanas de la Academia: "monumentos, ruinas y vestigios" 2 del pasado}

La colección de antigüedades romanas consta de más de 700 piezas, a parte de las publicadas en los anteriores volúmenes, que abarcan todo tipo de materiales, desde la cerámica hasta el hueso, pasando por el metal y por supuesto la piedra. Entran en este grupo piezas sobresalientes como el Disco de Teodosio, una de las principales joyas del Bajo Imperio (Almagro-Gorbea 2000), profusamente estudiado por A. Delgado (1849), J. Ramón Mélida (1930), J. M. Navascués (1976), H. Schlunk y Th. Hauschild (1978), A. García y Bellido (1949), K. J. Shepherd, J. Meischner y otros autores como Almagro-Gorbea, Álvarez Martínez, Blázquez Martínez y Rovir (2000). El missorium de Teodosio, obra cumbre de la metalística de la Antigüedad Tardía, fue hallado en Almendralejo (Extremadura) en 1847, siendo adquirido por la Academia ese mismo año. Otra de las piezas maestras de esta colección es la cabeza de Venus de la Isla de las Palomas (Cádiz) (Almagro Gorbea 2010), donada a la Academia por D. Francisco de Asís Vera y Chilier. Se trata de un fragmento escultórico de una figura ideal femenina de mármol blanco de gran

\footnotetext{
*Agradezco al Dr. Martín Almagro-Gorbea, Anticuario de la Real Academia de la Historia, y al Dr. Jorge Maier la ayuda y la confianza prestada en el estudio de esta colección, así como el apoyo en todas mis investigaciones.

${ }^{1}$ Estatutos fundacionales de la Real Academia de la Historia, 1738.

${ }^{2}$ Recogiendo la definición de antigüedades que ha mantenido la Academia desde su fundación en el siglo XVIII.
} 
belleza. La Academia también conserva una escultura ideal masculina, esta vez de alabastro (VV.AA. 2001), que muestra a un personaje desnudo de aspecto joven y espléndida anatomía. También son importantes las múltiples estatuillas de bronce que representan a distintos dioses romanos (MartínEsperanza e.p.) y que son muy comunes en colecciones de este tipo, el conjunto de ánforas romanas, los mosaicos (Martín-Esperanza 2015), las figuras de terracota, así como numerosos fragmentos cerámicos que constituyen una muestra de la variada y rica colección de antigüedades de la Academia que permanece, casi en su totalidad, inédita. Los sarcófagos paleocristianos procedentes de Layos y Hellín (Sotomayor 1973; 1975; VV.AA., 2001; Abascal y Abad 2013: 50), y que actualmente ocupan una de las salas que da acceso a las escaleras principales del palacio del Marqués de Molins, edificio anexionado al Nuevo Rezado, sede de la Academia, son de gran interés para el estudio iconográfico.

No obstante, y, a pesar del notable valor arqueológico de algunas de las piezas, es su valor historiográfico el que, a mi juicio, suscita un mayor interés. Las personas que hallaron estos materiales, los académicos correspondientes encargados de las gestiones, las Comisiones de Monumentos, los donantes y, por supuesto, los Anticuarios, forman parte de la Historia de una institución de la máxima dignidad, por ser la primera en preocuparse por el desarrollo de los estudios históricos en España y por el cuidado del Patrimonio. Es mi intención, por tanto, abordar el proceso de formación de la colección romana para así dar cuenta del protagonismo que tuvo la Real Academia de la Historia, y todos los agentes que la conformaron, en el desarrollo de la Arqueología en España.

\section{Donantes, intermediarios y actores: la formación de una colección arqueológica}

A falta de la publicación del Catálogo de Antigüedades romanas de la Real Academia de la Historia ${ }^{3}$, la primera y única mención en un trabajo científico de muchas de las piezas de esta colección la encontramos en el Inventario de las antigüedades y objetos de Arte que posee la Real Academia de la Historia, elaborado en 1903 por el académico anticuario Juan Catalina García y López. Si bien no se incluyeron todas las piezas, las que sí lo hicieron fueron acompañadas de una escueta información, por lo que partimos de una importante dificultad para averiguar el origen y la procedencia de muchas de ellas.

A pesar de esto, y gracias a la documentación interna de la Academia y de las Comisiones de Antigüedades, se ha podido identificar una larga lista de los donantes que fueron conformando la colección, algunos de ellos cercanos al campo de la Historia, otros no. De esta forma, se han registrado más de cuarenta nombres de donantes y actores, esto es, intermediarios, académicos, anticuarios, que contribuyeron al ingreso de las piezas en la Academia, entrando, salvo alguna excepción, la mayoría de ellas a lo largo del siglo XIX, coincidiendo así con el periodo de mayor actividad del Gabinete (AlmagroGorbea 1999: 29). Estos objetos proceden tanto de donaciones y legados, como de compras, gestiones de los propios académicos, excavaciones arqueológicas amparadas por la Academia e incluso cesiones a partir de la Desamortización de Mendizábal. Precisamente por este motivo, podemos afirmar que la colección de antigüedades romanas de la Real Academia de la Historia es un testimonio perfecto del devenir de la Arqueología española, puesto que sus principales protagonistas y sus actuaciones científicas son, como veremos, responsables de la formación de esta colección.

\subsection{Los académicos correspondientes en las provincias y los académicos de número}

En el proceso de identificación y envío de los materiales arqueológicos a la Academia tuvieron especial relevancia los académicos correspondientes en las provincias. Este cargo, creado en 1770 para los historiadores de mérito que residieran alejados de la Corte, tuvo una importancia sin igual en el desarrollo de la arqueología hispana en las provincias. Como prueba de esto cabe citar el caso de Diego Jiménez de Cisneros y Hervás (1869-1933) (Diccionario biográfico español 2011: 814), correspondiente en Cartagena, que, tal y como informan las Actas de las Sesiones, donó a la Real Academia de la Historia un

${ }^{3}$ Este volumen correspondería al catálogo Antigüedades romanas III, en el que yo mismo trabajo desde febrero de 2014 y que se publicará en fechas recientes. 
conjunto de materiales arqueológicos, inventariados con el n. ${ }^{\circ} 1221$, que se localizan en una caja que conserva una etiqueta manuscrita con el texto: "Objetos romanos procedente de Cartagena, donativo del correspondiente D. Diego Jiménez de Cisneros. Acta de 15 de enero de 1909".

Los objetos de dicho lote suman un total de 14 piezas, de diversos materiales, siendo el más relevante un ara cuadrangular de piedra arenisca, con molduras en los extremos, que presenta también una etiqueta manuscrita, posiblemente del momento del ingreso, en la que se lee: "Ara romana procedente de Cartagena donativo del correspondiente Diego Jiménez de Cisneros (Acta 15 de enero de 1909”. Del mismo modo, en el lote aparecen varias fíbulas y otros elementos broncíneos (agujas, aretes), así como dos punzones de hueso de tipo subulae (Mezquíriz 2009: 163). Sin ánimo de adentrarnos en cuestiones arqueológicas, cabe preguntarse por la procedencia de estos materiales y, especialmente para este trabajo, por el motivo de la tenencia de estos objetos por parte de Jiménez de Cisneros y por su posterior donación a la Academia.

Lo cierto es que, siguiendo el curriculum de Jiménez de Cisneros, no resulta difícil encuadrarle en el grupo de arqueólogos e intelectuales que operaban en materia de Patrimonio arqueológico en la España de principios del siglo XX. Científico sobresaliente, dedicado al campo de la Industria desde 1900, destacó como arqueólogo en todos los lugares donde estuvo (Diccionario bibliográfico español 2011: 814). Desde su nombramiento como correspondiente de la Real Academia de la Historia en 1905, coincidiendo con la fecha de donación del lote de objetos, redactó numerosos informes dirigidos a la Academia acerca de los hallazgos de los que tenía conocimiento, especialmente en Cartagena, motivo por el cual puede considerarse pionero de la arqueología cartagenera. De ello dan cuenta las publicaciones relacionadas con la Arqueología que escribió para el Boletín de la Real Academia de la Historia, entre las que destaca su publicación más excelente, "Foro romano de Cartagena" (1908).

De este modo, la primera identificación del foro romano de Cartagena pertenece a Diego Jiménez de Cisneros, quien en 1900 habría sido testigo de una excavación de urgencia con motivo de la construcción de la casa de Celestino Martínez, entre la calle del Aire y la calle Jara (Jiménez de Cisneros 1908, Calderón 2013: 51). Después de describir los materiales encontrados, señala lo siguiente en sus conclusiones: "Creo que se trata de un foro romano y de uno de los pórticos que lo limitaban, y en atención á las lápidas sobredichas, me atrevería á bautizarlo con el nombre de foro de Numisio [sic]" (Jiménez de Cisneros op. cit., 495). Aquellos materiales, encontrados en el solar donde se levantó en 1907 el Gran Hotel, y que fueron depositados por el propio Jiménez de Cisneros en el Museo de la Económica, sí están vinculados con el foro de la colonia de Carthago Nova, aunque en una fase de posterior reutilización (Noguera y Abascal 2003: 51).

A pesar de que los materiales encontrados en el foro no tienen relación aparente con los que donó a la Academia, sí que sirven para constatar dos cosas: el compromiso de los correspondientes de informar a la Academia de cuantos hallazgos acontezcan en su ámbito provincial -tal y como vemos en el caso del foro- y, segundo y no menos importante, la no obligación de entregar los materiales encontrados al Gabinete de Antigüedades, como prueba el hecho de que, libremente, Jiménez de Cisneros los entregara al Museo de la Económica.

Por tanto, la naturaleza de las donaciones que hacen los correspondientes a la Academia es a título personal, si bien tiene, en la mayoría de los casos, un interés científico como prueba de que ha existido un descubrimiento y de que el correspondiente ha cumplido su función. El caso de Jiménez de Cisneros es ilustrativo en este sentido y, además, abre la puerta a un estudio más pormenorizado de este arqueólogo puesto que, tal y como se extrae de sus artículos, perteneció al círculo del Padre Fita, de quien conservó su correspondencia (Jiménez de Cisneros 1918), del Marqués de Cerralbo, junto al que estudió las Cuevas de Santiesteban (San Juan y Jiménez de Cisneros 1916), en las que participó también Hugo Obermaier, y de José Ramón Mélida, con el que coincidió en la Academia. 
La colección también es testimonio de la inconmensurable tarea llevada a cabo por otros dos correspondientes en importantes empresas arqueológicas: Buenaventura Fernández Sanhauja en Tarragona y Lorenzo Aguirre en Tiermes. En el siglo XIX son muchas las donaciones procedentes de Tarragona que recibe la Real Academia de la Historia, debido, en parte, al papel que juega en esos años la Comisión de Monumentos de Tarragona, la primera creada en Cataluña en 1844 (Remesal, Aguilera y Pons 2000: 34). De Tarragona conservamos un total de 62 piezas y, si bien es cierto que queda por identificar la procedencia de un gran número de ellas, este número corresponde a casi un $9 \%$ de la colección. Dado que estas piezas ingresaron en la Academia antes de 1903, es probable que las donaciones se realizasen entre la mitad y el último tercio del s. XIX, época de Hernández Sanahuja, una de las figuras más relevantes de la arqueología catalana decimonónica y académico correspondiente de la Real Academia de la Historia desde 1851.

Prueba de ello es el ungüentario ( $n^{o}$ inv. 269) que conserva una etiqueta manuscrita en la que puede leerse: "cogido de las ruinas del Templo de Neptuno, en el Fuerte Real" y que está fechada en 1859, coincidiendo con la época en la que Hernández Sanahuja desempeñaba el cargo de Inspector de Antigüedades de Cataluña y Valencia y, a su vez, era miembro supernumerario de la Comisión de Monumentos de Tarragona (Ibid. 40).

En relación con esto, cabe señalar las antigüedades procedentes del yacimiento arqueológico de Tiermes (Soria), catalogadas con el n. ${ }^{\circ}$ de inventario antiguo 227 por García y López (1903), quien apuntaba en la descripción de las piezas lo siguiente: "Una caja con tres trozos de mosaico, y cuatro de vaso de barro, de barniz rojo, con labores hechas con impronta (de los llamados saguntinos) y un remate de vaso de barro común". Este lote fue enviado a la Academia por el académico correspondiente Lorenzo Aguirre en 1887, coincidiendo la entrada de estos materiales con una época de interés por Tiermes encabezada por autores como Nicolás Rabal, quien publicaba unos años después en el Boletín de la Real Academia de la Historia una descripción minuciosa de lo que podía apreciarse en el yacimiento. Dado que no se realizaron en esa época excavaciones, se entiende que las piezas de este lote se encontraban en superficie, siendo enviadas por Aguirre a la Academia para dar cuenta del potencial del yacimiento.

Por último, en lo que concierne a los correspondientes, es preciso mencionar a algunos extranjeros que desempeñaron estas funciones y que donaron sus piezas a la Academia, como es el caso de Eugène Dognée, correspondiente en Bélgica, que donó en 1914 un lote de objetos cerámicos, de gran calidad, de los cuales desconocemos su procedencia. Del donante sabemos que fue miembro del Institut des Provences de France y que escribió varias publicaciones relacionadas con el mundo romano, como prueba uno de los volúmenes que envió a la Real Academia de la Historia: "Les Phaléres des guerrieres romaines" (1867).

Estos ejemplos muestran el papel activo de los académicos correspondientes en la promoción de excavaciones arqueológicas y en la consiguiente formación de las colecciones de la Academia con los materiales de dichas campañas, si bien no fue ésta la única vía de ingreso de las piezas. También los académicos de número llevaron a cabo importantes donaciones fruto de sus trabajos, destacando especialmente entre ellos la figura de Eduardo Saavedra y Moragas; entre sus donaciones más curiosas, destaca la maleta-expositor que adjuntó al cuidado manuscrito sobre la Descripción de la Vía romana de Uxama a Augustóbriga, un trabajo excepcional que constituye una de las joyas de la colección (VV.AA. 2001).

\subsection{El Anticuario: figura fundamental desde 1763}

Especialmente relevantes son, por otro lado, las adquisiciones y compras de los Anticuarios, quienes llevaron a cabo un auténtico servicio de información con la ayuda de los académicos correspondientes que condujo a una recepción ininterrumpida de piezas arqueológicas (Rumeu de Armas 2001: 56). Baste 
recordar el ingreso por adquisición en 1847 del Disco de Teodosio (Maier 2008: 65). No debe extrañarnos que la Academia, por medio de los Anticuarios, comprara todo tipo de piezas arqueológicas, pues así lo había dictaminado la Real Cédula de Carlos IV del 6 de julio de 1803, en cuyo art. $2^{\circ}$ indica que se debe informar a la Academia de los descubrimientos para que determine su adquisición por medio de compra, gratificación o acuerdo con el dueño (Tortosa y Mora 1996: 197).

Este proceso está perfectamente ejemplificado en las donaciones y adquisiciones de Antonio Delgado y Hernández, que desempeñó el cargo de Anticuario durante casi treinta años, desde 1848 a 1867, y sin duda es la gran figura del Gabinete de Antigüedades del siglo XIX (Almagro-Gorbea 2001: 13). Como notable epigrafista y arqueólogo, su brillantez erudita no sólo se palpa en sus publicaciones, como la Memoria histórico-crítica sobre el gran disco de Theodosio, sino también en las cuidadas adquisiciones que hizo para la Academia. Conservamos multitud de cartas, informes y expedientes que dan cuenta de su actividad anticuaria y de su estrecha relación con empresas arqueológicas de la talla de Sagunto y Tarraco. Su red de contactos era amplia y abarcaba no sólo el mundo de los historiadores y humanistas sino también el de la política, actividad en la que participó hasta poco antes de su muerte (Ibid. 13). No cabe extrañar, por tanto, que sus actuaciones en el seno del Gabinete de Antigüedades destaquen respecto a las de otros académicos. Es especialmente llamativa su intercesión en 1852 para que Jorge Loring, el entonces propietario de los bronces de Malaca y Salpensa, pusiera a disposición de la Academia las leyes municipales para su estudio (CAMA/9/7962/10/04).

No obstante, abordar la labor arqueológica de Antonio Delgado y Hernández requeriría un capítulo aparte, por lo que voy a centrarme exclusivamente en aquellas actuaciones que afectaron a la colección que nos ocupa. La primera pieza donada por Delgado corresponde a una magnífica estatuilla masculina de bronce que representa a Júpiter Stator y que habría sido hallada a principios de 1853 en la Villa de Martos (Jaén) (GA 1854/1(2)). Desconocemos cómo llegó dicha escultura a manos de Antonio Delgado, si bien es cierto que este tipo de objeto era muy común entre las colecciones arqueológicas privadas del siglo XIX. No es, por ello, de extrañar que sólo en la colección de la Academia encontremos 40 figuras masculinas y femeninas, muchas de ellas representando a divinidades del panteón romano que llegaron al Gabinete por distintas vías. De las adquiridas por Delgado destacan la Venus de Sagunto, donada en 1860, y la de actor con máscara grotesca procedente de Tarragona y donada en 1861 (GA 1996/5).

Este ingreso se hizo junto a otras antigüedades romanas procedentes todas de Tarragona que habían sido adquiridas por 300 reales a propuesta de Antonio Delgado (Maier, 2008: 255). Entre ellas destaca el busto de Hermes báquico, un anzuelo de bronce romano, varias agujas, estilos de marfil y hueso y alguna pieza de cerámica. La relación de Antonio Delgado con Tarragona era estrecha, como muestran los informes del resultado del viaje que, como comisionado del Gobierno, realizó a dicha ciudad en la que contó, además, con Buenaventura Hernández Sanhauja como anfitrión (CAT/9/7974/05(32)).

También dirigió las excavaciones en Huete (Cuenca), llevadas a cabo en 1858 (GA 1860/7(1)), de donde proceden varias piezas de la colección, siendo la más relevante el pondus de piedra estudiado por Hübner (1862) y que ha sido estudiado en otras ocasiones por lo que no me detendré en él.

Por otro lado, no es casual que, durante los años que Antonio Delgado estuvo al frente del Gabinete, ingresaran a la Academia piezas tan excepcionales como los sarcófagos paleocristianos de Layos y Hellín (Sotomayor 1973; 1975; Abascal y Abad 2013: 50; VV.AA. 2010), empresas en las que participó activamente Aureliano-Fernández Guerra, así como otras piezas menores que, en definitiva, fueron engrandeciendo una colección con vistas a la formación de un Museo Nacional de Antigüedades. 


\subsection{Donaciones, regalos y encuentros casuales}

Otra vía de ingreso, especialmente común a lo largo del siglo XIX, fue el envío de piezas encontradas de forma casual por personas ajenas al mundo erudito. Es curiosa la anécdota de los colegiales de la Compañía de Jesús que, en el invierno de 1917, estando en una excursión en Alarcos, encontraron un pondus romano y no dudaron en remitirlo a la Academia, en aquel entonces institución de referencia en todo lo relacionado con el Patrimonio arqueológico.

Más comunes son los ejemplos de intelectuales y eruditos que, integrados en la órbita de la Academia, enviaban piezas como donación personal o regalo al Anticuario. Entran en este grupo los materiales arqueológicos que el Marqués de la Vega de Armijo, Antonio Aguilar y Correa, encontró en su finca de Bobadilla, en la localidad de Antequera (Málaga) a finales del siglo XIX, como el "vaso de cobre de forma elegante encontrado en su posesión de Bobadilla" o el "remate de bronce en forma de carnero" (CAMA/9/7962/21(01); CAMA/9/7962/21(08); Catalina García, 1903: 347). Precisamente en esa finca el Marqués de la Vega de Armijo llevó a cabo sucesivas "exploraciones" arqueológicas que dieron como resultado la aparición de diferentes objetos, entre ellos inscripciones romanas, tal y como se extrae de la correspondencia entre el marqués y el entonces Anticuario, Facundo Riaño (CAMA/9/7962/21(09)). Estos descubrimientos llevaron al Marqués a iniciar, a finales del año 1891, una serie de excavaciones que concluyeron con la aparición de unos mosaicos correspondientes al pavimento de una villa romana (Rodríguez 1984). Ocho años después, envió los materiales a la Academia.

Como vemos, el seguimiento de estos trabajos estaba marcado, en última instancia, por la pauta de la Real Academia de la Historia, pues a ella pertenecía la labor de salvaguardar el patrimonio histórico nacional. No obstante, a lo largo del siglo XIX y como consecuencia de la dispersión de los bienes, tanto eclesiásticos como civiles, ocasionada por las desamortizaciones, surgen nuevos problemas (Mora y Tortosa 1997: 190).

En esta línea, es curiosa la anécdota del ladrillo paleocristiano que, según Juan de Dios Rada (1876) había sido comprado en el Rastro de Madrid por Tomás Muñoz y Romero y depositada después en el Gabinete. Este hecho, el de la compra de antigüedades en el mercado negro, nos introduce de lleno en las que sin duda son las donaciones más importantes de todas las que registra esta colección. Me refiero a las donaciones post mortem de aquellos académicos que durante su vida formaron una colección de antigüedades que sería donada después, por sus familiares o por ellos mismos según constara en su testamentaria, a la Real Academia de la Historia. De todas ellas, la de Pascual de Gayangos, conocido orientalista del siglo XIX, es sin duda la más especial, no sólo porque el número de piezas donadas corresponde a un $6 \%$ del total de las antigüedades del Gabinete, sino porque la calidad y variedad de las mismas es más que notable (Almagro-Gorbea 2010: 107).

\section{Valoración final}

La colección incluye un nutrido número de antigüedades romanas, que suman más de sesenta y que constituyen, junto a las múltiples piezas correspondientes a otros periodos históricos, como los ushebtis egipcios, los bajorrelieves del palacio asirio de Senaquerib (Nínive) o el primer vaso minoico llegado a España, uno de los casos más llamativos del parco coleccionismo español del siglo XIX. De hecho, Emil Hübner ya hace referencia a la "Colección Gayangos" al interesarse, en 1862, por un templo corintio hexástilo con una inscripción, procedente de Mérida que por entonces estaba en posesión de Gayangos y que, a día de hoy, se conserva en el Gabinete (Hübner 2007). Sobre la procedencia de esta interesante y variada colección, Almagro considera que debió formarse durante los viajes realizados por Gayangos a París y a Londres, donde formó parte de los círculos burgueses en los que se desarrollaba el ambiente anticuario (Almagro-Gorbea 2010: 109). Pese a todo, la documentación de la Real Academia de la Historia muestra una estrecha relación entre Pascual de Gayangos y los arqueólogos y anticuarios de la institución 
de la segunda mitad del siglo XIX, como el ya citado Antonio Delgado, Aureliano Fernández Guerra o su yerno, Facundo Riaño. Precisamente fue durante el desempeño del cargo de Anticuario por Facundo Riaño cuando los hijos de Gayangos donaron la colección íntegra de su padre a la Academia, una casa con la que sin duda mantuvo contactos durante toda su vida.

En definitiva, la colección romana del Gabinete de Antigüedades se fue fraguando a lo largo del siglo XIX mediante la actuación de los académicos correspondientes y de los Anticuarios, pero también gracias a donaciones generosas de particulares que no dudaron en confiar sus hallazgos a la Real Academia de la Historia. Este proceso se ralentizó en el siglo XX con el auge del Museo Arqueológico Nacional, si bien la colección romana no ha quedado estancada, puesto que se ha seguido engrandeciendo con algunas donaciones. Destaca, por ejemplo, la actuación de García y Bellido en la elaboración de una copia del busto de Trajano encontrado en Ostia o, ya en la primera década de este siglo, las donaciones de Max Turiel.

Abordar el proceso de formación de esta colección supone un repaso de prácticamente toda la historiografía de la arqueología hispanorromana puesto que fueron sus principales figuras, especialmente durante el siglo XIX, las que engrandecieron los fondos del Gabinete de Antigüedades de la Real Academia de la Historia, una institución de máximo prestigio por ser la primera en preocuparse del cuidado del Patrimonio arqueológico en España. La colección completa, que se publicará en forma de catálogo, verá la luz en fechas próximas.

\section{Documentos de la Real Academia de la Historia.}

Signaturas:

$\begin{array}{lll}\text { CAMA/9/7962/21(01) } & \text { CAMA/9/7962/21(08) } & \text { CAMA/9/7962/21(09) } \\ \text { CAMA/9/7962/10/(04) } & \text { CAT/9/7974/05(32) } & \text { GA 1854/1(2) } \\ \text { GA } 1860 / 7(1) & \text { GA } 1996 / 5 & \end{array}$

\section{BiBLIOGRAFÍA}

Abascal, J.M. y Abad, L. (2013), 'El descubrimiento y recuperación del sarcófago romano de Hellín. Una aventura arqueológica decimonónica' en R. Cid y E. García (eds.): Estudios en homenaje al profesor Julio Mangas Manjarrés, Oviedo, Universidad de Oviedo: 45-62.

Almagro-Gorbea, M., Álvarez Martínez, J. M.a , Blázquez Martínez, J. M.a y Rovir, S. (2000), El disco de Teodosio, Madrid, Real Academia de la Historia.

Almagro-Gorbea, M. (1999), El Gabinete de Antigüedades de la Real Academia de la Historia. Madrid, Real Academia de la Historia.

- (2000), El Disco de Teodosio. Madrid, Real Academia de la Historia.

- (2001), 'Presentación' en A. Delgado y Hernández, Estudios de numismátca arábugo-hispana. Considerada como comprobante histórico de la dominación islámica de la Península, Madrid, Real Academia de la Historia.

- (2002), 'La Real Academia de la Historia y la Arqueología española', en Quero Castro, S. y Pérez Navarro, A., Historiografía de la Arqueología española. Las instituciones, Madrid, Museo de San Isidro: 91-121.

- (2010), 'La colección de Antigüedades de don Pascual de Gayangos', en G. Anes y Álvarez de Castrillón (coord..): Pascual de Gayangos. En el bicentenario de su nacimiento, Real Academia de la Historia.

- (2010), 'La cabeza de Venus de la Isla de las Palomas (Cádiz)', en J. M. Abascal y R. Cebrián (eds.): Escultura romana en Hispania IV. Homenaje a Eva Koppel, Murcia: 119-218. 
Calderón Sánchez, M. (2013), Primeras noticias y excavaciones de época moderna en Cartagena, Bastetania 1: 49-57.

Catalina García, J. (1903), Inventario de las antigüedades y objetos de Arte que posee la real Academia de la Historia, Madrid.

Delgado Hernández, A. (1849), Memoria histórico-crítica sobre el gran disco de Theodosio encontrado en Almendralejo, leída en la Real Academia de la Historia por su anticuario don Antonio Delgado en la junta ordinaria de 9 de septiembre de 1848. Madrid, Imprenta de la viuda de Calero (reimpreso en 2000).

Díaz-Andreu, M. y Mora, G. (1995), Arqueología y política: el desarrollo de la arqueología española en su contexto histórico, Trabajos de Prehistoria 52.1: 25-38.

García y Bellido, A. (1949), Esculturas romanas de España y Portugal, Madrid.

Hübner, E. (2007), Die antiken Bildwerke in Madrid, Berlín, 1862; id., Madrid (trad. por J. Maier y T. Schattner).

Jiménez De Cisneros y Hervás, D. (2011), Diccionario Biográfico Español, vol. XXVII.

- (1908), Foro romano de Cartagena, BRAH 52: 489-495.

- (1918), Otro informe inédito del Rvo. Padre Fita, BRAH 72: 385-391.

Maier Allende, J. (2008), Noticias de Antigüedades de las Actas de las Sesiones de la Real Academia de la Historia (1833-1874), Madrid, Real Academia de la Historia.

Martín-Esperanza Montilla, P. (2015), Los mosaicos romanos de la colección de antigüedades romanas de la Real Academia de la Historia, BRAH 202, cuaderno III: 377-403.

- (e.p.), Mercurio en el Lararium. Cuatro figuras de bronce de la Real Academia de la Historia, BRAH.

Mélida, J. R. (1930), El disco de Teodosio. Resumen de la memoria que le dio a conocer don Antonio Delgado y los trabajos de sus comentaristas, Madrid.

Mezquíriz, M. A. (2009), Producción artesanal romana: objetos de hueso encontrados en yacimientos navarros, Trabajos de Arqueología Navarra 21: 161-198.

Mora, G. y Tortosa, T. (1997), 'La Real Academia de la Historia: in Patriam, Populumque fluit' en G. Mora y M. Díaz-Andreu (eds.), La cristalización del pasado: génesis y desarrollo del marco institucional de la Arqueología en España, Málaga: 187-196.

Navascués y de Juan, J. M. de (1976), Informe sobre el Disco de Teodosio, BRAH 173, Cuaderno 3: 427437.

Noguera, J. M. y Abascal, J. M. (2003), Fragmentos de epígrafes e inscripción con litterae aureae del foro y del Augusteum de Carthago Nova, Mastia 2: 11-63.

Remesal, J., Aguilera, A. y Pons, L. (2000), Comisión de Antigüedades de la Real Academia de la Historia. Cataluña. Catálogo e índices, Madrid, Real Academia de la Historia.

Rodríguez Oliva, P. (1984), 'Los mosaicos de la Villa romana de Bobadilla (Málaga)', Il Congreso Andaluz de Estudios Clásicos, Antequera-Málaga: 137-169.

Rumeu de Armas, A. (2001), La Real Academia de la Historia, Madrid.

Sanjuán Moreno, M. y Jiménez De Cisneros, D. (1916), Descubrimientos arqueológicos realizados en las cuevas existentes en las proximidades de Castellar de Santiesteban (Jaén), BRAH 68: 170-209

Schlunk, H. y Hauschild, T. (1978), Hispania Antiqua. Die Denkmäler der frühchristlichen und westgotischen Zeit, Mainz.

Sotomayor, M. (1973), Datos históricos sobre los sarcófagos romano-cristianos de España, Granada.

- (1975), Sarcófagos romanos-cristianos de España. Estudio Iconográfico, Granada.

Tortosa, T. y Mora, G. (1996), La actuación de la Real Academia de la Historia sobre el Patrimonio Arqueológico: ruinas y antigüedades, Archivo Español de Arqueología 69: 191-217.

VV.AA. (2001), Tesoros de la Real Academia de la Historia, Madrid. 


\title{
Historia y arqueología en el siglo XVIII en el Reino de Murcia: el descubrimiento de la antigüedad del Puerto de las Águilas
}

\author{
Pedro Pérez Mulero \\ Universidad de Murcia
}

\section{Resumen}

El objetivo de este trabajo es proporcionar una descripción detallada de las noticias arqueológicas e históricas de la población murciana a través del estudio de la bibliografía y de las fuentes documentales. Nos centramos en la ciudad costera de Águilas en la actual Región de Murcia, denominada por entonces Puerto de Las Águilas. Para ello, tenemos en cuenta el contexto histórico y político en el que se encuentra nuestra localidad y su evolución. Un ejemplo que creemos va a aportar luz al incipiente estudio de la historia de Murcia y del Sureste español, desde el punto de vista de la Historiografía de la Arqueología.

\section{La primera recopilación de datos históricos}

La publicación en 1713 de las Ordenanzas y privilegios de la muy noble y leal ciudad de Lorca proporciona la primera recopilación oficial del pasado de Águilas. El dato más antiguo que proporciona es el del rey Alfonso X el Sabio en 1266, quien marca esta tierra como uno de los límites geográficos del Obispado de Cartagena. Se destacan también las siguientes fechas: 16 de Agosto de 1414 (fecha equivocada que debería decir 1514) en que una Cédula de la reina Doña Juana pedía que Lorca levantara una torre en las Águilas; el 4 de Septiembre de 1650, a través de un Privilegio de Confirmación dado por el rey Felipe IV, se destaca la merced a la ciudad de Lorca de las almadrabas de Cope y Calabardina, y por último, en 1654 existen otras Cédulas para que se reparasen las torres de las Águilas y Cope (Anónimo 1713: 178,181 y 187).

Como vemos, el pasado de esta zona sirve para validar el presente político y religioso del año 1713, la tradicional frontera cristiana castellana se sitúa como garante del orden y poder de los anteriores monarcas católicos desde el siglo XIII con Alfonso X hasta el siglo XVII con Felipe IV. Observamos, por tanto, que el territorio de Águilas sale a escena porque aporta un papel necesario en la defensa de los bienes de la corona, como parte de la frontera marítima y límite contra los oponentes granadinos y musulmanes. La realidad cotidiana no hacía sino reforzar esta idea de defensa y protección contra el enemigo en un tiempo de inestabilidad.

Con la paz y la calma tras la guerra de Sucesión Española, los eruditos de la nación comienzan a investigar la importancia histórica de Murcia, tierra de tradición monárquica y católica. El Cardenal Belluga en 1717, al informar al rey Felipe $\mathrm{V}$ de esta geografía, identifica al pueblo fronterizo de Águilas como parte de su identidad histórica, reconociendo que este pueblo costero con la denominación de Penaguila ya aparecía en el Privilegio concedido por Alfonso X en el año 1266 al delimitar los términos del Obispado de Cartagena. Nos dice que este territorio está organizado "empezando en el mar por Alicante, y concluyendo en Penaguila, hoy llamado el Puerto de las Aguilas" (Belluga 1717: 93).

La Monarquía, que ya había comenzado a controlar el territorio por derecho tras la victoria en la guerra, manda realizar el mapa oficial del Reino de Murcia y del Obispado de Cartagena en 1724, encargándose el geógrafo lorquino Felipe Vidal (Vidal 1724), en el que tanto Las Aguilas como la vecina Cope vienen señalados con la imagen de una torre, símbolo de su fuerza defensiva para moradores y comercio.

La Torre de las Águilas es reconocida y apreciada durante los años veinte junto a otros puertos nacionales por donde salen diversas mercancías como barrilla y sosa (Ulloa 1749: 44 y 209; Uztariz 1757: 286-288).

A pesar de la calma de posguerra y de la baja densidad de población con ocho familias en 1726 (Ibáñez 
Vilches 1986: 154), los moradores costeros nunca dejaron de estar pendientes de los peligros del mar, cuyas noticias de asaltos y capturas de piratas seguían siendo reales (García Antón 1992: 189-190).

En este contexto debemos comprender la venida a Águilas en 1728 de José de Balaguer, Administrador de Rentas Reales y Factor de las Reales Tropas de Su Majestad en Lorca y su partido, cuyo objetivo principal iba a ser el de informar al Concejo de Lorca y por extensión a la Corona de todos los movimientos costeros. Construye tres grandes almacenes para depositar las harinas, granos y otros materiales, que serían enviados a varios lugares como el Principado de Cataluña y las vecinas plazas de África, donde destaca Orán, que perdida por España en 1708 sería reconquistada en 1732.

Balaguer hace construir una casa de carácter defensivo rodeada por un campo de pequeña explotación con dos ceñas que reciben el agua de dos balsas. La casa principal está situada poco más de $2 \mathrm{~km}$ de la costa, con clara visión de la torre. También sabemos que Balaguer levantó una ermita dedicada al Patriarca San José, necesaria para todos aquellos que iban a pasar indefinidos periodos de tiempo en esta tierra (Morote Pérez 1741: 43, 60 y 127).

\section{Los primeros restos materiales hallados en Águilas}

$\mathrm{Al}$ abrir los cimientos para las construcciones de Balaguer comienzan a aparecer diversos materiales que ofrecen la oportunidad de comprender las antigüedades de esta tierra.

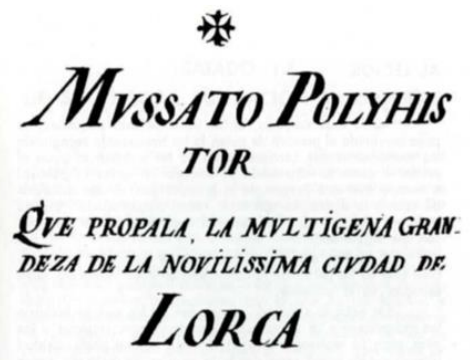

EN EL EPITTME DE SVS MO NIMENTOS QVE EN CA TORZE TRATADOS VOSQVETA VN sV HIJO AMANTE ANO D I 1734

Fig. 1. Portada de la obra Mussato Polyhistor de Gálvez.
Si tuviéramos que marcar una fecha y una obra que nos indicara el comienzo de la "investigación arqueológica" de Águilas sería el año 1734 con la obra Mussato Polyhistor del religioso lorquino Ginés Antonio Gálvez Borgoñoz. El manuscrito se ha mantenido inédito hasta 1991 (Fig. 1).

El propósito de Borgoñoz es realizar una historia de la ciudad de Lorca, que comienza con un asentamiento costero en tiempos antiguos en las Águilas, cuya población posteriormente se traslada al interior fundando Lorca. Su objetivo es intentar demostrar que la sede religiosa de Lorca es la más antigua del Reino de Murcia, y por lo tanto la que tiene más derecho a volver a tener la preponderancia que tuvo antaño, por encima del obispado de Murcia y de Cartagena.

En la presentación al lector, Borgoñoz indica que había llegado a sus manos una moneda de plata de quienes la descubrieron, y que, tras un año sin prestarle atención, al limpiarla, se podía ver muy clara su leyenda, estimando su antigüedad en más de 2800 años. Moneda que le da pie a escribir la obra por amor a su patria, de quien con tanta escasez hablan los autores.

En el tratado primero: De su primera fundación y nombres, la historia de Lorca va a comenzar con la destrucción de Troya y la llegada de los supervivientes a unos cabezos de la costa lorquina, donde tras mucho navegar reconocieron diversas águilas, una señal propicia para el asentamiento. Algunos de estos troyanos desembarcaron con su caudillo Eluhlcohstruzio en el Cabezo de las Aguilas. Del mismo modo como está atestiguado que a España vienen fenicios, cartagineses, vándalos, alanos y visigodos, piensa Borgoñoz, los troyanos son uno más de los pueblos que por causa de la destrucción de su tierra tuvieron que embarcar hacia nuestras costas.

El autor habla que en las Águilas se encuentran vestigios antiguos como son una balsa y cañerías, así como también comenta otras construcciones, que a su parecer son realizadas por los troyanos, conectando estos restos con los orígenes y fundación de la población en un intento de ensalzar todo lo que encuentra. La moneda citada que había guardado y limpiado se había hallado en el año 1728. Nos dice así: 
'que hasta hoy de presente se reconocen en diferentes partes, y también muchos y diversos cimientos de varios edificios, los que demoliéndolos se han sacado muchas monedas en diversos tiempos. Y al el presente, por el año de 1728, se ha experimentado el que abriendo los cimientos para edificar los almacenes, casa y ermita, que en distintos llanos se hicieron, el haberse hallado diversas monedas en los cimientos antiguos, que se demolieron a fin de aprovechar la piedra y dejar en planta llana los que se pretendían hacer para dichas obras, entre piedras labradas que se encontraron, evidenciándose con dichas monedas la antigüedad de la fundación y nombre que ha tenido esta ciudad'

(Gálvez Borgoñoz 1991: 25-26).

La leyenda de la moneda dice lo siguiente: "ELVHLCOHSTRVTIVS VORCVES". Para el autor la moneda sirve para verificar el nombre de su fundador, de Eluhlcohstrutius derivará Eliocrota, es decir, Lorca, y de Vorcues, Urce, topónimo antiguo según la tradición del puerto de las Águilas. Borgoñoz admite que es normal que las ciudades tengan por nombre el de su fundador, poniendo por ejemplo entre otros el caso de Setúbal por Tubal y Ulisipo por Ulises (Fig. 2).

En el tratado segundo: Cómputos de la antigüedad de su fundación, se centra en el tema que realmente le interesa, el de la cronología, ya que como afirma: la antigüedad es una de las mayores excelencias de una ciudad. Estima que Lorca tiene una antigüedad de 1181 años, directamente relacionada con la fecha comúnmente aceptada de la destrucción de Troya, por lo tanto 431 años más antigua que la ciudad de Roma, ya que la datación aceptada para Rómulo, el primero de sus reyes se fecha en $750 \mathrm{o}$ 749 años a.C. Borgoñoz realiza el cómputo con tablas cronológicas ya

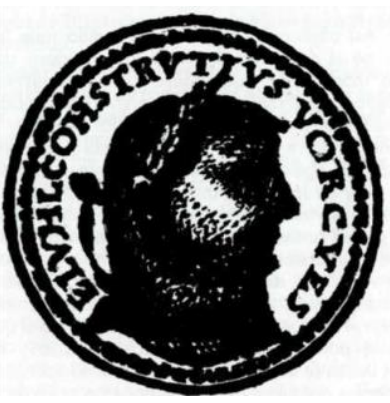

Fig. 2. Moneda en la que se interpretan los nombres antiguos de Eliochrota y Urce (Gálvez Borgoñoz 1991, 26). existentes y aceptadas, con lo cual sus conclusiones son perfectamente válidas en la época para demostrar la antigüedad de su ciudad. Una cronología que se comprueba, finalmente con la lectura de otra moneda que al parecer se había descubierto años antes en 1717, supuestamente sobre el rey Procos, estimada también cercana al tiempo de la destrucción de Troya.

El autor también lee en la moneda las palabras Canite Tuba que rápidamente relaciona con las Sagradas Escrituras, símbolo de la predicación a través de la trompeta celestial, cuyo sonido hicieron resonar los profetas Isaías, Ezequiel, Jeremías y Joel entre otros.

Borgoñoz, siguiendo el famoso Diccionario de Ambrosio Calepino del siglo XVI, dirá que Procas fue un rey de Albania. Dice que es Proca rey de los albanos, padre de Amulio y Numitor y abuelo de Rómulo y Remo. Ofreciéndose, además, la referencia a fuentes clásicas como Tito Livo y Virgilio. Borgoñoz no parece conocer bien las leyendas de fundación de Roma y confunde información, como por ejemplo que no se diga rey de Alba sino de Albania, indicando la tierra actual de los Balcanes, y no la de Italia (Calepini 1609: 67 y 388). También busca información sobre el rey Proca en la obra del Padre Juan Musancio y encuentra, al parecer, que está relacionado con la fundación de Lugdunum (Lyon) (Dominico Musancio 1701: 93). Aquí comete un error de interpretación, ya que el Padre Musancio no se refiere al rey Proca cuando dice: Munatium Plancum Procos, sino al político y militar romano Munacio Planco, quien durante su proconsulado en la Galia en 44-43 a.C. había fundado la ciudad de Lugdunum. Procos es la habitual abreviación latina de Procónsul, pero Borgoñoz llevado por el entusiasmo de identificar y dar realce a la lectura de la moneda que analiza, se basta con una búsqueda superficial.

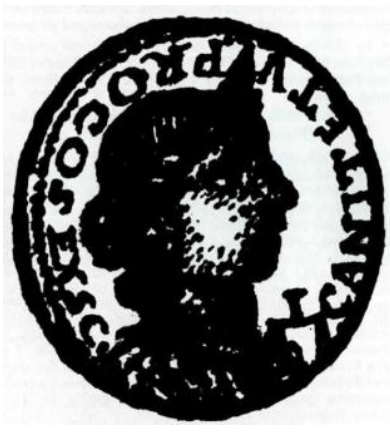

Fig. 3. Moneda que se interpreta como del rey Proco utilizada para dar cronología a la antigüedad de Lorca (Gálvez Borgoñoz 1991, 31). 
La moneda se entiende en un momento en el que los troyanos fundaban ciudades y dejaban memoria de sus líderes maś aclamados, como bien lo deja reflejado Borgoñoz de Virgilio: Proco, gloria de la gente troyana. Porque lo que la tradición oral sí había entendido muy bien era que, en un tiempo remoto, las fundaciones de las ciudades las habían llevado a cabo los héroes o personajes importantes. La lógica de Borgoñoz, en el momento en el que escribe, es irrefutable: 'siendo como es Lorca fundada en tiempo del reinado de Procos, y Roma en el de Rómulo, descendiente de Procos, mediando como median entre las dos distintas generaciones de reinados, corre con llaneza el exceso de antigüedad que Lorca hace a Roma' (Gálvez Borgoñoz 1991: 32-33) (Fig. 3).

La zona costera de Águilas, desde esta perspectiva, forma parte del primer capítulo de la historia de Lorca.

No era la primera vez que se relacionaba la venida de troyanos a esta lejana costa del Mediterráneo occidental. La leyenda de fundación de la población costera se inserta en la mentalidad de la época como sucede en tantas otras poblaciones, como una necesidad de determinar los acontecimientos del pasado, que a priori, siempre son vistos como importantes y gloriosos. En el caso de la costa lorquina ya había sido escrito en la segunda mitad del siglo XVI en el poemario de Ginés Pérez de Hita. En su Libro de la población y hazañas de la M[uy]. N[oble]. y M[uy]. L[eal]. ciudad de Lorca escrita en 1572, ya cuenta que, tras la guerra de Troya, Eneas marcha junto con los leucros a Occidente. En Cartagena, denominada Testa, no le consienten la entrada, desembarcando en Cope, donde consagran sacrificios a Venus para aplacar la cólera de Juno. Al ver venir águilas reales volando, uno de los compañeros de Eneas, príncipe del linaje de los leucros, quienes presentan un águila en su escudo como emblema de clan, pide a Eneas quedarse junto con los suyos en este paraje por considerar a las aves de buen agüero. Posteriormente, también marchan al interior atravesando la sierra y fundando en la fértil vega la ciudad de Lucra, es decir, Lorca (Acero y Abad 1888: 208-208).

Como es conocida, la figura de Eneas ya está presente en la Ilíada de Homero, forma parte del bando defensor de Troya, y es presentado en la obra como el pastor de gentes, y uno de los guerreros más importantes después de Héctor, y tras su muerte, sucesor de su estirpe.

La presentación de esta leyenda, relacionada con las monedas halladas en la costa lorquina, defendida por

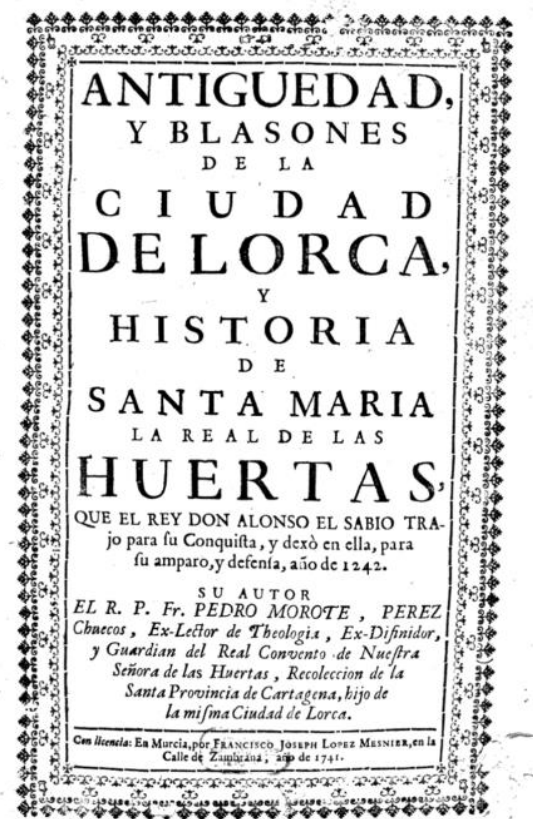

Fig. 4. Portada de la obra

Antigüedad, y blasones de la ciudad de Lorca del Padre Morote.
Borgoñoz, es asumida y extendida por su contemporáneo y también religioso Pedro Morote Pérez Chuecos, más conocido por Padre Morote (Fig. 4). Este religioso lorquino defiende en 1741 que en las Águilas se situó la antigua ciudad de Urci, mencionada por las fuentes literarias griegas y latinas. Posición a la que se aferra y afianza por la aparición de la primera moneda que Gálvez Borgoñoz le ha hecho llegar a sus manos.

Primero identifica el nombre Eluhl, y como segundo nombre o apellido Vorcues: 'El primero, acomodado à nuestra pronunciacion, es el nombre Elio, nombre del Principe Troyano, que le diò à Lorca su nombre; y el segundo, que pudo ser su apellido acomodado à nuestro modo de hablar, es el nombre propio de Urce' (Morote Pérez 1741: 43). Así Cohstrutius, haría referencia a la construcción de las dos antiguas ciudades de Eliocrota, en base al nombre, y de Urce, por el apellido.

Morote se basa para defender sus afirmaciones en la dignidad de autores anteriores. Nos muestra que no se inventa nada, al seguir al Padre Vargas, a Gabriel Orbaneja y a Méndez de Silva, quienes ya hablaban de los troyanos como fundadores de Lorca. Fray Alonso de Vargas en el año 1625 habla de la antigüedad de Lorca (Vargas 1625: 40-41) y nos dice que el primer nombre que tuvo la ciudad 
fue Eliocrota, tomando por dicha en Elio, el nombre de su fundador, el qual pudo ser Elisa, hermano de Tarsis, ambos visnietos de Noe, que costeando el mar mediterraneo, llegaron a España, donde fundaron algunas ciudades, y les pusieron sus nombres. El religioso no afirma tal posibilidad, pero la propone como opción. Del mismo modo también admite que existe una tradición antigua: pero la tradicion antigua tiene, que un Principe Troyano, llamado Helio fundò a Lorca, y le dio su nombre. Vargas dice también que este fundador parece que fue griego, ya que le añadió al nombre '-crota', relacionando este término con un topónimo existente Croto o Creto en la Magna Grecia, un lugar del mismo modo agradable para vivir, del que dice que Estrabón cantó hazañas.

Méndez de Silva en 1675 hace una simple referencia a la fundación de Lorca: 'segun algunos, fue Fundada de Griegos Focenses (...) Otros quieren por un Principe Troyano, nombrado Heilo, dandola su nombre. Heliocrata' (Mendez Sylva 1675: 184).

Por último, Gabriel Pasqual de Orbaneja también hace referencia al pasado de Lorca, pero no hace mención a que la ciudad fuera fundada por troyanos, simplemente dice: 'Es cierto en diversos Historiadores fue poblacion de los Griegos despues de la destruccion de Troya' (Pasqual de Orbaneja 1699: 127).

De este modo, la aparición de la moneda se observa como un objeto portador de la verdad que atestigua los datos procedentes de los investigadores del pasado.

Este esfuerzo de análisis no tenía otro objetivo para los dos religiosos lorquinos que el de fundamentar la antigüedad y dar histórica validez a las dos ciudades de Águilas y Lorca. Paso previo necesario para comenzar una seria reivindicación de un futuro obispado para Lorca. Ambas ciudades estaban relacionadas con las sedes episcopales de la Hispania cristiana Eliocrota y Urci, cuyos obispos y presbíteros asisten a diversos concilios de la Iglesia, pero, al parecer, hasta el siglo XVIII, no se había tenido que acudir a acreditar su pasado. Para los lorquinos era conocida la ermita de San Indalecio, primer obispo de Urci, cuyos orígenes se encontraban en unas cuevas visibles donde el santo se retiraba tras su predicación. La venida de San Indalecio y su obispado en Urci lo acredita Borgoñoz mencionando a la venerable Madre Sor María de Jesús de Ágreda, quien en su Mística Ciudad, obra realizada por inspiración divina, afirma que el Apóstol Santiago viajó desde la ciudad oriental de Jope (Jafa) hacia España, desembarcando en el puerto de Cartagena, con el objetivo de ir a Yliberia (Granada), y que en su peregrinación fue dejando discípulos por obispos en diferentes ciudades de España (Gálvez Borgoñoz 1991: 97-98; María de Jesús 1668: 221 у 226).

Aun así, estos dos autores tenían como precedentes a otros que habían realizado el estudio de este topónimo. Borgoñoz menciona la entrada "Urci" del mencionado Diccionario de Calepino en el que se basa en Plinio. Ciudad situada en la frontera entre la Hispania Bética y Tarraconense y cercana a la costa. Entre sus investigaciones Borgoñoz observa que en este asunto existen dudas y contradicciones en numerosos autores. El Propio Pascual Orbaneja, que defiende en su obra la ubicación en la ciudad de Almería, dice también que: 'no se halla mucha luz en los autores de la fundación de Urci, ni cuándo Almería se fundó en sus ruinas (...) de donde se reconoce la incostante certeza que podemos tener en la aplicación del nombre urcitano' (Gálvez Borgoñoz 1991: 100).

Lo que nos lleva a comprender que la relación del topónimo 'Urci/Urce' con Águilas no comenzó en el siglo XVIII sino mucho antes. Robert Estienne ya había publicado en 1543 en su famoso y posteriormente reeditado Thesaurus Linguae Latinae, en la entrada 'Urce' este topónimo antiguo relacionado con el topónimo de su propia época llamado Aquile (Stephani 1543: 1531). Contenido que mantiene vivo en el siglo XVIII Ferrario, quien nos dice al hablar de Urci: 'popularmente se llama Aquile, todavía conserva el nombre' (Ferrarius 1738: 277).

En todas las ediciones del Thesaurus aparece la misma información sobre 'Urci': topónimo perteneciente a la parte tarraconense de Hispania, según el geógrafo griego Ptolomeo en su libro 2, capítulo 6, y que se 
conoce o se identifica con el topónimo Aquile.

Al parecer el Thesaurus recoge la información directamente de los primeros mapas que se elaboran basándose en el testimonio de la obra de Ptolomeo. El ejemplo más temprano que conocemos es el mapa ptolomaico de Francesco di Nicola Berlinghieri Fiorentino del año 1482, quien interpreta e identifica los pueblos modernos a los que se estaría refiriendo Ptolomeo (Fig. 5). En el lugar del topónimo Urci indica el topónimo Aqvile (Berlinghieri 1482).

Aqvile (Águilas) se sitúa entre los topónimos Margo (Terreros) y Cepo (Cope). Para la investigación se trata del primer mapa impreso de España, y el primer ptolomaico trazado corrigiendo los datos con los portulanos. El topónimo Aqvile parece ser la lectura latinizada del castellano Aguila, que según el idioma en el que se traduzca será presentado durante la Edad Media con diversas lecturas como podemos observar en los portulanos conservados que mencionan este lugar en la costa mediterránea del Sureste Peninsular (Pareja Muñoz 1995: 89).

\section{La aportación del Padre Flórez a la nueva Ilustración}

Es en este contexto de búsqueda histórica y defensa de la patria en el que debemos comprender a quien es considerado el símbolo de los investigadores desde mediados del siglo XVIII: el Padre Enrique Flórez con la extensa obra titulada España Sagrada, comprendida como un monumento de la nueva Ilustración.

El Padre Flórez, Catedrático de Teología en la Universidad de Alcalá de Henares y eminente erudito, también va a comentar, en su parte dedicada al Obispado de Cartagena, la antigüedad de Águilas. En el tomo I comenta la geografía de la costa mediterránea, hace referencia al Seno Urcitano o Virgitano, al que sitúa entre el Promontorio Caridemo en Almería y el Promontorio Scombrario en Cartagena. A la ciudad de Urci, o Virgi, la sitúa al Oriente de Almería, sin ofrecer más precisión, sin decantarse por ningún pueblo de esta costa. En la misma obra Flórez hace referencia a las divisiones de la España romana, presentando las palabras de Plinio para el límite entre la Bética y la Tarraconense. Dice que utiliza a Plinio $(N H, \mathrm{X}, 1)$ por ser uno de los primeros que tratan el tema, así como por haber tenido el cargo de Questor de esta provincia y por tanto fuente directa. Pone el límite oriental de la Bética entre Murgi y Urci, de modo que Murgi, a la que identifica con Mujacra era de la Bética (Murgis Beticae finis) y Urci, ò Urgi principio de la Tarraconense (A fine Urgitano Citerior, eademque Tarraconensis) (Florez 1747: 22 y 205).

En el tomo V vuelve a decir lo mismo al presentar los límites de la provincia Carthaginense. En esta ocasión indica como posible el margen Oriental del Río Almanzor, actual Almanzora, como la zona donde ha de ubicarse la ciudad de Urci. Para ello nos muestra el testimonio de Francisco Gil, Vicario del Partido de la ciudad de Vera, y residente en la vecina Villa de Cuevas, quien le da testimonio que en la playa del margen oriental del referido río: 'se vèn claros vestigios de una antiquissima poblacion muy extendida por la rivera del mar, y con bastante extensión en lo que mira tierra à dentro, aunque no tanta como lo que se alarga por la costa' (Florez 1750: 3-4). Flórez no se va a decantar tajantemente por esta situación, posiblemente los restos de la actual Villaricos, pero demuestra así que también tiene en cuenta los restos materiales arqueológicos y las novedades a este respecto como posibles jueces para resolver el dilema de la ubicación de la ciudad antigua.

En su tomo VIII correspondiente al año 1752 se centra de manera más pormenorizada en la ubicación de Urci (Florez 1752: 212-219). Primero recuerda la obra del Padre Morote y la moneda hallada 'en unas 
ruinas del puerto de las Aguilas', hallada en 1728, en la cual se interpretó la existencia de un personaje famoso denominado Elio que construyó Urci. En este caso Flórez rectifica al religioso lorquino Morote, determinando que aquel análisis e interpretación basado en leyendas había sido uno de los mayores borrones que pueden estamparse por ignorancia de la ciencia numismática, pues aquella medalla la identifica con el emperador Constancio Cloro. El Padre Flórez zanja con una certera aserción todo lo dicho tanto por Borgoñoz en 1734 como por Morote en 1741, y deja sin fundamento la supuesta base verídica de la leyenda de la fundación de Urci por un líder troyano. Flórez, toda una institución en el campo de las letras y de la historia, había leído la moneda con unos nuevos ojos críticos, sin el prejuicio que anteriormente se necesitaba para comprenderla. En la moneda ya no se lee ELVHL COHSTRVTIVS VORCVES, ahora las letras identificadas corresponden a FL. IVL. CONSTANTIVS. NOB. CAES., que completadas dan 'Flavius Julius Constantius nobilis Caesar'. Así Águilas se queda sin una de sus más importantes antigüedades en la defensa de su relación con Urci, pero gana la moneda de un emperador romano. Para puntualizar a Flórez, podemos decir que esta nueva lectura de la moneda no haría en realidad referencia al emperador romano Constancio Cloro, como asegura, sino a su nieto Constancio II, César entre los años 337-361 d.C., cronología en la que se ha de encuadrar la moneda y primer testimonio arqueológico romano reconocido para el Puerto de las Águilas.

Tras esta novedad, Flórez maneja las fuentes que hacen referencia a Urci. Ptolomeo la menciona en griego Ourke, es decir, Urce, pero estima como lo más común Urci, tal como aparece en Plinio, el Itinerario de Antonino y Marciano Capela. También aparece como Virgi en Pomponio Mela y en Plinio. Para Flórez todos estos topónimos pertenecen a la misma ciudad, debiéndose leer en Plinio Urcitano y no Urgitano como presentan algunos manuscritos.

En conclusión, Flórez piensa con las fuentes en la mano la posible ubicación de la ciudad antigua de Urci y deja abierta la posibilidad de situarla tanto en la costa oriental del Río Almanzora, donde se observan vestigios de una antigua población, así como más al Norte siguiendo la costa en el Puerto de las Águilas, ya que debido a su corta distancia les son favorables la graduación de Ptolomeo y la de Antonino (Florez 1752: 214). Rectifica a diversos autores al determinar que sus conclusiones son erróneas porque no han tenido en cuenta el total de las fuentes existentes sobre el tema y aun teniéndolas no han sabido leerlas.

Contestando las conclusiones de Ferrari al relacionar Urci con la actual Orce, nos dice según lo que hasta ese momento nos muestran las fuentes históricas: 'pues más arreglado es recurrir al Puerto de las Aguilas, que à ninguna poblacion mediterranea'. Lo mismo piensa sobre las palabras del Padre Harduino que la sitúa en Almazarron y Baudrand que propone Vera, pero en este caso determina no Águilas sino Villaricos, ofreciendo también la otra posibilidad en una investigación en la que todavía no se podía decir la última palabra (Florez 1752: 218).

Las investigaciones posteriores continuarán indicando lugares concretos sin tener en cuenta todo lo dicho por Flórez, sin embargo, la situación había cambiado, el modo de aventurarse a una solución debía tener en cuenta a los autores anteriores, así como a restos arqueológicos concretos, a pesar de que la tradición tenía todavía un peso notable.

\section{Actuación de Fernando VI en las Águilas}

Durante estos años en los que habla Flórez se está preparando un nuevo reordenamiento del Puerto de las Águilas por parte del rey Fernando VI, que va a presentar como símbolo central la construcción de una fortaleza militar. El visto bueno de las obras lo da el Marqués de la Ensenada como Ministro de Hacienda, Guerra, Marina e Indias, a petición del veterano Capitán General de las Reales Armadas Duque de Caylus, que había supervisado esta costa bajo su cargo de Capitán General.

Aunque las obras se demoran más de lo previsto debido a la gran presión de los piratas del mar y la falta de personal cualificado para llevarla a cabo, el proyecto de construcción de la fortaleza comienza en mayo de 1754 y finalmente estará concluida en abril de 1756 (García Antón 1986: 69; García Antón 1988: 38- 
39).

La posibilidad de que en estas obras apareciera material arqueológico no era pequeña, como excavaciones científicas posteriores han podido comprobar. Debemos recordar que el Ingeniero Director Sebastián Feringán había dado cuenta al Marqués de la Ensenada en 1752 del hallazgo de un buen lote de monedas encontradas en las excavaciones en curso del Hospital de Marina en Cartagena, así como dos ánforas, dos cántaros largos y puntiagudos, de diferentes zonas de la ciudad portuaria. Además, había mandado dos dibujos donde se reproducen dos lápidas romanas, una estudiada y conocida y la otra hasta entonces inédita (Béthencourt Massieu 1963: 82-83). Del mismo modo, sabemos que el Duque de Caylus era un entusiasta de las antigüedades, y que también pudo llegar a sus manos algún objeto procedente de Águilas. Caylus tenía un gabinete donde mostraba diversos objetos más o menos curiosos, procedentes de todo el mundo, que pudo ser inventariado y publicado en 1772, pero en el que no se especifica el lugar concreto de los hallazgos (Anónimo 1772). Quizá no sea extraño citar aquí que su sobrino era el viajero entusiasmado por las antigüedades y anticuario Anne Claude Philippe (1692-1765), reconocido como uno de los franceses ilustrados más importantes coleccionistas y considerado padre redescubridor de la Grecia clásica. Demuestra su gran talento la publicación de su obra en siete tomos justo por estos años dedicada a las antigüedades egipcias, etruscas, griegas, galas y romanas (Caylus 1752-1767).

La construcción de una fortaleza militar en Águilas se muestra como un verdadero acto de fuerza por parte de la monarquía, que estaba defendiendo la costa española de posibles enemigos, un ejemplo clarificador de la 'Paz armada' como ha sido etiquetado el reinado fernandino. Águilas se beneficia, en este caso, de su situación geográfica, por ser auxiliar del importante enclave que representa Cartagena, así como punto de conexión con Andalucía. El objetivo seguía siendo, como en años anteriores, el de evitar los desembarcos que pudieran amenazar los extensos campos de Lorca. El enclave aguileño, por lo tanto, comienza a ser tenido en cuenta ahora de un modo más contundente a nivel geopolítico, con vistas a un puerto mercantil resguardado por una renovada fortaleza. Por extensión, la nueva construcción en lo alto del Monte de las Águilas va a permitir dar claridad a la idea de la creación en su falda de una nueva población, al parecer, como había tenido en épocas remotas.

En 1758 el castillo se encuentra debidamente guarnecido con un cargo de gobernador militar y comienzan las peticiones de pobladores para asentarse en el nuevo establecimiento. Un tiempo nuevo había comenzado, y con su resurgir, de manera paralela, van a salir de la tierra los restos materiales de su pasado.

\section{La construcción de la nueva población borbónica descubre a las antiguas poblaciones de Águilas}

Con la proclamación del nuevo monarca Carlos III en 1759 la labor comenzada por Fernando VI se va a continuar y completar. En la ciudad de Lorca los festejos duraron varios días, buen ejemplo de la excelente relación entre la tierra murciana y la Casa de Borbón. Cuatro Regidores de la ciudad se encargan de preparar las celebraciones, y se manda a Pedro Matías Martínez de la Junta que pase todo por escrito. Da como resultado una obra, en cuyo comienzo se destacan los orígenes de Lorca (Martinez de la Junta 1760).

Este autor lorquino escribe lo que se creía en la mentalidad popular de la época sobre el origen de su ciudad, relacionado con la guerra de Troya, con el paso de sus héroes emigrados a la costa lorquina y el augurio de un águila que fue determinante para fundar la población costera de Águilas, origen y consecuencia de la fundación de la gran ciudad de Lorca, denominada Ciudad del Sol, así como también Eliocròta y Eliòpoly en Castilla. Un augurio de águilas en vuelo que sigue manteniendo viva la antigua tradición oral.

En el puerto de las Águilas, con el recién fundado castillo, se van a elaborar distintos proyectos de repoblación para crear a los pies de la fortificación una nueva ciudad.

Mateo Vodopich es el encargado de dirigir el levantamiento de la nueva población desde 1762. El primer proyecto de 1756 es anulado y ahora la nueva población no será una plaza fuerte, sino un enclave comercial, más acorde a los nuevos tiempos (García Antón 1986: 72-73 y 82). 
Con la aprobación del Conde de Aranda desde Cartagena en Julio de 1765, se marca el inicio oficial de la creación de una nueva población, en la que se ponen muchas esperanzas de crecimiento y obtención de beneficios para la corona. Aranda había tenido una muy buena impresión de su viaje a Águilas. Concluye con la recomendación y necesidad de construir un puerto, argumentando como razón que desde Cartagena a Málaga no hay refugio semejante contra temporales y corsarios (Hernández Franco 1986: 127).

Desde el mismo año 1765 ya existe un ambiente de construcción general ejemplificado en la abertura de tantas zanjas como edificaciones se pretendían levantar. En el Acta Capitular del Concejo de Lorca de 20 de Julio, en la que como era de esperar, se respondió favorablemente a la construcción de la nueva población, figura un listado con 45 vecinos lorquinos que, siguiendo a los doce primeros propietarios, solicitan fundar casas en el Puerto de Águilas (García Antón 1986: 76).

En las sesiones celebradas en el Ayuntamiento de Lorca comienza a hacerse eco de los primeros trabajos, indicando que ha de pagarse 'el gasto ejecutado en las zanjas abiertas para el señalamiento en terreno del trazado de la nueva población’ (García Antón 1992b, 643).

El murciano José Moñino, más tarde Conde de Floridablanca, como Fiscal miembro del Consejo de Castilla, recomienda el visto bueno del proyecto, que será aprobado oficialmente por el rey Carlos III mediante el Real Decreto de 4 de enero de 1766.

El profesor García Antón, que ha estudiado los planos de la nueva población, destaca la construcción progresiva de los diversos edificios, deduciendo que 'Ello indica la prosperidad del lugar y su extensión en sólo doce años' (García Antón 1974-1975: 188-189) (Fig. 6).

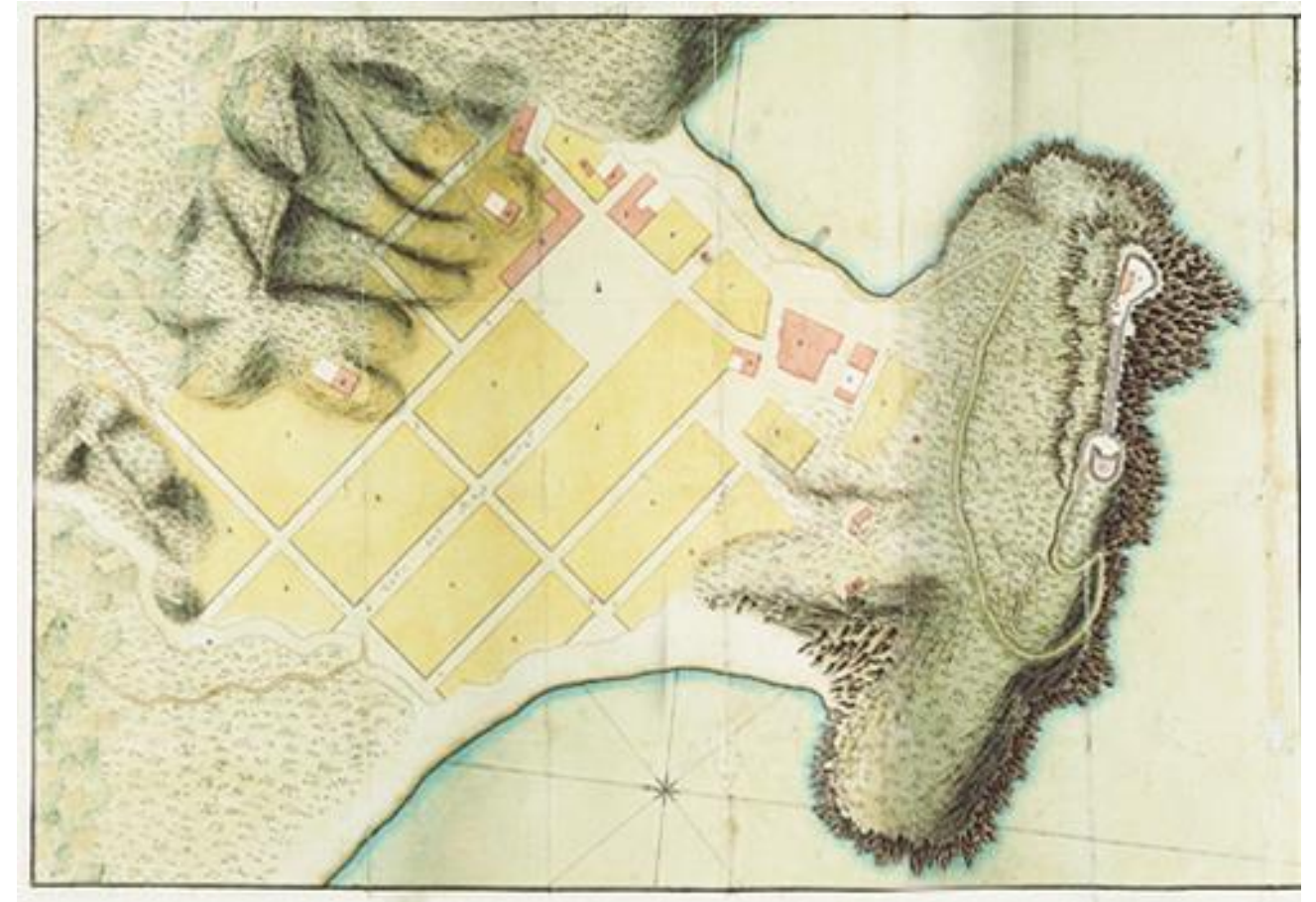

Fig. 6. 'Plano en que se muestra la situación del monte de las Aguilas, de su fuerte nombrado San Juan Baptista y la batería de San Pedro... y proyecto de la nueva poblacion que se manifiesta en este plano...' con el visto bueno del Conde de Aranda. Mateo Vodopich, Cartagena, 10-Sep.-1765. Archivo General de Simancas (FR,AGS,Diapositiva, 228).

Sin mucho esperar, será el 16 de junio de 1766 cuando se haga referencia a que los primeros habitantes de la nueva población están utilizando para la construcción de sus edificios cimientos antiguos que aparecen 
al levantar el suelo. Diego Leonés, uno de los regidores de la ciudad de Lorca, como procurador general de las obras hace referencia a las zanjas en Águilas. Para evitar tales acciones, se acuerda mandar al Diputado de dicho partido Gabriel Pérez para que no permita que nadie saque piedra de cimientos y murallas antiguas, pero que si lo hacen deberían taparlas para no perjudicar las zanjas (Díaz Martínez 1991: 59).

Así que, desde los primeros momentos constructivos, comienzan a emerger del suelo de la población vestigios antiguos, que los nuevos habitantes van a intentar reaprovechar para sus edificios.

En 1768 el Conde de Aranda, ya como presidente del Consejo de Castilla, pide un informe sobre la situación del puerto de las Águilas al corregidor de Lorca, Francisco Ruiz Albornoz, quien junto a Diego Leonés visitarán las obras guiados por el gobernador militar del castillo Juan Chardenoux (Hernández Franco, Mula Gómez, Gris Martínez 1988: 317 y 324). El corregidor le notifica el incremento registrado desde 1765, que pasa de 11 a 26 casas, ocupadas por unos cuarenta vecinos. Quizá por estas fechas Diego Leonés se hizo con las Monedas antiguas que pocos años después regalaría al Padre Flórez en su visita a Lorca el 20 de mayo de 1770, de las que desconocemos su contenido (Mendez 1780: 247).

El principio de población y las prometedoras perspectivas de futuro favorecen que la corona se centre en el territorio lorquino y en la necesidad de hacer prosperar sus fértiles campos, pero también quiere su propio beneficio. La monarquía decide que la nueva población costera le pertenece ya que ha vuelto a renacer y tener esperanzas de mejora bajo su amparo, aunque tradicionalmente era considerada propiedad del Concejo de Lorca. Para resolver la posible pugna José Antonio de la Cerda, Oidor de la Real Chancillería de Granada, pide al Concejo de Lorca en marzo de 1773 que resuelva varias cuestiones que ha planteado el rey, de la que destacamos la primera sobre qué derecho tenía la ciudad de Lorca en el terreno proyectado para la nueva población (Fig. 7). El Concejo lorquino responde en abril que 'el terreno de Aguilas es del Corregimiento de Lorca por las mercedes de los señores reyes predecesores, haciéndole dueño de todos sus territorios en recompensa de los muchos servicios que desde tiempo inmemorial han prestado sus vecinos al servicio de la Corona, especialmente Felipe IV (...) este soberano ordenó al alcalde de Lorca a que hiciera varios reparos en la torre de las Aguilas, como dueño de aquel territorio'. Campomanes destaca que Lorca no aporta documento alguno sobre esta cuestión y determina que ser considerada tierra de Lorca desde tiempo inmemorial no demuestra que sea de su propiedad. Al considerar que había sido una tierra abandonada, Campomanes estima que debe pasar directamente a dominio de la Corona, quien debería conceder las correspondientes concesiones de tierras a los nuevos pobladores (Díaz Martínez 1991: 64).

La Comisión de la Real Cámara y Consejo de Castilla, pide al Oidor de la Chancillería de Granada que realice un reconocimiento de este puerto para valorar sus posibilidades de habitabilidad, para lo que se manda al Teniente Coronel de Ingenieros Juan de Escofet.

Junto a un elaborado plano, Escofet escribe una carta-informe a José Antonio de la Cerda en agosto de 1773. Se centra en aspectos técnicos en base a las características geográficas de la zona estudiada, identificando numerosos topónimos de la zona. Insiste en la posibilidad de traer agua potable, para lo que examina la calidad y distancia de las ramblas, manantiales, fuentes, balsa y norias más cercanas a la nueva población. Sus análisis tienen como objetivo sacar el mayor provecho de una tierra árida muy mineralizada y donde escasean las lluvias.

Escofet mantiene la idea de buscar agua potable en una tierra tan inhóspita tal y como la había planteado el militar Vicente Tofiño, quien señaló que el agua era salada porque se habían perdido las conducciones de agua dulce que hubo en tiempo de los romanos, refiriendo que todavía eran visibles algunos restos de las cañerías que la habían conducido (Díaz Martínez 1991: 88).

En esta descripción de las facultades y posibilidades que ofrece la tierra, Escofet informa que existe la Noria de Murillo, al parecer, la misma de la finca de José Balaguer construida 45 años antes, así como 
examina la fuente del Cocón de las Posadas con el fin de hallar cualquier atisbo de pozo o manantial de donde extraer agua potable (Escofet 1773: 8).

Debido a la búsqueda de agua reflexiona sobre los vestigios antiguos hallados, que demuestran que ya fue un sitio habitado en la antigüedad. Nos muestra una primera imagen del material hallado al afirmar que con todo el movimiento de tierras que se ha realizado en los últimos años han aparecido tanto monedas como lápidas de época romana, e incluso se aventura a indicar que los romanos 'la poseyeron después de los Phenicios' (Escofet 1773: 1).

Insiste que los antiguos debieron elegir este lugar para asentarse debido a sus buenas condiciones, pero también admite que tras su estudio del terreno no ha podido reunir pruebas de cañería ni por la superficie que se ha excavado ni en las ruinas descubiertas en la construcción de los modernos almacenes.

Escofet piensa que la tierra tuvo que estar poblada en el pasado de los mismos olivos y algarrobos que observa en su tiempo (Escofet 1773: 15).

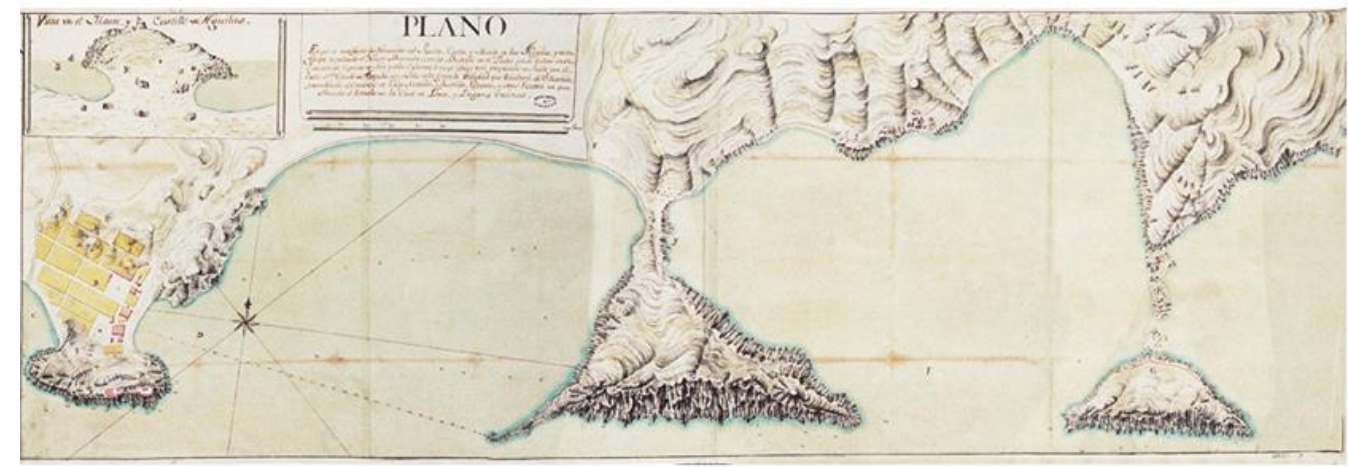

Fig. 7. Plano con vista de la costa de Águilas. Firmado por Juan de Escofet en Lorca, 1 de septiembre de 1773. Archivo General de Simancas. Signatura: MPD, 23, 041.

Un aspecto destacado de la descripción de este ingeniero es la referencia directa a la isla del Fraile. Informa que en su falda existen ruinas de edificios que manifiestan haber sido habitada. Describe la existencia de un muro "por toda ella" de buena mampostería de cal y canto con varios ángulos entrantes y salientes de quinientas varas de longitud, que a pesar de encontrarse en ciertas zonas erosionado por el batimiento de las olas conserva una solidez que demuestra la antigüedad de su buena construcción (Escofet 1773: 4 y 5). Un tema del que nadie volverá a hablar hasta el siglo XX.

Con la noticia de la aparición de diverso material arqueológico, a partir de ahora la expectación por las antigüedades de este lugar se acrecienta hasta el punto de ser foco de atracción de anticuarios, coleccionistas y eruditos. Una muestra la tenemos entre los años 1775 y 1778 cuando el Corregidor de Lorca Diego Joaquín Leonés da noticia al erudito y anticuario Conde de Lumiares de diferentes hallazgos en Águilas caso de monedas, fustes de columnas y otros objetos (Morel-Fatio 1896: 68).

Al preguntar el Conde de Lumiares por un plano de Águilas, así como por las antigüedades de esta población, a la que al parecer hacía unos años había visitado, Leonés se esfuerza en describir las noticias que ha podido conocer para causarle una buena impresión al erudito alicantino, personaje que tenía como objetivo recoger todas las inscripciones del Sureste y Levante español.

Leonés se remonta al año 1775: 'el año de Seten[ta] y Cinco haziendo unos Zimientos en m[edi]o de la Plaía, se encontraron los trabaja[do]res en un Botezillo de Barro hasta och[o] [m]onedas de Oro de las que pude Logra[r] [dos] La una de Constantino, Y la otra de Juli[a]no Apostata'. Leonés se las regaló a José Antonio de La Cerda, por entonces Consejero de Industria que se hallaba en esta ciudad tramitando la conduccion de aguas potables, quien se las llevó a Madrid (Leonés 1778: 33). 
Diego Leonés indica que posee algunas de estas monedas: 'todas las monedas qu[e] [e]ncuentran Son pequeñas de Constanza, C[ons]tantino y Constancio, algunas de Plata $\mathrm{q}[\mathrm{ue}]$ [t]engo en mí poder Arabigas, (...)'. Las monedas, en general, salen de la arena de la playa muy deterioradas: 'pues de las muchas que he Reco[gido] [d]e gran Bronze solo dos he podido Reco[noc]er dos, una de Jano, y otra de Alexan[dro] Sebero'. También informa sobre el hallazgo de lápidas, sin duda, uno de los aspectos que más le podían interesar al Conde de Lumiares, aunque aparecen sin epígrafes.

En su intento por agradar las espectativas de Lumiares, Leonés describe con detalle que apareció una cabeza humana de la que él mismo conserva un diente, y que junto a ella se encontró varias monedas romanas, así como otros objetos muy frágiles parecidos al vidrio. De este lugar conserva un ara que le falta una esquina, objetos de cerámica como pequeños jarros y fragmentos de color 'encarnado', presumiblemente sigillata. En este listado también habla de losetas y piezas de barro que relaciona con 'arcabuzillos' rellenos con cal en su interior (Leonés 1778: 33 y 34).

Al no disponer de más noticias de Águilas, Leonés hace referencia a otros objetos descubiertos en zonas vecinas, como son las magníficas inscripciones de Mazarrón halladas en 1776 pertenecientes a tres estatuas de época romana, así como a una llave, probablemente moderna, y un idolillo de Tirieza descubiertos en Agosto de 1777, que por su dibujo parece ser más una terracota romana de gladiador. La carta de Leonés es interesante porque es una fuente de primera mano, ya que conoce personalmente la población costera y ha visto salir objetos arqueológicos de su suelo ${ }^{1}$.

Sabemos que a las manos del Conde de Lumiares llegan desde Águilas diferentes objetos arqueológicos, como lo deja reflejado él mismo en un listado de materiales enviado a la Real Academia de la Historia, que creemos puede fecharse en 1776, tras haber visitado la costa murciana. El documento aparece en el Fondo Manuscrito de la Biblioteca de la Real Academia de la Historia, sig. CAI-A/9/3929/5(1) = RAHA-9-3929-5/1. En su obra Barros Saguntinos, Lumiares destaca que de este lugar se han sacado monedas, inscripciones, cerámica, ánforas, entre otros objetos. Lo más destacado es una inscripción romana con crismón de la que muestra dibujo (Lumiares 1779: 31).

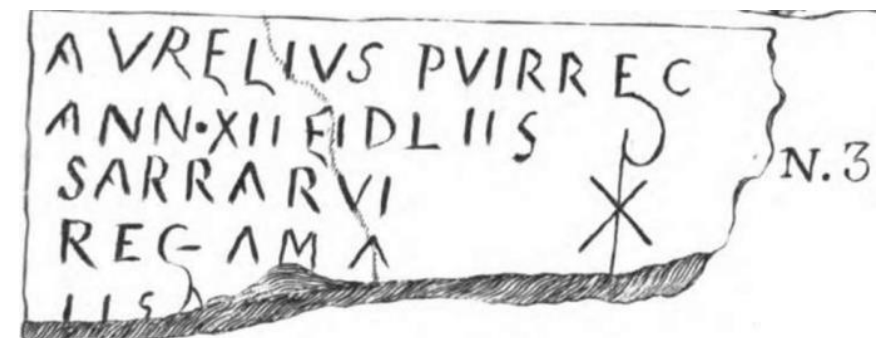

Fig. 8. Inscripción romana procedente de Águilas (Murcia), Lumiares, Barros Saguntinos, tav. IV, no 3.
En la inscripción funeraria aparece el niño Aurelio fallecido a los 12 años, siendo fiel, junto a un crismón, y la niña Sara fallecida a los (-) años [fiel?] (Fig. 8).

En base al análisis del contenido, por el concepto fidelis, la existencia de un crismón y el modelo narrativo que introduce ideas cristianas en un formulario esquemático de tradición pagana se ha datado entre finales del siglo IV y los inicios del siglo V d.C.

La historia de la investigación sobre esta inscripción ha sido recientemente analizada, confirmándose que procede de Águilas (Pérez Mulero, Llorach Asunción e.p.).

Una primera visión nacional que recoge información de los diversos materiales hallados la proporciona Bernardo Espinalt, Oficial del Correo General de Madrid, quien publica en 1778 su obra Atlante español, y el primer tomo lo dedica al Reino de Murcia (Espinalt 1778: 106-109). Nos dice que se han hallado 'varios cimientos, que denotan haver sido Poblacion grande, y los más de ellos se dirigen, y quedan sumergidos en el Mar: En las excavaciones que se hicieron para erigir en él las casas que se fabricaron à proposicion del Excelentisimo Señor Conde de Aranda (...), se encontraron pedazos de Columnas, y Cornisas de orden Toscano, varios muebles de piedra, barro, y hierro, y bastantes Monedas de Oro, Plata,

\footnotetext{
${ }^{1}$ El documento completo nos lo ha facilitado el profesor de la Universidad de Alicante Don Juan Manuel Abascal a quien damos las gracias por su esfuerzo desinteresado.
} 
y Metal, con los Sellos de Onorio, Constantino, Octaviano, Julio, y otros Emperadores de Roma, y del Oriente'.

Como complemento a los datos arqueológicos, los libros de Geografía actualizan sus datos, y el caso de la nueva población se muestra con su propia entrada en el Reino de Murcia. Se destaca que tiene una población de 40 vecinos, que está fortificada y defendida por un castillo y cuatro baterías, y que su puerto es bastante seguro y cómodo para todo género de embarcaciones. También se indica que en el pasado había sido sin duda una gran población 'porque en las excavaciones que se hicieron antiguamente, se han hallado muchos monumentos y antigüedades Romanas' (Jordan y Frago 1779: 363-364). Información que servirá de base y se copiará en numerosos diccionarios geográficos (Montpalau 1783: 71; Vegas 1795: 187-188).

\section{La nueva imagen del Puerto de las Águilas}

Al parecer, la existencia de restos materiales antiguos debió ser tan evidente, que es utilizada como reivindicación por parte de los comerciantes de Lorca en carta enviada a Campomanes. Estiman que la economía depende de la venida de agua potable a la nueva población, y que es posible traerla porque como puede observarse en los vestigios de la existencia de una antigua población 'como lo demuestran los cimientos, monedas y otras señales nada equívocas' (Cáceres Pla 1910: 288; Mula Gómez, Gris Martínez 1986: 117).

Un ejemplo de la aparición de objetos concretos lo proporciona una carta fechada en Madrid el 22 de agosto de 1780 del Comisario de Guerra y Superintendente de las Obras hidráulicas de Murcia, Pedro López de Lerena, que remite a la Real Academia de la Historia (Cebrián 2002: 30 y 241). Lerena distingue claramente los arruinados edificios de los nuevos que se están construyendo. Nos dice que a 40 pasos del puerto de Levante 'se hallaron entre los arruinados Cimientos que se buscan para valerse de la Piedra en las modernas obras las monedas, Clavos y Jarro que presento'. Se informa que suele ser frecuente la aparición de monedas, clavos y de otros muebles que salen de los antiguos cimientos, así como que muchas monedas ya se las habían llevado los vecinos de Lorca.

El director Campomanes presenta estos objetos ante los asistentes de la Academia en sesión ordinaria el día 1 de septiembre de 1780: tres clavos de bronce de diferentes tamaños, varias monedas romanas y un jarro de barro encarnado. Se acuerda en la sesión que estos materiales se entreguen a José de Guevara Vasconcelos, Anticuario de la Academia, para que los reconozca, coloque y guarde (Maier 2011: 367).

Durante estos años, en 1782, la edición de una obra en la Real Academia de la Historia a cargo de Eugenio de Llaguno Amirola, va a proporcionar una nueva cita desconocida hasta entonces del pasado aguileño. En la edición de La Crónica de don Pedro Niño de Gutierre Diez de Games, conocida en nuestros días por El Victorial, se hace referencia que en dos ocasiones durante el año 1403 varias galeras se vieron obligadas por el temporal a arribar durante la noche al puerto de las Aguilas, marchando por la mañana al más seguro de Cartagena (Diez de Games 1782: 55 y 83).

La referencia de los sucesos de Pedro Niño va a quedar como meros acontecimientos anecdóticos en el pasado aguileño, recuerdo de un tiempo de frontera y una tierra marcada por la despoblación.

En el mismo año de esta publicación en 1782, la fama que estaba comenzando a tener la nueva población en el campo de las antigüedades, hizo que el Archidiácono y Canónigo de Valencia, Francisco Pérez Bayer, erudito orientalista de setenta años de edad visitara Águilas. Gran conocedor de la lengua hebraica, Bayer realiza un viaje científico por toda la costa mediterránea española con el objetivo de buscar y reivindicar la importancia de las monedas de procedencia oriental, a las que llama hebreas y samaritanas (Perezii Bayerii 1790: 36). Muestra a modo de itinerario lo que fue viendo por diferentes pueblos de la costa valenciana y murciana indicando en cada caso algún dato importante relacionado con su antigüedad. En mayo de 1782 tras visitar Mazarrón (Almazarròn) y Lorca (Ilorci), se dirige dirección Sur hacia el mar donde identifica Águilas a la que denomina Acle, la que considera que para algunos es la Vrci del sino 
Virgitano, en consideración de Plinio, una tierra austera e inhóspita situada entre Deitania y Mavitania.

Pérez Bayer es el investigador que por primera vez presenta la lectura árabe Acle, procedente de los geógrafos medievales árabes Al-Bakri del s. XI y Al-Idrisi del s. XII, aunque no nos dice de quién exactamente.

Del mismo modo, el también canónigo valenciano Vicente Blasco conociendo la información de Pérez Bayer, en su reedición de la obra del Padre Mariana al tratar de los inicios del cristianismo en España, defiende la ubicación de Urci o Virgi como más probable en el puerto que llaman de las Águilas en el Reyno de Murcia, que algunos han llamado Acle a seis leguas de Lorca. No comparte la información del propio Padre Mariana, quien al hablar de Urci la había relacionado con un pueblo denominado Verga en Navarra, a pesar de ser consciente que otros escritores la identificaban en Almería y Murcia (Mariana 1785: 12,349 y 420).

Del mismo modo en 1788 Francisco Pérez Bayer volverá a decir que hay que actuar con cautela poniendo como ejemplo al Padre Flórez. No comparte la antigua identificación de Urci con la ciudad de Almería como en su momento hizo el erudito Nicolás Antonio en 1672 al comentar la participación de esta ciudad en el concilio eclesiástico de Córdoba del siglo X. Bayer opina que hay que tener en cuenta que existen otras localidades con las que se puede asignar más al Este de la ciudad de Almería como es el caso del puerto de Aguilas (portus Acle) (Antonio 1788: 469).

En el plano político, desde 1784 el favor del rey permite que el arquitecto Gerónimo Martínez de Lara, sucesor de Juan de Escofet, junto al arquitecto de la Corte Juan de Villanueva, reconozcan en el campo de Lorca el lugar idóneo para la construcción de un camino cómodo y un acueducto para la conducción de agua potable hasta Águilas.

Para la realización del proyecto de esta monumental obra debemos destacar la figura del murciano José Moñino y Redondo, Conde de Floridablanca, Primer Secretario de Estado, quien daría impulso a la repoblación del puerto de las Águilas a través de su cuñado el lorquino Antonio Robles Vives, destacado jurista que es designado Superintendente y Comisionado Regio para las Reales Obras de Lorca. Robles Vives acabaría ostentando el mando total de la repoblación de la nueva población entre los años $1785 \mathrm{y}$ 1792 (Hernández Franco 1986: 130) (Fig. 9).

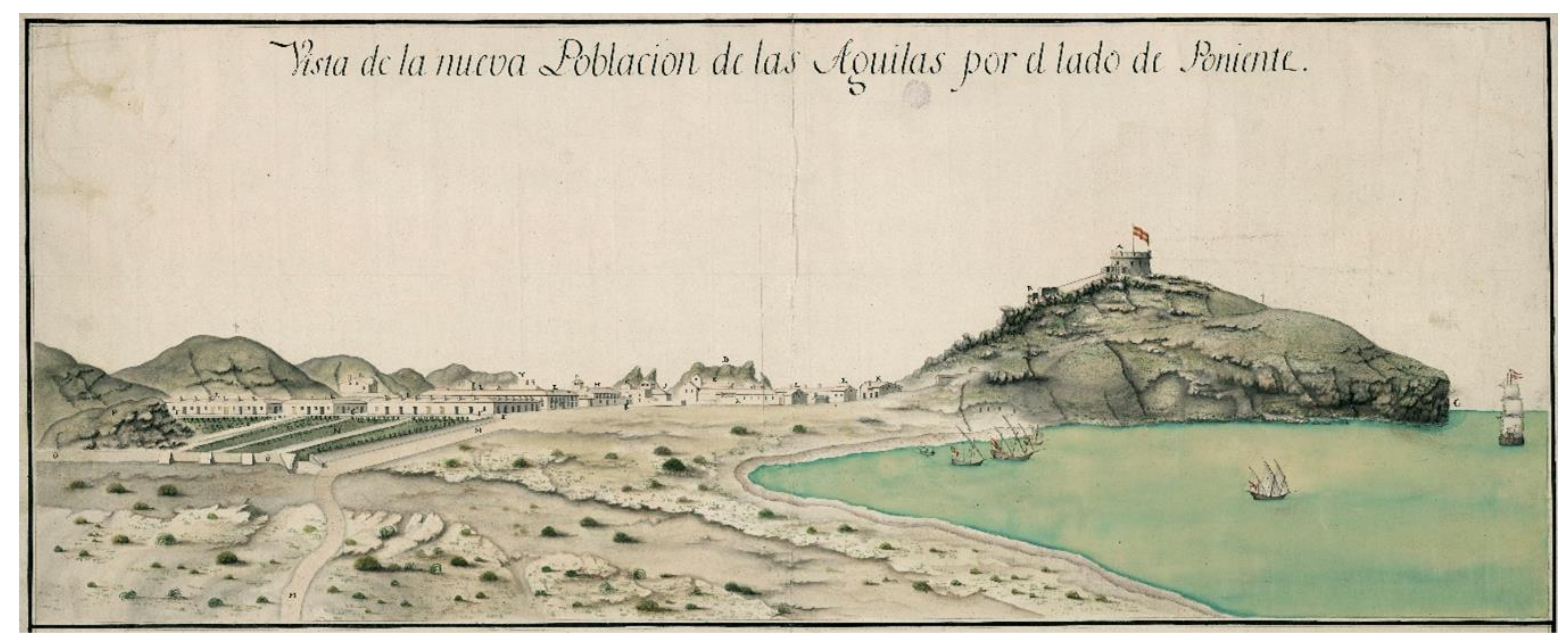

Fig. 9. Vista de la nueva Población de las Águilas por el lado de Poniente atribuida a Gerónimo Martínez de Lara. Biblioteca Nacional de España.

\section{El descubrimiento de las termas romanas}

Robles Vives informa desde Lorca a Floridablanca el 28 de febrero de 1788 del hallazgo de la primera 
estructura arqueológica identificada y analizada de época romana en Águilas. Al excavar los cimientos para la construcción de una casa para su hermano Manuel, abad de la Colegiata de San Patricio de Lorca, aparecieron los restos de unas termas romanas (Robles Vives 1788; Jorge Aragoneses 1974: 17).

Robles Vives intenta ofrecer un panorama de la evolución histórica de la población. Tras un resumen de anteriores informes de los ingenieros Juan Escofet y Vicente Tofiño, se detiene a examinar como prueba de la antigüedad de Águilas las monedas romanas de las que tiene constancia. Distingue aquellas en las que se cita una ciudad romana, y las que hacen referencia a un emperador. En total describe 58 monedas, según si son de las propias termas, del resto del terreno de Águilas o del campo circundante. Describe las estancias de las termas con detalle e informa de los objetos recuperados. A continuación, realiza unas reflexiones sobre el tiempo de la destrucción de la población cuando es abandonada y olvidada. Por último, informa de su presente y de sus progresos.

Para Robles Vives los restos de edificios, la copiosa suma de monedas romanas que aparecen a diario y las termas demuestran que fue una población numerosa y rica en la antigüedad, y piensa que se trata de la Urci tan buscada hasta entonces.

Robles presenta el hallazgo de una inscripción funeraria romana, y se lamenta de la posible pérdida de otros objetos similares, que son reutilizados para la construcción de almacenes y casas.

Es interesante su descripción, dibujo e intento de lectura de una inscripción sepulcral romana hallada cerca de las últimas casas y que pudo rescatar de ser reutilizada por los jornaleros. Se queja del posible material perdido por este uso de los que califica de ignorantes.

La lectura de Robles presenta muchos interrogantes: "Yo leo Deo Maximo Summo Primulos annorum XXXV et filia ejus Primula etate binnua (lo siguiente que parece terminar en TI no lo adivino) imperante Julio Cesare, Juliano ó Justiniano ó Justino pues a todos hacen las dos Letras iniciales JU". La copia del original pudo malinterpretar varias letras, que no se verían bien o estarían fracturadas, de ahí la dificultad de lectura y su interpretación.

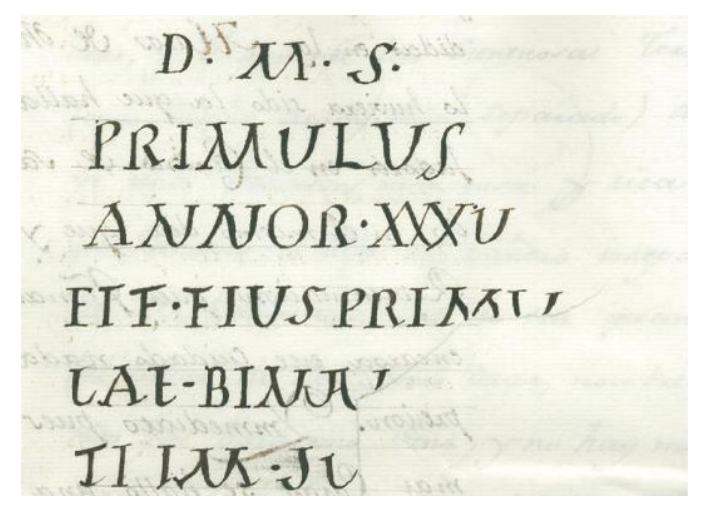

Fig. 10. Dibujo de la inscripción romana hallada en Águilas el $\mathbf{2 8}$ de febrero de 1788. Informe de Antonio Robles Vives al Conde de Floridablanca. Archivo Histórico Nacional, Madrid, Consejos 17750-1, 007.
La inscripción informa que a los treinta y cinco años de edad fallece Primulo, enterrado junto con su hija Primula, cognomen de la hija heredado de su padre. La posibilidad de lectura de la última línea conservada puede hacernos pensar en la expresión pii in suis, en referencia a que ambos eran queridos por su familia.

Posteriormente si seguimos la narración de Robles Vives, la inscripción fue reutilizada, apareció como parte de la tapa de un sepulcro rectangular y en su interior un ánfora que guardaba entremezclados con la tierra los huesos de un individuo infantil.

La inscripción se ha fechado entre los siglos II y III d.C. y posiblemente fue reutilizada a lo largo del siglo III d.C. (Pérez Mulero 2016).

Robles sigue la obra del Padre Flórez y estima que puede ser que Urci existiese antes de los fenicios, tal como lo indica la terminación de su nombre, común en los antiguos pueblos de esta parte de España como Ylici, Murgi, Basti, Acci, Yliberi e Yliturgi entre otros, que son nombres de pueblos que aquellos conquistadores hallaron en estas comarcas.

En su análisis de la descripción de Plinio, Robles identifica la antigua Barea con la actual Villaricos, y no así como hasta ahora era lo común con la propia Vera. Lo hace debido a que Vera no está en la costa sino 
en el interior, y también porque no se han encontrado testimonios materiales de época romana, considerada de construcción árabe. Su conclusión de identificar Villaricos con Baria, le hace marcar en este lugar el límite interprovincial y relacionar así Urci inevitablemente hacia su Oriente ya perteneciente a la tarraconense, en el Puerto de las Águilas.

Robles Vives hace referencia al que cree acertado pensamiento del autor del Tesoro de la lengua latina, el más antiguo de los modernos en identificar Urci con Águilas.

Tras analizar la ubicación del topónimo Urci también rastrea en los archivos las referencias a la población aguileña, pudiendo identificar por una Real Cédula del año 1552 que el término de Lorca por la parte de Águilas llegaba hasta la Sierra y Torre de Montroy, a cuyo pie está Villaricos. Documento que para Robles comprueba que Águilas fue el primer pueblo de la Tarraconense.

Por último, se centra en los restos materiales hallados. Los restos arqueológicos le sirven para defender sus argumentos de antigüedad. Realiza un apartado completo sobre las monedas descubiertas a las que considera tantas que podrían enriquecer algunos gabinetes, aunque admite que antes de su llegada a esta tierra muchas ya se habían perdido, al ser vendidas por los operarios a los plateros y almireceros, considerados enemigos de la ciencia numismática. Aunque destaca la labor de un caballero de Lorca, que bien pudiera ser Leonés, aplicado en recoger algunas para curiosos que se las pedían.

Las monedas que presenta a modo de catálogo comentado proceden de los últimos días, cuando nos dice que ya se pensaba que no iban a salir más, apareciendo centenares. Solo nos muestra las 58 que ha podido identificar. Una moneda de plata consular, denominación que se daba a las republicanas (Chaves 2005: 14), 11 en las que se puede leer la ciudad que la produce con dos de Carthago nova, y una de Acci, Calagurris, Cesar Augusta y Leptis y otras dudosas, y 46 de emperadores romanos desde Augusto a Teodosio, destacando diez de Graciano y cinco de Constantino.

Robles explica que las monedas que ha recogido geográficas como consulares y desconocidas han sido halladas en las inmediaciones de Águilas por los labradores del campo, y que todas las de las termas son de emperadores. Del mismo modo destaca que no ha aparecido ninguna ni goda ni árabe, lo que le ayuda a marcar el fin de la población tras la estancia de los romanos, de lo que se aventura a deducir fue provocado por la acción destructiva de los godos o por la erupción de un volcán que empujó el mar hasta inundar la tierra.

Tras describir y analizar el aspecto monetario, se centra en la descripción detallada de las termas romanas. Confiesa que su excavación fue minuciosa porque pensaba que podía hallar alguna inscripción o moneda que pudiera acabar con la polémica sobre la ubicación de Urci.

El conocimiento que Robles muestra delata sus posibles lecturas e interés por las antigüedades, y pronto va a comprender que lo que está excavando es parte de un edificio termal de época romana: 'Limpiadas algunas piezas conocí ser de Termas, y quizá de Palestra, enlas quales havia tamvien Baños Termales'. La excavación proporciona diversidad de materiales arqueológicos que intenta identificar: 'Se encontraron Amphoras, Vasos y Utensilios de Barro en abundancia, Trozos y Vasas de Columnas, Lumbreras de piedra fuerte batida del fuego, Losas y revestimientos de Marmol Blanco, destrozos de cornisas, clabos de Cobre, Ladrillos como y de todas las clases que descrive Vitrubio à saver Didoxon, Tetradoxon, Pentadoxon, y los que llama Tegula Bipedales'. Teniendo como guía a Vitruvio, quizá le fue sencilla la labor de identificación de las diferentes estancias que suelen componer un edificio termal: 'Reconoci el Albeum, la Schola, los Hornillos, ò Hipocaustium, los Laconicos, los Tepidarios, los Sitios para los vaños movibles ò Labrum, vaños semicirculares con su Pulvino ò Canape ysu Pluteo'.

Para su mejor comprensión, proporciona un detallado dibujo explicativo de cada una de sus estancias en el que completa su alzado: 'Lo existente và manifestado en el Perfil con color encarnado y el suplemento con amarillo'. 
A través de las letras y números muestra su descripción física y la interpretación del uso que debía tener cada estancia. Tras un pórtico, en el que se encontraron los restos de cuatro columnas de orden toscano con sus respectivas basas, el edificio se articulaba a partir de una scola o habitación de espera. Desde aquí se entraba a las sucesivas estancias de aguas frías, templadas y calientes tan reconocibles por presentar en su subsuelo una serie de pilares y arquillos construidos a base de ladrillos cerámicos. Del mismo modo es característica la presencia de bañeras semicirculares denominadas por Robles estufas con sus correspondientes oquedades o entradas que hacen la función de horno para el combustible.

Se muestra la necesidad que Robles tiene de dejar bien explicada cada estancia, y su minuciosa descripción e identificación de materiales reconocibles facilita que el Conde de Floridablanca, a quien va dirigido el escrito, pueda comprender que se está ante un importante descubrimiento de arquitectura romana.

De estas estancias destaca la existencia de distintos materiales. Del baño "V" identifica 'cinco Conductos de Arcaduzes que bajan perpendiculares hasta el fondo de los Hornillos sin señales de haver tenido fuego'. Los dos baños "8" y "10" están "revestidos en los costados de las Gradas y Canapes con planchas de Marmol blanco y Azul deuna pulgada de grueso". Menciona que aparecieron diversas lucernas (candiles) así como una especie de botecitos con el cuello de unos en la base de los otros envueltos con argamasa y formando una pared o cúpula (Fig. 11).

Tras la descripción de las distintas estancias que conforman el conjunto del edificio, resume en las últimas páginas de su escrito una breve narración sobre lo más destacado de la historia de la población.

Robles prosigue la narración histórica de Águilas tras ser destruida la cultura romana. Menciona directamente el periodo de reconquista. Para él la costa de Lorca durante esta época iba desde Montroy hasta más allá de Mazarrón, es decir, desde la actual Villaricos en Almería por el Oeste hasta el límite con Cartagena por el Este. Presenta la costa como una zona desierta en la que los Moros entravan à cautivar hasta en los campos de Lorca. No será hasta la conquista del Reino de Granada cuando Lorca comenzó a repoblar su costa. Así en el año 1490 pide licencia a los Reyes Católicos para levantar una torre en el Puerto de Almazarron, y en 1514 a la reina Juana para hacer lo mismo en el Puerto de las Aguilas. Al parecer estas torres no se construyeron, ya que en 1552 se vuelve a pedir otra vez

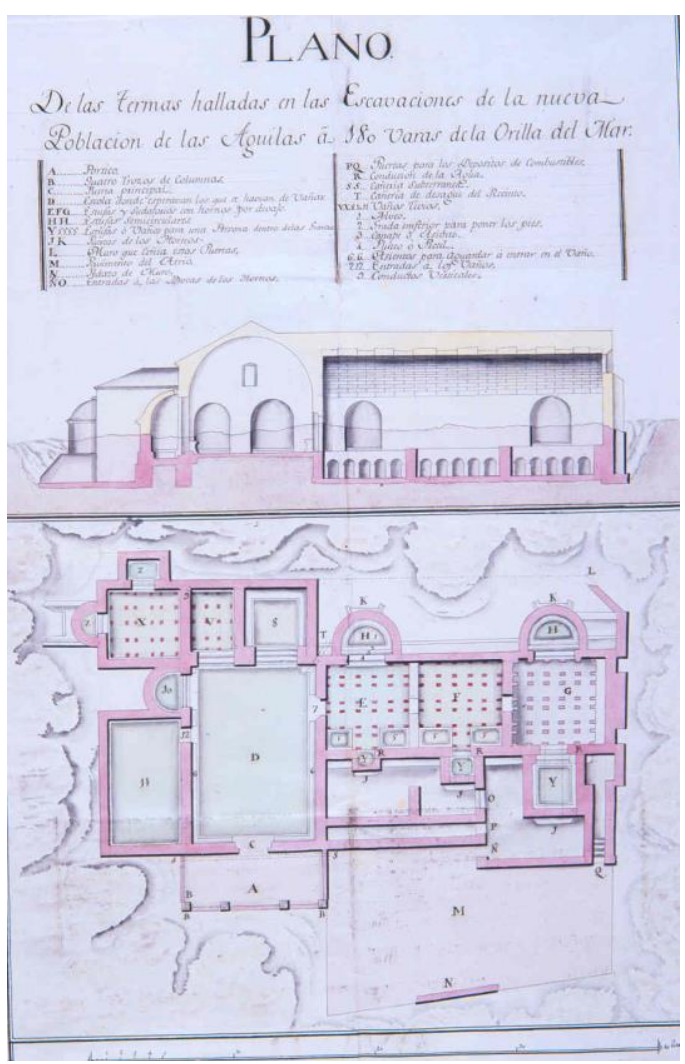

Fig. 11. Plano De las termas halladas en las Excavaciones de la nueva Población de las Águilas á 180 Varas de la Orilla del Mar. FR, Archivo Histórico Nacional, Diapositiva 74. para repoblar tanto la costa como el interior y repartir sus heredades. Robles Vives copia literalmente el documento de esta última petición: 'que tenia diez ò doze leguas de Costa de Mar despoblada y que en ella havia tres ò quatro Puertos de Mar despoblados con sus Muelles que antiguamente eran poblados de ciudades è Villas con sus castillos que estavan derrivados maltratados y despoblados por el peligro delos Moros de Africa: E assi mismo à quatro ò cinco leguas dela Mar, havia otras muchas Villas è Lugares despoblados por el dicho miedo de los Moros, y al reedor havia grandes Campos y Terrenos montuosos y Yermos que no se panificaban y muchas Fuentes que no se provechavan'.

Sin mencionar año, Robles dice que en una Cédula Lorca pide facultad para imponer un arbitrio en estos lugares, para hacer tres estancias de guardas de tres hombres en cada una, que al parecer fueron las torres de Cope, Águilas y Terreros. 
Del mismo modo indica que hubo varios pleitos entre los años 1511 y 1742 entre las ciudades de Vera y Lorca por sus límites, un periodo en el que la frontera fue variando dependiendo de los jueces en el espacio comprendido entre Montroy y Terreros.

Considera, por lo tanto, que tras la Real Orden de Carlos III de asignar a la nueva población de las Águilas dos leguas de territorio para su propia jurisdicción y la consiguiente incorporación de parte de la costa andaluza hasta el límite con Villaricos, que habían vuelto a su primitivo límite las Provincias Betica y Tarraconense y los dos Reinos de Murcia y Granada.

La noticia de tales hallazgos pronto se difunde entre otras localidades cercanas. Así en otoño de 1789 Antonio José Navarro, canónigo y tesorero de la Colegial de Baza, ilustrado naturalista, se interesa tanto por su naturaleza como por los recientes restos arqueológicos (Navarro 2000: 93-114).

La importancia del documento de Antonio José Navarro es máxima debido, sobre todo, a que esta fuente ha sido considerada anónima hasta fechas muy recientes. Su viaje, iniciado en Baza, tenía como objetivo realizar una Historia Natural, por lo que sus descripciones están repletas de elementos geográficos, tipos de minerales y diversos componentes destacables del terreno. Al llegar al campo de Lorca se detiene en el cortijo de su amigo Antonio Robles Vives, momento en el que recibiría con toda clase de detalle la información de las últimas novedades de la población costera. En su travesía hacia el Puerto de las Águilas despierta su atención cualquier circunstancia. Distingue las ruinas del pequeño castillo de Tébar y anda por su monte diferenciando los tipos de roca que lo conforma. Tras salir de una cueva de estalactitas en Tébar y diferenciar dos buenas haciendas en el entorno, señala el comienzo de la conducción de agua que recientemente se ha construido para abastecer a la población (Navarro 2000: 94). Con el mar como horizonte nos informa que antes de llegar se ven algunas balsas de fábrica que considera romanas y restos de conducción de argamasa.

Al entrar en la población costera hace referencia a 'los vestigios de antigüedad que se hallan en esta playa', y supone un puerto principal para la zona conocida como el Bol, donde también cree que se encontraría la antigua población romana. Piensa que el lugar elegido para la nueva población es estrecho, y que por lo tanto se correspondería a las afueras de la ciudad romana, sugiriendo que es una idea que se confirma por el hallazgo de sepulcros en este lugar, ya que es sabido que los romanos no enterraban dentro de los pueblos.

Del mismo modo, hace referencia a una inscripción: 'mui inmediato al sitio de la actual población se descubrió la lápida sepulcral' (Navarro 2000: 100 y 108). Dice que esta lápida la dibujó en la estampa XXXI, pero todas las que realizó se han perdido. Deducimos que se trata de la misma inscripción citada por Robles.

El Padre Navarro, del mismo modo como había hecho Robles Vives, ante la observación de los hallazgos, cree que es el momento de afirmar la importante antigüedad de esta población: 'Las medallas que siempre se han encontrado en este terreno y las ruinas de edificios antiguos havian ya hecho sospechar que fue pueblo grande en otro tiempo, pero hasta haora no se han mirado estas cosas con atencion' (Navarro 2000: 103).

Navarro se centra en dos puntos, en la descripción de la terma romana recién descubierta y en el análisis del topónimo Urci. Las termas las considera públicas basándose tanto en sus dimensiones como en la existencia de multitud de monedas halladas en su entorno, observación que hoy día se acepta por válida (Manderscheid 1988: 46).

Navarro vuelve a describir lo dicho con anterioridad por Robles Vives, pero no copia sus palabras, ya que tanto para el recorrido e identificación de las diversas estancias utiliza su propio criterio.

El número 1 de Navarro corresponde a las letras A y B de Robles Vives, al parecer un atrio, en donde se ven los restos de cuatro columnas de piedra franca, carcomidas. El número 2 de Navarro corresponde a la 
letra D de Robles Vives, estancia a la que denomina schola, en donde esperaban los concurrentes a los baños. Estaba toda rodeada de un banco o canapé, y tenía los baños al occidente y mediodía, según el precepto de Vitrubio. La descripción continúa con el resto de salas y habitaciones hasta completar el conjunto del edificio.

Realiza una detallada descripción de la técnica constructiva, identificando diversos elementos arquitectónicos utilizados en el arte romano: arcos perimetrales, ladrillos bipedales, capa de mortero, lecho o capa de arcilla, mortero con ladrillo picado y pavimento entre otros. Teniendo en cuenta la construcción ideal de unas termas, Navarro se muestra atento a lo que observa o a lo que debería presentar tal o cual estancia analizada.

Los objetos que se habían rescatado de la excavación puede examinarlos detenidamente, distinguiendo lucernas (lámparas), ánforas de varias clases, unos ojos de piedra probablemente para dar luz a los lacónicos, grandes basas de columnas, o cilindros de barro que se engruesan y acaban en punta que bien pudieran ser los clavos utilizados en las termas, así como aquellos tubos que se sitúan entre cámaras para guardar el calor. En cuanto a las monedas sigue el listado de Robles Vives (Figs. 12-21), pero amplía la información al identificar a dos nuevos emperadores como son Neron y Constancio Chloro.

En conclusión, el religioso de Baza utiliza una metodología al estilo moderno, primero describe los materiales que han salido en la excavación, intenta comprender el complejo arquitectónico, y después busca paralelos de algunas de las monedas para su identificación.

Navarro se lamenta que no exista una inscripción en la que aparezca el nombre de la población, pero decide introducirse en los geógrafos para ver qué dicen sobre los pueblos de esta costa. Hace recapitulación de los posibles lugares con los que se ha relacionado el topónimo Urci: Pechina, Orce, Almazarrón, Villaricos y Águilas. Indica que el mejor modo de decidir tales disputas es leer a los geógrafos y cotejar sus descripciones viendo las costas personalmente: 'Los escritores que no salen de sus gavinetes cometen muchos errores geograficos. Escuche vuestra merced a los antiguos'. Descarta la opción de Pechina propuesta por Orbaneja, ya que, según los geógrafos, Urci está al Oriente de Vera y no al Occidente. Sobre Villaricos, Navarro indica que hay base geográfica y arqueológica, pero también considera con el Padre Flórez que el sitio de la torre de las Águilas es propicio para esta situación.

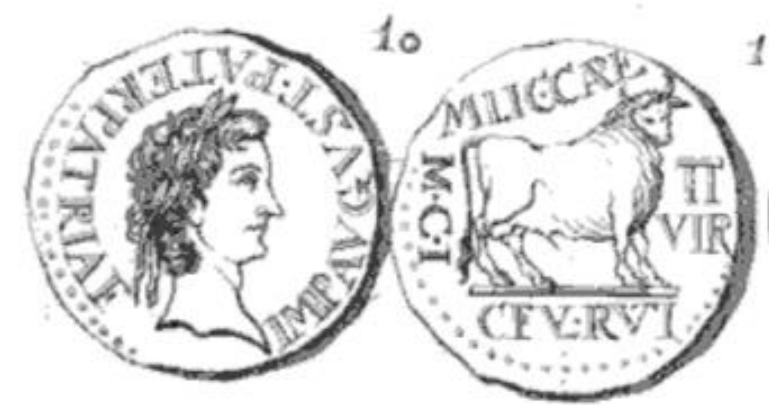

Fig. 12. Moneda de Calagurris en Florez, 1757, tabla $12, \mathrm{n}$ 10, según Robles 1788 dice que se parece a la de Águilas.

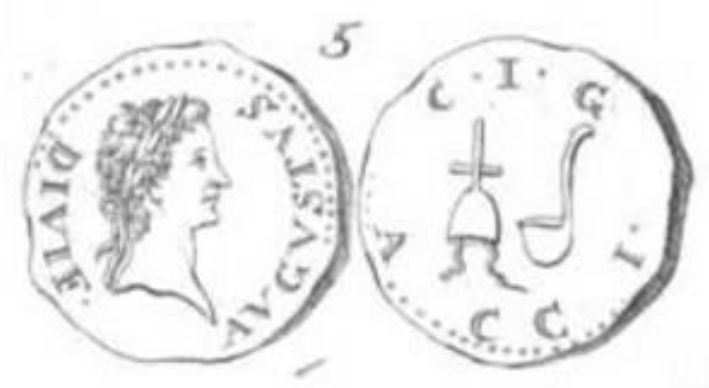

Fig. 13. Moneda de Acci en Florez 1757, tabla II, no 5, según Robles 1788 y Navarro 1789 es como la de Águilas. 


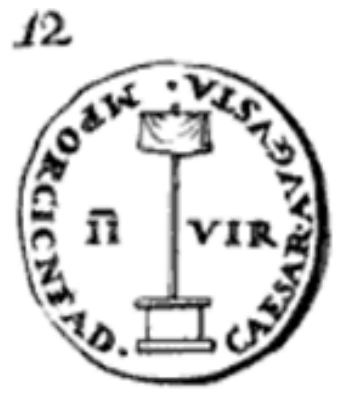

Fig. 14. Moneda de Cesar Augusta en Florez 1757, tabla 7, no 12, según Robles 1788 y Navarro 1789 es como la de Águilas.

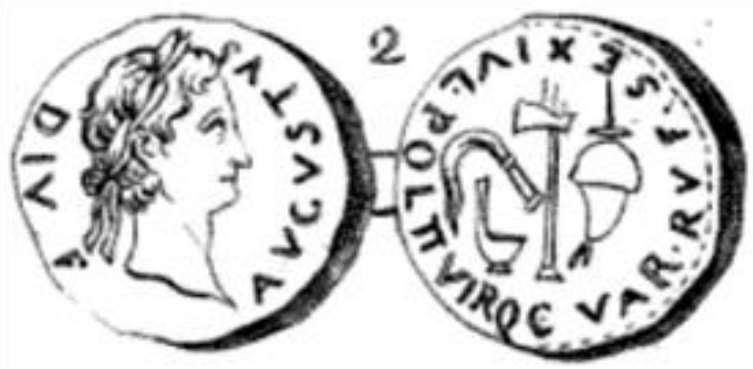

Fig. 16. Moneda posiblemente de Cartagena en

Florez 1757, tabla 56, no 2, según Robles 1788 y Navarro 1789 con alguna probabilidad es como la de Águilas.

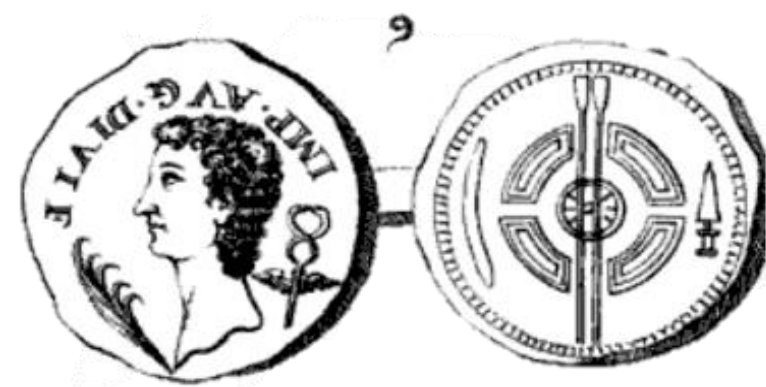

Fig. 15. Moneda de Carthago nova en Florez 1757, tabla 16, no 9, según Robles 1788 y Navarro 1789 es la misma con poca diferencia a la de Águilas.

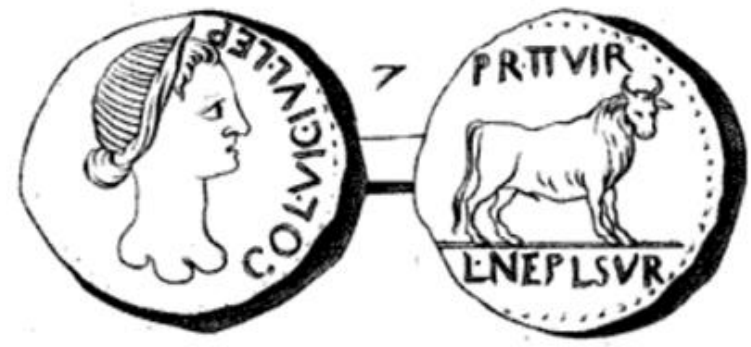

Fig. 17. Moneda de Leptis en África en Florez 1757, tabla 58, no 7, según Robles 1788 y Navarro 1789 es como la de Águilas.
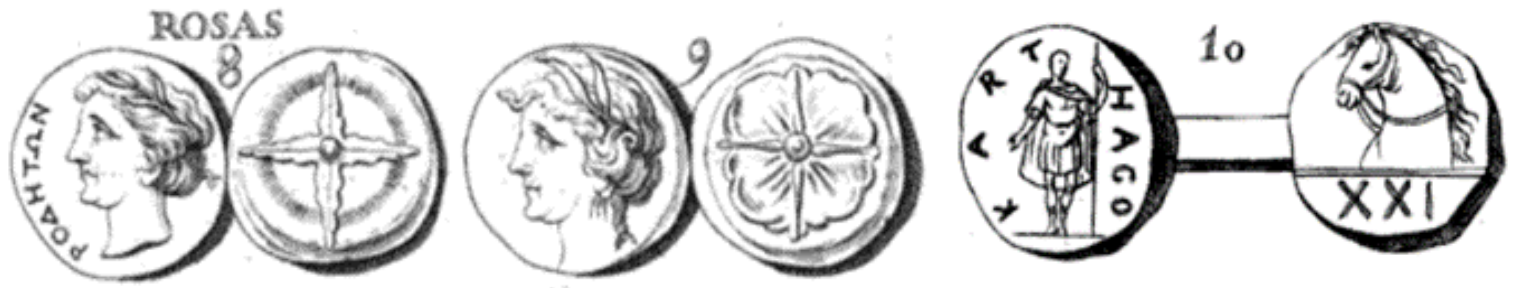

Fig. 18. (Izquierda y central) monedas de Rosas en Florez 1757, tabla 65, no 8 y no 9, según Robles 1788 el anverso de ambas se parece a la de Águilas. Navarro 1789 dice que el anverso de la no 8 se parece a la de

Águilas. Navarro también dice que el anverso de tal moneda es como la de Florez 1757, tabla 58, no 10

(Derecha), pero sin freno ni tan extendida la crin del caballo.
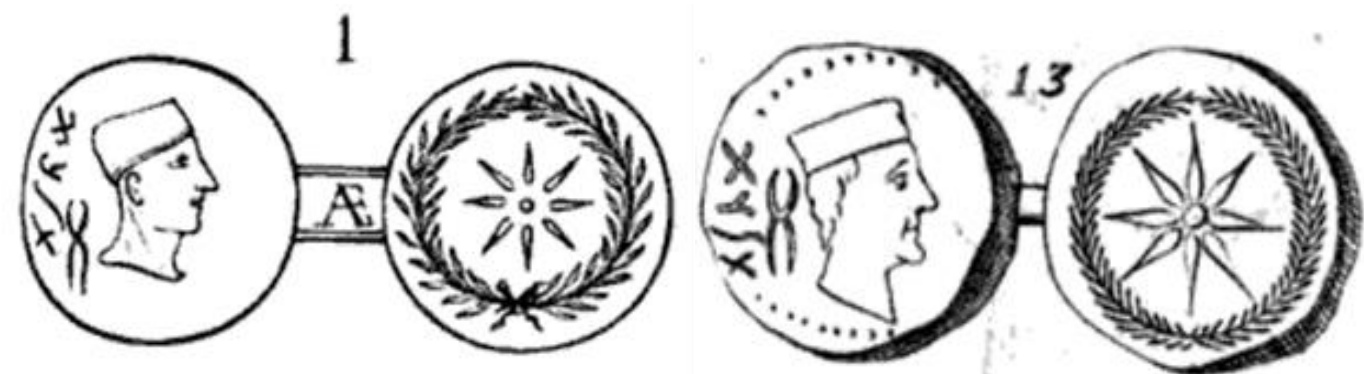

Fig. 19. (Izquierda) moneda en Florez 1757, tabla 56, no 13, según Robles 1788 se suele atribuir a Sanlúcar de Barrameda, es como la de Águilas. (Derecha) Moneda en Velázquez, 1752, tabla 17, no 1, según Navarro 1789 es como la de Águilas. 


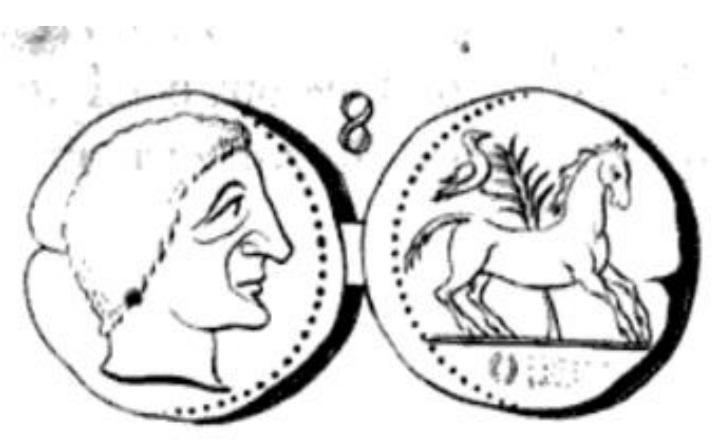

Fig. 20. Moneda en Florez

1757 , tabla 67, no 8, según Robles 1788 se parece a la de Águilas, pero sin el ibis. Según Navarro 1789 se parece a la de Águilas.

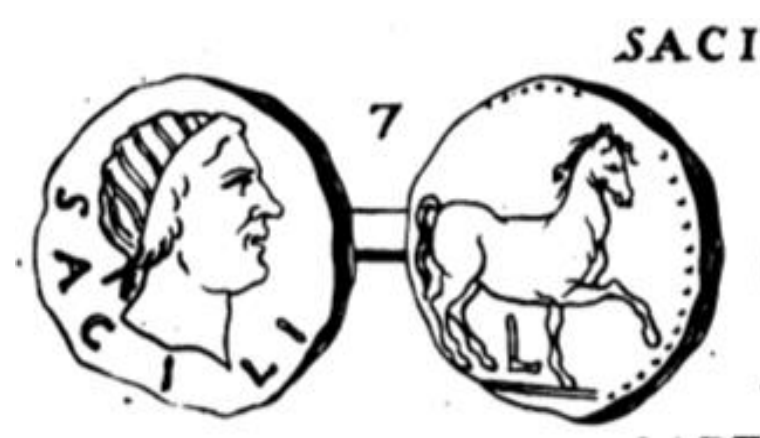

\section{ILI}

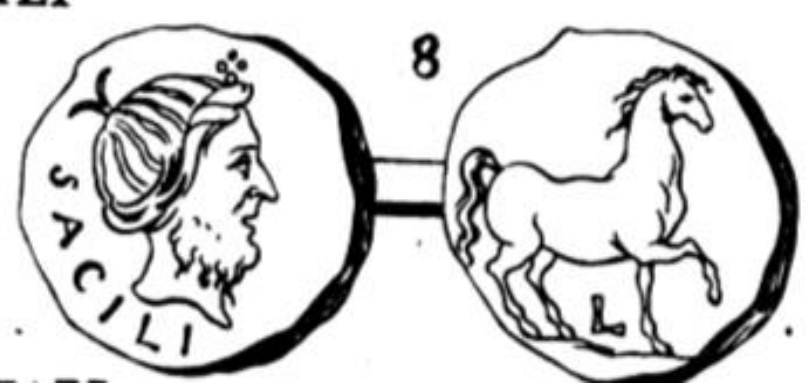

Fig. 21. Monedas de Sacili en Florez 1757, tabla 39, n으 $\overline{7}$ y no 8, según Robles 1788 es como la de Águilas.

Con una reflexión muy moderna, indica que, si Barea fuera la actual Vera, bien podría situarse Urci en Villaricos, pero, del mismo modo, si Barea estuviera en Villaricos, necesariamente Urci tendría que situarse en Águilas. Navarro pisa el terreno del que habla, y reflexiona con las fuentes geográficas en la mano, concluyendo que 'Despues de haver recorrido aquellos sitios y costas, he llegado a persuadirme que Vera no es la antigua Barea, sino que esta devio estar en donde oy las ruinas de los Villaricos'. Para tal veredicto se basa en la ausencia de material arqueológico romano que pueda relacionarse con la ciudad de Vera, así como por estar situada al interior y retirada de la costa, ya que Barea, según los geógrafos estaba en la costa. No será hasta un siglo después cuando se descubra una inscripción que reafirme lo propuesto por Navarro y pueda relacionarse la actual Villaricos con la antigua Barea (Siret 1909: 381-382 y 471).

La importancia de los restos del edificio termal favoreció que se extendiera con más validez la idea de asignar a Águilas el topónimo ibero-romano Urci, haciendo visible una placa conmemorativa en la fachada de la nueva vivienda inaugurada en 1790 en la que se leía: 'Aqui se hallaron las grandes termas de la antigua Urci año mdccxc'.

El redescubrimiento de los restos de las termas a finales del siglo XX fue un acontecimiento esperado y valorado por los investigadores y eruditos locales, que volvieron a dar fuerza al análisis del topónimo Urci, y dieron como resultado el punto de salida de la investigación arqueológica científica en el municipio. Excavados bajo la dirección del arqueólogo D. Sebastián Ramallo entre el 11 de febrero y el 7 de marzo de 1981, a 1,80 m de profundidad. Se halló tanto la piscina semicircular, elemento del caldarium como también un horno de fabricación de anforillas (Palacios Morales 1982: 58-59 y 72-74). Estructuras que fueron fechadas entre los siglos IV-V d.C. debido a la presencia de terra sigillata clara D. (Ramallo Asensio 1984: 105-110; Ramallo Asensio 1985: 436; Ramallo Asensio 1986: 45-58; Ramallo Asensio 1989-1990: 165-168).

\section{El reinado de Carlos IV y el fin del siglo XVIII}

El conocimiento general sobre la población fue ampliándose bajo el reinado de Carlos IV (1788-1808) 
debido al estudio de la costa tal como se puede observar en diversas cartas náuticas, planos y mapas, así como en diccionarios geográficos.

En 1790 se elabora la Carta-plano a cargo de la Marina Francesa (García Antón 1974-1975: 196 y 209). Este documento se centra exclusivamente en nuestra población e indica de manera precisa el conocimiento del terreno.

A pesar de la inestable intrahistoria política de los primeros años de vida de la nueva población, Águilas es considerada a finales del siglo XVIII una zona geográfica y económica importante, del mismo modo que se destaca su relevancia arqueológica. El religioso jumillano Juan Lozano la menciona en su completa obra Bastitania y Contestania del Reino de Murcia de 1794. En el Puerto de las Águilas se destacan hallazgos de ruinas y vestigios: 'Las de Aguilas, son muchas, muy romanas, y respiran magnificencia'. Identificada con la antigua Urci nos muestra que 'Los Arabes la llamaron Castillo de Acle'. Lozano resume que fue un puerto famoso en la antigüedad, precisando también que va a serlo en sus días, debido a que mientras escribe se está restaurando su imagen. El religioso jumillano llega a confesar que las obras de construcción han hecho florecer de su tierra preciosos monumentos de que se hace apetecible una buena colección. Menciona que es conocido que el Señor Navarro, Abad de la Catedral de Baza, es poseedor de estos monumentos, de los que destaca varios ídolos y monedas, que el propio Lozano ha conseguido dos: una del emperador Claudio y otra de Adriano (Lozano 1794: 5-6, 72-75, 78, 82, 85, 120, 143).

Es interesante destacar en esta obra el uso del topónimo Castillo de Acle para hablar de Águilas según lo llamaron los árabes, término que había utilizado Francisco Pérez Bayer. Lozano como buen traductor se interesa por este topónimo que había pasado casi inadvertido a lo largo de todo el siglo, información únicamente apta para arabistas como José Antonio Conde, que unos pocos años después publicará la importante edición española de la obra de Al-Idrisi, pero en la que no se va a traducir el topónimo de la misma manera, indicándose no Acle, sino Hisn-Ecla, es decir, fuerte de Aguila (Conde 1799: 73: 218). Ambos topónimos arábes Acle y Hisn-Ecla se muestran como los nombres más antiguos atestiguados de la moderna y renaciente Águilas, pero debido a su carácter filológico y a la dificultad de su estudio, así como la mal conocida por entonces historia medieval bajo dominio musulmán, no tendrán continuidad entre los investigadores.

Complementario a la obra del Padre Lozano se va a publicar el mapa de Juan López, geógrafo del rey Carlos IV, que muestra la Bastitania y Contestania a través de las fuentes antiguas. Habla de las ciudades más importantes y entre ellas sitúa a Urci en el Puerto de las Águilas (Lopez 1795:10). Juan López se percata que la Urci del Itinerario de Antonino y Plinio se menciona como Urce en otros autores como Ptolomeo y Marciano de Heraclea, así como en Pomponio Mela es Virgi, que dio nombre al golfo Virgitano. Cree que todos los topónimos hacen referencia a la misma localización. Pero, por otra parte, piensa que otras distintas denominaciones que también se han relacionado con Urci como Urgi y Murgi se han identificado erróneamente con la misma situación geográfica. Para defender esta idea se basa en el Itinerario de Antonino donde aparecen dos nombres distintos, así como en Plinio, quien distingue claramente la Urci de la Tarraconense de la Murgis de la Bética. López analiza sus mapas anteriores y rectifica al pensar que había malinterpretado estos datos tal como otros investigadores habían hecho antes: 'En mi mapa de España antigua coloqué por equivocación á Urci donde hoy Mujácar; pero en el de la Bastitania reduxe dicha mansion al Puerto de las Águilas, siguiendo en esto la opinión más bien recibida', ejemplo que demuestra la fama e importancia de la antigüedad que había adquirido la población murciana.

Los restos arqueológicos visibles otorgan a finales del siglo XVIII veracidad a la idea de antigüedad que se tenía de la población, hasta entonces existente por medio de la leyenda y la tradición oral. Al darse alta probabilidad en la relación entre Águilas y Urci, la historia de su pasado se ve envuelta inevitablemente en el marco geográfico de esta tierra. En este sentido se reactiva la idea de que la fundación de la Silla Episcopal de los primeros tiempos del cristianismo expandida por la Bética tuvo su entrada por la costa murciana. José de Vargas y Ponce, que había trabajado en la elaboración de la carta náutica de esta costa junto con Vicente Tofiño, aprovecha su estancia en Cartagena para investigar su antigüedad, indicando en 
su Descripción de Cartagena, fechada entre 1795-98, que el puerto de Águilas podía presentarse como uno de los posibles lugares de desembarco de los Varones Apostólicos consagrados por san Pedro y San Pablo entre los años 62 a 65 d.C. (Vargas Ponce 1978: 97). Esta relación de los Varones Apostólicos, entre los que se encuentra San Indalecio, primer obispo de Urci, era toda una realidad entre los primeros habitantes de Águilas. Una concepción del pasado que favorece que la parroquia de la localidad se dedicase a la advocación de San Indalecio junto a la Purísima Concepción (Palacios Morales 1969: 155).

En conclusión, parece que la importancia de los hallazgos antiguos y su difusión fue evidente y conocida, sus restos arqueológicos rápidamente se comprendieron en la red de poblaciones selectas en el mapa nacional. Aparece en una relación de localidades a modo de carta arqueológica de España redactada por el Canónigo valenciano Fray José Ortiz y Sanz, a quien le había sido aceptado un viaje arquitectónicoanticuario en 1788. El objetivo era realizar una serie de viajes que comenzaron en ese mismo año, pero que se tuvieron que suspender por diversos motivos. En espera de que la empresa se reanudara, el autor ofreció al público en 1797 el recorrido que hasta entonces tenía previsto realizar por toda España. Indica

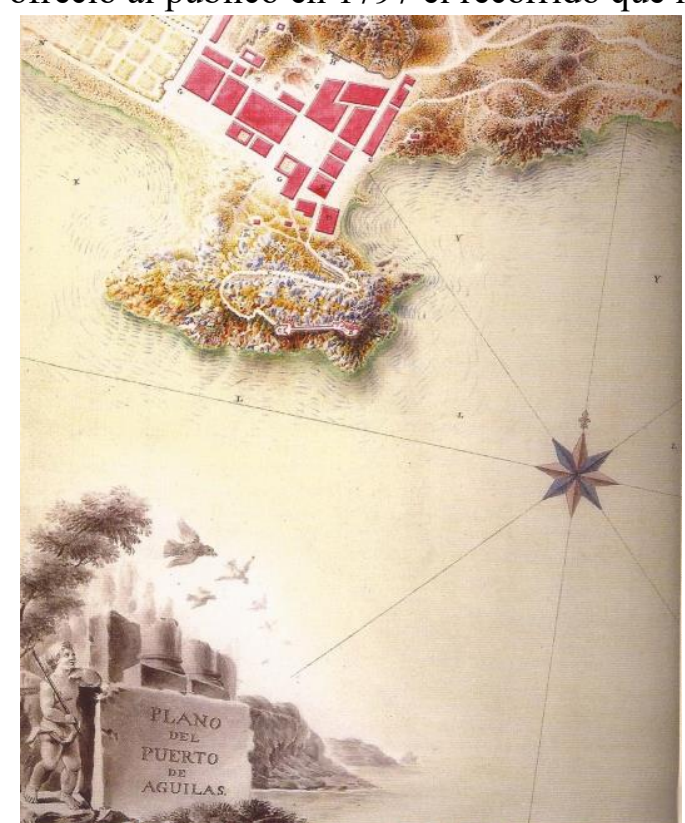

Fig. 22. Detalle del plano del Puerto de Águilas (no 25) (Ordovás 2005). las ciudades y despoblados en los que se tenía noticia de restos monumentales o arqueológicos dignos de ser catalogados. De un total de 229 ciudades, del Reino de Murcia destaca diez, y junto a Murcia, Cartagena, Lorca y Archena se nombra el Puerto de Águilas (Canto 2001: 48). Un dato bastante evidente para apreciar por lo menos el interés suscitado entre los eruditos por las diversas antigüedades que aparecieron a lo largo del siglo.

Para terminar, es interesante advertir la obra Atlas politico y militar del Reyo de Murcia del ingeniero militar Juan José Ordovás, fechado en 1799 y enviado al Reino de Murcia con el objetivo de elaborar un inventario de las construcciones defensivas de la costa (Ordovás 2005: 2, planos 24-26).

Presenta unos planos de gran calidad acompañados de unas notas aclaratorias. Ordovás no se contenta con la mera descripción de lo que ve, también estima necesario acudir a la evolución histórica de la población. En su concepción Águilas se muestra como uno de los lugares que primero se poblaron de todo el reino, con una antigüedad tal en la que la leyenda sigue viva, al destacar su fundación por el troyano Eneas. Tras desembarcar Teucro y fundar Cartagena, los barcos siguieron la costa y se detuvieron al ver que unas gaviotas se asentaron en el paraje de la actual Águilas y fundaron Urci.

La idea legendaria y popular de la fundación la supo encuadrar Ordovás en su obra cartográfica, a la que en el plano $\mathrm{n}^{\mathrm{o}} 25$ le complementó la nueva imagen del material arqueológico ejemplificado en los fustes de columnas sobrevolados por unas gaviotas. Así puede enriquecer la tradición junto con la historia rescatada de su subsuelo (Fig. 22).

\section{Conclusión}

Siguiendo al profesor García Antón (2002: 61) podemos decir que Águilas se presenta al entrar el s. XVIII como una pequeña población de la costa murciana perteneciente a la Villa de Lorca, donde sus gentes viven como pueden mirando al mar en unas pocas casas, en cuevas artificiales y en chozas, al amparo de una torre, que desde el s. XVI había sido levantada y reparada en diferentes ocasiones. Esta parte de la costa lorquina, fronteriza con el Reino de Granada, muestra la imagen de un lugar semidesierto, debido tanto a su clima como a la aridez de su tierra. Una verdadera zona de frontera, tierra de nadie y de conflictos 
entre cristianos y musulmanes desde época de la Reconquista medieval.

A pesar de las puntuales acciones de peligro, por su condición de zona costera, será a finales del siglo XVII y el siglo XVII cuando los progresos se vean más notables, debido, sobre todo, a la instalación de las almadrabas en Cope y Calabardina.

Con la Guerra de Sucesión Española (1700-1714) y los años de inestabilidad, la nueva monarquía de los Borbones franceses instalados en España con Felipe V, intenta controlar toda la nación hacia una postura más centralizada. Una vez concluida la guerra se refuerzan las fronteras marítimas, y nuestra población se ve beneficiada por la presencia de Cartagena, la gran capital naval mediterránea.

La Corte Real interviene en Águilas a través de su representante José de Balaguer en 1728. Se controla y administra el territorio directamente desde el terreno. Balaguer escoge para su asentamiento, al parecer, los restos de una balsa y construcciones abandonadas de tiempo inmemorial, que bien para nosotros pudiera corresponder a fábrica medieval o romana, hizo pensar a los contemporáneos en los inicios antiquísimos de la fundación de la ciudad. A partir de entonces van a aparecer diversos estudios que relacionan las leyendas e historias orales y escritas con los restos materiales arqueológicos que comienzan a salir de la tierra. La suma de todos dará la imagen de un glorioso pasado que afianza las decisiones de la corona de defender esta parte de costa.

Los primeros estudios se producen en el marco de la historia de Lorca. La imagen que ha quedado del religioso Padre Morote, a la que hay que añadir y anteponer la del religioso Gálvez Borgoñoz, es la de un defensor a ultranza de la localización de Urci en Águilas, aunque como hemos apreciado, ambos se basan en unas obras muy anteriores que les han sido heredadas. Águilas se entiende como el primer capítulo de la historia de Lorca, a cuya costa los héroes legendarios observan buenos augurios.

Es la existencia de materiales arqueológicos la que proporciona verdad y refuerza las ideas tradicionales heredadas.

Desde mediados de siglo y bajo el nuevo ideal de estudio de la Real Academia, que intenta comprender con documentos fehacientes la verdad del pasado, el padre Flórez realiza el primer acercamiento científico a esta población, ya no relacionado con tiempos heroicos sino con la época romana imperial y paleocristiana a través de un exhaustivo análisis de las principales fuentes geográficas y arqueológicas.

Águilas se relaciona con la ciudad iberorromana de Urci que mencionan los geógrafos clásicos, aunque es un topónimo del que todavía no se puede decir la última palabra. Lo que queda claro es la existencia de una ciudad romana como puede verse por el edificio de las termas, monedas, inscripciones, lucernas y ánforas, ocupación que se observa más intensa durante el Bajo Imperio, sobre todo en el s. IV d.C. por la datación de las monedas. De la época medieval Diego Leonés habla de la existencia de moneda arábiga, objeto que se comprende con el topónimo árabe que recibe la población: Acle como indica Bayer o Hisn Ecla según Conde, siguiendo al geógrafo árabe Idrisi. La inexistencia de materiales identificados de esta etapa y el propio proceso de reconquista muestran que la tierra de Águilas se despuebla siendo un territorio de frontera en el que era peligroso vivir. Las noticias siguientes son de documentos de archivo en los que la ciudad de Lorca pide a la Corona de Juana y Carlos la fortificación de la costa con torres defensivas y que conectan con la historia más reciente y reconocida. La monarquía de los Borbones en última instancia decide en el s. XVIII, tras el cese de la piratería, reforzar las defensas y repoblarlas, haciendo posible el nacimiento de la ciudad de Águilas.

Interesante es el resumen que ofrece Robles Vives en un intento por presentar una panorámica de la evolución histórica de la población. Tal vez su cercanía y favor de la corte le facilitó el acceso a los archivos del reino, documentos que utiliza copiados literalmente para poder dar respuesta a ciertas cuestiones sobre los límites jurisdiccionales entre los territorios de Lorca y Granada. Asunto político al que se volverá durante el siglo $\mathrm{XX}$. 
La imagen del pasado de Águilas se amplía debido a la actualidad de su repoblación, la existencia de una población antigua que se muestra por sus ruinas, y el interés del rey Carlos III centrado en esta geografía. La Corona comienza el experimento de las Reales Obras de Lorca, de la que Águilas se beneficia directamente y en la que participan figuras de primer orden político. Floridablanca se muestra como el enlace entre la monarquía y Águilas por medio de su cuñado Antonio Robles Vives, descubridor de las termas romanas y gran defensor del pasado perdido por los siglos.

Se ha podido advertir que comprender el pasado a través de los restos materiales hallados en el suelo de la población es una labor que realizan los eruditos y que aporta validez a los estudios sobre el pasado. En el siglo XVIII las ideas y opiniones de la memoria tradicional y la leyenda se complementan a la de anticuarios e investigadores, que rechazan o aprueban su veracidad, pero como hemos podido observar las leyendas siguen vivas a nivel popular, ya que forman parte de su propia cultura. La aportación de investigadores como el Padre Bayer o Antonio José Navarro, que viajan y conocen personalmente la localidad, hace de Águilas una pieza más a tener en cuenta en el complejo mosaico de las antigüedades de la nación.

TABLA 1

\begin{tabular}{|c|c|c|c|c|c|}
\hline \multicolumn{6}{|c|}{ MONEDAS ROMANAS HALLADAS EN ÁGUILAS EN EL SIGLO XVIII } \\
\hline \multicolumn{6}{|c|}{ Borgoñoz 1734 = Morote 1741 = Flórez 1752; Leonés 1778; Espinalt 1778; Robles Vives 1788; Navarro 1789; Lozano 1794 } \\
\hline SIGLO I a.C. & SIGLO I d.C. & SIGLO II & SIGLO III & SIGLO IV & SIGLO V \\
\hline $\begin{array}{l}\text { Consular de plata } \\
\text { Carthago Nova (2) } \\
\text { Calagurris } \\
\text { Acci } \\
\text { Cesar Augusta } \\
\text { Leptis } \\
\text { Rosas (?) } \\
\text { San Lucas de } \\
\text { Barrameda (?) } \\
\text { Sacili (?) } \\
\text { Sagunto (?) } \\
\text { Incierta } \\
\text { Jano } \\
\text { Julio (?) }\end{array}$ & $\begin{array}{l}\text { Augusto / } \\
\text { Octaviano (3) } \\
\text { Tiberio } \\
\text { Germánico } \\
\text { Claudio (2) } \\
\text { Nerón } \\
\text { Vespasiano (2) } \\
\text { Nerva }\end{array}$ & $\begin{array}{l}\text { Adriano (2) } \\
\text { Antonino Pio } \\
\text { M.Aurelio (2) } \\
\text { Faustina (2) }\end{array}$ & $\begin{array}{l}\text { Alejandro } \\
\text { Severo } \\
\text { Maximino } \\
\text { Gordiano (4) } \\
\text { Galieno } \\
\text { Probo } \\
\text { Maximiano }\end{array}$ & $\begin{array}{l}\text { Constancio Cloro } \\
\text { Constanza } \\
\text { Constantino (8) } \\
\text { Costantino Mozo } \\
\text { Crispo } \\
\text { Constancio (5) } \\
\text { Constancio II } \\
\text { Juliano Apóstata } \\
\text { Valentiniano (2) } \\
\text { Graciano (10) } \\
\text { Teodosio }\end{array}$ & Honorio \\
\hline 14 & 11 & 7 & 9 & 32 & 1 \\
\hline \multicolumn{6}{|l|}{ TOTAL: 74} \\
\hline \multicolumn{6}{|c|}{ Sin identificar: moneda de Procas (Borgoñoz 1734; Morote 1741) ocho monedas (Leonés 1778) } \\
\hline TOTAL: 83 & & & & & \\
\hline
\end{tabular}

tabla 2: Objetos Arqueológicos Procedentes Del Puerto De las Águilas Documentados En El Siglo XVIII

\begin{tabular}{|l|l|l|}
\hline \multicolumn{1}{|c|}{ Fecha } & \multicolumn{1}{|c|}{ Fuente } & \multicolumn{1}{c|}{ Descripción del objeto } \\
\hline 1717 & Borgoñoz 1734 & Moneda de Procas \\
\hline 1717 & Morote 1741 & Monedillas. Moneda de Procas \\
\hline 1728 & Borgoñoz 1734 & Diversas monedas. Moneda de la fundación de Urci \\
\hline 1728 & Morote 1741 & Antiguas monedas. Moneda de la fundación de Urci \\
\hline 1728 & Flórez 1752 & Relectura de la moneda de la fundación de Urci, adscripción al emperador Constancio \\
\hline
\end{tabular}




\begin{tabular}{|c|c|c|}
\hline & & Cloro (en realidad Constancio II) \\
\hline $1765 \mathrm{ss}$ & $\begin{array}{l}\text { Bernardo Espinalt } \\
1778\end{array}$ & $\begin{array}{l}\text { Pedazos de columnas, y cornisas de orden toscano } \\
\text { Varios muebles de piedra, barro y hierro } \\
\text { Bastantes Monedas de oro, plata y metal con los sellos de Honorio, Constantino, } \\
\text { Octaviano, Julio, y otros emperadores }\end{array}$ \\
\hline $1765 \mathrm{ss}$ & Robles Vives 1788 & $\begin{array}{l}\text { Las Medallas son tantas que serían bastantes para enriquecer algunos gabinetes } \\
\text { Se encontraron monedas en la construcción de las primeras casas antes de las Reales } \\
\text { Obras }\end{array}$ \\
\hline 1766 & \begin{tabular}{lr|} 
Libro & Capitular \\
Archivo & Municipal \\
Lorca junio & 1766
\end{tabular} & Se sacan piedras buscando cimientos y murallas antiguas para construir las nuevas casas \\
\hline 1773 & Escofet 1773 & $\begin{array}{l}\text { Vestigios y fragmentos descubiertos en las excavaciones hechas a la inmediación y } \\
\text { orilla del mar } \\
\text { Monedas y lápidas halladas en las mismas } \\
\text { Ruinas descubiertas en los almacenes modernos } \\
\text { Diversas estructuras antiguas en la Isla del Fraile: presenta una estrecha falda con ruinas } \\
\text { de edificios, vestigios de una obra fortificada, se descubre un muro de buena } \\
\text { mampostería de cal y canto }\end{array}$ \\
\hline 1775 & \begin{tabular}{|ll} 
Carta Diego & J. \\
Leonés 1778
\end{tabular} & Botecillo de barro con ocho monedas, una de Constantino y otra de Juliano Apóstata \\
\hline h. 1776 & $\begin{array}{l}\text { Informe Lumiares a } \\
\text { la RAH } \\
\text { Lumiares } 1779\end{array}$ & $\begin{array}{l}\text { Monedas, inscripciones, cerámica, ánforas } \\
\text { Inscripción romana con crismón (Aurelio y Sarra) }\end{array}$ \\
\hline 1778 & $\begin{array}{l}\text { Carta Diego Joaquín } \\
\text { Leonés } 1778\end{array}$ & $\begin{array}{l}\text { Basas de columnas, monedas } \\
\text { Monedas pequeñas de Constanza, Constantino y Constancio } \\
\text { Algunas monedas de plata arábigas } \\
\text { Moneda de gran bronce de Jano } \\
\text { Moneda de gran bronce de Alejandro Severo } \\
\text { Fragmentos de mármol anepigráficos } \\
\text { Enterramiento: Calavera, estructura tapada con cal, porción de monedas como las } \\
\text { referidas, piedras parecidas al vidrio } \\
\text { Ara que le falta una esquina, jarruchos pequeños, fragmentos de cerámica que semeja } \\
\text { al búcaro encarnado (sigillata), algunas losetas, piezas de barro colorado parecidos a } \\
\text { arcabucillos de alguna conducción que presentan su hueco macizado con cal }\end{array}$ \\
\hline $\begin{array}{l}\text { Junio } \\
1780\end{array}$ & $\begin{array}{l}\text { Carta comerciantes } \\
\text { de Lorca } 1780\end{array}$ & $\begin{array}{l}\text { Vestigios antiguos que al presente se reconocen de la antigua conducción de agua } \\
\text { Cimientos, monedas y otras señales nada equívocas de la antigua población }\end{array}$ \\
\hline $\begin{array}{l}\text { Agosto } \\
1780\end{array}$ & $\begin{array}{l}\text { Carta Pedro López } \\
\text { de Lerena } 1780 \\
\text { Maier } 2011\end{array}$ & $\begin{array}{l}\text { Tres clavos de bronce de diferentes tamaños, varias monedas romanas y un jarro de } \\
\text { barro encarnado }\end{array}$ \\
\hline $\begin{array}{l}\text { Febrero } \\
1788\end{array}$ & $\begin{array}{|ll|}\text { Antonio } & \text { Robles } \\
\text { Vives } 1788 & \end{array}$ & $\begin{array}{l}\text { Fragmentos de estatuas y columnas, sillares gruesos y otras piezas, y además una gran } \\
\text { variedad de monedas romanas de todos metales y tamaños. } \\
\text { Pequeña lápida sepulcral (Primulo y Primula) unida a otras dos que formaban la cubierta } \\
\text { (reutilizada) de un sepulcro regular Ánfora grande dividida verticalmente en dos } \\
\text { mitades y dentro de ella los huesos del cuerpo de un individuo infantil } \\
\text { Centenares de monedas } \\
58 \text { monedas romanas analizadas en el catálogo } \\
\text { Edificio de las termas romanas: Una serie de pilares y arquillos construidos a base de } \\
\text { ladrillos cerámicos. Se encontraron ánforas, vasos y utensilios de barro en abundancia, } \\
\text { fragmentos y basas de columnas, lumbreras de piedra fuerte batida del fuego, losas y } \\
\text { revestimientos de mármol blanco, destrozos de cornisas, clavos de cobre, ladrillos de } \\
\text { todas las clases que describe Vitrubio a saber didoxon, tetradoxon, pentadoxon, y los }\end{array}$ \\
\hline
\end{tabular}




\begin{tabular}{|l|l|l|} 
& & $\begin{array}{l}\text { que llama tegula bipedales } \\
\text { Cinco conductos de arcaduces que bajan perpendiculares hasta el fondo de los hornillos } \\
\text { En los baños identifica el revestimiento de gradas y canapés con planchas de mármol } \\
\text { blanco y azul de una pulgada de grueso (...) las cúpulas, diversas lucernas y una especie } \\
\text { de botecitos de cerámica agujereados por el fondo y metidos el cuello de unos por la } \\
\text { base de los otros, llenos todos de una masa que parecía yeso o cal }\end{array}$ \\
\hline $\begin{array}{l}\text { Otoño } \\
1789\end{array}$ & Navarro 1789 & $\begin{array}{l}\text { Ruinas del pequeño castillo de Tébar } \\
\text { Balsas de fábrica romana y trozos de conducción de argamasa en el camino entre Tébar } \\
\text { y Águilas } \\
\text { Se han hallado sepulcros } \\
\text { Muy inmediato al sitio de la actual población se descubrió una lápida sepulcral } \\
\text { Termas romanas: Muchas monedas romanas, lucernas, ánforas de varias clases, ojos de } \\
\text { piedra acaso para dar luz a los lacónicos, grandes basas de columnas, cilindros de barro } \\
\text { que al fin se engruesan y acaban en punta } \\
\text { Moneda de Nerón y de Constancio Cloro } \\
\text { Grandes basas de columnas, clavos y utensilios de cobre }\end{array}$ \\
\hline 1794 & Lozano 1794 & $\begin{array}{l}\text { Varios ídolos y monedas } \\
\text { Monedas de Claudio y Adriano }\end{array}$ \\
\hline
\end{tabular}

\section{Bibliografía}

Acero y Abad, N. (1888), Ginés Pérez de Hita. Estudio biográfico y bibliográfico, Madrid.

Anónimo (1713), Ordenanzas y privilegios de la muy noble, y leal ciudad de Lorca dados à la estampa de su acuerdo, Granada.

Anónimo (1772), Catalogue du Cabinet d'Histoire Naturelle et d'Antiquités de M. le Duc de Caylus, Grand d'Espagne de la premiere classe, Paris.

Álvarez Terán, Ma.C., Fernández Gómez Ma..C. (2000), Archivos Murcianos. Catálogo de mapas, planos y dibujos del Reino de Murcia en el Archivo General de Simancas, Murcia: Archivo General de la Región de Murcia.

Antonio, N. (1788), Bibliotheca Hispana Vetus. Curante Francisco Perezio Bayerio, Tomus primus, Matriti. Belluga, L. (1717), Memorial, que ofrece a su magestad el Obispo de Cartagena, Don Luis Belluga, Murcia. Berlinghieri, F. (1482), Geographia di Francesco Berlinghieri Fiorentino in terza rima et lingva toscana di stincta con le sve tavole in varii siti et provincie secondo la Geographia et distinctione dele tauole di Ptolomeo, [s.l.].

Béthencourt Massieu, A. (1963), El marqués de la Ensenada y la arqueología: hallazgos romanos en las obras de cimentación del arsenal de Cartagena (1750-1752). Boletín del Seminario de Estudios de Arte y Arqueología 29: 77-88.

Cáceres Pla, F. (1910), Cosas de Lorca, Lorca.

Calepini, A. (1609), Dictionarium octolingue, ed. I. Passeratius, Coloniae Allobrogum.

Canto, A. Mạ. (2001). El Viaje Arquitectónico-Anticuario de fray José Ortiz y Sanz: una Carta arqueológica de España a fines del XVIII. SPAL, 10: 29-55.

Caylus (1752-1767), Recueil d'antiquités egyptiennes, etrusques, grecques et romaines, 7 tomes, Paris.

Cebrián Fernández, R. (2002), Comisión de antigüedades de la Real Academia de la Historia. Antigüedades e inscripciones. 1748-1845. Catálogo e índices, Madrid: Real Academia de la Historia.

Chaves, F. (2005), Monedas romanas. I. República, Madrid: Real Academia de la Historia.

Conde, J.A. (1799), Descripcion de España de Xerif Aledris, conocido por el Nubiense, Madrid.

Díaz Martínez, L. (1991), Aguilas en los vaivenes de la historia, Murcia.

Diez de Games, G. (1782), Cronica de don Pedro Niño conde de Buelna. Edición de Eugenio de Llaguno Amirola, Madrid: Antonio de Sancha. 
Dominico Musancio, I. (1701), Fax Chronologica ad omnigenam historiam (...), Rome.

Escofet, J. (20-agosto-1773), Relasion del reconocimiento del Puerto de las Aguilas que acompaña el Plano de la cituacion y Proyecto de su Nueba Poblacion (Carta- informe dirigida a Joseph Antonio de la Zerda), Lorca.

Espinalt, B. (1778), Atlante español, ó descripcion general de todo el Reyno de España. Tomo I. Reyno de Murcia, Madrid.

Ferrarius, Ph. (1738), Novum lexicom geographicum in quo universi orbis, tomus secundus, Venetiis.

Florez, H. (1747), España Sagrada. Theatro Geographico-Historico de la Iglesia de España, (...). Tomo I, Madrid.

Florez, H. (1750), España Sagrada. Theatro Geographico-Historico de la Iglesia de España, (...). Tomo V, Madrid.

Florez, H. (1752), España Sagrada. Theatro Geographico-Historico de la Iglesia de España, (...). Tomo VIII, Madrid.

Florez, H. (1757), Medallas de las colonias, municipios y pueblos antiguos de España. (...), Madrid.

Gálvez Borgoñoz, G. A. (1991), Mussato Polyhistor que propala la multigena grandeza de la novilissima ciudad de Lorca en el epitome de sus monimentos que en catorze tratados vosqueja un su hijo amante. Año de 1734, Mula.

García Antón, J. (1974-1975), Aguilas. Planificación y nacimiento de una población en el S. XVIII, Anales de la Universidad de Murcia (Filosofía y Letras) 34. 1-4: 177-211.

García Antón, J. (1986), Aportaciones a los orígenes de Aguilas, en A. Morata (dir.), Aproximación a la historia de Aguilas. Aguilas. Excmo. Ayuntamiento de Aguilas: 63-85.

García Antón, J. (1988), Fortificaciones en la costa de Aguilas (Siglos XVI al XIX), Murcia: Caja Murcia.

García Antón, J. (1992), La costa de Lorca antes de la fundación de Aguilas en J. García Antón, Estudios históricos sobre Águilas y su entorno. Murcia. Academia Alfonso X el Sabio: 161-199.

García Antón, J. (1992), Aportaciones al estudio de la fundación de Aguilas, en J. García Antón, Estudios históricos sobre Águilas y su entorno. Murcia. Academia Alfonso X el Sabio: 449-470.

García Antón, J. (2002), Breve Historia de Águilas, Murcia: Diego Marín.

Hernández Franco J. (1986), Hechos y figuras en el setecientos. Su repercusión en Aguilas, en A. Morata (dir), Aproximación a la historia de Aguilas. Aguilas. Excmo. Ayuntamiento de Aguilas: 123-135.

Hernández Franco, J., Mula Gómez A.J., Gris Martínez J. (1988), Las obras públicas en la nueva población de san Juan de las Aguilas, en M. Avilés, G. Sena (eds), Carlos III y las "nuevas poblaciones". Tomo I. Córdoba. Universidad de Córdoba: 315- 325.

Ibáñez Vilches, J.A. (1986), La población de Aguilas en la segunda mitad del siglo XVIII en A. Morata (dir), Aproximación a la historia de Aguilas. Aguilas. Excmo. Ayuntamiento de Aguilas: 153-167.

Jordan y Frago, J. (1779), Geografia moderna (...): traducida y aumentada con una geografia nueva de España, Tomo III, Madrid.

Jorge Aragoneses, M. (1974), Arqueología en S. Alonso (coord), Águilas. Murcia. Patronato de Cultura de la Excma. Diputación Provincial de Murcia: 17-20.

Leonés, D. J. (7-febrero-1778), Carta al Conde de Lumiares. Lorca.

Lopez, J. (1795), Disertacion ó memoria geográfico-histórica sobre la Bastitania y Contestania, Madrid.

Lozano, J. (1794), Bastitania y Contestania del Reino de Murcia, Murcia.

Lumiares (1779), Barros Saguntinos. Disertacion sobre estos monumentos antiguos (...), Valencia.

Manderscheid, H. (1988), Bibliographie zum römischen Badewesen unter besonderer Berücksichtigung der öffentlichen Thermen, München: Druck und Einband.

Maier Allende, J. (2011), Noticias de Antigüedades de las Actas de Sesiones de la Real Academia de la Historia (1738-1791), Madrid: Real Academia de la Historia.

María de Jesús. (1668), Mistica Ciudad de Dios. Milagro de su Omnipotencia. Historia divina y vida de la Virgen María (...), Madriti. 
Mariana, J. (1785), Historia general de España(...), tomo segundo, Valencia.

Martinez de la Junta, P. M. (1760), Rasgo rhythmico de las plausibles, solemnes fiestas, que en la Real proclamacion de nuestro Catholico Mornarca, y Señor Don Carlos Tercero, celebrò la Muy Noble, y Muy Leal Ciudad de Lorca, quien lo dedica al Principe, Ntro. Señor (...), Murcia.

Mendez, F. (1780), Noticias de la vida y escritos del Rmo. P. Mro. Fr. Henrique Florez (...) Con una Relacion individual de los Viajes que hizo à las Provincias y Ciudades mas principales de España, Madrid.

Mendez Sylva, R. (1675), Poblacion General de España. Sus Trofeos, Blasones, y Conquitas Heroicas (...), Madrid.

Montpalau, A. (1783), Diccionario Geográfico Universal (...). Quarta edición, corregida y enmendada, tomo tercero, Madrid.

Morel-Fatio, A. (1896). Lettres d'antiquaires espagnols de la fin du XVIIle siècle adressées au Comte de Lumiares. Bibliothèque de l'École des Chartes, 57: 64-76.

Morote Pérez, P. (1741), Antiguedad, y blasones de la ciudad de Lorca (...), Murcia.

Mula Gómez, A. J., Gris Martínez J. (1986), De Aranda a Floridablanca. Fundamentos económicos y comerciales de la repoblación de Aguilas, en A. Morata (dir), Aproximación a la historia de Aguilas. Aguilas. Excmo. Ayuntamiento de Aguilas: 87-121.

Navarro, A. J. (2000), Viajes de un naturalista ilustrado por los reinos de Granada y Murcia. Edición y estudio de Javier Castillo Fernández, Murcia: Universidad de Murcia.

Ordovás, J.J. (2005), Atlas politico y militar del Reyno de Murcia, Madrid: Mimarq.

Palacios Morales, F. (1969), Estampas de mi tierra: Aguilas, Murcia: Caja de Ahorros Provincial de Murcia. Palacios Morales, F. (1982), Aguilas desde la Prehistoria, Murcia: Editora Regional de Murcia.

Pareja Muñoz, F. (1995), Historia cartográfica de la costa de Lorca. (Águilas y su entorno) Del siglo XIII al XIX (Sinus Urcitanus), Murcia: Cajamurcia y Real Academia Alfonso X El Sabio.

Pasqual de Orbaneja, G. (1699), Vida de San Indalecio, y Almeria Ilustrada en su antiguedad, origen, y grandeza, Parte II, Almeria.

Perezii Bayerii, F. (1790), Nvmorvm Hebraeo-Samaritanorvm Vindiciae, Valentia.

Pérez Mulero, P. (2016). Revisión de una inscripción de época romana hallada en Águilas (Murcia) en 1788. Alberca: Revista de la Asociación de Amigos del Museo Arqueológico de Lorca 14: 123-145.

Pérez Mulero, P., Llorach Asunción, A.R. (e.p.). Inscripción paleocristiana de Águilas (Murcia) en un informe del Conde de Lumiares. Antigüedad y Cristianismo.

Ramallo Asensio, S. (1984). Algunas consideraciones sobre el Bajo Imperio en el litoral murciano: Los hallazgos romanos en Águilas. Anales de la Universidad de Murcia 42 (3-4): 97-124.

Ramallo Asensio, S. F. (1985), Envases para salazón en el Bajo Imperio (I), en VI Congreso internacional de Arqueología Submarina, Cartagena 1982. Madrid. Ministerio de Cultura: 435-442.

Ramallo Asensio, S. (1986), Las termas romanas de Águilas, en A. Morata (dir), Aproximación a la historia de Águilas. Águilas. Ecmo. Ayuntamiento de Aguilas: 41-62.

Ramallo Asensio, S. (1989-1990). Termas romanas de Carthago Nova y alrededores. Anales de Prehistoria y Arqueología, 5-6: 161-177.

Robles Vives, A. (1788), Representación del estado actual de la nueva población de Águilas. Lorca. (Obra inédita)

Siret, L. (1909). Villaricos y Herrerías. Antigüedades púnicas, romanas, visigóticas y árabes. Memoria descriptiva e histórica. Memorias de la Real Academia de la Historia, 14: 379-479.

Stephani, R. (1543), Dictionarium, seu Latinae lingua Thesaurus (...), t. II, Parisiis.

Ulloa, B. (1740), Restablecimiento de las fábricas, y comercio español: errores que se padecen (...), Madrid.

Uztariz, G. (1757), Theorica, y Practica de Comercio, y de Marina, en diferentes discursos(...)Tercera impresion, Madrid.

Vargas, A. (1625), Relacion votiva, ó donaria de la Antigüedad de la Imagen de Nuestra Señora de las 
Huertas que el Rey D. Alonso el Sabio colocó en la Iglesia de Lorca, Granatae.

Vargas Ponce, J. (1978), Descripción de Cartagena. Ed. de José María Rubio Paredes, Murcia: Academia Alfonso $X$ el Sabio.

Velazquez, J.L. (1752), Ensayo sobre los alphabetos de las letras desconocidas, Que se encuentran en las mas antiguas Medallas, y Monumentos de España, Madrid.

Vegas A. (1795), Diccionario Geográfico Universal (...) Sexta edición, corregida y añadida, tomo quinto, Madrid.

Vidal, Ph. (1724), Mapa del Obispado de Cartagena y Reyno de Murcia, Matriti. 


\title{
Del lugar donde fue lliberri (Granada): historiografía de un debate
}

\author{
Amparo Sánchez Moreno
}

\author{
Universidad de Granada
}

La ubicación de la antigua ciudad iberorromana de Iliberri suscitó un debate historiográfico entre intelectuales de diferentes épocas durante los cinco siglos que estuvo vigente, hoy día ampliamente superado. Es por ello que el título del presente artículo es una alusión al libro escrito por Leopoldo Eguílaz y Yanguas en 1881 en el que refleja esta realidad historiográfica. Otra frase que sintetiza de manera gráfica esta problemática fue la que escribió Manuel Gómez-Moreno Martínez a principios del siglo XX: 'El sitio de Iliberri es la cuestión de geografía española que ha dado pie a debate más enconado y largo' (GómezMoreno Martínez 1905: 44).

Esta polémica, que desde el siglo XVI hasta nuestros días se ha venido planteando en torno a la localización de dicha ciudad, alcanzó su máximo apogeo en la segunda mitad del siglo XIX, cuando una serie de instituciones dirigidas por los eruditos del momento intentaban dilucidar arqueológicamente esta premisa. Para ello se sirvieron principalmente de la prensa local, aunque también en este período fueron publicadas numerosas monografías que recogían este tema. Sin embargo, no fue hasta la segunda mitad del siglo XX cuando la comunidad científica pudo demostrar arqueológicamente el emplazamiento de Iliberri y establecer una secuencia cronológica del mismo.

\section{Medina Elvira - Albaicín (Granada)}

Para explicar el debate historiográfico que surgió en torno a la ubicación del asentamiento iliberritano se debe hacer mención en un primer momento a los enclaves que optaban a tal título. Desde momentos tempranos de la investigación dos fueron las localizaciones principales, aunque no las únicas, que se barajaron como sede de la antigua ciudad de Iliberri (Fig. 1):

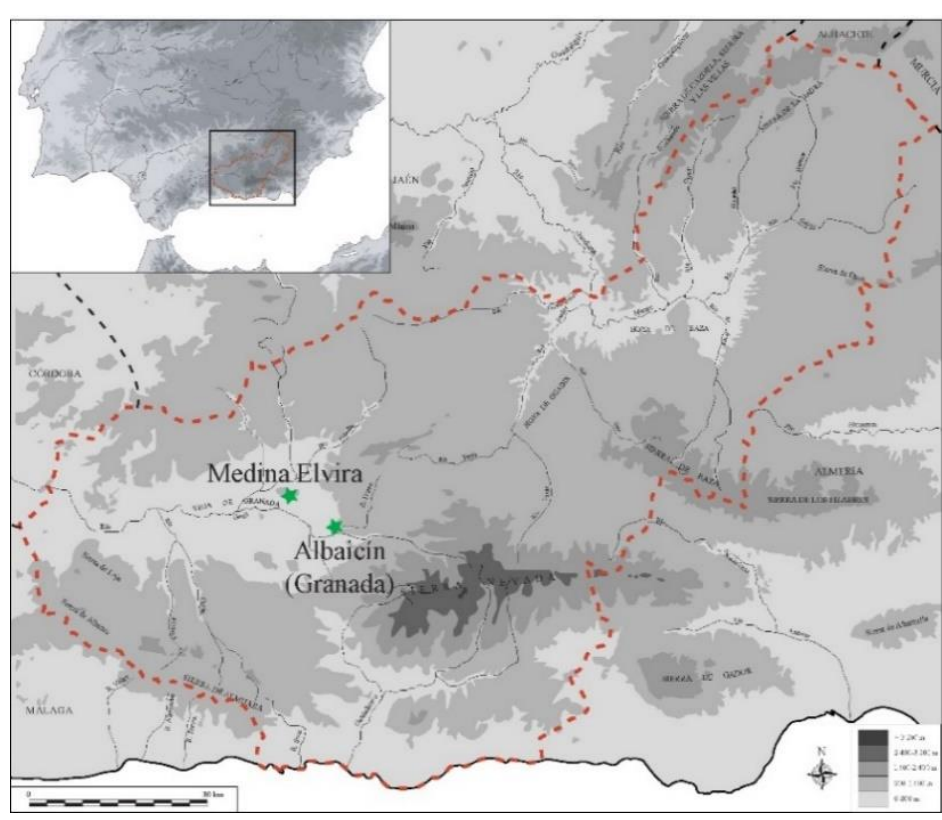

Fig. 1. Mapa con la ubicación de Medina Elvira y el barrio del Albaicín en Granada.

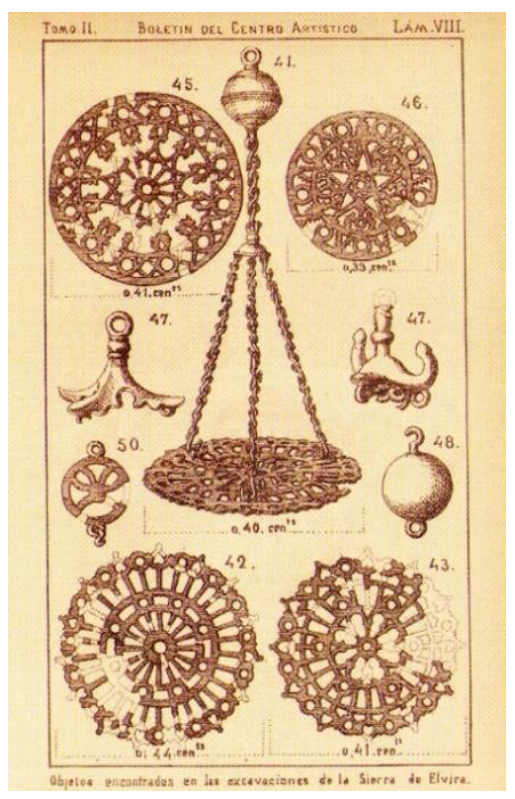

Fig. 2. Dibujo de las lámparas de bronce de la Mezquita mayor de Medina Elvira realizados por M. Gómez-Moreno (1888a: lám. VII). 
- Medina Elvira, situada a unos $10 \mathrm{Km}$ al NW de la actual ciudad de Granada. En ella se localizan los restos arqueológicos de la urbe más importante de la Vega de Granada entre los siglos VIII y $\mathrm{X}$, y que fue objeto de excavaciones desde el siglo XIX. Uno de sus artífices fue Manuel GómezMoreno González, quien en 1888 publicó un breve libro sistematizando los hallazgos documentados en este yacimiento y dando a conocer algunos de los objetos más interesantes, como las lámparas de bronce de su mezquita mayor (Fig. 2), conservadas en el Museo Arqueológico de Granada.

A finales del siglo XX se iniciaron nuevas intervenciones arqueológicas, ya con una metodología moderna, que han permitido conocer la importancia que tuvo este enclave en época medieval (Malpica 2013).

- Albaicín o Alcazaba Cadima, nombre con el que tradicionalmente era conocido este barrio (Fig. 3). Aunque se tienen noticias de hallazgos arqueológicos casuales en él desde el siglo XVI, no fue hasta la segunda mitad del siglo XVIII cuando se realizaron las primeras excavaciones de la mano de Juan de Flores y Oddouz (Sotomayor 1988 y 2007; Sotomayor y Orfila 2004: 2006 y 2011). Este personaje, coleccionista de objetos arqueológicos y artísticos, fue consciente de que desde hacía dos siglos habían ido apareciendo inscripciones en esta zona de la ciudad, por lo que compró una casa allí y comenzó sus excavaciones. En ellas sus genuinos descubrimientos iban acompañados de una serie de falsificaciones con extraños caracteres, en los que llegó a inventarse hasta quince alfabetos diferentes (Fig. 4). Todo esto desembocó en un juicio en el que los objetos fueron declarados falsos, las piezas destruidas en gran parte y los restos arquitectónicos desestructurados y enterrados de nuevo, para borrar así cualquier huella de aquel sonado fraude. Esta suerte fue la que corrió una de las más claras evidencias topográficas sobre la Granada romana y su identificación con la Iliberri/Florentia Iliberritana de las fuentes literarias, epigráficas y numismáticas: el foro de la ciudad (Fig. 5). También de manera recurrente ha justificado que algunos investigadores negaran en su día, y en menor número también hoy, esta evidencia confirmada con los estudios recientes de los planos realizados por Flores (Sotomayor y Orfila 2011) y las últimas excavaciones arqueológicas (Rodríguez Aguilera 2011).

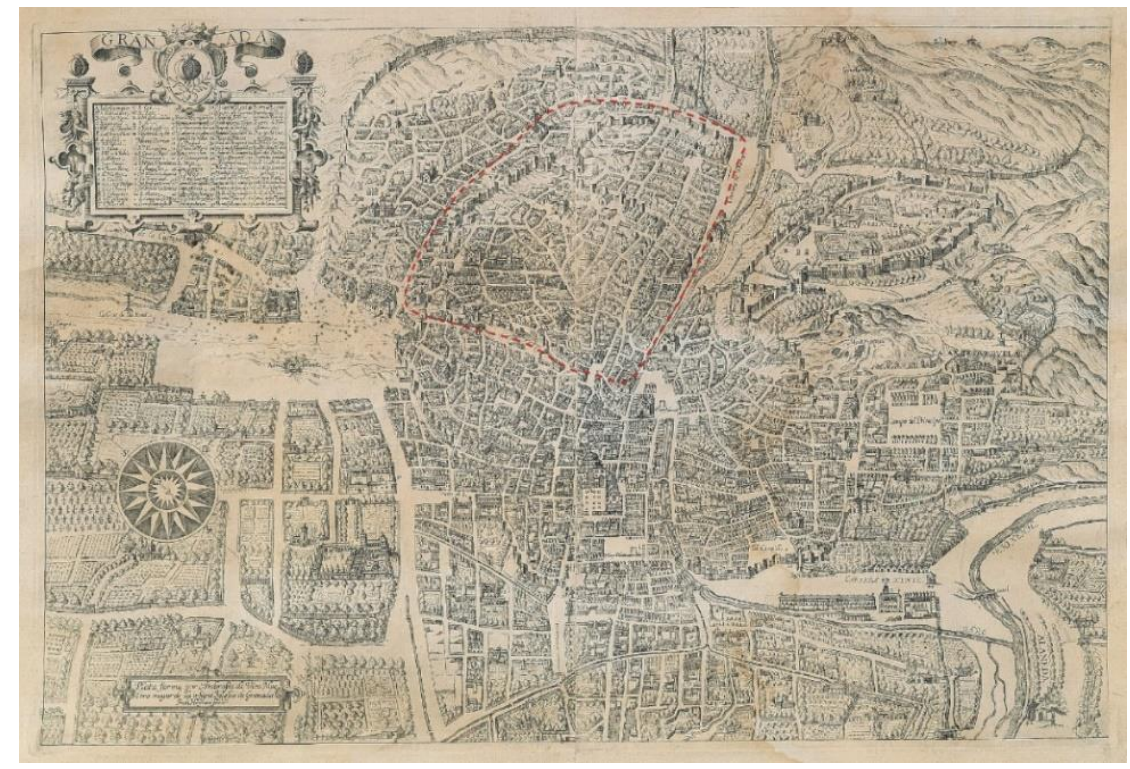

Fig. 3. Localización del barrio del Albaicín o Alcazaba Cadima sobre la Plataforma Vico (1595-1613: Plataforma por Ambrosio Vico Maestro Mayor de la insigne Iglesia de Granada, Salamanca. Mapa rectangular: 45 x 64 cm. Reproducción: Prieto, F., 1795. Número de control: IECA1988015125). 


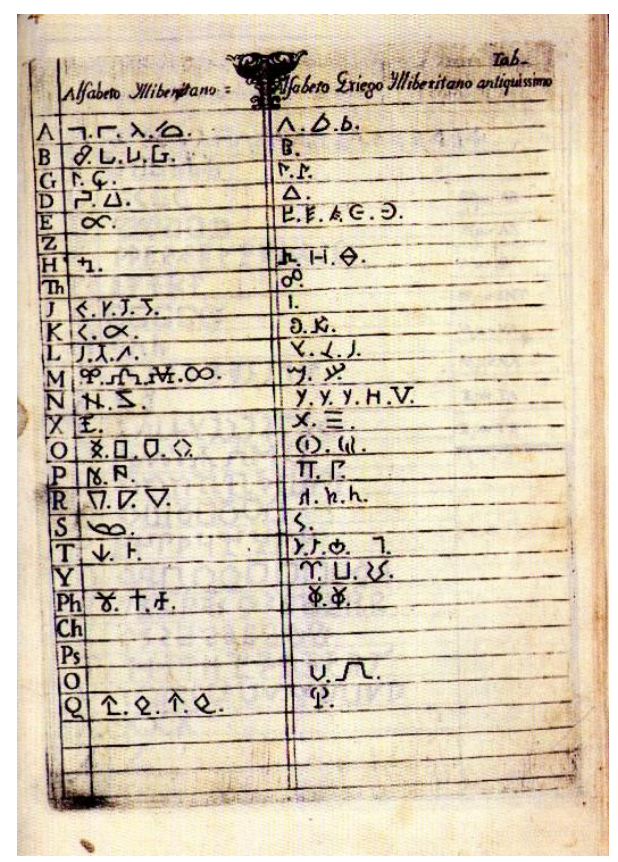

Fig. 4. Alfabeto iliberritano y griego lliberritano Antiguo creado por Flores (Sánchez López y Marín 2012: 32).

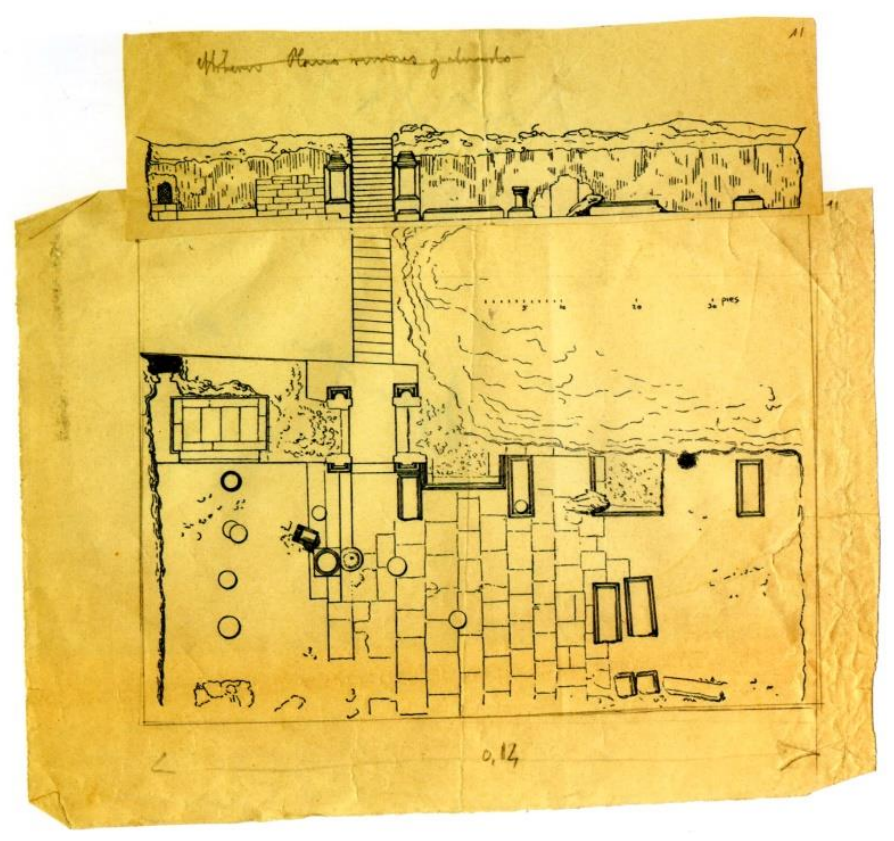

Fig. 5. Dibujo del foro romano realizado por uno de los colaboradores de Flores en 1768 (Sotomayor 2008: 30).

Este episodio en el que realidad y ficción iban de la mano supuso un duro golpe para la arqueología granadina, del que tardó casi dos siglos en recuperarse, además de reavivar el conocido debate historiográfico en torno a la ubicación de la primitiva ciudad en el barrio del Albaicín o en la vecina Medina Elvira.

Las excavaciones en el Albaicín no volvieron a retomarse hasta 1982, cuando la restauración de un tramo de la muralla zirí del siglo XI (Fig. 6) posibilitó que se iniciaran estas intervenciones en el Carmen de la Muralla, dirigidas en esta primera etapa por Manuel Sotomayor y cuyo principal objetivo era demostrar

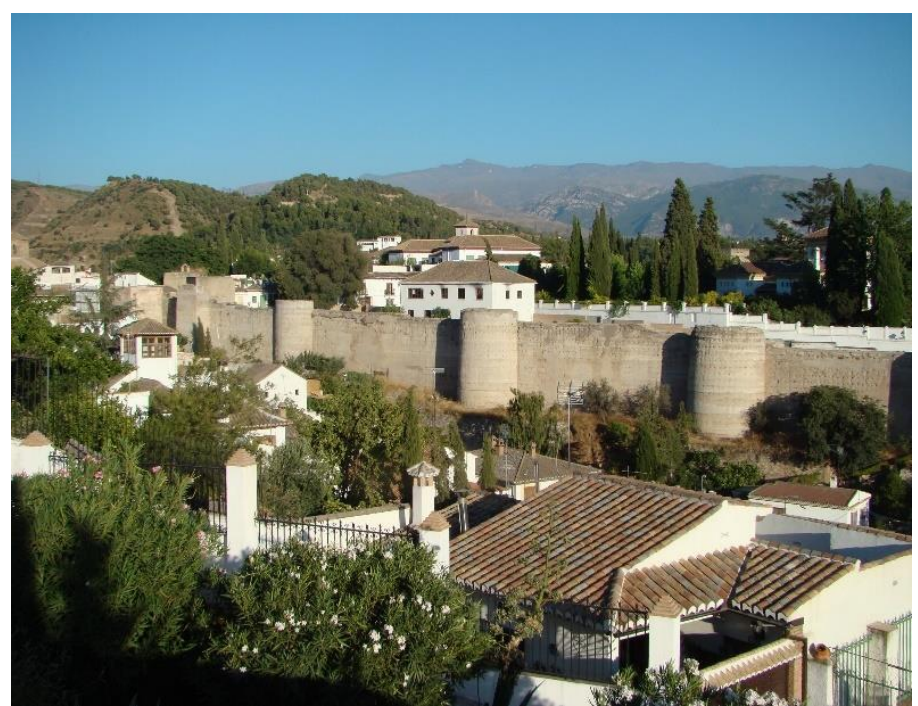

Fig. 6. Imagen exterior de la muralla zirí del siglo XI. En su interior se realizaron las primeras intervenciones arqueológicas en 1982. arqueológicamente lo que durante más de cuatro siglos se había ido debatiendo en torno a la ubicación de Iliberri (Sotomayor et al. 1984). Estas actividades arqueológicas fueron los antecedentes inmediatos del primer proyecto arqueológico que se centró en el pasado iberorromano y medieval de la ciudad y permitió realizar una evolución histórica de la ciudad desde el siglo VII a.C. hasta 1492 (Moreno et al. 1993: 1994 y 1995; Roca et al. 1988).

\section{Origen y desarrollo del debate historiográfico}

Actualmente sabemos muy bien el papel que desempeñaron en la historia cada uno de los asentamientos, Medina Elvira e Iliberri, pero no siempre fue así. El emplazamiento de la ciudad antigua de Illiberri empezó a 
interesar a la historiografía a partir de la toma cristiana de Granada en 1492, que, tras ocho siglos de ocupación árabe, volvía a ser cristiana, y para muchos autores era el momento de escribir una historia de la ciudad que legitimara su pasado romano y cristiano. Probablemente el origen de esta polémica pudo estar en una interpretación errónea de los cronistas árabes y de las noticias que se tuvieron de la ciudad una vez que adquirió esta nueva identidad.

En 1494 el viajero alemán Jerónimo Münzer fue el primer autor moderno que comentó la existencia de ruinas en Sierra Elvira, como antes lo habían hecho cronistas árabes, con estas palabras: 'en la cercana llanura, álzase una gran montaña, hacia el norte del Albaicín, verdadera ciudad fuera de la muralla de la antigua ciudad de Granada, pero con calles tan sumamente estrechas...' (García Mercadal 1952: 358).

Sin embargo Andrea Navagero, uno de los grandes humanistas del Renacimiento italiano, fue el que mencionó por primera vez en el siglo XVI la existencia de un debate en torno a la localización de la antigua Iliberri, dejando claro que estaría situada en Sierra Elvira, conocida como 'Granada la vieja': 'La parte de la ciudad que está en el llano tiene buenas casas...; hay en ella una calle principal bastante ancha y muy larga, que llaman la calle Elvira, nombre que tiene también la puerta que hay al lado de ella. El nombre de Elvira es corrupción de la palabra Ilibiris, pues por dicha parte se va a la antigua ciudad así llamada, de la que se ven ruinas como a una legua de Granada.' (Navagero 1563: 50-51).

Por otro lado Navagero fue conocedor de la localización de inscripciones en el Albaicín, sin darles importancia puesto que, como él mismo señaló, pudieron ser trasladadas en un momento indeterminado desde Medina Elvira, y para ello tuvo en cuenta la cercanía de este enclave a la capital y su toponimia, Elvira, evolución de Iliberri: 'Dicho dia fuimos a Puente Pinos, que hay tres leguas; en el camino, antes de llegar a este pueblo, en la falda de un monte a mano derecha, se ven vestigios y ruinas de una ciudad que se cree fue la antigua Iliberis y ahora la llaman Granada la Vieja; piensan otros que Iliberis estuvo donde ahora está Granada, porque en ella se encuentran inscripciones donde se nombra los Iliberianos, pero han podido llevarse de un lugar tan vecino.' (Navagero 1563: 64). Este argumento del traslado fue un recurso muy utilizado en las centurias siguientes por otros autores como Antolínez de Burgos, José Antonio Conde, Francisco Javier Simonet o los hermanos Oliver y Hurtado para defender su postura, como se verá más adelante.

En el siglo XVI otro 'elvirista' fue el historiador Gonzalo de Illescas, quien hizo referencia a la ciudad de Granada dejando clara su posición respecto al debate: 'aunque en la verdad Illiberis no fue donde oy es Granada, sino allí acerca de dos leguas' (Luque 1994: 47). Esta misma opinión compartía Ginés Pérez de Hita a través de su novela histórica en la que mezclaba realidad y ficción, tan característica de estos momentos: 'fue su fundación en una muy hermosa y espaciosa vega, junto de una sierra llamada Elvira, porque tomó el nombre de la fundadora Infanta, la qual se llamava Ilibiria, dos leguas de donde agora está...' (Pérez de Hita 1595-1609: 1-2). Sin embargo, hubo autores como Fernando de Mendoza o Luis del Mármol Carvajal que anotaron diferentes ubicaciones, añadiendo este último una nueva localización cerca del pueblo de Pinos Puente (Mármol 1600: 128-129), por lo que tal vez se refiriera a las ruinas de Ilurco y no a los vestigios de Sierra Elvira.

En esta centuria los defensores de la ubicación de la antigua ciudad en el barrio del Albaicín también reflejaron en sus obras sus opiniones al respecto; entre ellos cabe señalar a Pedro de Medina o a Esteban de Garibay.

En el siglo XVII el historiador Francisco Bermúdez de Pedraza se propuso reconstruir la historia de Granada de acuerdo con las exigencias contrarreformistas de la ortodoxia católica impuesta por Felipe II. De esta manera en 1608 publicó Antigüedades y Excelencias de Granada, obra estructurada en cuatro libros que se convirtieron en un alegato en defensa de la antigüedad de la ciudad de Granada frente a Sierra Elvira: 'Este es el sitio que oy tiene Granada, al pie de Sierra Nevada, en medio de la espaciosa vega con 
ríos que la limpian y fertilizan: todo lo qual falta en el sitio de Sierra Elvira. Luego esta es la mesma que fue la antigua Illiberia, comprobado por sus lindes.' (Bermúdez 1608: II, 32). A pesar de la defensa a ultranza y justificada de Bermúdez de Pedraza con respecto a la ubicación de la antigua ciudad en Granada, en este momento también hubo autores que seguían localizándola en Sierra Elvira, como los historiadores Justino Antolínez de Burgos o Francisco Henríquez de Jorquera.

Durante el siglo XVIII el estudio de las antigüedades continuó suscitando interés, lo que originó el nacimiento de la Arqueología como una disciplina auxiliar de la Historia para ilustrarla, basándose en el estudio de la epigrafía, la numismática, la toponimia antigua y los monumentos antiguos, aunque se centraba principalmente en el mundo romano (Mora 1998: 58). Una de las novedades de este período fue el desarrollo de excavaciones arqueológicas, algunas de ellas financiadas por la Corona, como las intervenciones desarrolladas en Pompeya, Herculano y Estabia siendo Carlos VII rey de Nápoles (Alonso 1992 y 2012; Mora 1998). El interés borbónico por las actividades arqueológicas napolitanas no tuvo el mismo efecto en España; no obstante, en Andalucía se realizaron algunas intervenciones, incluida Granada, y es en este contexto en donde deben situarse las 'exploraciones' de Juan de Flores y Oddouz en el Albaicín granadino, al que hacíamos referencia al comienzo del discurso. Uno de sus colaboradores, el padre Juan Velázquez de Echevarría, era el encargado de publicar referencias sobre dichas intervenciones a través de sus Paseos por Granada y sus contornos (1764). Entre 1754 y 1763 Flores realizó numerosas

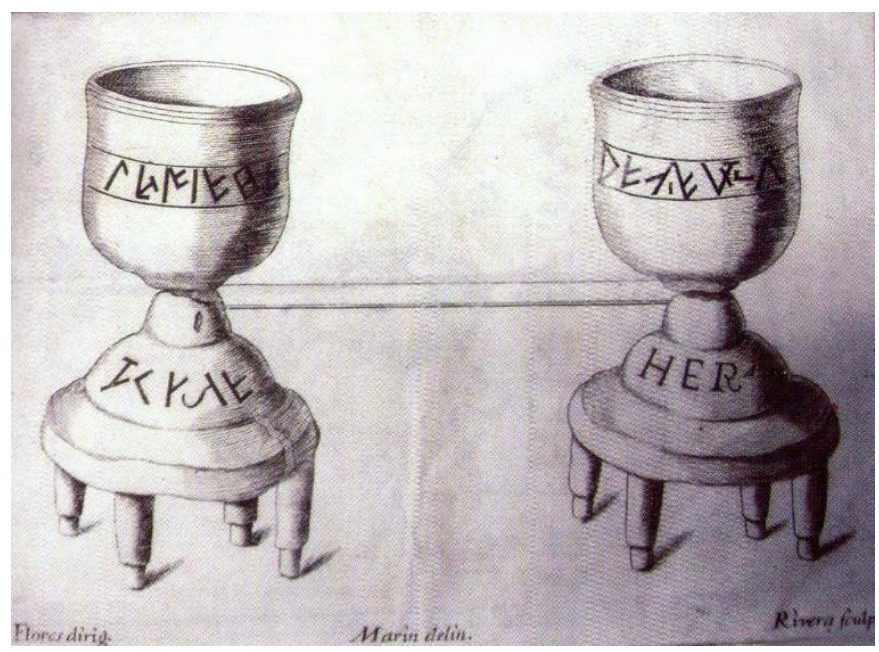

Fig. 7. Grabado de una falsificación de las excavaciones de Flores (Sánchez López y Marín 2012: 37). excavaciones, en las que se documentaban falsificaciones (Fig. 7) que iban apareciendo de manera planificada para confirmar hallazgos o hipótesis planteadas (Sotomayor 2007). En 1777 Flores y sus cómplices fueron condenados por falsificadores y se ordenó enterrar y cercar los lugares donde se había excavado, además de destruir las falsificaciones. Los objetos auténticos que formaban parte de la colección de Flores fueron llevados a los sótanos de la Real Chancillería de Granada, donde los estudió Francisco Pérez Bayer, convirtiéndose posteriormente en una de las colecciones fundadoras del Museo Arqueológico y Etnográfico de Granada (Salas 2010:185).

Uno los objetivos principales de esta falsa ideada por Flores era demostrar que la ubicación de la primitiva ciudad iberorromana de Iliberri estaba en el Albaicín, sede en la que se celebró el Concilio de Elvira (Mora 1998: 89). Sin embargo, las actividades ilícitas de este pícaro no hicieron más que aumentar la polémica entre los partidarios de uno y otro bando, que alcanzó su punto álgido en la segunda mitad del siglo XIX.

\subsection{El siglo XIX y la labor de las instituciones}

En los primeros años de este siglo aún no se había olvidado el episodio de las falsificaciones de Juan de Flores, y ante el descrédito científico en que había quedado sumida la cultura arqueológica e histórica granadina, Simón de Argote escribió Nuevos paseos históricos, artísticos, económicos-políticos por Granada y sus contornos (1805-1807). Sus 'nuevos paseos' corregían a los de Echevarría y con ellos intentaba 'limpiar' la historia de Granada de leyendas mitológicas y piadosas, tradiciones y falsedades acumuladas por la religiosidad imperante, prestándole especial interés a la epigrafía y a la numismática. Se trataba de un ambicioso proyecto de descripción global de la ciudad cuya realización quedó interrumpida por la Guerra de Independencia y el exilio de su autor. Argote defendió la hipótesis de que 
Granada-Elvira eran dos ciudades distintas, y afirmaba que era muy probable que Iliberri estuviese fundada en la planicie de la Vega, cerca de las riberas del río Beiro. Para estas declaraciones utilizaba como argumentos el nombre del río, que en árabe parecía significar 'ciudad' o 'población', y la distancia del castillo de Granada que señalaban los árabes. Dada la naturaleza de los terrenos y las inundaciones de la Vega sostenía que la acumulación de sedimentos había posibilitado la ocultación de esta ciudad (Calatrava 2000).

En este siglo la epigrafía siguió siendo considerada una fuente fundamental para el estudio del pasado; así, en 1832 se publicó la obra póstuma de Juan Agustín Ceán Bermúdez Sumario de las antigüedades romanas que hay en España, en especial las pertenecientes a las Bellas Artes. Consistía en una recopilación de vestigios romanos ordenada por las provincias romanas: Tarraconense, Bética y Lusitania. En el apartado destinado a Granada se hizo eco del debate en torno a la ubicación de la ciudad antigua, pero su postura era muy clara y basó su argumentación en las inscripciones que habían ido apareciendo en la ciudad (junto a la Cartuja, en el barrio del Albaicín o en la Alhambra): 'Granada, ciudad antigua y famosa... Llamáronla los romanos Iliberi, Iliberris é Illiberris, y fue municipio Florentino...pero los mas estan de acuerdo en que estuvo en la misma ciudad de Granada, aunque discordes sobre sitio ó barrio.' (Ceán 1832: 363-364).

Sin embargo, este enfrentamiento conoció su época más virulenta durante la segunda mitad del siglo XIX, cuando los restos arqueológicos de Granada y el conocimiento de la Iliberri romana comenzaron a estudiarse con un criterio científico. En el desarrollo de este debate jugaron un papel muy importante las dos instituciones que velaban por las antiguiedades de la provincia: el Liceo Artístico y Literario y la Comisión Provincial de Monumentos, y posteriormente el Centro Artístico.

En 1833 surgió en la ciudad una asociación de índole cultural que sería el origen del Liceo Artístico y Literario fundado en 1839, y que estuvo funcionando hasta finales del siglo XX. Se dividía en tres secciones: Artes, Letras y Música; además disponía de la publicación La Alhambra (Fig. 8), que se hacía eco de toda la vida cultural que en estos momentos gozaba la capital. Fue éste el medio en el que los historiadores granadinos dieron a conocer la historia de la ciudad de Granada y donde defendieron sus antigüedades. Desde 1839 hasta 1924, fecha en que dejó de publicarse, esta revista, que en ocasiones se denominó periódico, pasó por diferentes etapas (Molina 1979: 91-117).

Entre los años 1836 y 1842 se produjeron una serie de

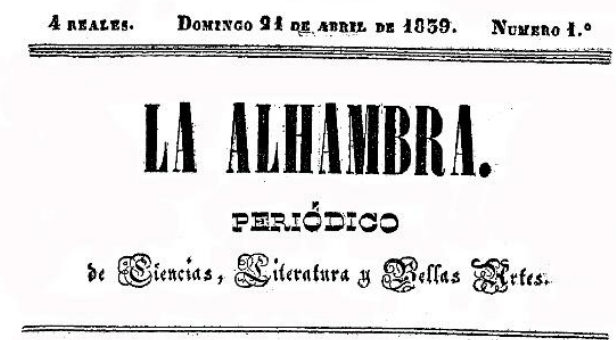

FISONONIA HISTORICA DE GRANADA.

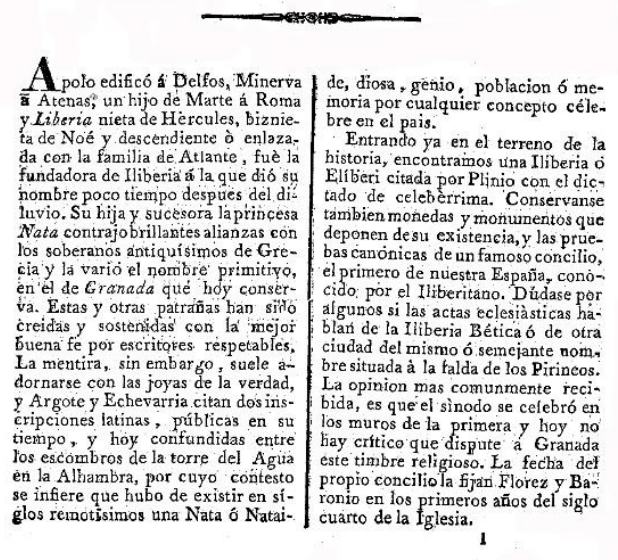

Fig. 8. Portada del primer número de $L a$ Alhambra el 21 de abril de 1839 con un artículo de José de Castro y Orozco titulado 'Fisonomía histórica de Granada'. hallazgos casuales en Sierra Elvira y se expoliaron tumbas en el Pago del Marugán por parte de jornaleros sin trabajo de las poblaciones cercanas, en su afán por encontrar tesoros (Espinar et al. 1995). Estos descubrimientos despertaron el interés del Liceo Artístico y Literario de Granada, que decidió realizar una excursión de trabajo y determinar la autenticidad de los restos. El acta de esta visita realizada el 26 de abril de 1842 fue publicada en los días posteriores en su órgano comunicativo, el periódico La Alhambra (Moreno y Bernedo 1842: 129-131); de igual modo se mandó una copia a la Real Academia de la Historia, y se encargó a dos de sus miembros, Miguel Lafuente Alcántara y Nicolás Peñalver y López, el estudio 
detallado de estos hallazgos, cuyos resultados fueron publicados en el mismo periódico durante el mes de mayo de 1842.

El historiador Lafuente Alcántara en su artículo 'Antigüedades romanas recientemente descubiertas en Sierra Elvira. Conjeturas sobre la posición de la antigua Iliberis. Examen de las opiniones de Bermúdez de Pedraza' (1842) relató los hechos constatando la autenticidad de las antigüedades. En palabras del autor se expoliaron más de 200 sepulturas, acompañadas de sus ajuares, y como conclusión apuntó que la antigua ciudad de Iliberri se situaba en Sierra Elvira. En la última parte de su escrito realizó una dura crítica a la obra de Bermúdez de Pedraza que, como ya se ha señalado anteriormente, en el siglo XVII defendió que Iliberri y Granada fueron siempre la misma ciudad ubicada en la Alcazaba Cadima.

En el otro artículo publicado en La Alhambra por estas fechas, 'Cementerio de Sierra Elvira' (1842), escrito por Nicolás Peñalver y López, se estudiaron los objetos documentados para poder datar las tumbas encontradas: anillos, aretes o zarcillos, brazaletes, hebillas o broches de cinturón, una figura de cobre, cuentas de vidrio, ánforas y otros objetos, muchos de ellos adquiridos por el Liceo Artístico y Literario. La conclusión a la que llegó este autor estimaba que eran manufacturas romanas.

En estos textos el planteamiento que ofrecieron Lafuente y Peñalver fue muy diferente: mientras que el primero trató el tema desde un punto de vista histórico-geográfico, el segundo le dio al estudio un enfoque más arqueológico (Espinar et al. 1995: 19-25). Estos dos trabajos fueron utilizados por José de Castro y Orozco para redactar la memoria de las antigüedades de Sierra Elvira (1865), que presentaría a la Real Academia de la Historia en 1842, donde criticó la no divulgación de los materiales, dada su importancia para la arqueología granadina. Los tres autores se declararon 'elviristas' ante la magnitud de los descubrimientos que llegaron a tener repercusión nacional con la publicación de estos hallazgos en el Semanario Pintoresco Español de la mano de Manuel de la Corte y Ruano (1843a, 1843b y 1843c).

Pero no todos los eruditos pensaban de la misma forma, de ahí la respuesta a la crónica de Miguel Lafuente Alcántara por parte de Mariano Segundo de Pineda, en el mismo medio de comunicación, en el que fue rebatiendo cada una de las argumentaciones de Lafuente, además de evidenciar numerosas contradicciones que encontraba en su escrito. De esta forma aportó una relación de autores defensores de la posición 'alcazabista', enumeró los diferentes hallazgos que se habían documentado en el Albaicín, y concluyó con la siguiente frase: 'la situación de la antigua Iliberis en la Sierra de Elvira no puede ser sino una conjetura ú opinión y de ningún modo una evidencia’ (Segundo 1842: 203).

En ese mismo año se publicó el libro de José Hidalgo Morales Iliberia o Granada. Memoria históricacrítica, topográfica, cronológica de sus antigüedades (1842). Como bien explicó el autor en el capítulo introductorio, el objetivo de esta obra era escribir una historia formal de Granada, ya que las falsificaciones de la torre Turpiana, del Sacromonte y de Juan de Flores, así como las diferentes opiniones escritas en las crónicas respecto a su fundación, nombre e historia, impedían llegar a conocer esta ciudad. A pesar de que las teorías de los cronicones de los siglos XVI y XVII basándose en leyendas míticas para explicar el origen de España estaban ya casi superadas, Hidalgo hizo gala en todo su discurso de estas fuentes, e incluso averiguó la fecha exacta de la fundación de Iliberia: 'Resulta pues, que Iliberia fue fundada el año 1651 antes de la era cristiana, y 2233 de la creación del mundo, llevando hasta el día 3607 de existencia; aunque ha sido destruida en parte, y reedificada varias veces como después se dirá.' (Hidalgo 1842: 2223). A lo largo del texto repitió varias veces que la antigua ciudad se encontraba en el Albaicín y que esta urbe nunca estuvo en Sierra Elvira, a pesar de que en un primer momento señaló lo contrario (Hidalgo 1842: 77), y para ello se basó en la cantidad de hallazgos localizados en esta zona de la ciudad.

Entre los años 1843 y 1854 Miguel Lafuente Alcántara escribió una extensa Historia de Granada, comprendiendo las de sus cuatro provincias Almería, Jaén, Granada y Málaga, desde remotos tiempos hasta nuestros días. En el prólogo del primer tomo llevó a cabo una crítica a las leyendas de los falsos 
cronicones, dirigida principalmente a Hidalgo Morales, puesto que en el siglo XIX muchos académicos pensaban que este asunto ya estaba erradicado. Al final de este libro insertó un apéndice titulado 'Recientes descubrimientos de Sierra Elvira' (Lafuente 1843a: 363-375), que era el mismo artículo publicado en el periódico La Alhambra (op. cit.), defendiendo su posicionamiento "elvirista", motivo por el cual posiblemente no incluyó ningún epígrafe procedente del Albaicín en el apartado 'Antigüedades, ruinas é inscripciones romanas notables de las cuatro provincias de Granada'. En otra de sus obras publicada ese mismo año, El libro del viajero en Granada, volvió a insistir en su teoría sobre Iliberri: 'Han escrito tambien con poco acierto los que suponen que Granada ocupa el mismo sitio que la romana Illiberi.' (Lafuente 1843b: 8).

Esta serie de relatos del estilo de las guías iniciada por Lafuente Alcántara fue seguida por José Giménez Serrano en su Manual del artista y del viajero en Granada (1846), donde no dejó clara su postura en relación al debate historiográfico. Sin embargo, a lo largo de su discurso se refirió a Granada como la antigua Iliberri (Serrano 1846: 3), y comentó que la ausencia de vestigios romanos en la ciudad se debió en buena parte a la destrucción de bárbaros y árabes, aunque se tenía constancia de la existencia de templos en los cerros de la Alhambra, llamada por entonces Nativola (Serrano 1846: 36).

La segunda institución desatacada fue la Comisión Provincial de Monumentos Históricos y Artísticos, creada a mediados del siglo XIX por la Real Academia de la Historia para velar por los bienes patrimoniales. En 1866 José de Castro y Orozco fue nombrado presidente de dicha Comisión, y como ya hiciera anteriormente en el Liceo, el principal objetivo de sus proyectos estribó en el renacimiento cultural para recuperar del olvido la provincia, intentando dilucidar el emplazamiento de la ciudad de Iliberri. La labor de Castro fue de vital importancia en la conservación del patrimonio arqueológico de la provincia, como ya manifestó con los descubrimientos de Sierra Elvira en 1842. Entre los diversos trabajos que quería realizar la Comisión se hallaba la creación de un catálogo de monumentos propiedad del Estado en la provincia. Para conseguir tal fin algunos de sus miembros donaron objetos arqueológicos al gabinete de antigüedades que formaba parte de la Comisión, entre ellos Manuel Gómez-Moreno González. La etapa en la que fue secretario de la Comisión Gómez-Moreno González (1870-1876) coincidió con el período de mayor actividad de esta institución (Moya 2004: 19-24).

Dos hechos motivaron que la Comisión intentara buscar una solución al debate historiográfico: por un lado, en 1867 se encargó un estudio de Sierra Elvira a Manuel de Góngora y Martínez, en el que comentó

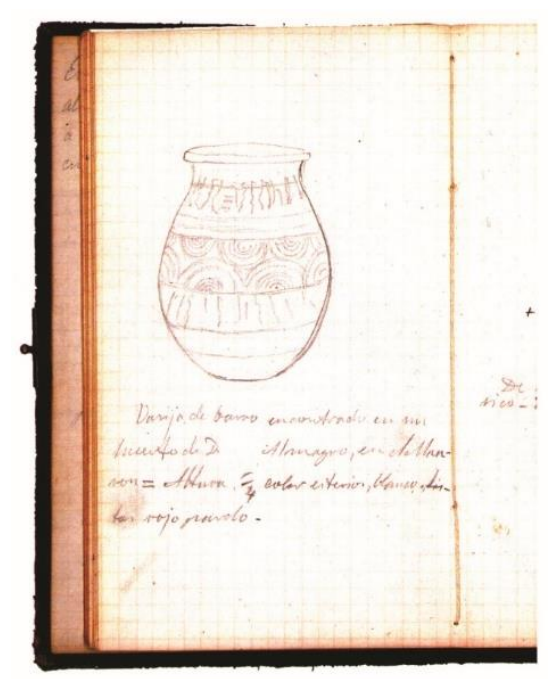

Fig. 9. Dibujo de una de las urnas ibéricas realizado por $M$. GómezMoreno González (Moya 2004: 43). que la entidad de los restos arqueológicos documentados hasta el momento no correspondía a una gran ciudad romana; ese mismo año informó a la Academia de la Historia sobre el descubrimiento de dos vasos de cerámica romana junto al Generalife, un busto de sátiro en la Alhambra y dos cabezas de mujer en el Albaicín, posiblemente de cronología augustea (Góngora 1867: 95-96). Por otro lado, la construcción de una nueva carretera de Atarfe a Pinos Puente en 1868 hizo que se descubrieran en las cercanías de Sierra Elvira varias estructuras y objetos arqueológicos de época romana, entre ellos una moneda de Iliberri.

Ante los descubrimientos en Sierra Elvira y en la Alcazaba la Comisión de Monumentos decidió realizar investigaciones simultáneas en ambos lugares en 1869 para llegar a aclarar la ubicación de Iliberri. Se crearon dos subcomisiones formadas por tres miembros cada una que se encargarían de llevar a cabo las excavaciones. La subcomisión del Albaicín estaba compuesta entre otros por Góngora y Gómez-Moreno González, aunque dicha intervención nunca se realizó por falta de medios y hubo de 
suspenderse. Ello no impidió a Gómez-Moreno González estudiar otros materiales localizados en la ciudad, como dos urnas cinerarias ibéricas documentadas en el Mauror (Fig. 9), que en aquel momento pasaron por romanas, o materiales procedentes de la zona de Cartuja o del mismo Albaicín. En este mismo año la Comisión consiguió acceder y estudiar los materiales procedentes de las excavaciones de Juan de Flores, depositados en los sótanos de la Real Chancillería (Moya 2004: 41-43).

Los hallazgos en Sierra Elvira se fueron sucediendo, y en 1870, a instancias de la Comisión de Monumentos, fueron analizados por Manuel Oliver Hurtado y Manuel Gómez-Moreno González; así lo reflejaron en su Informe sobre varias antigüedades descubiertas en la Vega de esta ciudad (1870). La Comisión decidió excavar la zona entre 1870 y 1872, y posteriormente entre 1875 y 1878, fecha en la que finalizaron los trabajos, siendo en este período cuando tuvieron lugar los hallazgos más importantes (Figs. 10-12). Uno de los principales problemas fue el expolio continuo al que se vio sometido el yacimiento, incentivado en parte por la compra de estos objetos por la Comisión de Monumentos (Malpica 2013: 36$37)$.

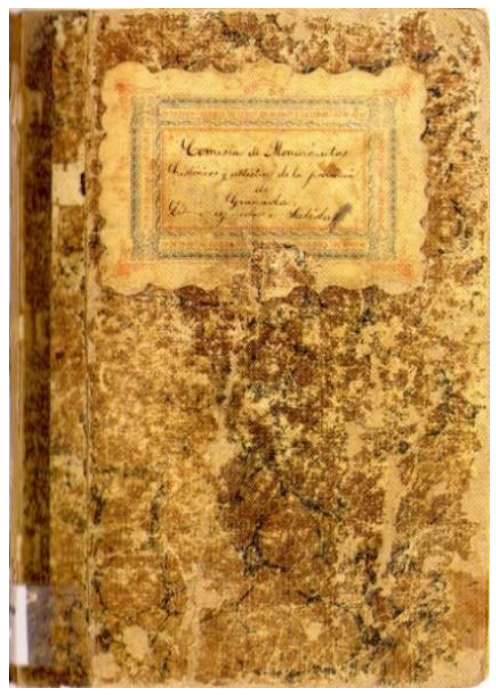

Fig. 10. Cuaderno de la Comisión de Monumentos en el que se registraba todo lo relativo a los hallazgos arqueológicos de Medina Elvira (Malpica 2013: 37).

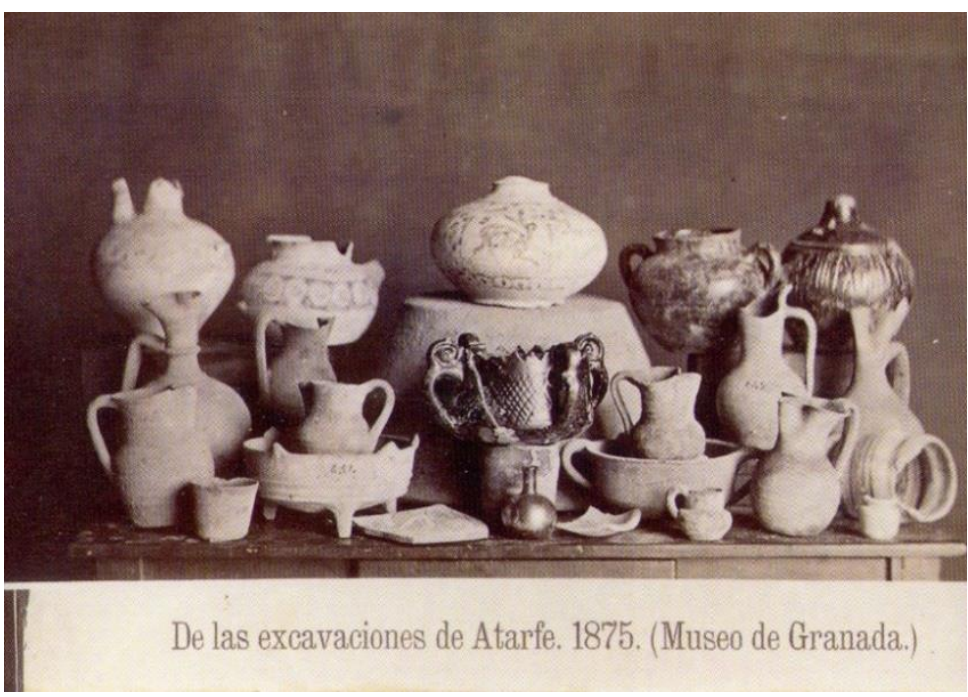

Fig. 11. Imagen con algunas de las piezas documentadas en Medina Elvira durante las excavaciones de 1875 (Malpica 2013: 44).

En estas excavaciones participaron los hermanos Oliver Hurtado (Fig. 13), quienes redactaron una obra bajo el título Iliberri y Granada (1870). En ella reunieron una serie de reflexiones sobre el debate de estos dos asentamientos dirigida a D. Juan Facundo Riaño, historiador y reconocido elvirista. Iliberri fue la antigua población ibérica como reflejaban sus monedas y se asentaba en Sierra Elvira atendiendo a los siguientes argumentos: el origen árabe de los muros más antiguos de la Alcazaba Cadima, y no fenicios o romanos como señalaban algunos autores; las inscripciones romanas documentadas en el Albaicín habían aparecido todas en la misma zona y apiladas, por lo que podrían haber sido trasladadas, ya que la distancia era corta y llana, esgrimiendo la observación de Pascual de Gayangos 'los moros rara vez habitaban en las ciudades romanas, si no que construían otras nuevas con sus ruinas' (Oliver y Hurtado 1870: 21); las excavaciones de Juan de Flores y su actividad delictiva, quién fabricó las falsificaciones con material de Sierra Elvira, además de coincidir con Argote en señalar la supuesta basílica descubierta por Flores como unos baños árabes; el edificio interpretado por Pedraza como un templo frente a San Miguel no era más que un palacio beréber (Oliver y Oliver 1870: 14-39). A estas reflexiones añadieron el listado de autores partidarios de esta corriente elvirista y los recientes descubrimientos localizados allí (Oliver y Oliver 1870: 48-53). Otro volumen de estos hermanos en el que defendían la ubicación de Iliberri en Medina Elvira 
fue Granada y sus monumentos árabes (1875), donde volvían a exponer las mismas reflexiones que ya se han citado.

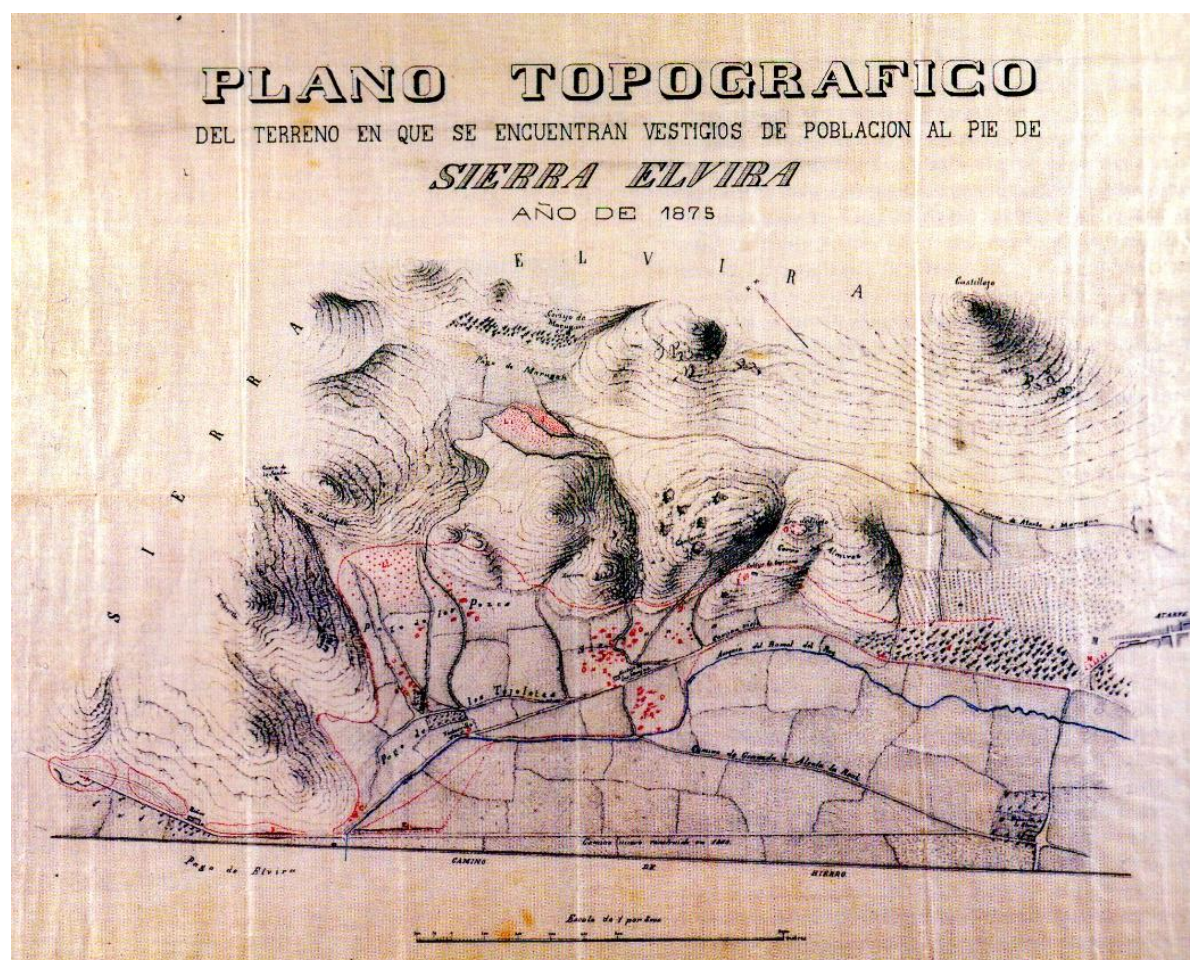

Fig. 12. Plano topográfico de Sierra Elvira realizado por M. Gómez-Moreno González en 1875 (Moya 2004: 58).

En este período en la Comisión de Monumentos existían dos bandos claramente identificados: los elviristas, encabezados por José y Manuel Oliver y Juan Facundo Riaño, defensores de la ubicación de Iliberri en Atarfe; y los alcazabistas, partidarios de que el asentamiento primitivo se situaba en el Albaicín granadino, representados por Francisco Javier Simonet y Manuel de Góngora, quien expresó su postura en su obra Consideraciones acerca del Concilio Iliberitano, primero de los sínodos de España y aurora del triunfo definitivo de la iglesia sobre el gentilismo (1871). En esta división de grupos hubo igualmente 'conversos' que fueron variando su postura al amparo de los nuevos descubrimientos en Sierra Elvira o en Granada. Es el caso de Castro y Orozco (habiendo redactado el informe de los hallazgos de Sierra Elvira de 1842) o del arabista holandés Reinhart Dozy, que pasó de elvirista a alcazabista al leer las obras de Aureliano Fernández-Guerra (1841: 1866 y 1867). La postura del epigrafista Emil Hübner pudo estar influenciada por su amistad con Manuel Rodríguez de Berlanga (reconocido elvirista), y así se observó en su evolución en la que comenzó defendiendo que la antigua ciudad estaba en el Albaicín, para ser partidario después de Sierra Elvira al realizar un viaje a Granada en 1888 acompañando a Berlanga, y finalmente rendirse a la evidencia alcazabista.

Uno de los trabajos de Fernández-Guerra, 'Epigrafía romano-granadina' (1867), fue una carta dirigida a Emil Hübner en la que analizó las inscripciones documentadas en Granada capital desde el siglo XVI; un total de 31 de las cuales 18 habían aparecido en el Albaicín, la última comprada por Manuel de Góngora para el Museo Arqueológico de la ciudad, hallada en la calle María la Miel, además de aludir a las medallas ibéricas y latinas de Iliberri. Esta misma carta fue utilizada textualmente por Juan de Dios de la Rada y Delgado en su Crónica de la provincia de Granada (1869) para defender el asentamiento de Iliberri en el Albaicín. Previamente este autor había presentado una memoria a la Real Academia de la Historia en 1854 bajo el título Situación de la antigua Iliberis, que posteriormente publicó en la revista El Museo Universal (Rada, 1863a, 1863b y 1863c), postulándose en la mencionada defensa. 


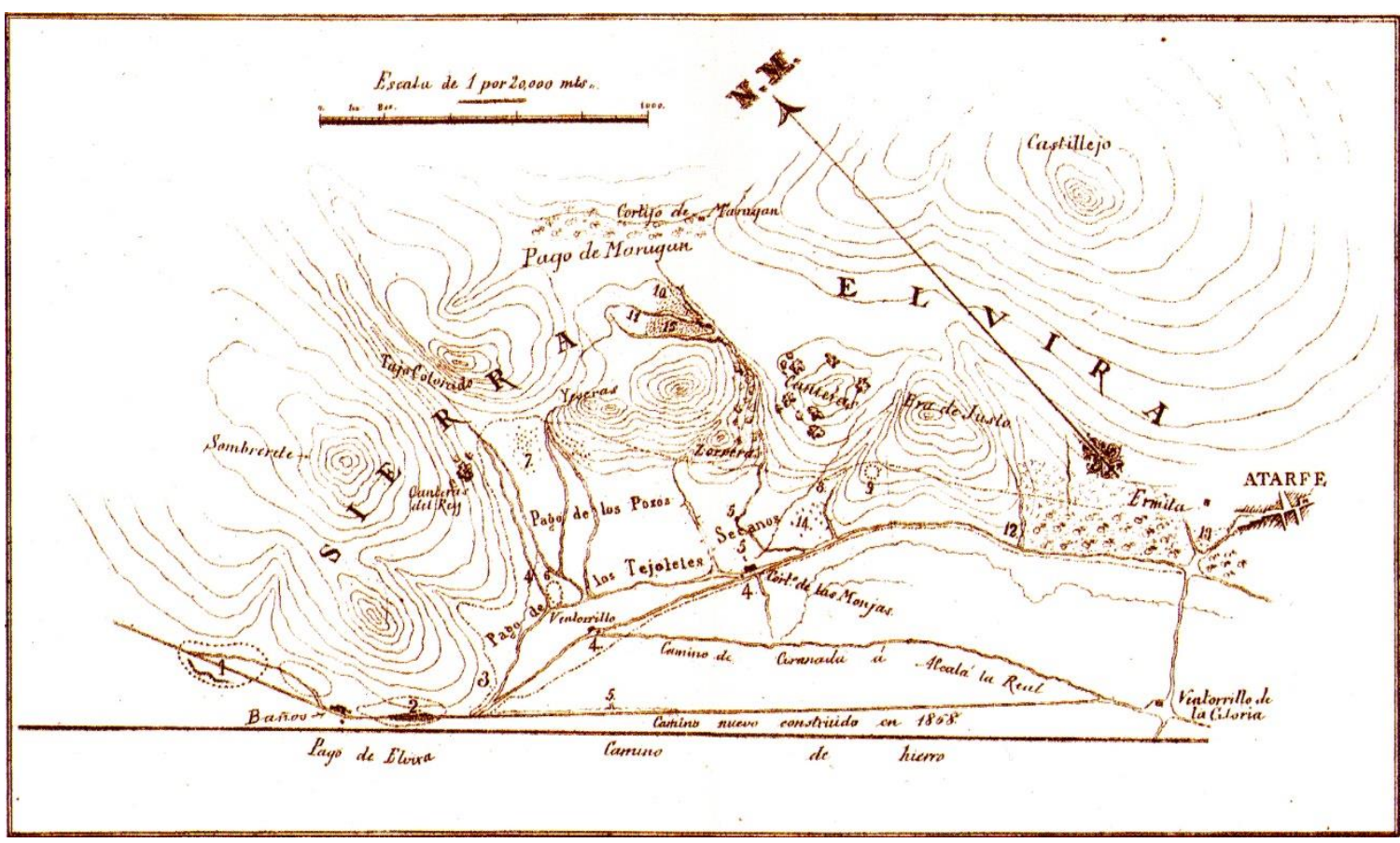

Fig. 13. Mapa con las excavaciones de Sierra Elvira realizado por los hermanos Oliver Hurtado (1875: 617-618).

El arabista Leopoldo Eguílaz y Yanguas defendió también en su obra Del lugar donde fue Iliberis (1881) que Granada e Iliberri eran la misma ciudad separadas por el río Darro y para ello se basó en los textos de numerosos cronistas árabes y en los datos arqueológicos. Para este autor el traslado de la capital sólo supuso cruzar el Darro, y remarcó que la Iliberri de Plinio se localizaba en la Alcazaba Cadima; calificó la Medina Elvira de Atarfe como un lugar sin importancia, que no reunía los requisitos indispensables

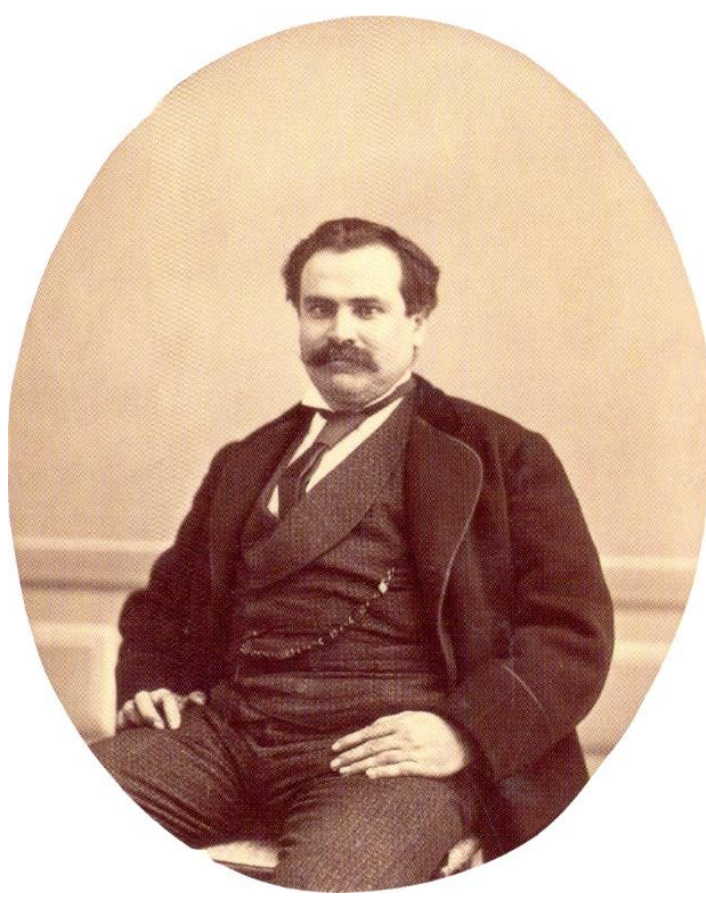

Fig. 14. Retrato de M. Gómez-Moreno González (Malpica 2013: 38). para ser una gran ciudad; $y$ terminó su obra de esta forma: 'Desde Andrea Navaghiero el espíritu escéptico de ciertos arqueólogos viene repitiendo que las inscripciones encontradas en el siglo XVI en el atrio de la basílica iliberitana, han podido ser trasladadas á la alcazaba Cadima desde el inmediato pueblo de Atarfe, sin otra razón que la de ser un sitio cercano. Contra este supuesto, siguen protestando la invención en el centro de la gran ciudad de aquellos enormes cipos, y en letras grandes, gallardas y elegantísimas, los sendos epígrafes en que se lee: Municipium florentinum Iliberritanum.' (Eguílaz 1881: 58).

\subsection{Manuel Gómez-Moreno González y el Centro Artístico de Granada}

Sin embargo, la figura de Manuel Gómez-Moreno González (Fig. 14) fue de las más importantes en esta segunda mitad del siglo XIX, principalmente por el papel que desempeñó en intentar solucionar el debate historiográfico en torno a la localización de Iliberri cuando dicha controversia se encontraba en su máximo apogeo. En la capital buscó evidencias de la importancia de la ciudad romana y eran frecuentes sus escritos a la 
Comisión informando sobre la localización de restos romanos (Moya 2004: 46-47). Por otro lado, participó activamente en la creación y en el desarrollo del Centro Artístico de Granada, institución fundada en 1885 para promover el progreso y la formación de las Bellas Artes granadinas, y que continúa funcionando actualmente (Fernández de Toledo 1989); del mismo modo se creó un Boletín donde se publicaban las actividades del centro y dio la oportunidad a Gómez-Moreno de tratar asuntos arqueológicos (Fig. 15). Es por ello que en 1888 influido por la visita de Hübner y Rodríguez de Berlanga a Granada decidió publicar en once entregas en el Boletín del Centro Artístico todos los descubrimientos y excavaciones realizados en Sierra Elvira a lo largo del siglo XIX bajo el título Medina Elvira. La obra estaba dividida en tres partes: una revisión historiográfica a modo de introducción; en la segunda parte explicaba las excavaciones que se realizaron entre 1842 y 1875 ; y un último apartado de conclusiones en el que señaló la existencia de un poblamiento romano en Sierra Elvira llamado Castilia o Castala, que luego pasó a llamarse Medina Elvira en época musulmana, diferente de Iliberri ubicada en la Alcazaba Cadima. También incluyó dos apéndices en los que explicaba los descubrimientos sobre un plano (Fig. 12) y un catálogo con los objetos documentados con sus correspondientes dibujos. La novedad de esta obra era que basaba sus hipótesis sobre datos arqueológicos claramente presentados y no sobre fuentes escritas, como se había hecho hasta el momento, para intentar resolver el problema de la antigua ciudad. Simonet llegó a opinar que con esta investigación se daba por concluido dicho debate historiográfico (Moya 2004: 122).

Al año siguiente de la publicación Gabriel de Burgos Torrens, aficionado a la arqueología y dueño del haza cercana al Cortijo de las Monjas de Atarfe, publicó una serie de artículos en el Boletín del Centro Artístico de Granada en los que criticaba la postura de Gómez-Moreno González respecto a Iliberri, ya que ésta según él sólo se basaba en el cambio de opinión de Dozy, de elvirista a alcazabista, y terminó aludiendo al fraude de las excavaciones de Juan de Flores para justificar la antigüedad de Sierra Elvira frente a Granada (Burgos 1889a, 1889b, 1889c y 1889d).

Igualmente, el Centro Artístico permitió a finales de 1889 a Gómez-Moreno González dar una serie de conferencias sobre 'Arqueología granadina' cuyo tema central era el emplazamiento de Iliberri y el estudio de los diferentes materiales documentados en Granada. El principal argumento que utilizaba para defender su hipótesis alcazabista era la localización de monumentos epigráficos iliberitanos en varios puntos del Albaicín. El Boletín de dicha institución publicó resúmenes de estas conferencias en la 'Crónica del Centro', redactados por su hijo Manuel Gómez-Moreno Martínez (1889a, 1889b y 1889c), quien también editó en este medio su trabajo Monumentos romanos y visigóticos de Granada (1889d, 1890a y 1890b), recopilación de todos los hallazgos arqueológicos documentados hasta el momento en la ciudad. De igual modo, en este período fue elaborada por un miembro de la Comisión, Antonio Almagro y Cárdenas, la obra manuscrita Curiosidades del pueblo de Atarfe y ruinas de Elvira (1890), donde advertía que la ubicación de Iliberis en la Alcazaba Cadima estaba más que demostrada (Granados y Espinar 2013).

Sin duda uno de los grandes proyectos de Gómez-Moreno González fue la Guía de Granada (1892), donde recopiló las investigaciones de treinta años de trabajo; más que una guía fue una historia del arte de la ciudad como ya advirtió

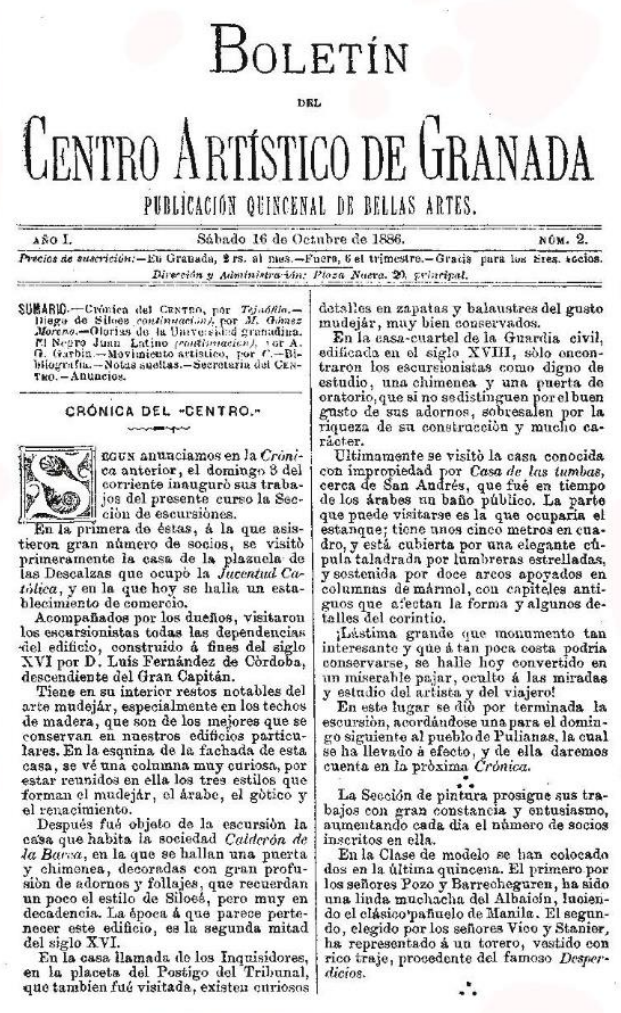

Fig. 15. Portada del Boletín del Centro Artístico de Granada. 
el propio autor en el prólogo de la obra. Respecto a la antigüedad de la urbe defendió el origen ibérico de Iliberri, desvinculándose de las corrientes orientalistas. Hay que tener en cuenta que el estudio de la cultura ibérica comenzó en esta segunda mitad del siglo XIX cuando se dieron a conocer diversos hallazgos ibéricos en diferentes puntos de la Península Ibérica, siendo el arqueólogo francés Pierre Paris el primero en ordenar y clasificar como ibéricos los elementos arquitectónicos y los restos de cultura material que habían aparecido hasta entonces (Almagro Basch 1975: 2-3). A lo largo del discurso de la Guía anotó lugares en los que se habían documentado restos arqueológicos en diversos puntos de la ciudad y respecto a las murallas y puertas de la Alcazaba antigua señaló que habían sido tenidas por romanas y aun fenicias, pero él defendía que fueron construidas en época árabe (Gómez-Moreno González 1892: 436). En la descripción que hizo del barrio del Albaicín dedicó un apartado a los descubrimientos romanos hallados en las excavaciones de Juan de Flores (Fig. 16), donde se documentó un gran edificio que anotó podría ser parte del foro de la ciudad romana (Gómez-Moreno González 1892: 438-443).

Otro artículo de Gómez-Moreno González en el que informó sobre nuevos descubrimientos en el Albaicín fue publicado en el periódico El Defensor de Granada (9 de septiembre de 1897). En él hacía referencia

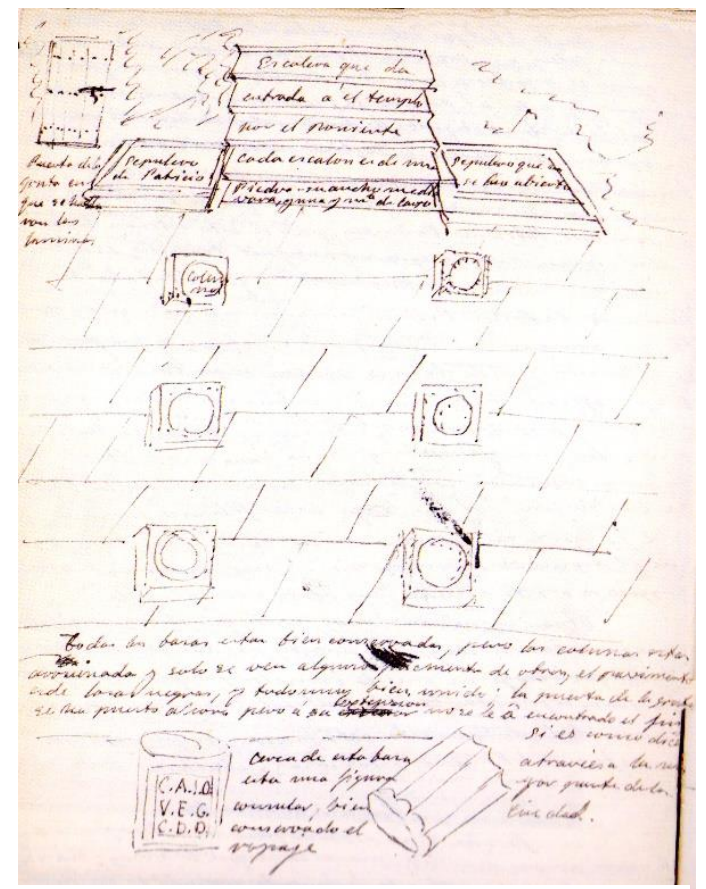

Fig. 16. Copia de M. Gómez-Moreno González de un dibujo con los descubrimientos documentados en el siglo XVIII tras las excavaciones de Flores (Moya 2004: 57). a los descubrimientos de 1895 en este barrio de Granada, defendió su postura, criticó a los elviristas hermanos Oliver que opinaban que lo documentado en la Alcazaba no era más que las ruinas de un baño árabe con inscripciones romanas empotradas en sus muros, y concluyó con estas palabras: ' ...hubo un pueblo romano en la demarcación de las antiguas parroquias de S. José, S. Miguel y S. Nicolás. Cuál fuera este pueblo, claramente lo pregonan diez de las veintidos inscripciones auténticas registradas en la Alcazaba: la antigua ciudad ibera de Iliberri, que bajo el dominio romano fue Municipio Florentino Iliberritana, acuñó monedas desde sus más remotos tiempos hasta el de los godos, y donde se celebró el importante Concilio del siglo IV.' (Gómez-Moreno González, 9 de septiembre de 1897).

M. Gómez-Moreno González frecuentemente contó con la colaboración de su hijo, M. Gómez-Moreno Martínez, quien, consciente de que el debate historiográfico sobre Iliberri había llegado a su máximo apogeo en la segunda mitad del siglo XIX, publicó en 1905 'De Iliberri a Granada', artículo en el que aportó a través de una revisión metódica de los cronistas árabes una interesante explicación acerca de la identificación de la ciudad de Granada y Elvira en la Antigüedad y en la Edad Media.

Muchos investigadores vieron en este artículo el fin del conocido debate en el que quedaba demostrado que Iliberri era la antigua ciudad de la actual Granada. La errónea interpretación de los cronistas árabes junto a las noticias de viajeros e historiadores desde el siglo XVI había sido el origen de este malentendido, que no todos terminaron de asumir.

La escasa repercusión que tuvo en estos momentos el artículo de Gómez-Moreno Martínez (1905) se reflejó en la Guía de Granada. Historia, descripciones, arte, costumbres investigaciones arqueológicas (1906) de Francisco de Paula Valladar. En su discurso abordó el tema de la ubicación de Iliberri, y al citar las ruinas de Sierra Elvira anotó 'Iliberis ó Elvira', aunque al considerar falsos todos los hallazgos del Sacromonte y del Albaicín, incluidos los vestigios romanos, estaba mostrando su opinión respecto al 
conflicto (Valladar 1906: 529-531), y concluyó con estas palabras: 'Solamente algún descubrimiento decisivo es el que puede resolver esta cuestión; entre tanto debiera procurarse reanudar las excavaciones en la antigua Iliberis de la falda de Sierra-Elvira.' (Valladar 1906: 531).

\section{Iliberri y el Albaicín: la confirmación arqueológica}

A partir del siglo XX el debate siguió vigente, aunque sin la importancia de las centurias anteriores, porque como se ha anotado anteriormente, las obras de los Gómez-Moreno sirvieron para dotar de una base científica esta controversia y poner de acuerdo a la mayoría de los intelectuales, como así lo demostró Antonio Gallego y Burín en sus guías de la ciudad de Granada: 'Carece de base científica la teoría sostenida por algunos escritores de que Iliberis fue la misma ciudad musulmana de Elvira situada al pie de la Sierra de este nombre. En Elvira no se ha hallado inscripción ninguna de Iliberis y sí en Granada, donde no se encuentran de otra ciudad y es ley arqueológica que el nombre de ésta lo revelan las inscripciones halladas en sus ruinas. Pensar y afirmar, como algunos lo hacen, que los árabes se trajeron a Granada los materiales de la destruida Elvira para aprovecharlos en la construcción de la ciudad nueva, es el mayor de los dislates, rechazado por los hechos y por la critica moderna, apoyada además en el testimonio de los más antiguos geógrafos árabes que señalan a Granada como la más antigua ciudad del término de Elvira, capital suya y asiento de la Sede episcopal, es decir, como Iliberis misma.' (Gallego 1961: 55).

Pero no fue hasta la década de los años 80 del siglo XX cuando se realizaron los primeros estudios propiamente arqueológicos y que proporcionarían una nueva información sobre el antiguo tema del solar de la antigua ciudad ibérica y romana de Iliberri, objeto de uno de los capítulos de discusión más importantes de la Historia de Granada en los últimos siglos, como ya se ha venido exponiendo a lo largo del presente artículo. Es por ello que en 1985 comenzó su andadura el Proyecto de Investigación 'La ciudad iberorromana y medieval de Granada' (Moreno et al. 1993: 1994 y 1995; Roca et al. 1988), que pretendía indagar en los orígenes del asentamiento iliberitano ante el desconocimiento en el que estaba sumida la arqueología en Granada. A éste le siguió en 1993 el 'Proyecto de Arqueología Urbana de Granada' (PAUG), cuyo objetivo residía en planificar todas las excavaciones que se hicieran en la ciudad para conseguir así resultados científicos óptimos, centrándose sobre todo en el estudio de la ciudad ibérica y romana (Contreras et al. 1999). A pesar del éxito en el volumen de las intervenciones, este modelo de ejercer la arqueología urbana concluyó a finales de 1996, y desde ese momento se produjo una cierta profesionalización de la actividad arqueológica sin el respaldo de ninguna institución.

Actualmente, tras más de 30 años de intervenciones arqueológicas en el barrio del Albaicín se ha podido demostrar que fue la sede de la primitiva ciudad gracias a la existencia de un oppidum ibérico (Adroher 2014; Adroher et al. 2005; Sánchez Moreno 2016) y de una posterior ciudad romana bajo dicho suelo (Orfila 2008 y 2011), con evidencias que dejan clara la ubicación de Iliberri en la ciudad de Granada.

\section{BibLIOGRAFÍA}

Adroher Auroux, A. Mạ. (2014), Granada antes de Granada. Origen, desarrollo y romanización en el oppidum de lliberri. Cuadernos de los Amigos del Museo de Osuna 16: 74-81.

Adroher Auroux, A. Ma .; Caballero Cobos, A.; Sánchez Moreno, A. (2005), 'El oppidum ibérico de IlturirIliberri', en C. Vílchez Vílchez, I. de la Torre Castellano y A. N. Adroher Auroux (coords.), Los vidrios griegos en Granada, Granada: 75-88.

Almagro Basch, M. (1979), Los orígenes de la Toreútica Ibérica. Trabajos de Prehistoria 36: 173-212.

Almagro y Cárdenas, A. (1890), Curiosidades del pueblo de Atarfe y ruinas de Elvira, Granada.

Alonso Rodríguez, Ma . del C. (1992), Las excavaciones arqueológicas en el siglo XVIII: el descubrimiento de las ciudades de Herculano, Pompeya y Estabia. Cuadernos de Ilustración y Romanticismo: Revista del Grupo de Estudios del siglo XVIII 3: 205-214. 
Alonso Rodríguez, Mạ. del C. (2012), La política cultural del reino de las Dos Sicilias y la publicación de los descubrimientos arqueológicos. Revista de historiografía (RevHisto) 17: 65-74.

Argote, S. de (1805-1807), Nuevos paseos históricos, artísticos, económicos-políticos por Granada y sus contornos, Edición facsímil 1985, Granada.

Bermúdez de Pedraza, F. (1608), Antigüedades y Excelencias de Granada, Granada.

Burgos Torrens, G. de (1889a), Cuestiones de crítica histórica I. Boletín del Centro Artístico de Granada 65: 150-151.

Burgos Torrens, G. de (1889b), Cuestiones de crítica histórica II. Boletín del Centro Artístico de Granada 66: 159-161.

Burgos Torrens, G. de (1889c), Cuestiones de crítica histórica III. Boletín del Centro Artístico de Granada 68: $176-179$.

Burgos Torrens, G. de (1889d), Cuestiones de crítica histórica IV. Boletín del Centro Artístico de Granada 69: 185-187.

Calatrava Escobar, J. (2000), Un retrato de Granada a principios del siglo XIX: los 'Nuevos paseos' de Simón de Argote. Demófilo: Revista de cultura tradicional 35: 95-110.

Castro y Orozco, J. de (1839), Fisonomía histórica de Granada. La Alhambra, periódico de ciencias, literatura y bellas artes 1: 1-3.

Castro y Orozco, J. de (1865), 'Examen de las antigüedades de Sierra Elvira. Memoria presentada a la Real Academia de la Historia en 1842' en Obras poéticas y literarios de D. José de Castro y Orozco, marqués de Gerona, de la Real Academia de Ciencias Morales y Políticas, Madrid: 7-88.

Ceán Bermúdez, J. A. (1832), Sumario de las antigüedades romanas que hay en España, en especial las pertenecientes a las Bellas Artes, Madrid.

Contreras Cortés, F.; Molina González, F. y Moreno Onorato, M. A. (1999), 'La defensa de la ciudad como yacimiento arqueológico: los proyectos de arqueología urbana', en XXV Congreso Nacional de Arqueología, Valencia: 275-279.

Corte y Ruano, M. de la (1843a), Antigüedades Españolas: Descubrimiento de la Sierra Elvira. Semanario Pintoresco Español 3: 20-22.

Corte y Ruano, M. de la (1843b), Antigüedades Españolas: Descubrimiento de la Sierra Elvira. Semanario Pintoresco Español 5: 35-37.

Corte y Ruano, M. de la (1843c), Antigüedades Españolas: Descubrimiento de la Sierra Elvira. Semanario Pintoresco Español 6: 43-44.

Eguílaz y Yanguas, L. (1881), Del lugar donde fue lliberis, Edición facsímil 1987, Granada.

Espinar Moreno, M.; Quesada Gómez, J. J.; Amezcua Pretel, J. (1995), Medina Elvira. Los primeros descubrimientos de Sierra Elvira. Materiales para el estudio de la arqueología granadina. En la España medieval 18: 9-38.

Fernández de Toledo, T. (1989), El Centro Artístico, Literario y Científico de Granada (su labor científica): 1885-1989, Granada.

Fernández-Guerra y Orbe, A. (1841), Notas para la historia de Granada. La Alhambra, periódico de ciencias, literatura y bellas artes 4/3: 25-30.

Fernández-Guerra y Orbe, A. (1866), Inscripciones cristianas y antiguos monumentos del arte cristiano español. El Arte en España 5: 73-87.

Fernández-Guerra y Orbe, A. (1867), Epigrafía romano-granadina, Carta de Don Aureliano Fernández Guerra. Revista de Bellas Artes y Arqueología 44: 352-357.

Gallego Burín A. (1961), Granada. Guía artística e histórica de la ciudad, Edición facsímil 1982, Granada. García Mercadal, J. (1952), Viajes de extranjeros por España y Portugal. Tomo I Siglo XVI: Desde los tiempos más remotos hasta fines del Siglo XVI, Madrid.

Giménez Serrano, J. (1846), Manuel del artista y del viajero en Granada, Edición facsímil 1981, Granada. 
Gómez-Moreno González, M. (1888a), Medina Elvira. Boletín del Centro Artístico de Granada 37: 107110.

Gómez-Moreno González, M. (1888b), Medina Elvira, Edición Facsímil 1986, Granada.

Gómez-Moreno Martínez, M. (1889a), Crónica del Centro. Boletín del Centro Artístico de Granada 75 : 17-19.

Gómez-Moreno Martínez, M. (1889b), Crónica del Centro. Boletín del Centro Artístico de Granada 76: 25-26.

Gómez-Moreno Martínez, M. (1889c), Crónica del Centro. Boletín del Centro Artístico de Granada 78: 4142.

Gómez-Moreno Martínez, M. (1889d), Monumentos romanos y visigóticos de Granada, Edición facsímil 1988, Granada.

Gómez-Moreno Martínez, M. (1890a), Monumentos romanos y visigóticos de Granada. Boletín del Centro Artístico de Granada 83: 81-87.

Gómez-Moreno Martínez, M. (1890b), Monumentos romanos y visigóticos de Granada. Boletín del Centro Artístico de Granada 87: 113-118.

Gómez-Moreno González, M. (1892), Guía de Granada, Edición Facsímil 1982, Granada.

Gómez-Moreno González, M. (1897, 9 de septiembre), La Alcazaba. El Defensor de Granada 9.761.

Gómez-Moreno Martínez, M. (1905), De lliberri a Granada. Boletín de la Real Academia de la Historia 46/1: 44-61.

Góngora y Martínez, M. de (1871), Consideraciones acerca del Concilio lliberitano, primero de los sínodos de España y aurora del triunfo definitivo de la iglesia sobre el gentilismo, Granada.

Hidalgo Morales, J. (1842), Iliberia o Granada. Memoria histórica-crítica, topográfica, cronológica de sus antigüedades, Granada.

Lafuente Alcántara, M. (1842), Antigüedades romanas recientemente descubiertas en Sierra Elvira. Conjeturas sobre la posición de la antigua lliberis. Examen de las opiniones de Bermúdez de Pedraza. La Alhambra, periódico de ciencias, literatura y bellas artes, Serie II, Tomo I: 132-140.

Lafuente Alcántara, M. (1843a), Historia de Granada, comprendiendo las de sus cuatro provincias Almería, Jaén, Granada y Málaga, desde remotos tiempos hasta nuestros días, Tomo I, Granada.

Lafuente Alcántara, M. (1843b), El libro del viajero en Granada, Madrid.

Luque Moreno, J. (1994), Granada en el siglo XVI: Juan de Vilches y otros testimonios de la época, Granada.

Malpica Cuello, A. (2013), Mil años de Madinat Ilbira, Granada.

Mármol Carvajal, L. del (1600), Historia de la rebelión y castigo de los moriscos, Málaga.

Molina Fajardo, E. (1979), Historia de los periódicos granadinos (siglos XVIII y XIX), Granada.

Mora Rodríguez, G. (1998), Historias de Mármol: La arqueología clásica española en el siglo XVIII, Anejos de Archivo Español de Arqueología 18, Madrid.

Moreno Onorato, M. A.; Burgos Juárez, A. y Casado Millán, P. J. (1993), ‘Proyecto: la ciudad iberorromana y medieval de Granada. Consideraciones generales', en Investigaciones arqueológicas de Andalucía. 1985-1992. Proyectos, Huelva: 661-668.

Moreno Onorato, M. A.; Burgos Juárez, A. y Orfila Pons, M. (1995), 'Evolución del núcleo urbano de lliberri. El Albaicín, Granada', en V. M. Oliveira Jorge (coord.), 1o Congreso de Arqueología Peninsular, Oporto, 1993, vol. 5, Trabalhos de Antropologia e Etnologia, 35/1: 169-178.

Moreno Onorato, M. A.; Orfila Pons, M.; Roca Roumens, M. y Sotomayor Muro, M. (1994), 'Iliberri. Estudio de la ciudad ibero-romana ubicada en el barrio del Albaicín, Granada', en X. Dupré Raventós (coord.), La Ciudad en el Mundo Romano. Actas del XIV Congreso Internacional de Arqueología Clásica, Tarragona, 1993, vol. 2: 295-297.

Moreno y Bernedo, V. (1842), Acta de la Junta de Gobierno del 24 de abril de 1842. La Alhambra, periódico de ciencias, literatura y bellas artes. Serie II, I: 129-131. 
Moya Morales, J. (2004), Manuel Gómez-Moreno González. Obra dispersa e inédita, Granada.

Navagero, A. (1563), Viaje por España (1524-1526), Edición 1983, Madrid.

Oliver y Hurtado, M.; Gómez-Moreno González, M. (1870), Informe sobre varias antigüedades descubiertas en la Vega de esta ciudad, Granada.

Oliver y Hurtado, J. y Oliver y Hurtado, M. (1870), Iliberri y Granada, Madrid.

Oliver y Hurtado, J. y Oliver y Hurtado, M. (1875), Granada y sus monumentos árabes, Málaga.

Orfila Pons, M. (2008), Granada en época romana: Florentia lliberritana, Granada.

Orfila Pons, M. (2011), Florentia lliberritana. La ciudad de Granada en época romana, Granada.

Peñalver y López, N. (1842), Cementerio de Sierra Elvira. La Alhambra, periódico de ciencias, literatura y bellas artes, Serie II, Tomo I, 5: 145-159.

Pérez de Hita, G. (1595-1609), Historia de las bandas de los zegríes, caballeros moros de Granada, y de las guerras que hubo en ella, Zaragoza-Cuenca.

Rada y Delgado, J. de D. de la (1863a), Estudios arqueológicos. Situación de la antigua Illiberis I. El Museo Universal 7/25: 194-195.

Rada y Delgado, J. de D. de la (1863b), Estudios arqueológicos. Situación de la antigua Illiberis II. El Museo Universal 7/28: 219-220

Rada y Delgado, J. de D. de la (1863c), Estudios arqueológicos. Situación de la antigua Illiberis III. El Museo Universal, 7/29: 230-23.

Rada y Delgado, J. de D. de la (1869), Crónica de la provincia de Granada, en Crónica General de España, Madrid.

Roca Roumens, M.; Moreno Onorato, M. A.; Lizcano Prestel, R. (1988), El Albaicín y los orígenes de la ciudad de Granada, Monográfica Arte y Arqueología, 2, Granada.

Rodríguez Aguilera, A. (2011), 'Excavación arqueológica en María la Miel, 11', en M. Orfila Pons (ed), Florentia lliberritana. La ciudad de Granada en época romana, Granada: 100-101.

Salas Álvarez, J. (2010), La recuperación del patrimonio arqueológico de Andalucía durante la llustración (1736-1808), Tesis doctoral, Universidad de Sevilla.

Sánchez López, E.; Marín Díaz, P. (2012), 'La llíberris de Flores versus Florentia lliberritana', en En torno a la Granada falsificada, Granada: 17-76.

Sánchez Moreno, A. (2016), La formación del oppidum ibérico de lliberri y la evolución diacrónica de su territorio, Tesis doctoral, Universidad de Granada.

Segundo de Pineda, M. (1842), Observaciones al programa conjeturas sobre la posición de llíberis, y examen de las opiniones de Bermúdez de Pedraza. La Alhambra, periódico de ciencias, literatura y bellas artes, Serie I, Tomo II, 7: 193-203.

Sotomayor Muro, M. (1988), Cultura y picaresca en la Granada de la llustración. D. Juan de Flores y Oddouz, Granada.

Sotomayor Muro, M. (2007), D. Juan de Flores y Oddouz pícaro y mártir. Cultura y picaresca en la Granada de la llustración, Granada.

Sotomayor Muro, M. (2008), '¿Dónde estuvo lliberri? Una larga y agitada controversia ya superada', en M. Orfila Pons (coord.), Granada en época romana: Florentia lliberritana, Granada: 23-32.

Sotomayor Muro, M. y Orfila Pons, M. (2004), 'Un paso decisivo en el conocimiento de la Granada romana (Municipium Florentinum Iliberritanum)'. Archivo Español de Arqueología 77: 1-17.

Sotomayor Muro, M. Y Orfila Pons, M. (2006), D. Juan de Flores y el Carmen de la Muralla en el Albaicín. Florentia lliberritana 17: 411-431.

Sotomayor Muro, M. y Orfila Pons, M. (2011), El Foro de la Granada romana. Planos, plantas, alzados y dibujos. Cuadernos de Prehistoria y Arqueología de la Universidad de Granada 21: 349-403.

Sotomayor Muro, M.; Sola Márquez, A. y Choclán Sabina, C. (1984), Los más antiguos vestigios de la Granada íbero-romana y árabe, Granada. 
Valladar y Serrano, F. de P. (1906), Guía de Granada. Historia, descripciones, arte, costumbres, investigaciones arqueológicas, Edición facsímil 2000, Granada.

Velázquez de Echevarría, J. (1764), Paseos por Granada y sus contornos, Granada. 


\title{
Apuntes para una historiografía de la arqueología en la ciudad de Guadix (Granada). Entre los mitos y la realidad
}

\author{
Antonio López García* y Antonio Reyes Martínez** \\ * Real Academia de España en Roma \\ ** LAAC (Laboratorio de Arqueología y arquitectura de la ciudad. Granada)
}

\section{La Historiografía de Guadix}

La ciudad de Guadix se sitúa al Noreste de la provincia de Granada y actualmente es la cabecera comarcal de un territorio del que forman parte 32 municipios. Desde el punto de vista geográfico la ciudad se sitúa en una de las hoyas que conforman la cadena de depresiones que se intercalan en las Cordilleras Béticas y está circundada por Sierra Nevada, la Sierra de Baza, Sierra Arana y el Mencal. Su altitud media, próxima a los 950 metros, que le da ese carácter de altiplanicie.

Esta zona reúne en una escasa franja territorial gran cantidad de yacimientos arqueológicos que arrancan desde la Prehistoria y cuyo fulgurante pasado llamó tempranamente la atención de los investigadores, especialmente desde el siglo XVI hasta la actualidad.

Fray Diego de Guadix (Moreno 2007) es uno de estos primeros autores que analiza con cierto detenimiento la historia de Guadix en su famoso diccionario de arabismos de 1593. El profundo conocimiento que este franciscano posee sobre Guadix se explica por ser su ciudad natal y el lugar en el que vivió parte de su vida como religioso.

A partir de este momento encontrarnos citas, descripciones, alusiones e interpretaciones más o menos extensas sobre Guadix, procedentes de viajeros, geógrafos, historiadores y eruditos en general, que con mayor o menor fortuna tratan de analizar la historia de Guadix basado en el puzle compuesto por epígrafes,

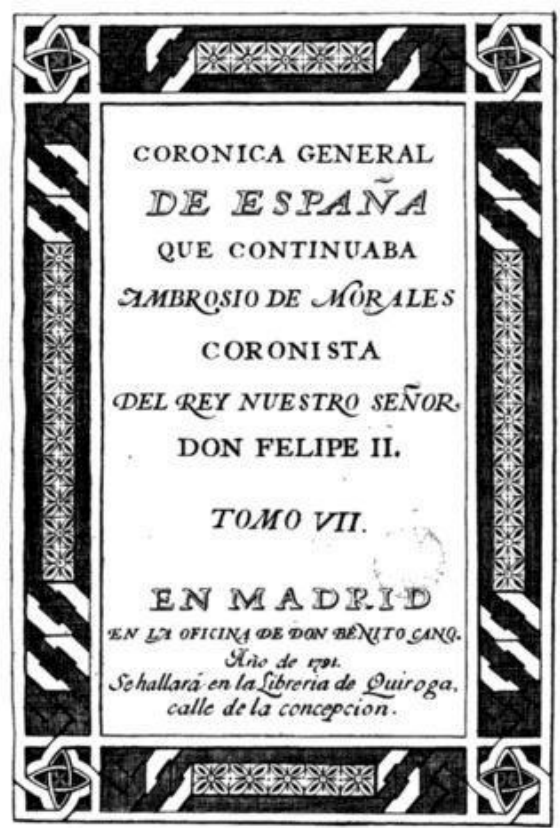

Fig. 1. Crónica General de España de Ambrosio de Morales (1574). monedas, cerámicas, restos arqueológicos en general o citas de escritores latinos y árabes. Como es natural la línea que separa la ciencia de la ficción es muy delgada y no todos los que han escrito sobre esta ciudad han optado por lo científico: a veces la ausencia de datos ha sido suplida con leyendas más o menos inverosímiles o fabulosas. En esta línea el geógrafo holandés Jean Blaeu sitúa en su 'Atlas Maior', publicado en 1662, la fundación de Acci en el año 1000 a.C. por los fenicios, en concreto por Pigmalión regente de Tiro y hermano de la fundadora mítica de Cartago (Blaeu 1662).

Ambrosio de Morales, historiador, arqueólogo y cronista del reino, en su 'Crónica General de España' publicada en 1574, fija la demarcación del obispado y al relatar la historia de San Torcuato y los Varones Apostólicos describe brevemente la ciudad romana, mezclando la tradición con los datos eruditos conocidos del momento. Hace referencia al culto a Netón, siguiendo la cita de Macrobio y finalmente describe una lápida existente en Guadix dedicada a Julia Mammea, cristiana y madre del emperador Marco Aurelio (Morales 1574). En el tomo VI de la Crónica cita a los sucesivos obispos visigodos que pastorearon la diócesis y que acudieron a los concilios toledanos. 
En 1696 Pedro Suárez de Cazalilla, sacerdote e historiador accitano, publica en Madrid su 'Historia del Obispado de Guadix'. Aunque el mismo autor alerta de que su obra no es un estudio histórico sino eclesiástico, ofrece al lector una síntesis de la evolución de la ciudad desde su fundación, realizando una minuciosa disertación de las diferentes épocas, especialmente la romana y la musulmana. De la etapa romana se detiene en analizar la ciudad, toda la epigrafía conocida, las citas de los autores clásicos, dedicando especial atención a una de las discusiones historiográficas más enconadas hasta hace poco, como es la llegada del cristianismo a la Península Ibérica, que según la tradición fue de la mano de los varones apostólicos (Suárez 1696).

El controvertido erudito Enrique Flórez publica 'La España Sagrada' en 1766, una extensa obra en la que él se encargó de los primeros 29 volúmenes. El volumen VII titulado "De las Iglesias sufragáneas antiguas de Toledo", incluía las diócesis de Acci, Arcávica, Basti, Reacia, Bigastro, Cástulo, Compluto, Dianio, Elotana Ilici, Mentesa, Oreto y Osma, con algunos apéndices que incluyen por ejemplo 'La vida de San Fandila', santo local martirizado en Córdoba en el siglo IX.

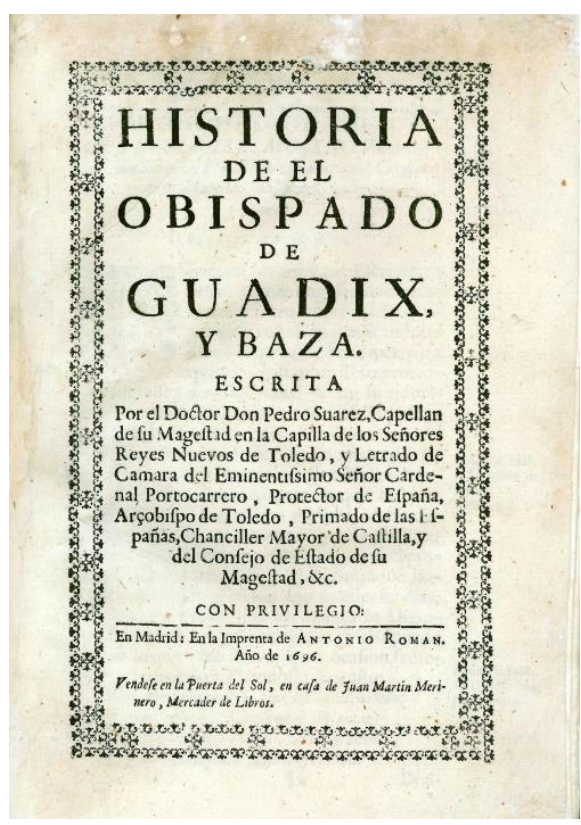

Fig. 2. Historia del Obispado de Guadix y Baza de Pedro Suárez (1696).

En el capítulo dedicado a la diócesis accitana llega de forma sorprendente a concluir que el Acci romano no se encuentra bajo la actual ciudad de Guadix, sino en un punto entre ésta y un municipio próximo llamado Benalua (Flórez 1766). Él llega a esta conclusión analizando los textos, probablemente legendarios, de la predicación de San Torcuato en Guadix en el siglo I. La tradición cuenta que llegando este varón apostólico y sus compañeros a Acci fueron perseguidos por los romanos. Estos enviados apostólicos consiguen escapar por un puente próximo a la ciudad, que se vendrá abajo una vez que ellos

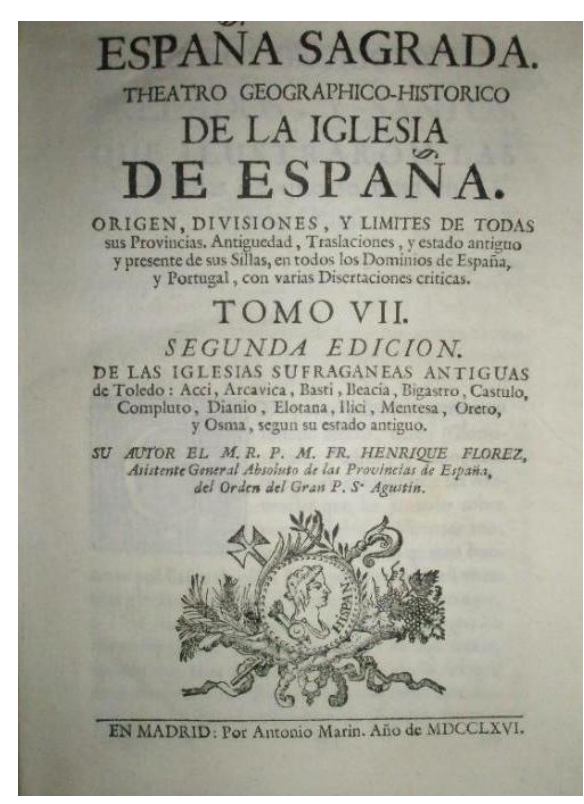

Fig. 3. La España Sagrada de Enrique Flórez (1776). estén a salvo, a la vez que provoca el ahogamiento de los perseguidores. Este suceso fue interpretado por el resto de la población como un milagro y a partir de este instante los accitanos se convirtieron a la nueva religión. A Enrique Flórez no le cuadra la posición del puente y el río con respecto a la ciudad actual de Guadix y busca un antiguo puente sobre el río Fardes, en el municipio de Benalua, donde descubre las ruinas de una fortificación que hoy está plenamente identificada como un hisn de época emiral.

Juan Agustín Ceán Bermúdez, historiador del arte y anticuario, insiste en la misma idea de Flórez y señala: 'Guadix El Viejo, despoblado de la provincia de Granada, distante cinco cuartos de legua al noroeste de la ciudad de Guadix y uno del rio Fardes. Aquí fue donde estuvo la ciudad de Acci, colonia Gemela Julia, en la región de los bastitanos; y aquí estableció Augusto los veteranos de la legión VI, y Tiberio los de la legión III, por lo que se llamó Gemela, y fue inmune'. 'Se conservan en este despoblado las ruinas y vestigios de su antigua población, con cuyas piedras labradas y con las del antiguo puente sobre el dicho rio se construyó el nuevo Guadix, ciudad episcopal, á la que se trasladaron varias lápidas con inscripciones romanas' (Ceán Bermúdez 1832:81). 
A nivel de campo los eruditos más o menos formados que trabajan en Guadix a las órdenes de la Comisión de Antigüedades desarrollan una labor centrada principalmente en la identificación y documentación de yacimientos y en la puesta a buen recaudo de epígrafes, cerámicas y restos arqueológicos de interés. Ello se deduce de la correspondencia cruzada entre la comisión y estos eruditos, que en la mayoría de las ocasiones se limitan a responder a los cuestionarios que se envían desde Madrid, realizar calcos de epígrafes, describir cerámicas, monedas, etc., sin profundizar demasiado en el contexto histórico ni en otro tipo de problemáticas arqueológicas o interpretativas. Esto no quiere decir que los conocimientos de los encargados de recoger la información fueran personas con escasa formación, sino que el objetivo más acuciante en esos momentos era documentar para salvaguardar, dado que había muchos monumentos que corrían serio peligro de desaparición por venta, demolición o expolio. Sirva como ejemplo esta noticia recogida en las actas de sesiones de la Real Academia de la Historia: 'En el año de mil ochocientos veinte y ocho se descubrió un pavimento mosaico en el término de la ciudad de Guadix, como media legua al poniente de la ciudad, en el cerro Doraique, junto al pago llamado de Mahoma, entre los caminos que se dirigen a Purullena y a la aldea de Bejarín. Tenía de longitud veinte y una varas, y cinco de latitud (18 $\mathrm{m}$ de largo por $4 \mathrm{~m}$ de

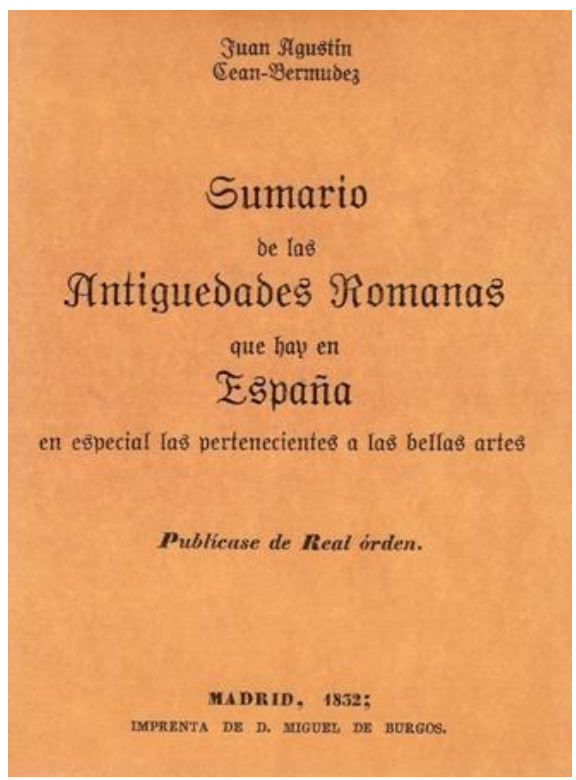

Fig. 4. Sumario de las Antigüedades Romanas que hay en España de Ceán Bermúdez (1852) ancho), y estaba formado, no de piedras sino de trocitos de barro cocido de varios colores, blanco, amarillo, encarnado, negro y aplomado, con una faja ó cenefa de piedrecitas blancas alrededor. La codicia de gente ignorante, que se lisonjeaba encontrar allí algún tesoro, destruyó este notable monumento, del que no ha quedado más que la memoria, y el dibujo que desde dicha ciudad remitieron a la Academia sus individuos correspondientes Fray José Lucas y don José Ventura y Vercin' (MRAH 1832: 17).

\section{DISERTACION SOBRE \\ EL DIOS ENDOVELLICO, $\mathrm{Y}$ noticia de otras Deidades GENTILICAS \\ de la España antigua. \\ POR D. MICVEL PEREZ P.ASTOR, Presbytero.

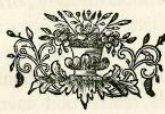 \\ Con las licencias neceffarias. \\ MADRUD. Por Joachin Ibarra, calle de las Urofas. M. DCC. LX.}

Fig. 5. Disertación sobre el dios Endovellico y noticia de otras deidades gentílicas de la España Antigua de Pérez Pastor (1760).
No había por parte de las administraciones locales, salvo escasas excepciones, una sensibilidad hacia la protección del patrimonio. De hecho, la Comisión de Antigüedades incentivó esta sensibilidad premiando a aquellos alcaldes que coloraran en los trabajos encargados a los eruditos. En este grupo destaca Fray José Lucas, guardián de franciscanos descalzos de Guadix, Torcuato y Lorenzo Martínez de Dueñas o José Ventura y Verzin, que mandó copias a la Academia de las inscripciones romanas halladas en el Torreón del Ferro, una de las torres de la muralla de la ciudad, en 1818, por lo que fue recompensado con el nombramiento de Académico Correspondiente. Aunque realmente el impulso de la investigación local lo dan desde la academia los propios accitanos: en primer lugar, Miguel Pérez Pastor y Molleto y Juan Bautista Barthe.

Miguel Pérez Pastor y Molleto (Guadix, 1721-Madrid, 1763) fue colegial de San Bartolomé y Santiago de la Universidad de Granada, graduándose en Derecho. Fue sacerdote (1748), miembro de la Real Academia Española y de la Real Academia de la Historia honorario (1753), supernumerario (1756) y su primer Anticuario desde 1763. Desde sus inicios la R.A.H. fue coleccionando medallas, monedas y todo tipo de metales de interés; la importancia que fue adquiriendo el Gabinete de 
Antigüedades reclamó la necesidad del oficio de Anticuario. Este cargo lo desempeñó Pérez Pastor hasta su muerte en 1763. Publicó el libro titulado: 'Disertación sobre el dios Endovellico y noticia de otras deidades gentilicias de la España antigua' (1760). Su abuelo Berenguer Pérez Pastor, también erudito, colaboró con la Academia, enviando copias de algunas inscripciones de Tobarra, su pueblo natal (Almagro 1999: 121122).

Juan Bautista Barthe nació en Guadix en 1790 o 1795 y murió en Madrid el 4 de septiembre de 1853. Ocupó diversos puestos en la administración del estado. Inicialmente trabajó de Oficial Mayor de la policía en Sevilla y de secretario de la policía en Jaén. En 1829 fue concejal del ayuntamiento de Guadix, en 1843 «consiliario» de la Diputación Provincial de Madrid y desde 1850 administrador principal de Correos en Toledo (Almagro 1999: 30). No se conoce mucho sobre su formación académica, pero sí sabemos que tenía predilección por la numismática y la epigrafía. Desde 1829 fue Correspondiente de la Real Academia de la Historia. Su discurso 'Ilustración a la inscripción y bajo relieves de un pedestal de Acci' le valió la condición de Supernumerario en 1836 y en 1847 se convirtió en Numerario. Su traslado administrativo a Toledo le devolvió a la categoría de

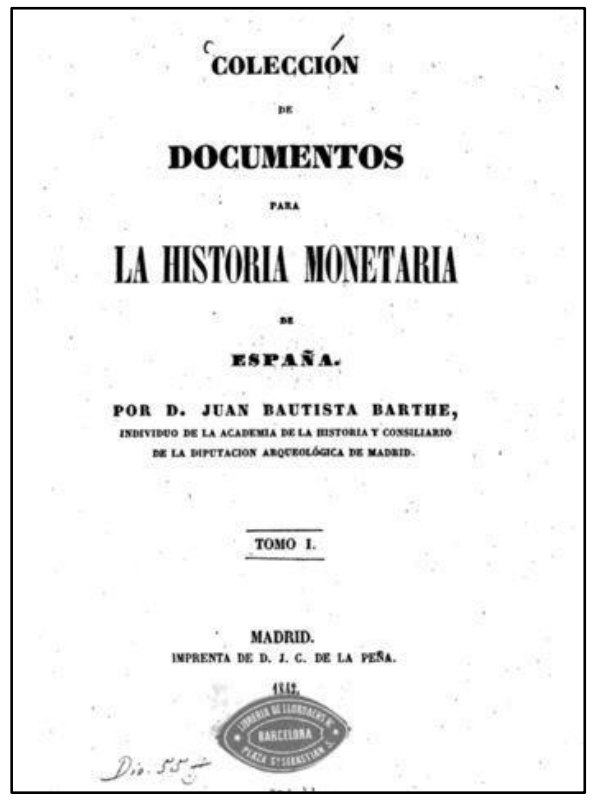

Fig. 6. Colección de documentos para la historia monetaria de España de Barthe (1843). Correspondiente en 1850, después de haber sido Anticuario en el periodo 1836-1848. El 12 de marzo de 1847 le fue encargado el arreglo y custodia de la colección de monedas de la Academia, institución a la que cedió su colección numismática personal al fallecer. Sobre ella publicó Antonio Delgado y Hernández un catálogo en 1854. Entre sus obras destacan su estudio de las medallas de Su Majestad la Reina Doña Isabel II, publicada en 1841 y su Colección de documentos para la historia monetaria de España, que vio la luz en 1843 (Reyes 2016: 13).

En 1862 veía la luz el libro 'Historia de Guadix, Baza y pueblos del obispado', del accitano Torcuato Tárrago, en él recoge toda la tradición historiográfica publicada hasta el momento, aunque sin ningún juicio crítico, pues mezcla lo histórico con lo estrictamente legendario (Tárrago Mateos 1862).

Fidel Fita Colomé, arqueólogo, epigrafista, filólogo e historiador nacido en 1835 analizó las lápidas visigodas de Guadix, publicándolas junto con otras de gran interés de las ciudades de Cabra, Vejer, Bailén y Madrid. También realizó un informe para la comisión de antigüedades de la Real Academia de la Historia relativo a los hallazgos de cerámicas en Alcudia de Guadix (Fita Colomé 1896).

La labor del arqueólogo Manuel de Góngora se centró en el descubrimiento de nuevos yacimientos argáricos en Alcudia de Guadix, de numerosos dólmenes en la zona de Gor-Gorafe y en localizar algunas inscripciones romanas para trasladarlas al museo arqueológico de Granada. De ellas solía hacer calcos para enviarlas a Hübner, que, tras su pertinente estudio, se encargó de incorporarlas al Corpus Inscriptionum Latinarum.

Con fecha de 28 de octubre de 1861 envió un informe al ayuntamiento de Guadix sobre la alcazaba de esta ciudad en el cual incide en la conveniencia de su conservación, justificado su importancia con un detallado estudio histórico. No olvidemos que en esos momentos la alcazaba había sido puesta a la venta por el ayuntamiento y desde la Real Academia presionaron para evitarlo (Maier y Salas 2007: 200).

Luis Siret, considerado el precursor de la arqueología del sudeste español, fue una figura importantísima en esta disciplina entre finales del siglo XIX y primer tercio del XX. Pasó cinco décadas dedicado a la 


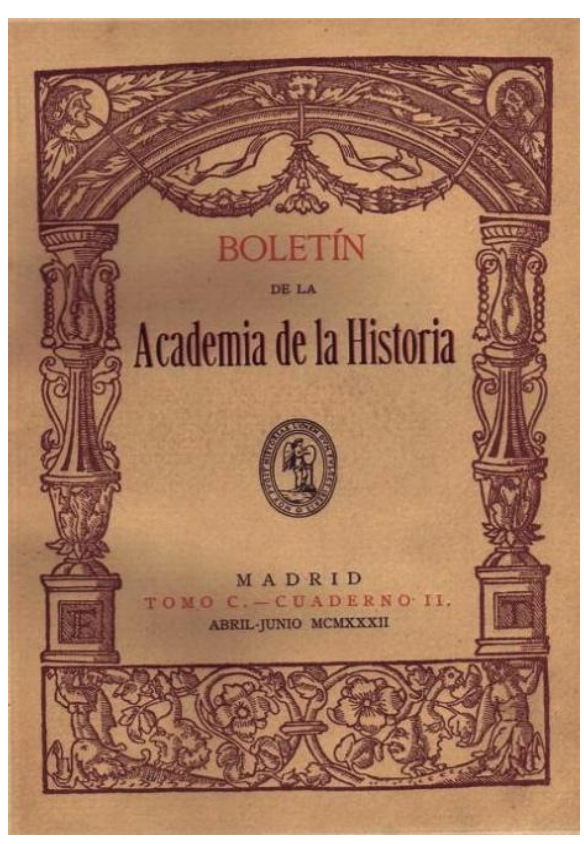

Fig. 7. Lápidas visigóticas de Guadix, Cabra, Vejer, Bailén y Madrid por Fita Colomé (1896).

investigación en los yacimientos prehistóricos. Excavó parte de los dólmenes repartidos por los términos municipales de Gor, Gorafe y Guadix (García Sánchez y Spahni 1959: 43-114).

Las primeras visitas a Guadix y su comarca con carácter plenamente científico mediante la rápida consulta de sus archivos, inspección de lugares de interés artístico y realización de bosquejos y fotografías se deben a Manuel Gómez-Moreno González y Manuel Gómez-Moreno Martínez, su hijo, durante la última década del pasado siglo. Llegaron a Guadix en septiembre de 1891 entre otros motivos para informar a la Comisión acerca de las inscripciones de época romana que habían aparecido a lo largo del siglo y que habían sido repartidas por distintos puntos de la ciudad. En efecto, tal y como señala Rodríguez Domingo (1997: 185): 'la cultura anticuaria siempre había demostrado su afición por Guadix, enclave romano de la máxima importancia, cuyos hallazgos epigráficos hablaban del esplendor de la antigua Colonia lulia Gemella Acci’.

Además de la reseña de las conocidas lápidas del Pósito y de la Catedral, los Gómez Moreno examinaron las halladas al pie del Torreón del Ferro en marzo de 1808. Se trataba, en primer lugar, de los pedestales con inscripciones honorarias dedicadas a las figuras de Cayo Valerio Restituto (s. II d.C.), destacado miembro de los Valerii de Acci y a Publio Octavio Flavo (s. I d.C), perteneciente a la aristocrática familia de los Octavii.

\section{La Arqueología en Guadix}

Después de todo este recorrido historiográfico no cabe duda que la antigua Acci romana subyace bajo la actual ciudad de Guadix, aunque la idea de una antigua ciudad romana abandonada sigue aún hoy en día en el imaginario de muchos accitanos, si bien Hübner (CIL II, 458; RE I 140-141) desmintió la posibilidad de identificar un yacimiento romano en los vestigios de los Llanos de Almagruz, correspondientes a la época islámica, e identificó la antigua Acci en la actual ciudad de Guadix gracias al uso de la toponomástica, derivando las palabras Guadix-Wadi Ash, el río de Acci.

Guadix hunde sus raíces en el Bronce Pleno, momento en el que se produce la primera ocupación sistemática, atestiguada con la aparición en el registro arqueológico de restos de la Cultura Argárica. Según Adroher y López Marcos, de esta época se han conservado algunos fondos de cabaña excavados en las arcillas (Adroher et al. 2002: 86-87).

A lo largo del Bronce Final se produce una expansión del asentamiento en el interior de lo que en época medieval se convertirá en el recinto amurallado árabe, visible en algunos tramos en la actualidad. El asentamiento, enclavado en una colina, era una zona fácilmente defendible, controlando desde allí todo el valle del río Guadix, usando como límites orográficos las propias ramblas que rodean la colina. En las inmediaciones de la Calle San Miguel se documentaron restos de viviendas pertenecientes al siglo IX a.C., entre las que caben ser destacadas algunas cabañas excavadas en la roca de planta circular. Ya en el siglo VI a.C. se conformaría un oppidum ibérico que ocuparía el centro histórico de la ciudad (Adroher et al. 2002: 88). En el antiguo Cine Acci aparecieron en 1996 una serie de estructuras domésticas de planta rectangular con subdivisiones internas y muros de adobe con zócalos de piedra. En 1997 fueron descubiertas estructuras domésticas del mismo periodo en la Calle Palacio. 


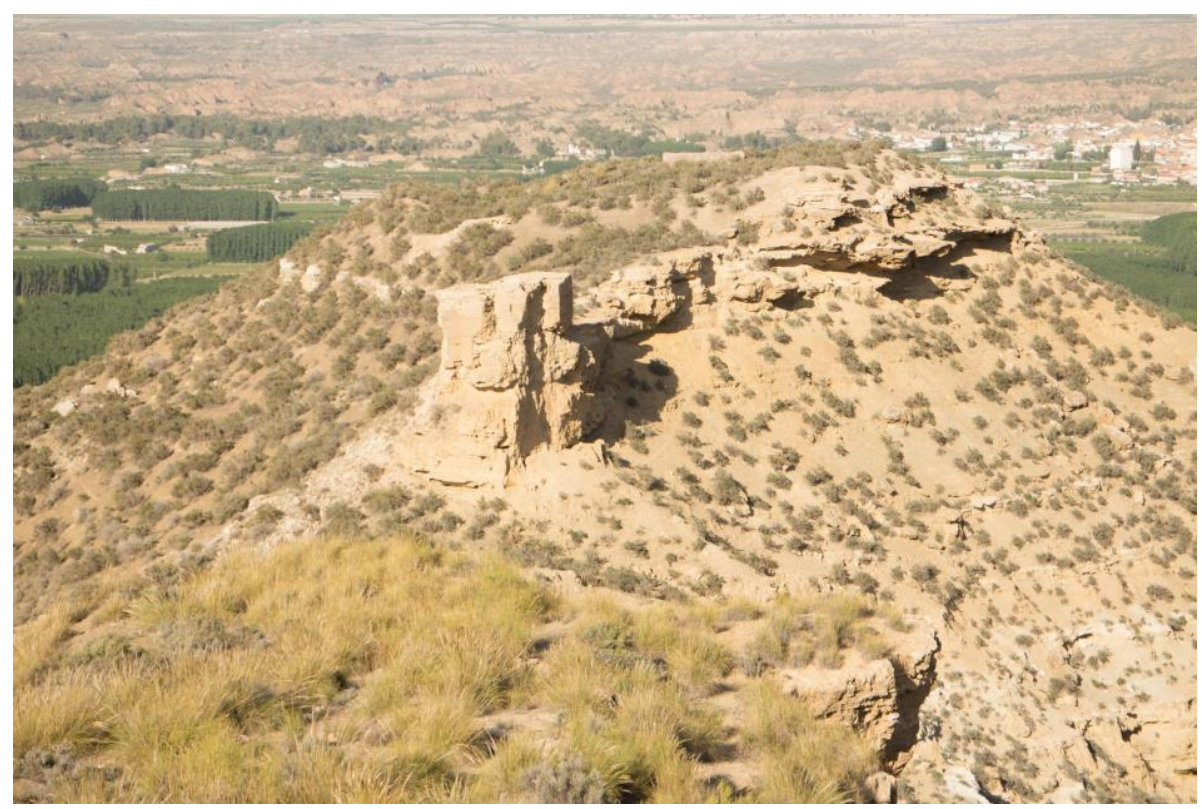

Fig. 8. Restos del Castillo de Luchena, reconocidos por Florez como ‘Guadix El Viejo’.

En lo que respecta al periodo Ibérico Pleno (ss. IV-III a.C.) se documentaron en 1993 en la Calle Concepción unos muros de grandes dimensiones y restos del pavimento de una calle, siendo éstos reutilizados hasta época bajoimperial. En la Calle Palacio a su vez fueron descubiertos algunos muros de gran entidad y estructuras domésticas con suelos de habitación que aparecieron arrasadas por un posible criptopórtico de época republicana. En la zona del Torreón del Ferro se localizaron también estructuras pertenecientes al periodo Ibérico Pleno, dando a entender que las dimensiones del oppidum ibérico ya pudieron ser similares a las de la posterior colonia romana.

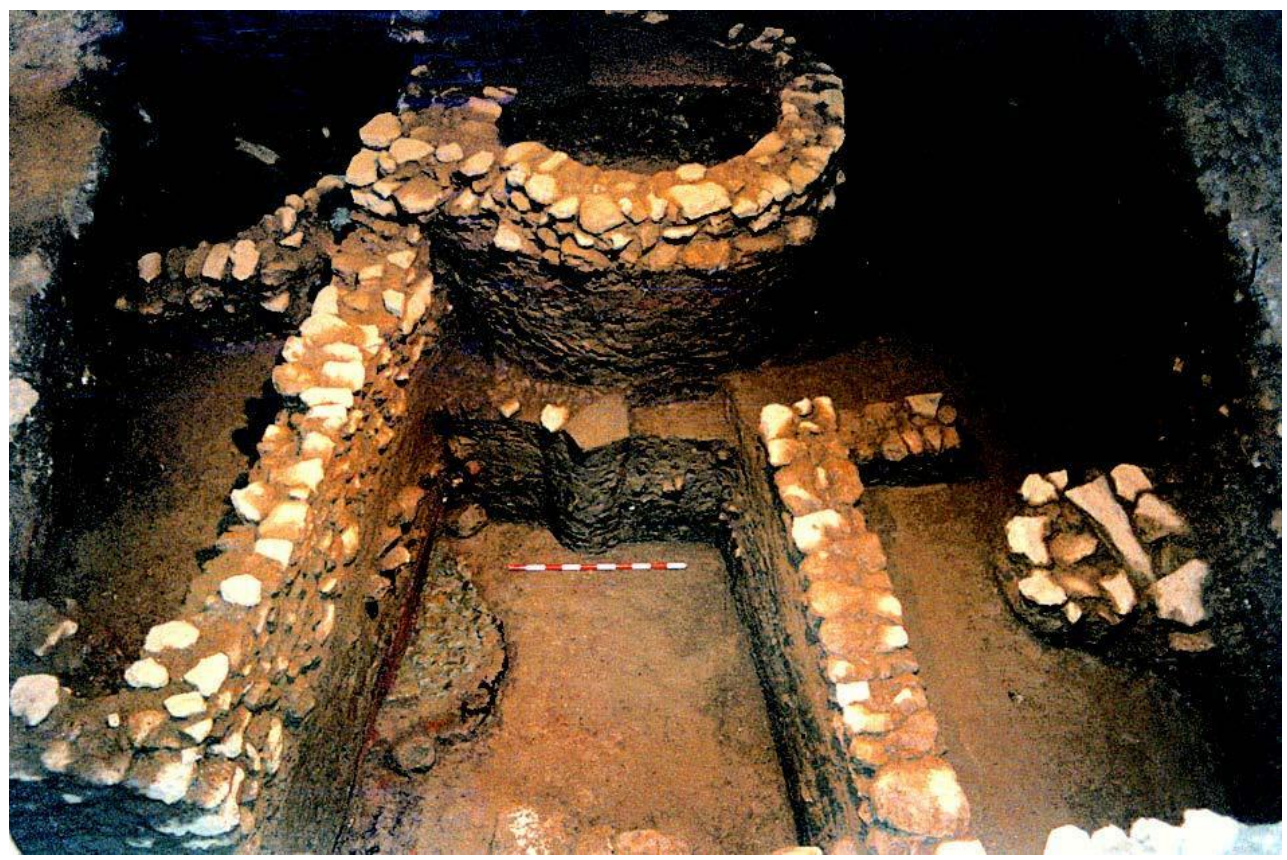

Fig. 9. Estructuras ibéricas en el antiguo Cine Acci. 


\subsection{La fundación de la ciudad romana}

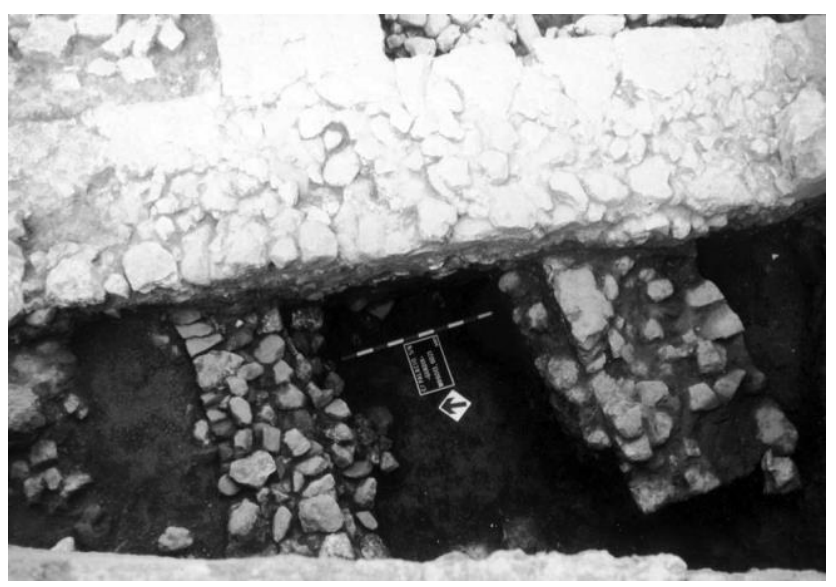

Fig. 10. Estructuras del periodo ibérico pleno en la Calle Palacio de Guadix.

El Periodo Romano aparece reflejado en la historiografía en numerosos estudios, poniendo especialmente atención al estudio de las fuentes, que hasta finales de la década de 1980 o principios de los noventa no aparecerán apoyados sobre una base arqueológica. Cabe ser destacado el trabajo de Santero (1972), que por primera vez planteó un análisis pormenorizado de las fuentes clásicas para el estudio de la colonización romana del oppidum de Acci, siendo consciente de la necesidad de apoyar sus estudios en la realización de futuras excavaciones arqueológicas. Ptolomeo (Geogr. 2.6.60) es el primero en dejar constancia del nombre y la localización de Acci, cuando la menciona como la última de una lista de quince ciudades dominadas por los Bastetanos. Posteriormente Plinio (Nat. Hist. 3.3.25) menciona la Accitana Gemellensis con ius italicum como perteneciente al conventus Cathaginensis, dentro de la Hispania Tarraconense. Ya Santero planteó una hipótesis sobre el sobrenombre Gemellensis, coincidente con las abreviaturas GEM y G. que aparecen en varias inscripciones y monedas de la colonia (CIL II, 3391, 3393, 3394; Vives 1924: láms. CLXVI, CLXVII; Santero 1972: 203). Aparte del sobrenombre de Gemella tenemos constancia del sobrenombre Iulia, que con toda probabilidad alude a la fundación de la colonia. Sin duda el nombre de Acci es de procedencia indígena, repitiéndose el sufijo $-c c i$ que aparece en otras ciudades ibéricas del entorno del sur de la Península Ibérica.

Según Zonaras (9.8) en el 208 a.C. Escipión mandó a su hermano Lucio a la Bastetania para afianzar el territorio conseguido. Es posible, según Hübner (Hübner 1893), que en ese momento algunas ciudades bastetanas como Acci se hubiesen aliado con los romanos, debido a la existencia de algunas monedas romanas con caracteres indígenas aparecidas en las inmediaciones de Guadix, en las que pueden apreciarse las leyendas icloe, icloekn e iclonekn, quizás, siempre según la óptica de Hübner, existiese un clan - el de los iclonetes - asentado en Acci.

En lo que respecta a la fundación de la colonia romana podría plantearse la hipótesis de una deductio militar, que según Santero (1972: 205-206) se vería reflejada en las monedas acuñadas en Acci (Vives 1924: Láms. CLXVI, CLXVII), en las que aparecen águilas legionarias e insignias militares dobles, junto a las abreviaturas del nombre de la colonia. Según Flórez (1776: 17) se deduce de la leyenda L III la posibilidad de que la legio tertia se hubiese establecido en la ciudad, sin embargo, desde la perspectiva de Grotefend (1840: 654), posteriormente secundada por Santero cabría la posibilidad de que la leyenda en las monedas fuese L I II, un hecho que junto a las dobles águilas legionarias en las monedas - y al hecho del sobrenombre Gemella de la propia colonia - plantearían la hipótesis de un establecimiento de las legiones prima et secunda. Esta teoría, muy extendida, plantea la hipótesis de una deductio para la fundación de la colonia con veteranos de las dos legiones. La no aparición de monedas de época anterior a Augusto ha hecho pensar a varios autores (Vittinghoff 1952: 107, 149) en una fundación augustea de la colonia, una teoría bastante simplista, ya denunciada por Santero. Kornemann (RE. IV, s.v. Colonia, $\mathrm{n}$. 91) propuso una fundación por parte de Lépido en el 42 a.C. hecha en nombre de Augusto, una teoría apoyada en un momento por García y Bellido que se contradice a sí mismo un par de años más tarde (García Bellido 1959: 474-476 contra García y Bellido 1961: 116-119), y por Blázquez (1962: 71-129). 

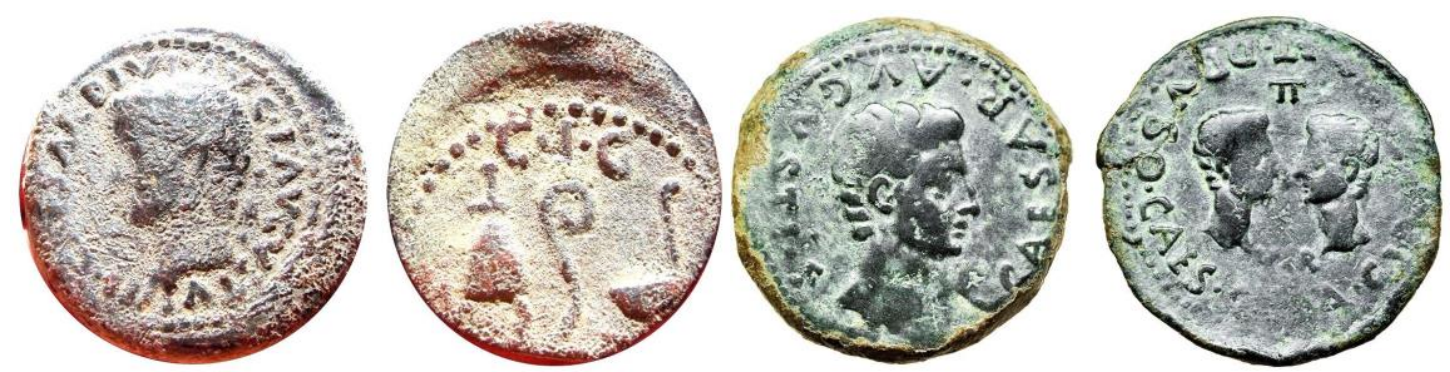

Fig. 11. Acuñaciones monetarias accitanas de Augusto, Tiberio y Calígula.

En lo que respecta al nombre de la colonia - Iulia Gemella Acci -, Santero vio la dificultad de plantear una fundación en época augustea, ya que relativamente cerca de Acci tenemos la colonia Augusta Gemella Tucci en Martos (Jaén), y si Guadix hubiese sido una fundación de Octaviano con toda probabilidad habría recibido del mismo modo que Martos el sobrenombre de Augusta. La hipótesis de Santero (1972: 214215), apoyada sobre las teorías de Sánchez Albornoz (1949) y Sutherland (1939: 128-129) plantea una fundación por las legiones de los veteranos de la legio prima vernacula y la secunda, que habrían permanecido en Hispania hasta el momento en que César repartió tierras (Suet., Caes. 38, 42) tras la batalla de Munda en el 45 a.C. Entre Acci y Abula - en Fiñana - apareció una inscripción con el nombre de Casio Longino, que ratificaría la teoría de la fundación de Acci por parte de las dos legiones mencionadas, ya que está atestiguado el paso de Casio Longino por aquellas tierras siguiendo la vía dirección a Corduba con las dos legiones que estaban bajo su mando. La colonia debió pertenecer al conventus Carthaginensis en la Hispania Tarraconense si tenemos en cuenta el texto de Plinio, si bien, en la época de su fundación habría formado parte de la Hispania Ulterior, siendo durante un tiempo considerada como parte de la Bética desde el 27 a.C., hasta que entre el 7 y el 2 a.C. con la nueva reforma administrativa de Augusto pasaría a integrarse en la Tarraconense (Albertini 1932: 34-35; Santero 1972: 216). Ambos hechos están atestiguados por las fuentes, ya que la pertenencia a la Cartaginense nos la menciona Plinio y una descripción dedicada al flamen de la Bética, P. Octavio Flavo, que, si bien tiene una datación de época imperial avanzada, puede demostrar que aún existían lazos religiosos entre la Bética y algunas ciudades de la Tarraconense como Cástulo o Acci que habrían cambiado de provincia. Asenjo Sedano se limita a repetir la teoría de Santero (Asenjo Sedano 2002: 57-58). Sin embargo, no es esta la única hipótesis. Nicolás Marín apunta que esta teoría de las dos legiones deducida de las inscripciones numismáticas es insuficiente, así como la fundación de la colonia por parte de César en el 45 a.C. tras la Batalla de Munda, ya que, según él, el famoso discurso de Híspalis en el que el dictador habría ordenado el repartimiento del territorio y la fundación de colonias habría requerido un tiempo prudencial para la organización del reparto, y teniendo en cuenta que el asesinato de César ocurriría tan solo un año más tarde, quizás no hubiese sido tiempo suficiente como para fundar colonias en Hispania y estas fundaciones se habrían producido ya en tiempo de Augusto, que se habría erigido como continuador de la obra de César, fomentando los asentamientos de veteranos en las ciudades con estatus de colonia (Marín Díaz 1990: 1516). El carácter militar de la fundación queda sin duda atestiguado en la numismática accitana con la aparición de águilas legionarias e insignias militares en las monedas. Tanto González Román como Degrassi concluyen que la deductio debió realizarse en una fecha imprecisa, que pudo corresponder a César o con posterioridad al segundo triunvirato (Degrassi 1971: 89; González Román 1992: 162; González Román 2011: 310-320). Por su parte, Sánchez Martínez (1993: 11-12) se atreve a afirmar en que en Acci se habría asentado un contingente militar en activo, no formado por militares retirados, sino por soldados de las legiones I Adiutrix y la II Augusta, sin embargo, aunque la teoría ha sido rechazada por la mayor parte de los investigadores, ha calado en el imaginario popular. En lo que respecta al apelativo Gemella la historiografía ha generado varias teorías que parecen no acabar de satisfacer a ninguno de los estudiosos que las han producido. Este sobrenombre aparece confirmado por la referencia de Plinio, así como en las emisiones monetarias y en varias inscripciones honoríficas. La explicación más extendida es la que alude a la duplicidad de las dos legiones que fundaron la ciudad, supuestamente la Vernacula y la 
Secunda. Sin embargo, se ha propuesto la posibilidad de que el apelativo Gemella sea el propio de una legión constatada a finales de la República (Caes., BCiv., 3.4.1), una de las legiones que habría apoyado a Pompeyo en los momentos previos a Farsalia, formada a partir de dos legiones, conocida como Gemella. González Román propone la posibilidad de que el término aluda a la fundación de la colonia en un núcleo junto al preexistente oppidum ibérico, de manera que quizás existiese una cierta dualidad entre ambos núcleos poblacionales. También ha atribuido el sobrenombre a la existencia de una dualidad a la hora de la fundación de la colonia, ya que es posible que fuese realizada por dos tribus: la Pupinia, quizás de origen itálico y la Galeria, formada por nuevos ciudadanos procedentes de la propia Hispania (González Román 2011: 315-316). Por último, ha surgido una nueva teoría, teniendo en cuenta el descubrimiento de un epígrafe en el Cortijo de Periate (Pastor 2000: 155-164; Stylow 2000: 775-806; Laffi 2004: 235-254; González Román 2011: 317), en la carretera de Pínar a Iznalloz, datado en el siglo II d.C., en el que se honra a L. Aemilius Propinquus, considerado como accitanus vetus, mientras que los decuriones que decretan la erección del monumento se consideran parte de un ordo accitanorum veterum, dos hechos que han sido relacionados con la posible existencia de un municipio llamado Acci Vetus; sin embargo, no está probada la existencia de tal municipio.

\subsection{La topografía y la toponimia de la ciudad antigua}

Gracias a las intervenciones arqueológicas que se vienen desarrollando de forma reglada desde 1989 hemos asistido al desarrollo del conocimiento de la topografía de la ciudad romana, que hasta los años noventa era completamente desconocida. Hasta el momento contábamos tan solo con una hipótesis planteada por Asenjo Sedano, que habría querido identificar el cardo y el decumano de la ciudad en el trazado de la ciudad actual, planteando la existencia del decumano en un tramo viario que atraviesa la ciudad desde la zona de la alcazaba hasta la catedral - la actual Calle Concepción -, confluyendo con el cardo en la supuesta iglesia paleocristiana de San Juan. Lo cierto es que la propuesta de Asenjo Sedano no carece de controversias, pues toma como modelo la topografía de la ciudad actual, con una planta que esencialmente muestra la trama de la ciudad islámica y atribuye una supuesta antigüedad a restos arqueológicos que de romanos tienen poco o nada como por ejemplo dos supuestos baños romanos. Sin embargo, la hipótesis no carece de importancia, planteando por primera vez en la historiografía una teoría acerca de la urbanística de la colonia romana, que será repetida hasta la saciedad por diversos autores sin

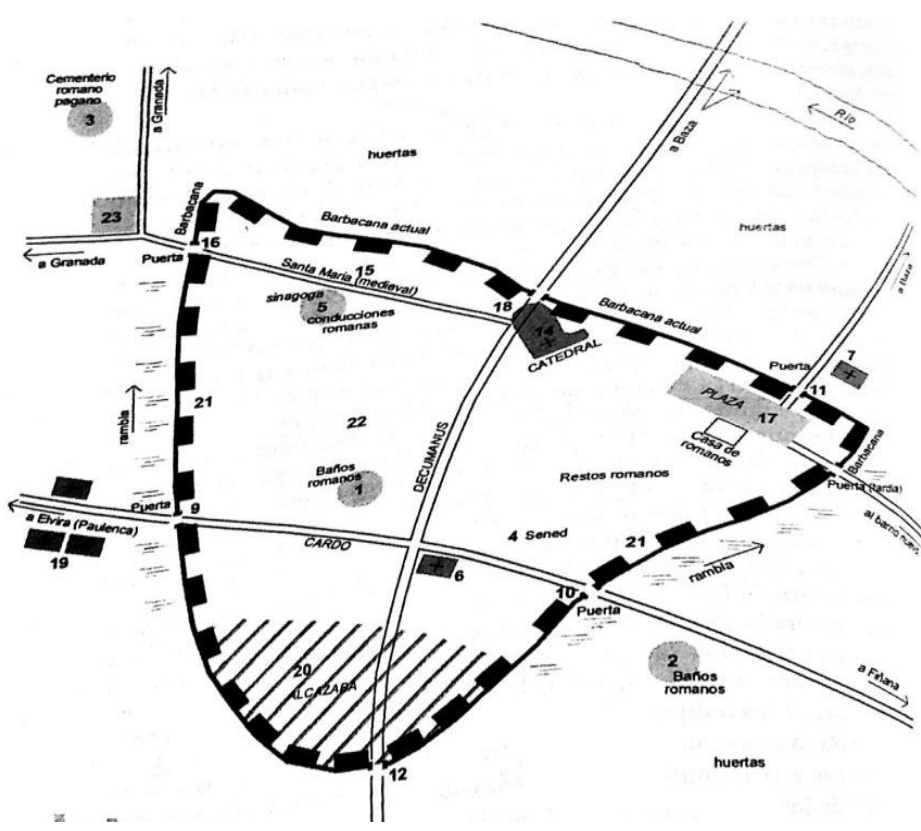

Fig. 12. Hipótesis topográfica planteada por Asenjo Sedano (2002). indagar más allá durante más de veinte años, hasta que ya entrado el siglo XXI se ha producido el gran descubrimiento del teatro romano y alguna domus tardoantigua a los pies de la muralla medieval, unas posibles termas en pleno centro de la ciudad, y una vivienda romana al sur, fuera de los supuestos límites de la colonia que planteaba Asenjo Sedano.

La toponimia ha sido una disciplina de gran ayuda y tradicionalmente ha constituido el punto de partida para reconstruir el poblamiento romano en la actual comarca de Guadix, para identificar posibles núcleos de población menor como mansus o villae. Sirvan como ejemplo los nombres de los municipios de Graena, Purullena, Exfiliana, Fiñana o Luchena, éste último muy común en toda la Península, incluso detectado en Francia 
e Italia, deriva del nombre latino Lucius o Lucianus (Galmés de Fuentes 2000: 65). Su origen probablemente sea el del propietario de la correspondiente villa romana. Este mapa se ha ido completando con los hallazgos casuales, como el de de la villa de Paulenca, una villa bajoimperial situada en las proximidades de Guadix, en el antiguo camino que lleva a Granada, y que fue excavada por José María Santero Saturnino en 1970.

La información proporcionada por los itinerarios, especialmente el Itinerario de Antonino ha facilitado las ubicaciones en el mapa tanto de Acci como del resto de los enclaves urbanos con los que tenía estrecha comunicación viaria: Agatucci, Bactara, Basti y Tutugi. Recientemente hemos asistido al descubrimiento de un tramo de la vía romana que debía conectar la ciudad con Basti a través de Gor, por lo que se podrían confirmar algunas de las hipótesis planteadas acerca de las conexiones viarias entre Cartago Nova y Cástulo a través de la antigua Acci.

\subsection{Los cultos religiosos en la época romana}

En lo que respecta a la religión en Acci, la historiografía se ha hecho eco principalmente de dos cultos: el dios Netón y la diosa Isis.

Macrobio (Sat. 1.19.5) aportó datos acerca de la religión de los accitanos que debían adorar al dios Neto, una divinidad solar asimilada al dios romano Marte. El Padre Flórez señaló que 'los accitanos recibieron la voz Netón de los egipcios y que ésta era significativa del Toro o monumento en que adoraban al Sol...' Miguel Pérez Pastor en su libro se refiere a esta problemática de la siguiente manera: '...porque hasta ahora ni por inscripción ni por medalla ha descubierto el tiempo más noticia de este dios de los accitanos que la que nos conservó Macrobio. Bien desearía poder ilustrar esta antigüedad de mi patria, pero han sido ineficaces mis diligencias para llenar mis deseos. Nada tenemos original sino la autoridad de Macrobio a

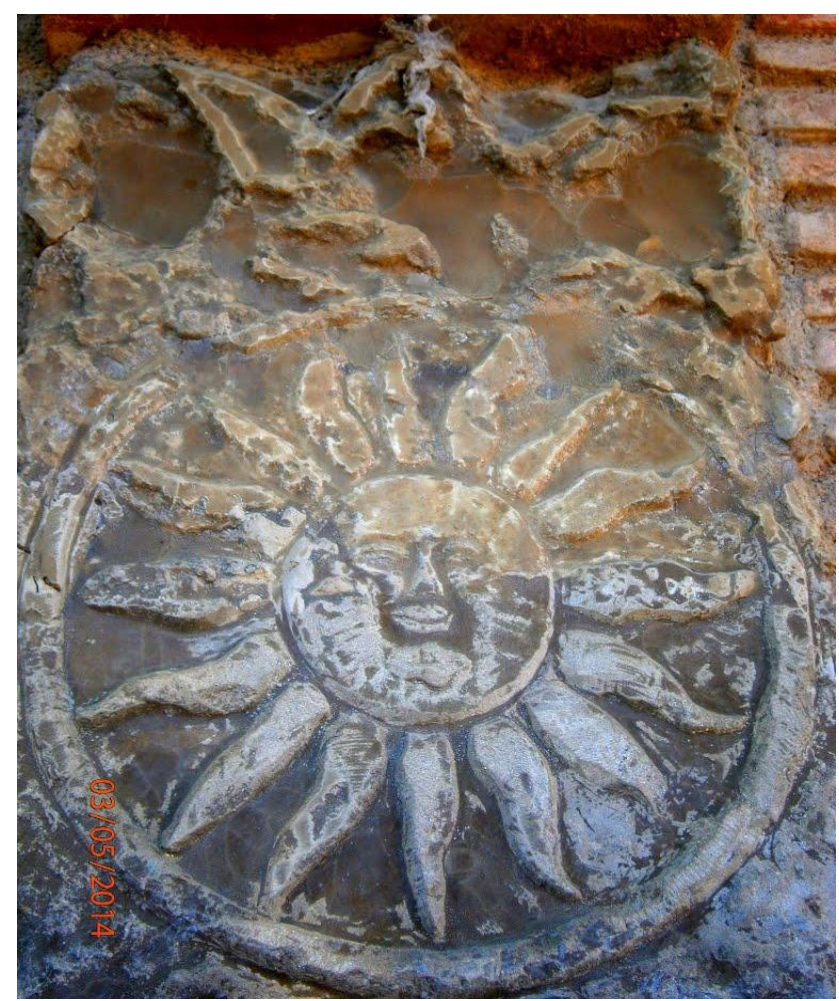

Fig. 13. Restos reconstruidos del bajorrelieve del Caño de San Antón que se asemejan a la descripción del dios Netón realizada por Macrobio.

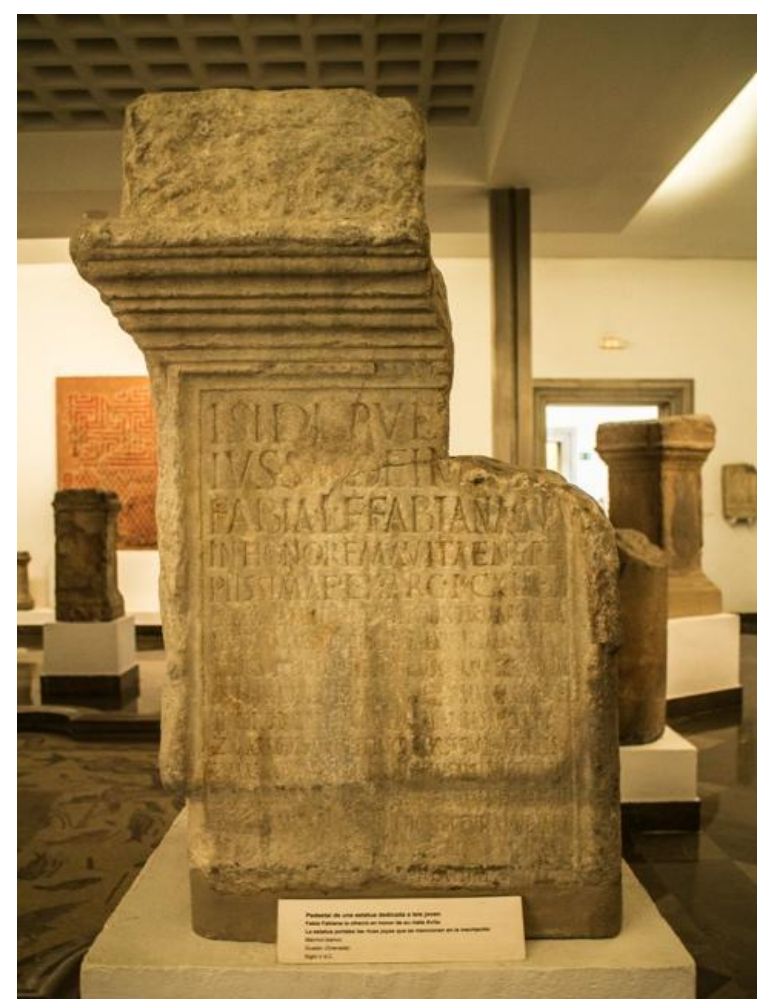

Fig. 14. Pedestal de Isis en el Museo Arqueológico de Sevilla. 
quien por estas palabras debemos la noticia: Accitani Hispanae gens simulacrum Martis radiis ornatum maxima religione celebrant Neton vacantes'.

Recientemente González Román ha publicado un artículo respecto al culto al dios Netón en Acci, en el que pone en relación esta divinidad con el Niethoi que aparece en un cuenco del siglo VI a.C. encontrado en el santuario empórico de Onuba, quizás una derivación de la divinidad céltica Neton, que habría penetrado por la ría de Huelva con la influencia de los pueblos celtas en el mundo tartésico (Olmos 1985: 109-112; Almagro-Gorbea 2002: 37-70; González Román 2014: 622-623). Incluso, en la actualidad Sainero Sánchez (2014: 2016), director del Instituto de Estudios Celtas, propone una cierta relación con el héroe Muneto que aparece en los Annales Hiberniae que recopilan antiguos manuscritos irlandeses, poniendo en relación la conquista de Irlanda con Galicia y el culto a Netón en el sureste de la Península Ibérica. Ya Hübner (CIL II, 458) puso su atención en el culto a Netón, asimilándolo a un bajorrelieve existente en el Caño de San Antón de Guadix que representaría un astro radiado.

Podríamos plantear la hipótesis de una relación del topónimo/onomástico San Antón con Netón, teniendo en cuenta la existencia de un santuario con una ermita junto al propio caño que quizás habría mantenido hasta nuestros días su significado original transformando el culto pagano en culto cristiano, si bien no podemos confirmar esta hipótesis a través de las fuentes arqueológicas o escritas.

Respecto al culto a Isis tenemos un monumental pedestal conservado en el Museo Arqueológico Provincial de Sevilla (CIL II, $3386=I L S 4422=I L P G r 63=\operatorname{HEp~5,~1995,~351)~que~tiene~una~dedicatoria~de~Fabia~}$ Fabiana a esta diosa en honor de su nieta Avita en la que se ofrecen numerosas joyas. Fue calificado por García y Bellido como uno de los monumentos isiacos más importantes del Imperio Romano. Algunos investigadores han puesto este culto en relación con el culto a Netón. La existencia de otro epígrafe (CIL II, 3387 = ILPGr 64 = CILA IV, 2002: 132) en paradero desconocido, el de Livia Chalcedonica, devota de Isis, confirma la devoción de los accitanos a la diosa Isis.

\subsection{La ciudad visigoda}

Otra cuestión que sigue sin explicarse con suficiente precisión son los hiatus que se producen entre diferentes civilizaciones. Si va quedando meridianamente claro es que se produce una significativa reducción de la ciudad romana que a partir del siglo III empieza a contraerse quedando reducida a la mínima expresión, de hecho, parece que la población se desplaza a la parte oriental de la ciudad. Los grandes edificios públicos y de ocio, como el recién descubierto teatro romano, son abandonados. Sus sillares serán reutilizados para otras construcciones, como la muralla musulmana, donde todavía son visibles.

Otro de los problemas que sigue a día de hoy sin resolverse de manera absoluta es el de la ciudad visigoda de Acci. Sabemos que continuó ubicada en el mismo lugar que la ciudad romana y también conocemos que tuvo su importancia dentro del reino visigodo, ya que se acuñó moneda durante los reinados de Sisebuto, Suintila, Sisenando, Chintila y Egica, con la titulatura en el reverso de Iustus Acci y fue cabecera de un obispado cuya antigüedad se retrotrae al siglo IV y cuyos obispos acuden a los concilios de Toledo, IV, V, VI, VIII, IX, X, XI, XII, XIII y XIV y a los concilios de Sevilla. Tenemos constancia de la fundación de una iglesia en el año 652, a través de la inscripción de su ara de fundación. Esta fecha se enmarca en el reinado de Chindasvinto con su hijo Recesvinto, asociado al trono, y el año de pontificado del obispo Justo, firmante del concilio VI de Toledo. Pese a todo esto, la ciudad visigoda casi no se ha dejado ver en las excavaciones efectuadas en el núcleo urbano de Guadix. La clave nos la puede dar la inscripción antes reseñada, localizada al este de la ciudad, en el llamado Barrio de la Cruz. ¿Pudo la ciudad desplazarse a esta zona?, o ¿realmente había un urbanismo muy disperso? Estas cuestiones de momento siguen sin respuesta. La propia inscripción también generó un debate sin resolver hasta el momento al analizar las reliquias que se depositaron en esta iglesia y que aparecen mencionadas en la inscripción. 
Existe otra inscripción en la que tampoco los investigadores se han puesto de acuerdo. Se trata de un ara de fundación localizada en el siglo XVI en la Alhambra, que hace referencia a la consagración de unas iglesias en un lugar llamado Nativola, del que desconocemos su ubicación exacta. Fueron costeadas por un personaje llamado Gudiliuva (Canto 1995: 343-346) entre finales del siglo VI y principios del VII. La inscripción reza: 'En el nombre de Dios Nuestro Señor Jesucristo fue consagrada la iglesia de San Vicente, mártir valenciano, por el santo Liliolo, obispo de Guadix el día 22 de enero del año octavo del reinado del muy glorioso señor y rey Recaredo en el año 632 de la era $(594$ d. C.); asimismo fue consagrada la iglesia de San Juan Bautista (el día... año del reinado... año de la era); y también, (pero) en el lugar de Natívola, fue consagrada la iglesia de San Esteban promártir, por el santo Pablo, obispo de Guadix, el día... mes... del año... de nuestro señor el muy glorioso rey Witerico, año 645 de la era (607 d. C). Estos tres santos tabernáculos fueron edificados, con la ayuda de los santos (patronos) a gloria de la Santísima Trinidad, por el ilustre (jefe militar) G(u)ndiliuva, a su costa y con obreros propios... '.

Según Salvador Ventura (1988: 347; Díaz Martínez 1987: 60), se trataría de templos construidos en propiedades latifundistas en las que el propietario tenía sobre ellas ciertos derechos, aunque su administración estuviese en manos del obispo. La cuestión es saber dónde se localizaba Nativola. Algunos autores creen que se situaba justo donde apareció, en la colina de la Alhambra, otros en cambio piensan que fue llevaba desde algún punto de la diócesis de Guadix, porque no se entiende que los obispos accitanos se desplazaran hasta la diócesis vecina de Granada para consagrar iglesias fuera de su territorio episcopal.

\section{5 ¿Hubo una conquista bizantina?}

No existe ninguna prueba que nos indique que la ciudad de Acci perteneció a la provincia bizantina hispana, dado que no se ha podido documentar ni en las fuentes ni arqueológicamente. Según E. A. Thompson si los bizantinos hubieran controlado el sureste peninsular, desde Cartagena a Málaga, lo lógico es que Acci también hubiera estado bajo este dominio. A pesar de ello, esta opinión se ha ido generalizando con el tiempo y se ha dado por buena (Thompson 1971: 367). Sabemos que Leovigildo en el año 570 realizó una expedición militar en la zona de Baza, ciudad próxima a Guadix, sin detallar si llegó a conquistarla o no. Otros autores como P. Goubert consideran que sí fue conquistada por este rey visigodo. En contra de esta teoría encontramos a E. A. Thompson que piensa que Basti (Baza) nunca llegó a ser bizantina. Actualmente se da por sentado que la ciudad fue tomada por Leovigildo a los imperiales en el 570. Tampoco en esta ciudad se ha constatado la presencia arqueológica bizantina (Montanero Vico 2005: 55-56). En el ámbito religioso es donde se podría encontrar una hipótesis más sólida sobre la cuestión de la pertenencia bizantina de estas zonas del norte de la provincia de Granada: el nombramiento de un nuevo obispo para la silla de Acci, Liliolo, quien coincide en el tiempo con el del bastetano Teodoro y la huida del obispo Esteban de la sede granadina, pudiendo tratarse de tres sedes recuperadas a los bizantinos (García Moreno, 2008: 47). En Guadix apareció en un hallazgo casual un conjunto de monedas estudiadas por Pedro Barceló (1985: 311-318) entre las que se encuentra un follis de Heraclio. Esto no implica ni mucho menos la pertenencia de la ciudad a la provincia bizantina, aunque quizás sí abra una nueva vía de investigación a la hora de analizar los posibles intercambios comerciales entre visigodos y bizantinos a diferente escala y especialmente en territorios fronterizos como es el caso de Acci. Para el periodo comprendido entre los siglos VIII - XV quedan pendientes de respuesta otras cuestiones no menos importantes como la identificación de los primeros asentamientos emirales y si el castillo de Luchena era el centro de poder principal desde el cual se controlaba el resto del territorio. Finalmente, otras cuestiones que todavía están pendientes de una explicación definitiva son el fenómeno troglodítico, la perduración de la comunidad mozárabe en el tiempo y la evolución demográfica de la ciudad medieval que habrá que analizar detenidamente a través de la aparición de los arrabales. 


\section{BIBLIOGRAFÍA}

Adroher A., López A. y Pachón J.A. (2002), La cultura ibérica. Granada Arqueológica, Diputación de Granada.

Albertini E. (1932), Les divisions administratives de l'Espagne romaine, París.

Almagro Gorbea, M. (1999), El Gabinete de Antigüedades de la Real Academia de la Historia: ciclo de conferencias pronunciadas en la Real Academia de la Historia del 3 al 17 de mayo de 1998. Madrid: 121-122.

Almagro Gorbea M. (2002), Tartessos, una cultura literaria: textos, iconografía y arqueología, Bolskan: Revista de arqueología del Instituto de Estudios Altoaragoneses, 19, 2002, pp. 59-74.

Asenjo Sedano C. (2002), De Acci a Guadix: aproximación a la protohistoria de una ciudad del sudeste peninsular hispánico, inserta en un fenómeno de mutación de topónimo: una hipótesis de reconstrucción urbana, Universidad de Granada.

Barceló, P. (1985), 'Un hallazgo de monedas en Acci'. Saguntum: Papeles del Laboratorio de Arqueología de Valencia, 19: 311-318.

Blaeu J. (1662), Atlas Maior.

Blázquez, J. M. (1962), Religiones primitivas de Hispania, CSIC-R.

Canto A. M., (1995), Inscripción conmemorativa de tres iglesias, Arte islámico en Granada. Propuesta para un museo de la Alhambra. Catálogo de la exposición. Granada: 343-346.

Ceán Bermúdez J. A. (1832), Sumario de las antigüedades romanas que hay en España, en especial las pertenecientes a las bellas artes. Madrid.

Degrassi, A., 1971, L'administrazione delle citta, Scritti vari di antichita, Trieste: 67-98.

De Guadix, D. (2007), Diccionario de arabismos: recopilación de algunos nombres arábigos. María Águeda Moreno Moreno (ed.). Universidad de Jaén.

Díaz Martínez, P. (1987), Formas económicas y sociales en el monacato visigodo. Salamanca.

Fita i Colomé, F. (1896), Lápidas visigóticas de Guadix, Cabra, Vejer, Bailén y Madrid, Boletín de la Real Academia de la Historia, tomo 28: 403-426.

Flórez, E. (1776), España Sagrada, Theatro Geographico-Histórico de la Iglesia de España, Madrid.

Galmes de Fuentes, A. (2000), Los topónimos sus blasones y trofeos (La toponimia mítica), Real Academia de la Historia, Madrid.

García y Bellido, A. (1959), Las colonias romanas de Hispania, AHDE 29: 447-512.

García y Bellido, A. (1961), El Exercitus Hispanicus desde Augusto hasta Vespasiano, AEArq 34: 116-119.

García Moreno, L. A. (2008), Leovigildo unidad y diversidad de un reinado. Real Academia de la Historia, Madrid.

García Sánchez, M., Spahni, J. C. (1959), 'Sepulcros megalíticos de la región de Gorafe (Granada) ', Archivo de Prehistoria Levantina, VIII: 43-114.

González Román, C. (1992), La Colonia Julia Gemella Acci y la evolución de la Bastetania, Dialoghi di Archeologia, 10.1-2: 155-164.

González Román, C. (2011), 'Colonia Julia Gemella Acci (Guadix, Granada)'. En: González y J. C. Saquete, Colonias de César y Augusto en la Andalucía romana, Roma: 297-341.

González Román, C. (2014), 'Netón y la integración accitana' en A. Caballos y E. Melchor (eds.), De Roma a las provincias: Las élites como instrumento de proyección de Roma, Sevilla: 617-632.

Goubert, P. (1946), 'L'Espagne byzantine. Administration de I'Espagne byzantine (suite). Influences byzantines religieuses et politiques sur l'Espagne wisigothique', Revue des études byzantines, 4: 71-134.

Grotefend, L. C. (1840), Zimmermann's Zeitschrift für die Altertumwissenschaften, Giessen.

Jaramillo, M. (2004), 'Aproximación histórica a la vida y a la obra de Pedro Suárez', Boletín del Centro de Estudios «Pedro Suárez, 17: 267-284. 
Hübner, E. (1893), Monumenta Linguae Iberica, Berlín.

Laffi, U. (2004), Le colonie romane con l'appelativo Gemela o Gemina, Artissimum memoriae vinculum. Scritti di geografia storica e di antichità in ricordo di Gioia Conta, Firenze: 235-254.

Lucas J. y Ventura J. (1832) Memorias de la Real Academia de la Historia, Volumen 7, Real Academia de la Historia, Madrid: 490.

Maier allende, J. y Salas Álvarez J. (2007) Los inspectores de antigüedades de la Real Academia de la Historia en Andalucía. En Las instituciones en el origen y desarrollo de la arqueología en España. Belén Deamos, M., Beltrán Fortes, J. (Eds.). Sevilla: 175-238.

Montanero Vico, D. (2005), La problemática sobre el limes bizantino en la península ibérica: ¿realidad histórica o construcción historiográfica?, Ex novo: revista d'historia y humanitats, II: 55-56.

Morales, A. (1571), Crónica General de España.

Olmos, R. (1985), Una inscripción jonia arcaica en Huelva, Lucentum, 4: 107-114.

Pastor Muñoz, M. (2002), Corpus de inscripciones latinas de Andalucía. IV. Granada.

Rodríguez Domingo, J. M. (1997), 'La actividad de la Comisión Provincial de Monumentos de Granada en las comarcas de Guadix y Baza (1867-1923) ', Boletín del Instituto de Estudios Pedro Suarez, 10: 171-188.

Sainero Sánchez, J. R. (2014), Neto héroe y dios de los brigantes gallegos conquistadores de Irlanda, El Correo Gallego, 21/12/2014, http://www.elcorreogallego.es/tendencias/el-correo2/ecg/netoheroe-y-dios-de-los-brigantes-gallegos-conquistadores-de-irlanda/idEdicion-2014-12-

21/idNoticia-907024/ [En Línea, 09/03/2016].

Sainero Sánchez, J. R. El dios Neto de los hispanos conquistadores de Irlanda, Canal UNED, http://contenidosdigitales.uned.es/fez/view/intecca:VideoCMAV-46747 En Línea, 09/03/2016).

Salvador Ventura, F. (1988), 'El poblamiento en la provincia de Granada durante los siglos VI-VII', Antigüedad y cristianismo, 5: 339-352.

Sánchez Albornoz, C. (1949), El proceso de romanización de España desde los Escipiones hasta Augusto, Anales de Historia Antigua y Medieval, Buenos Aires.

Sánchez Martínez, M. (1993), Colonia Julia Gemella Accitana, Boletín Instituto de Estudios Pedro Suarez, 6: 7-12.

Santero, J. M. (1972), Colonia Iulia Gemella Acci, Habis, 3: 203-222.

Stylow, A.U. (2000), Die Accitani veteres und die Kolonie lulia Gemella Acci. Zum Problem von veteres, Alt-Stadt und Kolonie in der Hispania Ulterior, Chiron 30: 775-806.

Suarez de Cazalilla, P. (1696), Historia del Obispado de Guadix, Madrid.

Sutherland, C. V. (1939), The Romans in Spain 217 B.C., A.D. 117, Londres.

Reyes Martínez, A. (2016), 'Barthe, un accitano en la Real Academia de la Historia'. Ideal, 30- 4- 2016.

Tárrago y Mateos T. (1862), Historia de Guadix, Baza y pueblos del obispado. Granada.

Thompson, E. A. (1971), Los Godos en Hispania, Madrid.

Vittinghoff, F. (1952), Römische Kolonisation und Bürgerrechtspolitic under Caesar und Augustus, Wiesbaden.

Vives, A. (1924), La moneda hispánica, Madrid.

VVAA. (1832), Memorias de la Real Academia de la Historia. Tomo VII, Madrid: 17. 


\title{
La Arqueología en la prensa nacional: el caso de La llustración Española y Americana
}

\author{
Rebeca Arranz Santos* \\ Universidad Complutense de Madrid
}

\section{Prensa y periodismo de finales del siglo XIX y principios del siglo XX}

\subsection{La Revista, impulsora de las Artes Gráficas}

El desarrollo y el perfeccionamiento de las Artes Gráficas ${ }^{1}$ se debió a un número selecto de factores culturales, si bien, uno de los principales fue sin duda la denominada: Revista Ilustrada ${ }^{2}$. Este tipo de publicaciones atrae al lector no por el interés inmediato de conocimiento de la noticia ${ }^{3}$ (de ello se encarga cuidadosamente el diario), sino por la utilización de otros elementos técnicos entre los que, naturalmente, el grabado ocupa un primer puesto.

El sometimiento de la actualidad a un "revisión" más severa permite el hallazgo de esa suma de matices subjetivos en los que está la clave de un nuevo periodismo que cabría en la definición de "literario", así como también la creación artística allanó el camino hacia el contacto inmediato con importantes masas de lectores (Gómez Aparicio 1971: 604).

La atracción del escritor y el artista, y el mejoramiento de los medios para la divulgación de sus obras respectivas son fenómenos rigurosamente paralelos. Las revistas gráficas dan al grabado la utilidad del mismo, que no es otra que la exclusivamente ilustrada, porque la reproducción mediante el dibujo de las escenas vivas no se ha conocido aún por el momento.

Este período llegó con la fundación, en 1842 en Londres, del Ilustrated London New, y en el año siguiente, de L'illustration Française, de París, y la Ilustrierte Zeitung, de Leipzig, revistas innovadoras y pioneras, pues crearon un arte nuevo; el de la traslación al lector, por el dibujo de la noticia actual, con lo que el periodismo ilustrado se convirtió en el periodismo gráfico (Gómez Aparicio 1971: 605).

La invención tardó en llegar a España, pero en 1857 Gaspar y Roig ${ }^{4}$ lo asimilaron, fundando así El Museo Universal, en el que la incipiente información gráfica tiene ya cultivadores tan célebres como Francisco Ortego (Perera 1960), Valeriano Bécquer, Bernardo Blanco y Alfredo y Daniel Perea. Fue el salto preparatorio para alcanzar la cima de este género informativo-artístico: La Ilustración Española y

\footnotetext{
* Este artículo es fruto de la investigación realizada para la elaboración del TFM titulado: "La arqueología en la prensa nacional de la segunda mitad del siglo XIX y comienzos del XX: el caso de La Ilustración Española y Americana" dentro del programa del Máster universitario oficial "Arqueología del Mediterráneo en la Antigüedad clásica (Universidad Complutense de Madrid)', presentado el 28 de septiembre de 2015 y tutorizado por el Doctor Jesús Salas Álvarez.

${ }^{1}$ El concepto de Artes Gráficas se refiere a un conjunto de oficios, de técnicas, trabajos y de profesiones que intervienen en la gráfica o en la editorial, por consiguiente, todas las áreas de diseño gráfico, como la prensa.

${ }^{2}$ El grabado informativo comienza siendo una copia tosca y restrictiva del referente histórico, pero acabará imponiéndose como medio de acceso a los objetos que acaban sustituidos por su reproducción a plena satisfacción del consumidor.

${ }^{3}$ A ello alude precisamente la denominación de "Revista", que "revé" o "vuelve a ver" la noticia ya dada a conocer por el diario para incorporarle nuevos aditamentos que la completen y le proporcionan un mayor valor.

${ }^{4}$ Los catalanes José Gaspar Maristany (grabador en su juventud) y José Roig Oliveras crearon en Madrid en 1845 una sociedad para el negocio de la imprenta y librería denominada Gaspar y Roig.
} 
Americana, con su máximo artífice: Juan Comba $^{5}$ (sobre la labor de este artista en La Ilustración Española y Americana Ayrault 1996).

En el aspecto de la técnica impresora, La Ilustración se caracteriza por otra innovación: el empleo de la zincografía. En aquel momento había sido inventada la fotografía e irrumpe vertiginosamente la técnica revolucionaria del fotograbado (sobre la evolución de las reproducciones de las imágenes en las ilustraciones, véase Fontbona 1996). Con ello arraigó el Periodismo Gráfico propiamente dicho, la "instantánea" obtenida por medios mecánicos pide una consideración fundamental cuando supera al dibujo informativo, y la noticia por la imagen empieza a reclamar de los periódicos un trato de igualdad con la noticia escrita (Gómez Aparicio 1971: 2).

\subsection{La legislación de los periódicos ilustrados}

El Sexenio Revolucionario (1868-1874) abrió la posibilidad de hacer realidad el modelo modernizador y democrático sufragado por los sectores más dinámicos de la burguesía y por segmentos de la aristocracia que se habían mantenido al margen del poder oligárquico. El intento se vio desbordado por la desunión de las fuerzas políticas, la oposición armada de los carlistas y la radicalización de republicanos y políticos. Finalmente, los productores de la experiencia, entre los que se contó la prospera burguesía catalana, llegaron al compromiso que se selló con la Restauración (Martínez 2001: 55-69).

Con el referente de la Corona representada en la persona de Alfonso XII (1874-1885) y, posteriormente, de la Regente María Cristina (1885-1905), el sistema de la Restauración fue un pacto entre élites para asegurar la alternancia que diera paso a la estabilidad. Valera Ortega dispone la eliminación de la intrusión de los militares, la mejoría de la gobernabilidad y el hecho de que libertades políticas y clásicas se generalizaran social y geográficamente. No fue un régimen construido para el ciudadano, sino para los profesionales de la política que se "alternaran" en el reparto del poder (Martínez 2001: 3).

El Gobierno Provisional nacido de la revolución "Gloriosa" en 1868 pronunció una libertad de prensa hasta entonces desconocida en España. La Constitución de 5 de junio de 1869 establecía el sometimiento de los delitos relativos a la imprenta a la legislación común y suprimía todo tipo de censura. Sólo al final del período la inestabilidad política llevó a los últimos gobiernos a intervenir y eliminar los periódicos federales y carlistas.

El eje de la política de la Restauración fue el artículo 13 de la Constitución del 30 de junio de 1876 que establecía una vez más la libertad y el derecho de expresar ideas y opiniones, y que desarrollaría plenamente el gobierno de Sagasta en la Ley del 26 de julio de 1883. En los aspectos sustanciales como la supresión de la jurisdicción especial para los delitos de imprenta, la Ley estaba conectada con la reglamentación del sexenio y estaría vigente hasta entrado el siglo XX.

El marco legal y medio social quedará reflejado en varias pautas evolutivas marcadas por el propio gobierno a través de los decretos: de diciembre de 1874, de enero de 1875 y de diciembre de 1875 , que permitieron controlar a la prensa disidente mediante distintas fórmulas de censura gubernativa. Posteriormente la Ley del 7 de enero de 1879 vino a modificar el procedimiento, suprimiendo la licencia previa, pero introduciendo un criterio económico de depósitos a los que pretendieran iniciar una empresa periodística.

La cultura española entra en la Restauración, calificada por la historiografía como 'Edad de Plata' (18751936) dadas las fuerzas de las expresiones científicas, literarias y artísticas que alcanzan un notable prestigio en Europa e Hispanoamericana, donde estaban surgiendo corrientes hispanistas que valoran la aportación española a la construcción de las naciones (Martínez 2001: 3).

\footnotetext{
${ }^{5}$ Los grabados de La Ilustración Española y Americana fueron realizados por el precursor español del reportaje gráfico, Juan Comba.
} 
Antes del desastre del 98', los intelectuales reflexionaron sobre la realidad del país que, a pesar de los avances, contrastaba cada vez más con la modernidad de las potencias más desarrolladas. Las manifestaciones culturales oscilaban entre el seguimiento de los modelos extranjeros y la observación de 10 "Propio". Una vez más, la prensa se hizo eco de estas inquietudes y se convirtió en la forma de difusión del único difusor de tendencias ${ }^{7}$ (Martínez 2001: 3).

\subsection{Principales periódicos culturales españoles}

La difusión del periodismo gráfico en España durante el siglo XIX se produce, como en el resto de Europa, en dos momentos. El primero (1834-1849) corresponde al momento de las publicaciones enciclopédicas y pintorescas, lecturas variadas para familias en las que predomina el paisajismo y el costumbrismo, siguiendo el modelo de los magazines británicos y franceses. El testimonio pionero lo aportó la revista gaditana Almacén pintoresco o el Instructor (1834-1835), la única que tradujo literalmente el término magazine o magasin al castellano (Alonso 1996).

Hay una fase indefinida (1841-1868) en la que la nota universal, no muy abundante pero muy calificada por figurar en la cabecera de las más importantes revistas madrileñas de aquellos años: La Ilustración. Periódico Universal (1849-1857) y Museo Universal (1857-1869), parece perfilar un proyecto periodístico superador de los magacenes pintorescos, prácticamente agotados hacia 1868 (Alonso 1996).

El clima revolucionario alentado por la septembrina se llevó lo "pintoresco-romántico" para afirmar la supremacía definitiva de las "ilustraciones realistas" que venían pugnando por imponerse desde veinte años atrás. Esto supuso un cambio significativo, porque en términos de periodismo gráfico durante la segunda mitad del XIX en España lo viejo se apellida pintoresco y lo nuevo se llama Ilustración (Alonso 1996).

Detrás de esta circunstancia se esconde seguramente un problema de consumo cultural, dudosamente explicable por la hipótesis de que en España no hubiera público para mantener la coexistencia de las dos grandes líneas del periodismo gráfico europeo ni gusto para salvar la tradición de los magacines y museos pintorescos. Existía una demanda de enciclopedismo y curiosidades que se desviaba hacia otro tipo de publicaciones misceláneas o era absorbida por revistas que, en el aludido período de transición, se intitulaban convencionalmente Ilustraciones, pero no respondían al inexcusable principio de información gráfica de actualidad propio de este último tipo de periódicos (Alonso 1996).

El segundo momento (1849-1921) corresponde a una larga fase de creciente competitividad informativa y ampliación de mercados, que introdujo de manera masiva representaciones de la actualidad política, militar, artística, científico-tecnológica o de sucesos, cuya difusión estaba subordinada al acelerado progreso de las técnicas de reproducción de la imagen seriada que la xilografía hubo de dejar paso al vértigo renovador de los medios de comunicación y a la era del fotograbado aplicado tanto a la reproducción de dibujos como a la de fotografías. Es la época de las Ilustraciones, cuya fase dorada se extiende hasta el último decenio del XIX ${ }^{8}$ (Alonso 1996).

Su decadencia se inició hacia 1891, con de la aparición de Blanco y Negro, semanario que inauguró un concepto más ágil y variado del periodismo gráfico, perfeccionado muy pronto por Nuevo Mundo, Mundo Gráfico y El Globo: un exceso de papel cuché, fotografía, tricromía y lujo en la impresión para desarrollar

\footnotetext{
${ }^{6}$ Con la observación de lo "propio", nos referimos a las corrientes literarias del realismo y el naturalismo.

${ }^{7}$ Sus artífices y consumidores fueron los sectores medios de la burguesía, intelectuales y profesionales y políticos con vocación de cambio porque todavía los elevados precios y el tipo de contenidos excluían a buena parte de la sociedad.

${ }^{8}$ La difusión de las ilustraciones en España tiene su foco inicial en Madrid, y otros secundarios, pero con personalidad propia en la periferia mediterránea, en núcleos urbanos de particular vitalidad cultural y económica (Barcelona, Valencia o Málaga).
} 
un gusto "moderno" y estimular en el público una nueva sensación de ruptura entre lo nuevo y lo viejo?. Al comienzo de los años veinte del siglo pasado, las ilustraciones estaban agotadas como vehículo informativo y se limitaban a alimentar la nostalgia (Alonso 1996).

Por otro lado, era muy difícil competir con las empresas extranjeras que tendían sus propias redes informativas en España cuando la ocasión lo merecía. Fueron dos decenios de tentativas inseguras, años de aclimatación con fracasos y rectificaciones, durante un período en que la única Ilustración de alcance nacional fue el Museo Universal, editado por Gaspar y Roig. Su desaparición en 1869 fue el germen de La Ilustración de Madrid. Ésta revista se frustró al poco de nacer por la competencia de La Ilustración Española y Americana, empresa creada por Abelardo de Carlos que reivindicó para sí la continuación del Museo Universal (Alonso 1996).

La revolución democrática de 1868 supuso la afirmación del género ${ }^{10}$, sólo a partir de 1880 la creciente prosperidad de Barcelona propició la brillantísima aparición de las únicas ilustraciones que por su capacidad llegaron a estar en condiciones de competir con aquélla: La Ilustración, del editor Luis Tasso, La Ilustrado Catalana, La Ilustración Artística, de Montaner y Simó, y La Ilustración Ibérica (Alonso 1996: 48). Fue el momento de máxima pujanza en que se intensificó la dispersión geográfica de los periódicos ilustrados, así como su especialización temática (Alonso 1996).

\subsection{Principales periódicos culturales internacionales: The Illustrated London News, y L'Illustration}

\section{The Illustrated London News}

La primera observación que se puede hacer acerca de The Illustrated London News, la primera revista de este tipo (1842) (Fig. 1), es que, en la muy rica bibliografía sobre la prensa inglesa de la época victoriana, no ha merecido estudios particulares. En Inglaterra The Illustrated London News se considera como una más de las numerosas revistas ilustradas que florecieron en los años 1840, a pesar de ser la primera revista del mundo de información semanal.

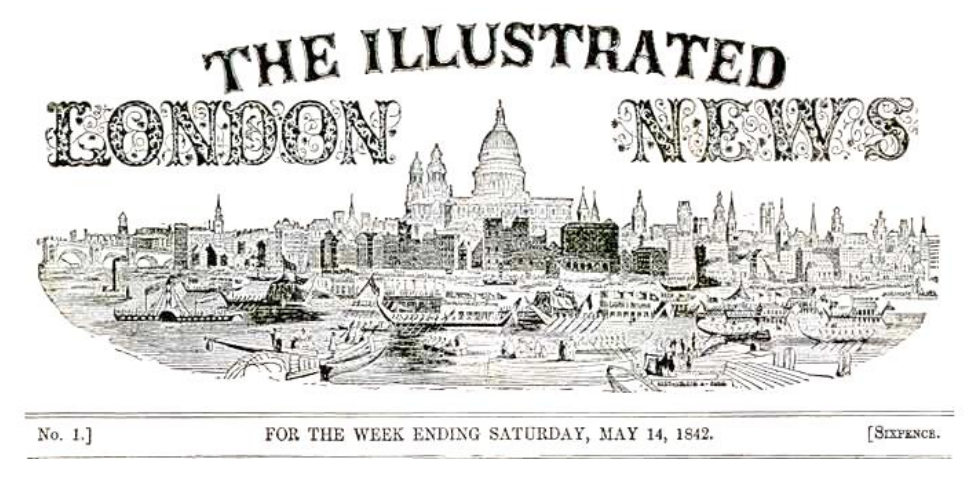

Fig. 1. Encabezado del periódico The Illustrated London News.

La revista que para los historiadores de la prensa victoriana marca realmente el nacimiento de una prensa basada en la imagen destinada a un público de masa es The Penny Magazine, que salió en 1832 y duró hasta 1945. The Penny Magazine que, como lo indica su título, sólo valía un penny y se destinaba a un público de clase baja o medio baja, no era precisamente un diario de noticias, pero su existencia como la de sus tres seguidores que aparecen en 1845 -The London Journal, Reynold's Miscellany y Cassell's Illustrated Family Paper, todas profusamente ilustradas- explica el impacto de la imagen en la sociedad victoriana (Trenc 1996: 57).

Herbert Ingram publicó en Londres un semanario de información que dependería totalmente de las ilustraciones. Contrató a periodistas, dibujantes y grabadores imprescindibles para la reproducción de las imágenes a través del procedimiento de la xilografía, y el 14 de mayo de 1842 aparecía el primer número

\footnotetext{
${ }^{9}$ Lo viejo era ahora las ilustraciones que habían adquirido ya la rancia pátina de lo demodé y se identificaban, por su fidelidad, al grabado a buril con el gusto más conservador, en convivencia agónica con las nuevas formas, más aptas para rebasar los límites del consumo burgués.

${ }^{10}$ Centralizado en la capital madrileña durante los años siguientes, y acentuando su consagración, La Ilustración Española y Americana.
} 
de The Illustrated London News, con 16 páginas y 32 grabados, cuyas características eran: la universalidad, la afición a las catástrofes, los crímenes, la crónica mundana, la revista de teatros y de libros y tres páginas de anuncios comerciales (Trenc 1996: 57).

Para los lectores de la pequeña tipografía de los diarios victorianos, The Illustrated London News fue una revelación. Las revistas de información gráfica, aparte del progreso considerable de las artes gráficas del siglo XIX, deben su éxito a toda una serie de progresos técnicos que permitieron a las noticias llegar de lugares lejanos en un corto intervalo de tiempo, que parecía increíble sólo unos años antes, gracias a los buques de vapor y al ferrocarril. Las noticias llegaban a Londres en doce días desde Nueva York y en treinta días desde la India ${ }^{11}$ (Trenc 1996: 58).

Conocer el pasado ya no bastaba en una época de desarrollo considerable del conocimiento en todos los campos del saber (Houghton 1982). Por eso los editores de la prensa victoriana tomaron conciencia de la necesidad de instruir a la sociedad. The Illustrated London News afirmaba en su prefacio: 'sus ilustraciones eran el registro pictórico de la historia del mundo y que eran capaces de formar la mente de los hombres y de enaltecerlos a través de las cualidades permanentes del arte: la universalidad, la verdad y la totalidad'. Charles Knight describe admirablemente la falsificación de la verdad que suponía este tipo de revista (Knight 1864-5: 246-247).

The Illustrated London News se adaptaba a su público, perteneciente mayoritariamente a la clase media y media alta de ideología tradicionalista y conservadora, dándole una visión superficial y convencional de la sociedad. De allí viene su éxito y su extraordinaria longevidad.

\section{L'Illustration}

Cuatro periodistas republicanos liberales que colaboraban en el periódico Le National crearon en 1843, un año después de la aparición de The Illustrated London News, el periódico L'Illustration (Fig. 2). Alexandre Paulin asumió rápidamente la dirección y renovó el periodismo en Francia, (inspirándose en el modelo británico) mediante la lectura de la prensa extranjera, el envío de corresponsales al lugar de los acontecimientos, a la colaboración
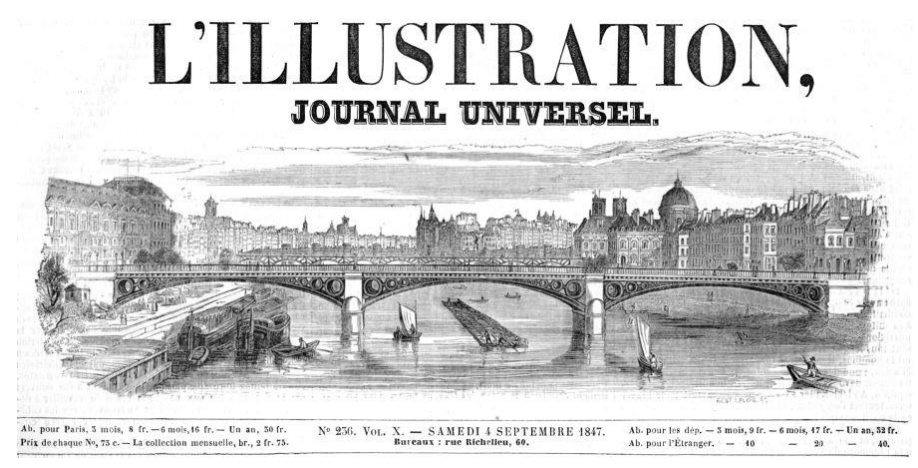

Fig. 2. Encabezado del Periódico L'Illustration. voluntaria de los lectores de L'Illustration repartidos por el mundo entero y a una nueva técnica de exposición de los hechos (Trenc 1996: 59) (Fig. 2).

L'Illustration exploró el terreno de la búsqueda de las fuentes de la información, lo que será la base del periodismo moderno. Como su homóloga británica, pretendió la universalidad, de ahí que sus noticias de política, bellas artes, música, teatro, bibliografía y mundanidades se mezclasen en la revista, poniendo el énfasis en la Ilustración, la imagen. El formato es de un gran tamaño $(28$ x $32 \mathrm{~cm})$, el más grande de las revistas ilustradas francesas, antes de la aparición de Le Monde IIlustré (Trenc 1996: 59).

L'Illustration salía cada sábado, contaba con 16 páginas y a veces llevaba grabados fuera de texto. El rasgo fundamental de la revista era el número y la calidad de los grabados, para los que contaba con los mejores dibujantes de la época ${ }^{12}$. Las noticias de las guerras, los grandes asuntos diplomáticos internacionales, también incluyen la novedad y lo insólito de reportajes de viajes lejanos o bien en una perspectiva

\footnotetext{
${ }^{11}$ Las Ilustraciones españolas estaban destinadas en un porcentaje no desdeñable al mercado hispanoamericano para el cual era vital esa reducción considerable del tiempo del viaje.

${ }^{12}$ El recurso de la imagen se justifica por el criterio de la eficacia, lo que convertía a la revista en un fiel espejo donde se reflejaba la vida de la sociedad del siglo XIX.
} 
geográfica o etnográfica, o bien en relación directa con la actualidad política o el acontecimiento (Trenc 1996: 60).

A lo largo de su historia (1843-1944), L'Illustration aparece como una de las revistas más características de la burguesía tradicional francesa, una revista moderada, seria, y muy patriótica. Como señala Marchandiau (Marchandiau 1987), L'Illustration en el siglo XIX era un poco como la televisión hoy en día, el mensaje aceptado sin contestación gracias al poder de su evocación. La revista quería describir y contar el acontecimiento con la prueba evidente de la imagen dibujada, sin analizar, ni sobre todo entrar en polémicas.

En el primer tercio del siglo XX, L'Illustration vino a ser una vitrina de Francia en el mundo, un potente medio de fomento de la civilización francesa donde se mezclaban el lujo, la alta cultura y el gusto por el progreso técnico, y la vulgarización científica de las modernas invenciones, lo que la transformó en la revista gráfica más lujosa del mundo, sin equivalente en ningún otro país (Trenc 1996: 61).

\subsection{El fin de los periódicos ilustrados}

La desaparición de La Ilustración Española y Americana, en 1921 puede considerarse como el fin de todo un género cuyo arquetipo constituía esta revista. Pero su muerte es precedida de un largo proceso de decadencia coincidente con la floración de una serie de publicaciones nuevas. A principios de los años 1890, La Ilustración Española y Americana era todavía el modelo de referencia de la prensa ilustrada, incluso para quienes intentan cuestionar su supremacía. Hasta entonces, todos los que han pretendido competir con ella básicamente lo han hecho imitándola. Pero el cambio se inicia con la creación, en 1891, de Blanco y Negro (Desvois 1996: 343).

En 1894 nace El Nuevo Mundo, que se transformó rápidamente en Nuevo Mundo. Su fundador fue José del Perojo, que fue colaborador asiduo de La Ilustración Española y Americana y lanzó ya dos publicaciones: Revista Contemporánea, en 1875, en la que volcó su ambición de desarrollar la filosofía de Kant, y el diario La Opinión, en 1886. Esta vez Perojo apuntó al gran público. A diferencia de Torcuato Luca de Tena, fundador de Blanco y Negro, no dispuso de una fortuna personal que le proporcionase un sólido respaldo a su empresa. Pero gracias a la astucia de su asociado, Mariano Zavala, a quien se le ocurrió crear paralelamente una hoja informativa semioficial que informaba del movimiento del personal administrativo en Ultramar, alcanzó un nivel de ventas interesante. En 1896 incluso lanza un suplemento literario (Desvois 1996: 343).

Pero más aún que todas las consideraciones anteriores, la lectura de todos estos periódicos es la que da la clave de su éxito, que hace de los años 1900 la edad de oro de la prensa ilustrada en España. En comparación con La Ilustración Española y Americana, en conjunto ofrecen un contenido diferente. Hacia 1900, La Ilustración viene siendo una revista literaria ilustrada.

Sus competidores también se basaban en la asociación de texto e imagen que le dieron el éxito. Pero Blanco y Negro, Nuevo Mundo y Mundo Gráfico estaban en relación mucho más directa con la actualidad y recurrían mucho más a la fotografía. Otra diferencia era la función que desempeña el texto: se hablaba poco de temas serios, especialmente de política. Como La Ilustración Española y Americana, sus competidores pretenden enseñar y deleitar a la vez, pero insisten más en este último aspecto. Evitan ese didactismo, esas largas y pesadas explicaciones que hacen indigesta a la venerable revista, y a la utilización del exotismo que imitan de ella, añadiéndole todo lo que puede darles una tonalidad festiva (Desvois 1996: 346-347).

De ello resultó otro tipo de presentación: un formato reducido, una utilización mucho mayor de la imagen, y en especial de la fotografía, que desbancó al grabado, base del éxito de las Ilustraciones. La Ilustración Española y Americana merece especial insistencia en la calidad de su presentación. Desde su creación, no cesó de innovar y fue pionero en las nuevas técnicas de impresión, siendo el primer periódico español que utilizó la bicromía en 1897, la tricromía en 1899 y, poco después, la cuatricromía. De hecho, la única 
publicación periódica que se pudo comparar entonces con Blanco y Negro, superándola incluso, es La Esfera. En el segundo decenio del siglo, la reproducción de obras de arte en color cede el paso ante la fotografía en blanco y negro (Desvois 1996: 347).

El fin de las Ilustraciones parece deberse a una triple mutación de la prensa de entretenimiento: económica, técnica y de contenidos. La vuelta del siglo señala la transición en España de una prensa de tipo artesanal a una prensa de tipo industrial. Los semanarios que nacen en los años 1890-1900 saben utilizar los nuevos medios que se les ofrecen para preceder la espera del público y seducir a masas crecientes de lectores. Al lado de los diarios, que informan y reflexionan sobre la actualidad, y ofrecen colorido y evasión, las Ilustraciones están condenadas a desaparecer o a renovarse, adoptando otras pautas: en la práctica viene a ser lo mismo, pues si cambian de fórmula dejan de pertenecer a un género que así acaba extinguiéndose (Desvois 1996: 348).

\section{La llustración Española y Americana}

El primer número de La Ilustración Española y Americana apareció el 25 de diciembre de 1869 y tenía, inicialmente, una periodicidad semanal. Desde el 5 de agosto de 1870 pasó a tener periodicidad decenal, con un formato de 415 x $290 \mathrm{~mm}$. En el subtítulo de la publicación figuraba Museo Universal. Periódico de Ciencias, Artes, Literatura, Industria y Conocimientos útiles ${ }^{13}$ (Fig. 3).

El dibujo de la cabecera era original de Bernardo Rico y varió conforme pasaron los años. En el primer artículo, firmado por el propio Abelardo de Carlos, se dirigía al

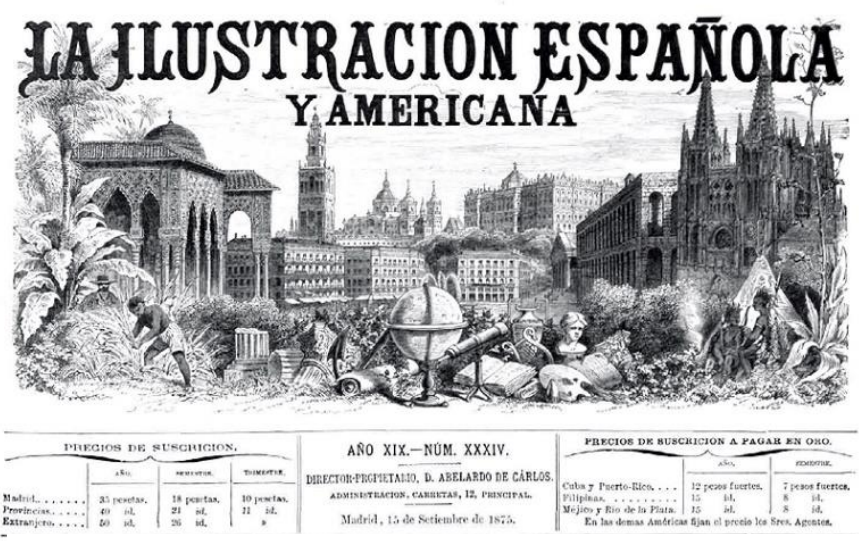

Fig. 3. Encabezado de La llustración española y Americana. público en estos términos:

'En conformidad con lo que manifestamos en el último número de El Museo Universal y en el prospecto de La Ilustración Española y Americana que hemos publicado, nos presentamos hoy al público deseosos de demostrar prácticamente nuestro pensamiento. Escusamos insistir en nuestras ofertas y nos concretamos á decir que haremos cuanto nos sea dable para lograr que La Ilustración Española y Americana llegue antes de mucho, si no á superar, porque esto es por ahora imposible en España, al menos á igualarse á las publicaciones que de su clase ven la luz pública desde hace muchos años en el extranjero, ${ }^{14}$.

La publicación se encuadernaba en dos volúmenes anuales, que se paginaban independientemente en cada uno de ellos ${ }^{15}$. Las tapas eran de color rojo, con estampaciones en negro y oro, lo que confería una atractiva presentación $^{16}$. La Ilustración que abría las páginas interiores de los volúmenes encuadernados fue

\footnotetext{
${ }^{13}$ La Ilustración Española y Americana, año 14, n ${ }^{\circ}$, Madrid, 25 de diciembre de 1869.

${ }^{14}$ De Carlos, A, Al público. La Ilustración Española y Americana, año 14, n 1, Madrid, 25 de diciembre de 1869.

${ }^{15}$ Aunque sostenemos que se encuadernaban en dos volúmenes por año, hemos podido verificar que algunos años, especialmente durante la primera etapa de la publicación, están encuadernados en un solo volumen. Ignoramos si esto fue realizado por los propietarios de las colecciones o estaba así previsto por el editor, ya que el segundo volumen de cada año comienza con una nueva numeración de las páginas.

${ }^{16}$ Esta encuadernación es la original, facilitada por los editores de la publicación. No obstante, hemos visto varias colecciones encuadernadas en otros colores, seguramente por encargo de los propietarios de las mismas.
} 
realizada por el pintor Eduardo Rosales (Rubio 2002: 121), a petición de Abelardo de Carlos (Márquez 2005: 194).

De Carlos estuvo a la vanguardia de los avances tecnológicos en materia de imprenta y de la calidad del papel. A su previsión y nobles esfuerzos se debe asimismo la parte que tomó en la propiedad de unas fábricas de papel en Tolosa, casi destruidas durante la última guerra carlista, para contribuir a casi duplicar su industria. Pretendió así la emancipación contra el consumo de papeles finos extranjeros ${ }^{17}$. Las fábricas de papel fueron inauguradas por el rey Alfonso XII, tal y como se recoge en las informaciones aparecidas en el $n^{\circ} 31$ de la publicación, de fecha 22 de agosto de $1884^{18}$ (Márquez 2005: 202).

La Ilustración Española y Americana no se distribuía únicamente en la Península, sino que llegaba también a tierras americanas, donde tenía un amplio número de suscriptores. Cuando Abelardo de Carlos empezó a entablar sus relaciones editoriales con América, apenas existían comunicaciones con la mayor parte de aquellos estados: no era posible hallar corresponsales ni había protección ni tratados ni medios de constituir ninguna empresa formal y duradera. Las dificultades vencidas hasta llegar a conseguir una organización sólida y regular, tan sencilla como la que actualmente funciona, constituye una epopeya mercantil $1^{19}$ (Márquez 2005: 202).

Junto a estas publicaciones se editaron unos almanaques ${ }^{20}$ anuales, donde colaboraron las firmas más prestigiosas del momento. Otra de las empresas del fundador del periódico fue la Biblioteca Selecta de Autores Contemporáneos. Su primera publicación fue en 1872 con los Recuerdos de Italia, de Castelar; y El Gaban y La Chaqueta, de Trueba ${ }^{21}$. En la biblioteca publicaron sus obras autores como Mesonero Romanos, Castelar, Ortega Munilla, Juan Valera y Pedro Antonio de Alarcón, entre otros. Por espacio de dos años, entre 1874 y 1875, se publicó otra revista, El Bazar, que seguía la línea de La Ilustración Española y Americana, aunque con papel e impresión de inferior calidad, menor tamaño y precio más reducido (Márquez 2005: 203).

\subsection{Dirección}

D. Abelardo de Carlos y Almansa nació en Cádiz el 3 de noviembre de $1822^{22}$ (Botrel 1996: 91). Casi nada se sabe de la infancia y juventud, así como de su formación (López Núñez 1929: 137-138). Es indudable que debió ser una persona culta para su época. Fue un hombre que siempre se mantuvo al margen de las controversias políticas con una templanza que contrastaba con el ímpetu que demostró en sus actividades empresariales ${ }^{23}$. Lo poco que sabemos acerca del aspecto físico de De Carlos apareció publicado en las páginas de La Ilustración Española y Americana ${ }^{24}$.

Hay quienes, como Gómez Aparicio (Gómez Aparicio 1971), sostienen que estuvo en América (Gómez Aparicio se ha basado en la obra de López Núñez 1929), pero aceptar esta hipótesis es difícil, especialmente tras haber rastreado en el Archivo de Indias su pista, con resultados negativos. La suposición de la estancia de Abelardo de Carlos en América puede deberse a dos factores: los excelentes tratos comerciales que desarrolló durante su vida con los países situados al otro lado del Atlántico, o una

${ }^{17}$ La Ilustración Española y Americana, Madrid, año 28, n ${ }^{\circ}$, Madrid, 8 de abril de 1884. Pág. 210. En tal sentido conviene mencionar que la publicación dedicó un amplio reportaje a las fábricas de papel adquiridas, con imágenes del propio Comba.

${ }^{18}$ La Ilustración Española y Americana, año 28, n³1, Madrid, 22 de agosto de 1884. Págs. 100-109.

${ }^{19}$ La Ilustración Española y Americana, año 28, n 13, Madrid, 8 de abril de 1884. Pág. 211.

${ }^{20}$ Los almanaques de La Ilustración Española y Americana se editaban a finales de cada año y se vendían independientemente de la revista, si bien los suscriptores los recibían gratis.

${ }^{21}$ Fernández Bremón, J. La Ilustración Española y Americana, año 28, nº13, Madrid, 8 de abril de 1884. Pág. 211.

${ }^{22} \mathrm{La}$ fecha de nacimiento propuesta por Botrel, diciembre, difiere de la que aparece en La Ilustración Española y Americana, que la sitúa en noviembre del mismo año y que aceptamos como correcta.

${ }^{23}$ Fernández Bremón, J. La Ilustración Española y Americana, año 28, n¹3, Madrid, 8 de abril de 1884. Pág. 214.

${ }^{24}$ Fernández Bremón, J. La Ilustración Española y Americana, año 28, n¹3, Madrid, 8 de abril de 1884. Pág. 214. 
mala interpretación del texto de Fernández Bremón ${ }^{25}$ que, no obstante, deja meridianamente claro que no emigró (Márquez 2005: 188).

La mayor parte de las colecciones de La Ilustración Española y Americana han sido despiezadas para vender como láminas sueltas los grabados impresos en la misma. Es frecuente, pues, ver aún en los mercadillos, librerías de viejo o ferias del libro antiguo, algunas láminas procedentes de la misma. Ello es normal porque a los propietarios de dichos negocios les resulta más económicamente rentable vender así las obras que hacerlo con el tomo encuadernado.

Cuando D. Abelardo de Carlos deja en 1881 la dirección de las revistas y nombra director de $L a$ Ilustración Española y Americana a su hijo Abelardo José de Carlos y Hierro, la empresa poseía un gran capital accionarial. En 1882 tiene lugar una ampliación de capital por un importe y pasan a formar parte de la empresa su otro hijo, Isidoro de Carlos Hierro, así como los esposos de sus hijas Trinidad y Milagros, Alejandro y Manuel Moreno y Gil de Borja, respectivamente (Botrel 1996: 93). Sin embargo, a la muerte de D. Abelardo, acaecida el 8 de abril de 1884, el capital ascendió a números estrepitosos.

La estancia de Abelardo José como director de la revista duraría hasta 1898. Nació en Cádiz el 16 de julio de 1848 y falleció en Madrid el 8 de enero de 1910. Como hemos podido apreciar, no asumió la dirección de la empresa a la muerte de su padre, sino unos años antes. Esta es una de las muchas inexactitudes que tiene la obra de Gómez Aparicio, quien refiere: "Fallecido don Abelardo de Carlos el 6 de abril de 1884, le sucedió su hijo don Abelardo José, que, requerido por otras actividades, no dedicó a La Ilustración la atención que le era necesaria" (Gómez Aparicio 1971: 611).

La labor al frente de la publicación fue de marcado carácter continuista de la labor de su padre y fundador. Estuvo siempre al día en lo concerniente a la innovación tecnológica y fue bajo su mandato cuando se publicaron las primeras fotografías en las páginas de La Ilustración Española y Americana, en 1895, así como las primeras ilustraciones en color $^{26}$. Ignoramos las verdaderas razones que llevaron a Abelardo José a presentar la dimisión de su cargo en 1898. No obstante, en las páginas de la propia publicación se exponen algunas que podemos aceptar como válidas ${ }^{27}$. Es decir, que dejó la actividad periodística para pasar a ocuparse de las empresas fabricantes de papel (Cabrera 1994).

El sucesor de Abelardo José, al frente de La Ilustración Española y Americana, fue Alejandro Moreno y Gil de Borja, quien ejerció la dirección de la publicación hasta su venta, en diciembre de 1914. Bajo su mandato se consolida la información fotográfica y la Ilustración gráfica desaparece prácticamente (sobre la Ilustración gráfica en España véase, Bozal, 1979; Pla Vivas 2010). En el último número del año 1914 de La Ilustración Española y Americana, el hasta entonces director, comunicaba a los lectores el traspaso de la propiedad de La Ilustración Española y Americana ${ }^{28}$. En el primer número del año 1915 la nueva propiedad de la publicación se dirigía a los lectores en otros términos ${ }^{29}$.

Tras la venta de la publicación, baja la calidad de la misma hasta el límite de que los nuevos propietarios se ven obligados a rescatar grabados antiguos, publicados con anterioridad, con el fin de intentar atraer de nuevo a la clientela que se había marchado a otras publicaciones periódicas como Blanco y Negro, de Luca de Tena, y a la recién aparecida La Esfera.

\footnotetext{
${ }^{25}$ Fernández Bremón, J. La Ilustración Española y Americana, año 28, n ${ }^{\circ}$, Madrid, 8 de abril de 1884. Pág.211.

${ }^{26}$ La primera Ilustración en color que se publicó apareció en el año 32, n 47, del 22 de diciembre de 1888. Era una lámina central, no paginada, titulada El Invierno.

${ }^{27}$ Fernández Bremón, J. Abelardo José de Carlos y Hierro. La Ilustración Española y Americana, año 54, n², Madrid, 18 de enero de 1910. Pág. 18.

${ }^{28}$ La Ilustración Española y Americana, año 58, nº 48, Madrid, 30 de diciembre de 1914. Pág. 398.

${ }^{29}$ La Ilustración Española y Americana, año 59, ${ }^{\circ} 1$, Madrid, 10 de enero de 1915. Pág. 2.
} 
Con el año 1921, finalmente, desaparece una de las más importantes publicaciones de siglo XIX y parte del XX, que marca la transición de la información gráfica a la fotográfica en España, y que es toda una crónica gráfica del período de nuestra historia que se ha dado en llamar La Restauración.

\subsection{La revista: línea editorial}

La dirección literaria de la nueva publicación corrió a cargo de Román de Goicoerrotea y la artística a cargo de Bernardo Rico. El sumario de la revista estaba constituido fundamentalmente por unas secciones que responden al siguiente esquema, entiéndase que el orden de inserción de las mismas cambió varias veces a lo largo de la existencia de la publicación (Palenque 1990):

1. Portada. En la que predomina la información gráfica, con escaso texto. Se dedicaba a la noticia más importante de las que aparecían en cada número. La norma era la inserción de una imagen con el título de la misma al pie.

2. Nuestros grabados. En esta sección se ofrecía una detallada información acerca de la contenida en los grabados que se insertaban en el número. Solía especificarse además el nombre de los dibujantes y grabadores.

3. Crónica general. También se denominó en ocasiones Crónica y Crónica contemporánea, donde se ofrecían informaciones variadas de acontecimientos de interés-sucesos, necrológicas, viajes regios, noticias internacionales, crónicas bélicas, etc.

4. Artículos de divulgación sobre temas de interés general. Historia, literatura, avances científicos, expediciones intercontinentales, artes y biografías de personalidades.

5. Relatos. De ficción, históricos, poesía, etc., originales de autores de reconocido prestigio, tanto vivos como clásicos.

6. Crítica de libros. Tanto de nuevos libros que salían a luz por primera vez, como reediciones de libros antiguos que la sociedad parecía pedir.

7. Noticias de actualidad. De índole tanto internacional como nacional, siempre buscando la captación inmediata.

8. Grabados. Es la parte más importante de la publicación, especialmente desde el interés visual. Estaban distribuidos a lo largo de cada número. Tras la portada, venían dos páginas de texto, dos de grabados, otras dos de texto y así se iban alternando hasta las páginas finales.

9. Pasatiempos y curiosidades. Habitualmente jeroglíficos, problemas de ajedrez, noticias curiosas, etc. Se incluían en las páginas finales de cada número.

10. Publicidad. Iba inserta en las últimas páginas y la contraportada.

11. Sueltos y suplementos. En ocasiones se insertaban hojas independientes con grabados de interés. Unas veces eran reproducciones a doble página, tanto en blanco y negro como en color, y otras eran grabados desplegables de un tamaño equivalente al de cuatro páginas de la revista, es decir, 83 x 58 $\mathrm{cm}$. aproximadamente ${ }^{30}$. En otras ocasiones se insertaba un cuadernillo suplementario.

La primera redacción del periódico fue organizada por Julio Nombela, quien contrató a Rosales y Palmaroli para efectuar ilustraciones destinadas a ser publicadas en las páginas de la revista, según

\footnotetext{
${ }^{30}$ Las librerías de la época, especialmente las de la Puerta del Sol de Madrid, solían utilizar como reclamo la exposición, en los escaparates, de los ejemplares de la revista, abiertos por las páginas de información gráfica. Esto hacía que numeroso público se concentrase ante los mismos para documentarse acerca de los acontecimientos que se mostraban en la publicación.
} 
manifiesta en sus memorias: 'Grata tarea fue para mí organizar la redacción de aquella importante revista, que debía enriquecerse con la colaboración de los más distinguidos literatos y artistas' (Nomblea 1976: 780). Pero la labor de Nombela no se centró únicamente en la organización de la revista durante los primeros números, sino que tuvo una participación bastante activa en la misma con la inserción de diversos artículos y la explicación de los grabados, como él mismo recuerda (Nomblea 1976: 780).

Don Abelardo de Carlos no descuidó nunca la calidad de las ilustraciones de la publicación, que eran intercambiadas con las de las más importantes revistas europeas ${ }^{31}$ (Alonso 1996: 25-30). Entre los ilustradores con que llegó a contar se encontraron dibujantes de la talla de Bernardo Rico ${ }^{32}$, Alejandro Ferrant, Juan Comba, José Luís Pellicer, Domingo Muñoz, Francisco Ortego, Daniel Perea, José Riudavets, Mariano Pedrero, Caula, Arturo Carretero, Tomás Carlos Capuz y Domingo Muñoz. De los escritores sobresalen José Zorrilla, Ramón de Campoamor, Juan Valera, Leopoldo Alias Clarín, Emilio Castelar y, ya en los últimos años de la publicación, Valle Inclán y Unamuno.

De Carlos fue un empresario muy hábil que quiso siempre mantener buenas relaciones con sus trabajadores. Para ello, contrataba a otras personas que, en la sombra, ejercían el trabajo 'sucio'. Este fue el caso de Castro y Serrano, un escritor que llegó a ser Académico de la Lengua. Su labor en La Ilustración Española y Americana consistía en censurar (sobre la censura gubernativa, Alonso 1996: 32) secretamente los originales que los colaboradores enviaban a la revista para su publicación (Nomblea 1976: 780-781).

\subsection{Periodistas y corresponsales}

Quienes redactan los periódicos del siglo XIX eran en su mayoría hombres dedicados a las letras. Una lista comparativa de los literatos españoles del siglo XIX, confrontada con la de quienes han escrito prensa, nos da un amplio número de superposiciones de nombres: 'En el siglo XVIII y XIX, el periodista es un escritor' (Valls 1988: 24). El periodismo del siglo XIX une íntimamente literatura y política, pero también es un periódico de la historia contemporánea, en la que los hombres más cultos e ilustrados han ocupado los gobiernos. En realidad, nos encontramos ante una clase social, la burguesía, que, aunque es minoría, opera a través de una "inteligencia" también muy reducida. Hasta la aparición de los primeros diarios informativos, cuyas bases se asientan a partir de la segunda mitad del siglo XIX, cuando comenzará a definirse la figura específica del que se dedica a escribir en periódicos; periodista y escritor, en este tiempo, tiene el mismo significado funcional (Valls 1988: 24-25).

Incluso los escritores ilustrados son conscientes de que escriben para ellos mismos, para los grupos ilustrados. La irrupción de la burguesía y la consolidación de los mecanismos para reestructurar la sociedad desde la perspectiva capitalista exige contar con la movilización de amplias capas de la sociedad, que en el Antiguo Régimen tienen que permanecer mudas en el campo, en fórmulas de precaria subsistencia. Los escritores político-periodistas son conscientes de que tienen que romper el círculo de los intelectuales y aleccionar a las masas. El periodismo comienza a tomar consciencia de su largo camino hacia la popularización de la literatura a fin de alcanzar a las nuevas clases y grupos que van a tener un rol específico en la nueva sociedad (Valls 1988: 27).

De este modo, La Ilustración Española y Americana solía cubrir las informaciones con enviados especiales, tanto gráficos como literarios, siempre que ello fuese posible, o recurría a colaboradores habituales que ejercían las funciones de corresponsales como Beauchy, Laurent, Ramiro Franco, Coyne, Ricardo Huerta, Montenegro, Rocafull, Compañy o Almagro 33 (Márquez 2005: 203).

\footnotetext{
${ }^{31} \mathrm{La}$ dependencia de fuentes iconográficas extranjeras fue especialmente intensa en la fase inicial de difusión de los periódicos españoles, tanto mediante la importación y reutilización de planchas originales como por medio de la simple compra de aquellas.

${ }^{32}$ Bernardo Rico fue el Director Artístico hasta su fallecimiento, ocurrido el 8 de diciembre de 1894.

${ }^{33}$ La Ilustración Española y Americana, año 51, n47, Madrid, 22 de diciembre de 1907.
} 
Una de las vías que La Ilustración Española y Americana encontró para sacar a la luz nuevos valores, ya fueran escritores o pintores, fue la organización de concursos, como lo citan las propias líneas de las publicaciones ilustradas ${ }^{34}$. Para llevar a cabo estos certámenes artísticos, Abelardo de Carlos no dudó en recurrir a las figuras más señeras del momento en cada especialidad en la que ejercieran como miembros del jurado ${ }^{35}$. Años más tarde, cuando ya el nuevo medio de expresión, la fotografía, había adquirido relevancia artística, se unió a los certámenes pictórico y literario ${ }^{36}$.

\section{El estudio de la documentación ${ }^{37}$}

\subsection{Próximo Oriente: Egipto y Mesopotamia}

Las noticias arqueológicas encontradas en La Ilustración Española y América, que responden al epígrafe de "Próximo oriente: Egipto y Mesopotamia", podrían prescindir de la última región, dado que no se ha encontrado ninguna noticia que haga referencia a la cultura mesopotámica, ningún yacimiento, expedición legal o ilícita, objeto arqueológico o cualquier indicio de su existencia. No obstante, como ha constatado la historiografía posterior, en el siglo XIX se realizaron numerosos trabajos arqueológicos en esta zona (sobre esta cuestión Chevalier 2002; Da Riva y Vidal 2014; Margueron 2002).

Los primeros sondeos en la región oriental se llevaron a cabo en 1786 por orden del vicario general de Babilonia y correspondiente de la Academia Real de las Ciencias de esta capital Joseph de Beauchamps, pero hubo que esperar hasta 1842 para la primera excavación arqueológica real. Ésta fue realizada por el arqueólogo Austen H. Layard y motivada por el cónsul francés en Mosul, Paul Émile Botta, centrándose en el área de Tell Kujunjik, cerca de Nínive. Aparecieron unos bajorrelieves asirios, lo que supuso el primer hallazgo histórico de las civilizaciones mesopotámicas, desde las que, hasta entonces, sólo se sabía

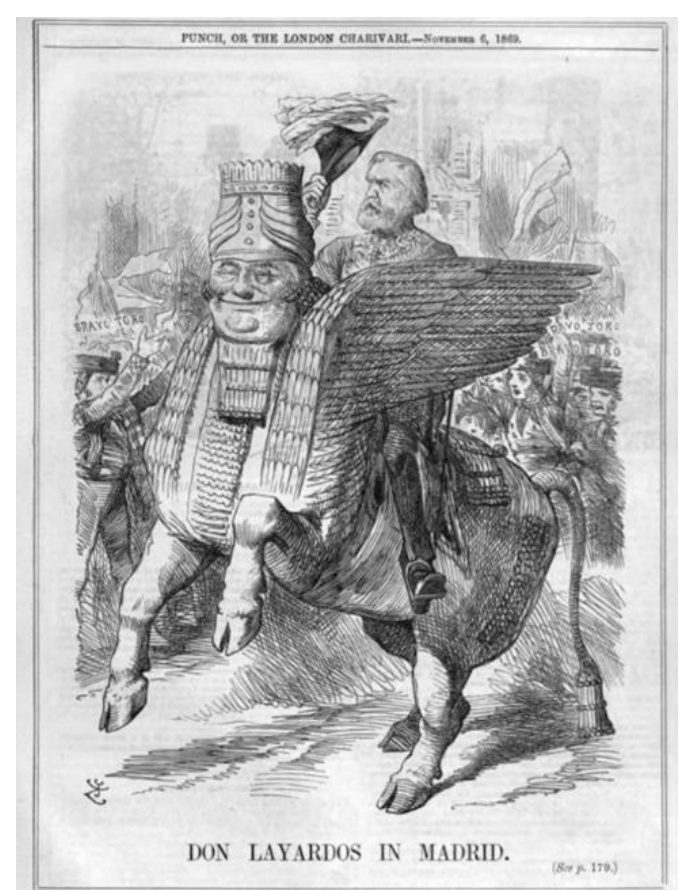
por las menciones en la Biblia.

A partir de este momento la investigación arqueológica estuvo caracterizada por la rivalidad entre dos potencias, la inglesa y la francesa. Los primeros hallaron el umbral de la biblioteca de Asurbanipal, los segundos el palacio de Sargón II en Khorsabad, hallazgos que tuvieron un desgraciado fin al hundirse en el Tigris una embarcación con 235 cajas de material. En el área del sur, en la década de 1850, se descubrieron las ciudades de Uruk, Susa, Ur y Larsa, pero no fue hasta 1875 cuando se hallaron evidencias de la civilización sumeria.

Incluso en las primeras décadas del siglo $\mathrm{XX}$ aparecieron noticias sobre los descubrimientos de gran cantidad de restos procedentes de la cultura mesopotámica, entre los que destacó el hallazgo de un gran número de estatuas de Gudea. En esta etapa igualmente comenzaron a florecer las

Fig. 4. Punch, (6 de noviembre de 1869): Don Layardos in Madrid. p. 179.

\footnotetext{
${ }^{34}$ La Ilustración Española y Americana, año 51, n47, Madrid, 22 de diciembre de 1907.

${ }^{35}$ La Ilustración Española y Americana, año 51, n47, Madrid, 22 de diciembre de 1907.

${ }^{36}$ La Ilustración Española y Americana, año 51, n 47, Madrid, 22 de diciembre de 1907.

${ }^{37}$ Anexo 1. Listado de noticias arqueológicas divididas según la temática.
} 
excavaciones de alemanes y estadounidenses (Margueron 2002). Mas España parece mantenerse al margen de los ecos de estos descubrimientos, en cuanto a lo que refirieron las páginas de La Ilustración Española y Americana.

Austen H. Layard estuvo en la capital de España, según traslada una caricatura grotesca del periódico satírico londinense Punch el 6 de noviembre de $1869^{38}$. Según cuenta el mismo arqueólogo, 'apenas doce personas conocían mi nombre realmente en España' (Fig. 4). Este testimonio esclarece la imagen que se proyectó en España entre el siglo XIX y principios del $\mathrm{XX}$ : un inexistente interés histórico ante esta cultura de oriente.

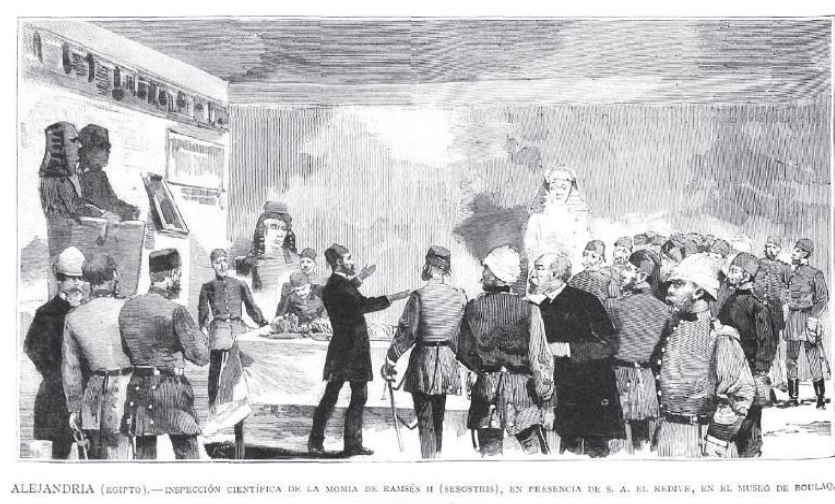

Fig. 5. La llustración Española y Americana, AÑO XXX-NÚM XXVII (julio, 22 de 1886): Museo de Boulaq, descubrimiento e inspección facultativa de la momia de Sesostris. p. 35.

Las noticias arqueológicas localizadas en relación directa con Egipto no fueron más afortunadas que las anteriores. Sólo se han documentado 17 noticias que hagan referencia a la egiptología en 52 años de vida de la publicación (Anexo 2). Lo que lleva a pensar en un Egipto que "no es novedad"; nos referimos a que los grandes descubiertos sobre Egipto han tenido lugar en el siglo anterior, el siglo XVIII (Mariette 1880). En aquel momento lo que primaba eran los viajes ${ }^{39}$, las imágenes fugaces de escenas de pintor ${ }^{40}$ que evocan al romanticismo latente en la sociedad burguesa de la época ${ }^{41}$.

Fueron pocas las noticias que transcurrieron en los años de vida de la publicación ilustrada que puedan ser tratadas como verdaderas noticias arqueológicas en nuestro país (Martí Valentí 1992-1994); entre ellas se encuentran los descubrimientos de momias (Fig.5), en donde aparecen arqueólogos con nombres propios $^{42}$, junto con los grabados que reproducen los lugares de excavación ${ }^{43}$. Estas noticias muestran una arqueología que, aunque en este momento está muy desgastada, aún sigue dando frutos ${ }^{44}$.

\subsection{Grecia}

Opuesto a lo ocurrido con las temáticas anteriores, todas las noticias de índole arqueológico-artística que están relacionadas con Grecia siguen unas líneas arqueológicas muy marcadas. Esto quiere decir que dicha ciencia se encontraba en un momento donde los descubrimientos sobre la antigua civilización helénica se han asentado por completo. Se sabía qué buscar, cómo debían hacerlo y dónde podían encontrarlo.

\footnotetext{
${ }^{38}$ Punch, (noviembre, 6 de 1869): Don Layardos in Madrid. p. 179.

${ }^{39}$ La Ilustración Española y Americana, AÑO XVI-NÚM XIV (abril, 8 de 1872): Viajes. Una excursión a las pirámides, por E.B. pp. 222-223.

${ }^{40}$ La Ilustración Española y Americana, AÑO XVI- NÚM XX (mayo, 24 de 1872): Las estatuas de Memnon, cuadro de MR. Werner's Nibildern. p. 341.

${ }^{41}$ La Ilustración Española y Americana, AÑO XXVII-NÚM VIII (febrero, 28 de 1883): Un cuento egipcio (versión castellana de la traducción de un papiro egipcio del Museo Británico), por José Ramón Mélida. pp. 131-134.

42 La Ilustración Española y Americana, AÑO XXV-NÚM V (febrero, 8 de 1881): Mariette-Bey y sus descubrimientos en Egipto, por E. Martínez de Velasco. pp.75-78.

${ }^{43}$ La Ilustración Española y Americana, AÑO XXXV-NÚM XV (abril, 22 de 1891): Nuevos Descubrimientos de momias en Egipto. La extracción de sarcófagos del pozo de Deir-El-Bahuri. p. 243.

${ }^{44}$ La Ilustración Española y Americana, AÑO XXXV-NÚM XVII (mayo, 8 de 1891): Nuevos Descubrimientos de momias en Egipto. Traslación de los sarcófagos del Nilo, para conducirlos al Cairo, por E. Martínez de Velasco. p. 275 .
} 


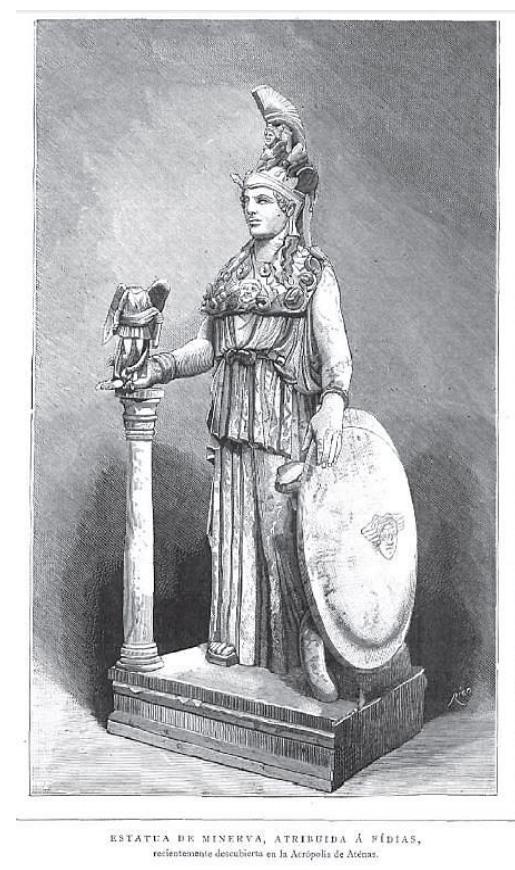

Fig. 6. La llustración Española y Americana, AÑO XXV-NÚM X (marzo, 15 de 1881): Estatua de Minerva, descubierta en Atenas. pp. 162-163.

No es extraño que todas las noticias que se han encontrado sobre temas griegos sean nuevos descubrimientos ${ }^{45}$ o nuevas teorías sobre piezas encontradas recientemente ${ }^{46}$, las cuales necesitaban de una explicación ${ }^{47}$, como se ha apuntado anteriormente, por esa idea de asentamiento de las bases que conforman los estudios arqueológicos griegos (Fig. 6). Mas es importante marcar cómo las noticias arqueológicas sobre hallazgos se incrementaron a partir de la fecha de 1897 (Anexo 3), coincidiendo con un viaje de estudios para conmemorar el 50 aniversario de la creación de la Escuela Francesa en Atenas (Gran Aymerich 2001: 263-284, y Dyson 2008: 117-172).

La trascendencia de este viaje no sería tan importante si no fuera por la participación en él de distinguidas personalidades del mundo de la arqueología que dieron a conocer los resultados de los descubrimientos más significativos del siglo. Uno de ellos fue José Ramón Mélida (Casado Rigalt 2006), entonces jefe de la Sección de Protohistoria del Museo Arqueológico de Madrid y futuro director de este museo y del de Reproducciones Artísticas, quien resumió sus impresiones y su experiencia en una extensa memoria ${ }^{48}$, recogida en su obra Viaje a Grecia y Turquía (Mélida Alinari 1899).

La intención del viaje fue la de acercar España al mundo científico internacional y establecer intercambios de vaciados y reproducciones ${ }^{49}$ entre los museos griegos y turcos con los españoles. Aprovechando esta ocasión, Mélida vio la oportunidad de situar España a la misma altura de las academias europeas y de aprovechar el beneficio que aportaría a la arqueología española el aprendizaje de los métodos didácticos y científicos de la Escuela Francesa, lo que contribuiría a aumentar el prestigio cultural de nuestro país ${ }^{50}$.

De lo que no cabe duda es que Mélida aprendió la lección, como lo demostraría años después en las excavaciones que llevó a cabo en Mérida y Numancia, utilizando el trabajo de campo y la catalogación sistemática como herramientas imprescindibles de la arqueología (Mélida Alinari 1897). Los artículos que llevaban el sello griego eran siempre fruto de admiración y curiosidad, cualidad que se explotó sobre todo

\footnotetext{
${ }^{45}$ La Ilustración Española y Americana, AÑO XXXVIII-NÚM XLVIII (diciembre, 30 de 1894): Hallazgos en las ruinas de la antigua ciudad de Delfos. p. 395, y también: La Ilustración Española y Americana, AÑO XVIII-NÚM XXIX (agosto, 8 de 1874): Antigüedades Troyanas, por N. p. 455.

${ }^{46}$ La Ilustración Española y Americana, AÑO XXXVI-NÚM XVI (abril, 30 de 1892): Las chulas griegas, por José Ramón Mélida. pp. 261-263.

${ }^{47}$ La Ilustración Española y Americana, AÑO XXV-NÚM X (marzo, 15 de 1881): Estatua de Minerva, descubierta en Atenas. pp. 162-163.

${ }^{48}$ Mélida en su Memoria describe los lugares, museos y piezas arqueológicas que a su juicio eran las más interesantes para el estudio de la evolución del arte griego. Es la primera impresión que se tiene de un arqueólogo español ante los descubrimientos más importantes de fines del XIX: Troya, Delos, Delfos, Olimpia, etc. estableciendo relaciones artísticas con elementos de nuestra Península (por ejemplo: las estructuras y aparejos de las ciudades de Tirinto y Gerona y los de Micenas con Tarragona), pero, sobre todo, plasma la fascinante experiencia de descubrir una época oscura en la historia de la humanidad.

${ }^{49}$ En esta época, el Museo de Reproducciones Artísticas estaba en pleno apogeo, y estaba formando una importante colección de vaciados de diversos museos europeos, para la formación de los artistas y de los estudiosos en general ${ }^{50}$ La Ilustración Española y Americana, AÑO XLIII-NÚM XIV (abril, 15 de 1899): La antigüedad clásica en el Museo Arqueológico Nacional, por José Ramón Mélida. pp. 216-217.
} 
con la difusión de imágenes de las ricas cerámicas griegas, con motivos publicitarios ${ }^{51}$ o como apoyo visual en artículos meramente divulgativos de temática general ${ }^{52}$.

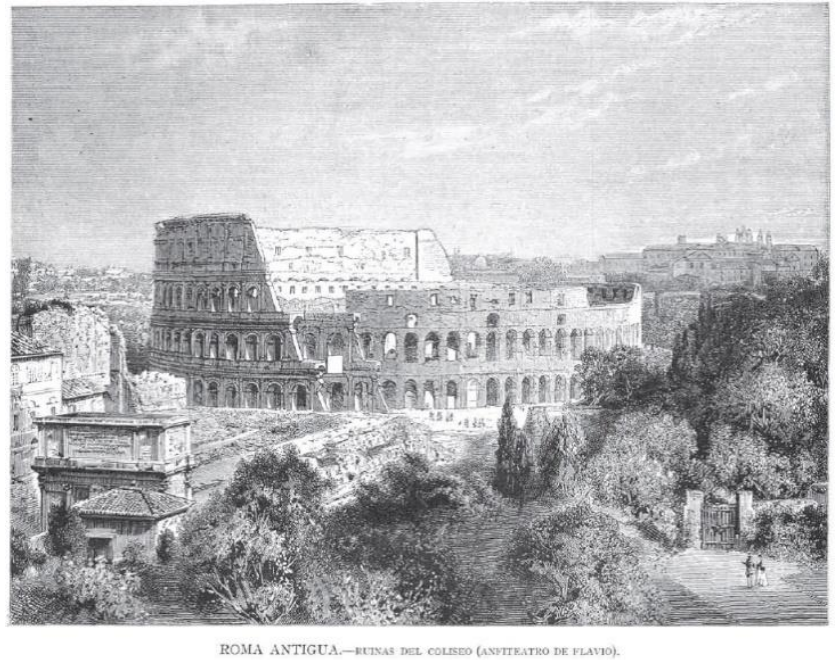

Fig. 7. La llustración Española y Americana, AÑO XXVINÚM XV (abril, 22 de 1882): Roma antigua. Ruinas del Coliseo (Anfiteatro Flavio). pp. 250-251.

\subsection{Roma}

Roma la ciudad eterna, se custodió en todo su esplendor en las páginas de La Ilustración Española y Americana. Aunque no fue la temática más numerosa (Anexo 2), fue sin embargo la que más alabazas recibió. Parecía que cada uno de los artículos vinculados a ella era parte de una veneración generalizada, adquirida con el paso de la tradición histórica. Todos los hallazgos arqueológicos, las descripciones de lugares y las piezas de origen romano eran considerados como fruto de la más alta calidad y todo lo romano era original, grandioso y perfecto ${ }^{53}$.

Las noticias encontradas bajo la temática romana pueden dividirse en tres clases diferenciadas. En primer lugar, las descripciones de paisajes arqueológicos o monumentos por el simple de hecho de mostrar la belleza de una imagen, donde lo que primaba, a parte de la conexión visual, era la descripción artísticas y técnicas. Dentro de este primer grupo se pondrían enmarcar dos monumentos, que se repetirán numerosas veces en la trayectoria de esta publicación: el Coliseo ${ }^{54}$ (Fig.7) y el Arco de Tito ${ }^{55}$. En ambos la información no cambia prácticamente y lo más llamativo eran sus proyecciones visuales en dibujos, grabados, fotograbados o en fotografías.

Un segundo grupo, es el directamente relacionado con la actividad arqueológica: se trataba de las excavaciones, las exploraciones y sobre todo de los descubrimientos más importantes de la época. Este tipo de artículo no sólo hace una introducción histórica de los lugares u objetos a tratar, sino que también documentaba los procesos de excavación con fotografías. Nos encontrábamos en un momento en donde la ciencia arqueológica estaba asumida y los procesos de extracción seguían unas normas establecidas. Los descubrimientos más importantes que se han documentado en La Ilustración Española y Americana fueron los sepulcros de la vía Appia ${ }^{56}$, las ruinas de Cartago $^{57}$ (sobre esta cuestión véase Gran Aymerich

\footnotetext{
${ }^{51}$ La Ilustración Española y Americana, AÑO XXVI-NÚM XX (mayo, 30 de 1882). Vasos griegos del Museo del Louvre, por B. p. 342.

${ }^{52}$ La Ilustración Española y Americana, AÑO LXI-NÚM XXIV (junio, 30 de 1917): Páginas de divulgación artística. Cerámica griega, por J. De Amaury. p. 371.

${ }^{53}$ La Ilustración Española y Americana, AÑO XXXIII-NÚM I (enero, 8 de 1889): Roma antigua. p. 3.

${ }^{54}$ Véase como ejemplo los artículos: La Ilustración Española y Americana, AÑO XV-NÚM.III (mayo, 5 de 1870):

El Coliseo Romano, por Emilio Castelar. Pp. 249-252; La Ilustración Española y Americana, AÑO XV-NÚM XIV (mayo, 15 de 1871): El coliseo Romano, por Emilio Castelar. pp. 239-242.

${ }^{55}$ La Ilustración Española y Americana, AÑO XIV-NÚM.7 (marzo, 25 de 1870): El arco de Tito en Roma, por Eugenio de Ochoa. p. 87.

${ }^{56}$ La Ilustración Española y Americana, AÑO XXIV-NÚM XI (marzo, 22 de1880): Antigüedades de Roma. La vía Apia. p. 179.

${ }^{57}$ La Ilustración Española y Americana, AÑO XXV-NÚM XXII (junio, 15 de 1881): Ruinas de Cartago, a cuatro kilómetros de Túnez. p. 382.
} 
2001: 154-158), las excavaciones en el foro de Roma $^{58}$, y el descubrimiento de Pompeya ${ }^{59}$ (Romero Recio 2012: 97-141).

La última categoría de noticias que se encontraba en este periódico ilustrado estaba en relación con cualquier temática externa a la arqueología. Se trataba, no obstante, de la utilización de la imagen de Roma para publicitar cualquier comercialización, como fue el caso de algún ejemplar de librería ${ }^{60}$. También se han encontrado artículos que pretendían ser diarios de viajes, en los que se contaba paso a paso un completo recorrido por la Antigüedad ${ }^{61}$. Al entrar en el siglo XX, la fama de Pompeya se incrementó gracias a los medios de comunicación de masas, lo que propicio un continuo flujo de visitantes anuales, al tiempo que proseguían las campañas arqueológicas (Sevilla Mompó, 2016: 165-190).

\subsection{Península Ibérica}

La tipología de noticias arqueológicas que alude a la propia Península Ibérica $^{62}$ fue la más numerosa (Anexo 2), aportando casi el cincuenta por ciento de las noticias relacionadas con el mundo de la Arqueología. Casi todas ellas estaban directamente relacionadas con un ámbito propiamente arqueológico, exceptuando las noticias de los últimos años de esta publicación, donde se pierde por completo el interés por la noticia innovadora.

Las noticias arqueológicas nacionales tenían como característica general la dimensión científica de las mismas, ya que todas ellas contaban con una descripción, una localización, un contexto histórico y una exposición de los hallazgos más importantes y de los que no lo eran. También es remarcable la tarea de documentación visual, ya sea por medio de dibujos ${ }^{63}$, grabados ${ }^{64}$ o fotografías ${ }^{65}$, pues todos ellos fueron utilizados para una muestra pública, creando así un nuevo contacto con el lector y animándole a continuar fijándose en las noticias de calibre arqueológico.

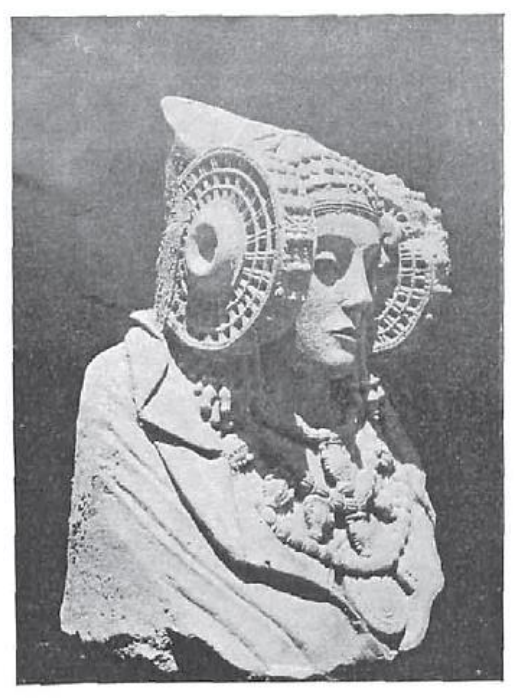

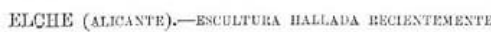
EX LAS RETSAS DE LA ANTHQUA COLOSTA H.LICE. (De fotogratia remititin yor D. Pedro Tharmi.)

Fig. 8. La llustración Española y Americana, AÑO XLI-NÚM XXXIII (agosto, 30 de 1897): Descubrimiento de una escultura (Elche). pp.126-127.

\footnotetext{
${ }^{58}$ La Ilustración Española y Americana, AÑO XLII-NÚM VII (febrero, 22 de 1899): Excavaciones en el Foro de Roma. p. 107.

${ }^{59}$ La Ilustración Española y Americana, AÑO XXI-NÚM VI (febrero, 15 de 1877): El anfiteatro de Pompeya, por Eusebio Martínez de Velasco. pp. 99-101; La Ilustración Española y Americana, AÑO LI-NÚM XXXIII (septiembre, 8 de 1907): Recientes descubrimientos en Pompeya, por R. Balsa de La Vega. pp. 146-147.

${ }^{60}$ La Ilustración Española y Americana, AÑO XXVI-NÚM XV (abril, 22 de 1882): Roma antigua. Ruinas del Coliseo (Anfiteatro Flavio). pp. 250-251.

${ }^{61}$ La Ilustración Española y Americana, AÑO XLVI-NÚM XII (marzo, 30 de 1902): Por Italia, notas de un viaje artístico. Roma, Nápoles y Pompeya, por R. Balsa de La Vega. pp. 183-187.

${ }^{62}$ Dentro de la denominación de 'Península Ibérica' se encuentran noticias arqueológicas de todas las temáticas: prehistórica, egipcia, fenicia, griega, etrusca, prerromana y romana; este muestreo permite conocer mejor qué tipo de arqueología peninsular se estaba llevando a cabo entre los años de publicación de La Ilustración Española y Americana y cuál es su aceptación y repercusión en la sociedad de mediados del siglo XIX y principios del XX.

${ }^{63}$ La Ilustración Española y Americana, AÑO XVI-NÚM IV (enero, 24 de 1872): Antigüedades. El collar de oro de Mellid, por Aureliano Fernández-Guerra y Orbe. p. 51.

${ }^{64}$ La Ilustración Española y Americana, AÑO XXXIX- NÚM XIV (abril, 15 de 1895): Bronce romano-celtibérico, por José Ramón Mélida. pp. 238-239.

${ }^{65}$ La Ilustración Española y Americana, AÑO LIV-NÚM 36 (septiembre, 30 de 1915): Castilla-Los toros de Guisando, por Alberto de Segovia. pp. 758-759.
} 
Dentro de las excavaciones y hallazgos más importantes publicados en los artículos de la revista, se encontraban los trabajos realizados en Tarraco ${ }^{66}$, Itálica ${ }^{67}$ (Amores y Beltrán 2011; López Rodríguez 2011), Híspalis ${ }^{68}$, Mérida ${ }^{69}$, el Cerro de los Santos (Rada y Delgado 1875; López Azorín 2011) y la singular escultura de La Dama de Elche (Fig.8). Esta última protagoniza uno de los casos más reseñables, ya que, a pesar de ser una de las piezas más polémicas de la arqueología de nuestro país, sólo se encontraron dos artículos que se hagan eco de ella. El primero fue el de su hallazgo, confundida con la estatua de un varón o un posible $\mathrm{Apolo}^{70}$. Su segunda aparición fue de forma indirecta, a través de una noticia de hallazgo de una diadema ${ }^{71}$ muy similar a la que porta la Dama de Elche. Esto lleva a pensar que la misión de las publicaciones ilustradas no era crear polémica, sino mostrar las noticias en el momento más oportuno, de ahí que este hallazgo no cuente con ninguna rectificación posterior.

\subsection{Cultura Islámica}

Una de las grandes señas de identidad de nuestro país, tanto en el siglo XIX como en la actualidad, es la de los monumentos que la cultura islámica dejo tras su paso por la Península ${ }^{72}$. Un hecho importante a destacar es el interés generalizado que en aquellos momentos se estaba desarrollando en toda Europa por las antigüedades clásicas, es decir, las griegas y las romanas, que estaban dando origen al nacimiento de la ciencia y los estudios arqueológicos; mientras tanto en España se prestaba atención por vez primera a las antigüedades de origen islámico.

Si bien las noticias estrictamente arqueológicas brillan por su ausencia en La Ilustración Española y Americana, destacaban aquellas que se apoyan en grandes obras puramente artísticas que copiaban escenarios. La noticia del deterioro de las pinturas existentes en la Alhambra ${ }^{73}$ (Fig. 9) promovió una movilización para evitar la pérdida de esos bienes de gran valor histórico (Barrios Rozúa 2010).

Pronto el interés se extendió a todo el conjunto de la Alhambra, abordándose su documentación desde aspectos distintos como el arquitectónico, el ornamental y el histórico, e interesándose de un modo especial por las inscripciones que forman parte de la decoración y que se pensaba que podían ser fuente para ilustrar la historia del monumento (Rodríguez Domingo 2007). Por primera vez se acometía la

\footnotetext{
${ }^{66}$ La Ilustración Española y Americana, AÑO XV-NÚM. XIV (mayo, 5 de 1871): Muros ciclópeos de Tarragona, por Buenaventura Hernández Saholuja. p. 237; AÑO XV-NÚM. XVI (junio, 5 de 1871): Muros ciclópeos de Tarragona, por Buenaventura Hernández Sanahuja. pp. 278-279; AÑO XV-NÚM. XVI (junio, 25 de 1871): Muros ciclópeos de Tarragona, por Buenaventura Hernández Saholuja. pp. 311-312.

${ }^{67}$ La Ilustración Española y Americana, AÑO XIX-NÚM II (enero, 15 de 1875): Itálica. Últimos descubrimientos de 1874, por Demetrio de los Ríos pp. 34-35; AÑO XIX-NÚM V (febrero, 8 de 1875): Itálica. Últimos descubrimientos de 1874, por Demetrio de los Ríos. pp. 83-86; AÑO XIX-NÚM VIII (febrero, 28 de 1875): Itálica. Últimos descubrimientos de 1874, por Demetrio de los Ríos. p. 134.

${ }^{68}$ La Ilustración Española y Americana, AÑO XX-NÚM XXI (junio, 8 de 1875): Las murallas antiguas de Sevilla. p. 371.

${ }^{69}$ La Ilustración Española y Americana, AÑO XIX-NÚM XXX (agosto, 15 de 1875): Arco de Trajano en Mérida, por Eusebio Martínez de Velasco. p. 74; AÑO XXI-NÚM XLIV (noviembre, 30 de 1977): Puente romano de Mérida, sobre el Guadiana. p. 339; AÑO LVI-NÚM XXX (agosto, 15 de 1912): Por la España romana. Mérida, por M. R. Blanco-Belmonte. pp. 90-91.

${ }^{70}$ La Ilustración Española y Americana, AÑO XLI-NÚM XXXIII (agosto, 30 de 1897): Descubrimiento de una escultura (elche). pp.126-127.

${ }^{71}$ La Ilustración Española y Americana, AÑO L-NÚM XII (marzo, 30 de 1906): Una Alhaja, por R. Balsa de la Vega. pp. 206-207.

${ }^{72}$ La Ilustración Española y Americana, AÑO XXVIII-NÚM XXXV (septiembre, 22 de 1884): Córdoba, portada del Mirhah en la antigua mezquita-aljama, hoy catedral, por N. Sentenach. p. 170.

${ }^{73}$ La Ilustración Española y Americana, AÑO XXXIV-NÚM XXXVI (septiembre, 30 de 1890): El incendio de la Alhambra. pp. 186-187
} 


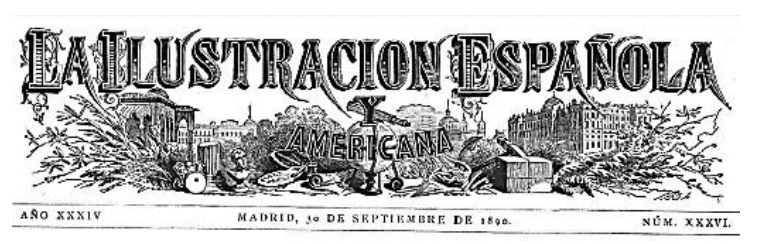

FL. INCENDTO DE LA ALATAMARR

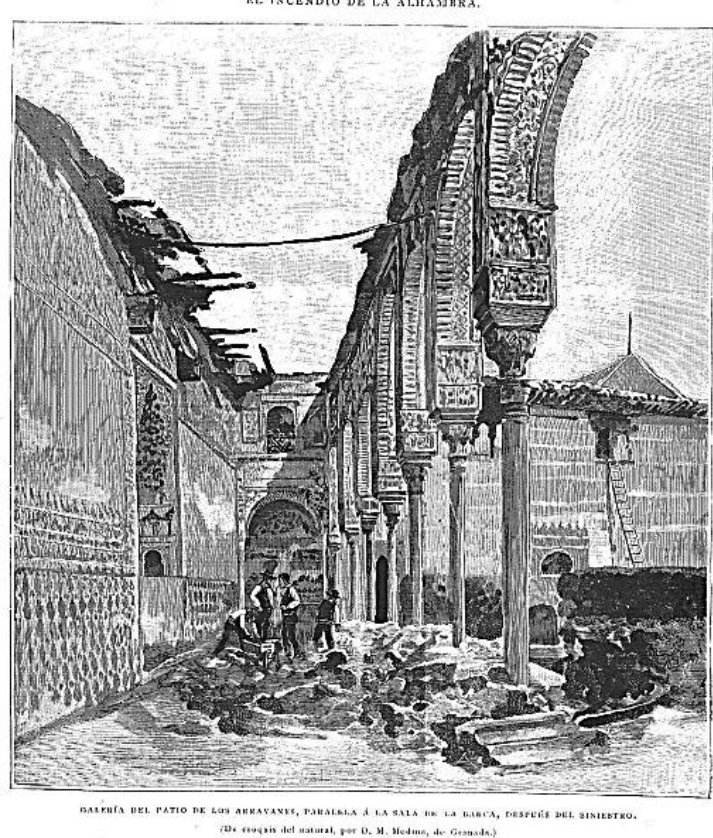

Fig. 9. La llustración Española y Americana, AÑO XXXIV-NÚM XXXV (septiembre, 23 de 1890): Efectos del incendio en la arcada principal de la galería de entrada al salón de los emperadores y en el patio llamado de Doña Juana La Loca. p. 171.

documentación y estudio de unos bienes patrimoniales con la única finalidad de dejar testimonio de ellos ante el peligro de su posible desaparición ${ }^{74}$.

La existencia de este proyecto ilustrado es una evidencia, sin duda, del nivel intelectual que alcanzaron varias instituciones españolas en el siglo XVIII, en particular las Reales Academias. Además, permite aseverar que la generación de trabajos con que los viajeros, artistas y escritores extranjeros durante el siglo XIX difundieron por Europa las originales creaciones del mundo andalusí no fueron ni únicos ni descubridores de esta realidad, mostrando en muchos casos que se inspiraron e incluso copiaron la obra acometida por la Real Academia de Bellas Artes de San Fernando y difundida a otros países de Europa (Bordes Caballero 2014).

Otra tipología de noticias que no se corresponde con el ámbito arqueológico en su sentido más propio es la de las noticias protagonizadas por Amador de los Ríos (Amador de los Ríos 1883) y su defensa de la existencia del estilo mudéjar ${ }^{75}$ en España ${ }^{76}$ (Amador de los Ríos 1996; Ruiz Souza 2010). Gracias a las discusiones que protagonizó con sus detractores, se vuelve a prestar atención a las antigüedades de origen islámico, donde posteriormente la arqueología ejercerá nuevas excavaciones $^{77}$ y hallazgos de gran relevancia ${ }^{78}$.

\subsection{Culturas prehispánicas}

Las culturas prehispánicas fueron uno de los temas menos recurrentes en cuanto a noticias arqueológicas (Anexo 2). Un número de 16 artículos es a nuestro parecer algo escaso para un periódico en cuya cabecera encontramos el nombre de La Ilustración Española y Americana. Con este título, y teniendo en cuenta que esta publicación cruzaba el Atlántico y se vendía en América, al igual que se hacía en España, se esperaba encontrar un reparto equitativo de noticias peninsulares y transoceánicas (Anexo 3).

\footnotetext{
${ }^{74}$ La Ilustración Española y Americana, AÑO XXIX-NÚM XXXI (agosto, 22 de 1885): Alicatados del templete norte en la Alhambra. p. 171.

${ }^{75}$ El término mudéjar alude a los musulmanes que siguieron profesando su religión y sus costumbres en aquellos territorios que, con el avance de la Reconquista hacia el sur de España, pasaban a dominio cristiano. Su aparición y desarrollo fue posible gracias al fenómeno social que supuso la convivencia pacífica de tres culturas, la cristiana, la musulmana y la judía. Así, el sistema de trabajo artístico, materiales, técnicas, elementos formales, de tradición islámica, pasó a influir notablemente tanto en la arquitectura como en las artes suntuarias cristianas.

${ }^{76}$ La Ilustración Española y Americana, AÑO XXIX-NÚM XXIX (agosto, 8 de 1885): El estilo Mudéjar, por Rodrigo Amador de los Ríos (cartas al Sr. D. José Gestoso y Pérez). pp. 78-79; AÑO XXIX-NÚM XXX (agosto, 15 de 1885): El estilo Mudéjar, por Rodrigo Amador de los Ríos (cartas al Sr. D. José Gestoso y Pérez). pp. 90-91.

${ }^{77}$ La Ilustración Española y Americana, AÑO XIV-NÚM.V (febrero, 15 de 1871): Jarrón árabe, propiedad de Don Celestino Pujol. pp. 76-78.

${ }^{78}$ La Ilustración Española y Americana, AÑO LV-NÚM IX (marzo, 8 de 1911): Restauración de la mezquitaAljama de Córdoba, por Amador de los Ríos. pp. 134-135.
} 
Es interesante ver cómo el mayor número de estas noticias tienen relación con algún tipo de viaje ${ }^{79}$, exposición ${ }^{80}$, conferencia o simples apuntes de piezas que guardan los museos ${ }^{81}$ (Fig.10). A lo largo de la lectura de sus artículos en La Ilustración Española y Americana no se ha tenido la posibilidad de experimentar un descubrimiento arqueológico complejo. Esto pudo deberse a la imposibilidad de mantener un corresponsal en América. Gran número de estas publicaciones eran cartas o noticias que se tomaron "prestadas" de las publicaciones extranjeras, siendo muchas de ellas traducciones literales.

Las noticias más interesantes eran las que aludían a los congresos internacionales $^{82}$ (Comas 1974), y este periódico, recogió el primero que se realizó en Madrid ${ }^{83}$. Estos congresos tenían como objetivo el estudio histórico y científico de América desde una perspectiva multidisciplinar. Las áreas temáticas podían llegar a variar, pero generalmente se centraban en los temas de: Arqueología, Antropología (social, cultural, etnología, física y bioantropología), Lingüística y literatura, Historia y Arte (etnohistoria, historia de la ciencia, historia del arte e iconografía), movimientos étnico-sociales y derechos humanos, estudios económicos, sociales y político-jurídicos, pensamiento, filosofía y educación, globalización, patrimonio y políticas públicas, ciencias, tecnología y medio ambiente (sobre la posterior expedición científica española a América véase Robert Ryal 1983).

\subsection{Patrimonio y Museos}

El apartado dedicado a Patrimonio y Museos puede distar de la concepción de Arqueología como ciencia, mas sin la existencia de ambas competencias sería imposible comprenderla. Los proyectos dedicados a la protección patrimonial no eran noticias que encendieran la atención de los lectores, pero su gran desarrollo visual en un conflicto bélico era imposible de escapar a las miradas de cualquier viandante (Fig. 11). Así encontramos una única noticia en la que se cuenta superficialmente este tipo de trabajos que indirectamente lanzaban un mensaje de protectorado de la historia y de sus monumentos ${ }^{84}$.

\footnotetext{
${ }^{79}$ La Ilustración Española y Americana, AÑO XX-NÚM II (enero, 15 de 1876): Apuntes de un viaje por el Perú. pp. 28-30.

${ }^{80}$ La Ilustración Española y Americana, AÑO XXXVII-NÚM XII (marzo, 30 de 1893): La exposición históricoamericana. Vasos peruanos hallados en la necrópolis del Gran Chimú. p. 203; AÑO XXXVII-NÚM XXVIII (Julio, 30 de 1893): La exposición histórico-americana de Madrid. Vasos peruanos, la necrópolis del Gran Chimú., pertenecientes al Museo-Biblioteca del Ministerio de Ultramar. p. 64.

${ }^{81}$ La Ilustración Española y Americana, AÑO XXXVI -NÚM XXVI (julio, 15 de 1892): Cráneos, ídolos y bustos americanos, por Eusebio Martínez de Velasco. p. 29.

${ }^{82}$ El Congreso Internacional de Americanistas se llevó a cabo por primera ocasión en Nancy, Francia, del 18 de junio al 18 de julio de 1875, mediante la iniciativa de la Société Américaine de France la cual emitió su convocatoria el 25 de agosto de 1874.1 Desde entonces, se han celebrado más de cincuenta reuniones durante más de 125 años.

${ }^{83}$ La Ilustración Española y Americana, AÑO XXV-NÚM XLIII (noviembre, 22 de 1881): Congreso americanista de Madrid. La exposición arqueológica, por Juan Pérez de Guzmán. pp. 306-307.

${ }^{84}$ La Ilustración Española y Americana, AÑO XV-NÚM.III (enero, 25 de 1871): Paris-Preparativos de defensa. p.55.
} 
El resto de noticias de esta sección estaba relacionado con la inauguración del Museo de Antigüedades de Barcelona $^{85}$ y con las peripecias del Museo Arqueológico Nacional (sobre la formación y evolución de las colecciones del Museo Arqueológico Nacional, véase Marcos Pous 1993). La exposición inicial del Casino de la Reina reflejaba el criterio de la época de exhibir todos los fondos existentes (Ariza Muñoz 1985). El primer Museo (1871-1893) en sus salas mostraba no sólo colecciones de los 'tiempos primitivos y antiguos', sino también de Edad Media y Moderna, Numismática y Etnografía, con objetos procedentes de lejanos países. Era la primera vez que en España se abría al público un museo con tal variedad de objetos y de tan amplio arco cronológico y cultural ${ }^{86}$.

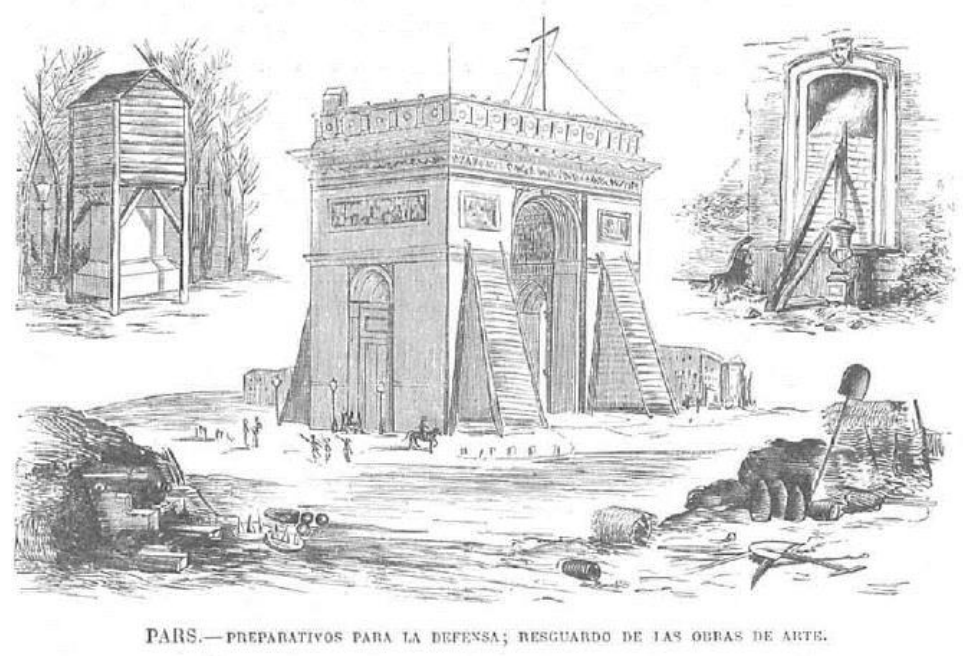

Fig. 11. La llustración Española y Americana, AÑO XVNúM.III (enero, 25 de 1871): Paris-Preparativos de defensa. p.55.

Desde la inauguración del Museo en el Palacio de Biblioteca y Museos, y durante el primer tercio del siglo $\mathrm{XX}$, los montajes de las salas variaron poco, aprovechando muchos elementos procedentes del Casino de la Reina y de las Exposiciones Conmemorativas de 1892 y $1893^{87}$. Se exhibía la mayor parte de las colecciones ordenadas cronológicamente o por tipologías, aunque se introducen nuevos criterios de clasificación relacionados con los conceptos de Historia, trabajo y vida social ${ }^{88}$ (Mélida Alinari 1895). Durante la Guerra Civil se desmontaron las salas para proteger las colecciones (Almagro Gorbea 2008; Ladero y Jiménez 2014).

\subsection{Otros temas (administración pública, biografías de arqueólogos, etc.)}

El último apartado es el totum revolutum de las noticias arqueológicas, y el menos numeroso (Anexo 2) y está dedicado a las noticias que no pueden clasificarse sólo por su temática. En este número de 5 artículos, contamos con una biografía, tres trabajos monográficos o de temática general y un último artículo de divulgación-publicitaria.

El primero de los artículos encontrados, la biografía de Juan Ramón de Iturriza ${ }^{89}$, llamó la atención por el hecho de tratarse de la única noticia dedicada a una persona del ámbito de la Historia y de la Arqueología de fama individualizada. No es extraño ver artículos dedicados a personalidades concretas en $L a$ Ilustración Española y Americana, pero todos estos hombres y mujeres que engrosaban sus páginas con sus retratos son personalidades del mundo de la política, la realeza o la alta burguesía, lo que no dejó de

${ }^{85}$ La Ilustración Española y Americana, AÑO XVII-NÚM XLVI (diciembre, 8 de 1873): Museo Arqueológico de Barcelona, por J. Puiggari. pp. 747-749.

${ }^{86}$ La Ilustración Española y Americana, AÑO XV-NÚM.XXI (julio, 5 de 1871): El Museo Arqueológico Nacional. pp. 362-363.

${ }^{87}$ La Ilustración Española y Americana, AÑO XXI-NÚM XLIII (noviembre, 22 de 1887): Bibliotecas y museos nacionales, estado actual de las obras de fábrica, por Eusebio Martínez de Velasco. p. 300.

${ }^{88}$ La Ilustración Española y Americana, AÑO XXXIX-NÚM XXVI (julio, 15 de 1895): La reapertura del Museo Arqueológico Nacional, por José Ramón Mélida. pp. 22-23.

${ }^{89}$ La Ilustración Española y Americana, AÑO XIV-NÚM.26 (noviembre, 15 de 1870): Peregrino e historiador, por Antonio de Trueba. pp. 403-406. 
ser un caso aislado al ocurrir en el primer año de publicación de este periódico y nunca se volvió a repetir.

El caso de noticias que carecían de una calificación suficientemente concreta es el que hemos denominado 'monográfico-divulgativas', debido a que trataban temas generales sin tener en cuenta referencias arqueológicas concretas más allá de la exposición de grabados o fotografías ilustrativas. Tanto la temática de los $\operatorname{cascos}^{90}$, la del tocador ${ }^{91}$ y la de los rituales funerarios ${ }^{92}$ responden a la misma línea compositiva: una introducción general, una clasificación por épocas y unas tipologías e imágenes aclaratorias. No presentaban una información lo bastante relevante para tratarla como una noticia de especial relevancia para el campo de investigación arqueológica, pero cumple una de las funciones principales que perseguía este tipo de publicaciones: la de educar al pueblo. Llama la atención la introducción de la publicidad por medio de cualquier tipo de publicación. Este fenómeno tuvo lugar sobre todo en los últimos años de la publicación. Los tiempos cambiaban y lo que se pretendía era la atracción a través de la visualización, y de este modo se intentaba obrar en el artículo dedicado a la medicina en la antigüiedad ${ }^{93}$ (Fig. 12).

\section{Conclusión}

Tras la realización de un estudio completo por la dilatada historia de La Ilustración Española América y teniendo como objetivo principal el estudio de la recepción social de las noticias arqueológicas, el seguimiento e interpretación de los nuevos descubrimientos, y las transformaciones de los intereses culturales y artísticos, se ha llegado a una serie de conclusiones. De este modo, intentaremos dar un amplio abanico de teorías, algunas de ellas comunes para todas las temáticas arqueológicas, y otras individuales, que nos ayudaran a comprender mejor el porqué de la disparidad.

Algunas noticias estaban escritas desde la más estricta ciencia y análisis arqueológico, sobre todo aquellas que eran publicaciones de cartas de arqueólogos envidadas desde el mismo lugar del yacimiento ${ }^{94}$ (Fig. 13). Esta es una de las características que se repiten en el mayor número de temas, con la salvedad de la

${ }^{90}$ La Ilustración Española y Americana, AÑO XXXI- NÚM XXI (agosto, 22 de 1887): Historia del casco, por José Ramón Mélida. pp. 103-107.

${ }^{91}$ La Ilustración Española y Americana, AÑO XXXVIII-NÚM XXXV (septiembre, 22 de 1894): Venus coqueta. La mujer de la antigüedad en el tocador, por José Ramón Mélida. pp. 178-179.

${ }^{92}$ La Ilustración Española y Americana, AÑO LXI-NÚM 35 (septiembre, 22 de 1917): Páginas de divulgación artística. Arqueología funeraria, por J. De Amaury. p. 555.

${ }^{93}$ La Ilustración Española y Americana, AÑO LXIV-NÚM 43 (noviembre, 30 de 1920): La medicina en la antigüedad, por Doctor Albiñana, pp. 563-564.

${ }^{94}$ La Ilustración Española y Americana, AÑO XXXV-NÚM XV (abril, 22 de 1891): Nuevos Descubrimientos de momias en Egipto. La extracción de sarcófagos del pozo de Deir-El-Bahuri. p. 243. Tanto La Ilustración Española y Americana, como las principales revistas y periódicos científicos de Europa se ocuparon de la noticia. El grabado reproduce un dibujo al natural por Bayara (colaborador artístico de L'Ilustration). En realidad, dicha noticia era una traducción de la carta publicada en por el arqueólogo M. Grebant, también director del Museo Egipcio de Gizeh. 
cultura islámica, que como se comentó con anterioridad, se debe al interés generalizado en aquellos momentos y en toda Europa por las antigüedades clásicas, griegas ${ }^{95}$ y romanas ${ }^{96}$, y que estaba dando origen al nacimiento de los estudios arqueológicos. Mientras tanto, en España se procuraba atención por vez primera a las antigüedades de origen islámico.

Otras noticias eran mucho más descriptivas, basándose únicamente en el aspecto formal de los

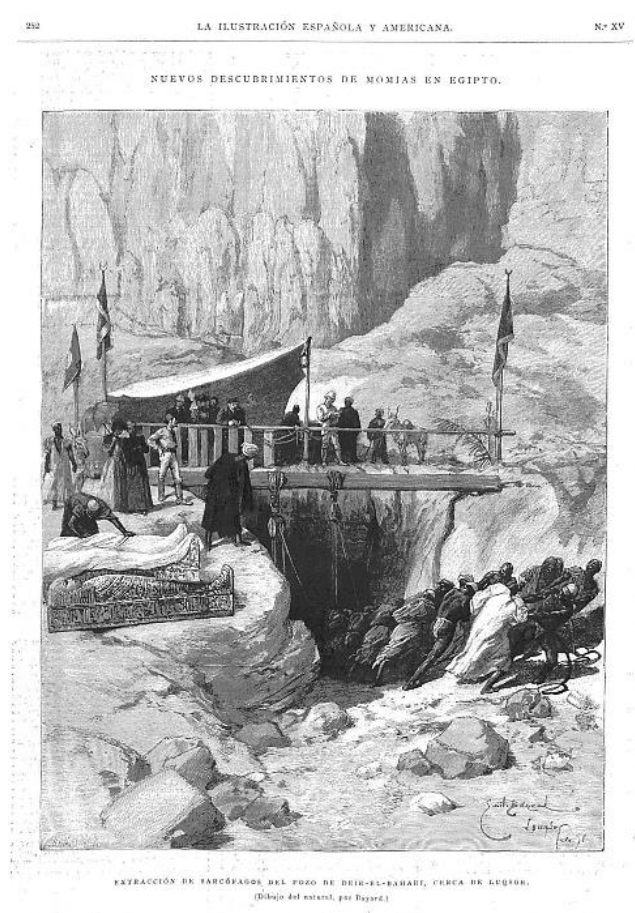

Fig. 13. La llustración Española y Americana, AÑO XXXV-NÚM XV (abril, 22 de 1891): Nuevos Descubrimientos de momias en Egipto. La extracción de sarcófagos del pozo de Deir-El-Bahuri. p. 243. monumentos ${ }^{97}$. Este tipo de noticias corría el peligro de convertirse en artículo subjetivo ${ }^{98}$, ya que en ellos el literatoperiodista plasma lo que está percibiendo en ese instante ${ }^{99}$. Con mucha frecuencia este tipo de noticias centraba la parte más importante de la información en aspectos diferentes al arqueológico por medio de la utilización del artículo como soporte publicitario para la venta de productos, como fue el caso de la utilización de imágenes adquiridas de libros a la venta. Se utilizaba la imagen para atraer a los lectores, cuando realmente las noticias de los artículos, anunciadas como un nuevo descubrimiento, eran la de la promoción y publicidad de un libro ${ }^{100}$ o para dar a conocer su autor a la sociedad.

Otras de las noticias arqueológicas, cuya información relevante era diferente a las referencias arqueológicas, fueron las descripciones-poéticas ${ }^{101}$. Con ellas nos referimos a los artículos que escapaban del concepto de noticia para embarcarse en un viaje por las ruinas de los monumentos antiguos, donde el romanticismo brilla por encima de cualquier contradicción científica, convirtiéndose en una noticia salpicada por completo de tintes literarios ${ }^{102}$.

Una de las tipologías más utilizadas para los artículos de índole arqueológico era la de las narraciones completas de diarios de viajes, verdaderos cuadernos de bitácora en los que se cuenta paso a paso los caminos, las llegadas, las impresiones y el contexto directo con las ruinas de la Antiguiedad. En ocasiones, estas experiencias quedaban documentadas por los propios artistas que se encuentran recorriendo las grandes capitales de los tiempos antiguos (Fig. 14). Así, volvían de sus viajes con una gran cantidad de notas, descripciones y muchos dibujos tomados

${ }^{95}$ La Ilustración Española y Americana, AÑO XXIX-NÚM XXIII (junio, 22 de 1885): Pinturas al fresco en el Parthenon. p. 370.

${ }^{96}$ La Ilustración Española y Americana, AÑO XXXIV-NÚM XLIII (noviembre, 22 de 1890): Ruinas romanas de Timegatte (Argelia). Arco del Triunfo. p. 308.

${ }^{97}$ La Ilustración Española y Americana, AÑO XXV-NÚM IX (marzo, 8 de 1881): Salón de embajadores en el Alcázar de Sevilla. p. 139.

${ }^{98}$ La Ilustración Española y Americana, AÑO XVII-NÚM XXX (agosto, 8 de 1873): Interior de una tahona en Pompeya. p. 486.

${ }^{99}$ La Ilustración Española y Americana, AÑO XLVII-NÚM (abril, 22 de 1903): Atenas, Grecia. p. 343.

${ }^{100}$ La Ilustración Española y Americana, AÑO XXVIII-NÚM VIII (febrero, 29 de 1884): Busto de "Zeus", encontrado en Etricoli, por Eusebio Martínez de Velasco. p. 131.

${ }^{101}$ La Ilustración Española y Americana, AÑO XVI-NÚM XLV (diciembre, 1 de 1872): El teatro romano de Sagunto, por P. García Cadena. pp. 719-720.

${ }^{102}$ La Ilustración Española y Americana, AÑO XXIV-NÚM XLVIII (diciembre, 3 de 1880): Monumentos egipcios: fachada del gran templo de Abu-Simbel, en el alto Nilo. pp. 894-895. 
del natural, que después convertirán en grabados, verdaderas joyas para la comprensión de muchos de los monumentos que actualmente incluso han llegado a desaparecer ${ }^{103}$.

Sabemos que quienes redactaban los periódicos del siglo XIX eran en su mayoría hombres dedicados a las letras. Una lista comparativa de los literatos españoles del siglo XIX confrontada con la de quienes habían participado en la prensa nos daría un amplio número de superposiciones de nombres. En el siglo XVIII y XIX, el periodista es un escritor y bajo esta premisa se encuentran los grandes especialistas en el campo de la Arqueología, hombres ilustrados que mostraban sus conocimientos no sólo en las instituciones, sino también en el ambiente de la prensa, el exponente más cercano a la sociedad civil. Entre estas celebridades se encontraban Juan Valera, José Ramón Mélida y Amador de los Ríos.

Juan Valera inició estudios de filosofía y derecho en la Universidad de Granada (Cremades Rubio 2003). Empezó a ejercer la carrera diplomática en Nápoles y allí estuvo aprendiendo griego y entablando una amistad profunda con Lucía Paladí, marquesa de Bedmar. Después, distintos destinos lo llevaron a viajar por buena parte de Europa y América: Dresde, San Petersburgo, Lisboa, Río de Janeiro, Nápoles, Washington, París, Bruselas y Viena. De todos estos viajes dejó constancia en un entretenido epistolario inmediatamente publicado en España.

José Ramón Mélida es considerado por gran parte de la Historiografía como el padre de la Arqueología clásica española no sólo por sus trabajos, sino por la escuela que supo crear. Efectivamente, desde 1916 simultaneó su cargo de Catedrático de Arqueología Clásica con el de director del Museo Arqueológico Nacional, donde tuvo una intensísima labor, aumentando sus colecciones e introduciendo orden en la exposición y clasificaciones, pudiéndose considerar a sus catálogos como verdaderos manuales de Arqueología. Además, dirigió las excavaciones de Numancia y de Mérida, fue Académico de número de la Real de la Historia y de la Real de San Fernando, perteneció a la Comisión Romano-Germánica del Instituto Arqueológico Alemán, a la Sociedad de Anticuarios de Londres y a la Hispanic Society de Nueva York, desempeñó la Cátedra de Arqueología de la Universidad Central y fue Consejero de Instrucción Pública.

Rodrigo Amador de los Ríos, ingresó en el Museo Arqueológico Nacional en 1868. Fue el principal especialista en arqueología islámica en España durante el último cuarto del siglo XIX. Realizó el estudio de las inscripciones árabes de España y Portugal (1883) e ingresó en la Real Academia de Bellas Artes en 1890. En la última década del siglo XIX se encontró en su trayectoria con el ascenso de Catalina García y López, quien contaba con el apoyo del ala derecha del Partido Liberal-Conservador. Después de la muerte de José Ramón Mélida' fue nombrado director del Museo Arqueológico Nacional entre 1911 y 1916 y asumió la dirección de las excavaciones en Itálica (Fig. 15) (sobre la historia y descripción de sus ruinas véase Amores Carredano y Beltrán Fortes 2011).

Estos hombres de la Ilustración eran colaboradores asiduos de La Ilustración Española y Americana. Cada uno ofrecía lo mejor de sus conocimientos, así como muchas veces utilizaban este tipo de publicaciones para dar a conocer sus propios trabajos y descubrimientos arqueológicos ${ }^{104}$. Al fin y al cabo, se trataba de una colaboración, en tanto que los propios investigadores como el periódico salían beneficiados ${ }^{105}$, pues

${ }^{103}$ La Ilustración Española y Americana, AÑO XIX-NÚM XIV (abril, 15 de 1875): Restos del templo de Isis, en la isla de Phyle. p. 235.Se trataba de un traslado exacto de una acuarela al grabado del alemán Karl Werner's Nilbildern, el cual contaba cómo, después de su primer viaje artístico, hizo otro en 1874, en el cual recorrió de nuevo Egipto, trayendo consigo unas 12 acuarelas.

${ }^{104}$ La Ilustración Española y Americana, AÑO XIX-NÚM II (enero, 15 de 1875): Itálica. Últimos descubrimientos de 1874, por Demetrio de los Ríos pp. 34-35; AÑO XIX-NÚM V (febrero, 8 de 1875): Itálica. Últimos descubrimientos de 1874, por Demetrio de los Ríos. pp. 83-86; AÑO XIX-NÚM VIII (febrero, 28 de 1875): Itálica. Últimos descubrimientos de 1874, por Demetrio de los Ríos. p. 134.

${ }^{105}$ La Ilustración Española y Americana, AÑO XXVIII-NÚM XXIX (agosto, 8 de 1884): Sobre las esculturas de barro cocido, griegas, etruscas y romanas del Museo Arqueológico Nacional, por José Ramón Mélida. p. 75; AÑO XXVIII-NÚM XXX (agosto, 15 de 1884): Sobre las esculturas de barro cocido, griegas, etruscas y romanas del 


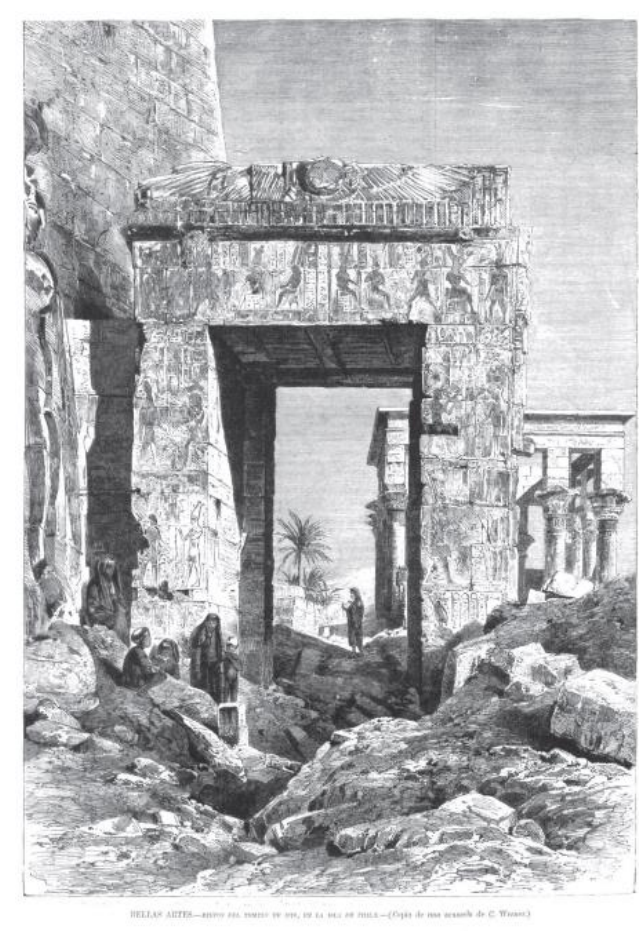

Fig. 14. La llustración Española y Americana, AÑO XIX-NÚM XIV (abril, 15 de 1875): Restos del templo de Isis, en la isla de Phyle. p. 235.

ambos estaban prestando una información de calidad a todo lector de La Ilustración Española y Americana.

Después de haber realizado un estudio exhaustivo de todos los números que conformaban esta tirada periódica, nos damos cuenta de que no existía un afán por mostrar noticias arqueológicas; así lo demostraban actos tales como la repetición de algunos de los grabados cuando volvían a dialogar sobre un monumento que se había tratado con anterioridad en la publicación, aunque la información sea diferente. Un cierto porcentaje de las noticias que transcurren sobre la arqueología eran copias y traducciones de un periódico extranjero. No obstante, las imágenes también eran incluidas en esa copia. Otras veces se producía un intercambio de planchas de grabados entre periódicos internacionales o simplemente se compraban, ya que siempre sería más beneficioso para la empresa comprar que crear.

En el principio de este tipo de publicaciones ilustradas primaba la educación, las artes y las ciencias, y así lo demostraba el subtítulo de esta publicación, manifestado principalmente durante los primeros años de publicación en los que las noticias dedicada al mundo de las Bellas Artes son mucho más numerosos que en algunos momentos centrales (Anexo 3). En los años centrales de vida de La Ilustración Española y Americana, encontramos muchos altibajos en relación a las publicaciones de carácter arqueológico (Anexo 3); esto se pudo deber en algunas ocasiones a los períodos de entreguerras, momentos de la historia donde tanto las batallas como las relaciones políticas impedían realizar expediciones arqueológicas en determinados lugares. No obstante, las noticias no se publicaban porque no existían.

Los últimos años de esta publicación se vivieron de forma muy confusa. Los constantes cambios de dirección no ayudaron a estabilizar la línea editorial de la revista. A partir del año 1917 los artículos de cualquier índole cultural se volvieron completamente divulgativos y se perdió el interés de la noticia, con primacía de la fotografía y la imagen (Anexo 3). La pérdida por el interés científico de las noticias llegó a su punto extremo cuando, en el mes de julio de 1921, se publicaron en una misma tirada periódica la información de los días 22 y 30 de julio de 1921, es decir se publican conjuntamente ${ }^{106}$.

El número de noticias arqueológicas encontradas es de 176 (Anexo 2), un número bastante bajo para una publicación que estuvo en la calle durante un período de tiempo superior a medio siglo. Los resultados obtenidos han sido inferiores, en cuanto a los números de noticias arqueológicas en el ámbito internacional, a las expectativas con las que se comenzó el estudio. Partiendo de la premisa de que se trataba de la publicación ilustrada más importante en la España de finales del siglo XIX y principios del siglo XX con un gran número de lectores los cuales demandaban la reedición de los números para no

Museo Arqueológico Nacional, por José Ramón Mélida. p. 96; AÑO XXVIII-NÚM XXXI (agosto, 22 de 1884): Sobre las esculturas de barro cocido, griegas, etruscas y romanas del Museo Arqueológico Nacional, por José Ramón Mélida. p. 101; AÑO XXVIII-NÚM XXXI (agosto, 30 de 1884): Sobre las esculturas de barro cocido, griegas, etruscas y romanas del Museo Arqueológico Nacional, por José Ramón Mélida. p. 116.

106 La Ilustración Española y Americana, AÑO LXV-NÚM 27 y 28 (julio, 22 y 30 de 1921): Hallazgos arqueológicos. p. 314. 
perderse ni un solo grabado de los que allí se publicaban, se esperaba una mayor predilección por las noticias que cubren el campo de la cultura y las ciencias.

Las noticias arqueológicas en el ámbito nacional responden a una gran exposición (Anexo 2), en comparación con las de ámbito internacional, posiblemente debido a la cercanía geográfica y la fácil comprensión de las mismas, pues no hay que olvidar que muchos de sus descubridores eran colaboradores de $L a$ Ilustración Española y americana. Las noticias y yacimientos más importantes se corresponden con ciudades como Tarraco, Itálica, Híspalis, Mérida y el Cerro de los Santos con la singular escultura de La Dama de Elche.

A pesar del bajo número de publicaciones dedicadas al campo de la Arqueología, nos encontramos ante el primer impulso de difusión de esta disciplina a las grandes masas. Por primera vez y a escala centenar las noticias sobre Arqueología inundaban los kioscos de las grandes capitales de España y América (sin contar las subscriciones que se mandaban al extranjero). No obstante, la labor que ejerció La Ilustración Española y americana, independientemente de la calidad de algunas de las noticias de sus publicaciones, fue un estímulo para ampliar las fronteras de difusión de la Arqueología y ganar adeptos que comenzaran a interesarse por la historia del pasado, por las construcciones monumentales que el tiempo convirtió en ruinas y por el saber de la Arqueología.

\section{BIBLIOGRAFÍA}

AAVV. (1996), La prensa ilustrada en España: Ias ilustraciones 1850-1920: Coloquio Internacional-Rennes, Montpellier. Université Paul Valéry.

Almagro Gorbea, M. (2008), El expolio de las monedas de oro del Museo Arqueológico Nacional en la Segunda República española. Boletín de la Real Academia de la Historia 205-1: 7-72.

Alonso, C. (1996), 'Antecedentes de las “Ilustraciones"'. La prensa ilustrada en España: Las Ilustraciones, 1850-1920. Coloquio Internacional-Rennes, 1988. Montpellier. Université Paul Valéry: 13-44 y $45-$ 46.

Amador de los Ríos, R. (1883), Memoria acerca de algunas inscripciones arábigas de España y Portugal, Madrid.

Amador de los Ríos, J. (1996), El estilo mudéjar en arquitectura: discurso de Excmo. Sr. Don José Amador de los Ríos, leído en la Junta Pública de 19 de junio de 1859, discurso del Excmo. Sr. Don Pedro de Madrazo, en contestación al anterior, Valencia. Servicio de Reproducción de Libros, D.L.

Amores Carredano, F. y Beltrán Fortes, J. (eds.) (2011), Itálica. Historia y descripción artística de esta infortunada ciudad y de sus ruinas. Láminas. Demetrio de los Ríos. 1879, Sevilla. Fundación Itálica de Estudios Clásicos y Editorial Proyecto Sur.

Ariza Muñoz, C. (1985), El Jardín Botánico, el Casino de la Reina y Vista-Alegre: Jardines madrileños que fueron del Real Patrimonio, Madrid. Patrimonio Nacional.

Ayrault, P. (1996), 'El reportaje gráfico en "La Ilustración Española y Americana" y Juan Comba'. La prensa ilustrada en España: Las Ilustraciones, 1850-1920. Coloquio Internacional-Rennes, 1988. Montpellier. Université Paul Valéry: 99-118. 
Barrios Rozúa, J.M. (2010), 'José Contreras, un pionero de la arquitectura neoárabe: sus trabajos en La Alhambra y en La Alcaicería'. La invención del estilo hispano-magrebí. Presente y futuros del pasado, Barcelona. Anthropos: 311-338.

Bordes Caballero, J. (2014), Monumentos Arquitectónicos de España (1852- 1881), Madrid. Real Academia de Bellas Artes de San Fernando y Escuela Técnica Superior de Arquitectura de Madrid, UPM.

Botrel, J.F. (1996), 'A. de Carlos y "La Ilustración Española y Americana". El empresario y la empresa'. La prensa ilustrada en España: Las Ilustraciones, 1850-1920. Coloquio Internacional-Rennes, 1988. Montpellier. Université Paul Valéry: 91-98.

Bozal, V. (1979), La Ilustración gráfica del XIX en España, Madrid Comunicación.

Cabrera, M. (1994), La industria, la prensa y la política: Nicolás Ma. de Urgoiti (1869-1951), Madrid. Alianza, D. L.

Casado Rigalt, D. (2006), José Ramón Mélida (1856-1933) y la arqueología española, Madrid. Real Academia de la Historia.

Chevalier, N. (2002), La recherche archéologique française au Moyen Orient (1842-1947). Paris.

Comas, J. (1974), Cien años de Congresos Internacionales de Americanistas, México. Universidad Nacional Autónoma de México.

Cremades Rubio, E. (2003), Biografía de Juan Valera, Madrid. Castalia.

Da Riva, R. y Vidal, J. (Eds.) (2014), Descubriendo el Antiguo Oriente. Pioneros y arqueólogos de Mesopotamia y Egipto a finales del XIX y principios del XX, Barcelona. Bellaterra.

Desvois, J.M. (1996), 'El fin de las Ilustraciones: el caso de Madrid'. La prensa ilustrada en España: Las Ilustraciones, 1850-1920. Coloquio Internacional-Rennes, 1988. Montpellier. Université Paul Valéry: 343-348.

Dyson, S.L. (2008): En busca del pasado. Una historia de la Arqueología del mundo grecolatino en los siglos XIX y XX, Barcelona. Ariel.

Fontbona, F. (1996), 'Las llustraciones y la reproducción de sus imágenes'. La prensa ilustrada en España: Las Ilustraciones, 1850-1920. Coloquio Internacional-Rennes, 1988. Montpellier. Université Paul Valéry: 73-79.

Gómez Aparicio, P. (1971), Historia del periodismo español (Tomo 2), De la Revolución de Septiembre al desastre colonial, Madrid. Editora nacional.

Gran Aymerich, E. (2001), Les chercheurs de passé (1798-1945). Aux sources de l'archéologie, Paris. CNRS.

Houghton, W. E. (1982), 'Periodical literature and the articulate classe's. The Victorian periodical press; samplings and soundings, Leicester. Leicester University Press.

Knight, C. (1864-5), Passages of a Working Life During Half a century, 3 vols. London, Tomo III: 246-247. Ladero Galán, A. y Jiménez Rubio, J. (2014), 150 años de obras y reformas en el Museo Arqueológico Nacional. Historia y catálogo documental. Boletín del Museo Arqueológico Nacional 32: 81-102.

López Azorín, F. (2011), 'El relojero de Yecla y las falsificaciones del Cerro de los Santos', en Hombres o dioses: una nueva mirada a la escultura del mundo ibérico. Madrid. Comunidad de Madrid, Museo Arqueológico Regional: 279-296.

López Núñez, J. (1929), 'La llustración Española y Americana. Don Abelardo de Carlos y su obra'. Románticos y bohemios, Madrid. Editorial Ibero-Americana.

Marchandiau, J. N. (1987), L'Illustration 1843/1944, Toulouse. Privât.

Marcos Pous, A. (coord.) (1993), De Gabinete a Museo. Tres siglos de historia. Madrid. Ministerio de Educación, Cultura y Deporte.

Margueron, J.C. (2002), La evolución de la exploración arqueológica. Los mesopotámicos. Fuenlabrada, Cátedra. 
Mariette, A. (1880), Itinéraire de la Haute-Égypte : comprenant une description des monuments antiques des rives du Nil : entre le Caire et la première Cataracte, Paris. Maissonneuve et Cie, LibrairesÉditeurs.

Márquez, M. B. (2005), D. Abelardo de Carlos y La llustración Española y Americana. Ámbitos 13-14: 185209

Martí Valentí, F. (1992-1994), Notas para una historia de la Egiptología en España. Boletín de la Asociación Española de Egiptología 4-5: 173-195.

Martínez Riaza, A. (2001), 'El reinado de los periódicos. La prensa española hasta la Crisis de la Restauración (1833-1898)'. Periodismo y periodistas. De las Gacetas a la red, Barcelona. Editorial España Nuevo Milenio.

Mélida Alinari, J. R. (1895), El Museo Arqueológico Nacional en el Palacio Nuevo. La España Moderna LXXX: 38-51.

Mélida Alinari, J. R. (1897), Historia del Arte Griego. Madrid.

Mélida Alinari, J. R (1899), Viaje a Grecia y Turquía. Madrid.

Nomblea, J. (1976), Impresiones y recuerdos, Madrid. Tebas, D.L.

Palenque, M. (1990), Gusto poético y difusión literaria en el realismo español. La llustración Española y Americana (1869-1905), Sevilla. Ediciones Alfar.

Perera, A. (1960), 'Vidas olvidadas. Francisco Ortego, el Gavarni español'. Arte Español, Madrid.

Pla Vivas, V. (2010), La llustración gráfica del siglo XIX. Funciones y difusiones, Valencia. PUV, Universitat de València.

Rada y Delgado, J. de D. (1875), Antigüedades del Cerro de los Santos en el término de Montealegre, conocidas vulgarmente bajo la denominación de antigüedades de Yecla. Museo Español de Antigüedades VI: 249-290.

Robert Ryal, M. (1983), Por la ciencia y la gloria nacional: la expedición científica española a América (1892-1866), Barcelona. Ediciones del Serbal.

Rodríguez Domingo, J.M. (2007), 'La Alhambra restaurada: de ruina romántica a fantasía oriental'. Luz sobre papel: la imagen de Granada y la Alhambra en las fotografías de J. Laurent. Granada: 83-98.

Romero Recio, M. (2012), Ecos de un descubrimiento. Viajeros españoles en Pompeya (1748-1936), Madrid. Polifemo.

Rubio Gil, L. (2002), Eduardo Rosales, Barcelona Aguazul.

Ruiz Souza, J.C. (2010), Construcción y búsqueda de un estilo nacional, el estilo mudéjar, ciento cincuenta años después, Barcelona. Anthropos.

Sevilla Mompó, J. A. (2016), 'Las excavaciones arqueológicas en Pompeya y Herculano y su reflejo en la prensa española ("La Época" \& "La Correspondencia de España") de 1849 a 1936'. Estudios arqueológicos del área Vesubiana II, British Archaeological Reports (BAR): 165-190.

Trenc, E. (1996), 'Los modelos extranjeros, "The Illustrated London News" y "L'Illustration"'. La prensa ilustrada en España: Las Ilustraciones, 1850-1920. Coloquio Internacional-Rennes, 1988. Montpellier. Université Paul Valéry: 57-62.

Valls, J.F. (1988), Prensa y burguesía en el XIX español, Barcelona. Anthropos Editorial del Hombre.

\section{Anexos}

\section{Anexo 1: Listado de noticias arqueológicas divididas según la temática}

\section{Próximo Oriente: Egipto y Mesopotamia}

- AÑO XIV-NúM.2 (enero, 10 de 1870): Inauguración del Canal de Suez: Agujas de Cleopatra. pp. 2326.

- $\quad$ AÑO XVI-NÚM XIV (abril, 8 de 1872): Viajes. Una excursión a las pirámides, por E.B. pp. 222-223. 
- AÑO XVI-NÚM XX (mayo, 24 de 1872): Las estatuas de Memnon, cuadro de MR. Werner's Nibildern. p. 341.

- AÑO XVII-NÚM XXVI (julio, 8 de 1973): Templo "Hypethreo" de Isis en la isla de Phile. p. 421.

- AÑO XVIII-NÚM XXV (julio, 8 de 1874): Nuevos descubrimientos en las pirámides de Egipto, por Eusebio Martínez de Velasco. p. 387.

- AÑO XIX-NúM XIV (abril, 15 de 1875): Restos del templo de Isis, en la isla de Phyle. p. 235.

- AÑO XIX-NÚM XLV (diciembre, 8 de 1875): Alejandría. Agujas de Cleopatra, ofrecida a Inglaterra por el Bajá de Egipto Mehemet Alí. p. 354.

- AÑO XXI-NÚM XXXVII (octubre, 8 de 1877): Translación de la aguja de Cleopatra a Inglaterra, por Eusebio Martínez de Velasco. pp. 219-221.

- AÑO XXII-NÚM XXX (agosto, 15 de 1878): Ruinas del Tempo egipcio de Hardasek. p. 90.

- AÑO XXIV-NÚM XLVIII (diciembre, 3 de 1880): Monumentos egipcios: fachada del gran templo de Abu-Simbel, en el alto Nilo. pp. 894-895.

- AÑO XXV-NÚM V (febrero, 8 de 1881): Mariette-Bey y sus descubrimientos en Egipto, por E. Martínez de Velasco. pp. 75-78.

- AÑO XXV-NÚM XLIII (noviembre, 22 de 1881): Momias egipcias de animales sagrados, por Eusebio Martínez de Belasco. p. 299.

- AÑO XXVII-NÚM VIII (febrero, 28 de 1883): Un cuento egipcio (versión castellana de la traducción de un papiro egipcio del Museo Británico), por José Ramón Mélida. pp. 131-134

- AÑO XXX-NÚM XXVII (julio, 22 de 1886): Museo de Boulaq, descubrimiento e inspección facultativa de la momia de Sesostris. p.35

- AÑO XXXV-NúM XV (abril, 22 de 1891): Nuevos Descubrimientos de momias en Egipto. La extracción de sarcófagos del pozo de Deir-El-Bahuri. p. 243.

- AÑO XXXV-NÚM XVII (mayo, 8 de 1891): Nuevos descubrimientos de momias en Egipto. Translación de los sarcófagos del Nilo, para conducirlos al Cairo, por Eusebio Martínez de Velasco. p. 275.

- AÑO XLIII-NÚM VII (febrero, 22 de 1899): La restauración del templo de Karnak. pp. 103-105.

\section{Grecia}

- AÑO XVI-NÚM XXXII (agosto, 24 de 1872): El Partenón de Atenas. p. 503.

- AÑO XVIII-NÚM XXIX (agosto, 8 de 1874): Antigüedades Troyanas, por N. p. 455.

- AÑO XXV-NÚM X (marzo, 15 de 1881): Estatua de Minerva, descubierta en Atenas. pp. 162-163.

- AÑO XXVI-NÚM XX (mayo, 30 de 1882). Vasos griegos del Museo del Louvre, por B. p. 342.

- AÑO XXIX-NÚM XXIII (junio, 22 de 1885): Pinturas al fresco en el Parthenon. p. 370.

- AÑO XXXVI-NÚM XI (marzo, 22 de 1892): Cádiz. Una necrópolis fenicia. p. 175.

- AÑO XXXVI-NÚM XVI (abril, 30 de 1892): Las chulas griegas, por José Ramón Mélida. pp. 261-263.

- AÑO XXXVIII-NÚM XLVIII (diciembre, 30 de 1894): Hallazgos en las ruinas de la antigua ciudad de Delfos. p. 395.

- $\quad$ AÑO XLVII-NÚM (abril, 22 de 1903): Atenas, Grecia. p. 343.

- AÑO LV-NÚM-XXVIII (julio, 30 de 1910): Italia. La fabulosa estatua griega "La Fanciula de Anzio". Recientemente instalada en el Museo Nacional de Roma. p. 49

- AÑO LXI-NúM XXIV (junio, 30 de 1917): Páginas de divulgación artística. Cerámica griega, por J. De Amaury. p. 371.

\section{Roma}

- AÑO XIV-NÚM.2 (enero, 10 de 1870): Inauguración del Canal de Suez: Columna de Pompeyo. pp. 2326.

- AÑO XIV-NÚM.2 (enero, 10 de 1870): Inauguración del Canal de Suez: los velocípedos. Pp. 29-30.

- AÑO XIV-NúM.4 (febrero, 10 de 1870): Apuntes sobre los primeros tiempos de la historia romana, por Eugenio de Ochoa. pp. 51-54. 
- AÑO XIV-NÚM.7 (marzo, 25 de 1870): Apuntes sobre los primeros tiempos de la historia romana, por Eugenio de Ochoa. pp. 83-86.

- AÑO XIV-NÚM.7 (marzo, 25 de 1870): El arco de Tito en Roma, por Eugenio de Ochoa. p. 87.

- AÑO XIV-NÚM.21 (septiembre, 25 de 1870): El castillo de Sant Angelo. p. 327.

- AÑO XV-NÚM.III (enero, 25 de 1870): Autunn y Le Mans p. 55.

- AÑO XV-NÚM.III (abril, 25 de 1871): Inscripciones inéditas de Ampurias. pp. 240-241.

- AÑO XV-NúM.III (mayo, 5 de 1870): El Coliseo Romano, por Emilio Castelar. pp. 249-252.

- AÑO XV-NÚM XIV (mayo, 15 de 1871): El coliseo Romano, por Emilio Castelar. pp. 239-242.

- AÑO XVI-NÚM. II (enero, 8 de 1872): Inscripción romana (inédita), por Fidel Fita. p. 26.

- AÑO XVII-NÚM XXX (agosto, 8 de 1873): Interior de una tahona en Pompeya. p. 486.

- AÑO XVIII-NÚM XVI (abril, 30 de 1974): Ruinas del "Forum" romano. p. 243.

- AÑO XVIII-NÚM XXVI (julio, 15 de 1874): Busto de Julio César, en mármol, en el Museo Británico, por Eusebio Martínez de Velasco. p. 403.

- AÑO XVIII-NÚM XXXVII (octubre, 8 de 1974): Roma. La casa de Rienzi. p. 579.

- AÑO XIX-NÚM XXI (junio, 8 de 1875): Entrada triunfal del emperador Tito en Roma, después de la conquista de Judea. p. 361.

- AÑO XXNÚM-XXVII (julio, 22 de 1876): Roma: Monumento del Siglo I de la era cristiana. p. 35.

- AÑO XXI-NÚM VI (febrero, 15 de 1877): El anfiteatro de Pompeya, por Eusebio Martínez de Velasco. pp. 99-101.

- $\quad$ AÑO XXIV-NúM XI (marzo, 22 de1880): Antigüedades de Roma. La vía Apia. p. 179.

- $\quad$ AÑO XXV-NÚM XXII (junio, 15 de 1881): Templo de Castur y Polux, en Giberti. p. 382.

- AÑO XXV-NÚM XXII (junio, 15 de 1881): Ruinas de Cartago, a cuatro kilómetros de Túnez. p. 382.

- AÑO XXV-NÚM XXIV (junio, 30 de 1881): Urania, Baco y Diana, pinturas murales descubiertas en Pompeya. p. 415.

- AÑO XXVI-NÚM XV (abril, 22 de 1882): Roma antigua. Ruinas del Coliseo (Anfiteatro Flavio). pp. 250251.

- AÑO XXVIII-NÚM VIII (febrero, 29 de 1884): Busto de "Zeus", encontrado en Etricoli, por Eusebio Martínez de Velasco. p. 131.

- AÑO XXXIII-NÚM I (enero, 8 de 1889): Roma antigua. p. 3.

- AÑO XXXIV-NÚM XLIII (noviembre, 22 de 1890): Ruinas romanas de Timegatte (Argelia). Arco del Triunfo. pp. 308.

- AÑO XXXV-NÚM XIV (abril, 15 de 1891): Roma pagana: El Palatino, por Eusebio Martínez Velasco. Pp. 227.

- AÑO XLII-NÚM VII (febrero, 22 de 1899): Excavaciones en el Foro de Roma. p. 107.

- AÑO XLIV-NÚM XX (mayo, 30 de 1900): Roma Antigua. p. 311.

- AÑO XLVI-NÚM XII (marzo, 30 de 1902): Por Italia, notas de un viaje artístico. Roma, Nápoles y Pompeya, por R. Balsa de La Vega. pp. 183-187.

- $\quad$ AÑO XLVII-NÚM XLI (noviembre, 8 de 1903): El "Ara Pacis Augustae". p. 275.

- AÑO LI-NÚM XXXIII (septiembre, 8 de 1907): Recientes descubrimientos en Pompeya, por R. Balsa de La Vega. pp. 146-147.

- AÑO LII-NÚM XXXIV (septiembre, 15 de 1908): Roma Antigua. El arco de Tito delante del Coliseo. p. 157.

- AÑO LIX-NÚM 41. (noviembre, 8 de 1915): Funerales romanos, E. González Fiol. pp. 852-854.

Península ibérica

- AÑO XIV-NÚM.3 (enero, 25 de 1870): Descubrimientos prehistóricos en Gibraltar, por Francisco M. Tubino. pp. 37-38 
- AÑO XIV-NÚM.21 (septiembre, 25 de 1870): El arco de Bara: los pueblos llergetes y los cassetanos en la provincia tarraconense, por Aureliano Fernández-Guerra y Orbe. pp. 326-327.

- AÑO XIV-NúM.22 (octubre, 5 de 1870): El arco de Bara: los pueblos llergetes y los cassetanos en la provincia tarraconense, por Aureliano Fernández-Guerra y Orbe. pp. 339-341.

- AÑO XIV-NÚM.26 (noviembre, 15 de 1870): Una expedición a las ruinas de Bobastro, por Francisco Javier Simonet. pp. 410-411.

- AÑO XIV-NÚM.28 (diciembre, 5 de 1870): Una expedición a las ruinas de Bobastro, por Francisco Javier Simonet. pp. 438-443.

- AÑO XIV-NÚM.30 (diciembre, 25 de 1870): Una expedición a las ruinas de Bobastro, por Francisco Javier Simonet. p. 475.

- AÑO XV-NÚM. XIV (mayo, 5 de 1871): Muros ciclópeos de Tarragona, por Buenaventura Hernández Saholuja. p. 237.

- AÑO XV-NúM. XVI (junio, 5 de 1871): Muros ciclópeos de Tarragona, por Buenaventura Hernández Sanahuja. pp. 278-279.

- AÑO XV-NúM. XVI (junio, 25 de 1871): Muros ciclópeos de Tarragona, por Buenaventura Hernández Saholuja. pp. 311-312.

- AÑO XV-NÚM. XXIII (agosto, 15 de 1871): Excavaciones en la antigua Iruña, por F. pp. 391-394.

- AÑO XV-NúM. XXIII (agosto, 15 de 1871): Monumento megalítico de San Miguel de Arrechinaga, por Miguel Rodriguez-Ferrer.p. 387.

- AÑO XVI-NúM IV (enero, 24 de 1872): Antigüedades. El collar de oro de Mellid, por Aureliano Fernández-Guerra y Orbe. p.51.

- $\quad$ AÑO XVI-NÚM XIII (abril, 1 de 1872): Palacio Romano de Tarragona, p. 203.

- AÑO XVI-NÚM XIX (mayo, 16 de 1872): Restos Romanos. Últimamente descubiertos en Barcelona, por J.P. pp. 303-304.

- AÑO XVI-NÚM XLV (diciembre, 1 de 1872): El teatro romano de Sagunto, por P. García Cadena. pp. 719-720.

- AÑO XVII-NÚM II (enero, 8 de 1873): Cueva de Hércules en Toledo, por Mariano de la Torre Roldán. pp. 51-52.

- $\quad$ AÑO XVII-NÚM VI (febrero, 8 de 1873): Templo romano en la entrada del puente de Alcántara. p. 53.

- AÑO XVII-NÚM XII (marzo, 24 de 1873): Trujillo: ruinas de la torre de Julio César. p. 179.

- AÑO XVI-NÚM XXXIII (septiembre, 1 de 1873): El acueducto de Segovia. p. 559.

- AÑO XVIII-NÚM XVI (abril, 30 de 1874): Antigüedades romanas de la provincia de Zamora, por Cesáreo Fernández Duro. p. 246

- AÑO XVIII-NÚM XVII (mayo, 8 de 1874): Antigüedades romanas de la provincia de Zamora, por Cesáreo Fernández Duro. pp. 262-263.

- AÑO XVIII-NÚM XXII (junio, 15 de 1874): Antigüedades romanas de la provincia de Zamora, por Cesáreo Fernández Duro. pp. 343-347.

- AÑO XVIII-NÚM XXII (junio, 15 de 1874): Tarragona. Acueducto romano, Ilamado vulgarmente "EI puente del diablo". p. 339.

- AÑO XIX-NÚM II (enero, 15 de 1875): Itálica. Últimos descubrimientos de 1874, por Demetrio de los Ríos pp. 34-35.

- AÑO XIX-NÚM V (febrero, 8 de 1875): Itálica. Últimos descubrimientos de 1874, por Demetrio de los Ríos. pp. 83-86.

- AÑO XIX-NÚM VIII (febrero, 28 de 1875): Itálica. Últimos descubrimientos de 1874, por Demetrio de los Ríos. p. 134.

- AÑO XIX-NÚM XXX (agosto, 15 de 1875): Arco de Trajano en Mérida, por Eusebio Martínez de Velasco. p. 74. 
- AÑO XIX-NÚM XXXIX (octubre, 22 de 1875): Lápidas romanas encontradas en Clunia. p. 243.

- AÑO XX-NÚM XXI (junio, 8 de 1875): Las murallas antiguas de Sevilla. p. 371.

- AÑO XXI-NÚM I (enero, 8 de 1877): De lo prehistórico en las provincias vascongadas, por Francisco Navarro Villaslada. pp. 6-10.

- AÑO XXI-NÚM II (enero, 15 de 1877): De lo prehistórico en las provincias vascongadas, por Francisco Navarro Villaslada. pp. 30-31.

- AÑO XXI-NÚM II (enero, 15 de 1877): Mosaico romano encontrado en término de Gerona. p. 27.

- AÑO XXI-NÚM XV (abril, 22 de 1877): Restos de construcciones romanas, en Mérida. pp. 259-262.

- AÑO XXI-NÚM XLIV (noviembre, 30 de 1977): Puente romano de Mérida, sobre el Guadiana. p. 339.

- $\quad$ AÑO XXII-NÚM IV (enero, 30 de 1878): Retogenes Caurino, por Miguel Gutiérrez. p. 79.

- AÑO XXII-NÚM IX (marzo, 8 de 1878): El Hércules de La Guardia, por Eusebio Martínez de Velasco. p. 158.

- AÑO XXIII-NÚM XXXI (agosto, 22 de 1879): Bustos romanos, hallados en las excavaciones de Támara (Palencia). p. 107.

- AÑO XXIV-NÚM XLVIII (diciembre, 3 de 1880): El maestrazgo en los templos prehistóricos, por José J. Landerer. pp. 402-403.

- AÑO XXV-NÚM XVI (abril, 30 de 1881): Los brazaletes prehistóricos, por Manuel de Góngora. pp.278279.

- AÑO XXVI-NÚM XXXI (agosto, 22 de 1882): Sobre los vasos griegos, etruscos e itálico-griegos del Museo Arqueológico Nacional, por José Ramón Mélida. pp. 102-106.

- AÑO XXVI-NúM XXXII (agosto, 30 de 1882): Sobre los vasos griegos, etruscos e itálico-griegos del Museo Arqueológico Nacional, por José Ramón Mélida. pp. 122-123.

- AÑO XXVI-NúM XXXIV (septiembre, 15 de 1882): Sobre los vasos griegos, etruscos e itálico-griegos del Museo Arqueológico Nacional, por José Ramón Mélida. pp.132-133.

- AÑO XXVI-NúM XXXV (septiembre, 22 de 1882): Sobre los vasos griegos, etruscos e itálico-griegos del Museo Arqueológico Nacional, por José Ramón Mélida. pp. 142-143.

- AÑO XXVIII-NÚM XVII (mayo, 8 de 1884): Antiguas murallas de Ronda. p.286.

- AÑO XXVIII-NÚM XXIX (agosto, 8 de 1884): Sobre las esculturas de barro cocido, griegas, etruscas y romanas del Museo Arqueológico Nacional, por José Ramón Mélida. p. 75

- AÑO XXVIII-NÚM XXX (agosto, 15 de 1884): Sobre las esculturas de barro cocido, griegas, etruscas y romanas del Museo Arqueológico Nacional, por José Ramón Mélida. p. 96

- AÑO XXVIII-NÚM XXXI (agosto, 22 de 1884): Sobre las esculturas de barro cocido, griegas, etruscas y romanas del Museo Arqueológico Nacional, por José Ramón Mélida. p. 101

- AÑO XXVIII-NÚM XXXI (agosto, 30 de 1884): Sobre las esculturas de barro cocido, griegas, etruscas y romanas del Museo Arqueológico Nacional, por José Ramón Mélida. p. 116

- AÑO XXIX-NÚM VIII (febrero, 28 de 1885): Piezas de cerámica romana halladas en Tarragona, por J. Puiggari. p. 122.

- AÑO XXIX-NÚM XLIII (noviembre, 22 de 1885): Apuntes Arqueológicos de la isla de Menorca, por Francisco Hernández Sanz. p. 310.

- AÑO XXX-NÚM XXI (junio, 8 de 1886): El Dolmen. Cueva de Menga por Rafael González Anleo. pp. 355-356.

- AÑO XXX-NúM XXVII (octubre, 8 de 1886): Al nacimiento de Atenea, asunto decorativo en un mármol griego del Museo Arqueológico Nacional. pp. 203-206.

- AÑO XXX-NÚM XLI (noviembre, 8 de 1886): Las momias egipcias, por Eduardo Toda. pp. 263-267.

- AÑO XXXI-NÚM XXXV (septiembre, 22 de 1887): Los bronces desaparecidos del Museo Arqueológico Nacional, por José Ramón Mélida. p. 167

- $\quad$ AÑO XXXIV-NÚM XXVI (julio, 15 de 1890): Monumentos antiguos de Sádaba (Zaragoza). p. 19. 
- AÑO XXXVII-NÚM XX (mayo, 30 de 1893): Exposición histórico-natural y etnográfica. Sala oriental. p. 351.

- AÑO XXXVII-NÚM XXV (julio, 8 de 1893): Exposición histórico-natural y etnográfica. Sala egipcia, por José Ramón Mélida. p. 15.

- AÑO XXXIX- NÚM XIV (abril, 15 de 1895): Bronce romano-celtibérico, por José Ramón Mélida. pp. 238-239.

- AÑO XL-NúM XXXII (agosto, 30 de 1896): Los fenicios en Galicia, por Federico Maciñera Pardo (Cronista de Ortiguera). pp. 123-126.

- $\quad$ AÑO XLI-NÚM XXXIII (agosto, 30 de 1897): Descubrimiento de una escultura (elche). pp.126-127.

- AÑO XLIII-NÚM XIV (abril, 15 de 1899): La antigüedad clásica en el Museo Arqueológico Nacional, por José Ramón Mélida. pp. 216-217.

- AÑO XLIX-NÚM XXXIV (septiembre, 15 de 1905): Numancia, las excavaciones hechas por los profesores alemanes, Shulten y Könen, por Vicente Vera. pp. 154-155.

- AÑO L-NÚM XII (marzo, 30 de 1906): Una Alhaja, por R. Balsa de la Vega. pp. 206-207.

- AÑO LI-NÚM VII (febrero, 22 de 1907): Movimientos primitivos de Menorca, por Francisco Hernández Sanz. pp. 103-106.

- AÑO LV-NÚM XIV (abril, 15 de 1911): Las ruinas de Itálica. Noticias de algunas de las excavaciones en ellas practicadas, por Rodrigo Amador de los Ríos. pp. 218-219.

- AÑO LVI-NÚM XXIX (agosto, 8 de 1912): Por la España romana. Mérida, por M. R. Blanco-Belmonte. pp. 72-74.

- AÑO LVI-NÚM XXX (agosto, 15 de 1912): Por la España romana. Mérida, por M. R. Blanco-Belmonte. pp. 90-91.

- AÑO LVII-NÚM XXXIII (septiembre, 8 de 1913): Una estación prehistórica cerca de Almendralejo, provincia de Badajoz, por Ramón Martínez de Pinillo. pp. 150-151.

- AÑO LIV-NÚM 36 (septiembre, 30 de 1915): Castilla-Los toros de Guisando, por Alberto de Segovia. pp. 758-759.

- AÑO LIX-NÚM 46 (diciembre, 15 de 1915): Arqueología española. Últimos descubrimientos arqueológicos de Cádiz. p. 948.

- AÑO LX-NÚM 11 (marzo, 22 de 1916): España a través de los siglos. Historial de antiguas grandezas. Las ruinas de Ampurias, por Agustín Murua y Valerdi. pp. 169-168.

- AÑO XLX-NÚM XXIII (junio, 22 de 1917): Acueducto de Segovia. p. 358.

- AÑO LXI-NÚM XXVI (junio, 15 de 1917): Páginas de divulgación artística. Cerámica numantina, por J. De Amaury. p. 403.

- AÑO LXV-NÚM 27 y 28 (julio, 22 y 30 de 1921): Hallazgos arqueológicos. p. 314.

\section{Cultura islámica}

- $\quad$ AÑO XIV-NÚM.V (febrero, 15 de 1871): Jarrón árabe, propiedad de Don Celestino Pujol. pp. 76-78.

- AÑO XIV-NÚM.V (septiembre, 22 de 1878): Ruinas del Castillo de Calatrava por V. pp. 176-178.

- $\quad$ AÑO XXV-NÚM IX (marzo, 8 de 1881): Salón de embajadores en el Alcázar de Sevilla. p. 139.

- AÑO XXVIII-NÚM X (marzo, 15 de 1884): Capiteles Árabes del castillo de la Alfajería. p. 163.

- AÑO XXVIII-NÚM XV (abril, 22 de 1884): Monumentos arquitectónicos de España, exteriores de la Gran Aljama de Córdoba. p. 251.

- AÑO XXVIII-NÚM XXXV (septiembre, 22 de 1884): Córdoba, portada del Mirhah en la antigua mezquita-aljama, hoy catedral, por N. Sentenach. p. 170.

- AÑO XXIX-NÚM XXIX (agosto, 8 de 1885): El estilo Mudéjar, por Rodrigo Amador de los Ríos (cartas al Sr. D. José Gestoso y Pérez). pp. 78-79.

- AÑO XXIX-NÚM XXX (agosto, 15 de 1885): El estilo Mudéjar, por Rodrigo Amador de los Ríos (cartas al Sr. D. José Gestoso y Pérez). pp. 90-91. 
- $\quad$ AÑO XXIX-NÚM XXXI (agosto, 22 de 1885): Alicatados del templete norte en la Alhambra. p. 171.

- AÑO XXXIV-NÚM XXXV (septiembre, 23 de 1890): Efectos del incendio en la arcada principal de la galería de entrada al salón de los emperadores y en el patio llamado de Doña Juana La Loca. p. 171.

- AÑO XXXIV-NÚM XXXVI (septiembre, 30 de 1890): El incendio de la Alhambra. pp. 186-187.

- AÑO LV-NÚM IX (marzo, 8 de 1911): Restauración de la mezquita-Aljama de Córdoba, por Amador de los Ríos. pp. 134-135.

- AÑO LV-NúM XI (marzo, 22 de 1911): Arquetas arábigas de marfil, del tesoro de la catedral de Zamora, por N.S. pp. 174-175.

\section{Culturas Prehispánicas}

- AÑO XIV-NÚM.2 (enero, 10 de 1870): Homenaje a Colón, por Eusebio Martínez de Velasco. pp. 2122.

- $\quad$ AÑO XX-NúM II (enero, 15 de 1876): Apuntes de un viaje por el Perú. pp. 28-30.

- AÑO XXV-NÚM XXXVIII (octubre, 15 de 1881): La Paleo-arqueología cubana. Instalación cubana en la exposición de objetos americanos, por M. Rodríguez Ferrer. pp 219-221.

- AÑO XXV-NÚM XXXVIII (octubre 22 de 1881): Exposición de objetos Americanos. Ídolos de Puerto Rico, por Sr. Pérez de Guzmán. pp. 235.

- AÑO XXV-NÚM XXXVIII (octubre, 22 de 1881): La Paleo-arqueología cubana. Instalación cubana en la exposición de objetos americanos, por M. Rodríguez Ferrer. pp. 242-243.

- AÑO XXV-NÚM XLIII (noviembre, 22 de 1881): Congreso americanista de Madrid. La exposición arqueológica, por Juan Pérez de Guzmán. pp. 306-307.

- AÑO XXVII-NÚM II (enero, 15 de 1883): Antigüedades americanas, por Ángel de Gorostizaga. p. 30.

- AÑO XXVII-NÚM XLVI (diciembre, 15 de 1883): Arqueología mejicana: el calendario de los aztecas (reproducción fotográfica del vaciado que se conserva en el Museo Arqueológico Nacional), por Ángel de Gorostizaga. pp. 351-354.

- AÑO XXXXXII-NÚM XXIII (junio, 22 de 1888): Arqueología mejicana, la piedra de los sacrificios, por Eusebio Martínez de Velasco. p. 365.

- AÑO XXXIV-NÚM XLVII (diciembre, 22 de 1890): Antigüedades aztecas "Mictalacihuatl o diosa de la muerte". p. 371.

- AÑO XXXVI-NúM XV (abril, 22 de 1892): Museo Nacional de Méjico. La escultura monolítica de "ChacMool". p. 241.

- AÑO XXXVI-NÚM XXVI (julio, 15 de 1892): Cráneos, ídolos y bustos americanos, por Eusebio Martínez de Velasco. p. 29.

- AÑO XXXVII-NÚM X (marzo, 15 de 1893): La exposición histórico-americana. Costa Rica, por José Ramón Mélida. pp. 168-169.

- AÑO XXXVII-NÚM XII (marzo, 30 de 1893): La exposición histórico-americana. Vasos peruanos hallados en la necrópolis del Gran Chimú. p. 203.

- AÑO XXXVII-NÚM XXVIII (julio, 30 de 1893): La exposición histórico-americana de Madrid. Vasos peruanos, la necrópolis del Gran Chimú., pertenecientes al Museo-Biblioteca del Ministerio de Ultramar. p. 64.

- AÑO 60-NúM 28 (julio, 30 de 1916): Leyendas Aztecas. Juego de pelota, por Feliciano Herrero de Tejada. pp. 442-443.

\section{Patrimonio y museos}

- AÑO XV-NúM.III (enero, 25 de 1871): Paris-Preparativos de defensa. p.55.

- AÑO XV-NÚM.XXI (julio, 5 de 1871): El Museo Arqueológico Nacional. pp. 362-363.

- AÑO XVI-NÚM.XXXIII (septiembre, 1 de 1872): El Museo Arqueológico Nacional. pp. 515-517 
- AÑO XVII-NÚM XLVI (diciembre, 8 de 1873): Museo Arqueológico de Barcelona, por J. Puiggari. p. 747-749.

- AÑO XXI-NÚM XLIII (noviembre, 22 de 1887): Bibliotecas y museos nacionales, estado actual de las obras de fábrica, por Eusebio Martínez de Velasco. p. 300.

- AÑO XXXIX-NúM XXVI (julio, 15 de 1895): La reapertura del Museo Arqueológico Nacional, por José Ramón Mélida. pp. 22-23.

\section{Otros}

- AÑO XIV-NÚM.26 (noviembre, 15 de 1870): Peregrino e historiador, por Antonio de Trueba. pp. 403406.

- $\quad$ AÑO XXXI- NÚM XXI (agosto, 22 de 1887): Historia del casco, por José Ramón Mélida. pp. 103-107.

- AÑO XXXVIII-NÚM XXXV (septiembre, 22 de 1894): Venus coqueta. La mujer de la antigüedad en el tocador, por José Ramón Mélida. pp. 178-179.

- AÑO LXI-NÚM 35 (septiembre, 22 de 1917): Páginas de divulgación artística. Arqueología funeraria, por J. De Amaury. pp. 555

- AÑO LXIV-NÚM 43 (noviembre, 30 de 1920): La medicina en la antigüedad, por Doctor Albiñana, pp. 563-564.

\section{Anexo 2: Gráfico de noticias arqueológicas en porcentaje según la temática}

\section{GRÁFICO DE NOTICIAS ARQUEOLÓGICAS}

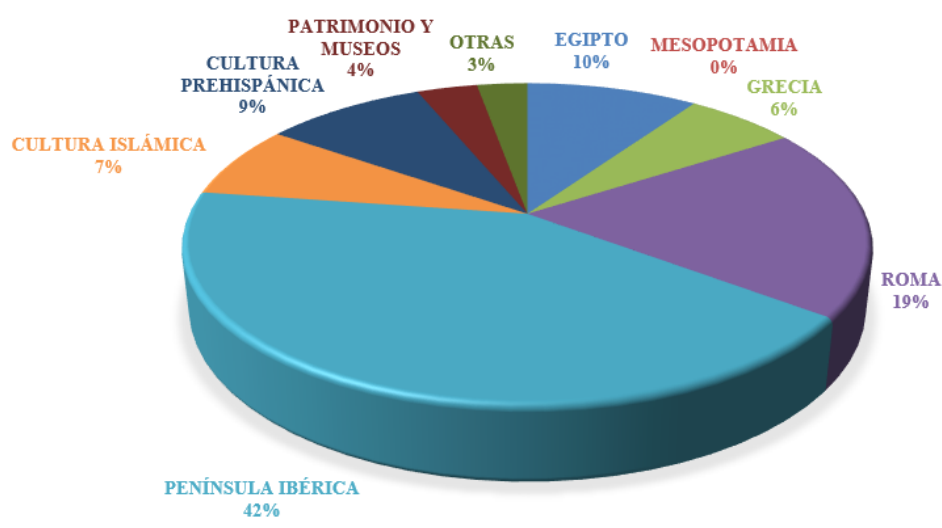

Anexo 3: Gráfico de noticias arqueológicas por año

Gráfico de noticias arqueológicas por año

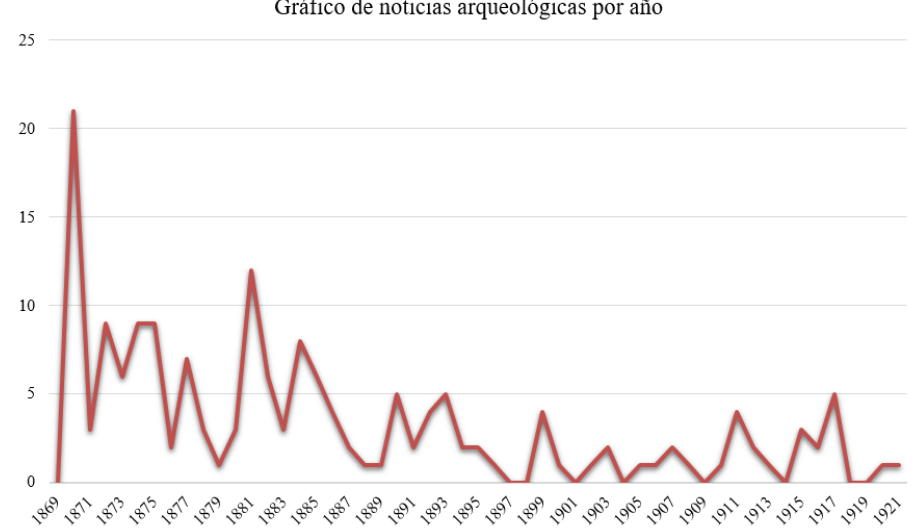




\title{
La formación arqueológica y en historia del arte del joven Manuel Gómez-Moreno Martínez (1870-1899)
}

\author{
Alfredo Mederos Martín ${ }^{1}$
}

Universidad Autónoma de Madrid

\section{Introducción}

La etapa formativa de Gómez-Moreno, representante de la mejor generación del 98 española, no sólo es interesante para valorar adecuadamente a uno de los principales arqueólogos e historiadores del arte españoles del primer tercio del siglo XX, sino que muestra que cuando fue designado en 1900 por Facundo Riaño para desarrollar el Catálogo Monumental de España, su formación precedente con su padre desde 1885 en múltiples visitas dentro la ciudad de Granada y su provincia, plasmada en la Guía de Granada (1892), le convertían en una persona idónea y suficientemente joven para realizar en solitario la labor de campo, documentación de archivo, dibujos y fotografías, y la redacción final de los catálogos.

\section{Entorno familiar}

Manuel -Carlos Felipe Félix Pascacio de la Santísima Trinidad- Gómez-Moreno Martínez nació en Granada el 21 de febrero de 1870, a las 12 de la noche, hijo de Manuel Gómez-Moreno González y Dolores Martínez Almirón. Sus abuelos paternos fueron Carlos Gómez-Moreno Puchol, de Viznar, pueblo de la vega de Granada y Concepción González de Granada. Como abuelos maternos, Eugenio Martínez de Alcalá la Real (Jaén) y María Antonia Almirón de Luque (Córdoba) (AGA 32/16148). Fue bautizado por el párroco Antonio Devalque, natural de Cogollos-Vega, a 14 km de Granada (AGA 32/16148), en la iglesia de San Gil y Santa Ana, en la plaza de Santa Ana de Granada (Gómez-Moreno Rodríguez 1995: 30), siendo uno de los tres testigos el abogado Manuel Rodríguez Bolívar. Fue el primero de un total de ocho hijos que nacieron entre 1870-1886, Concepción -Concha- en 1872, Sacramento en 1874, Eugenia en 1876, Carlos en 1879, Dolores y María en 1882 y José -Pepe- en 1887. La pareja se había casado un año antes, en 1869, teniendo Gómez-Moreno González 35 años, al ganar una plaza por oposición de profesor de Dibujo en el Colegio Universitario de San Bartolomé y Santiago (Gómez-Moreno Martínez 1928/1986: xxix; Gómez-Moreno Rodríguez 1995: 29). De sus hermanos, primero falleció una de las gemelas, María, en 1885. Su hermana mayor, Concha, casada desde 1892 y con dos hijas, murió en agosto de 1896. El hermano pequeño, Pepe, se cayó de la tapia del huerto y con lesiones cerebrales convaleció hasta morir en 1898 (Gómez-Moreno Rodríguez 1995: 45, 65).

Nació en una casa del siglo XVI, sobre las ruinas de otra árabe en la plaza de Benalúa, 12, también llamada de los Aceituneros, en el seno de una familia de liberales afrancesados, impresores y libreros, desde su bisabuelo paterno, José Manuel Gómez-Moreno, continuada por su abuelo Carlos Gómez-Moreno Puchol, que vivía con la familia y que se ocupaba principalmente de su primer nieto, Manuel. En cambio, sus hijos optaron por nuevos rumbos artísticos, eligiendo Carlos, el hermano mayor de Manuel Gómez-Moreno González, la música y él la pintura, actividad poco rentable económicamente pues "tenía que seguir haciendo retratos de difuntos, faena que abominaba, pero constituía su más segura fuente de ingresos" (Gómez-Moreno Martínez 1928/1986: xxix; Gómez-Moreno Rodríguez 1995: 30-31). Gómez-Moreno González marchó a Madrid a formarse en la Real Academia de Bellas Artes de San Fernando en 1856,

\footnotetext{
${ }^{1}$ Departamento de Prehistoria y Arqueología, Facultad de Filosofía y Letras, Universidad Autónoma de Madrid, Campus de Cantoblanco, 28.049 Madrid. Email: alfredo.mederos@uam.es
} 
donde permaneció varios años hasta regresar a Granada en 1862 (Gómez-Moreno Rodríguez 1995: 2829).

\section{La Comisión Provincial de Monumentos de Granada}

Si a menudo se da por asumido que el interés por la Historia del Arte y la Pintura en Gómez-Moreno derivan de la trayectoria de su padre, menos conocido es su activo papel en la arqueología granadina hasta su marcha a Roma en 1878 .

Manuel Gómez-Moreno González, ingresó en la Comisión Provincial de Monumentos de Granada al reorganizarla el marqués de Gerona, José de Castro y Orozco en 1866, quien valoró muy positivamente los tres estudios que presentó para ser elegido miembro sobre Pedro de Mena, Alonso Cano y la Plaza Nueva de Darro (Gómez-Moreno Rodríguez 1995: 29). Desde ella vivió la dura discusión sobre el emplazamiento de Iliberri, lugar de la celebración del primer concilio en la Península Ibérica y en Occidente del cristianismo primitivo entre el 300-324 d.C. al que acudieron 19 obispos peninsulares para restaurar la disciplina en la iglesia católica, bajo la presidencia del obispo Félix de Acci, actual Guadix (Fig. 1).

El principal defensor de la ubicación de Iliberri en la alcazaba del Albaicín de Granada fue el académico Aureliano Fernández-Guerra

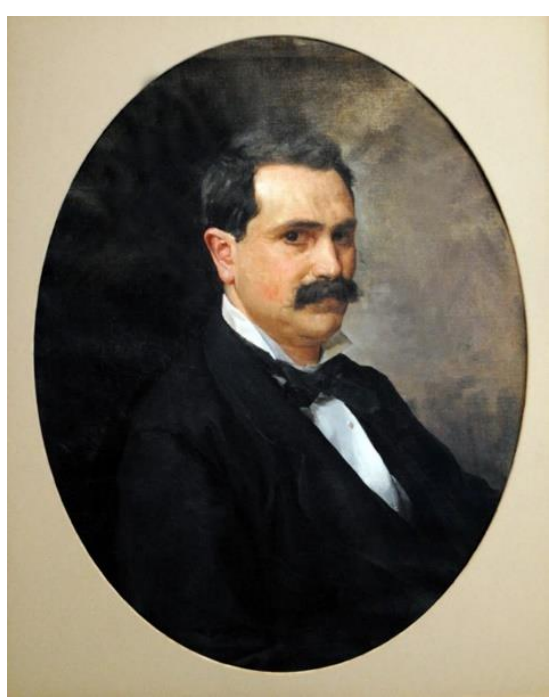

Fig. 1. Autorretrato de Manuel Gómez-Moreno González. 1877. Colección Particular. (1867), que se apoyaba en las inscripciones recuperadas en la ciudad, frente a la opinión que la situaba en Sierra Elvira, cerca de Atarfe, tras el descubrimiento en abril de 1842 de unos pendientes de oro en unas tumbas que provocó el expolio de más de 200 sepulturas en un cementerio situado en el pago de Marugán. El lugar fue visitado por una comisión del Liceo Artístico y Literario de Granada, los cuales compraron algunos de los hallazgos y abrieron 4 tumbas (Moreno 1842; Peñalver 1842; Pineda y Pineda 1842), siendo identificado con Illiberis (Lafuente 1842: 135) y finalmente objeto de una memoria del marqués de Gerona para la Real Academia de la Historia (Castro 1865: 32). Allí se menciona el hallazgo más significativo, una moneda del emperador del Imperio Romano de Oriente, Arcadio (395-408), descubierta en uno de los sepulcros abiertos por la comisión del Liceo, a la que también pertenecía Castro y Orozco. Sobre este tema estuvo Fernández-Guerra preparando entre 1832-69 una monografía nunca publicada, Iliberri, Natívola y Garnata, tres barrios de una ciudad, los cuales componían el Municipio Florentino Iliberritano (Cueto 1881: 123).

En medio de esta polémica, la Comisión Provincial de Monumentos encargó a Manuel de Góngora, Inspector de Antigüedades de Granada y Jaén, la exploración de Sierra Elvira en 1867, después de la cual rechazó su identificación con Iliberri (Góngora 1871). Sin embargo, unos desmontes en 1868 en la ladera de la sierra dieron lugar a la recuperación de nuevos materiales arqueológicos, con informe de Pedro de la Garza que se remitió a la Real Academia de la Historia en Madrid en mayo de 1868, desde donde se recomendó en junio intensificar las investigaciones. El 8 de abril de 1868, la Comisión Provincial de Monumentos decidió crear dos grupos de trabajo, uno para el Albaicín de Granada con Góngora, Bonifacio Riaño y Gómez-Moreno González, todos partidarios de la identificación con la Alcazaba de Granada, y un segundo grupo con de la Garza, Miguel Marín y Rafael Contreras para Sierra Elvira (Moya 2004: 4142).

La Comisión Provincial de Monumentos consiguió también la cesión por parte de la Audiencia de los restos arqueológicos procedentes de las excavaciones en el Albaicín de Granada del racionero de la catedral, Juan de Flores, entre 1754-63 (Flores 1875; Méndez 1780; Sotomayor y Orfila 2006: 431 fig. 10 y 2011: 395 fig. 13). Los objetos conservados se recibieron en agosto de 1869, y les sirvió para formar un 
Gabinete de Antigüedades, para el cual se nombró a Gómez-Moreno González, Secretario de la Comisión Provincial de Monumentos, como "conservador interino gratuito". Este gabinete desde 1872 ocupó una sala en la planta baja del ex convento de Santo Domingo, y desde 1873 fue denominado Museo Provincial de Antigüiedades, abriéndose en 1874 al público. Este cargo de conservador lo desempeñó hasta su marcha a Italia a finales de 1878, siendo sustituido por el almeriense Fabio de la Rada y Delgado (Moya 2004: 43, 49: 52-53, 60), catedrático de Instituciones de Derecho Romano en la Universidad de Granada desde 1884.

En la formación de Gómez-Moreno González fue importante colaborar, realizando dibujos y planos desde 1870, con el malagueño y académico Manuel Oliver Hurtado, que había detentado la cátedra de Epigrafía y Geografía Antigua de la Escuela Superior de Diplomática. Al ser destinado a Granada, se aprovechó para nombrarle Presidente de la Comisión de Monumentos de Granada, pues la Real Academia de la Historia le había encargado un estudio de los hallazgos arqueológicos en la Vega de Granada.

Entre los sitios estudiados, el primero fue el cortijo de Daragoleja (Pinos Puente), donde realizaron excavaciones en un edificio donde habían aparecido mosaicos romanos en septiembre de 1869, levantando Gómez-Moreno González el plano del edificio con los mosaicos (Moya 2004: 43, 45 fig.). También se continuaron durante 1870 las excavaciones en Sierra Elvira redactando Oliver el Informe sobre varias antigüedades descubiertas en la Vega de esta ciudad, con dibujos de Gómez-Moreno González (Oliver y Gómez-Moreno González 1870). Paralelamente, los hermanos Oliver (1870) publicaron Iliberri y Granada, donde defendían su identificación con Sierra Elvira. Años después mantuvieron esta propuesta (Oliver y Oliver 1875), pese a la opinión favorable por la Alcazaba de Granada que defendió Delgado (1873) a partir del estudio de las monedas (Fig. 2).

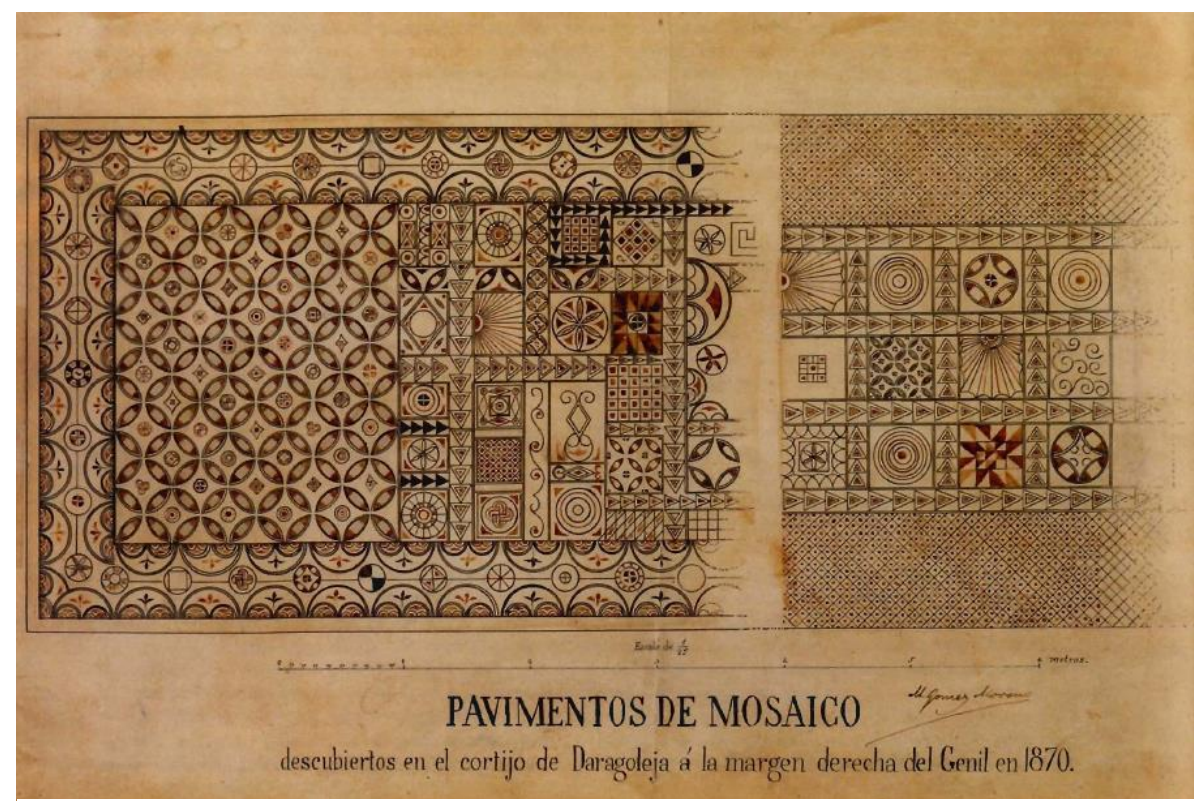

Fig. 2. Plano del mosaico de Daragoleja (Granada) por Gómez-Moreno González. 1870. Museo Arqueológico de Granada (Moya, 2004: 40 fig.).

A partir de 1871, al regresar Oliver a Madrid, Gómez-Moreno González comenzó a realizar exploraciones en solitario, informando a la Comisión Provincial de Monumentos, y a inicios de 1872 realizó en su nombre dos campañas en el Pago de Marugán, Sierra Elvira, entre el 1 de enero y el 10 de marzo, documentando más de 1200 tumbas (Moya 2004: 47 fig.) entre las expoliadas y las nuevas excavadas.

Poco después, teniendo noticia de la excavación en 1869 y 1871 por el gaditano de ascendencia escocesa, Guillermo MacPherson (1870-71), en la Cueva de la Mujer, Mesa del Baño (Alhama, Granada), del Neolítico Medio-Final, estimulado por la publicación de Góngora (1868) de la Cueva de los Murciélagos 
(Granada), Gómez-Moreno González realizó una nueva campaña de algunos días, entre el 11 de marzo y el 12 de abril de 1872, donde recuperó cerámicas neolíticas y restos humanos (Moya 2004: 48). Tres años después, entre el 2 y 4 de octubre de 1875, hizo una segunda campaña donde recuperó cerámicas, láminas de sílex o un hacha de piedra (Moya 2004: 57, 59 fig., 60 fig.).

En febrero y marzo de 1874 se reanudaron por Joaquín Lisbona las excavaciones en Sierra Elvira, concretamente en el sector del Secano de la Mezquita, que había explorado Gómez-Moreno González en 1872 descubriendo restos arquitectónicos, parte de cuyos materiales se ingresaron en el museo. Nuevos edificios fueron localizados en enero de 1875 en el sector del cortijo de Las Monjas (Moya 2004: 47, 5253), que impulsaron a Gómez-Moreno González a redactar una memoria inconclusa de todas las excavaciones efectuadas en Sierra Elvira desde 1842, para la cual debió levantar un plano general del yacimiento de 1875 (Moya 2004: 58 fig.) (Fig. 3).

Por otra parte, en 1874 se le encargó a Gómez-Moreno González la redacción del catálogo del museo, que previamente no habían hecho ni Oliver ni Góngora, el cual entregó con 816 descripciones el 30 de junio de 1875 (Gómez-Moreno González 1875; Moya 2004: 53), muy interesante porque indica su progresiva mejora en el conocimiento de los materiales arqueológicos de distintos periodos.

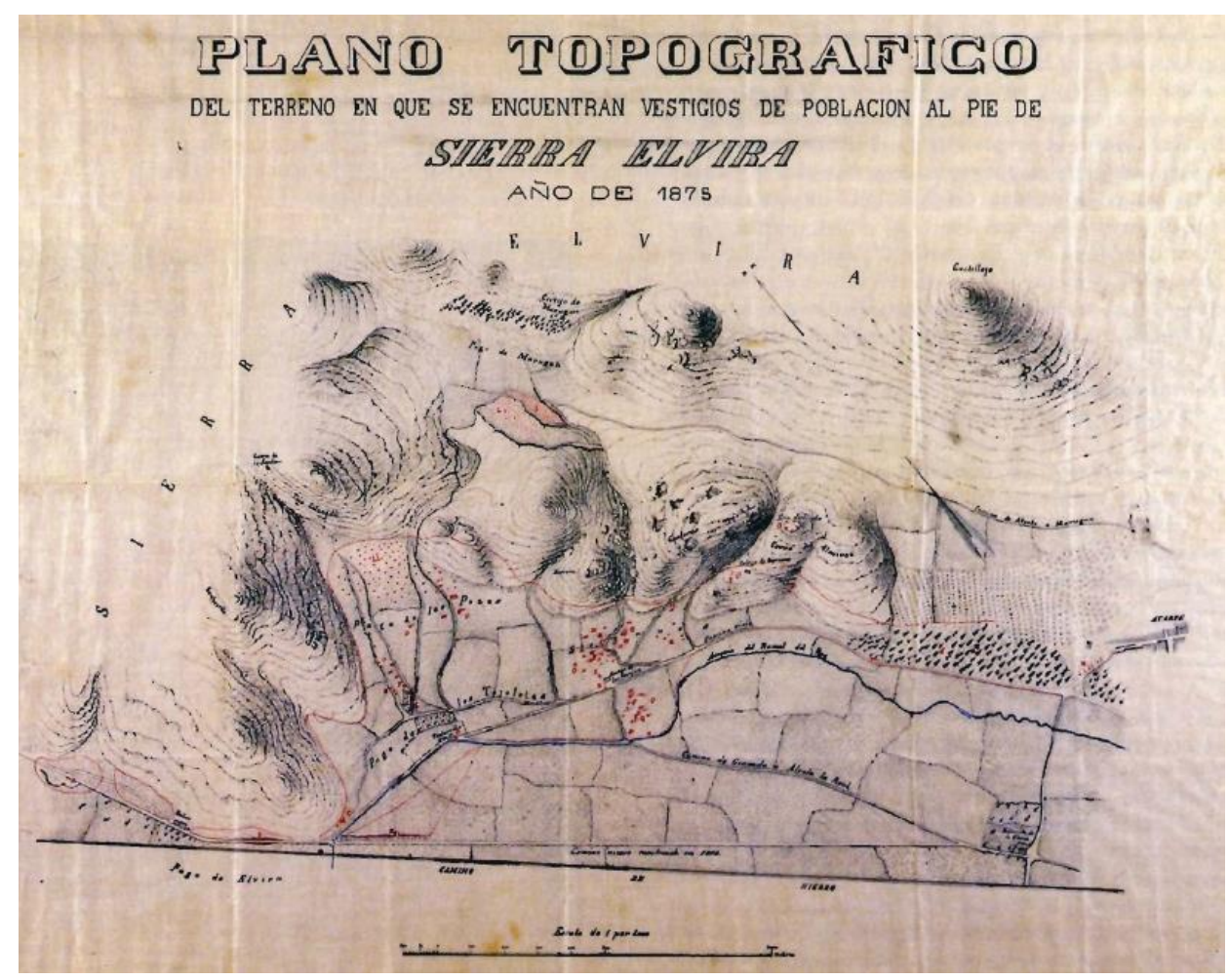

Fig. 3. Plano de Sierra Elvira (Granada) por Gómez-Moreno González. 1875. Museo Arqueológico de Granada (Moya, 2004: 58 fig.).

\section{Estancia en Roma}

Tres años después tuvo la oportunidad de marchar a Roma, becado por la Diputación de Granada, entonces presidida por Manuel Rodríguez-Bolívar Oliva, entre diciembre de 1878 y diciembre de 1880, para desarrollar estudios en Historia del Arte y Pintura. Aunque su mujer y el primogénito Manuel le acompañaron, sus tres hijas se quedaron en Granada con el abuelo de Gómez-Moreno Martínez y la "tía" Paca. El viaje de ida fue la primera salida de Granada del primogénito Manuel, haciendo escalas para visitar las ciudades de Madrid, Zaragoza, Barcelona y Marsella hasta llegar a Roma el 19 de diciembre. 
La marcha a Roma supuso abandonar la residencia familiar en la plaza de Benalúa que tenían alquilada (Gómez-Moreno Rodríguez 1995: 32-34, 39, 41) (Fig. 4).

Clave fue encontrarse con Alejandro Ferrant, compañero suyo en la Academia de San Fernando, que estaba al final de su pensionado, pues retrasó su marcha hasta finales de marzo para ayudar a GómezMoreno González a instalarse y ser el padrino de su nuevo hijo Carlos (Gómez-Moreno Rodríguez 1995: $34,36)$.

En Roma, el joven Gómez-Moreno quedó impactado de su arquitectura y museos (Gómez-Moreno Martínez 1951-58/1977: 55-56; Carriazo 1977: 17; Gómez-Moreno Rodríguez 1995: 29), comenzando "mi colección de tiestos romanos recogidos en el Pincio, a donde iba por las tardes con mi madre" (GómezMoreno Martínez 1952/1972: 12). También un amigo de su padre, entonces con 26 años, el futuro especialista en arqueología cristiana, Orazio Marucchi, que colaboraba con de Rossi desde 1870, lo paseaba por Roma cuando iba a visitar basílicas o catacumbas (Gómez-Moreno Rodríguez 1995: 36). Es posible que el inicio de la relación surgiese de la amistad común de Fernández-Guerra con Gómez-Moreno González y con G.B. de Rossi.

El padre no tenía claro sus aptitudes, "era zurdo para el manejo del lápiz, y sólo dejé de serlo ante la vigilancia paterna". Del mismo modo, tenía la costumbre de "leer y con cavilar y componer tendido" sobre una cama, pronosticándole el padre "que sería desgraciado "por mi flojera"” (Gómez-Moreno Martínez 1952/1972: 10-11).

Bastante introvertido, sin amigos en la escuela, "no congeniaba con los compañeros, quizá por timidez de carácter". También era muy enamoradizo, dejando en Roma "el apego por pocos días de cierta muchacha que me aventajaba en más de diez años". Después lo estuvo en la casa granadina de sus abuelos por la presencia de "una huérfana recogida por mi abuela paterna, que se mantuvo como ángel doméstico mío sobre todos" (Gómez-Moreno Martínez 1952/1972: 10-11, 13).

En su viaje de vuelta partieron el 11 de noviembre de 1880 de Roma, e hicieron un viaje por Italia antes de regresar. Primero fueron a Nápoles, Herculano y Pompeya durante 3 días, después a Pisa, para alcanzar Florencia y permanecer 4 días. Desde allí a Bolonia, para dirigirse a Venecia, donde se quedaron 5 días, y finalmente el trayecto de regreso con breves paradas: Verona, Milán, Génova, Marsella, Barcelona, Zaragoza, Madrid y Córdoba (Gómez-Moreno Rodríguez 1995: 38-39).

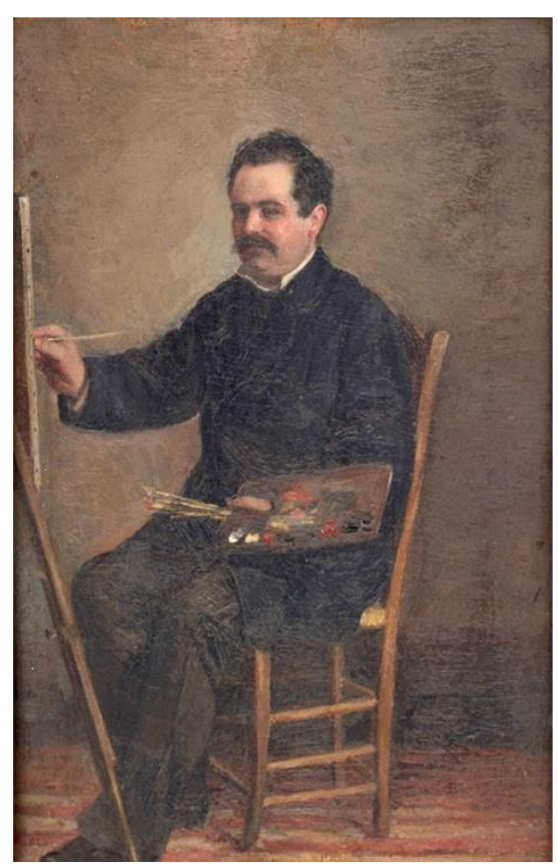

Fig. 4. Autorretrato de Manuel Gómez-Moreno González pintando. 1874. Museo de Bellas Artes de Granada.

\section{Estudios de Bachillerato y Universitarios}

A su regreso a Granada se instalaron en una nueva vivienda en la cuesta del Pescado (Gómez-Moreno Rodríguez 1995: 41). Gómez-Moreno Martínez comenzó a cursar el Bachillerato en el Colegio de los Padres Escolapios desde 1881, ubicado en el antiguo monasterio de San Basilio. Poco después, en junio de 1882, también nacieron sus hermanas gemelas, Dolores y María, lo que les obligó a cambiarse de casa pasando a residir en la Placeta de San José, al pie del Albaicín (Gómez-Moreno Rodríguez 1995: 41-42).

En el primer curso de 1881-82, obtuvo en Latín $1^{\circ}$ y Castellano $1^{o}$, sobresaliente con Matrícula de Honor y en Geografía, sobresaliente. En el segundo curso de 1882-83 obtuvo tres sobresalientes, Latín $2^{\circ}$, Castellano $2^{\circ}$ e Historia de España. Durante 1883-84 mantuvo estas buenas calificaciones con sobresaliente en Aritmética y Álgebra, Historia Universal y Retórica y Poética, presentándose al examen 
extraordinario para obtener un sobresaliente en Francés $1^{\circ}$. En el cuarto año de 1884-85 mantuvo los sobresalientes en Geometría y Trigonometría, Lógica y Ética o en Psicología, mientras nuevamente esperó al examen extraordinario para obtener sobresaliente en Francés $2^{\circ}$. El quinto y último curso de 1885-86 obtuvo de nuevo sobresaliente en Física y Química, Fisiología e Higiene y en Agricultura Elemental, obteniendo la calificación final de sobresaliente en el Bachillerato el 30 de junio de 1886, emitiéndose el título el 20 de septiembre (AHN 6567/14; Sánchez-Mesa 1972: 37). Los dos profesores que más recordaba eran el de Latín, Mariano García y el naturalista darwinista Rafael García Álvarez (Gómez-Moreno Martínez 1952/1972: 16). Entre sus compañeros con los que tuvo más trato estuvieron el futuro Conde de las Infantas, Joaquín Pérez del Pulgar y José Cazorla, tío de Emilio Camps Cazorla (Gómez-Moreno Rodríguez 1995: 43) (Fig. 5).

De joven, "muy muchacho aún", el padre ya sabía que "a lo que tiene afición es a las antigüedades" (Gómez-Moreno Martínez 1952/1972: 29) y su decisión debió tomarla en el entorno artístico y arqueológico de Roma, aún muy joven, pues reconoce que su estancia allí fue "un mundo nuevo, sobre cuyo recuerdo se ha fraguado mi vida", quizás por su contraste con Granada, pues la "vuelta a Granada representó la caída de todo aquello" (Gómez-Moreno Martínez 1952/1972: 12).

Por ello se decidió a cursar la carrera de Filosofía y Letras en Granada, entonces de tres años, entre 188689, pues la economía familiar no podía permitirse la otra alternativa, estudios como arquitecto en Madrid (Gómez-Moreno Martínez 1952/1972: 15).

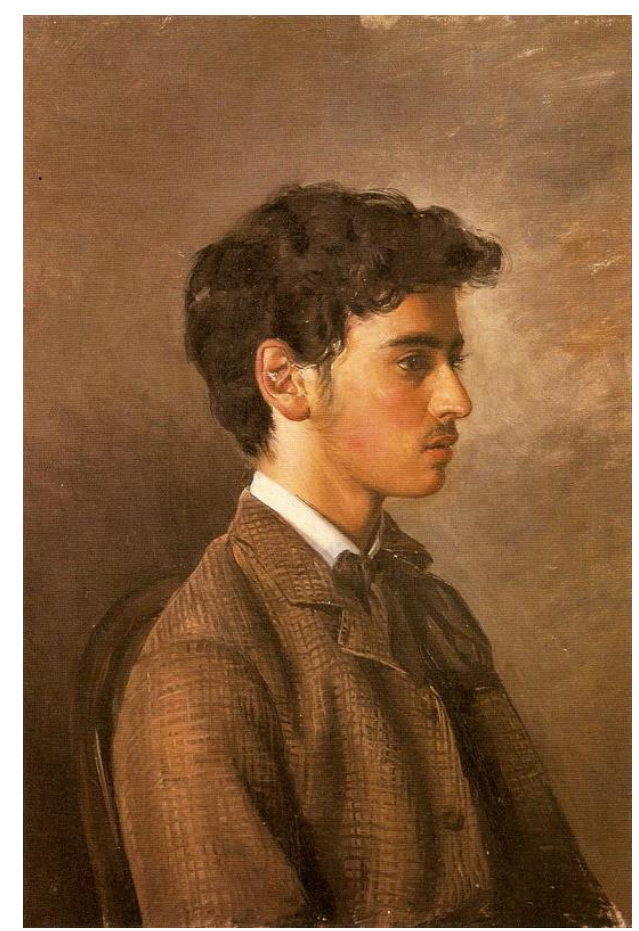

Fig. 5. Retrato de Manuel Gómez-

Moreno Martínez con 15 años por Gómez-Moreno González. 1885. Instituto Gomez-Moreno de la Fundacion Rodriguez Acosta
A partir del ingreso en la universidad, fue consolidándose su afición por las antigüedades. Así, desde 1886, con 16 años, "me llevó mi padre a excursiones arqueológicas en Elvira, el Tocón y Alhama, cuyo recuerdo mantengo vivísimo", destacando las visitas a Sierra Elvira. Del mismo modo, "por mi casa pasaban las adquisiciones, se estudiaban y restauraban a mi vista, y por cuenta propia en ausencia de mi padre, gozaba sacando de un armario el talego de monedas antiguas, para manosearlas" (Gómez-Moreno Martínez 1952/1972: 10-11). El propio Gómez-Moreno Martínez comenzó entonces una colección propia de monedas antiguas. "Mi abuelo me daba dinerillo (...) gastadas las más en monedas antiguas que iba coleccionando" (Gómez-Moreno Rodríguez 1995: 44; Carriazo 1977: 18).

El aprendizaje comenzó en su último año de bachillerato, 1885-86, cuando su padre estuvo extractando el archivo de diezmos del arzobispado de Granada, buscando noticias de arquitectura y escultura del siglo XVI. Así, al llegar el verano, comenzaron en julio de 1886 a visitar muchas de las localidades mencionadas por la documentación en la comarca de las Siete Villas, "para premiar, según dijo, mi fin de bachillerato, hicimos una excursión por los montes: Iznalloz, Piñar, [Cardela], Guadahortuna, Montejícar y Colomera (...) Mi padre dibujaba, yo tomaba notas, medidas, apuntes como podía (...) Viajábamos en caballerías, burros las más veces, nos alojábamos en posadas" (Gómez-Moreno Martínez 1952/1972: 14; Gómez-Moreno Calera 1989). Este modelo de trabajo de campo es importante porque lo siguió años después para elaborar los catálogos monumentales.

Por consejo de M. Rodríguez de Berlanga, amigo de su padre, Gómez-Moreno Martínez se convirtió en el ayudante de Emil Hübner para calcar inscripciones romanas en septiembre de 1886, durante la 
elaboración del Suplemento del volumen II del Corpus de Inscriptionum Latinarum, que Hübner (1892) dedicó a Gómez-Moreno pater et filius, lo que le permitió una excelente formación práctica como epigrafista desde muy joven. Sus funciones fueron "Calcar piedra, darme lecciones de epigrafía, dejarme un buen rollo de papel para calcos; luego, pedirme datos y más calcos, enviarme sus libros, trueque de consultas y ocurrencias mías (...) y un brevísimo pero elocuente augurio a mi favor: iuvenis optimae spei" (Gómez-Moreno Martínez 1952/1972: 14; Hübner 1869: 883 y 1892: 164; Carriazo 1977: 18-19).

En su primer año universitario, 1886-87, obtuvo sobresaliente en Lengua Griega $1^{\circ}$ y Literatura General, y notable en Historia Universal $1^{\circ}$ y Metafísica $1^{\circ}$. El expediente lo mejora el segundo año académico, 1887-88, con sobresaliente en Lengua Griega $2^{\circ}$, Literatura Griega y Latina, Metafísica $2^{\circ}$ e Historia Universal $2^{\circ}$. Finalmente, en tercer año, obtuvo también en todas sobresaliente, Historia Crítica de España, Literatura Española, en esta con opción a premio extraordinario, y Lengua Árabica, presentándose el 28 de junio al examen de grado con el tema Examen Analítico y Crítico de la Iliada, donde obtuvo también la calificación de sobresaliente, emitiéndose el título el 14 de junio de 1911 (AHN 6567/14; AGA 32/16148; Sánchez-Mesa 1972: 38-39).

Entre sus profesores tenía buena opinión del madrileño Fernando Brieva y Salvatierra, catedrático de Historia Crítica de España en Granada entre 1877-1895, con el que tuvo más trato en el Centro Artístico. Al igual que del murciano Leopoldo Eguílaz y Yanguas, catedrático de Literatura General y Española, "con más talento que saber". En cambio, no le gustó la docencia del malagueño Francisco Javier Simonet y Baca, presidente de la Comisión de Monumentos de Granada y catedrático de Lengua Árabe que "no lo enseñaba, sino que tomaba la lección uno a uno sobre apuntes suyos" (Gómez-Moreno Martínez 1952/1972: 14-15). En algunos casos como Eguílaz, sus conocimientos eran mucho más amplios siendo también buen conocedor del sánscrito y del árabe, sobre el que publicó un Estudio sobre el valor de las letras arábigas en el alfabeto castellano (Eguílaz 1874) y opositó a la cátedra de árabe en Granada frente a Simonet, a la vez que estaba interesado en la historia local, como la ubicación de Iliberis (Eguílaz 1881).

A veces creía que le tenían "malquerencia", como el catedrático de Historia Universal (Gómez-Moreno Rodríguez 1995: 46) el murciano Juan de Artero y González, que le puso un notable en primer curso. En otros casos, como Lengua Griega, con "el catedrático más temible de la Facultad, Don Manuel Garrido", le permitieron hacer especial amistad durante la carrera con Ángel Ganivet, "pues ambos se sentían desplazados y solitarios" y con el malagueño Carlos Gálvez, que vivía con sus tíos en Granada, pues durante el segundo curso los tres tuvieron que repartirse rotando la preparación de la lección, la traducción y los significados (Gómez-Moreno Rodríguez 1995: 46-47).

\section{El Centro Artístico y Literario de Granada}

El periodo de gran actividad de la Comisión de Monumentos, que había comenzado en 1866, llegó a su fin cuando sus miembros dimitieron el 17 de septiembre de 1884 a raíz del derribo por el Ayuntamiento de Granada de la Puerta de Bibarrambla el 5 de septiembre de 1884 (Moya 2004: 104, 106), a pesar de estar ya declarado Monumento Nacional.

Dos miembros de esta antigua Comisión de Monumentos fueron elegidos por la Real Academia de Bellas Artes de Granada como encargados del Museo de Bellas Artes, y concretamente Gómez-Moreno González fue nombrado académico-conservador del museo en 1886, responsabilizándose también de elaborar un catálogo del mismo que finalizó en 1892 (Moya 2004: 156-157).

Sin embargo, buena parte de sus esfuerzos se canalizaron en una nueva sociedad que tuvo una gran vitalidad durante la segunda mitad de la década de los ochenta, el Centro Artístico y Literario de Granada, fundado el 12 de abril de 1885, en el cual Gómez-Moreno González fue elegido Vicepresidente, cargo renovable anualmente, en el cual impartía clases de dibujo (Moya 2004: 113). Como órgano de la sociedad, al año siguiente y empezar el curso académico 1886-87, se comenzó a publicar desde el 1 de octubre de 1886 el Boletín del Centro Artístico de Granada, que pronto contó con una crónica de las 
excursiones semanales o quincenales realizadas por los miembros del centro, que lideraba Gómez-Moreno González como director de la sección de excursiones.

Este programa de excursiones, donde también participó su hijo, desarrolló entre octubre de 1886 y mayo de 1887 visitas a Pulianas, Pulianillas, Jun, Gabia la Grande, Monachil, Huétor Vega, Víznar, Alfacar, Fuente Grande, Alhendín, Otura, Ogíjares, Gójar, La Zubia, Maracena, Albolote, Atarfe e Íllora, además de Moclín en el mes de agosto (Moya 2004: 134).

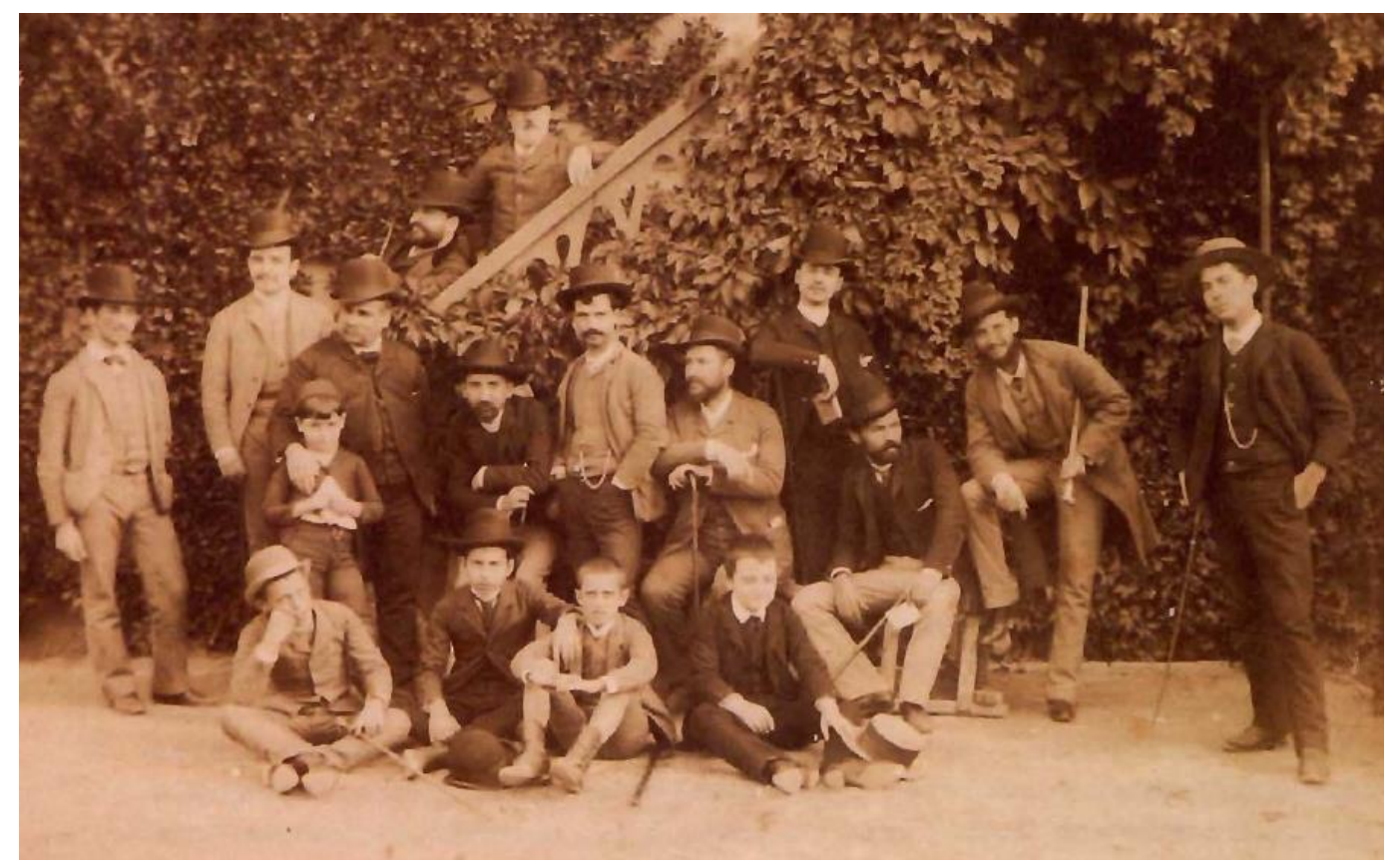

Fig. 6. Gómez-Moreno González y Gómez-Moreno Martínez en excursión con el Centro Artístico y Literario de Granada. 1877. Instituto Gomez-Moreno de la Fundacion Rodriguez Acosta (Moya, 2004: 120 fig.).

Gómez-Moreno González dejó la vicepresidencia el 12 de abril de 1887, aunque mantuvo la dirección de la sección de pintura, para irse centrando en unas oposiciones a la cátedra vacante de Composición Decorativa -Dibujo aplicado a las Artes y la Fabricación- de la Escuela de Bellas Artes de Granada, para lo cual viajó a Madrid en julio de 1887. Quería aprovechar su experiencia como profesor de dibujo en el Real Colegio de San Bartolomé y Santiago, plaza que gano a finales de 1888 (Moya 2004: 119, 123, 134, 139, 187). Fue durante esta etapa cuando Gómez-Moreno Martínez, por primera vez, asumió un cargo de responsabilidad, y una vez cursado su primer año de estudios universitarios, fue elegido como secretario de la sección de Excursiones del Centro Artístico y Literario de Granada, redactando las crónicas de las excursiones que inicialmente habían sido redactadas por el director del boletín, Diego Marín (GómezMoreno Martínez 1887 y 1952/1972: 17), llegando a publicar 20 crónicas de las excursiones efectuadas dentro de la ciudad de Granada durante el curso 1887-88. En estas visitas mejoró notablemente sus conocimientos en fotografía pues "con máquina ajena, comenzamos a fotografíar, sobre todo, imágenes, constituyendo un fondo de ellas que se vendían (...) lo que daba para costearlo todo" (Gómez-Moreno Martínez 1952/1972: 19). Ese verano de 1888, durante agosto, padre e hijo también hicieron una visita hacia el suroeste de Granada que incluyó Loja y Alhama (Moya 2004: 139) (Fig. 6).

Simultáneamente, tanto Hübner como Rodríguez de Berlanga habían insistido a Gómez-Moreno González que debía publicar una síntesis de las investigaciones realizadas en Sierra Elvira, labor que afrontó en 11 entregas en el boletín durante 1888, donde siguió manteniendo una ubicación de Iliberri en la alcazaba granadina, colaborando su hijo en el dibujo de las láminas (Gómez-Moreno González 1888). Rodríguez de Berlanga había convencido a Hübner (1888: 247 y 1890) de su ubicación en Sierra Elvira, abandonando 
la propuesta de Fernández-Guerra (1867), que se lo recriminó por carta e informó de ello a Gómez-Moreno González el 18 de febrero de 1889 (Moya 2004: 123, 129). Desde la propia Granada, Gómez-Moreno González programó una respuesta contra esta propuesta e inicio el curso 1889-90 con una serie de 5 conferencias en el Centro Artístico, entre octubre y noviembre, para defender su ubicación en la Alcazaba de Granada, destacando el hallazgo en 1887 de una inscripción de mármol con el nombre de Manlianvs, que le trascribió Hübner el 16 de mayo de 1888 (Moya 2004: 123-125, 124 fig.), a la que se unió la compra en 1891 de un sarcófago romano de mármol que había sido usado previamente en una casa de la calle Santi Spiritus, o su recuperación de un capitel romano corintio en la calle Muladar de doña Sancha (Moya 2004: 126, 127 fig.). Los resúmenes de las conferencias los publicó su hijo, quien dentro de esta defensa de la alcazaba publicó su primer artículo importante, Monumentos romanos y visigóticos de Granada (Gómez-Moreno González 1889; CIL II ${ }^{2} \mathrm{n}^{\circ}$ 619-640, 642-654, 658, 698, 705-706), donde hacia una nueva revisión de las 35 inscripciones romanas conocidas de Granada, trabajo que también se publicó por entregas en el boletín. Años después, Gómez-Moreno González retomó el tema en la prensa cuando apareció en septiembre de 1895 una gran basa de columna junto a la iglesia de San José, proponiendo la ubicación de la ciudad de Iliberri entre las parroquias de San José, San Miguel y San Nicolás (GómezMoreno González 1895; Moya 2004: 170 fig. a). A ello se sumó, a finales de 1898, el hallazgo de parte de una estatua romana de mujer en el huerto de la casa número 6 de la calle Gumiel, junto a la parroquia de San José (Moya 2004: 170 fig. b), que apoyaba esta propuesta suya, si bien no convencieron a Rodríguez de Berlanga (1899) (Fig. 7).

\section{Seminarista por breve tiempo y Profesor en la Escuela de Artes y Oficios}

Al finalizar sus estudios, Gómez-Moreno Martínez tuvo dos años de notables dudas personales, entre 1889-91, e inicialmente ingresó durante 2 meses en el Seminario Diocesano, pero salió pronto, al no tener segura su vocación, aunque en ese tiempo sí ingresó su tercera hermana, Eugenia, en las hijas de la Caridad (Gómez-Moreno Martínez 1952/1972: 18; Gómez-Moreno Rodríguez 1995: 51-52). También ingresó en los Jesuitas su compañero de carrera, Carlos Gálvez, en el Seminario de Murcia "y se pasaron dos años, yo en espera de coyuntura favorable para ir allá, que no se terciaba metido en complicaciones" (GómezMoreno Martínez 1952/1972: 18), en particular, finalizar la Guía de Granada. Años después, Carlos Gálvez fue clave en su primer Catálogo Monumental pues le recomendó al lectoral de la catedral de Ávila

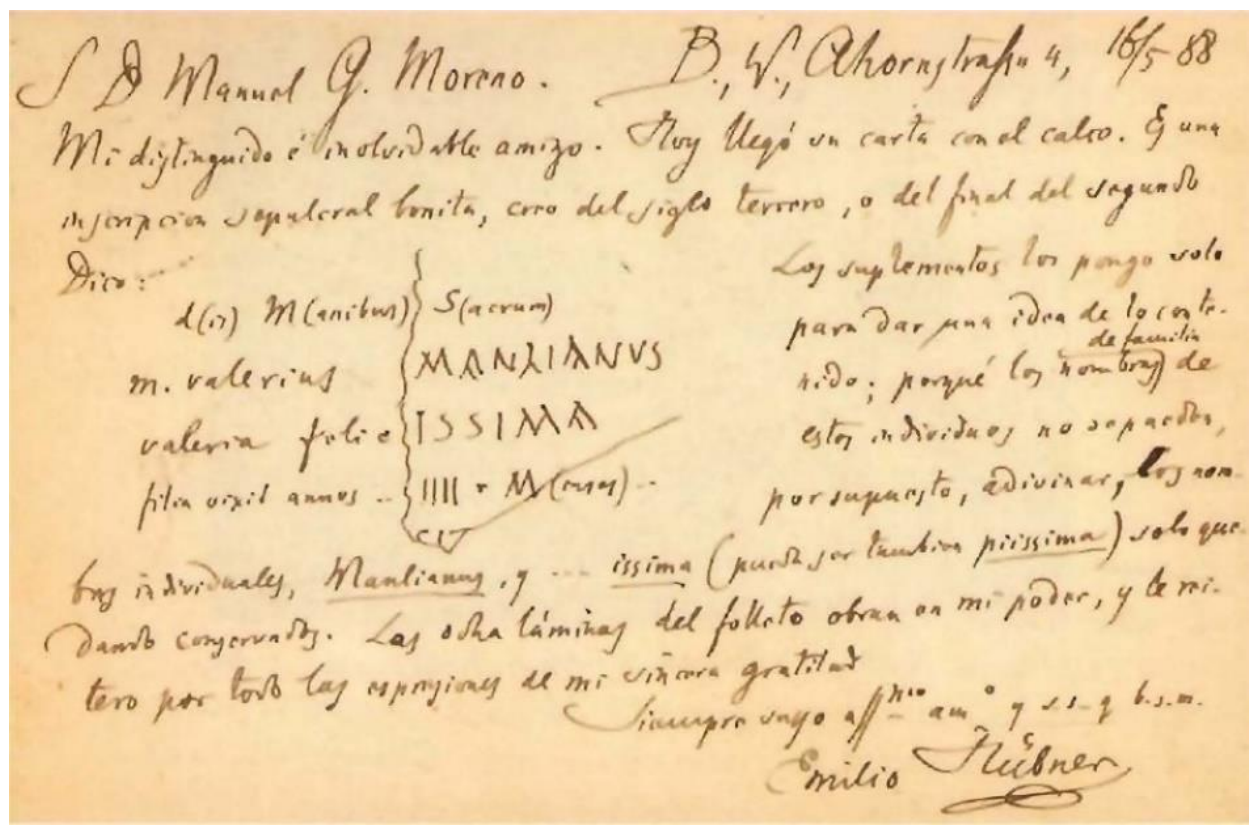

Fig. 7. Carta de Emil Hübner a Gómez-Moreno Martínez con transcripción de inscripción romana. 165-1888. Instituto Gomez-Moreno de la Fundacion Rodriguez Acosta (Moya, 2004: 124 fig.). 
(Gómez-Moreno Rodríguez 1991: 121). En todo caso, quedó en Gómez-Moreno Martínez una “formación religiosa profunda (...) y se manifiesta en un providencialismo un tanto fatalista" (Gómez-Moreno Rodríguez 1995: 149), que asumía la primacía de Dios, mientras el hombre era un instrumento en sus manos para los fines divinos.

Por otra parte, una vez licenciado, con 19 años, desde septiembre de 1889 comenzó a impartir clases de Artes Decorativas en la Escuela de Artes y Oficios y colaboraba en la copia y restauración de cuadros, gracias a que su padre había obtenido en la Escuela una plaza, por oposición, de profesor de Composición Decorativa (Carriazo 1977: 19; Gómez-Moreno Martínez 1928/1986: xxxix).

Mantuvo la colaboración con su padre y en septiembre de 1891 realizaron un nuevo viaje artístico hacia Guadix, La Calahorra y Baza, una diócesis diferente a la de Granada, por lo que iniciaron el viaje consultando los archivos parroquiales y cardenalicios. Además, le sirvió también a Gómez-Moreno González para adquirir cerámicas argáricas que habían aparecido en el entorno de la Ermita de El Zalabí que acabaron en su colección, pues la Comisión de Monumentos, que había decidido adquirirlas para el Museo de Antigüedades en junio de 1890, no había efectuado la compra. Procedentes de tumbas expoliadas, también se habían localizado cuchillos con remaches de plata, pendientes y zarcillos de bronce, etc. (Moya 2004: 145-147).

\section{La Guía de Granada y la decadencia del Centro Artístico y Literario}

El proceso de redacción de la Guía de Granada coincidió con una progresiva desvinculación de GómezMoreno González del Centro Artístico desde 1890, que sufrió una crisis interna, con cambio de local, y desde finales de 1891 la pérdida de la regularidad de su boletín, mientras las crónicas de las excursiones del curso 1891-92, redactadas por Gómez-Moreno Martínez, comenzaron a publicarse en el diario El Popular (GómezMoreno Martínez 1892; Moya 2004: 127-128).

El modelo seguido en la guía, por una parte, fue el que utilizó GómezMoreno en sus visitas durante su estancia en Roma, es decir el Itinerario di Roma e suoi dintorni de Antonio Nibby (1866), posteriormente actualizado por Filippo Porena. Por otra parte, se estaban publicando los tomos de Sevilla monumental y artística (Gestoso 1889, 1890 y 1892). En todo caso, suponía incidir sobre un tema recientemente trabajado por Valladar (1890) en su Novísima guía de Granada.

En la redacción de este libro "fue la decisión de mi padre de hacer su 'Guía de Granada', para la cual venía allegando datos y materiales de larga fecha: fue en 1891 (...) Tomé por mi cuenta lo árabe, y en discusión permanente fue saliendo lo demás; quiso mi padre que yo apareciese de coautor, pero me resultaba ello ridículo, cuando en realidad todo lo mío dimanaba de él y mi gusto artístico había ido formándose entre sugestiones suyas" (Gómez -Moreno Martínez 1952/1972: 19).

\section{GUIA}

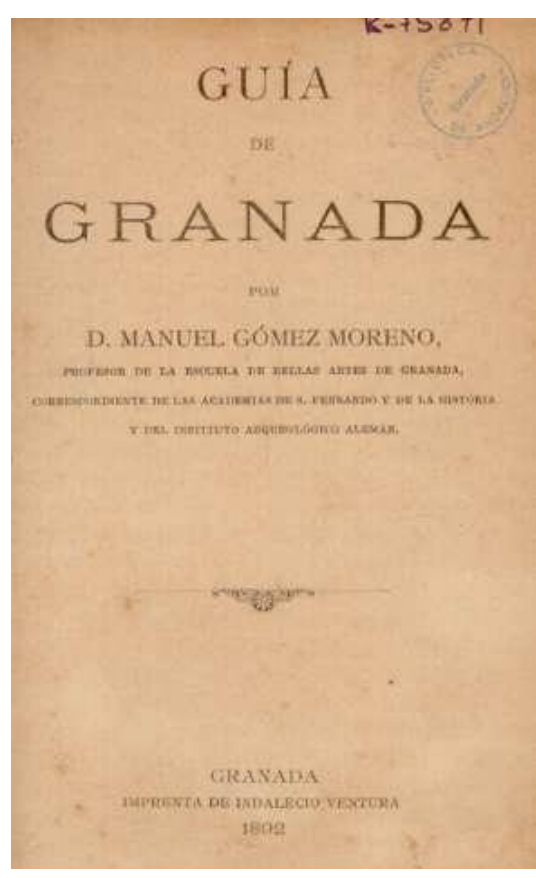

Fig. 8. Guía de Granada por Gómez-Moreno González y Gómez-Moreno Martínez. 1892.

La guía fue dedicada a los hermanos Manuel y Eduardo Rodríguez Bolívar (Gómez-Moreno González [y Gómez-Moreno Martínez] 1892), pues el primero, aparte de ser amigo íntimo de su padre desde la juventud fue quien, como Presidente de la Diputación de Granada, le consiguió una beca para marchar a Roma y consolidarse como pintor, pero al haber fallecido, se incluyó también a su hermano (GómezMoreno Rodríguez 1995: 27, 32, 53) (Fig. 8). 
El libro fue presentado en la Real Academia de Bellas Artes de San Fernando por Facundo Riaño el 15 de junio de 1893. Su atenta lectura y el conocer directamente Riaño que Gómez-Moreno Martínez había sido el autor de una parte importante de la Guía de Granada, como puede observarse en los 32 breves artículos que publicó en el Boletín del Centro Artístico de Granada entre 1887-90, 8 en 1887, 12 en 1888, 10 en 1889 y 2 en 1890, fue un factor que influyó en su futura elección como responsable de los primeros Catálogos Monumentales.

Después de la publicación de la guía, hubo un intento de reflotar el Centro Artístico, nombrándose a Fernando Brieva presidente en 1893, que incorporó en su equipo a Gómez-Moreno González nuevamente de vicepresidente y a Gómez-Moreno Martínez ya como director de la sección de excursiones (Moya 2004: 128), pero la sociedad acabó decayendo.

\section{Profesor de Arqueología Sagrada en la Universidad del Sacromonte}

Desde 1895, con 25 años, consiguió otro trabajo como Profesor de Arqueología Sagrada en la Universidad-Seminario del Sacromonte (Gómez-Moreno Martínez 1928/1986: xxxix; Carriazo 1977: 19). Deseaba impartir la asignatura de Arqueología Sagrada, que en principio se iba a encargar un profesor de Filosofía, primo suyo, pero por las gestiones de su padre, a petición expresa suya, consiguió que el Rector le encargarse su docencia, "yo con mi estancia en Roma y libros al propósito me consideraba idóneo, y embarqué a mi padre a que lo solicitase" (Gómez-Moreno Martínez 1952/1972: 20). Paralelamente impartió dibujo, los cursos 1895-96 y 1896-97, como Ayudante interino honorífico y gratuito de la asignatura de Dibujo de su padre (Moya 2004: 187), "para justificar lo cuantioso de la remuneración", cambiando después la docencia de Dibujo por la asignatura de Lengua Griega "donde hacía aprender más de lo que yo sabía" (Gómez-Moreno Martínez 1952/1972: 20).

Su padre "nunca ha[bía] sido aficionado a los viajes" (Gómez-Moreno Rodríguez 1995: 127), y con el dinero que ganaba, 5.000 o 6.000 reales anuales (Gómez-Moreno Martínez 1952/1972: 19), viviendo aún en casa de sus padres, lo que le permitía ahorrar, comenzó una serie de viajes por toda Andalucía en solitario. El primero lo hizo con varios amigos antes de tener el trabajo en el Seminario de Sacromonte, viajando a Sierra Nevada en julio de 1894 (Gómez-Moreno Rodríguez 1995: 55-56). El segundo se dirigió hacia la provincia de Almería en agosto de 1895, primero Fiñana, luego Abla para ver una inscripción que había copiado Góngora (Hübner 1869: CIL II 3401) y finalmente Almería para conocer la Alcazaba (Gómez-Moreno Rodríguez 1995: 61-62). En el mes de enero de 1896 fueron otras tres capitales de provincia andaluzas, Málaga para conocer sus iglesias y la Alcazaba. Después estuvo en Córdoba, que le permitió visitar por primera vez la Mezquita y finalmente se desplazó a Sevilla donde vio su catedral. En septiembre volvió a Córdoba y Sevilla, a la vez que coincidía con su hermana Eugenia, monja en Cádiz (Gómez-Moreno Rodríguez 1995: 63-66).

En dirección a Jaén viajó en julio de 1897, y después siguió hacia Martos donde Francisco Muñoz había encontrado al hacer una alberca una basílica cristiana con un sarcófago de piedra esculpido del siglo IV d.C. en el Molino del Rey, de lo que redactó un texto (Gómez-Moreno Martínez 1897), para finalizar en Úbeda (Gómez-Moreno Rodríguez 1995: 67-69). Una nueva ruta la hizo hacia Cádiz, aprovechando pasar una navidad con su hermana en diciembre de 1898, primero parando en Jerez y finalmente Cádiz, donde Gómez-Moreno Rodríguez (1995: 73) menciona que visitó el Museo Arqueológico.

Ese año le preguntó Hübner si había conseguido un puesto en el Museo Provincial de Antigüedades de Granada (IGM 5175; Bellón 2015: xxxvii), que detentó desde 1879 Francisco de Paula Góngora y del Carpio, el hijo de Manuel de Góngora, al pasar a depender del Cuerpo de Archivos, Bibliotecas y Museos, hasta su muerte en 1919. No obstante, Hübner le sugería su marcha a Madrid. "Como no abundan en España jóvenes de talento, como lo tiene V., y de tanto saber del latín, yo quisiera verle a V. en una posición más céntrica, en el Museo Nacional de Madrid. Se lo he escrito repetidamente a mis amigos en Madrid, cuánto estimo sus talentos" (IGM 5175; Bellón 2015: xxxvii), en particular a Aureliano Fernández-Guerra y al padre Fidel Fita. 


\section{Primer viaje a Madrid para preparar oposiciones a cátedra e introducción en los círculos sociales a través de Juan Facundo Riaño}

La convocatoria de una oposición hizo que tomase la decisión de mudarse a Madrid donde llegó el 23 de diciembre de 1898. Se trataba de la cátedra de Concepto e Historia de las Bellas Artes en la Escuela Central de Artes y Oficios de Madrid, que firmaron también José Ramón Mélida y Alinari y el arquitecto Vicente Lampérez y Romea, aunque luego ambos renunciaron, pues Mélida lo hizo un mes después de llegar Gómez-Moreno Martínez a Madrid, el 20 de enero de 1899 (AGA 31/6535; Díaz-Andreu 2004: xliii n. 70; Gómez-Moreno Martínez 1952/1972: 21; Gómez-Moreno Rodríguez 1995: 74, 93; Castillejo 1998). Allí permaneció viviendo en la casa del pintor y académico Alejandro Ferrant, compañero de su padre en Roma, hasta mayo de 1899 (Gómez-Moreno Rodríguez 1995: 73), cuando tuvo que regresar a Granada, porque se anularon las oposiciones al adjudicarse directamente por Real Orden la cátedra, cambiándole el título, nombrándose al cordobés Francisco Alcántara Jurado (Gómez-Moreno Martínez 1952/1972: 25), entonces con 45 años.

Al marchar a Madrid, su padre tuvo que asumir la suplencia de su docencia de Arqueología Sagrada en la Universidad-Seminario del Sacromonte (Gómez-Moreno Rodríguez 1995: 90) y su ausencia de 5 meses parece que llevo al Rector a plantear la supresión de la plaza para el curso 1899-1900 (Gómez-Moreno Rodríguez 1995: 113).

La clave para su futuro fue que trabó buena amistad con un amigo también granadino de su padre, Juan Facundo Riaño, catedrático de Historia de las Bellas Artes en la Escuela Superior de Diplomática (1863), Director General de Instrucción Pública (1881-83) con Sagasta, Anticuario de la Real Academia de la Historia (1894-1901) y Director de la Real Academia de Bellas Artes de San Fernando (18981901), que había estudiado en la Universidad de Granada (Muñoz González 2016) (Fig. 9).

Riaño había colaborado con su padre Gómez-Moreno González en los últimos años. Primero entre 1892-93 haciendo vaciados para el Museo de Reproducciones Artísticas que dirigía Riaño, quien a su vez le proporcionó a cambio vaciados de obras italianos para la Escuela de Bellas Artes donde trabajaba Gómez-Moreno González, quien fue entre 1892-98 el secretario de la Escuela hasta pasar a dirigirla en mayo de 1899 (Moya 2004: 187).

El lazo se retomaba todos los veranos porque Riaño y su mujer, Emilia Gayangos, tenían una casa en Pulianas, actualmente a $5 \mathrm{~km}$ de Granada "a quien solíamos visitar

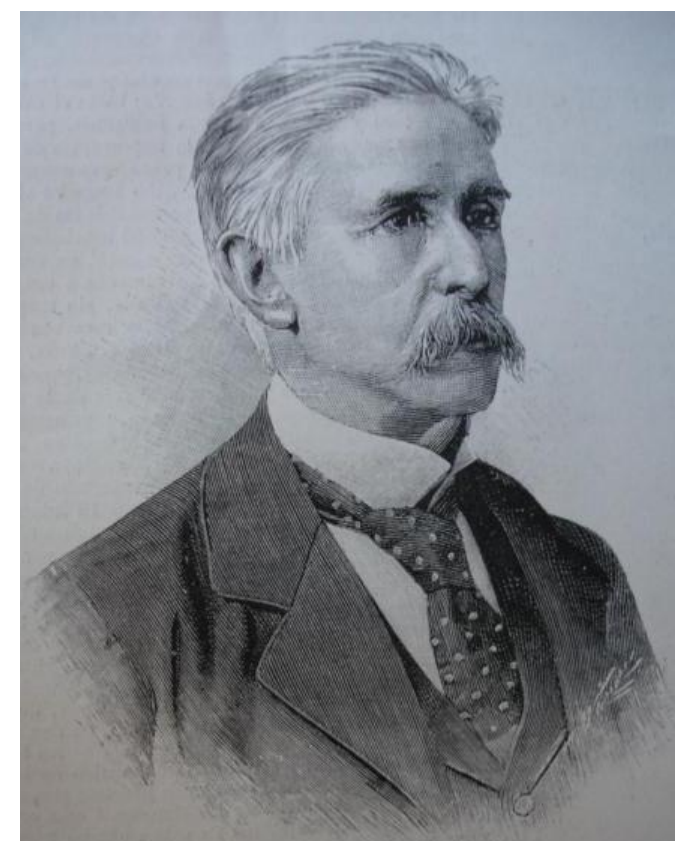

Fig. 9. Juan Facundo Riaño. La llustración Española y Americana. 1892. cuando veraneaba” (Gómez-Moreno Martínez 1952/1972: 23). Esa relativa confianza le permitió hacerle una broma, que le había gustado a Riaño, "estando en Granada tuve la ocurrencia de publicar un artículo dirigido a él, como cosa de mi padre y sin que éste se enterase, motivo de gran sorpresa para ambos y diversión mía" (Gómez-Moreno Martínez 1952/1972: 23) sobre la Capilla Real de Granada, que publicó durante el verano de 1895 en el periódico liberal El Defensor de Granada (Gómez-Moreno Martínez 1895).

Así, enterado Riaño por Ferrant de la presencia de Gómez-Moreno Martínez en Madrid (Gómez-Moreno Rodríguez 1991: 77), lo invitó a visitarlo convirtiéndose en "no sólo (...) asistente asiduo a su casa, sino comensal en sus cenas, periódicamente", los miércoles, después de conferencias en el Ateneo, junto con al arquitecto y restaurador Ricardo Velázquez Bosco y el granadino José Fernández Giménez (Gómez- 
Moreno Martínez 1952/1972: 23), abogado, diplomático, Director General de Instrucción Pública con Sagasta y miembro de La Cuerda Granadina como "El Sacristán" o "Ivon", grupo de amigos de juventud de Riaño (Jiménez Landi 1996: 87-88). Por otra parte, también los acompañaba los domingos, pues se reunían con un numeroso grupo junto al malagueño Francisco Giner en el bosque del Pardo (GómezMoreno Martínez 1952/1972: 25; Carriazo 1977: 20-21). Para ayudarle económicamente, le ofrecieron pagarle por ordenar la correspondencia de Pascual de Gayangos, padre de Emilia, pero al negarse a cobrar le dieron a cambio libros (Gómez-Moreno Martínez 1952/1972: 24). Así, su plan de trabajo en Madrid acabó siendo "la tarea matinal en la Biblioteca Nacional, el final de la tarde en casa de Riaño, y por la noche, paseo y rato de café con Ferrant" (Gómez-Moreno Rodríguez 1995: 95).

La excelente relación que pronto tuvo con Emilia Gayangos y Riaño, lo resume una carta suya de 1900, "Que pena nos da que un muchacho como V. esté enterrado donde está" (IGM 5561; Bellón 2015: lx n. 73), más aún porque Riaño también era granadino y pasaba allí sus vacaciones, pero refleja la baja consideración que tenían sobre la actividad cultural en Granada en el cambio de siglo.

La relación con Emilia Gayangos fue estrechándose hasta acabar ejerciendo de madre en Madrid, reconociendo su hija que tenía "hacia mi padre una cierta tutela maternal" (Gómez-Moreno Rodríguez 1991: 8), mientras que el propio Riaño en 1903 le escribía "con la confianza que V., como si fuera mi hijo, me inspira" (Gómez-Moreno Martínez 1952/1972: 24). La razón es que ambos encontraron en GómezMoreno Martínez un segundo hijo con similares aficiones que ellos, pues a su primogénito, Juan Riaño y Gayangos, del cuerpo diplomático desde 1886, "le amaban, pero sin congeniar con él sus padres, no se les parecía en nada y quedaba fuera de su círculo" (Gómez-Moreno Martínez 1952/1972: 24).

Durante sus meses en Madrid, Gómez-Moreno Martínez frecuentó la Biblioteca Nacional donde iba recomendado al Jefe de la Sección de Estampas, el cordobés Ángel Barcia, compañero de su padre en Roma, donde pasaba las mañanas. "Al final de cada mañana, cuando dejaba el trabajo, solían entrarle ganas de charlar" (Gómez-Moreno Martínez 1952/1972: 21-22). Otra opción era con el conservador del Museo de Reproducciones Artísticas entre 1891-1901, el académico y arabista malagueño Francisco Guillén Robles, que había estudiado en Granada entre 1862-68, para consultar la biblioteca pues tenía "una selecta biblioteca de arte" y estudiar directamente los vaciados (Gómez-Moreno Rodríguez 1995: $77,81)$. Otro lugar de trabajo fue la biblioteca del Ateneo "fácil de consulta y riquísima de contenido" de la que se hizo socio para también asistir a las conferencias que allí se impartían (Gómez-Moreno Rodríguez 1995: 91). En cambio, no frecuentó el Museo Arqueológico Nacional ni le gustó su exposición, que encontró “escaso, mal clasificado y sin papeletas de procedencia” (Gómez-Moreno Rodríguez 1995: $81)$.

Por otra parte, desde Madrid continuó su política de visitas a las provincias inmediatas que ya había realizado en Andalucía para mejorar su formación. De su entorno inmediato viajó a Ávila, Segovia y Toledo, que amplió posteriormente a un segundo anillo con Salamanca. La primera visita fue a Toledo en enero de 1899 donde estuvo 3 días (Gómez-Moreno Rodríguez 1995: 82). La segunda fue Ávila el 3 de mayo de 1899 que halló "rica e interesante, como la que más". De allí continuó hacia Salamanca y al no poder llegar por las lluvias a Valladolid, decidió visitar Segovia, regresando el 7 de mayo (Gómez-Moreno Rodríguez 1995: 107-110).

La publicación en mayo de 1899 de las impresiones de su viaje a Ávila en el periódico El Defensor de Granada (Gómez-Moreno Martínez 1899), muestra que seguía con la misma mecánica aprendida en las excursiones con su padre y continuadas dentro del Centro Artístico y Literario de tomar notas y redactar un resumen con lo más significativo. Con este primer conocimiento, cuando se le encargó redactar el primer Catálogo Monumental, por su proximidad a Madrid y las menores dimensiones de la provincia, le permitió a Gómez-Moreno Martínez sugerir Ávila como alternativa de Granada a Riaño (Gómez-Moreno Rodríguez 1991: 13), para evitar suspicacias por la relación de Riaño con su padre y “donde no se pudiera sospechar que mi padre, bien conocidas sus dotes de crítico de arte, había de aliviarme la carga" (GómezMoreno Martínez 1952/1972: 27). 
Perdida la opción de las oposiciones en Madrid, regresó a Granada el 24 de mayo de 1899 después de 5 meses de ausencia, donde se incorporó de nuevo a la Escuela de Artes y Oficios, preparándose para presentarse a la oposición para una plaza de Dibujo Artístico con nociones de Historia del Arte, a la vez que escribió a Riaño, quien "no contestó", y se "le pasó por las mientes el emigrar a América" (GómezMoreno Martínez 1952/1972: 25; Gómez-Moreno Rodríguez 1991: 110, 113), lo que sugiere que ya no pensaba quedarse en Granada.

\section{Conclusiones}

Aunque la actividad arqueológica de su padre, Gómez-Moreno González, entre 1868-1878, fue más importante de lo que a veces se piensa, dentro de la Comisión Provincial de Monumentos y en la organización e inventario del Museo Provincial de Antigüedades, su hijo entonces era muy pequeño. Cuando el padre realizó sus principales excavaciones, Sierra Elvira y la Cueva de la Mujer en 1872, donde volvió a trabajar en 1875, Gómez-Moreno Martínez apenas tenía 2 años. La estancia en Roma entre 18791880 consolidó la formación de Gómez-Moreno González como pintor y su mayor dedicación hacia la Historia del Arte, orientación que también primó en los 15 primeros años de aprendizaje de GómezMoreno Martínez, 1885-1899.

En cambio, su afición desde pequeño a las monedas antiguas fue su base para los conocimientos numismáticos, formación que se refleja en la finalización de la redacción del tomo introductorio de $L a$ Moneda Hispánica de Vives (1924-26), debido a su fallecimiento, que completó desde la página 82 hasta la 186 (Vives y Gómez-Moreno Martínez 1926: ix, cxcv). Mayor competencia tuvo en la epigrafía, gracias a la práctica inicial con Hübner, con el que colaboró en Granada en 1886, y mantuvo un regular contacto, lo que le permitió, con su ayuda en las transcripciones, hacer una revisión de todas las inscripciones romanas de Granada en 1889, con apenas 19 años, cuando acababa de licenciarse. La docencia en Arqueología Sagrada desde 1895 en la Universidad-Seminario del Sacromonte, con 25 años, le permitió incrementar su aprendizaje en Arqueología Cristiana, que plasmó en su estudio sobre una basílica, sarcófago e inscripciones de Martos en 1897. Su buena formación en Latín del bachillerato con Mariano García, lo completó con los dos cursos universitarios de griego, que tuvo que ampliar para su docencia sobre Lengua Griega que impartía también en el Sacromonte.

El método de trabajo que desarrolló Gómez-Moreno Martínez en los Catálogos Monumentales siguió una mecánica que había aprendido con su padre desde los 16 años, durante su último año de bachillerato. Primero la consulta de archivos, después la necesidad de conocer directamente las obras de arte, la realización de bocetos y descripciones en el trabajo de campo, la importancia del uso de la fotografía y finalmente, capacidad interpretativa. Este método fue inicialmente puesto en práctica durante las excursiones del Centro Artístico y Literario, que después coordinó, redactando 32 breves artículos, y se plasmó en su contribución a la Guía de Granada (1892).

La descripción del proceso de preparación del primer Catálogo Monumental de España. Provincia de Ávila (Gómez-Moreno Martínez 1900-01/1983) muestra como seguía esta dinámica de trabajo: primero la localización en

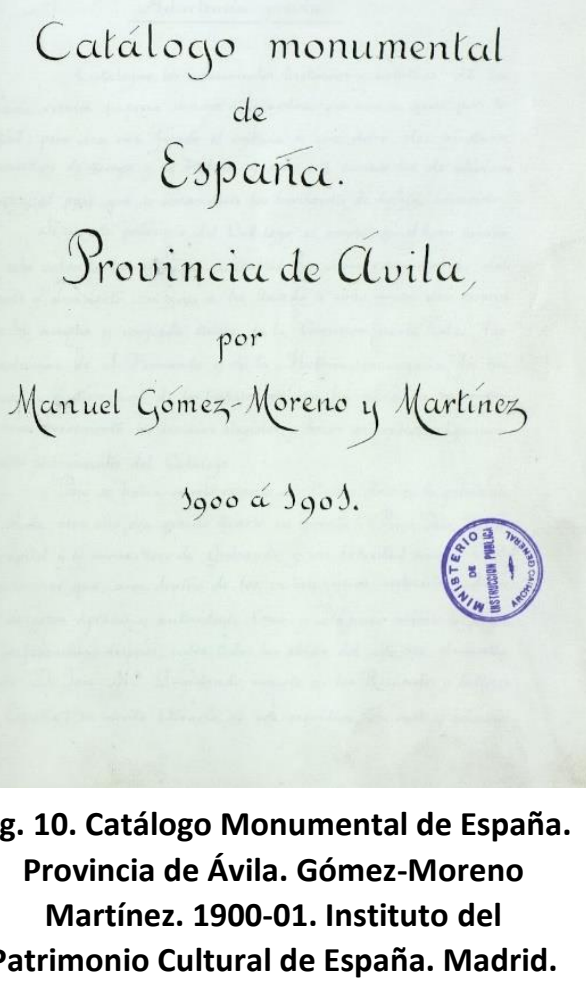

de

Espana.

Provincia de Cluila por

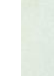


Madrid en el Archivo Histórico Nacional de "todo el archivo de la Catedral de Ávila". Su conocimiento directo de campo donde "El transporte normal es el burro, con preferencia a la mula, habitual en zonas montañosas (...) carga su maleta a un lado de la silla, el trípode y la máquina al otro, y va "tan ricamente"”. El proceso de documentación, pues "por tierras de Ávila su lápiz estuvo tan activo como el disparador de la máquina". Finalmente, "Ya en Granada se dedica a confeccionar el Catálogo con todo el material reunido: notas, dibujos y abundantes y buenas fotografías" (Gómez-Moreno Rodríguez 1991: 118, 124, 126, 135) (Fig. 10).

\section{Agradecimientos}

Queremos agradecer la invitación de Jorge García Sánchez a participar en las I Jornadas de Historiografía de la Arqueología. También las atenciones de Daniel Gozalbo en el Archivo General de la Administración (AGA), de Javier Moya Morales en el Instituto Gómez Moreno (IGM) de la Fundación Rodríguez-Acosta en Granada y a los bibliotecarios del Archivo Histórico Nacional (AHN). Este trabajo se adscribe al Grupo de Investigación Hum F-003 de la Universidad Autónoma de Madrid, sobre estudios historiográficos, dirigido por J. Blánquez.

\section{BibLIOGRAFíA}

Bellón Ruiz, J.P. (2015), 'Manuel Gómez Moreno: 100 años de arqueología española' en M. Gómez Moreno, Adam y la prehistoria. Urgoiti editores. Pamplona: i-cclxiv.

Carriazo y Arroquia, J. de M. (1977), El maestro Gómez-Moreno contado por el mismo. Discurso leído el día 8 de Mayo de 1977, en su recepción pública, por el Excmo. Sr. D. Juan de Mata Carriazo y Arroquia y contestación del Excmo. Sr. D. Emilio García Gómez. Real Academia de la Historia. Sevilla.

Castillejo, D. (1998), Epistolarios de José Castillejo y de Manuel Gómez-Moreno. El espíritu de una época (1910-1912). Castalia. Madrid.

Castro y Orozco, J. (1865), 'Examen de las antigüedades de Sierra Elvira. Memoria presentada á la Real Academia de la Historia, en 1842'. Obras poéticas y literarias. Imprenta y Estereotipa de M. Rivadeneyra. Madrid.

Cueto y Ribero, M. de (1881), D. Aureliano Fernández-Guerra. La llustración Católica, 2a S., 5 (14): 105-107, 5 (15): $114-115$ y 5 (16): 122-125.

Delgado y Hernández, A. (1871-73), Nuevo método de clasificación de las medallas autónomas de España. III. Imprenta de D. Antonio Izquierdo y García. Sevilla.

Díaz-Andreu García, M. (2004), 'Mélida: génesis, pensamiento y obra de un maestro' en J.R. Mélida y Alinari, Arqueología Española. Urgoiti Editores. Pamplona: ix-clxviii.

Eguílaz y Yanguas, L. (1874), Estudio sobre el valor de las letras arábigas en el alfabeto castellano y reglas de lectura. Carlos Bailly-Baillere. Madrid.

Eguílaz y Yanguas, L. (1881), Del lugar donde fue lliberis. Imprenta de los Señores Lezcano y Cía. Madrid. Fernández-Guerra y Orbe, A. (1867), Epigrafía romano-granadina. Carta de D. Aureliano Fernández-Guerra. Revista de Bellas Artes y Arqueología, 31 de agosto, 1 (44): 352-357.

Flores y Oddouz, J. de (1875), 'Breve explicación de las excavaciones que de orden de S.M. (Dios le guarde) dirige Don Juan de Flores, Racionero de la Santa Iglesia de la ciudad de Granada, en la Alcazaba de dicha ciudad' en J. Oliver y M. Oliver, Granada y sus monumentos árabes. Imprenta de M. Oliver Navarro. Málaga: 450-453.

Gestoso y Pérez, J. (1889-92), Sevilla monumental y artística. Historia y descripción de todos los edificios notables, religiosos, y civiles, que existen actualmente en esta ciudad, y noticia de las preciosidades artísticas y arqueológicas que en ellos se conservan. Oficina tipográfica de El Conservador. Sevilla. 
Gómez-Moreno Calera, J.M. (1989), Las iglesias de las Siete Villas: Colomera, Guadahortuna, íllora, Iznalloz, Moclín, Montefrío, Montejícar. Instituto Gómez-Moreno de la Fundación RodríguezAcosta. Granada.

Gómez-Moreno González, M. (1875), Catálogo de los objetos pertenecientes al Museo provincial de Antigüedades, adquiridos por la Comisión de Monumentos históricos y artísticos de Granada. Formada por el Conservador interino del Museo, D. Manuel Gómez Moreno. Ms. Archivo Histórico Provincial de Granada.

Gómez-Moreno González, M. (1888), Medina Elvira. Imprenta de La Lealtad. Granada.

Gómez-Moreno González, M. (1895), Iliberri y Granada. El Defensor de Granada, 12, 13, 15, 29 y 31 de diciembre de 1895.

Gómez-Moreno González, M. [y Gómez-Moreno Martínez, M.] (1892), Guía de Granada por D. Manuel Gómez Moreno, profesor de la Escuela de Bellas Artes de Granada, correspondiente de las Academias de S. Fernando y de la Historia y del Instituto Arqueológico Alemán. Imprenta de Indalecio Ventura. Granada.

Gómez-Moreno Martínez, M. (1887), La Colegiata y el inmediato convento de la Encarnación. Boletín del Centro Artístico de Granada 16: 137-138.

Gómez-Moreno Martínez, M. (1889), Monumentos romanos y visigóticos de Granada. Boletín del Centro Artístico de Granada 4 (83): 11-14, 4 (84): 10-13, 4 (85): 13-17, 4 (86): 13-16, 4 (87): 14-15.

Gómez-Moreno Martínez, M. (1892), Excursión a Monachil. El Popular, Granada, 7 de diciembre de 1892. Gómez-Moreno Martínez, M. (1895), La Capilla Real: Algo nuevo acerca de su edificación. Al Excelentísimo Señor Don Juan F. Riaño. El Defensor de Granada, 5 de agosto de 1895.

Gómez-Moreno Martínez, M. (1897), Antigüedades cristianas de Martos (con inscripciones inéditas). Granada.

Gómez-Moreno Martínez, M. (1899), Impresiones de un viaje artístico (Ávila, 4 de mayo). El Defensor de Granada, 30 de mayo de 1899.

Gómez-Moreno Martínez, M. (1900-01/1983), Catálogo Monumental de la Provincia de Ávila. A. de la Morena y T. Pérez Higuera (eds.). I-III. Institución Gran Duque de Alba-Dirección General de Bellas Artes y Archivos. Ávila.

Gómez-Moreno Martínez, M. (1928/1986), ‘Apuntes biográficos [de Don Manuel Gómez-Moreno González]' en M. Gómez-Moreno González, Medina Elvira. Grupo de Autores Unidos. Granada: xxiii-xli.

Gómez-Moreno Martínez, M. (1951-58/1977), ‘Un currículum vitae, autógrafo, del maestro GómezMoreno' en J. de M. Carriazo, El maestro Gómez-Moreno contado por el mismo. Discurso leído el día 8 de Mayo de 1977, en su recepción pública, por el Excmo. Sr. D. Juan de Mata Carriazo y Arroquia y contestación del Excmo. Sr. D. Emilio García Gómez. Real Academia de la Historia. Sevilla: 53-62.

Gómez-Moreno Martínez, M. (1952/1972), 'Don Manuel cuenta su vida en los años decisivos'. Homenaje a Gómez-Moreno 1870-1970. Universidad de Granada. Granada: 9-31.

Gómez-Moreno Rodríguez, Mạ.E. (1991), La Real Academia de San Fernando y el origen del Catálogo Monumental de España. Discurso de la académica electa Excma. Sra. Doña María Elena GómezMoreno leído en el acto de su recepción pública el día 3 de noviembre de 1991. Contestación del Excmo. Sr. D. Joaquín Pérez Villanueva. Real Academia de Bellas Artes de San Fernando. Madrid.

Gómez-Moreno Rodríguez, Mạ.E. (1995), Manuel Gómez-Moreno Martínez. Centro de Estudios Ramón Areces. Madrid.

Góngora y Martínez, M. de (1868), Antigüedades prehistóricas de Andalucía. Monumentos, inscripciones, armas, utensilios y otros importantes objetos pertenecientes a los tiempos más remotos de su población. Imprenta C. Moro. Madrid. 
Góngora y Martínez, M. de (1871), Consideraciones acerca del Concilio lliberitano, primero de los sínodos de España y aurora del triunfo definitivo de la iglesia sobre el gentilismo. Imprenta de Indalecio Ventura. Granada.

Hübner, E. (1869), Corpus de Inscriptionum Latinarum. II. Inscriptiones Hispaniae Latinae. Academiae Litterarum Regiae Borussiae. Georgium Reimerum. Berolini-Berlin.

Hübner, E. (1888), La arqueología de España. Tipografía-Litografía de los Sucesores de Ramírez y Cạ. Barcelona.

Hübner, E. (1890), Granada. Deutsche Rundschau, 1890: 358-377.

Hübner, E. (1892), Corpus de Inscriptionum Latinarum. II. Supplementum. Academiae Litterarum Regiae Borussia. Georgium Reimerum. Berolini-Berlin.

Hübner, E. (1893), Monumenta Linguae Ibericae. Academiae Litterarum Regiae Borussiae. Georgium Reimerum. Berolini-Berlin.

Jiménez Landi, A. (1996), La Institución Libre de Enseñanza y su ambiente: los orígenes de la institución. Editorial Complutense. Madrid.

Lafuente Alcántara, M. (1842), Antigüedades romanas recientemente descubiertas en Sierra Elvira. Conjeturas sobre la posición de la antigua Illiberis. Examen de las opiniones de Bermúdez de Pedraza. La Alhambra I: 132-140.

MacPherson y Hermás, G. (1870-71), La Cueva de la Muger. Descripción de una caverna conteniendo restos prehistóricos descubierta en las inmediaciones de Alhama de Granada. Primera y segunda parte. Imprenta de la Revista Médica, de D. Federico Joly. Cádiz.

Méndez, F. (1780), Noticias de la vida y escritos del Rmo. P. Mro. Fr. Henrique Flórez. Madrid.

Moreno y Bernedo, V. (1842), Acta del día 26 de abril de 1842. La Alhambra I: 130-131.

Moya Morales, J. (2004), Manuel Gómez-Moreno González. Obra dispersa e inédita. Instituto GómezMoreno de la Fundación Rodríguez-Acosta. Granada.

Muñoz González, I.A. (2016), Juan Facundo Riaño (1828-1901), un arqueólogo de las Bellas Artes en la España de la segunda mitad del siglo XIX. Tesis Doctoral. Universidad Autónoma de Madrid. Madrid.

Nibby, A. y Porena, F. (1866), Itinerario di Roma e suoi dintorni, corretto ed ampliato secondo le ultime scoperte e gli studi piu' recenti. Loescher. Roma.

Oliver y Hurtado, J. y Oliver y Hurtado, M. (1870), Iliberi y Granada. El Arte en España, 8: 76-82, 87-106 y 138162.

Oliver y Hurtado, J. y Oliver y Hurtado, M. (1875), Granada y sus monumentos árabes. Imprenta de M. Oliver Navarro. Málaga.

Oliver y Hurtado, M. y Gómez-Moreno González, M. (1870), Informe sobre varias antigüedades descubiertas en la Vega de esta ciudad, que por acuerdo de la Comisión provincial de Monumentos Históricos y Artísticos, han reconocido su Presidente y Secretario, D. Manuel Oliver Hurtado y D. Manuel Gómez Moreno. Imprenta de Don Indalecio Ventura. Granada.

Peñalver y López, N. (1842), Cementerio de Sierra Elvira. La Alhambra I: 145-159.

Pineda, M. de y Pineda, S. de (1842), Arqueología. Observaciones al programa 'Conjeturas sobre la posición de la antigua lliberis, y examen de las opiniones de Bermúdez de Pedraza. La Alhambra I: 193-203.

Rodríguez de Berlanga, M. (1899), 'Iliberris. Examen de los monumentos históricos genuinos iliberitanos'. Estudios de Erudición Española. Homenaje a Menéndez y Pelayo. II. Librería General de Victoriano Suárez. Madrid.

Sánchez-Mesa, D. (1972), 'Notas para un 'curriculum vitae”. Homenaje a Gómez-Moreno 1870-1970. Universidad de Granada. Granada: 35-56

Sotomayor, M. y Orfila, M. (2006), D. Juan de Flores y el 'Carmen de la muralla' del Albaicín. Florentia lliberritana 17: 411-431. 
Sotomayor, M. y Orfila, M. (2011), El foro de la Granada romana: planos, plantas y dibujos. Cuadernos de Prehistoria de la Universidad de Granada 21: 349-403.

Valladar, F. de P. (1890): Novísima guía de Granada. Imprenta y Librería de la Viuda e Hijos de P.V. Sabatel. Granada.

Vives y Escudero, A. (1924-26), La moneda hispánica. I-V. Real Academia de la Historia-Editorial Reus. Madrid.

Vives, A. y Gómez-Moreno Martínez, M. (1926), ‘Prólogo’ en A. Vives (ed.), La moneda hispánica. I. Real Academia de la Historia-Editorial Reus. Madrid: v-cxcvi. 


\title{
Ángel de los Ríos y los inicios de la arqueología medieval en el norte de la Península Ibérica
}

\author{
Enrique Gutiérrez Cuenca
}

Universidad de Cantabria

\section{Introducción}

Aunque se suele situar el inicio de la arqueología medieval en Cantabria y en el norte de Burgos y Palencia -los territorios que R. Bohigas (1986) definió como el 'sector central de la montaña cantábrica' - a partir de mediados del siglo XX, con los trabajos de M. A. García Guinea en la necrópolis de San Cristóbal de Espinilla (García Guinea, 1955), en El Castellar de Villajimena (García Guinea et al., 1963) o con los primeros intentos de caracterización de la cerámica altomedieval (García Guinea, 1966), existe un precedente de singular interés en la segunda mitad del siglo XIX con la figura de A. de los Ríos. La labor de este investigador ha pasado bastante desapercibida más allá del ámbito regional, a pesar de coincidir en el tiempo con el desarrollo de una primera arqueología medieval española (Salvatierra, 2013) y de su vinculación con la Real Academia de la Historia (RAH), institución de la que fue correspondiente y asiduo contribuyente durante más de tres décadas (vid. Giménez et al., 1999). De hecho, ni siquiera se le menciona en obras de síntesis como el Diccionario histórico de la arqueología en España (siglo XV-XX).

Sobre algunos de sus hallazgos y estudios envió informes, calcos e incluso piezas a la RAH, pero el grueso de la documentación generada por sus investigaciones permanece inédita en su archivo personal de la Torre de Proaño (Cantabria). A partir del repaso detallado de este fondo documental, presentamos aquí un primer acercamiento a su trayectoria como pionero de la arqueología medieval en la segunda mitad del siglo XIX. Autodidacta, independiente y con escasa presencia en publicaciones especializadas, la obra de A. de los Ríos no tuvo continuidad, aunque sí una marcada influencia en la historiografía local sobre algunos temas concretos, especialmente en el ámbito de la arqueología funeraria medieval.

\section{Vida y obra}

Ángel de los Ríos y Ríos (1823-1899) nació en Proaño (Cantabria) en el seno de una familia de 'rancio abolengo' cuyas raíces alcanzan a linajes medievales de los que siempre hizo gala, así como de su condición de hidalgo (Fig. 1) ${ }^{1}$. Cursó estudios de derecho e inició una carrera funcionarial auspiciada por su hermano mayor, Valentín de los Ríos y Ríos, marqués de Santa Cruz de Aguirre (1811-1888), que fue gobernador civil de Zamora y senador por esa misma provincia. Desempeñó diversos oficios públicos, primero en Reinosa (Cantabria) como administrador del Alfolí (1844) y después como comisario de Montes en Salamanca y Zamora (1846), antes de colocarse como jefe del Negociado de Obras Públicas de Burgos (1847). Sin embargo, no tardaría en cambiar esas ocupaciones burocráticas por una dedicación mucho más vocacional, la de escritor. Es posible que una incipiente sordera que se manifestó desde la infancia y que se agrava hacia 1843 hasta hacerle perder por completo el oído, influyese en su personalidad y en la búsqueda de una nueva ocupación profesional, más acorde con su progresivo aislamiento. A partir de 1850 y hasta 1856 colaboró como articulista en el diario carlista madrileño La Esperanza y sería este mismo medio el que editaría su primera obra, una traducción del francés de la epopeya nórdica Los Eddas (1856). En ese mismo año, la muerte de su madre motivó su vuelta de Madrid a su tierra natal, donde se instalaría definitivamente.

\footnotetext{
${ }^{1}$ Para trazar esta semblanza sobre su vida y obra partimos de los trabajos de F. Bolado (1905), J. Montero (1917), J. Martín de los Ríos (2007) y J. M. Cabrales Arteaga (2013). Además de la bibliografía generada por A. de los Ríos, se ha publicado una selección de sus escritos (Hoyos Sainz 1952).
} 
A partir de 1857 residirá en la Torre de Proaño y se hará cargo de las heredades de la familia, aunque el propietario por mayorazgo era su hermano Valentín. Desde entonces, iniciaría una fecunda actividad investigadora que pronto canalizó a través de la RAH. El primer envío que realizó fue un informe relativo a unas inscripciones procedentes de la ermita de Santa Marina y de la iglesia de los Santos Justo y Pastor, ambas en Villar (Cantabria), remitido en 1864 (RAH-S-9-7968-5/1-5). Poco tiempo después, el 26 de enero de 1866, fue nombrado correspondiente de la institución (Giménez et al. 1999: 15) y se mantendría activo en ese desempeño hasta 1898. También colabora con algunas instituciones locales, especialmente con la Comisión Provincial de Monumentos de Santander, que le requerirá información en 1867 para la elaboración del Catálogo Monumental de la provincia (Ordieres 1993: 52-55).

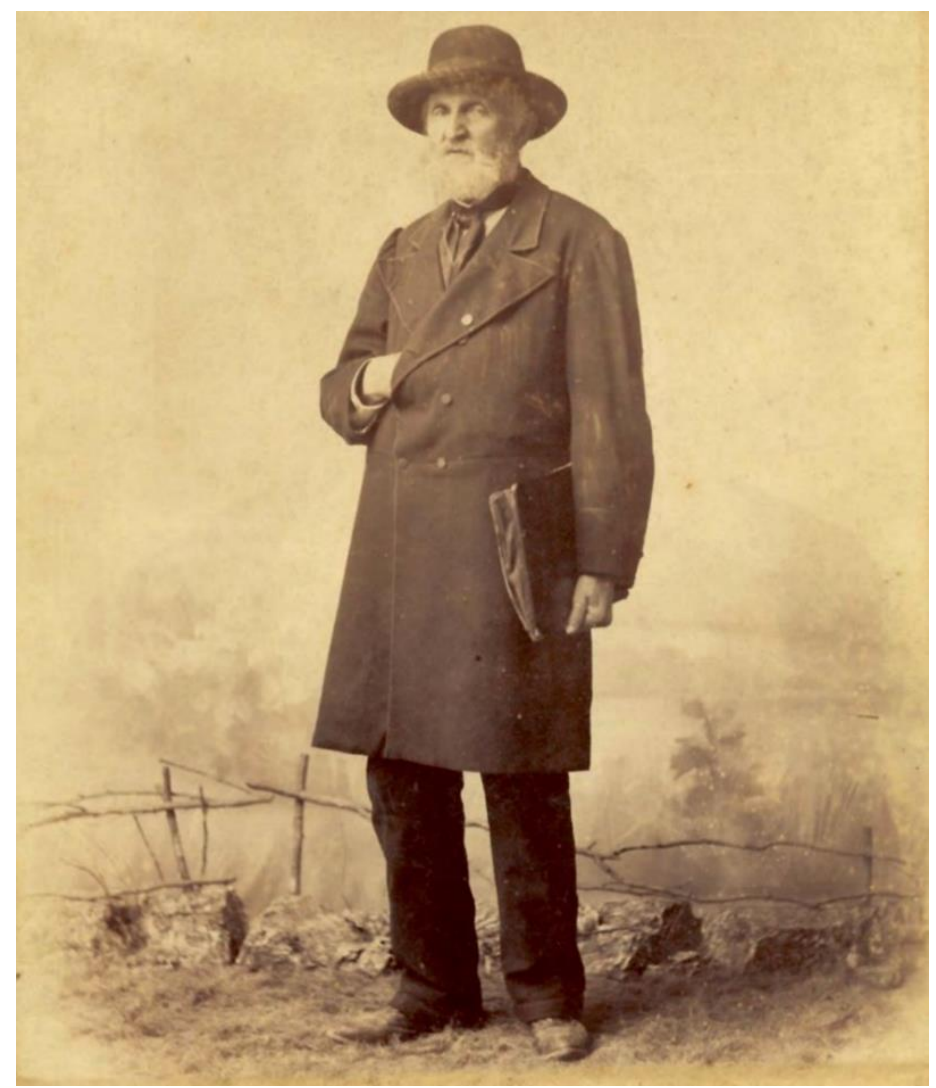

Fig. 1. Retrato de Ángel de los Ríos. Foto: ( B Biblioteca Menéndez Pelayo.

De ideología conservadora y tradicionalista, hizo alguna incursión breve en la actividad política, ejerciendo como diputado provincial por Reinosa (Cantabria) entre 1871 y 1872 por el partido Agrupación Católico-Monárquica y como alcalde de Campoo de Suso -municipio en el que se ubica su Proaño natalentre 1883 y 1887, con destitución y reposición de por medio.

La RAH premió en su concurso público de 1869-1870 la primera obra de carácter histórico de A. de los Ríos, el Ensayo histórico, etimológico y filológico sobre los apellidos castellanos desde el siglo X hasta nuestra edad (1871). Una temática ya específicamente medieval tuvo su siguiente trabajo titulado Noticia histórica de las behetrías, primeras libertades castellanas (1876), probablemente su obra más relevante.

De carácter más local fue su estudio Memorias sobre las antiguas y modernas comunidades de pastos entre los valles de Campoo de Suso, Cabuérniga y otros de la provincia de Santander (1878), en el que vuelve a abordar cuestiones de historia medieval. También escribió alguna obra de carácter biográfico como la Biografía del célebre poeta dramático don Pedro Calderón de la Barca (1884). Animado por M. Menéndez Pelayo, publicó La parte de los montañeses en el descubrimiento de América (1892), 
coincidiendo con las celebraciones del cuarto centenario de la llegada de Colón a América, efeméride que le llevó hasta Huelva en 1892 como cronista de la provincia de Santander.

Era una persona de carácter difícil, impulsivo y, de hecho, su hermano Valentín se mostró contrario a su participación en política por ese motivo. Los continuos conflictos en los que se vio involucrado le llevaron a estar procesado no menos de catorce veces y en 1895 influyentes personalidades de Cantabria, encabezadas por J. M. de Pereda y M. Menéndez Pelayo, firmaron una carta dirigida a la regente María Cristina solicitando un indulto para A. de los Ríos, condenado a dos años y cuatro meses de cárcel ${ }^{2}$. Polemizó también en el ámbito intelectual, como ejemplifica su sonado enfrentamiento con M. Sanz de Sautuola tras la publicación de su Breves apuntes sobre algunos objetos prehistóricos de la provincia de Santander (1880), que se plasma en las réplicas y contrarréplicas recogidas por el Eco de la Montaña entre 1880 y 1881 (Madariaga 2002: 83-118) y durante el que A. de los Ríos pone en duda el concepto de Prehistoria, la naturaleza de los instrumentos prehistóricos y la antigüedad de las pinturas de Altamira con argumentos bastante endebles y una vehemencia en ocasiones desproporcionada.

Esa fuerte personalidad y su particular forma de entender el mundo, calificada con frecuencia de 'quijotesca', hicieron de A. de los Ríos un personaje singular que incluso sirvió de inspiración al escritor costumbrista J. M. de Pereda en su novela Peñas Arriba (1895), en la que el erudito campurriano quedó inmortalizado como el 'señor de la torre de Provedaño'.

\section{3. Ángel de los Ríos y la arqueología medieval}

Una vez establecido en Proaño, a partir de 1857, A. de los Ríos dedicará buena parte de su tiempo a alimentar su insaciable curiosidad por el pasado, inmerso entre libros y legajos. Pero su interés pronto fue más allá del papel o el pergamino y comenzó a estudiar ruinas, inscripciones y monedas, iniciando lo que en la época se podría considerar una prolífica actividad arqueológica. De esta faceta quizás lo más conocido son sus investigaciones sobre los restos romanos de Retortillo (Cantabria) -identificados desde el siglo XVIII con la Iuliobriga de las fuentes clásicas-y las estructuras que relacionó con el campamento de la Legio IIII Macedonica en Castrillo del Haya (Cantabria), ya que se convirtieron en su única publicación sobre arqueología en una revista especializada (Ríos, 1889). Pero no fueron los únicos restos materiales de época romana que atrajeron su atención. En 1878 envío un informe a la RAH sobre el hallazgo de restos romanos en La Magdalena (Santander, Cantabria) (RAH-S-9-7968-13/1) y en 1886 describió una estructura termal localizada en San Martín (Santander, Cantabria) que interpretó erróneamente como "un horno de alfarería muy antiguo' ${ }^{3}$. También se conservan en su archivo personal documentos sobre los términos augustales de Valdeolea (Cantabria) ${ }^{4}$, sobre un miliario de Castro Urdiales $\left(\right.$ Cantabria) ${ }^{5}$, sobre la pátera de Otañes (Cantabria) ${ }^{6}$ o sobre el castro de Monte Bernorio (Pomar de Valdivia, Palencia), lugar que considera un 'campamento romano de Primavera' 7 . Incluso realizó algunas incursiones más o menos afortunadas en el estudio del megalitismo (Ríos 1857; Teira y Ontañón 2016).

De sus estudios y hallazgos de época medieval hay noticias gracias a la documentación enviada a la RAH entre 1864 y 1893 (Giménez et al. 1999; Abascal y Cebrián 2006). Estas noticias han sido recogidas en

\footnotetext{
${ }^{2}$ La carta fue reproducida por el semanario Nuevo Mundo en su no 78, de julio de 1895.

${ }^{3}$ Construcción greco-romana del castillo de San Martín en Santander, 1886. Doc. 6, ms. 168-10, Fondos Modernos, BMS.

${ }^{4}$ Términos augustales, s.f. Archivador II-M, Copia Instituto Sautuola, Archivo de A. de los Ríos, Torre de Proaño.

${ }^{5}$ Millar de Castro Urdiales, s.f. Archivador III-M, Copia Instituto Sautuola, Archivo de A. de los Ríos, Torre de Proaño.

${ }^{6}$ El Plato de Otañes, 1877. Carpeta Proaño MA 9, Copia Instituto Sautuola, Archivo de A. de los Ríos, Torre de Proaño.

${ }^{7}$ Vernorio (vernarium s. castrum), s.f. Archivador VI, Copia Instituto Sautuola, Archivo de A. de los Ríos, Torre de Proaño.
} 
algunos trabajos, especialmente las referidas a la ermita de San Miguel de Soto (Fernández Acebo 2007; Marcos y Mantecón 2009). También algunos de los documentos referidos a hallazgos de época medieval habían sido usados previamente, especialmente aquellos referidos a las estelas de Espinilla (Martín Gutiérrez 2000). Y, en nuestro caso, el interés se ha dirigido hacia los trabajos relacionados con manifestaciones funerarias de época medieval, para incorporarlos en nuestra tesis doctoral (Gutiérrez Cuenca 2015).

De todos los documentos enviados a la academia y de la correspondencia mantenida con la institución se conservan copias y borradores, en ocasiones con información más completa, en el archivo personal de A. de los Ríos que se custodia en el despacho de su residencia aneja a la Torre de Proaño ${ }^{8}$. En este fondo documental encontramos, además, información referida a otros estudios y hallazgos de los que no queda constancia en la Real Academia de la Historia, lo que permite completar la visión.
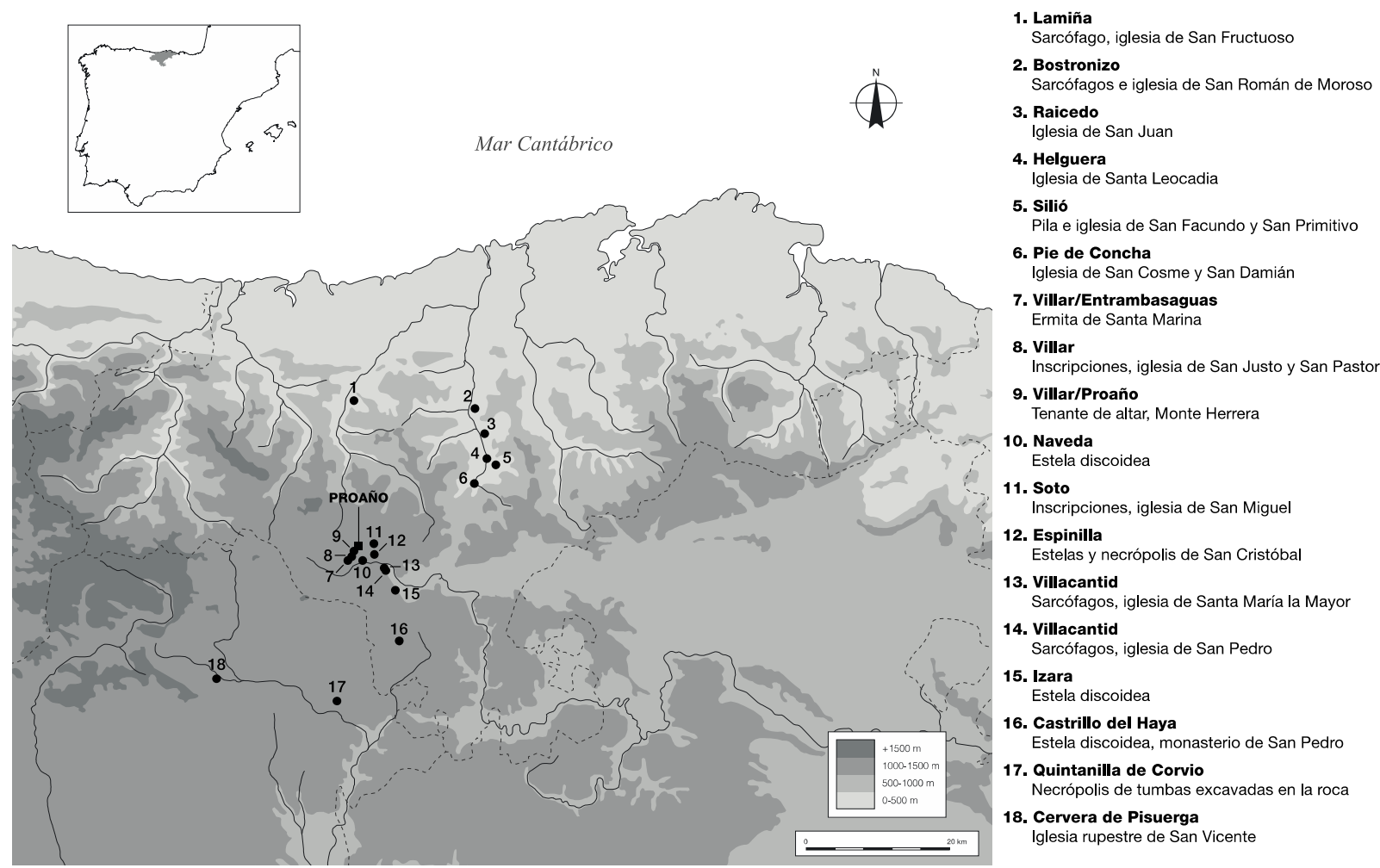

Fig. 2. Localización de restos medievales estudiados por Ángel de los Ríos.

La mayor parte de la documentación permanece inédita. Permite obtener una visión mucho más completa del alcance de sus estudios en el campo de la arqueología medieval que los registros de la RAH y la BMS, ya que ofrece datos de interés sobre los lugares que se relacionan a continuación (Fig. 2 ):

- Iglesia prerrománica y sepulcros de San Román de Moroso (Bostronizo, Cantabria). Dibujos fechados en 1858 del exterior del edificio con una caja de sarcófago junto a la puerta (Fig. 3) y

\footnotetext{
${ }^{8}$ Hemos manejado una copia de toda la documentación del archivo que se conserva en el Instituto Sautuola, clasificada parcialmente por E. Van den Eynde en la década de 1980, gracias a las facilidades dadas por M. A. García Guinea. También hemos tenido acceso a algunos documentos originales, parte de los cuales se reproducen en este trabajo. La consulta ha sido facilitada por los herederos de A. de los Ríos, quienes custodian en la actualidad su legado intelectual.
} 
detalle de la ventana monolítica del ábside. Hay una mención a un sepulcro con aspas grabadas que identifica con las armas de Villacantid ${ }^{9}$.

- Iglesia románica e inscripción de San Juan de Raicedo (Cantabria). Descripción de la iglesia, que califica de 'bizantina', y calco de la inscripción funeraria conservada en el exterior de la misma, con intento de transcripción ${ }^{10}$.

- Iglesia prerrománica de Santa Leocadia de Helguera (Cantabria). Dibujos de los canecillos de modillones de rollos y de una teja con motivos incisos ${ }^{11}$.

- Iglesia románica de San Facundo y San Primitivo de Silió (Cantabria). Descripción de la iglesia, que califica de 'bizantina', y de una pila con inscripción que considera la antigua pila bautismal ${ }^{12}$.

- Iglesia románica de San Cosme y San Damián de Bárcena de Pie de Concha (Cantabria). Calco y lectura de dos inscripciones, y descripción de la iglesia que califica de 'bizantina'. En una anotación fechada en 1870 relaciona la iglesia con el monasterio de Cillaperriel ${ }^{13}$.

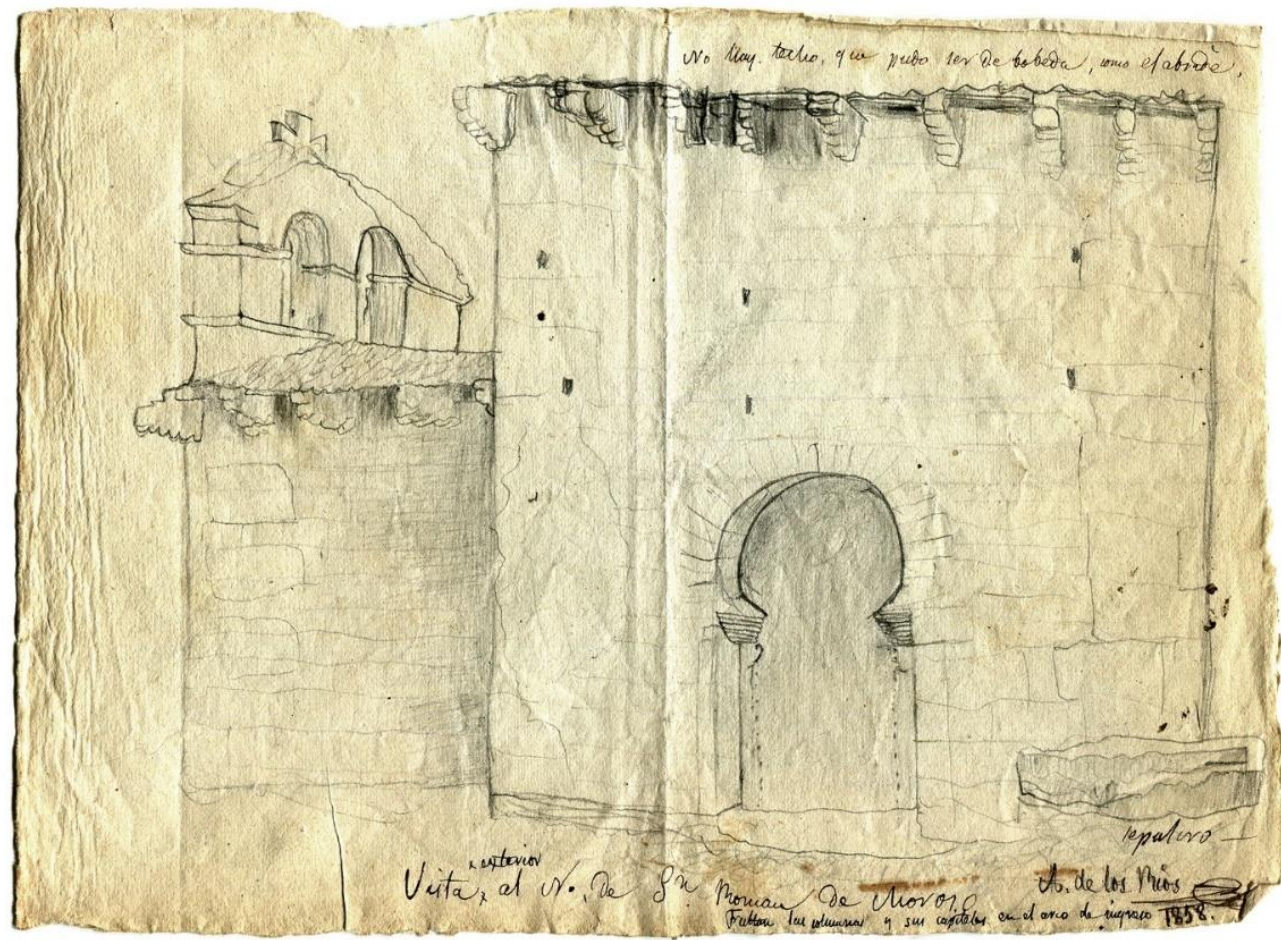

Fig. 3. Vista exterior al $\mathbf{N}$ de $S^{n}$ Román de Moroso, 1858. Archivo Ángel de los Ríos, Torre de Proaño.

\footnotetext{
${ }^{9}$ Vista al N. de $S^{n}$ Román de Moroso, 1888. Archivador IV-M, Copia Instituto Sautuola, Archivo de A. de los Ríos, Torre de Proaño. El documento original se acompaña de otro pliego con un apunte a lápiz del interior y de un dibujo atribuido al conde de Moriana.

${ }^{10}$ Iglesia de $S^{n}$ Juan de Raicedo, s.f. Archivador V-M, Copia Instituto Sautuola, Archivo de A. de los Ríos, Torre de Proaño.

${ }^{11}$ Elguera, s.f. Archivador V-M, Copia Instituto Sautuola, Archivo de A. de los Ríos, Torre de Proaño.

${ }^{12}$ Silió, s.f. Archivador V-M, Copia Instituto Sautuola, Archivo de A. de los Ríos, Torre de Proaño.

${ }^{13}$ Iglesia de Bárcena de Pie de Concha, s.f. Archivador V-M, Copia Instituto Sautuola, Archivo de A. de los Ríos, Torre de Proaño. Bárcena. Iglesia de $S^{n}$ Cosme y Damián, 1870. Archivador V-M, Copia Instituto Sautuola, Archivo de A. de los Ríos, Torre de Proaño.
} 
- Sarcófago de la ermita de San Fructuoso de Lamiña (Cantabria). Dibujo de cubierta de sarcófago con inscripción, transcripción y traducción, a partir de información remitida por Enrique García Cueto en $1872^{14}$.

- Ermita de Santa Marina, entre Villar y Entrambasaguas (Cantabria). Redacta una monografía sobre la ermita (Ríos, 1895), que cataloga como 'gótico-bizantina', y estudia las inscripciones que se conservan en la misma, de las que mandará noticia a la RAH en 1864 (RAH-5-9-7968-5/1-2). También se conserva documentación en la BMS.

- Sarcófago e inscripciones de la iglesia de San Justo y San Pastor de Villar (Cantabria). Dibujos de la cubierta de un sarcófago y calcos de tres losas con inscripciones, incluida la transcripción de las mismas ${ }^{15}$. Los calcos de estas inscripciones fueron remitidos a la RAH en 1864 (RAH-5-97968-5/1-5).

- Tenante de altar de Monte de Herrera, entre Villar y Proaño (Cantabria). Dibujo del tenante, calco y transcripción de la inscripción, hallada en 1845 junto con otros objetos al desmontar una antigua ermita ${ }^{16}$.

- Estela discoidea de Naveda (Cantabria). Descripción y dibujo de una estela que considera 'sepulcral', hallada hacia 1834 al hacer el cementerio del pueblo ${ }^{17}$.

- Inscripciones de la iglesia de San Miguel de Soto (Cantabria). Calcos, transcripciones y comentarios sobre tres losas con inscripciones de los siglos X-XI reutilizadas en la solera de la iglesia. Los calcos de las tres inscripciones fueron remitidos en 1866 a la RAH (RAH-S-9-79686/4). La copia de uno de los calcos conservada en la BMS incluye una anotación que menciona el hallazgo de 'dos calaveras muy grandes' bajo las losas ${ }^{18}$.

- Estelas y necrópolis de San Cristóbal de Espinilla (Cantabria), diversos hallazgos entre 1865 y 1892 (vid. infra).

- Sarcófago de la iglesia de San Pedro de Villacantid (Cantabria). Dibujo y descripción de una caja de sarcófago con vano antropomorfo (Fig. 4), hallado entre 1853 y $1856^{19}$.

\footnotetext{
${ }^{14}$ Piedra que sirve de poyo en La Miña de Cabuérniga, 1872. Archivador II-M, Copia Instituto Sautuola, Archivo de A. de los Ríos, Torre de Proaño.

${ }^{15}$ Inscripciones en varias losas del pavimento de la iglesia de Villar, en Campoo, s.f. Archivador III-M, Copia Instituto Sautuola, Archivo de A. de los Ríos, Torre de Proaño.

${ }^{16}$ Antigüedades Cántabras, s.f. Carpeta Proaño MA. 6, Copia Instituto Sautuola, Archivo de A. de los Ríos, Torre de Proaño. Sancti Marcelli, s.f. Carpeta Proaño MA. 6, Copia Instituto Sautuola, Archivo de A. de los Ríos, Torre de Proaño. Sobre este tenante de altar vid. Gutiérrez Cuenca, en prensa.

${ }^{17}$ Antigüedades-Naveda, s.f. Carpeta Proaño MA. 6, Copia Instituto Sautuola, Archivo de A. de los Ríos, Torre de Proaño. Sepulcros-Campoo, s.f., Proaño MA. 6, Copia Instituto Sautuola, Archivo de A. de los Ríos, Torre de Proaño.

${ }^{18}$ Borrador de carta enviada a la RAH, 6 de octubre de 1866, Sin ref., Copia Instituto Sautuola, Archivo de A. de los Ríos, Torre de Proaño. El documento de la BMS nos lo ha facilitado el arqueólogo Ignacio Castanedo Tapia.

${ }^{19}$ Sepulcros de Villacantid, s.f. Archivador V, Copia Instituto Sautuola, Archivo de A. de los Ríos, Torre de Proaño. El estudio es anterior a 1867.
} 
- Sarcófagos de la iglesia de Santa María la Mayor (Villacantid, Cantabria). Dibujos y descripciones de dos cubiertas de sarcófago, una de ellas decorada (Fig. 4). También se menciona la presencia de más 'sepulcros' alrededor de la iglesia ${ }^{20}$.

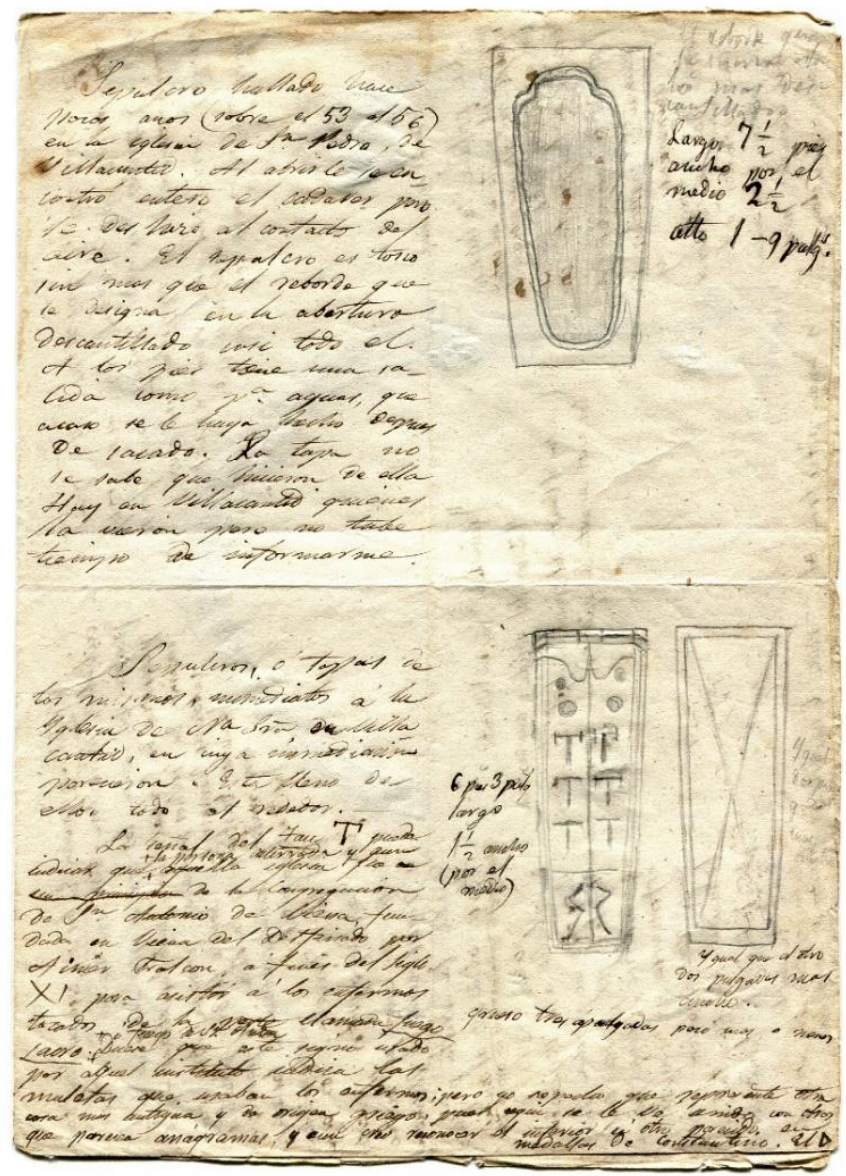

Fig. 4. Sepulcros de Villacantid. Archivo Ángel de los Ríos, Torre de Proaño.

Estelas discoideas de Izara (Cantabria). Noticia sobre la existencia de ' 3 o 4 piedras sepulcrales con cruz' en las inmediaciones de la iglesia del pueblo ${ }^{21}$.

- Estela discoidea del monasterio de San Pedro (Castrillo del Haya, Cantabria). Detalles sobre el hallazgo, descripción y dibujos de una estela discoidea con inscripción PELAIO (Fig. 5). En 1866 se remite la primera información acompañada de un calco a la RAH y en 1877 se envía la estela con un 'certificado de autenticidad' adherido ${ }^{22}$, que todavía se conserva en la pieza (Eiroa, 2006: 66).

${ }^{20}$ Sepulcros de Villacantid, s.f. Archivador V, Copia Instituto Sautuola, Archivo de A. de los Ríos, Torre de Proaño. El estudio es anterior a 1867.

${ }^{21}$ Iglesia de Izara, s.f. Archivador VI, 2-42, Sobre 18, Copia Instituto Sautuola, Archivo de A. de los Ríos, Torre de Proaño.

${ }^{22}$ Borrador de carta enviada a la RAH, 29 de septiembre de 1866, Sin ref., Copia Instituto Sautuola, Archivo de A. de los Ríos, Torre de Proaño. Borrador del certificado del hallazgo de la estela con inscripción PELAIO, febrero de 1877. Sin ref., Copia Instituto Sautuola, Archivo de A. de los Ríos, Torre de Proaño. 
- Necrópolis de tumbas excavadas en la roca de Quintanilla de Corvio (Palencia), descripción y dibujos de las tumbas realizados hacia 1865 (vid. infra).

- Iglesia rupestre de San Vicente (Cervera de Pisuerga, Palencia). Descripción y dibujo (Fig. 6) de la iglesia rupestre, junto a la que distingue al menos una tumba excavada en la roca, y de la iglesia románica que existía en el mismo paraje ${ }^{23}$.

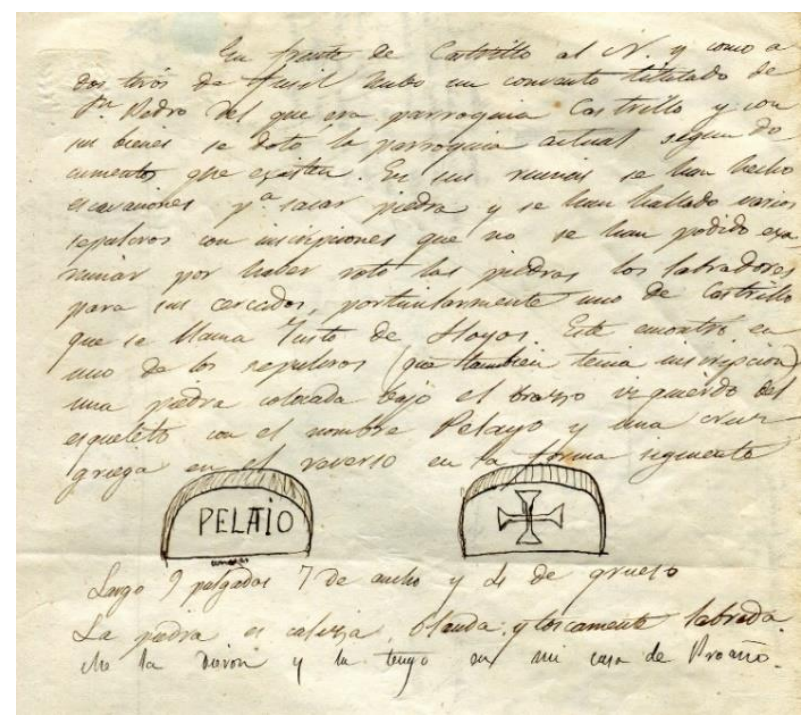

Fig. 5. Piedra con inscripción PELAIO, Archivo Ángel de los Ríos, Torre de Proaño.

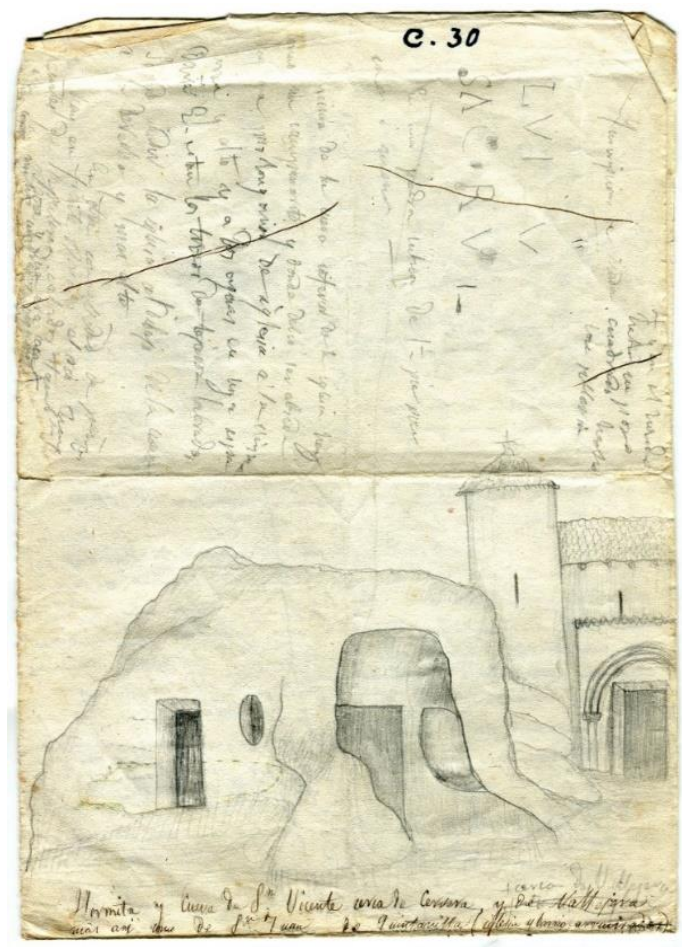

Fig. 6. Hermita y cueva de $S^{n}$ Vicente cerca de Cervera, Archivo Ángel de los Ríos, Torre de Proaño.

${ }^{23}$ Hermita y cuevas sepulcrales de S. Vicente. Archivador III-M, Copia Instituto Sautuola, Archivo de A. de los Ríos, Torre de Proaño. 


\section{La necrópolis de San Cristóbal de Espinilla y sus estelas}

La necrópolis altomedieval de San Cristóbal de Espinilla (Espinilla, Cantabria) fue descubierta de forma casual en 1865, al realizar unas obras de ampliación del ayuntamiento que afectaron al entorno de la iglesia de la localidad. Las obras y los hallazgos se repetirán en 1882 y 1892, y de todos ellos dará cuenta A. de los Ríos a la RAH, enviando informes, calcos y una de las estelas recuperadas en este lugar.

Es precisamente la amplia y singular colección de estelas (Fig. 7) recogidas desde mediados del siglo XIX en este enclave lo que ha llamado la atención de un buen número de investigadores en los últimos 150 años, dando forma a un auténtico 'serial historiográfico' sobre el que aún no se ha pronunciado la última palabra y que refleja, en gran medida, la propia evolución de la historia de la investigación sobre arqueología funeraria de la Edad Media en Cantabria (vid. Gutiérrez Cuenca 2015: cap. 4.1).

En 1865 se produjo el hallazgo de la primera estela, con la inscripción MARI, suelta dentro de 'sepulcros (...) hechos con piedras largas y delgadas (lanchas) ${ }^{24}$, similar a otras que aparecen en el lugar, que conservan en su interior algunos huesos entre tierra negruzca ${ }^{25}$. En una primera aproximación cronológica, A. de los Ríos atribuye la estela a la Alta Edad Media, a partir de criterios paleográficos y de otro tipo de consideraciones, como la idea aceptada en la época de que a partir del siglo XII se comienza a sepultar en las iglesias. Todo ello le hace suponer "que estas piedras son del siglo $\mathrm{X}^{\text {,26 }}$. Cuando en 1877 decide enviar la estela a la RAH junto con otras, por medio de su hermano Valentín, intenta afinar un poco más su interpretación, apuntando que la escritura puede pertenecer a época 'goda o gótico-leonesa' ${ }^{27}$, pero que el uso de inscripciones en piedra para señalizar sepulturas es algo propio de los hispano-romanos.

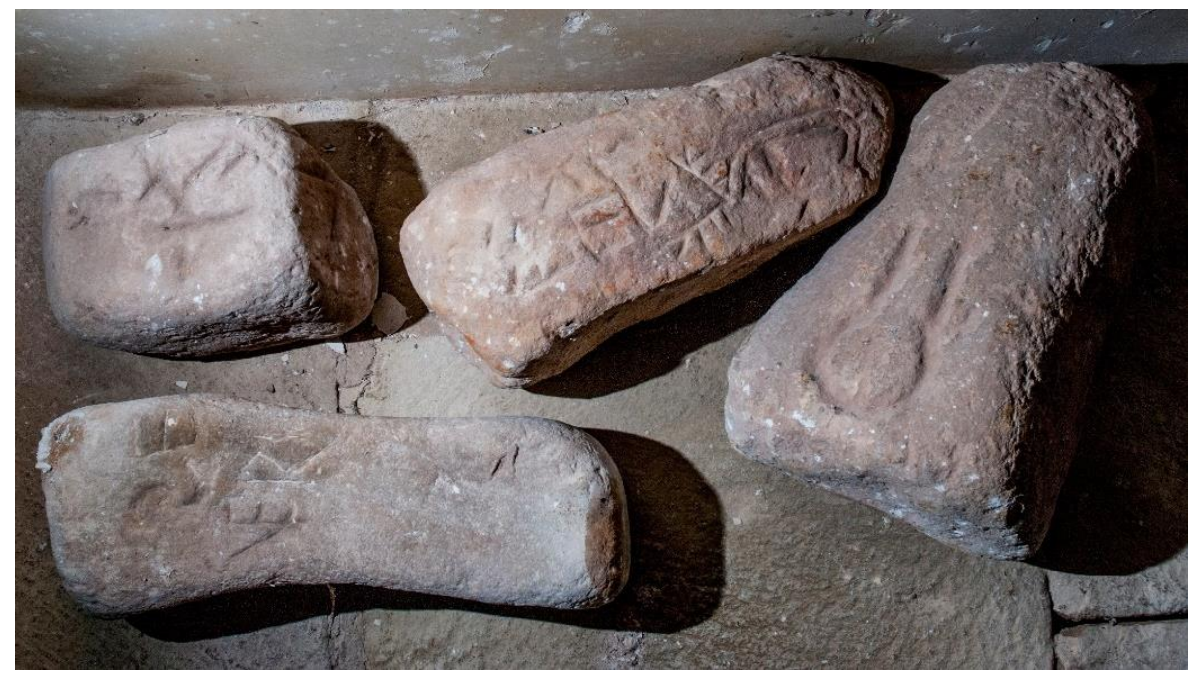

Fig. 7. Estelas de S. Cristóbal de Espinilla custodiadas en la capilla de la Torre de Proaño.

\footnotetext{
${ }^{24}$ Borrador de carta enviada a la RAH, 6 de octubre de 1866. Sin ref., Copia Instituto Sautuola, Archivo de A. de los Ríos, Torre de Proaño. En un documento posterior, precisa que las lajas empleadas en la construcción de la tumba son cuatro: Borrador del certificado de la estela con inscripción MARI, febrero de 1877, Sin ref., Copia Instituto Sautuola, Archivo de A. de los Ríos, Torre de Proaño.

${ }^{25}$ Carta adjunta al envío del calco (facsímil) de inscripción a la RAH, 30 de septiembre de 1866. Sin ref., Copia Instituto Sautuola, Archivo de A. de los Ríos, Torre de Proaño.

${ }^{26}$ Borrador de la carta adjunta al envío del calco (facsímil) de inscripción a la RAH, 29 de septiembre de 1866. Sin ref., Copia Instituto Sautuola, Archivo de A. de los Ríos, Torre de Proaño. El texto citado aparece tachado y la indicación cronológica no se incluye en la versión definitiva de la carta.

${ }^{27}$ Borrador de carta adjunta al envío de inscripción a la $R A H, 3$ de abril de 1877. Sin ref., Copia Instituto Sautuola, Archivo de A. de los Ríos, Torre de Proaño.
} 
En 1882 comunica a la RAH el hallazgo de seis nuevas estelas con inscripciones, aparecidas durante unas obras de explanación realizadas junto al ayuntamiento (Fig. 8). Por lo que respecta al lugar del hallazgo, menciona que 'todo el campo que media entre la indicada casa consistorial y la inmediata iglesia de S. Cristóbal de Espinilla es un cementerio donde a trechos suelen asomar sepulcros según se va desmoronando la tierra del pequeño cerro en que están situados ambos edificios' y detalla que las tumbas están construidas con 'lanchas o losas delgadas puestas de corte formando una especie de ataúd y con su tapa, pero sin fondo ${ }^{28}$. Está describiendo, sin duda, las tumbas de lajas propias de un cementerio medieval. No aporta en esta ocasión ninguna información sobre la cronología, simplemente menciona algunas formulas presentes en las inscripciones como propias de los romanos.

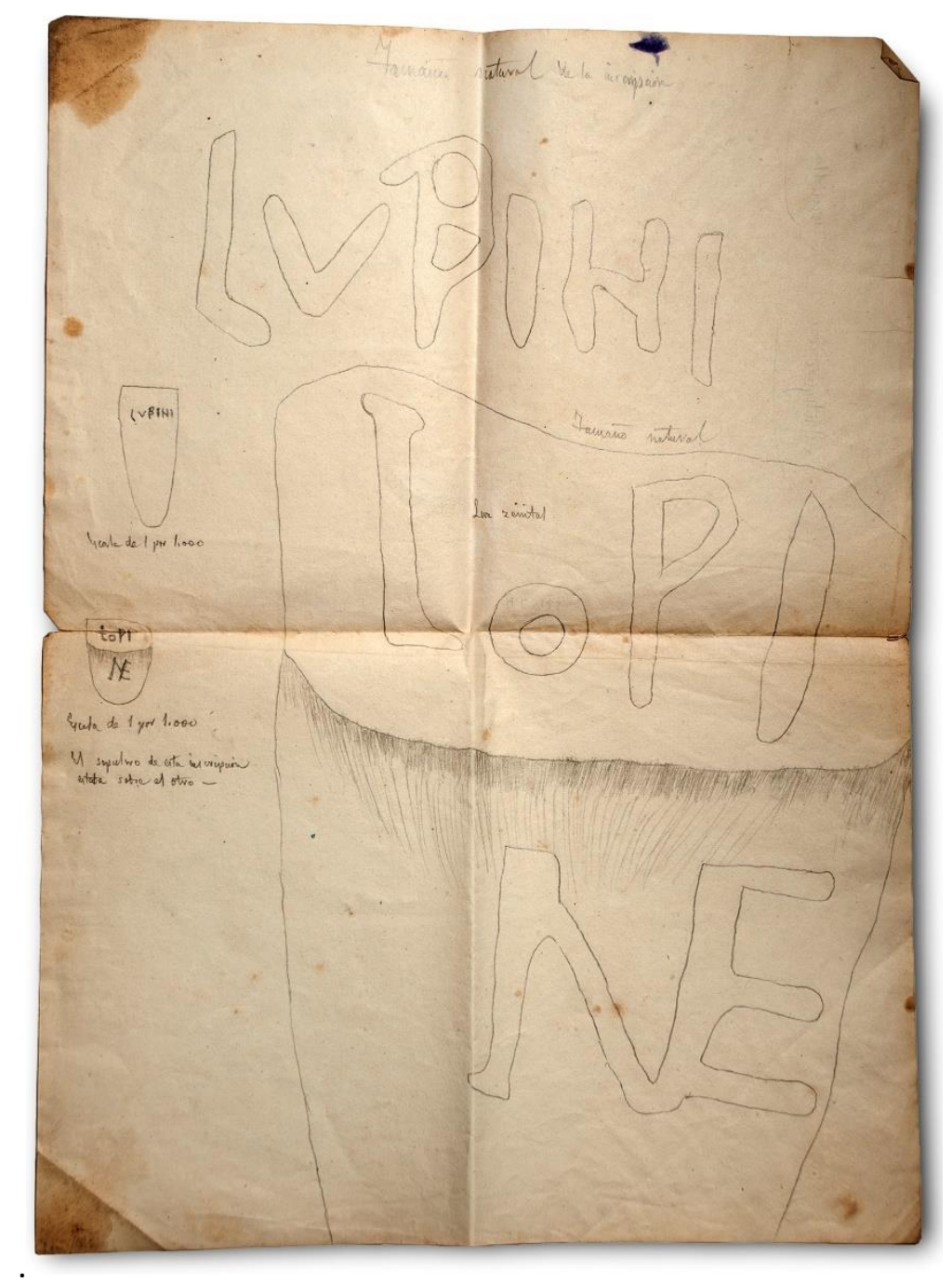

Fig. 8. Calcos de estelas de S. Cristóbal de Espinilla, 1882. Archivo Ángel de los Ríos, Torre de Proaño.

En 1892 aparecen dos sarcófagos y una estela, en esta ocasión con motivo de la ampliación de la iglesia de San Cristóbal. Los sarcófagos llaman la atención de A. de los Ríos, ya que son un tipo de tumba que no se había identificado hasta el momento en ese cementerio y, aunque no los describe de una forma precisa, menciona que son de 'toba blanca y muy fina' y que en el sarcófago más grande aparece el

${ }^{28}$ Borrador de la carta enviada con calcos de inscripciones a la RAH, 19 de junio de 1882. Sin ref., Copia Instituto Sautuola, Archivo de A. de los Ríos, Torre de Proaño. 
esqueleto de un adulto de sexo masculino, mal conservado, y en el más pequeño el de un adulto de sexo femenino, acompañado de una hoz de hierro (Fig. 9). En la cabecera de este último estaba la estela decorada con representaciones esquematizadas de ciervos (Fig.10). Estos hallazgos motivarán un giro radical en la interpretación que A. de los Ríos había hecho hasta ese momento de las estelas y del cementerio en el que aparecen. Considera que las sepulturas corresponden 'a una sacerdotisa druida, así como el sepulcro mayor a un jefe de aquella religión de los antiguos celtas primitivos pobladores de este país ${ }^{29}$. Esta interpretación en clave druídica, en la que se relaciona la hoz con la recogida del muérdago, le lleva a atribuir las estelas y sus inscripciones a época hispano-romana, señalando la cercana Iuliobriga como lugar de procedencia ${ }^{30}$. Incluso identifica al 'jefe druida' y la 'sacerdotisa' con Oroveso y Norma, protagonistas de la ópera de temática celta Norma (1831).

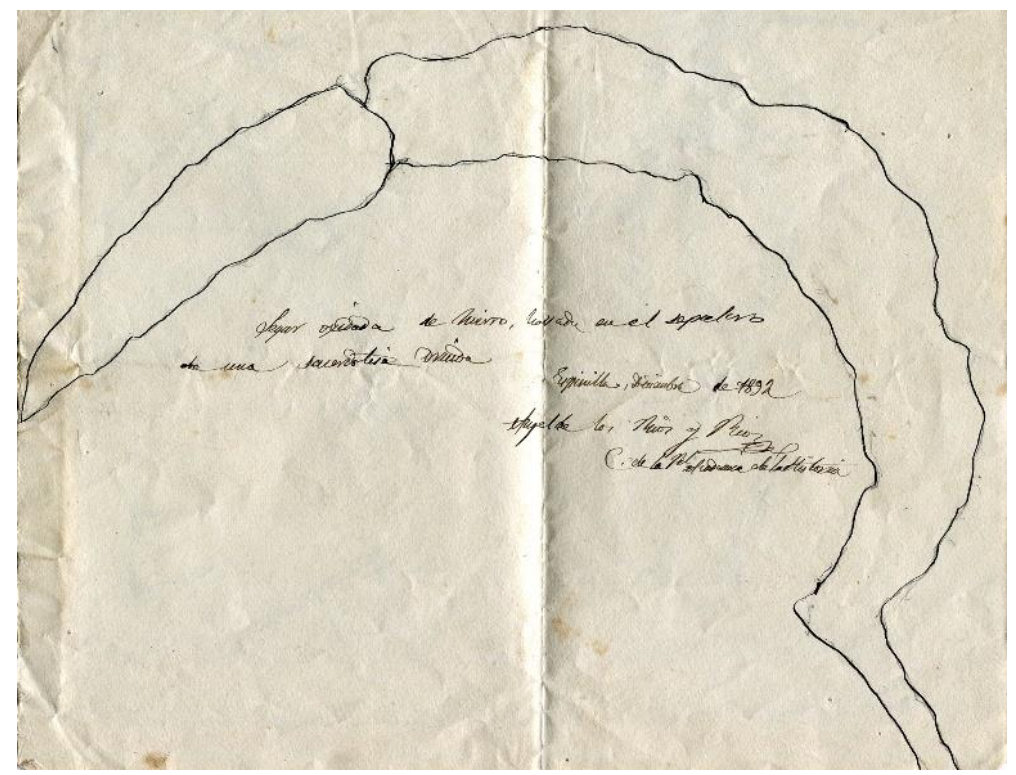

Fig. 9. Segur de hierro de S. Cristóbal de Espinilla, 1892. Archivo Ángel de los Ríos, Torre de Proaño.

Sin la más mínima crítica, la identificación de la necrópolis de Espinilla con los antiguos cántabros, y no su atribución a la Edad Media propuesta al principio, pasó a ser la interpretación asumida por los investigadores posteriores. Incluso cuando se producen nuevos hallazgos similares, particularmente tumbas de lajas, se recurre a la cronología erróneamente asentada por A. de los Ríos. Así sucede, por ejemplo, a principios del siglo XX cuando J. Carballo excava la necrópolis de Solía y la relacionada con los Cántabros de la Edad del Hierro (Carballo 1909), siguiendo la senda abierta por el erudito campurriano. De hecho, incluso L. de Hoyos Sainz (1900: 146), que realizó el estudio antropológico -o más bien 'craneológico', de acuerdo a los estándares de la época- de algunos restos óseos de la necrópolis de Espinilla, propuso su propia cronología, consideró que se trataba de sepulturas neolíticas, basándose en la aparición de un hacha dentro de una de las tumbas de lajas. Cualquiera de esas dos interpretaciones parecía más interesante que la de suponer que eran restos medievales.

\footnotetext{
${ }^{29}$ Carta a la RAH, 29 de diciembre de 1892. Sin ref., Copia Instituto Sautuola, Archivo de A. de los Ríos, Torre de Proaño. Se envió acompañada de dos calcos: 'Segur oxidada de hierro' y 'Tésera sepulcral', de los que se conserva copia en el archivo de la Torre de Proaño, y de una copia del artículo publicado en El Atlántico de 1 de enero de 1893.

${ }^{30}$ La interpretación se recoge en al artículo 'Monumento Cántabro' publicado en El Atlántico el 1 de enero de 1893 (BMS Hemeroteca M-154) y en el documento Crónica de la Provincia de Santander, 27 de junio de 1897, Archivador XI, Copia Instituto Sautuola, Archivo de A. de los Ríos, Torre de Proaño.
} 
Todavía a la altura de 1950 esa interpretación seguía vigente. Un buen ejemplo lo constituye la exploración realizada en la necrópolis de la iglesia de Santa María la Real de Las Henestrosas de las Quintanillas, sobre la que se considera que 'se trata, sin duda, de un cementerio primitivo pagano' y de la que se dice que 'es posible que se trate también de una necrópolis céltica', relacionada con el castro de Castillejo, de la misma manera que Espinilla era considerada la necrópolis del castro de Naveda (González Echegaray 1950: 113-114; González Echegaray 1966).

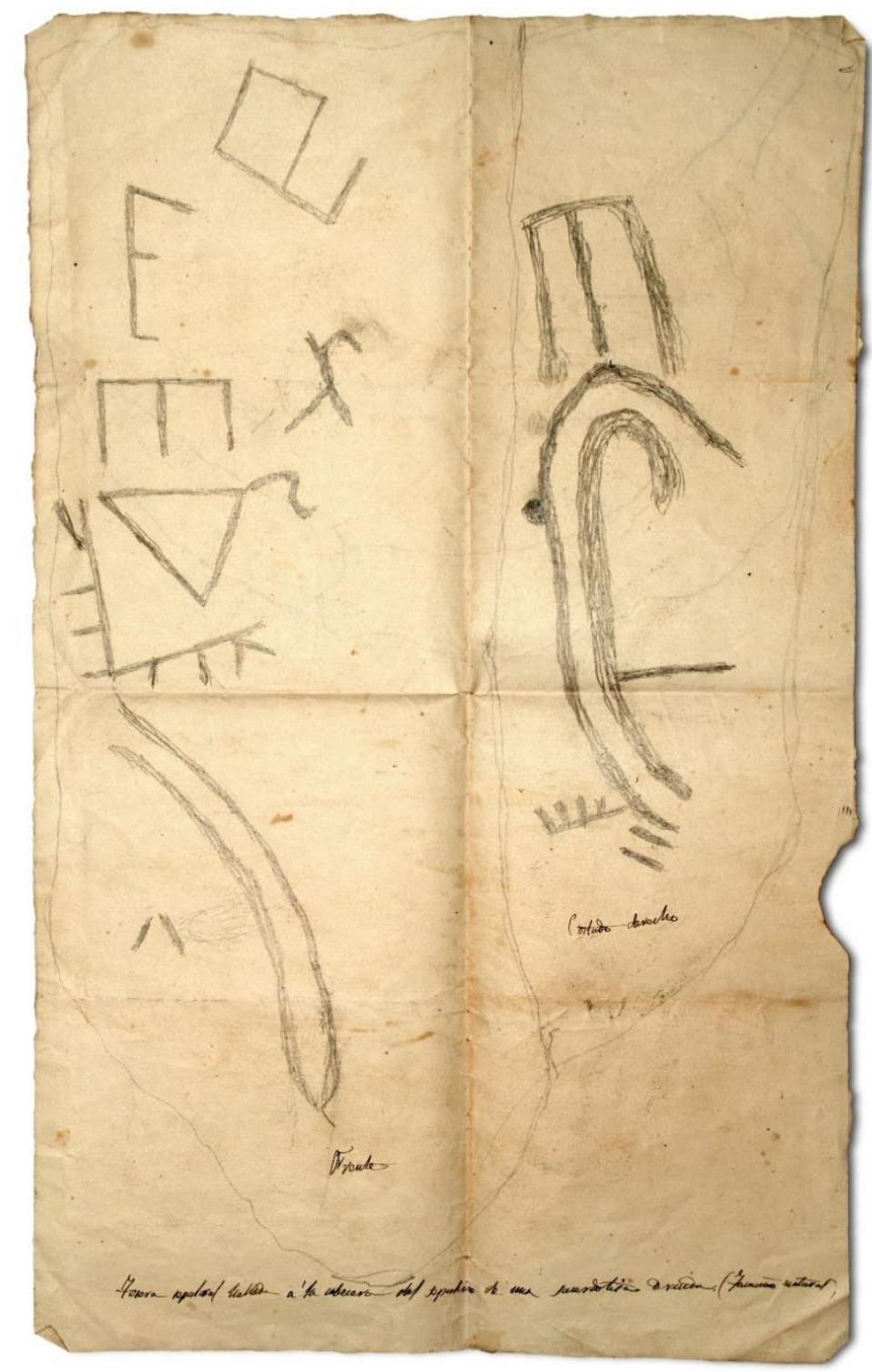

Fig. 10. Calco de estela de S. Cristóbal de Espinilla, 1892. Archivo Ángel de los Ríos, Torre de Proaño.

Será M. A. García Guinea (1948-1949: 214, nota 7) -significativamente, uno de los principales actores de la nueva arqueología medieval que comienza a desarrollarse en el norte de España a partir de mediados del siglo XX- quien vuelva a plantear una cronología medieval para este yacimiento, que considera que debe situarse 'entre lo visigodo y lo románico'. Poco después tendrá oportunidad de llevar a cabo la última excavación efectuada hasta la fecha en el cementerio, donde localizó una tumba de lajas que no conservaba restos óseos y una estela discoidea con la inscripción IERONCA en el anverso y una cruz techada en el reverso (García Guinea 1955). Estos hallazgos confirmarán la atribución de la necrópolis a un momento 
temprano de la Alta Edad Media, tal y como A. de los Ríos consideraba antes de iniciar en 1892 esa deriva druídica que tan convincente pareció durante más de medio siglo.

\section{La necrópolis de Quintanilla de Corvio}

Sobre esta necrópolis de tumbas excavadas en la roca existe un documento detallado, con descripción y dibujos $^{31}$, que será el que centre aquí nuestra atención, aunque el yacimiento y la estela que recogió allí aparecen mencionados con mayor o menor detalle en no menos de media docena de documentos del archivo personal de A. de los Ríos. El estudio fue realizado hacia 1865.

Sobre la ubicación de las tumbas excavadas en la roca, el documento refiere: 'Se hallan entre Corbio y Quintanilla de Corbio, más cerca (un tiro de fusil) al S.E. de este último lugar. Es una colina de piedra en partes cubierta de tierra y arbustos alta de unos 40 a 60 pies y tendida de S.E. a N.O. en cuyo extremo hay señales de una hermita o edificio hecho con mortero. Llamada el Cerro de San Vicente'. En la actualidad el lugar se encuentra cubierto de vegetación, no se distinguen más que un par de tumbas ${ }^{32}$ (Fig. 11), frente a los 'sobre 40 casi tocándose entre ellos 3 ó 4 de párvulos' que distingue A. de los Ríos, y no hay rastro de la posible ermita. Podría corresponderse con el lugar de Sant Vizente de Cantilo que el Libro Becerro de las Behetrías menciona en el Alfoz de Aguilar de Campoo.

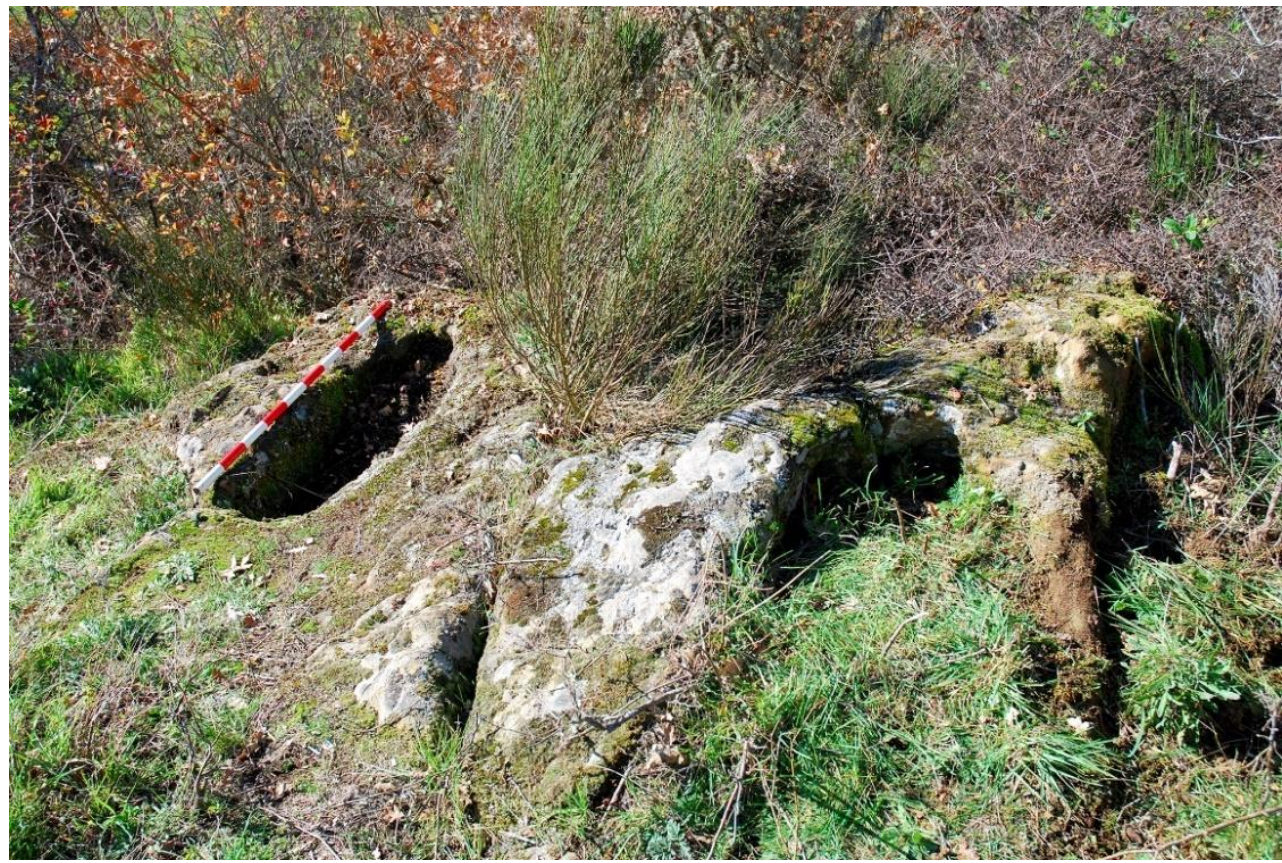

Fig. 11. Necrópolis de Quintanilla de Corvio en la actualidad.

El hallazgo de una estela discoidea en la que aparece una cruz es el principal elemento para establecer una cronología. Dice A. de los Ríos que 'la única señal que me hizo presumir fueran sepulcros cristianos es una piedra que conserva, rota y con señales de haber sido redonda, trazado en ella un círculo en hondo y

\footnotetext{
${ }^{31}$ Sepulcros de Corbio, s. f. Carpeta Proaño MA-6, Copia Instituto Sautuola, Archivo de A. de los Ríos, Torre de Proaño.

${ }^{32}$ La información sobre la ubicación de la necrópolis, que únicamente aparece señalada en un mapa de necrópolis excavadas en la roca del NE de Palencia (Nuño 2003: 146), nos fue facilitada por C. León Bustillo, arqueóloga del Servicio Territorial de Cultura de Palencia.
} 
dentro una cruz griega como la de Malta, en relieve'. De hecho, en un documento previo a su visita a la necrópolis especula con la posibilidad de que 'tal vez sea un cementerio céltico, ${ }^{33}$.

La estela fue remitida a la RAH en $1877^{34}$ junto con otras dos con inscripción procedentes de la citada necrópolis de San Cristóbal de Espinilla y del monasterio de San Pedro (Castrillo del Haya, Cantabria) a través de su hermano Valentín. En 1866 ya había remitido un informe en el que mencionaba la estela de Quintanilla de Corvio (RAH-S-9-7968-6/3). En la actualidad la estela (Fig. 12) se encuentra depositada en el Museo Arqueológico Nacional ( ${ }^{\circ}$ inv. 1907/32/108).

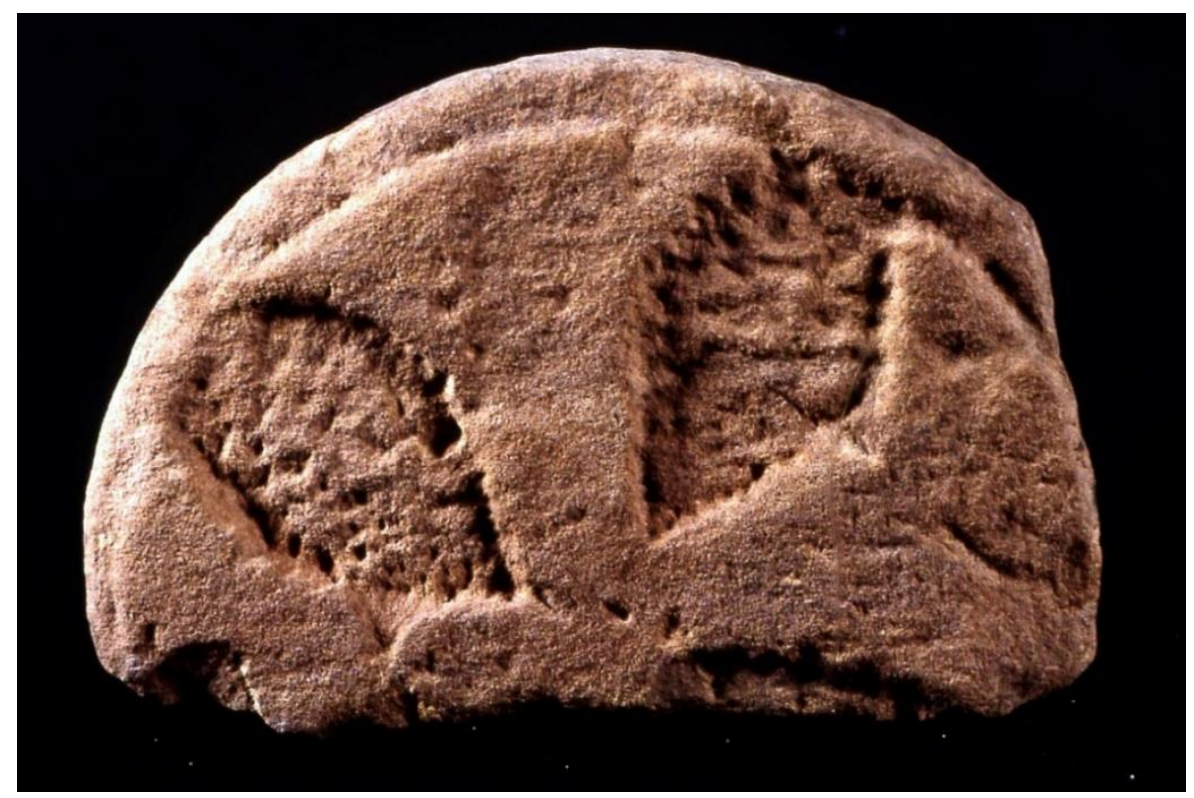

Fig. 12. Estela de Quintanilla de Corvio. Foto: (C) Museo Arqueológico Nacional.

Una de las ideas más interesantes que desarrolla A. de los Ríos sobre esta necrópolis es la identificación de determinadas asociaciones entre tumbas con agrupaciones de tipo familiar: 'Por lo que se deduce de la hechura de los sepulcros cuando son casi iguales y de dos en dos (como los mas) deben ser de marido y mujer el más estrecho y largo del hombre a quien la mujer da la derecha. Cuando son grande y pequeño juntos deben ser madre y su hijo', en la misma línea que planteará A. del Castillo (1970: 9-16) un siglo después para las necrópolis excavadas en la roca del Alto Arlanza. Sin embargo, remata la interpretación con una de sus aproximaciones intuitivas -ocurrencias, en muchas ocasiones cargadas de cierta ironía-, al considerar que 'igualmente los solos y anchos pueden ser de solterones o curas que suelen engordar'.

Lo más llamativo del trabajo de A. de los Ríos en esta necrópolis son los dibujos que acompañan a la descripción, en los que aparecen perfectamente delineadas las diferentes formas de cabecera: redondeada, cuadrangular, trapezoidal, y se han anotado las dimensiones y datos sobre inclinaciones, entre otros detalles (Fig. 13). Contrastan con las representaciones que más o menos en la misma época proponen otros estudiosos, más artísticas y menos científicas, como la que acompaña al estudio de B. Hernández Sanahuja sobre Olérdola, realizada en 1862 (Fig. 14). También hace constar otros datos relevantes como la orientación hacia el W de las cabeceras o la identificación de las cubiertas, reutilizadas en las cercas próximas a la necrópolis.

\footnotetext{
${ }^{33}$ Notas dadas por Pepe Cossío, s.f. Archivador III-M, Copia Instituto Sautuola, Archivo de A. de los Ríos, Torre de Proaño.

${ }^{34}$ Acuse de recibo de carta enviada a la RAH, 21 de abril de 1877. Sin ref., Copia Instituto Sautuola, Archivo de A. de los Ríos, Torre de Proaño.
} 


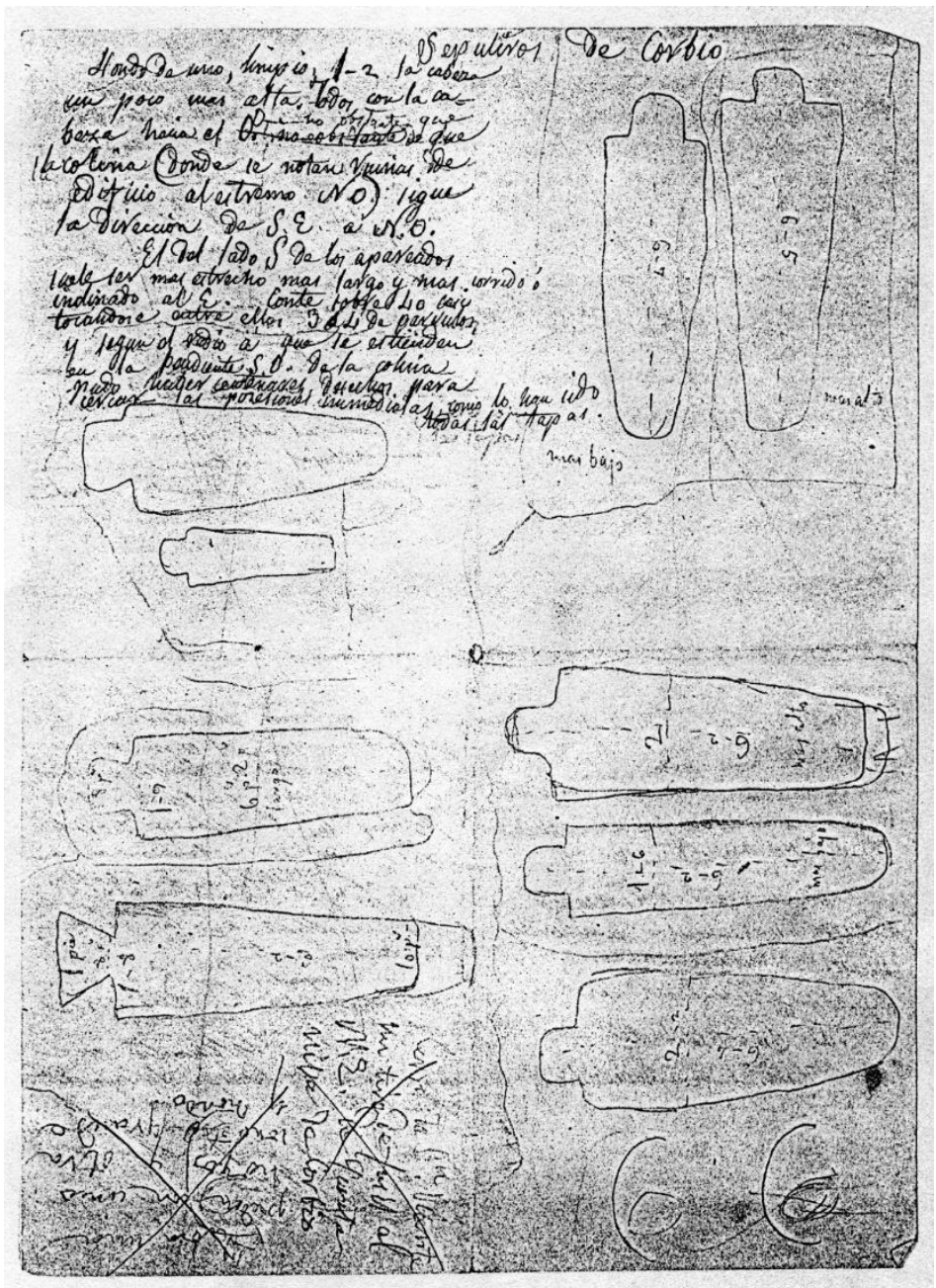

Fig. 13. Sepulcros de Corbio. Archivo A. de los Ríos, Torre de Proaño. Copia Instituto Sautuola.

La cronología de las tumbas excavadas en la roca era objeto de debate desde mediados del siglo XIX, siempre con la emblemática necrópolis de Sant Miquel d'Olérdola en el centro de la discusión (Molist 1999). Las voces más autorizadas situaban este tipo de manifestaciones funerarias en momentos anteriores a la romanización. Así, por ejemplo, B. Hernández Sanahuja consideraba en 1850 las tumbas de Olérdola como parte del legado de una 'civilización egipcia primitiva en España' (RAH-S- 9-7974-4/1). Y aunque A. de los Ríos no remitió su estudio completo sobre Quintanilla de Corvio a la RAH, las referencias sobre la asociación de la estela remitida en 1877 con tumbas excavadas en la roca sí serán tenidas en cuenta por los investigadores de esta institución. Será A. Fernández-Guerra (1875: 597), anticuario de la RAH desde 1867, uno de los primeros defensores del carácter cristiano de las tumbas excavadas en la roca, señalando la presencia de cruces en muchas de ellas, entre otras, esta de Quintanilla de Corvio. Aparecerá también mencionada en otros trabajos sobre el particular, como el de Botet y Sisó (1889: 238) que definitivamente cierre el debate y establezca la cronología de este tipo de tumbas entre los siglos VI y XII. De modo que, aunque sea de forma tímida e indirecta, sin participar abiertamente en el debate, A. de los Ríos contribuye a cimentar la cronología medieval de las tumbas excavadas en la roca. 


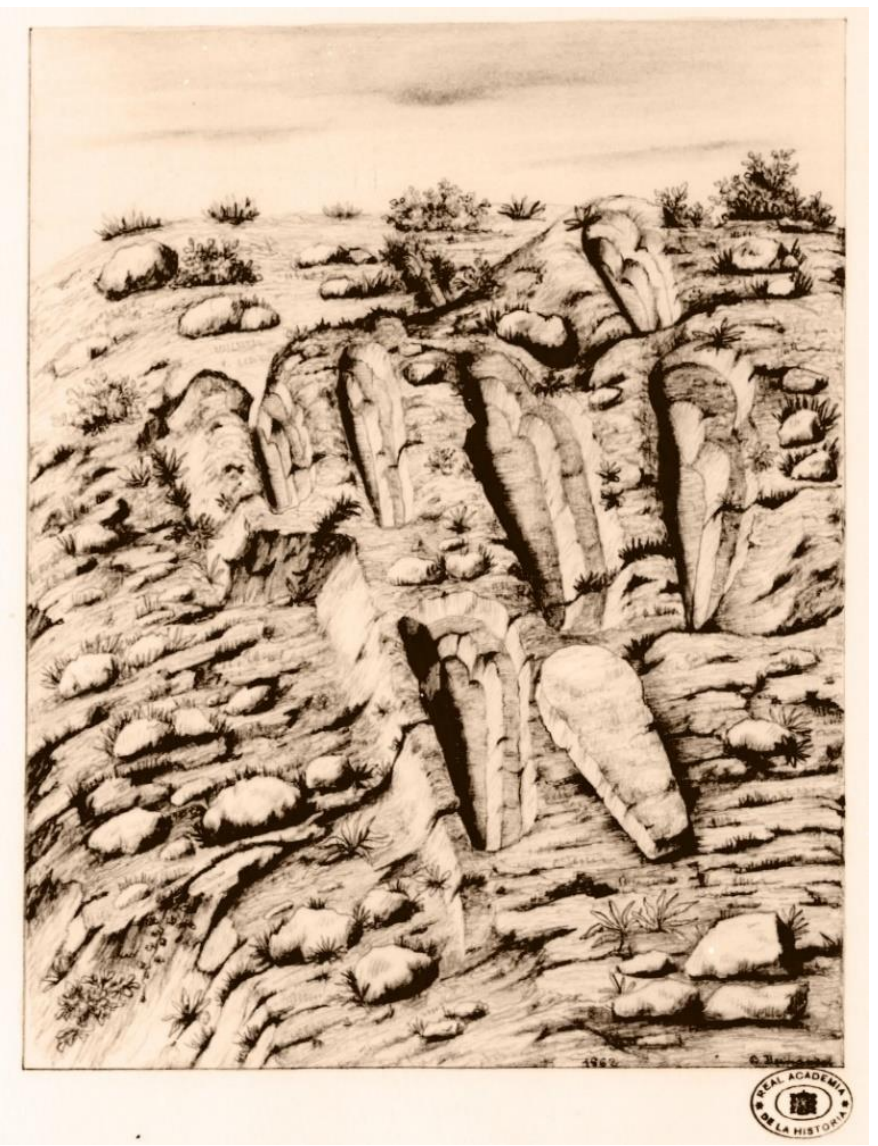

Fig. 14. Dibujo a lápiz de seis tumbas medievales. Dibujo: @ RAH, CAT/9/7974/08(7).

\section{Conclusiones}

A. de los Ríos desarrolló entre 1857 y 1899 una intensa actividad investigadora en el campo de los que, según los criterios de su época, se puede considerar arqueología medieval: estudio de inscripciones, ruinas, edificios, objetos, etc. El volumen y la calidad de sus estudios permiten considerarlo un pionero de la disciplina en el ámbito geográfico en el que desarrolla su actividad, principalmente Cantabria y de manera más ocasional el norte de Palencia y Burgos.

La escasa trascendencia que han tenido sus investigaciones sobre arqueología medieval tiene que ver con dos factores: la ausencia de publicaciones y falta de continuidad. Su figura, más próxima a la del erudito que a la del académico, queda deslucida por la ausencia de consolidación institucional, a pesar de su intensa labor como correspondiente de la RAH. Y, aunque la documentación conservada en su archivo personal es de gran interés, como se ha puesto manifiesto en estas páginas, las dificultades de acceso al mismo han contribuido a que se haya convertido en un recurso infrautilizado, si no ignorado. En cierto modo, la trayectoria truncada de este pionero de la arqueología medieval refleja bastante bien el proceso frustrado de la disciplina entre mediados del siglo XIX y principios del XX. Afortunadamente, en el caso del sector central de la montaña cantábrica, la recuperación no tendrá que esperar tanto como en otros lugares.

Los documentos conservados en la biblioteca de la Torre de Proaño muestran a A. de los Ríos como un erudito autodidacta, cuya obra está salpicada de ocurrencias o tesis 'ideicas', muchas veces abrigadas con citas clásicas o conocimiento etnográfico. Aunque muchas de sus opiniones son acertadas, resulta llamativo el hecho de que justamente una de sus propuestas menos afortunadas fue la que mayor eco tuvo 
en la investigación posterior. Su interpretación céltica, druídica, de las necrópolis de Espinilla se mantuvo vigente más de 50 años.

Consideramos que esta primera primera aproximación a la actividad investigadora de A. de los Ríos relacionada con la arqueología medieval es, además, una necesaria reivindicación de su figura y de su legado. Tanto de los resultados de su trabajo como de su valioso archivo personal, una fuente de información excepcional para entender la arqueología de la segunda mitad del siglo XIX.

\section{BibLIOGRAFíA}

Abascal, J.M. y Cebrián, R. (2005), Manuscritos sobre Antigüedades de la Real Academia de la Historia. Madrid. Real Academia de la Historia.

Bohigas Roldán, R. (1986), Yacimientos arqueológicos medievales del sector central de la montaña cantábrica. Santander. ACDPS.

Bolado Zubeldia, F. (1905), Estudio biográfico del cronista don Ángel de los Ríos. Santander. Imp. La Montaña.

Botet Sisó, J. (1889), 'Estudio sobre la antigüedad de algunas sepulturas talladas en la roca'. Revista de Gerona XIII: 236-247.

Cabrales Arteaga, J.M. (2013), Don Ángel de los Ríos: vida y obra. Madrid. Fundación Ignacio Larramendi.

Carballo, J. (1909), 'Una necrópolis en las minas de Solía (Santander)'. Boletín de la Real Sociedad Española de Historia Natural IX: 324-329.

Castillo, A. (1970), Excavaciones altomedievales en las provincias de Soria, Logroño y Burgos. Madrid. EAE 74.

Eiroa Rodríguez, J.A. (2006), Antigüedades medievales. Madrid. Real Academia de la Historia.

Fernández Acebo, V. (2007), 'Notas acerca del redescubrimiento de una lápida funeraria del siglo X en la ermita de San Miguel (Soto de Campoo, Cantabria)'. Altamira LXXIV: 171-180.

Fernández-Guerra Orbe, A. (1875), 'Sarcófago cristiano de la catedral de Astorga hoy depositado en el Museo Arqueológico Nacional'. Museo Español de Antigüedades VI: 587-601.

García Guinea, M.A. (1948), 'La iglesia románica de Santa María la Mayor de Villacantid (Santander)'. Boletín del Seminario de Arte y Arqueología XV: 211-239.

García Guinea, M.A. (1966), 'Sobre las cerámicas altomedievales de la Meseta Norte y Cantabria'. IX Congreso Nacional de Arqueología, Zaragoza: 415-418.

García Guinea, M.A. (1955), 'Una nueva estela de Espinilla (Santander)'. Boletín del Seminario de Arte y Arqueología XX: 225-227.

García Guinea, M.A., J. González Echegaray, y B. de la Campa. (1963), El Castellar, Villajimena (Palencia). Madrid. EAE 22.

Giménez, M.; Urbina C.; Lavín, A.C. y Espinosa, U. (1999), Comisión de Antigüedades de la Real Academia de la Historia: Catálogo e índices. Cantabria, País Vasco, Navarra, La Rioja. Madrid. RAH.

González Echegaray, J. (1966), Los Cántabros. Madrid. Guadarrama.

González Echegaray, J. (1950), 'Visita científica a Valdeolea'. Altamira VIII (1-2): 109-115.

Gutiérrez Cuenca, E. (2015), Génesis y evolución del cementerio medieval en Cantabria. Santander. Universidad de Cantabria. [hdl.handle.net/10803/311798]

Gutiérrez Cuenca, E. (en prensa), 'Un tenante de altar epigráfico altomedieval procedente de Campoo de Suso (Cantabria)' en Homenaje a Alberto Gómez Castanedo, Santander. Acanto.

Hoyos Sáinz, L. (1900), Etnografía: clasificaciones, prehistoria y razas americanas. Madrid. Romo y Füssel. Hoyos Sáinz, L. (1952), Ángel de los Ríos. Selección y estudios. Santander. Librería Moderna.

Madariaga Campa, B. (2002), Escritos de Marcelino Sáez de Sautuola y primeras noticias sobre el descubrimiento de la Cueva de Altamira. Santander. 
Marcos Martínez, J. y Mantecón Callejo, L. (2009), 'Trabajos de arqueología medieval en Campoo'. Cuadernos de Campoo 4 (ep. II): 45-67.

Martín de los Ríos, J. (2007), 'Don Ángel de los Ríos: el sordo de Proaño'. Cuadernos de Campoo 48: 2637.

Martín Gutiérrez, C. (2000), Estelas funerarias medievales de Cantabria (Sautuola VII). Santander. Gobierno de Cantabria.

Molist Capella, N. (1999), Olèrdola. Tarragona: Museu d'Arqueologia de Catalunya.

Montero, J. (1917), El solitario de Proaño. Santander. Imprenta Provincial.

Nuño González, J. (2003), 'Arqueología de los siglos románicos en el ámbito de la actual provincia de Palencia' en Palencia en los siglos del Románico, Aguilar de Campoo. Fundación Santa María la Real-Ayto. de Aguilar de Campoo: 129-165.

Ordieres Díez, I. (1993), Historia de la conservación del patrimonio cultural de Cantabria (1835-1936). Santander. Fundación Marcelino Botín.

Ríos y Ríos, A. (1857), 'Monumentos célticos de Campóo'. Semanario Pintoresco Español XXII: 249-252.

Ríos y Ríos, A. (1889). 'Campamentos romanos de Julióbriga'. Boletín de la Real Academia de la Historia 14: $510-513$.

Ríos y Ríos, A. (1895), 'Ermita de Santa Marina, en Campóo de Suso'. Nuevo Mundo 78: 384-385.

Salvatierra Cuenca, V. (2013), 'La primera arqueología medieval española. Análisis de un proceso frustrado (1844-1925)'. Studia Historica. Historia Medieval 31: 183-210.

Teira Mayolini, L.C. y Ontañón Peredo, R. (2016), 'Conjunto de hitos y estelas antropomorfas del Collado de Sejos' en Después de Altamira: Arte y grafismo rupestre post-paleolítico en Cantabria. Santander. Acanto: 271-276. 


\title{
Pedro de Madrazo y la arqueología española del siglo XIX
}

\author{
Alegra García García \\ Universidad Nacional de Educación a Distancia
}

El pasado año de 2016 tuvo lugar el bicentenario del nacimiento de Pedro de Madrazo y Kuntz (18161898), literato, académico, historiador y crítico de arte que a pesar de formar parte- o tal vez debido a ello- de una de las familias fundamentales en la vida cultural española del siglo XIX es uno de los grandes desconocidos de nuestra historiografía histórico-artística. No en vano, es frecuente encontrar en páginas web de mayor o menor rigurosidad pero gran alcance e incluso en libros especializados errores de bulto relativos a sus avatares vitales y profesionales, fruto sin duda en muchos casos de la obvia - aunque no disculpable- confusión que genera la prolífica saga de los Madrazo, cuyos miembros - con el patriarca José y su hijo Federico, hermano de Pedro como más destacados exponentes- estuvieron vinculados a la pintura, la arquitectura y la gestión de importantes instituciones del momento.

Sólo desde el ámbito de la literatura Pedro de Madrazo ha recibido en los últimos años cierta atención pormenorizada, especialmente de la mano de las investigaciones de Borja Rodríguez Gutiérrez (2005, 2011), quien ha intentado reivindicar a través de artículos y libros el papel de Pedro de Madrazo en nuestra literatura romántica. En cuanto a su faceta de historiador y crítico del arte, su aportación ha sido abordada de manera sucinta, casi nunca de manera monográfica e intensiva, siendo su nombre y algunas de sus obras mencionadas en textos sobre cuestiones más generales como las publicaciones periódicas del siglo XIX, la historiografía de la arquitectura o la crítica de arte.

Tratamiento similar ha tenido su figura en lo concerniente a la bibliografía de tema arqueológico. Si bien Pedro de Madrazo cuenta con una entrada en el Diccionario histórico de la arqueología en España (DíazAndreu García et alii, 2009), donde se hace una mención muy genérica a algunas de sus publicaciones y a su intento de excavación de Medina Azahara, en términos generales sólo es aludido y despachado en una línea o nota a pie en publicaciones relacionadas con la historia de la arqueología en España o las excavaciones de Guarrazar y de la ya mencionada ciudad palatina de Abd al-Rahman III.

Así pues, el objetivo de esta aportación es estudiar y valorar la figura y aportaciones de Pedro de Madrazo en el contexto de la gestación de la arqueología como disciplina durante el siglo XIX, tomando como punto de partida sus publicaciones de tema arqueológico, su desempeño en las academias de San Fernando y de la Historia así como su correspondencia privada y su vinculación personal a algunas excavaciones.

\section{Pedro de Madrazo: una vida rodeada de arte y artistas}

Pedro de Madrazo nació en Roma en 1816, hijo del pintor de corte José de Madrazo y de Isabel Kuntz, hija del pintor polaco Tadeus Kuntz; su hermano Federico había nacido un año antes. Siendo aún muy pequeño -demasiado para que el patrimonio romano dejase alguna impronta en su memoria-, Pedro regresa junto a su familia a España en 1819 y entre 1827 y 1831 cursa estudios en el Seminario de Nobles de Madrid, donde coincide, por primera pero no última vez, con José Zorrilla, un año menor que él. También compartirá estudios con el poeta vallisoletano en Toledo, cursando el bachiller entre 1832 y 1833, y en Valladolid, realizando la carrera de leyes hasta 1834. A finales de la década de 1830 viajará con Federico a París, donde se encontraba también el pintor Carlos Luis de Ribera, y después marchará a Bélgica, para a su regreso a España desarrollar en lo sucesivo, como muchos otros personajes del siglo XIX español, una doble carrera paralela en el campo del derecho y la política -llegará a ser secretario general del Consejo de Estado y senador por la Academia de Bellas Artes de San Fernando- y de la historia del arte. Además de miembro de las tres Academias, será nombrado secretario perpetuo de la Real 
Academia de Historia, director de la Academia de Bellas Artes tras la muerte de su hermano Federico en 1894 y director del Museo de Arte Moderno en 1897. Fallecerá un año después en Madrid.

Madrazo se rodeará desde su más temprana juventud de importantes personajes de la vida cultural española del momento. En su etapa de estudiante había coincidido no sólo con José Zorrilla, sino también con Enrique Gil y Carrasco. En Madrid frecuentará la tertulia de El Parnasillo, que se celebraba a comienzos de la década de 1830 en el madrileño Café del Príncipe junto a literatos y artistas como Mariano José de Larra, José Espronceda, Ventura de la Vega y Antonio María Esquivel y en París se relacionará con el barón Taylor y el pintor Adrien Dauzats, asiduos visitantes de España y buenos amigos de la familia Madrazo. Ya de regreso a España, acudirá a numerosas tertulias literarias, siendo un habitual de las crónicas de sociedad debido a sus recitales poéticos, y se moverá en el círculo de amistades de Mariano Roca de Togores, marqués de Molíns, donde coincidirá con personajes como Juan Eugenio Hartzenbusch, Leopoldo Augusto de Cueto, marqués de Valmar, José Amador de los Ríos, Ramón Campoamor o Manuel Bretón de los Herreros. Asimismo, a lo largo de toda su vida mantendrá una gran amistad con Valentín Carderera, escritor, dibujante, pintor, coleccionista y viajero incansable, fundamental en la difusión y protección del patrimonio histórico-artístico durante el siglo XIX.

Volviendo a su ámbito familiar, al margen de los cargos que llegaron a ocupar su padre y hermanos, conviene recordar la importancia de los Madrazo en el mundo del coleccionismo, que incluía además de pintura y escultura, objetos que hoy consideraríamos parte de colecciones de museos arqueológicos ${ }^{1}$. Así, su padre José llegó a atesorar una importante colección de libros, pintura y grabados y Mariano Fortuny, casado con su sobrina Cecilia, fue un destacado coleccionista interesado por pequeños bronces de animales, armas y armaduras de los siglos XV a XVIII, cerámicas y, sobre todo textiles, muchos de ellos procedentes de Oriente. Entre las piezas atesoradas por Fortuny, algunas de las cuales serían introducidas en sus pinturas, destacan el conocido como vaso de Fortuny, una pieza hispanomusulmana del siglo XIV que, tras ser vendida por su viuda, acabó formando parte de las colecciones del Museo del Hermitage y la pieza zoomorfa de bronce, hoy en el Museo del Louvre, conocida como ‘el león de Monzón’.

Como puede observarse, Pedro de Madrazo se mueve y relaciona en el ambiente del Madrid isabelino y romántico, dando sus primeros pasos en la historia y la crítica de arte paralelamente al desarrollo de las primeras iniciativas arqueológicas en España en un momento, el Romanticismo, en que la línea que separa arte y arqueología es aún tenue y esta última comprende, de manera amplia, el 'estudio de las cosas antiguas'. Así, estará visitando las ruinas de Itálica a mediados de la década de 1830 poco antes de que comiencen las excavaciones e impartirá en el Ateneo de Madrid entre 1843-44 la cátedra de ideas estéticas, institución en la que ya existía desde 1837 y seguirá funcionando hasta 1846 la de Arqueología Monumental, impartida por Basilio Sebastián Castellanos.

\section{Presencia en excavaciones: el caso de Medina-Azahara y Guarrazar}

A lo largo del siglo XIX se producirán importantes hallazgos arqueológicos en la Península de la mano de diversas campañas de excavación. Baste recordar, por citar sólo algunos, los casos de Mérida (desde 1836), Itálica (desde1839), Numancia, Sagunto y Tarraco (desde mediados de siglo) y, ya a finales de la centuria, el Cerro de los Santos (desde 1871). Debido a sus cargos en las Academia de la Historia y de Bellas Artes, Madrazo pudo seguir los avances de algunas de estas campañas; además, llegó a ser el promotor de una y estuvo presente en otra. Nos referimos, respectivamente, a Medina Azahara y Guarrazar.

\footnotetext{
${ }^{1}$ También fueron los Madrazo habituales asesores artísticos de destacados personajes de la aristocracia española y extranjera. Recuérdese, por ejemplo, el no exento de polémica asesoramiento a los franceses Adrien Dauzats y el barón Taylor cuando estos vinieron a España a comprar obras españolas para la Galería Española de Luis Felipe de Orleans.
} 
Fue la redacción del volumen dedicado a Córdoba para la colección de Francisco Javier Parcerisa Recuerdos y bellezas de España lo que le llevó en la primavera de 1853 hasta esta ciudad y sus inmediaciones con el fin de documentarse. Así, en mayo de ese año Pedro de Madrazo visitó los terrenos conocidos como la dehesa de Córdoba la Vieja, situados a escasos kilómetros de la ciudad, y, tras inspeccionar las ruinas que allí se encontraban, dedujo que aquella era la localización del conjunto palatino de Medina Azahara (siglo X d.C.), cuya ubicación hasta el momento había sido objeto de controversia, si bien algunos autores habían propuesto ya con anterioridad esta identificación. A este acontecimiento siguió el primer intento serio de excavación, cincuenta años antes de la campaña emprendida por el arquitecto Ricardo Velázquez Bosco (1843-1923). Conocemos gran parte del desarrollo de esta empresa, fallida, gracias a la correspondencia privada, conservada en la Fundación Lázaro Galdiano y la Biblioteca Nacional de España, que Madrazo mantuvo con varias personas pertenecientes a la comisión que se creó en Córdoba para dirigir unas excavaciones que, a pesar del empeño personal de Madrazo, terminaron al poco de comenzar debido a las severas e inamovibles condiciones que el dueño de los terrenos, el Marqués de Guadalcázar, impuso y a la coyuntura política (Vicalvarada del verano de 1854 al mando del general Leopoldo O'Donnell). Además de las epístolas, conservamos un borrador de informe en el que Madrazo establece las pautas a seguir durante la excavación, relativas a la custodia y almacenamiento de los objetos que se localicen.

De este descubrimiento han quedado el testimonio del propio Madrazo en su volumen de Córdoba, en el que incluyó los dibujos de varios fragmentos de ataurique que recogió en la dehesa de Córdoba la Vieja, y diversos artículos y textos debidos a él y otros personajes de la época en los que se hacía eco de un descubrimiento frustrado que, de haber contado con unas circunstancias más favorables, hubiera sido sin duda uno de los más importantes hallazgos arqueológicos del siglo XIX.

Más productiva resultó la participación de Madrazo en uno de los grandes hitos de la arqueología del siglo XIX: la localización del tesoro de Guarrazar, ocurrida de manera casual en 1858 tras unas lluvias torrenciales que dejaron a la vista dos cajas escondidas bajo tierra junto a la iglesia del monasterio de Santa María de Sorbaces, en Guadamur (Toledo). Parte de las alhajas fue llevada de manera subrepticia a París, lo que dio lugar a un gran escándalo que motivó el inicio oficial de las excavaciones en 1859 mediante Real Orden expedida por el Ministro de Fomento al gobernador de la provincia de Toledo. Según narra el propio Pedro de Madrazo en una de sus monografías para Monumentos Arquitectónicos de España, quedó establecido, a fin de evitar más robos, que las excavaciones sólo se realizasen delante del Gobernador o un delegado suyo, de dos individuos de la Academia de la Historia, de uno de la Comisión de Monumentos y de un oficial auxiliar del Ministerio. Pedro de Madrazo y el profesor de la Escuela Superior de Arquitectura Jerónimo de la Gándara acudieron hasta el yacimiento, descubriéndose un enterramiento correspondiente al presbítero Crispinus, fallecido a finales del siglo VII d.C.

El motivo por el que Madrazo acudió a Toledo hay que buscarlo, según él mismo relata en carta aparecida el 3 de mayo de 1859 en La Época, en que había ofrecido a la Real Academia de Historia, de la que era miembro desde febrero de ese mismo año, una memoria acerca de las coronas visigodas. Para que pudiese tener al día su trabajo de investigación se le permitió sumarse a las exploraciones, de manera que marchó con de la Gándara a corregir algunos errores en el trazado de planos. Fue entonces cuando descubrieron la sepultura de Crispín:

Era la primera vez de nuestra vida que, asistiendo al solemne espectáculo de la exhumación de un despojo humano de mil ciento y sesenta y seis años de antigüedad, disfrutábamos el inefable placer de descubrir originalmente esculpida en un monumento ignorado y casi intacto una fecha tan remota'.

Dos años más tarde, en 1861, tras ser entregada a la Reina la parte restante del tesoro que había sido guardada por un campesino, Madrazo y José Amador de los Ríos fueron llamados por Antonio Flores, secretario de la Intendencia de la Real Casa y Patrimonio a su despacho. 
Acerca de las piezas del tesoro entregadas a los franceses, declarará en una publicación posterior (Madrazo 1874: 37):

'para nosotros no fue una adquisición legítima, sino un mero acto de fuerza el del Gobierno francés al comprar al diamantista Navarro estas alhajas del tesoro de nuestros reyes visigodos: alhajas espiritualizadas por ofrenda de los mismos a la iglesia de España, y no abandonadas por ésta, sino simplemente escondidas con ánimo de recobrarlas pasada la calamidad de la irrupción agarena'.

\section{Artículos de tema arqueológico en la prensa de la época}

En 1835 Federico de Madrazo y Eugenio de Ochoa comienzan a publicar El Artista, revista sobre literatura y bellas artes inspirada en la francesa L'Artiste, de corta vida, pero gran importancia para la introducción de las ideas románticas en España. En ella Pedro de Madrazo publica varios poemas y relatos breves y da sus primeros pasos en la historia y la crítica de arte con comentarios a las exposiciones de la Real Academia de San Fernando y pequeños textos sobre artistas y obras destacados. Asimismo, se percibe ya su preocupación e interés por la protección del patrimonio, como deja patente por ejemplo el artículo 'Bellas Artes. Demolición de conventos', que fue publicado en varios periódicos además de El Artista. También encontramos alguna referencia, si bien sucinta, a su afición por la búsqueda de antigüedades y libros antiguos. Tal es el caso de la siguiente frase, aparecida en un artículo titulado 'Adición. A un personaje desconocido', en torno a su relato Alberto Regadón, aparecido en la misma revista:

'Viajaba yo por la Andalucía en busca de antigüedades y de manuscritos empolvados y carcomidos; llegue a Santiponce con el ánimo de hacer algún notable descubrimiento sobre las ruinas de la famosa Itálica' (Madrazo 1835: 203).

En los años siguientes publicaría en la revista El Renacimiento (1847) algunos textos relacionados con la decadencia y renacimiento de las artes, especialmente la arquitectura, y, ya en 1857, verían la luz en Semanario Pintoresco Español, la publicación fundada por Ramón de Mesonero Romanos, dos pequeños artículos de título 'Los hijos del yermo' y 'La dehesa de Córdoba la Vieja'. En ellos narraba su excursión a Córdoba la Vieja, que antes hemos comentado, y acompañaba el texto con la ilustración de varios fragmentos de ataurique copiados del natural por el pintor toledano Cecilio Pizarro (1825-1886), indicándose en la leyenda que son propiedad de Pedro de Madrazo.

En los años siguientes, y ya hasta su muerte, el tema arqueológico apenas está presente en los numerosos artículos que escribirá para importantes revistas como La Ilustración Española y Americana, publicación surgida como continuación del Museo Universal que se editó entre 1869 y 1921. Su selección de temas virará hacia la pintura, especialmente la del Siglo de Oro, y la teoría y estética del arte, volviendo a retomar la poesía, sobre todo la de tema religioso y moralizante. Las cuestiones arqueológicas las reservará para dos grandes y ambiciosos proyectos editoriales que comentaremos a continuación.

\section{Dos monografías para Monumentos Arquitectónicos de España}

Uno de los grandes proyectos editoriales de la segunda mitad del siglo XIX destinado al estudio y difusión del patrimonio histórico-artístico español fue Monumentos Arquitectónicos de España ${ }^{2}$. Promovida desde la Escuela Superior de Arquitectura y continuada desde 1870 por la Academia de Bellas Artes de San Fernando, esta publicación fue concebida como una edición de lujo que aunaba texto con litografías y cromolitografías de gran calidad, precisión técnica y tamaño. Su edición se desarrolló entre 1856 y 1881 y sus monografías fueron escritas por los principales eruditos del momento en materia de arte y arqueología. No exenta de dificultades (una de ellas la escasez de grabadores y litógrafos españoles y de material para la correcta realización de litografías, que en ambos casos se tuvo que traer del extranjero),

\footnotetext{
${ }^{2}$ Para conocer mejor el origen y desarrollo de publicación: Monumentos arquitectónicos de España (1852-1881) [catálogo de exposición] (2014). Madrid. Calcografía Nacional de la Real Academia de Bellas Artes de San Fernando.
} 
la empresa, demasiado costosa, quedó incompleta. Pedro de Madrazo, que pertenecía a la comisión organizadora del proyecto junto a José Amador de los Ríos y Manuel de Assas en calidad de autores 'especializados en estudios arqueológicos', contribuyó con dos monografías: La Universidad complutense, aparecida en 1878 junto a siete láminas, y Orfebrería de la época visigoda. Coronas y cruces del tesoro de Guarrazar, que se publicó en 1879 acompañada de tres láminas.

Es esta última una monografía de gran extensión, extensión que Madrazo justifica alegando que algunos aspectos por él tratados no habían sido debidamente estudiados con anterioridad, a pesar de la aparición en 1861 del importante texto de José Amador de los Ríos El Arte latino-bizantino en España, que Madrazo citará y alabará con frecuencia. Dividido en seis apartados, que incluyen desde la descripción de los objetos que componen el Tesoro a la narración de su descubrimiento, parece que inicialmente este texto iba a ser realizado conjuntamente por Madrazo y Amador de los Ríos, encargándose éste de la descripción de las piezas. No podrá faltar, tampoco, la alusión a su amigo desde su juventud Manuel de Assas, a quien le cabe 'la gloria de haber iniciado en España el estudio del verdadero arte visigodo'.

\section{Pedro de Madrazo y el Museo Español de Antigüedades}

El Museo Arqueológico Nacional había sido fundado en 1867 por Isabel II, teniendo su primera sede hasta finales de siglo en el denominado Casino de la Reina, una pequeña finca situada en los alrededores de la actual glorieta de Embajadores que en 1817 el Ayuntamiento de Madrid había regalado a la malhadada esposa de Fernando VII Isabel de Braganza. Allí se instalaron las colecciones del museo, formadas inicialmente, tal como se establecía en el decreto de fundación, por los fondos procedentes del Museo de Medallas y Antigüedades de la Biblioteca Nacional, del Museo de Ciencias Naturales y la colección de la Escuela Superior de Diplomática. A este conjunto inicial se unirían poco después objetos de donaciones y compras, así como de varias Comisiones Científicas llevadas a cabo dentro y fuera de España. Destaca, en relación con estas expediciones internacionales, la emprendida por la fragata Arapiles a Oriente con la finalidad de adquirir piezas para el Museo Arqueológico. Juan de Dios de la Rada y Delgado (1829-1901), que sería nombrado director de la institución en 1891, fue el responsable de esta expedición que trajo a España objetos arqueológicos de Grecia, Sicilia o Chipre entre otros lugares.

Precisamente fue Rada y Delgado el fundador en 1872 de la revista Museo Español de Antigüedades, publicación editada por José Gil Dorregaray y concebida como complemento de la ya citada Monumentos Arquitectónicos. Considerada por algunos de manera oficiosa la revista del Museo Arqueológico Nacional, sus más de 300 monografías, organizadas en once tomos que vieron la luz desde 1872 hasta 1880, estaban dedicadas a objetos arqueológicos y artísticos hoy conservados no sólo en el Museo Arqueológico, sino también en el Museo del Prado, catedrales y colecciones privadas. Cada monografía solía ir acompañada de varias láminas (litografías y cromolitografías de gran calidad) y los escritores fueron tanto facultativos del propio museo (Manuel de Assas, José Amador de los Ríos- director del Museo en 1868-, Vicente Boronat, el propio Juan de Dios de la Rada...), como autores considerados especialistas en materia de arqueología y arte (Isidoro Rosell y Torres, Francisco María Tubino). Dentro de esta última categoría podría encuadrarse a Pedro de Madrazo, que por aquel entonces ya era académico de San Fernando y de la Historia y, en lo político, estaba ocupando durante aquellos años el puesto de Secretario General del Consejo de Estado. En cuanto a las ilustraciones, como ha señalado Gloria Mora, aún fueron realizadas por artistas y no arqueólogos, si bien el 'aura romántica' propia de ilustraciones de décadas anteriores (recuérdense por ejemplo las de Francisco Javier Parcerisa para Recuerdos y bellezas de España) había dado paso a 'ilustraciones frías, exactas, más semejantes a una fotografía' (1995:169).

Pedro de Madrazo llegaría a publicar más de diez monografías en el Museo Español... desde 1872 hasta 1880. Se conservan, asimismo, el texto y las láminas que habrían debido ilustrar una monografía sobre pintura cristiana destinada al volumen número XI, que quedó incompleto. Los dibujos de estas láminas fueron realizados por el propio Madrazo. 
La temática diversa de las monografías da buena muestra de la variedad de intereses artísticos de Madrazo. Así, en el tomo I, aparecido en 1872, se incluyeron en el Museo español... dos textos dedicados a la colección de vasos italo-griegos del Museo Arqueológico Nacional y al mausoleo de los Reyes Católicos en Granada, obra de Bartolomé Ordóñez. En ambos casos los escritos se acompañaron de cromolitografías. Las correspondientes a los vasos fueron pintadas la primera por A.L. y cromolitografiada por Teófilo Rufflé y, la segunda, pintada por J. Nicolau y cromolitografiada por Eusebio de Letre. En cuanto al sepulcro de los Reyes Católicos, se incluyó una sola litografía firmada por Francisco Aznar.

En el tomo II, de 1873, Madrazo publicó una única monografía sobre la reproducción de la estela del soldado de Maratón Aristión, cuyo original se encontraba en Atenas y del que se había sacado copia durante la expedición del Arapiles. Latorre dibujó y Eusebio de Letre cromolitografió la única lámina que acompañaba al texto.

El año 1875 vio la publicación de los tomos IV, V y VI, en los que se incluyeron varios textos de Madrazo dedicados fundamentalmente a pinturas, esculturas y objetos de orfebrería conservados en el Museo del Prado, piezas que Madrazo conocía bien al ser él el responsable desde la década de 1840 de los catálogos del museo. En el caso del tomo IV se estudiaban las pinturas El Triunfo de la Iglesia sobre la Sinagoga (hoy Fuente de la Gracia, atribuida al taller de Jan van Eyck e incorporada a las colecciones del Museo del Prado en 1872), El Descendimiento de Roger van der Weyden y el Tesoro del Delfín. En el tomo V apareció una monografía dedicada a una pintura mural de la Almoyna de Barcelona, otra sobre San Salvador de Leyre, panteón de los reyes de Navarra, y La Coronación de la Virgen de Juan Vicente Macip (erróneamente identificado por Madrazo como Juan de Juanes), obra del Museo del Prado. En el tomo VI, por su parte, se incluyeron dos artículos: el primero sobre una escultura de la diosa Minerva (Museo del Prado) y el segundo, retomando el tema navarro, dedicado a un retablo de esmalte conservado en el santuario de San Miguel de Excelsis. Todos ellos se acompañaban de cromolitografías de gran calidad realizadas por artistas y grabadores como Ramón Soldevila (cromolitografías de Fuente de la Gracia y Descendimiento, Salero del Tesoro del Delfín), Jaume Serra (pintura de la Almoyna) o Francisco Aznar (pintura de la Almoyna).

Las siguientes tres colaboraciones de Madrazo serán esporádicas y aparecerán en los tomos IX, X y XI (años 1878, 1880 y 1881 respectivamente). Se trata de monografías sobre la espada del Duque de Alba, la importante tapicería del siglo XVI dedicada al Apocalipsis (hoy en Patrimonio Nacional) ${ }^{3}$ y el ambicioso y extenso ensayo que llevaba por título 'Bosquejo histórico de la pintura cristiana en España desde su principio hasta el Renacimiento', perteneciente al volumen XI, que quedó incompleto. En este caso las láminas corrieron a cargo de Ricardo Arredondo (dibujo de la espada del Duque de Alba), Juan Barroeta y Domingo Martínez (respectivamente dibujo y grabado de las ocho láminas dedicadas a los tapices del Apocalipsis) y el propio Madrazo, que calcó los dibujos de la última monografía.

Como comentábamos más arriba, es fácil comprobar la variedad de objetos y períodos que suscitaron el interés de Madrazo, si bien puede apreciarse que su campo de estudio giraba en torno a las colecciones del Museo del Prado, de lo que sería después Patrimonio Nacional (cuyos archivos conocía muy bien y había consultado numerosas veces para otras publicaciones) y, en menor medida, el Museo Arqueológico Nacional. Característico de todas estas monografías será la inclusión a su inicio de una amplia introducción retrotrayéndose a los orígenes del objeto a estudiar; así, en el caso de la tapicería del Apocalipsis, llegará a remontarse hasta el uso de la tapicería en la Edad Antigua (siendo los tapices objeto de estudio de mediados del siglo XVI), y para la espada del Duque de Alba trazará un amplio excursus sobre las connotaciones de la espada como defensa del caballero. Destacarán también las monografías por la

\footnotetext{
${ }^{3}$ Este conjunto de ocho tapices fue encargado por Carlos V en Flandes a Willem de Pannemaker, partiendo de cartones para tapiz del pintor Bernard van Orley inspirados en estampas de Alberto Durero. Se encuentra en la actualidad en La Granja de San Ildefonso, Segovia.
} 
variedad y cantidad de fuentes empleadas (incluso en latín y griego), convirtiéndose algunas en auténticos alardes de erudición para su autor.

\section{La arqueología en la correspondencia privada de Pedro de Madrazo}

De gran importancia para conocer sus inquietudes intelectuales y su círculo de amistades y contactos profesionales es la correspondencia de Pedro de Madrazo, conservada en su mayor parte en el archivo de la Fundación Lázaro Galdiano ${ }^{4}$. Otras cartas relevantes -como varias de las relacionadas con el intento de excavación de Medina Azahara que ya hemos comentado- se encuentran en la Biblioteca Nacional de España. A través de todas ellas queda patente una vez más la variedad de temas que despertaron su interés y que en muchos casos abordaría en sus publicaciones.

Así, por ejemplo, Madrazo cruzó correspondencia con Ricardo Velázquez Bosco (1843-1923) en $1867^{5}$. El futuro arquitecto se encontraba desde 1863 en León, donde trabaría amistad con Fidel Fita, por entonces vicepresidente de la Comisión Provincial de Monumentos. Durante esos años, y hasta 1870, Velázquez Bosco se encontraba vinculado a la restauración de la catedral de León -que había comenzado en 1859 bajo la dirección de Matías Laviña Blasco- y, desde 1866 formaba parte de la Comisión de Monumentos de León con el cargo de secretario. Para ella, además de realizar apuntes y dibujos varios, localizaría y recogería restos arqueológicos por toda la comarca leonesa. Precisamente, las cuatro cartas que Velázquez dirigió entre mayo y agosto de 1867 a Pedro de Madrazo, miembro de la Comisión Permanente de Monumentos, tenían como finalidad informar del avance de las diferentes inspecciones arqueológicas y del descubrimiento de posibles nuevos yacimientos. Aunque no nos consta que se conserven borradores o copias de las cartas enviadas por Madrazo a Velázquez Bosco, de las misivas de éste se deduce que cruzaron correspondencia y que previamente se habían entrevistado en persona, encargando Madrazo a Velázquez Bosco que le informase puntualmente de sus hallazgos en suelo leonés ${ }^{6}$.

A lo largo de las cuatro cartas conservadas, Velázquez Bosco da cuenta de varios descubrimientos e insiste en la necesidad de recibir más dinero a fin de continuar con las obras emprendidas en la catedral y el Panteón de san Isidoro y de dotar de una mínima protección a algunos yacimientos que se estaban viendo afectados por el expolio de los lugareños. Además de hacer mención de la localización de unos hornos romanos en Quintana de Raneros y el posible hallazgo de una mina de oro explotada por romanos en Astorga entre otros asuntos, Velázquez Bosco dedica especial atención al inicio de unos trabajos de excavación en Villasabariego, donde se habían encontrado mosaicos, restos de esculturas, monedas de Antonino y Faustina y un cementerio. Ya en la carta con fecha de 2 de junio Velázquez Bosco se atreve a aventurar si no será aquella la antigua Lancia astur y romana ${ }^{7}$. Ignoramos la respuesta de Madrazo, pero en las cartas sucesivas Velázquez Bosco se referirá al yacimiento como Lancia, de donde tomará algunos objetos pequeños (menciona un collar y unos pendientes pertenecientes al cadáver de una joven) que, según se indica en la misiva, fueron enviados a Madrazo junto a un croquis del terreno realizado a vuelapluma.

\footnotetext{
${ }^{4} \mathrm{Su}$ fecha de ingreso en la biblioteca de José Lázaro se ignora. Parte de este fondo se encuentra en el momento de redacción de este texto en estudio y catalogación gracias al proyecto de investigación La literatura y las artes en epistolarios españoles del siglo XIX. Proyecto I+D+i del Ministerio de Ciencia e Innovación HAR2011-26660. Web del proyecto: http://www.bibliotecalazarogaldiano.es/laee/.

${ }_{6}^{5}$ Madrazo, L 8-C21- 1 y siguientes.

${ }^{6}$ Una correspondencia similar, conservada en el Museo Arqueológico Nacional, mantuvieron Velázquez Bosco y José Amador de los Ríos durante el verano de 1868. Por esas fechas el futuro arquitecto del Ministerio de Fomento era representante en León del recién creado Museo Arqueológico Nacional. Véase: Baldellou 1990: 65-79.

${ }^{7}$ En 1882 el propio Madrazo elaborará un informe sobre un mosaico de Lancia para el Boletín de la Real Academia de Bellas Artes de San Fernando.
} 
No conservamos más correspondencia de Ricardo Velázquez Bosco, si bien en el verano de 1868 se le encargaría dirigir oficialmente las excavaciones en Lancia, dando cuenta de sus avances y descubrimientos por carta a José Amador de los Ríos, a la sazón director del Museo Arqueológico Nacional.

Junto a estas cartas de Velázquez Bosco se conservan en el fondo Madrazo algunas otras de tema arqueológico. Destacan, especialmente, las relativas al intento fallido de excavación en Medina Azahara, citadas más arriba, y las cruzadas con Carlos de Pravia, gobernador civil de León, y el pintor Jaime Serra durante 1865 sobre la restauración del Panteón de San Isidoro de León y la localización de varios sepulcros, restos humanos e importantes objetos como la cruz de don Fernando y doña Sancha, hoy en el Museo Arqueológico Nacional, y de la que el propio Serra realizó un dibujo que se litografió para Monumentos Arquitectónicos de España ${ }^{8}$. Asimismo, Madrazo intercambió algunas cartas con el militar y explorador español Emilio Bonelli y Hernando (1854-1926) en 1888 en las que éste le daba noticia de algunas ruinas y lápidas halladas en Marruecos.

\section{Conclusiones}

Hasta aquí este breve recorrido por las publicaciones, amistades e intereses arqueológicos de Pedro de Madrazo, un personaje generalmente recordado por su labor como autor de los catálogos del Museo del Prado y por haber sido miembro de las tres Academias que sin embargo, y siempre que sus obligaciones profesionales y su salud lo permitían, no dudaba en recorrer la Península en busca de pinturas y antigüedades. Así atestiguan esta faceta de viajero empedernido sus viajes por Andalucía o su periplo por Navarra y Logroño en 1865 junto al pintor Jaime Serra.

A través de estas líneas hemos intentado reivindicar su importancia dentro de la historiografía de la arqueología si no como un arqueólogo de formación y de profesión, tal como sería entendida ésta hoy día, sí como uno de tantos eruditos decimonónicos de curiosidad incansable y universal, versados en artes e historia, que contribuyeron con sus escritos e iniciativas al conocimiento y sobre todo a la difusión de un patrimonio que en muchos casos corría el peligro de perderse ${ }^{9}$.

\section{BiBLIOGRAFÍA}

Almagro-Gorbea, M. (2003), 250 años de arqueología y patrimonio: documentación sobre arqueología y patrimonio histórico de la Real Academia de la Historia. Estudio general e índices. Madrid. Real Academia de la Historia.

Balmaseda Muncharaza, L. J. (1996), Las versiones del hallazgo del tesoro de Guarrazar. Boletín del Museo Arqueológico Nacional 14 n. 1-2: 95-110.

Baldellou, M. Á. (1990), Ricardo Velázquez Bosco [catálogo de exposición]. Madrid. Ministerio de Cultura: 65-79

Boix, F. (1931), Obras ilustradas sobre Arte y Arqueología de autores españoles publicadas en el siglo XIX. Madrid.

Díaz-Andreu, M. y Cortadella, J. (coords.) (2009), Diccionario histórico de la arqueología en España (siglos $X V-X X)$. Madrid. Marcial Pons Historia.

\footnotetext{
${ }^{8}$ La correspondencia entre Madrazo y Jaime Serra, junto a los dibujos incluidos en las misivas, ha sido estudiada y publicada recientemente por Juan Antonio Yeves Andrés (2014): Pedro de Madrazo y Jaime Serra. Epistolario y viaje artístico por Zaragoza, Navarra y La Rioja. Madrid. Fundación Lázaro Galdiano.

${ }^{9}$ A este respecto no podemos evitar incluir, aunque sea en nota, la opinión que de Pedro de Madrazo tenía el historiador cordobés Luis Ramírez de las Casas-Deza en la década de 1850: 'D. Pedro Madrazo, el cual es joven de talento y de gusto, pero en mi juicio no tiene conocimientos generales y profundos ni hace los estudios concienzudos que en particular se necesitan para tratar la materia que se ha propuesto' (tomado de Ramírez de las Casas-Deza, L. M. (1977), Memorias de Don Luis M. Ramírez de las Casas Deza. Córdoba. Universidad de Córdoba: 146.
} 
González Reyero, S. (2007), La fotografía en la arqueología española (1860-1960). 100 años de discurso arqueológico a través de la imagen. Madrid. Real Academia de la Historia.

Hernández Hernández, F. (1998), Las revistas románticas españolas y su visión del patrimonio arqueológico. Complutum 9: 231-253.

Madrazo, P. de (1874), 'Orfebrería de la época visigoda. Coronas y cruces del Tesoro de Guarrazar'. Monumentos Arquitectónicos de España. Madrid.

Madrazo, P. de (1835), Adición. A un personaje desconocido. El Artista: 203.

Monumentos arquitectónicos de España (1852-1881) [catálogo de exposición] (2014), Madrid. Calcografía Nacional de la Real Academia de Bellas Artes de San Fernando.

Mora, G. (1995), 'La arqueología en las revistas de arte del siglo XIX', VII Jornadas de Arte. Historiografía del arte español en los siglos XIX y XX. Madrid. CSIC: 161- 170.

Perea, A. (2001), El tesoro visigodo de Guarrazar. Madrid. Consejo Superior de Investigaciones Científicas.

Rodríguez Gutiérrez, B. (2005), Los cuentos románticos de Pedro de Madrazo. Santander. Aula de Letras. Rodríguez Gutiérrez, B. (2011), La voluntad iconográfica y aristocrática de El Artista. Revista de literatura 146: 449-488. 


\title{
Pioneros de la Arqueología alicantina. La necrópolis de l’Albufereta
}

\author{
Enric Verdú Parra
}

Museo Arqueológico de Alicante (MARQ)

El estudio de la necrópolis de l'Albufereta plantea, al tratarse de unas excavaciones desarrolladas durante la primera mitad de la década de los años 30 del siglo XX, numerosos obstáculos debido sobre todo al tiempo transcurrido y a las insalvables lagunas de información existentes. Sin embargo, el análisis de la documentación inédita y del conjunto material conservado ha permitido alcanzar una visión renovada del yacimiento y un mayor conocimiento del lugar ${ }^{1}$.

\section{Algunos apuntes preliminares}

Cabe decir, a modo de introducción, que hacia 1930 la ciudad de Alicante se encontraba inmersa en pleno proceso de modernización demográfica y de crecimiento urbanístico imparable, contando por entonces con unos 73000 habitantes. Se trata de una ciudad muy dinámica, cuya actividad económica esencial giraba en torno al comercio, destacando el papel esencial ostentado por el puerto y el sector servicios, disponiendo además de algunos núcleos industriales de importancia (Moreno 1990a: 601 ss.). La clase dominante estaba constituida por una destacada burguesía comercial, dedicada también a otras profesiones liberales como la abogacía o la medicina.

En esta época, Alicante fue dotándose de una serie de edificios emblemáticos como el caso del Mercado Central, el palacio de la Diputación Provincial y el Hospital de San Juan de Dios, todos ellos obra del arquitecto Juan Vidal Ramos (Fig. 1), cuya mayor actividad se desarrolla precisamente en este momento. Del mismo modo, facetas de la vida cultural como la prensa, el arte, la historia, el teatro, etc., experimentaron también notables avances (Gil et al. 1984: 29 ss.). Pese a que el primer tercio del siglo XX fue un período de una gran inestabilidad social y política, la ciudad experimentó una auténtica 'Edad de Oro' de las letras y las artes.

Los intelectuales y artistas alicantinos de principios del XX se agrupaban en asociaciones como el 'Círculo de Bellas Artes' o el 'Ateneo Científico y Literario', que aglutinaban a periodistas, profesores, arquitectos, abogados, músicos, pintores, médicos, escritores, etc. (Moreno 1990b: 781-782; 2014: 99-106). En concreto, el 'Ateneo', reabierto en 1923 tras el golpe de estado del general Primo de Rivera, desarrolló una intensa actividad cultural (Ramos 1992: 31 ss.) (Fig. 2). Ubicado en el conocido Paseo de la Explanada, paralelo al puerto, disponía de un salón para reuniones, un espacio para exposiciones y una nutrida biblioteca. En estas instalaciones eran habituales los conciertos, exposiciones de obras de arte y conferencias de la mano de personajes como Emilio Varela, Daniel Bañuls, Rafael Altamira, Germán Bernácer, Óscar Esplá o Francisco Figueras.

Este ambiente de inquietud cultural, limitado por cierto a unas minorías pertenecientes a las clases medias (Moreno 1990b: 787), tuvo su continuidad durante la II República, momento en el que se produjo una creciente especialización de los investigadores, dando cabida a intelectuales de diversa formación y condición social.

\footnotetext{
${ }^{1}$ Resultado de esta tarea de investigación son, entre otras obras, la monografía dedicada a las excavaciones desarrolladas por Francisco Figueras (Verdú 2005a) y el estudio de conjunto del yacimiento, versión sintética y actualizada de nuestra tesis doctoral (Verdú 2015).
} 
Por un lado, se constata un tipo de cultura que se desprende de la burguesía heredera de las clases dirigentes del siglo XIX. Por otro, a partir de los años 20 se desarrolla y logrará imponerse una pequeña burguesía progresista, muy próxima a los postulados republicanos y a la heterodoxia religiosa (Moreno 2014: 97). Esta intelectualidad no se encontraba ajena a la inestabilidad política, a la polarización social y a la creciente conflictividad obrera previa al estallido de la Guerra Civil (Martínez Leal 1990: 656-657). También tendría su lugar una cultura que aglutinaba a la amplia clase obrera, deseosa de educar a un pueblo con un preocupante nivel de analfabetismo que rondaba el 38\% para la población masculina y el 44\% para la femenina (Rosser 2015: 104).
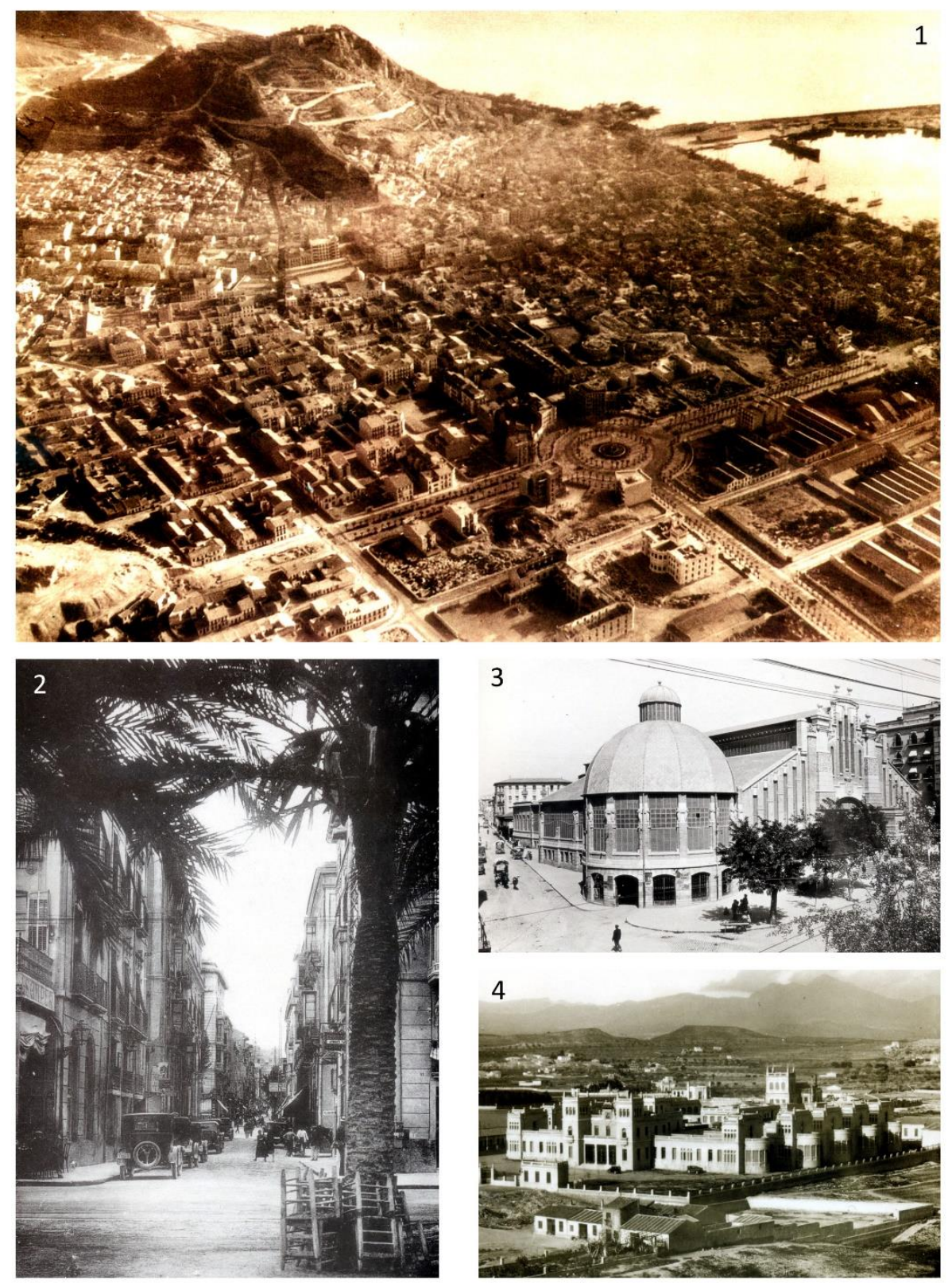

Fig. 1. La Alicante de los años 20-30 del siglo XX: 1. Fotografía aérea de la ciudad en 1932 (Martínez Morellá 1990: 647). 2. La calle Doctor Esquerdo en los años 30 (Moreno y Mateo 1991: vol. I, 117, no 8). 3. El Mercado Central alicantino en los años 20 (Moreno y Mateo 1991: vol. I, 135, no 3). 4. El nuevo hospital en el barrio del Pla, años 30 (Moreno y Mateo 1991: vol. I, 231, no 41). 

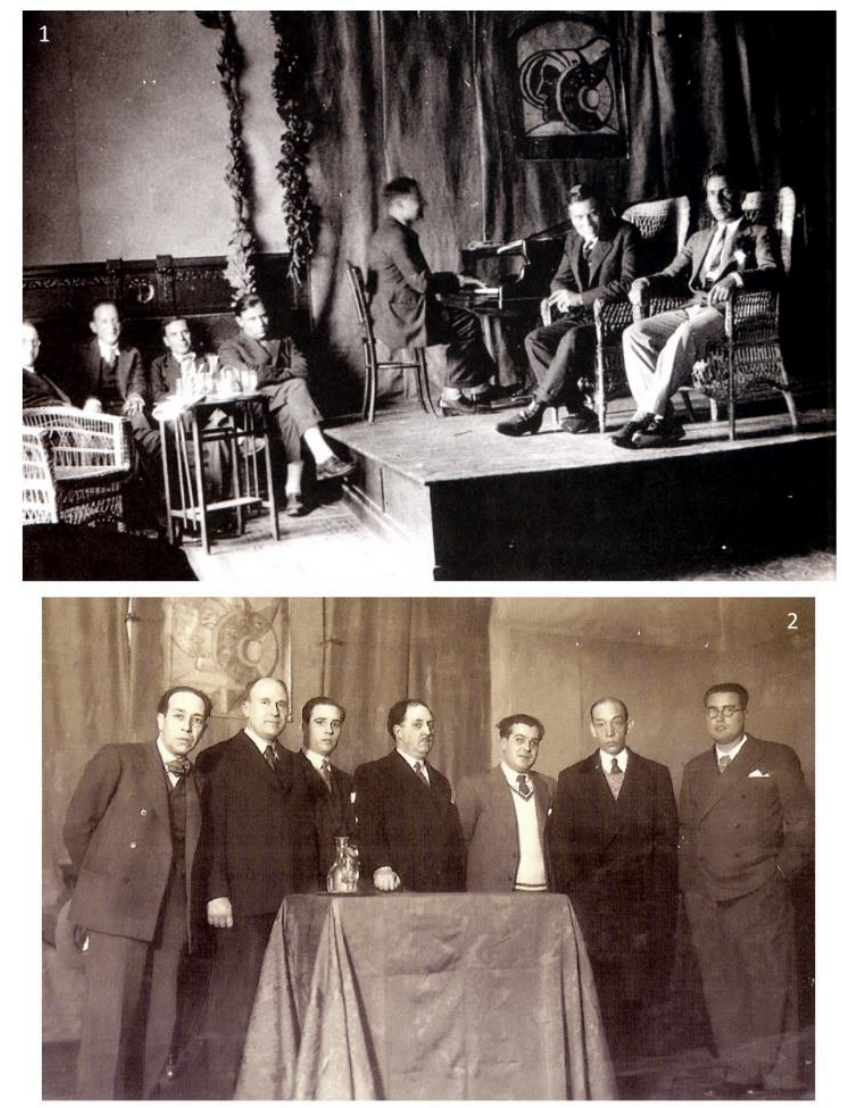

Fig. 2. La vida cultural en el 'Ateneo': 1. Reunión amenizada con música de piano, años 20 (Moreno y Mateo 1991: vol. II, 146, no 16). 2. Miembros del ‘Ateneo' en los años 20 (foto Alicante Vivo).

\section{Una Arqueología balbuceante}

Bajo el punto de vista de la Arqueología, desde fines del siglo XIX descubrimientos como los de las esculturas del Cerro de los Santos o la Dama de Elche, tras demostrar su autenticidad, habían inaugurado los estudios modernos sobre las huellas de la Cultura Ibérica en el sureste peninsular. En este sentido, figuras como Pierre Paris (Rouillard 1999: 25 ss.) o P. BoschGimpera, que incidía en la antigüedad y autoctonía de la cerámica ibérica (Rovira 2001: 213; Ruiz, Sánchez y Bellón 2006: 44-45), así como otros investigadores de la época, fueron perfilando con cierta dificultad y enorme imprecisión los principales rasgos de una cultura prerromana que había logrado un elevado nivel de desarrollo (Sanmartí-Grego 1999: 109-110). Para el caso alicantino, sin embargo, no llegó a configurarse una teoría completa sobre el nacimiento del mundo ibérico a la altura de la elaborada por el nacionalismo catalán y español ${ }^{2}$.

La labor desempeñada por la Junta Superior de Excavaciones y Antigüedades, institución nacida en 1914, resultó determinante hasta 1936 al planificar y centralizar numerosas intervenciones arqueológicas, delegando en la Comisión Provincial de Monumentos Históricos y Artísticos, organismo encargado de velar por la protección de todo resto antiguo, las decisiones más inmediatas. En Valencia, además, se creó en 1927 el Servicio de Investigación Prehistórica, en cuyo seno actuaron personajes tan célebres como Isidro Ballester (De Pedro 2006) o Domingo Fletcher, destacando los trabajos desarrollados en la Bastida de Moixent o en el Tossal de Sant Miquel de Llíria a partir de 1933 (Bonet 1999: 117-120) (Fig. 3). Son años de una gran actividad investigadora, como ocurre en otras regiones como la murciana o la alicantina, donde los estudios de historia local viven un momento de auge y se inician diversas prospecciones y excavaciones arqueológicas promovidas por una renovada Comisión de Monumentos, las cuales comenzaban a ser un tanto 'sistemáticas' (Enguix 1973: 22).

Es en este ambiente en el que se contextualizan las excavaciones en la Illeta dels Banyets, El Molar, el Tossal de Manises o l'Albufereta, en las cuales se sobrevaloró el carácter púnico de los hallazgos, condicionado fundamentalmente por el esplendor derivado de la fundación de Akra Leuka (Verdú 2005a: 98-99). Con el paso del tiempo, sin embargo, surgieron diversas opiniones en contra, destacando la celebración de los Congresos Arqueológicos del Sudeste Español y la labor de investigadores de la talla del citado Domingo Fletcher, uno de los mayores defensores de la identidad del pueblo ibero ${ }^{3}$, siendo muy

\footnotetext{
${ }^{2}$ Cabe señalar al respecto que en estas tierras surgió, como reacción 'antivalenciana', un ferviente 'alicantinismo' que simpatizaba más con los postulados madrileños y que puede considerarse como un fenómeno típicamente local (Ruiz, Sánchez y Bellón 2006: 48).

${ }^{3}$ Entre los diversos trabajos del autor sobre estas cuestiones destacamos su revelador artículo de 1949.
} 
crítico con la validez histórica de las fuentes clásicas y con la 'moda celtista' que, entre los años 30 y 40, incluso llegó a negar su existencia.
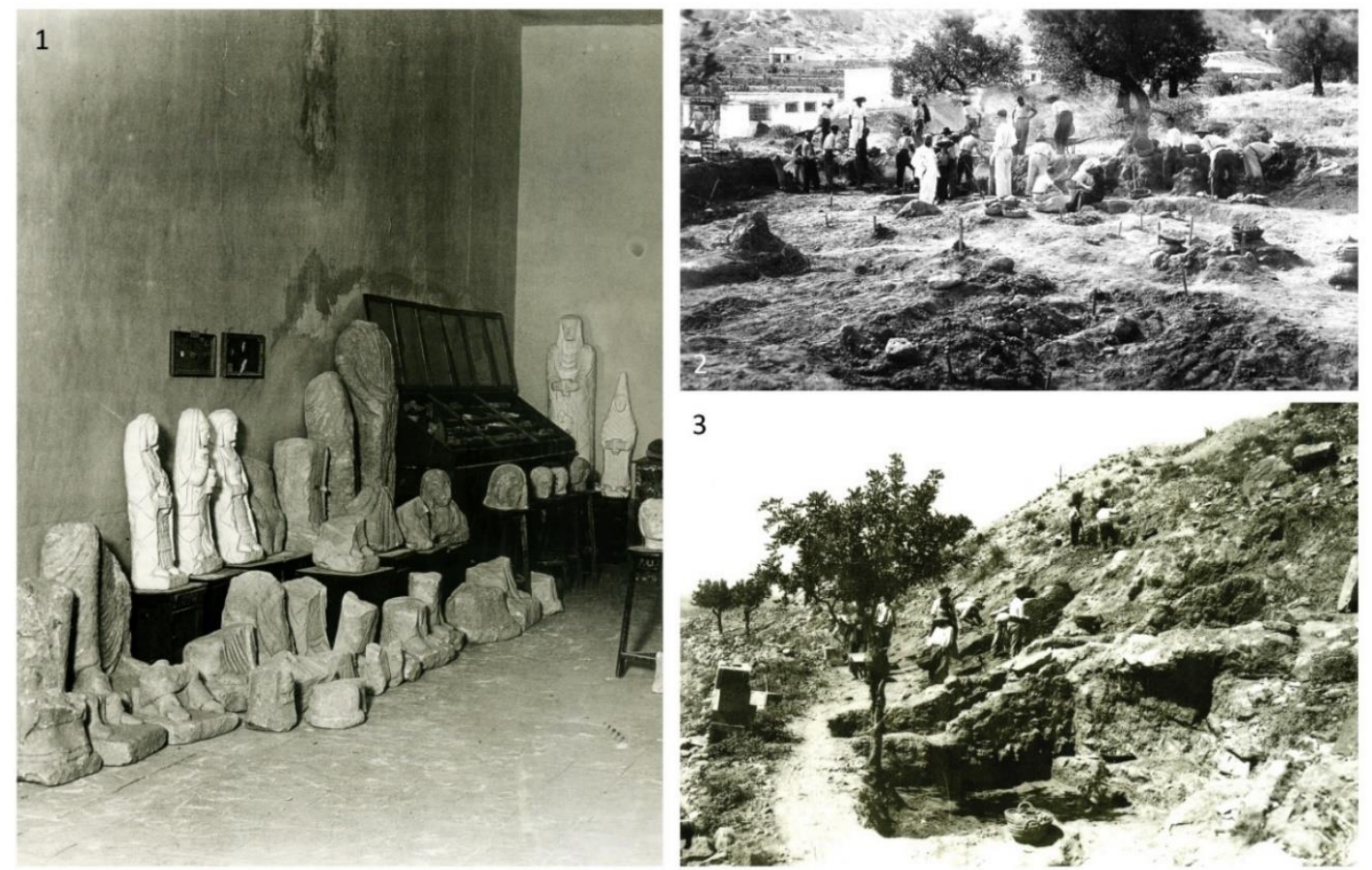

Fig. 3. 'Construyendo' la Cultura Ibérica: 1. Esculturas ibéricas del Cerro de los Santos en Yecla (foto Archivo Tani Ripoll recogida en López 1999: 213). 2. Primeras excavaciones en la necrópolis de Cabecico del Tesoro (Verdolay), año 1935 (foto Archivo Gratiniano Nieto recogida en Quesada 2001: 65). 3. Trabajos de 1936 en el Tossal de Sant Miquel (Llíria) (foto Servicio de Investigación Prehistórica recogida en Bonet 1999: 119).

Regresando al ámbito alicantino, conviene hacer referencia al papel ejercido por Miguel de Elizaicín España, presidente de la Comisión Provincial de Monumentos entre 1922 y 1926 (Soler 2000: 35 ss.). Militar y publicista de origen vasco, fue el principal impulsor de la creación en la ciudad de un Museo Arqueológico, siendo alcalde de la misma entre los años 1923 y 1924. Durante la década de los años 20

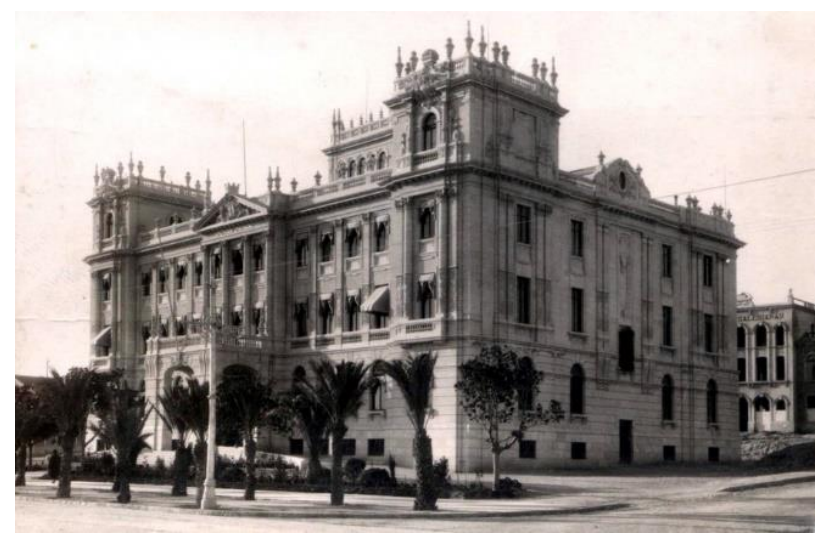

Fig. 4. El Palacio Provincial de Alicante, años $\mathbf{5 0}$ (foto Colección Francisco Sánchez, Archivo Municipal de Alicante). comenzó a tener más apoyo por parte de artistas y arqueólogos como José Lafuente, Francisco Figueras o Juan José Senent, y a partir de entonces empezaron a reunirse los objetos que conformarían la primera colección del Museo, procedentes tanto de excavaciones como de diversas donaciones (Soler y Olcina 2001: 11 ss.). Como consecuencia de todo ello, se estimó un espacio dentro el nuevo edificio destinado a la Diputación (Fig. 4), un nuevo proyecto del arquitecto Juan Vidal, que fue oficialmente inaugurado el 17 de enero de 1932 por el presidente de la República, Niceto Alcalá Zamora, ante el presidente de la Diputación Franklin Albricias (Olcina y Soler 2007; Roca de Togores 2006: 157 y 159; Soler 2001: 83-84). 
Por otra parte, en las reuniones de la Comisión Provincial de Monumentos, institución que tenía la misión de velar por la conservación, estudio y divulgación del patrimonio histórico-artístico de la provincia, se advertía el peligro que corrían los vestigios antiguos localizados en Alicante y, en concreto, en la zona de l'Albufereta, ante la amenaza de la construcción de una barriada de hoteles ${ }^{4}$. Tal preocupación sería trasladada a las autoridades competentes en busca de apoyo oficial. La Comisión se mostraba decidida a emprender excavaciones en el lugar (Olcina 2001: 110).

\section{Proyectando las excavaciones en l'Albufereta}

El entorno geográfico de la costa alicantina había sido muy favorable al asentamiento de grupos humanos desde el Neolítico hasta nuestros días, constituyendo el área de l'Albufereta, situada a unos $3 \mathrm{~km}$ al norte del centro de la ciudad de Alicante (Fig. 5), un territorio con una alta densidad arqueológica.

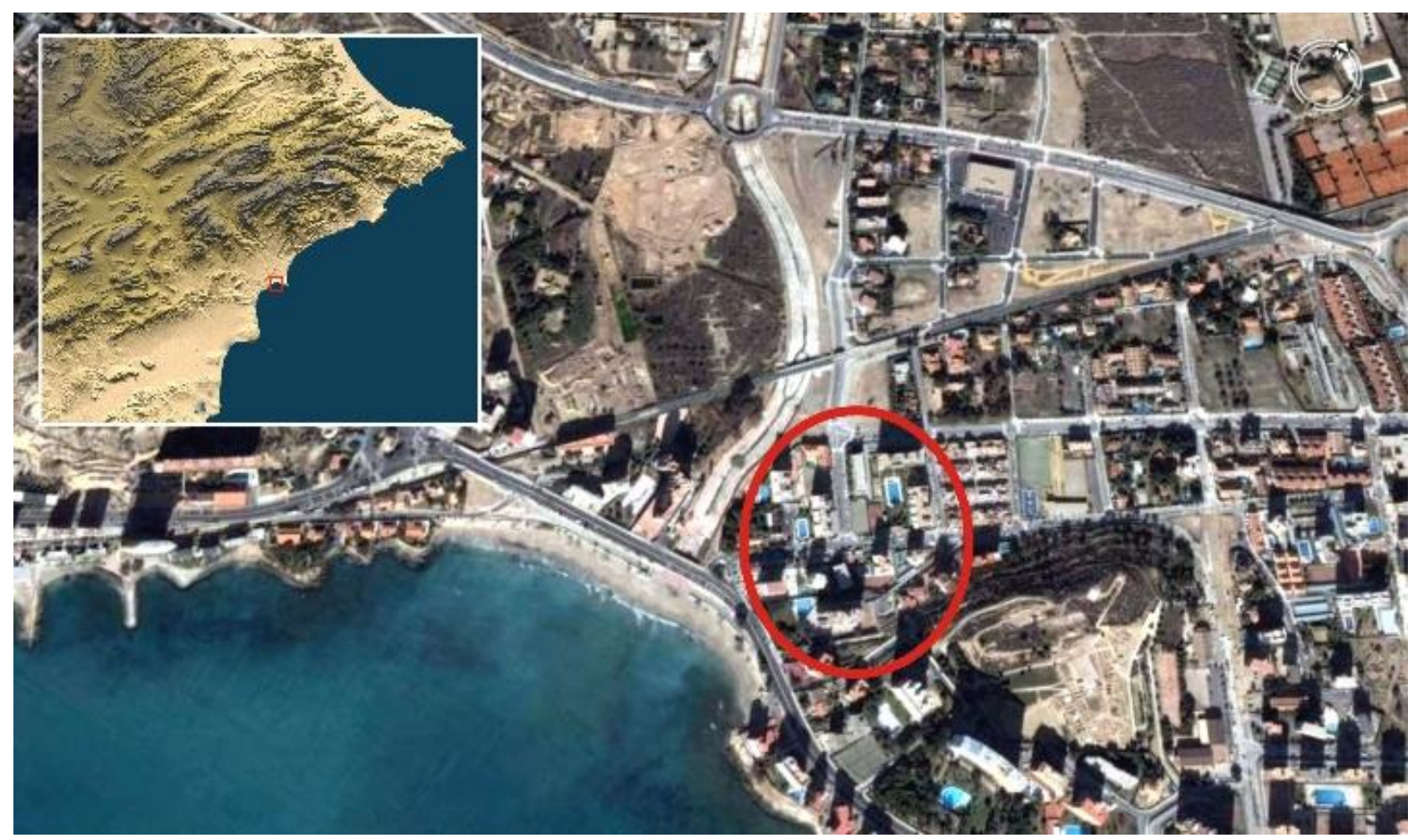

Fig. 5. Localización de la necrópolis de l’Albufereta.

El nombre de 'albufereta' hace alusión a la existencia en la zona de un antiguo marjal de agua dulce que debió alcanzar las 3,25 hectáreas, que con el paso del tiempo y su cierre al mar llegaba a pudrirse y generar serias enfermedades, de ahí que se decidiera su desecación en 1928 (Rosser 2015: 74; Verdú 2005a: 2022; 2015: 28-29). No obstante, la presencia de agua había sido determinante para el poblamiento antiguo, así como la ubicación costera de estos terrenos, que contaban además con elevaciones que favorecían su defensa, a la vez que eran aptos para la caza y la pesca.

Se trata en todo caso de un paraje particularmente atractivo para el turismo que se convirtió, a partir de los años 30 y sobre todo durante la segunda mitad del siglo XX, en uno de los lugares de recreo preferidos por los alicantinos y gentes de diversas procedencias, que buscaban en él las ventajas de un clima cálido y un mar agradable (Box 1987: 197) (Fig. 6). De este modo, la reconstrucción de la morfología originaria

${ }^{4}$ Asunto debatido sobre todo en la sesión del 2 de agosto de 1924. 
de la antigua albufera resulta hoy tarea prácticamente imposible a causa de la fuerte transformación sufrida por la zona.

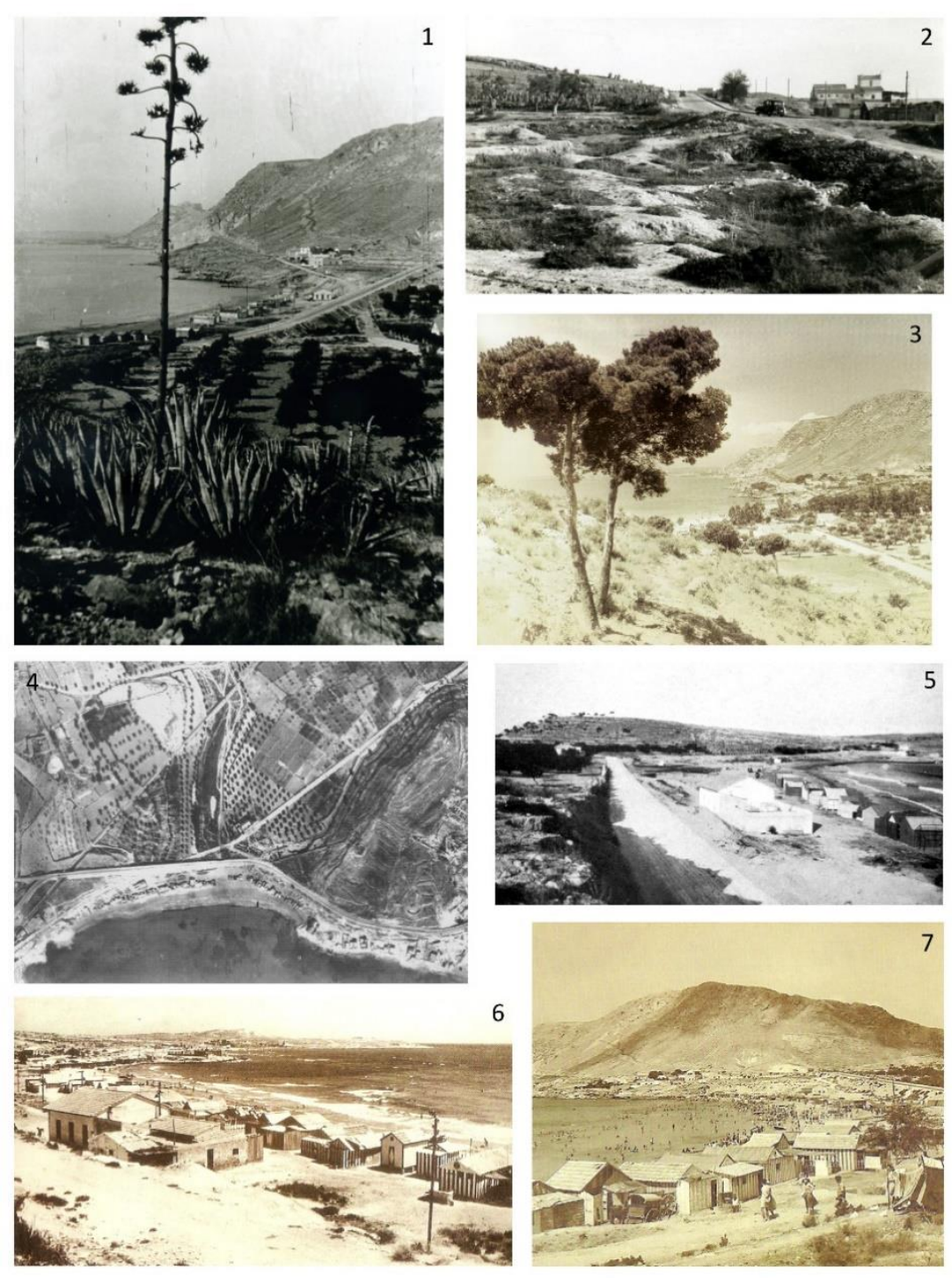

Fig. 6. La transformación del paisaje desde inicios del siglo XX: 1. Panorámica de l'Albufereta desde el Tossal de Manises, año 1939 (foto Archivo Gráfico MARQ). 2. La carretera del Cabo Huertas, años 30 (foto Alicante Vivo). 3. L'Albufereta desde el Tossal de Manises durante los años 50 (foto Alicante Vivo). 4. Vista aérea de l'Albufereta en los años $\mathbf{4 0}$ (fototeca digital del Instituto Geográfico Nacional). 5. Imagen de la zona de playa con el Tossal de Manises al fondo (Lafuente 1934: lám. I). 6. Casetas de bañistas en los años 30 (foto Alicante Vivo). 7. La playa de l'Albufereta en el año 1942 (foto Alicante Vivo).

En las actas que se conservan de la Comisión Provincial de Monumentos de Alicante es posible rastrear un ambiente de inquietud durante los convulsos años 20, destacando un deseo por promover investigaciones y evitar pérdidas irreparables de patrimonio. Por entonces ya se tenía constancia de restos antiguos que convenía excavar y estudiar en Calpe, Benidorm, el Campello, Santa Pola, Guardamar, etc. Por otra parte, con el paso de los años fueron ingresando en las filas de esta institución personajes que tendrían una gran trascendencia tras la proclamación de la II República el 14 de abril de 1931, cuando la Arqueología alicantina cobró un nuevo impulso. A José Lafuente siguieron en 1927 Francisco Figueras, 
que por entonces ya era cronista de la ciudad, y Juan José Senent, que ostentaba el cargo de inspector provincial de Instrucción Pública (Rosser 2013: 82-85). La Comisión encomendó a Figueras redactar un informe relativo a las condiciones actuales de l'Albufereta, memoria que fue presentada en enero de 1928 y en la que hacía hincapié en la importancia del lugar, puesto que en él situaba la Akra Leuka mencionada por las fuentes clásicas, la ciudad fundada por el caudillo cartaginés Amílcar Barca y en la que se había establecido su ejército.

El interés por el Ayuntamiento y la Comisión por la Arqueología alicantina, y en concreto por la situación de la zona de l'Albufereta era evidente, de ahí que, bajo el amparo de la Ley de Excavaciones de 1911, se solicitaran varias subvenciones para iniciar una actuación real sobre unos terrenos acerca de los cuales ya existían abundantes referencias sobre vestigios antiguos a partir del siglo XVII (Verdú 2015: 25-26) (Fig. 7), muchos de ellos aparecidos de manera fortuita a raíz de trabajos agrícolas o constructivos sin miras arqueológicas.

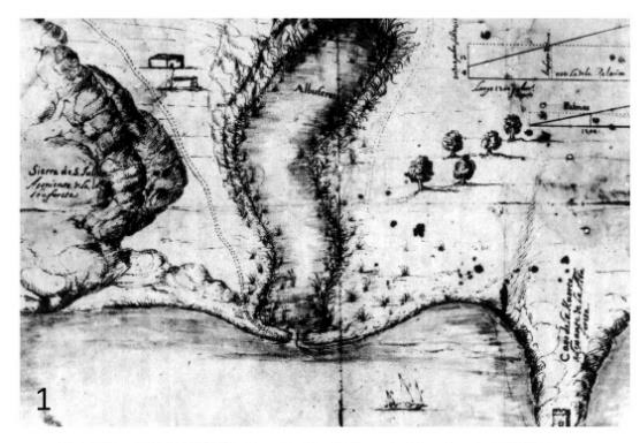

3

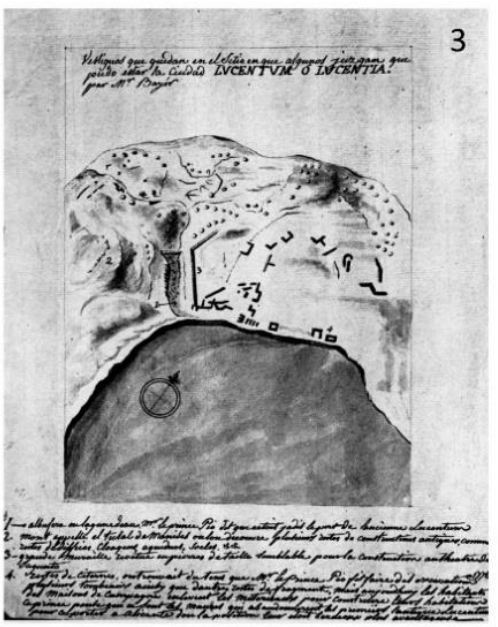

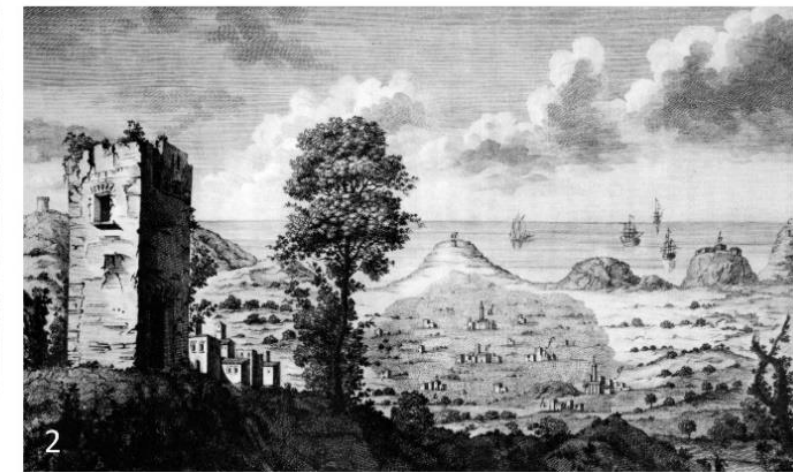

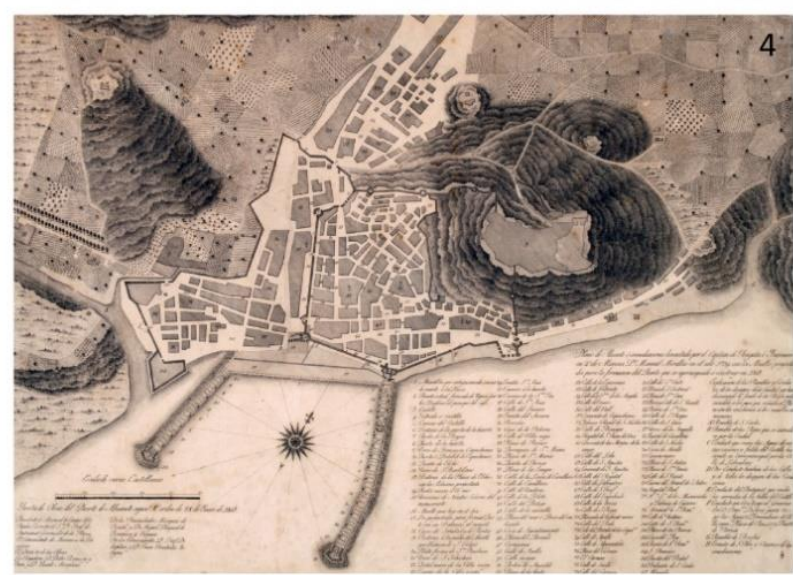

Fig. 7. La imagen histórica de la huerta de Alicante y l'Albufereta: 1. Mapa manuscrito del siglo XVII (foto Archivo Municipal de Alicante). 2. Grabado publicado por Antonio José Cavanilles en 1797. 3. Plano de fines del siglo XVIII con indicación de los vestigios conocidos en el paraje de l’Albufereta realizado probablemente por Francisco Pérez Bayer (Verdú 2015: fig. 1.2). 4. Plano de Alicante e inmediaciones levantado en 1794 por Manuel Miralles (foto Alicante.es).

Precisamente el descubrimiento de la necrópolis de l'Albufereta se produjo de forma casual durante el transcurso de las obras de construcción de una nueva carretera que uniría Alicante con la cercana población de Sant Joan, a orillas de la antigua laguna y junto a la costa (Verdú 2005b: 358). La noticia de este importante hallazgo generó una enorme expectación entre la intelectualidad alicantina. 


\section{El desarrollo de los trabajos arqueológicos}

Tras diversos trámites, la Comisión Provincial de Monumentos recibió en marzo de 1931 los fondos necesarios para emprender las excavaciones, siendo las sucesivas subvenciones oficiales siempre muy limitadas. En mayo se encargó la dirección de los trabajos en el Tossal de Manises y l'Albufereta a José Lafuente (Verdú 2015: 31 ss.) (Fig. 8) y en la Illeta dels Banyets (el Campello) a Francisco Figueras y Juan José Senent (Rosser 2013: 95).

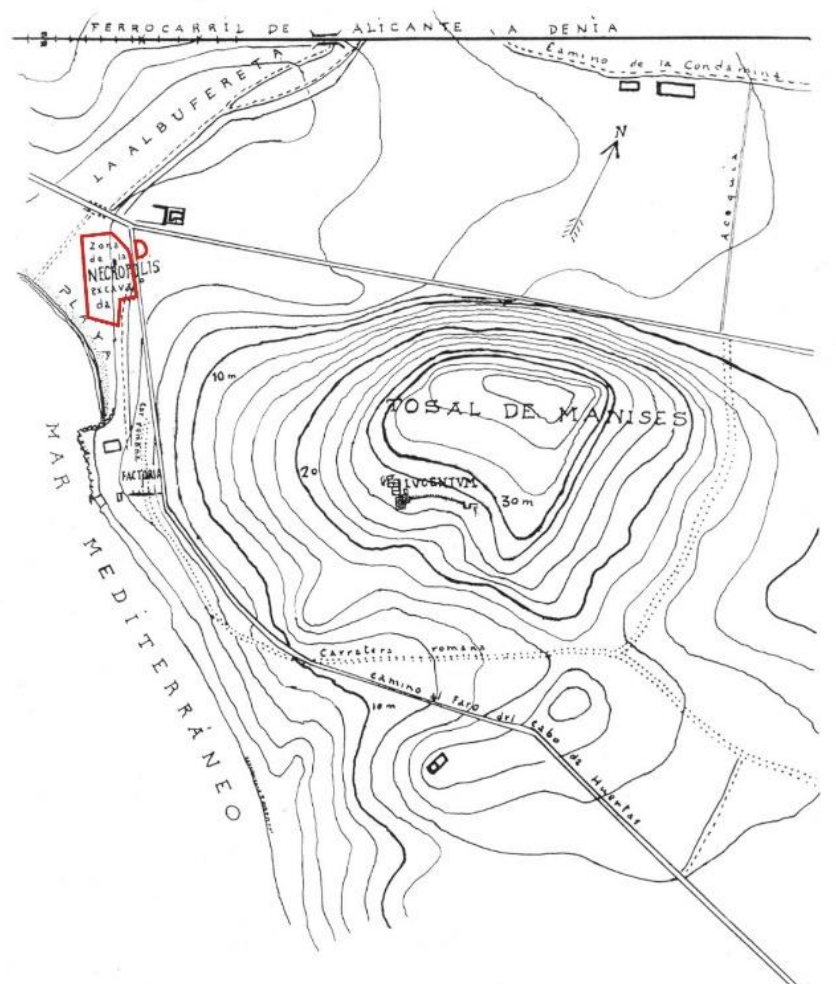

Fig. 8. Plano del Tossal de Manises y zona de la playa con indicación del área excavada de la necrópolis de l'Albufereta (a partir de Lafuente 1934: lám. XXI).
Las excavaciones en la por entonces considerada necrópolis 'cartaginesa' o 'iberopúnica', proporcionaron un interesante repertorio de materiales procedentes de un nutrido conjunto de sepulturas de cremación. Muchos daban por sentado la enorme importancia de la presencia púnico-cartaginesa en estas costas y las campañas se saldaron con un rotundo éxito al procurar los testimonios materiales que avalaban las teorías de sus excavadores (Verdú 2005a: 18-20), inaugurando una fecunda producción bibliográfica y convirtiendo al yacimiento en uno de los principales de la Protohistoria peninsular. Los materiales de la necrópolis ingresaron en el Museo Arqueológico y rápidamente se exhibieron como una de las colecciones más valiosas custodiadas por la institución.

Sin embargo, sobre estas excavaciones disponemos hoy de una información muy sesgada y que adolece de importantes carencias, puesto que se prestó mayor atención a la recuperación de los objetos que a los contextos en que éstos se hallaron.

\subsection{La Arqueología al servicio de las fuentes clásicas: la excavación Lafuente}

En cuanto a José Lafuente Vidal (1879-1966) (Fig. 9), natural de Cartagena, ejerció como director del Instituto Provincial de Segunda Enseñanza entre los años 1931 y 1937 (Gil et al. 1984: 51), habiendo alcanzado el cargo de catedrático de Historia Universal. De carácter culto y reservado, se le considera esencialmente un gran erudito de las lenguas clásicas y un amante del pasado histórico, despertando su verdadera pasión al participar en las excavaciones de Numancia, yacimiento que ya había empezado a ser explorado en 1906 y donde Lafuente estableció un contacto directo con el mundo de la Arqueología.

Desde 1924 ya era vocal en la Comisión Provincial de Monumentos Históricos y Artísticos de Alicante, de la que fue nombrado su vicepresidente en 1926 (Soler 2000: 36), participando activamente en sus decisiones. Siempre se declaró un acérrimo defensor de las excavaciones arqueológicas como método esencial para obtener conocimientos y demostrar sus teorías. En este sentido, en 1928 colaboró con Senent en las primeras excavaciones en la necrópolis ibérica de El Molar (San Fulgencio, Alicante), publicando los principales resultados obtenidos (Lafuente 1929; Peña 2003: 13-14). Este mismo año dirigió unas intervenciones arqueológicas en la vertiente norte del monte Benacantil, en el que asienta la fortaleza de 
Santa Bárbara, viéndose estos trabajos envueltos en una oleada intelectual ansiosa por conocer el origen de la ciudad puesto que en ellas se recuperaron numerosas cerámicas, muchas de las cuales fueron catalogadas como púnicas, si bien la mayoría de materiales aparecieron revueltos y descontextualizados (Verdú 2005a: 18; 2015: 30).
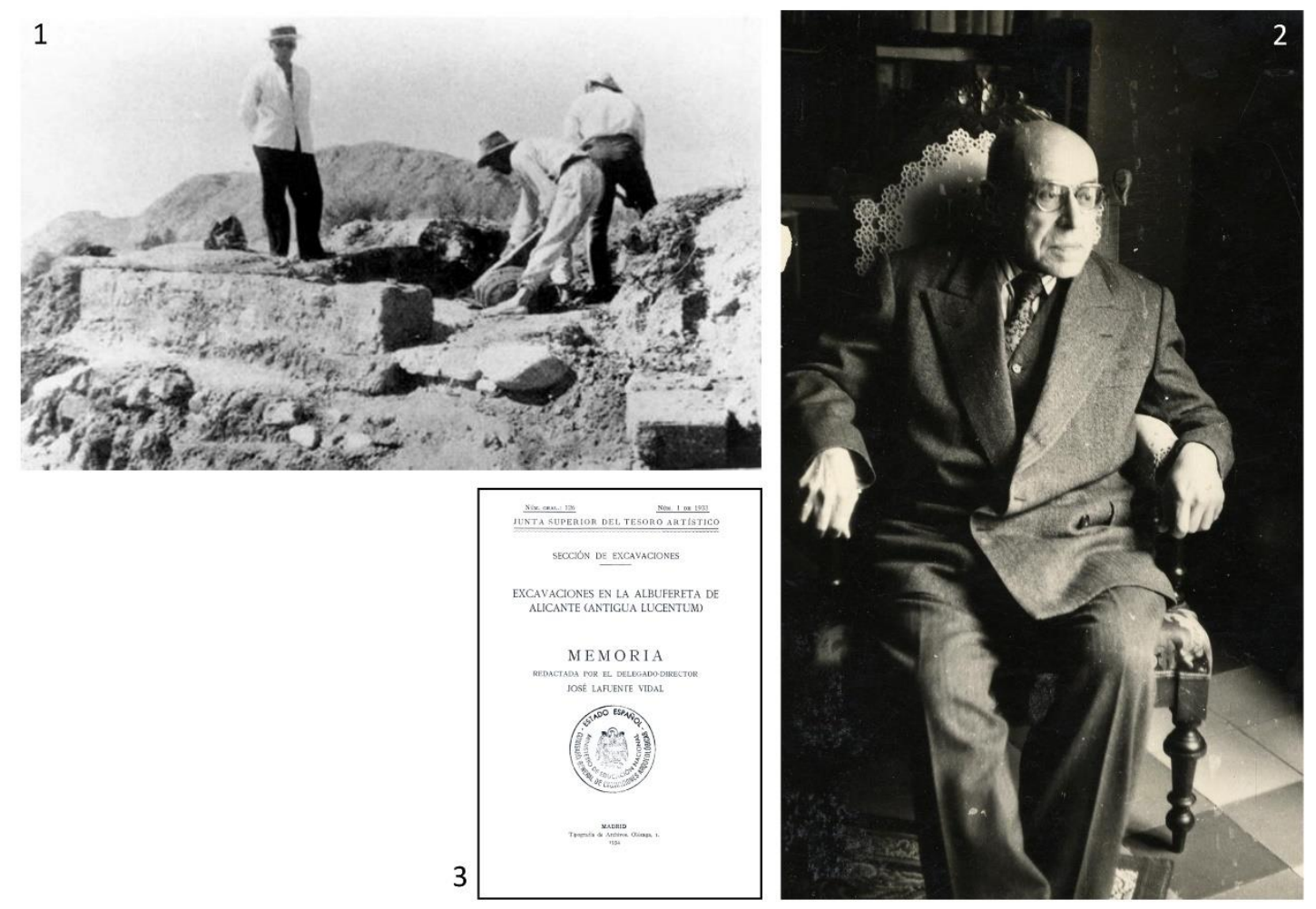

Fig. 9. 1. José Lafuente durante las excavaciones en el Tossal de Manises, años 30. 2. Lafuente en el Museo Arqueológico Provincial (fotos Archivo Gráfico MARQ). 3. Portada de la memoria de excavaciones en l'Albufereta de 1934.

Por lo que respecta al área de l'Albufereta, Lafuente estaba empeñado en probar que el Tossal de Manises tenía su origen en una colonia griega, posteriormente refundada por los cartagineses, defendiendo que en Alicante se había fundado Akra Leuka (Olcina 2001: 111). De este modo, buena parte de su producción científica giraba en torno a la reducción de los lugares arqueológicos a las ciudades citadas por los autores grecolatinos. Es por ello que el Ayuntamiento le encargó la redacción de un folleto sobre Lucentum, publicando además su libro Alicante en la Antigüedad (1932), reeditado y ampliado en 1957.

Lafuente se mantuvo al frente de las excavaciones entre los años 1931 y 1933, publicando algunos de sus resultados y destacando entre su producción científica su libro de 1934 titulado Excavaciones en la Albufereta de Alicante (antigua Lucentum). No obstante, debido a sus numerosos compromisos como catedrático, renunció a la dirección de las excavaciones a inicios de 1934, aunque se desconocen las causas reales de tal decisión. Años más tarde, sin embargo, y como también haría Francisco Figueras, Lafuente continuaba publicando nuevos trabajos sobre l'Albufereta y el Tossal de Manises, sin actualización bibliográfica alguna y sin modificar sustancialmente lo dicho en sus primeros escritos, buena muestra del aislacionismo intelectual que caracterizó la actividad de estos eruditos durante la posguerra (Rosser 2013: 164). 
El 7 de julio de 1952 el Museo Arqueológico cerró sus puertas y la Administración Provincial abogó por la creación de una plaza de conservador, hecho que no sucedería hasta una década después. Mientras tanto, José Lafuente estaba decidido a impulsar la institución, por lo que, una vez jubilado de sus actividades docentes, emprendió el inventario de sus fondos y la mejora del montaje, que databa de 1943. Para ello contó con la inestimable ayuda del restaurador Félix Rebollo y de la joven investigadora Solveig Nordström (Soler 2001: 87 y 89), becaria de doctorado de la Casa Real de Suecia y su principal discípula (Fig. 10). Fruto de esta colaboración es su obra fundamental, el Catálogo-guía del Museo Arqueológico Provincial de Alicante (1959). En 1954 dirigió unos trabajos de limpieza en el Tossal de Manises, en un momento en que se gestaban importantes operaciones financieras e inversoras para apoderarse de los terrenos del yacimiento sin atender a los importantes restos que conservaba (Rosser 2015: 236).
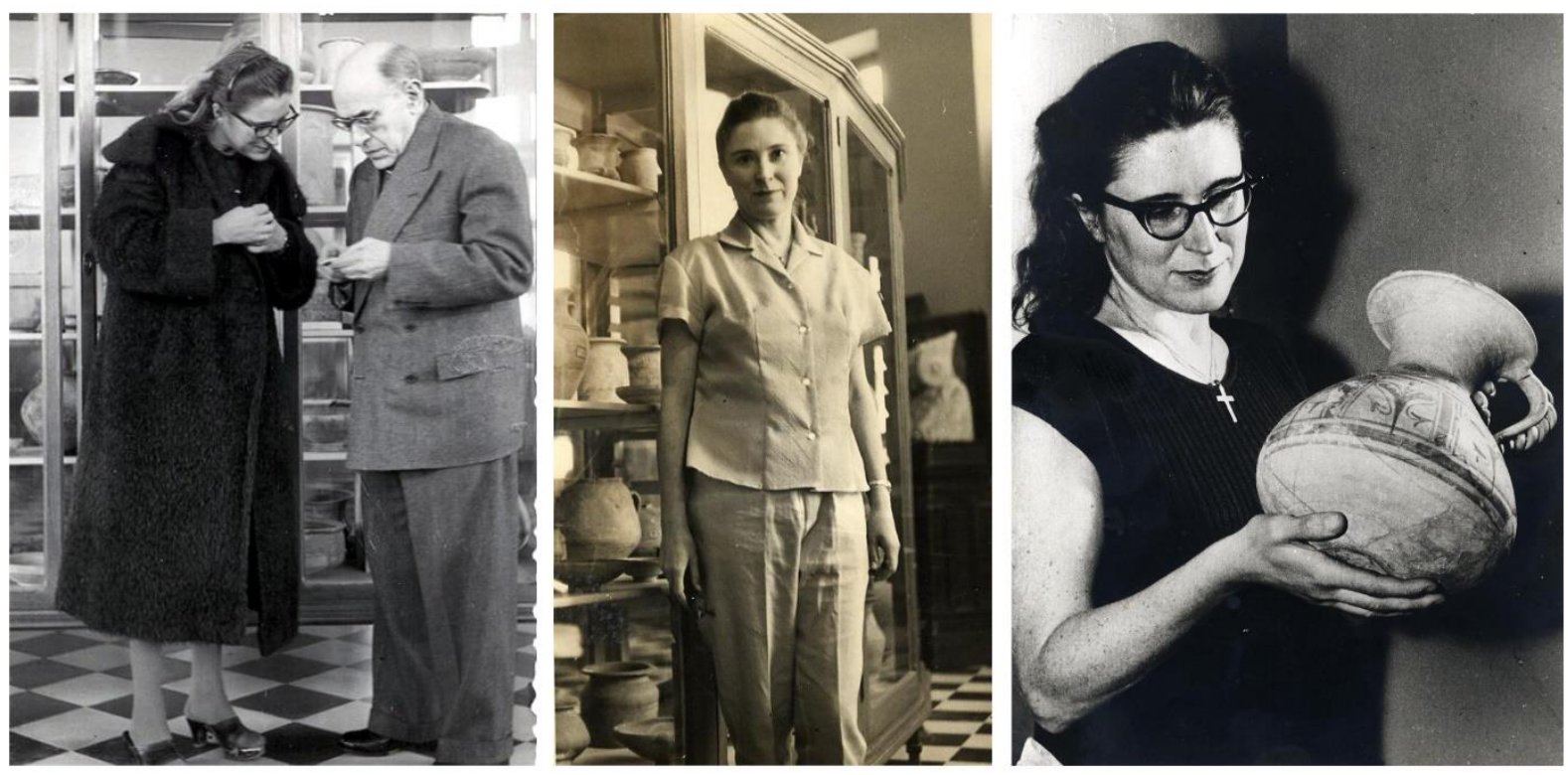

Fig. 10. Solveig Nordström en el antiguo Museo Arqueológico Provincial de Alicante (fotos Archivo Gráfico MARQ).

\subsection{Con la Iglesia hemos topado: el Padre Belda}

Durante las excavaciones en l'Albufereta Lafuente contó con la inestimable asistencia sobre el terreno de José Belda Domínguez (1890-1969), personaje un tanto extravagante y atípico, un reverendo de aspecto desaliñado que, no obstante, desempeñaría un papel determinante en la Arqueología de la época (Fig. 11).

Nacido en la localidad valenciana de Bocairent el 11 de agosto de 1890, tras sus primeros estudios en Valencia fue formado sacerdote en 1914 (Martínez Morellá 1970: 33 ss.) y ejerció sus funciones en diversas parroquias (Olleria, Catarroja, Tous), hasta que en 1922 fue trasladado a la de Nuestra Señora de la Asunción de Penàguila. Allí comenzó a reunir una pequeña colección de fósiles, emprendiendo además diversas prospecciones con miras arqueológicas por los alrededores. Ya por entonces eran criticados sus métodos poco ortodoxos. Pero no será hasta su llegada en 1925 al municipio de la Torre de les Maçanes cuando se emplee a fondo en sus estudios, muestra de lo cual son sus intervenciones de 1928 y 1929 en la eneolítica Cova de la Barcella, cuyos resultados publicaría poco después. Sin embargo, debido a la enemistad que le enfrentó con las autoridades locales y con algunos vecinos, él y su 'colección arqueológica' terminaron por mudarse en mayo de 1931 a la ciudad de Alicante, donde viviría con su anciana madre. 
Una vez instalado en la capital, adscrito a la Iglesia de Santa María, Belda participó en las excavaciones en el Tossal de Manises y l'Albufereta entre los años 1931 y 1934, encargándole Lafuente la supervisión de los trabajos de campo y de restauración de materiales (Abad 1984: 38). En 1933 fue nombrado académico correspondiente por la Real Academia de la Historia, lo que no evitó que el sacerdote, cuya fama de excavador clandestino era conocida por todos, fuera acusado de emprender exploraciones sin permiso legal y de no depositar los materiales adecuadamente. Por otra parte, pese a que se le había encargado organizar los fondos del Museo Arqueológico, la dirección del mismo pasó en 1935 a manos de Joaquín de Rojas (Roca de Togores 2006; Rosser 2015: 127-128 y 193-196).
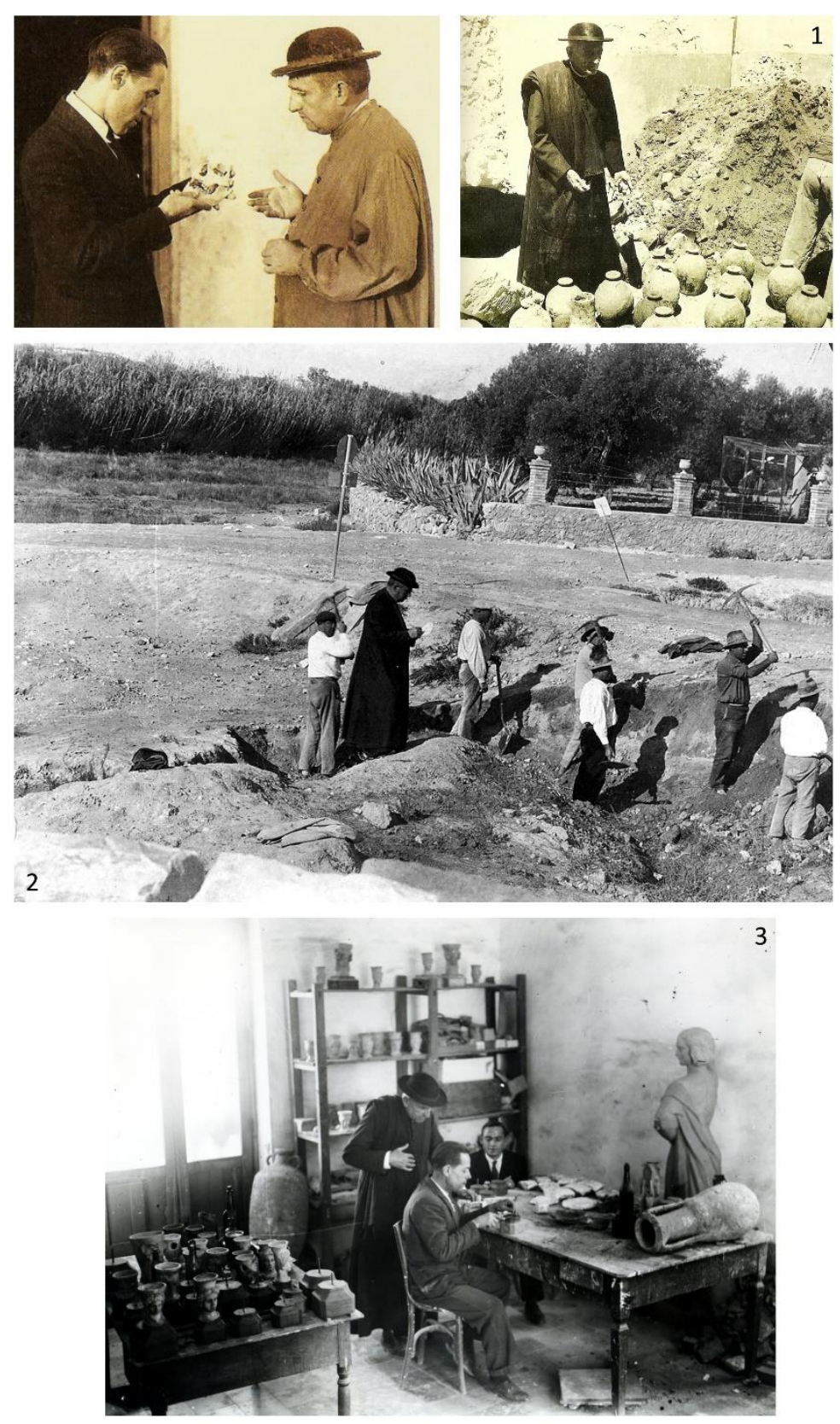

Fig. 11. 1. José Belda arqueólogo (fotos Alicante Vivo). 2. Belda supervisando las excavaciones en l'Albufereta (foto Archivo Gráfico MARQ). 3. Junto a Rebollo en el improvisado taller de restauración del Palacio Provincial, años 50 (foto Archivo Gráfico MARQ). 
Amante de las labores de campo, pero no de la investigación de gabinete, estos hechos tampoco frenaron a José Belda, puesto que tras la Guerra Civil realizó nuevas intervenciones arqueológicas, en ocasiones contando con la colaboración de la Peña Excursionista Alicantina, a la vez que participaba en congresos e impartía conferencias. Durante los años 40 excavó en el Castillo de la Torre Grossa de Xixona, el Tossal de la Cala de Benidorm, Cabezo Lucero, etc., no siempre con las debidas autorizaciones oficiales. Por desgracia, no se conocen los resultados de la mayoría de sus excavaciones, como sucede también con las que efectuó en la Illeta dels Banyets del Campello (Olcina, Martínez y Sala 2009: 50).

Tras la excedencia por motivos de salud de Joaquín de Rojas a fines de 1940, Belda ocupó su tan ansiada dirección del Museo Arqueológico Provincial (Roca de Togores 2006: 164), y disponiendo de una primera catalogación de los fondos efectuada por Figueras, culminó un segundo montaje a inicios de 1943, en el que sólo se exhibían los materiales arqueológicos ${ }^{5}$ (Soler 2001: 87) (Fig. 12). Ese mismo año se incorporó a la plantilla el ya mencionado Félix Rebollo Casanova, al que se le encargaría a partir de entonces la restauración de las piezas arqueológicas en una de las dos torres que flanqueaban la terraza del Palacio Provincial (Soler 2000: 39-40; Verdú 2005a: 37, fig. 7).
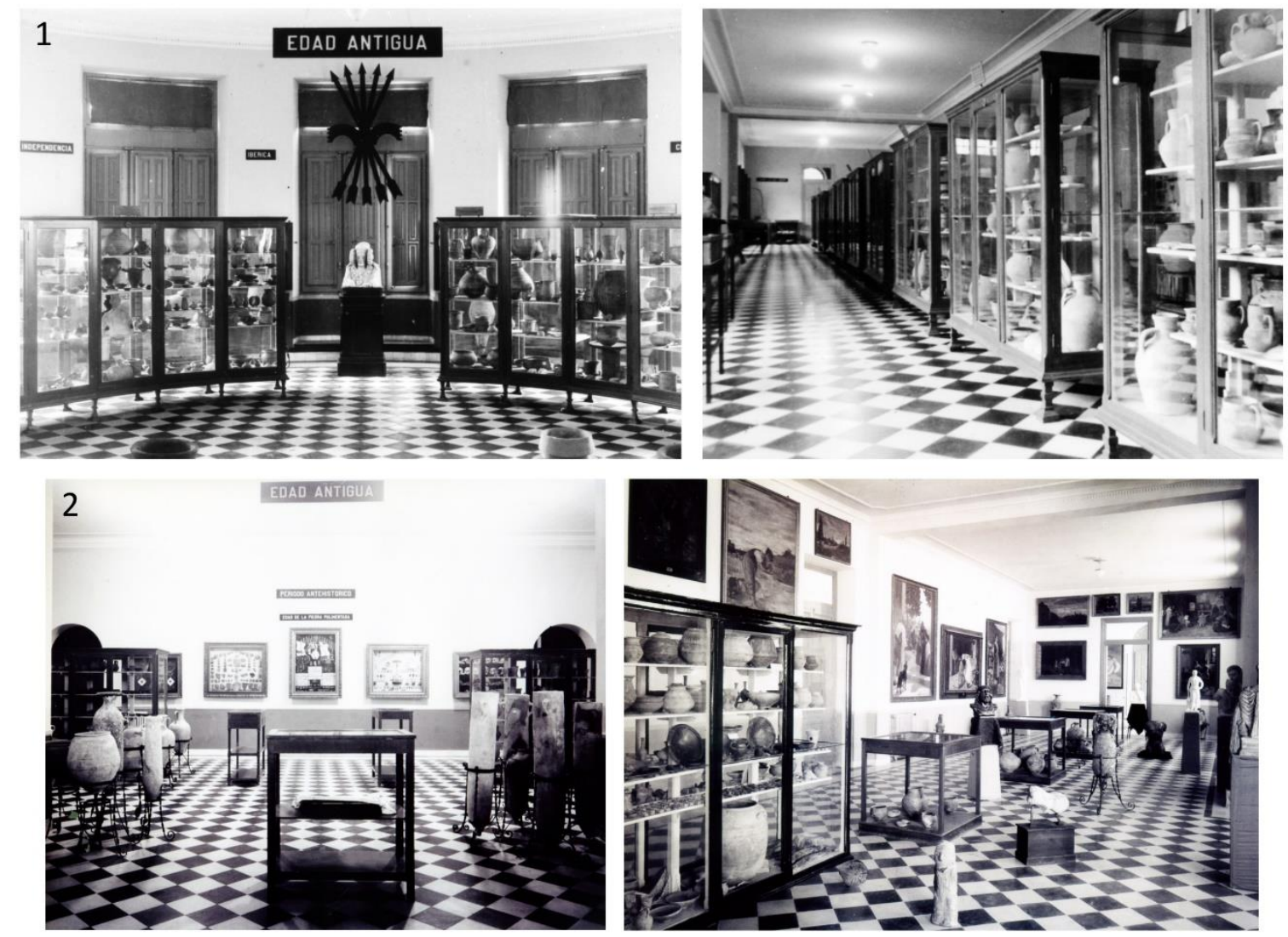

Fig. 12. 1. El primitivo Museo Arqueológico Provincial en los años 30. 2. El montaje de 1943 (fotos Colección Francisco Sánchez, Archivo Municipal de Alicante).

Durante los primeros años de la posguerra, el Padre Belda se benefició de que tanto Lafuente como Figueras estuvieran mal vistos por haber desarrollado su actividad científica durante el período republicano. Pese a ello, la Diputación de Alicante le abrió un expediente por dejación de sus funciones,

${ }^{5}$ Conviene aclarar que el Museo en el momento de su inauguración también mostraba diversas obras pictóricas y esculturas. 
aunque no podía ser cesado al haber sido propuesto como director por el Ministerio de Educación. Ante esta lamentable situación, el Museo cerró sus puertas el 7 de julio de 1952, pero José Belda consiguió que se le nombrara director honorario y se le concediera una pensión anual ${ }^{6}$.

Tras un grave accidente ocurrido al tomar un tranvía, la salud de Belda quedó seriamente afectada, ingresando en el hospital para sacerdotes de Quart de Poblet (Valencia), donde falleció en 1969.

\subsection{Un arqueólogo sereno y escrupuloso: Francisco Figueras}

El tercer protagonista de la historia de las excavaciones en l'Albufereta es Francisco Figueras Pacheco (1880-1960) (Fig. 13). Nacido en el seno de una familia de fuerte tradición militar y aristocrática residente en el barrio alicantino de Benalúa (Ramos 1970: 16 ss.; Verdú 2005a: 25 ss.), era hijo de Francisco Figueras Bushell, hombre de gran bagaje cultural pero que quedó ciego cuando el joven Figueras contaba solamente con cinco años, poco antes de fallecer su madre.
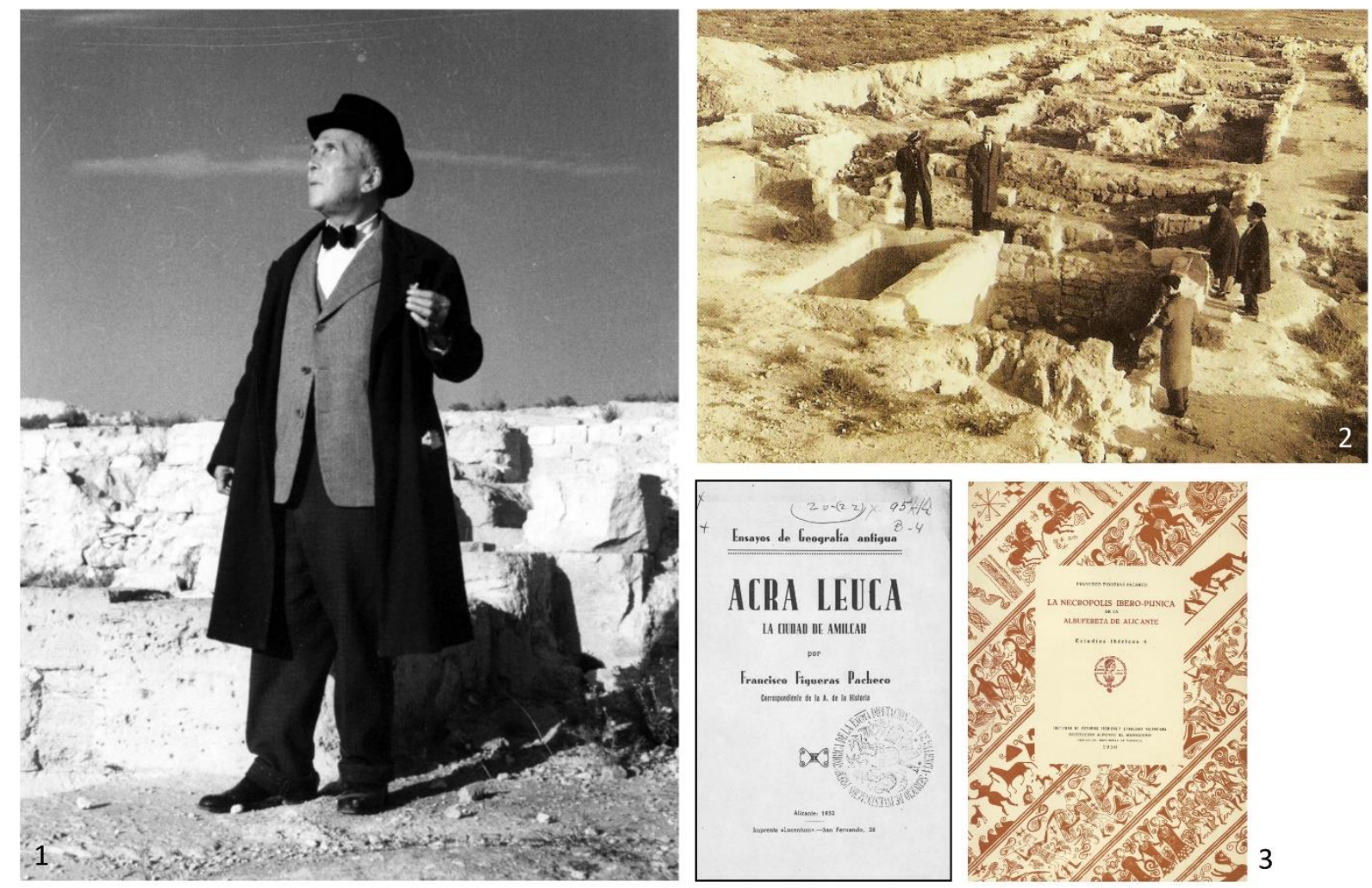

Fig. 13. 1. Francisco Figueras en el Tossal de Manises. 2. Explicando las cisternas de Lucentum (fotos Archivo Gráfico MARQ). 3. Dos de sus principales obras arqueológicas: su ensayo de 1932 y la monografía sobre la necrópolis de l'Albufereta publicada en 1956.

Cursó sus primeros estudios en Alicante y en el Colegio de la Inmaculada Concepción de Novelda, iniciando la carrera de Derecho en la Universidad de Valencia en 1896, etapa en la que le sobrevino una ceguera irreversible. Su hermana Matilde le leía los libros para estudiar, hasta que ésta falleció en 1907, año en que Francisco Figueras consiguió licenciarse. Obtuvo el título de doctor en Madrid en 1910 con la tesis titulada Filosofía de la guerra. Sin embargo, debido a su condición de invidente se le denegó la

${ }^{6}$ La plaza de director no sería ocupada hasta que la obtuvo por oposición Enrique Llobregat en 1966. 
cátedra universitaria, por lo que decidió estudiar otra carrera, en este caso Geografía e Historia, descubriendo así su auténtica vocación.

El año 1908 fue designado cronista oficial de la ciudad de Alicante, cargo que se convirtió en vitalicio en 1931. Trabajó en periódicos y revistas publicando obras teatrales, poemas y ensayos, haciendo gala de un gran talento literario, además de un genio fuerte y decidido. Un momento crucial en su vida llegó con el encargo realizado por el Dr. Francisco Carreras para redactar el libro dedicado a la provincia de Alicante dentro de la Geografía General del Reino de Valencia, lo que llevó a Figueras a recorrer pueblo a pueblo toda la región, editándose su extenso trabajo en 1914.

En el ya mencionado 'Ateneo Cultural' alicantino, donde pronunciaría diversas conferencias sobre los orígenes de la ciudad y del cual sería su presidente entre los años 1930 y 1931 (Ramos 1992: 46-49), Figueras comenzó a establecer contactos con otros estudiosos y literatos de la época como Gabriel Miró. En este sentido, el éxito de una ponencia efectuada años atrás y publicada bajo el nombre de Acra Leuca, la ciudad de Amílcar (1932), en la que defendía abiertamente que a esta ciudad citada por los textos clásicos deberían pertenecer las ruinas localizadas en el Tossal de Manises (Verdú 2005a: 17), llegó a oídos de la Comisión Provincial de Monumentos, que lo nombró vocal en 1928 y le encargó, como ya se ha dicho, un informe sobre el estado de los terrenos de l'Albufereta, determinando la necesidad de emprender excavaciones en el lugar. Un año después acudiría junto a Juan José Senent al Congreso Internacional de Arqueología e Historia de Barcelona.

Miembro de la Real Academia de Historia, la Institución Fernán González, el Instituto de Estudios Alicantinos, la Institución Alfonso V el Magnánimo y Lo Rat Penat, como arqueólogo destacan sus trabajos sobre Xàbia o la Illeta dels Banyets, donde además dirigió breves campañas debido a los escasos fondos disponibles entre los años 1931 y 1935 (Figueras 1934; Olcina, Martínez y Sala 2009: 35 ss.). Pese a su minusvalía, siempre se mostró diligente y escrupuloso en sus tareas, siendo por muchos conocida la anécdota de que reconocía las cerámicas al tacto.

Tras la renuncia de Lafuente a inicios de 1934, la Comisión de Monumentos le designó director de las excavaciones en el Tossal de Manises y la necrópolis de l'Albufereta, contando los primeros meses con la colaboración de José Belda (Olcina 2001: 115-116; Ramos 1970: 103-104; Rosser 2015: 124; Verdú 2005a: 30), así como del propio José Lafuente, que en principio no quedaba totalmente desvinculado del proyecto. Figueras dispuso para estas nuevas campañas de fondos procedentes tanto del Ayuntamiento donde gobernaban a partir de diciembre de 1933 las formaciones de izquierdas- como de la Diputación provincial -donde lo hacían los conservadores-, lo que le permitió reemprender con fuerza las excavaciones (Rosser 2015: 119). El interés por parte de ambas instituciones en la Arqueología alicantina, pese a los avatares políticos, se mantenía vigente, iniciándose además la primera petición para la declaración como Monumento Histórico-Artístico del Tossal de Manises. En mayo de 1936 se solicitó una nueva ayuda económica que nunca llegaría debido al estallido de la guerra y la paralización de toda actividad científica.

Rígido, severo y de mal genio, un 'arqueólogo inmenso' según palabras de Solveig Nordström, Figueras se declaraba abiertamente liberal, republicano y demócrata moderado, lo que le acarreó tras la Guerra Civil serios problemas. Al igual que le sucedió a su colega José Lafuente, fue acusado de 'izquierdista', y quedó recluido desde entonces en su casa de Benalúa, donde se dedicó a clasificar los objetos arqueológicos recuperados en sus últimas excavaciones, los cuales terminó depositando en el Museo una vez finalizada la contienda. De esta represión se salvaría Belda por su condición de sacerdote. Precisamente fue él quien había firmado la denuncia política el 31 de mayo de 1940 (Rosser 2015: 141 142). 
Pese al agravamiento de su estado de salud durante los años 50, no disminuyó el ritmo de sus publicaciones y su actividad profesional fue intensa, aprovechando habitualmente material elaborado con anterioridad. Entre las obras de Figueras cabe destacar la edición de 1956 de La Necrópolis ibero-púnica de la Albufereta de Alicante y en 1959 de Dos mil años atrás. Las ciudades, el puerto y la necrópolis de la Albufereta, que sirven de compendio y epílogo a toda su producción científica.

Al igual que ocurre para el caso de Lafuente, la actividad profesional de Francisco Figueras se enmarca en un ambiente político e intelectual en ebullición, prueba de lo cual es la habitual correspondencia y los encuentros en congresos y coloquios con figuras de la talla de Pierre Paris, Adolf Schulten, Domingo Fletcher o Antonio García y Bellido. La mayor parte de su obra, no obstante, tiene un carácter provisional, aunque no por ello dejó de ser un investigador escrupuloso y metódico. En este sentido, fijó una serie de principios metodológicos que se verían reflejados años más tarde en la Nueva Arqueología anglosajona y que tendrían como principal objetivo avalar sus teorías y divulgar sus descubrimientos (Verdú 2005a: 33 ss.; 2005b).

Como consecuencia de una grave caída en plena calle en 1958 Figueras quedó postrado en cama a inicios de enero de 1960 debido a una fuerte pulmonía y a dolencias renales y cardíacas diversas, falleciendo el 21 de marzo a los 79 años (Ramos 1970: 125 ss.).

\section{La Arqueología alicantina tras la contienda}

Pese a la desastrosa situación del país tras la Guerra Civil, los estudios sobre l'Albufereta continuaron de la mano de sus excavadores, trascendiendo su fama las fronteras españolas y convirtiéndose en referencia esencial en buena parte de la bibliografía arqueológica desde la década de los 40 (Rosser 2013: 108). Hasta los años finales del franquismo la Arqueología alicantina estuvo monopolizada por eruditos locales como Lafuente, Belda o Figueras, grandes profesionales que, sin embargo, habían quedado desfasados y desconectados científicamente por el ambiente de aislamiento intelectual generado por la dictadura (Rosser 2015: 14).

Del mismo modo, la ideología del régimen supuso una ruptura con la tradición de pensamiento liberal y con otros intentos modernizadores en la investigación, encargándose además de exaltar lo indígena como 'el origen de la raza española' y, por lo tanto, menospreciando cualquier aporte foráneo.

Las interpretaciones de Lafuente, Belda y Figueras arraigaron en la sociedad alicantina hasta el punto de que nombres como los de Akra Leuka, Amílcar o Lucentum eran por todos conocidos. Habían redactado la mayoría de sus trabajos de síntesis antes de la Guerra Civil, pero tras el conflicto publicaron nuevos estudios para lo que consultaron sus antiguas notas a las que aplicaron ligeros retoques (Abad 1984: 187), evidenciando un importante vacío de información y agravando el estancamiento científico.

\section{Revisando y reinterpretando una 'excavación antigua'}

Acerca de las excavaciones en la necrópolis de l'Albufereta durante los años 30 no contamos apenas con información suficiente para precisar ni el ritmo de trabajo ni la planificación de las tareas. Sólo disponemos del registro final de los hallazgos, así como de las descripciones de ciertas estructuras y otros apuntes adicionales (Verdú 2005a: 31). Sabemos que los trabajos de campo quedaron en manos de obreros de la construcción, lo cual, sumado a la falta de recursos, a la ausencia de monumentalidad y al interés prioritario por los objetos, provocaron pérdidas irreparables en el registro al quedar desatendidos los contextos. Además, muchas de las descripciones que nos ofrecen estos investigadores son imprecisas, generando una enorme confusión que, fundamentalmente, se traduce a la hora de reconstruir los ajuares funerarios, obstáculo que subsanaría en parte la monografía de Federico Rubio (1986). 
Los requerimientos de objetividad de la moderna Arqueología de la Muerte evidencian, para el caso de este tipo de excavaciones que hoy denominamos 'antiguas', importantes limitaciones en el registro e insalvables lagunas de información que pueden superarse en parte a través del examen de la documentación original y mediante el uso de nuevas herramientas de investigación arqueológica. En este caso, a falta de diarios, buenas son las fichas y tablas manuscritas y mecanoescritas reconocibles entre la documentación inédita referidas a l'Albufereta (Verdú 2005b: 362-363).

Sobre estas excavaciones disponemos hoy de una información muy sesgada y que adolece de importantes carencias. Es por ello que la revisión y crítica de la documentación original constituye hoy una herramienta imprescindible y fundamental para recuperar muchos yacimientos y actualizar su conocimiento, partiendo de nuevos enfoques y atendiendo a la información a nuestro alcance. En este sentido cabe destacar el enorme potencial de la obra inédita, cuyo detenido análisis ha sido crucial en estudios de revisión como los aplicados a las necrópolis de Hoya de Santa Ana (Blánquez 1986-87), Archena (García y Page 1990), Llano de la Consolación (Valenciano 2000), Pozo Moro (Alcalá-Zamora 2003), El Molar (Monraval 1992; Peña 2003; 2005) o La Solivella (Oliver 2014), por citar algunos ejemplos.

En cuanto a los yacimientos alicantinos, pese a la particular visión de sus excavadores y a los errores acumulados durante décadas, algunas de las cuestiones que plantearon han 'revivido' y cobrado un nuevo valor gracias a estudios actuales. En el caso concreto de l'Albufereta, a la documentación recopilada se han sumado los aportes de la bibliografía más reciente, cuya síntesis ha quedado articulada en cada uno de los puntos integrados en el proyecto de revisión (Fig. 14). De forma paralela, se ha efectuado un detenido reconocimiento del conjunto material conservado en el Museo Arqueológico de AlicanteMARQ, elaborándose un nuevo inventario, base para la confección de un catálogo actualizado, dotado de completas descripciones, nuevas fotografías y dibujos en formato digital. El objetivo principal de este trabajo ha consistido en reconstruir el ritual funerario y analizar sus huellas en el registro arqueológico, ofreciendo una visión renovada de la necrópolis en busca de una adecuada contextualización histórica y valoración en el marco de la Cultura Ibérica.

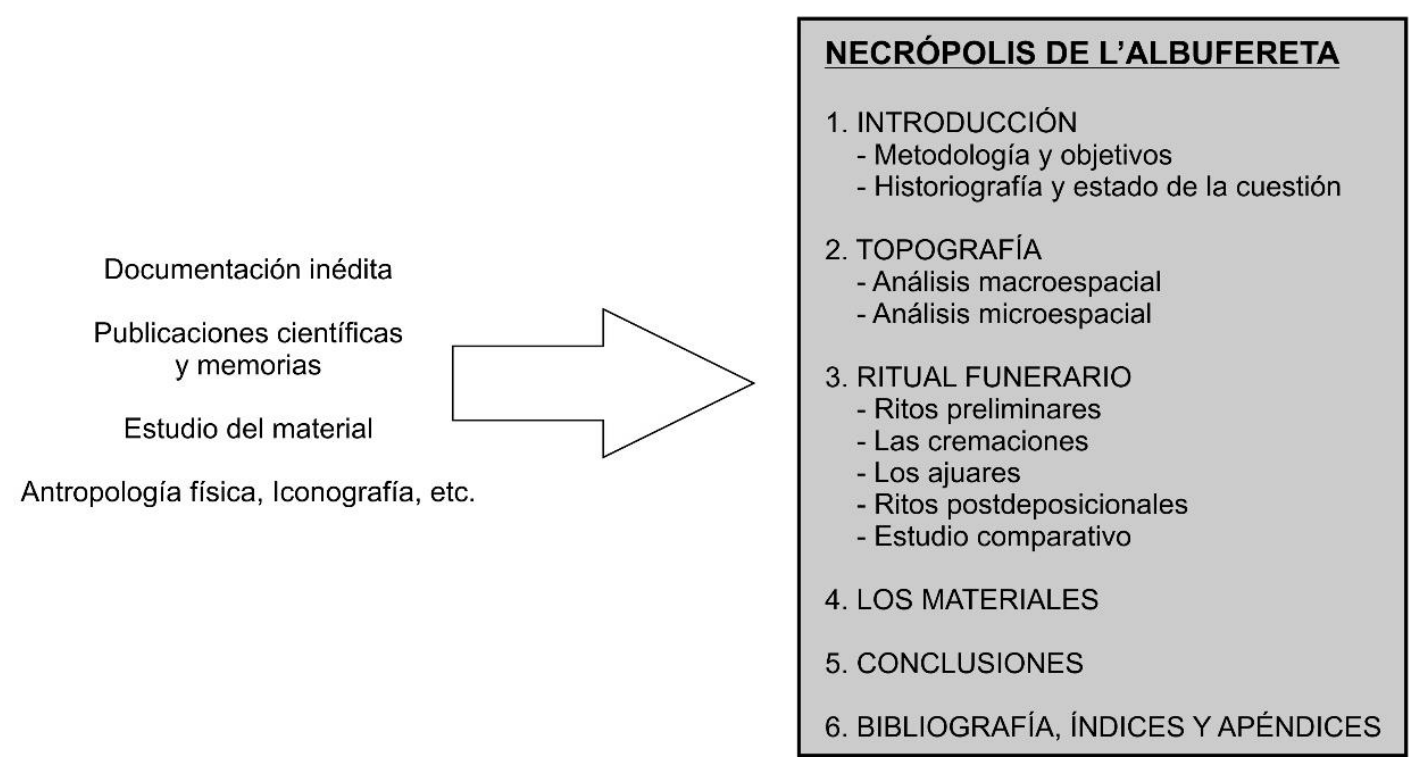

Fig. 14. Fuentes de información y esquema de trabajo para el estudio de la necrópolis de l’Albufereta.

Como ya se ha dicho, lamentablemente no disponemos de diarios propiamente dichos para el caso de l'Albufereta, bien por no haberse redactado nunca, bien por encontrarse desaparecidos o extraviados. De la campaña dirigida por José Lafuente Vidal se conocen sus publicaciones, limitándose este investigador 
más bien a indicar datos sobre la excavación entre los que no se incluyen descripciones individualizadas de las tumbas (Llobregat 1990: 94), descuidando los contextos. En cuanto a José Belda Domínguez, se tiene constancia de que redactó una especie de diario de campo (Belda 1947: 240, nota 1; Rubio 1986: 18 y 167-168; Verdú 2015: 35), aunque por desgracia se desconoce la suerte que corrieron tales anotaciones.
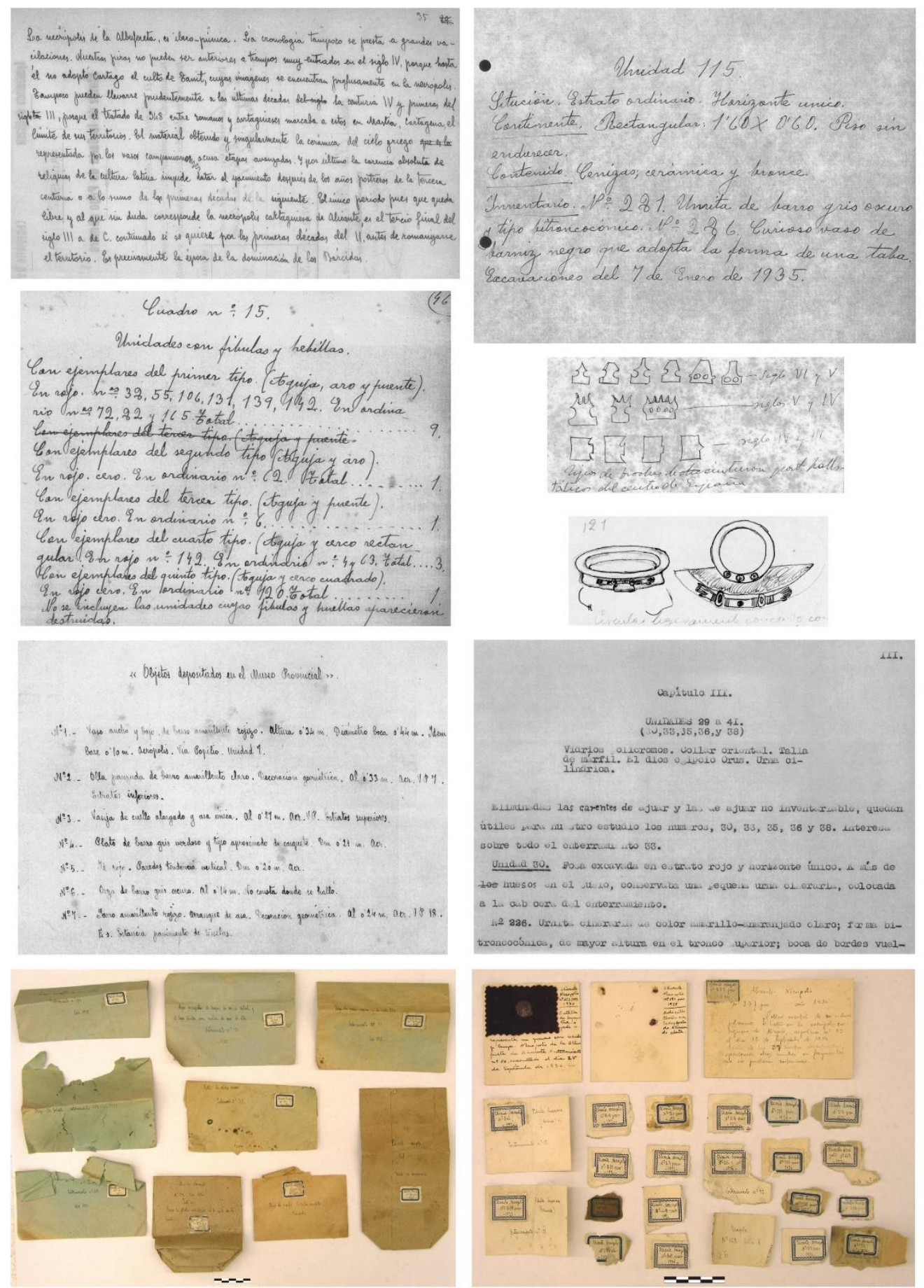

Fig. 15. Cuartillas manuscritas y mecanoescritas con descripciones de estructuras y objetos arqueológicos de la necrópolis de l'Albufereta (Biblioteca Gabriel Miró de Alicante), sobres y etiquetas identificativas (Museo Arqueológico de Alicante-MARQ). 
Figueras, por su parte, tuvo especial cuidado en registrar por escrito todo tipo de indicaciones. Sus numerosas notas, en cambio, no se corresponden con un diario de campo en sentido estricto, aunque en ellas se numeran, ordenan y caracterizan cada una de las estructuras descubiertas y se describen las piezas más interesantes que se conservaron en su interior (Fig. 15). Con todo ello elaboró un exhaustivo inventario que fue publicado en 1971. A su vez, a estas descripciones acompañan bellas obras gráficas realizadas por diversos dibujantes de la época ${ }^{7}$ (Fig. 16) y efectuadas a partir de bocetos y borradores en papel vegetal. En ciertas ocasiones incluso se llevó a cabo una 'restauración gráfica' de los materiales en peor estado de conservación (Figueras 1956: 33-34; Verdú: 2005a: 42-43, fig. 12; 2005b: 364), como sucede en el caso del denominado 'grupo escultórico' de la tumba F-100 (Figueras 1946), cuyo dibujo trataba de reproducir con vistosos colores la rica policromía que lo recubría, así como con los restos de 'braserillo' broncíneo de la sepultura F-62 (Fig. 17).
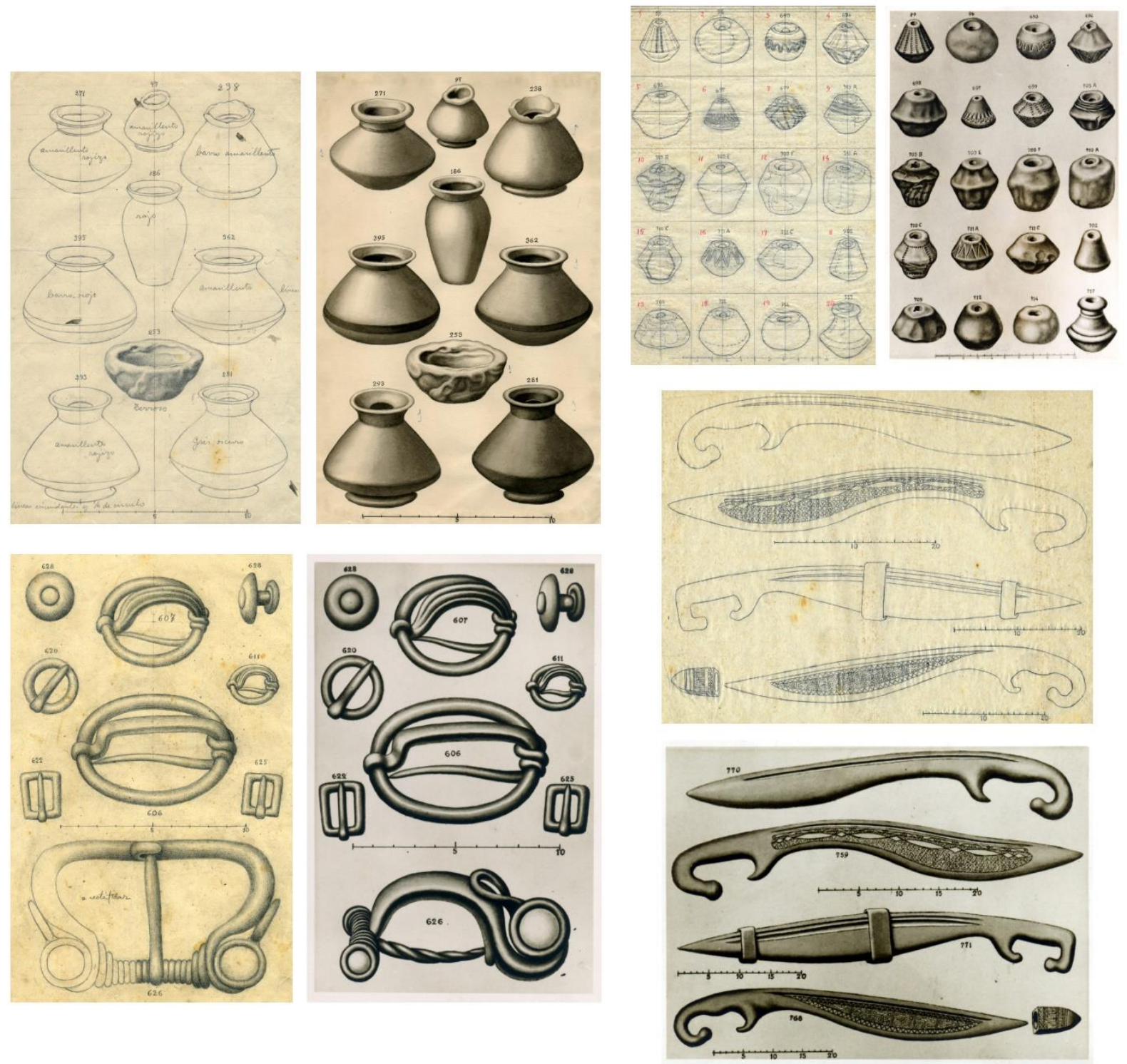

Fig. 16. Diversos borradores y bocetos finales de materiales de la necrópolis (fotos Archivo Gráfico MARQ).

\footnotetext{
${ }^{7}$ Entre ellos el principal fue Juan Such Roca.
} 

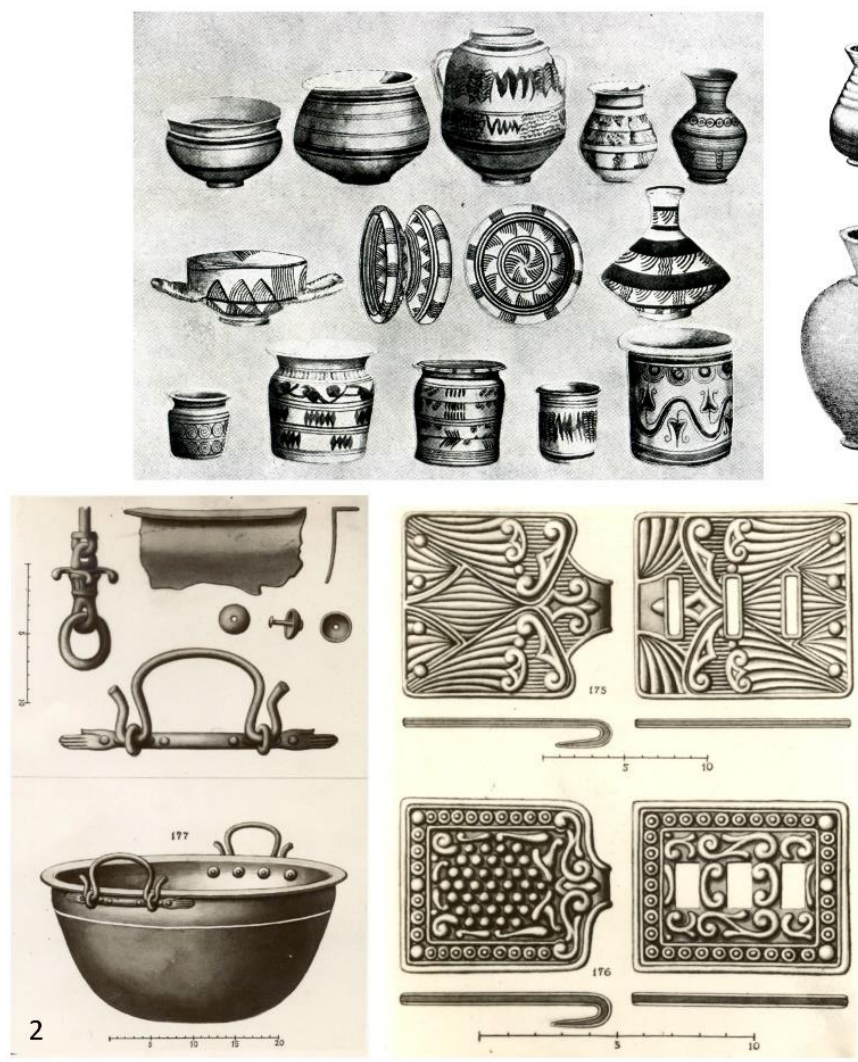
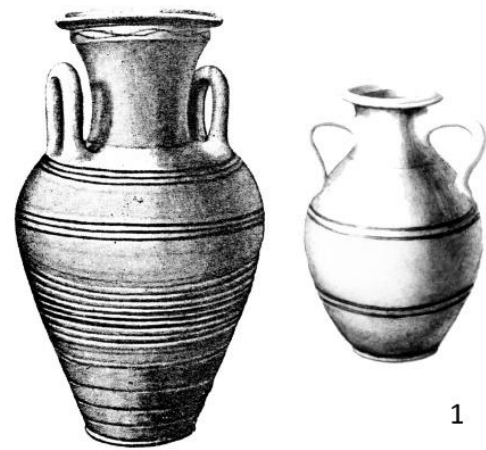

1
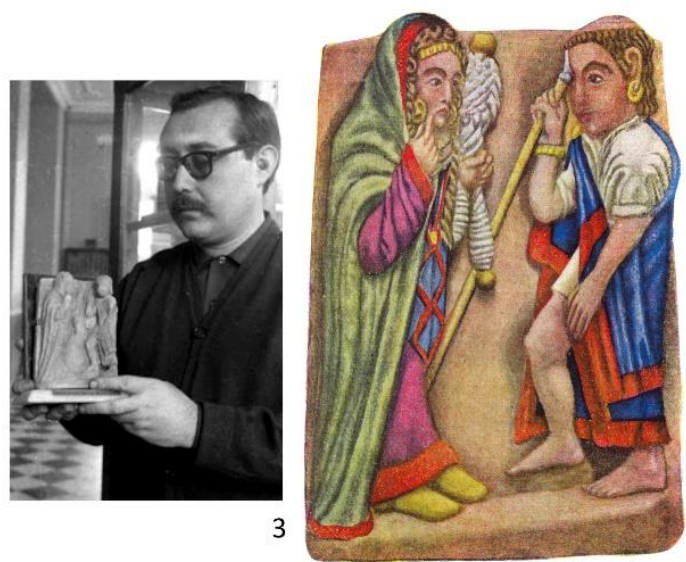

Fig. 17. 1. Cerámicas ibéricas (Lafuente 1959: lám. XI) y púnicas (Figueras 1956: láms. II, XXV y XXVII, y foto Archivo Gráfico MARQ) de la necrópolis de l'Albufereta. 2. 'Reconstrucción gráfica' de un 'braserillo' y dos broches de bronce (fotos Archivo Gráfico MARQ). 3. El 'grupo escultórico' de l'Albufereta (foto Archivo Gráfico MARQ) y reconstrucción de la policromía original (Figueras 1946: fig. 2).

Se conservan también varias imágenes tomadas en los años 30 del siglo XX en las antiguas instalaciones del Museo Arqueológico correspondientes a las piezas más emblemáticas de la necrópolis, a veces nada más ser rescatadas de la tierra y sometidas a una limpieza superficial. Entre estas instantáneas se aprecian distintos montajes o su colocación en diferentes vitrinas (Fig. 18).

Más allá de los objetos arqueológicos, no contamos más que con algunos croquis de los terrenos explorados, en ningún caso una auténtica planimetría (Verdú 2005a: 34-35, fig. 5; 2005b: 361-362, fig. 4; 2015: 55 ss., fig. 2.5), y sucintas descripciones que permiten una cierta aproximación a la apariencia original de la necrópolis. Asimismo, disponemos de muy pocas fotografías del proceso de excavación, caso de la de una sepultura exhumada durante la campaña Lafuente (1944: fig. 16; Verdú 2005a: 40, fig. 8), a partir de la cual se ha identificado la urna cineraria (Fig. 19).

Desde el punto de vista de las características topográficas, se ha recopilado toda la información relativa a la forma, dimensiones y otras peculiaridades de las cerca de 300 estructuras que integraban la necrópolis de l'Albufereta, clasificándolas según su funcionalidad y precisando algunos datos sobre el ritual funerario.

Del mismo modo, también se ha desarrollado un análisis en profundidad del repertorio material, sobre todo cerámico, en el que destaca un amplio abanico de importaciones de procedencia griega y del área púnica. Se ha emprendido además una clasificación formal y funcional de las cerámicas ibéricas, que suponen un 50\% de las producciones vasculares documentadas en el yacimiento (Fig. 20). 

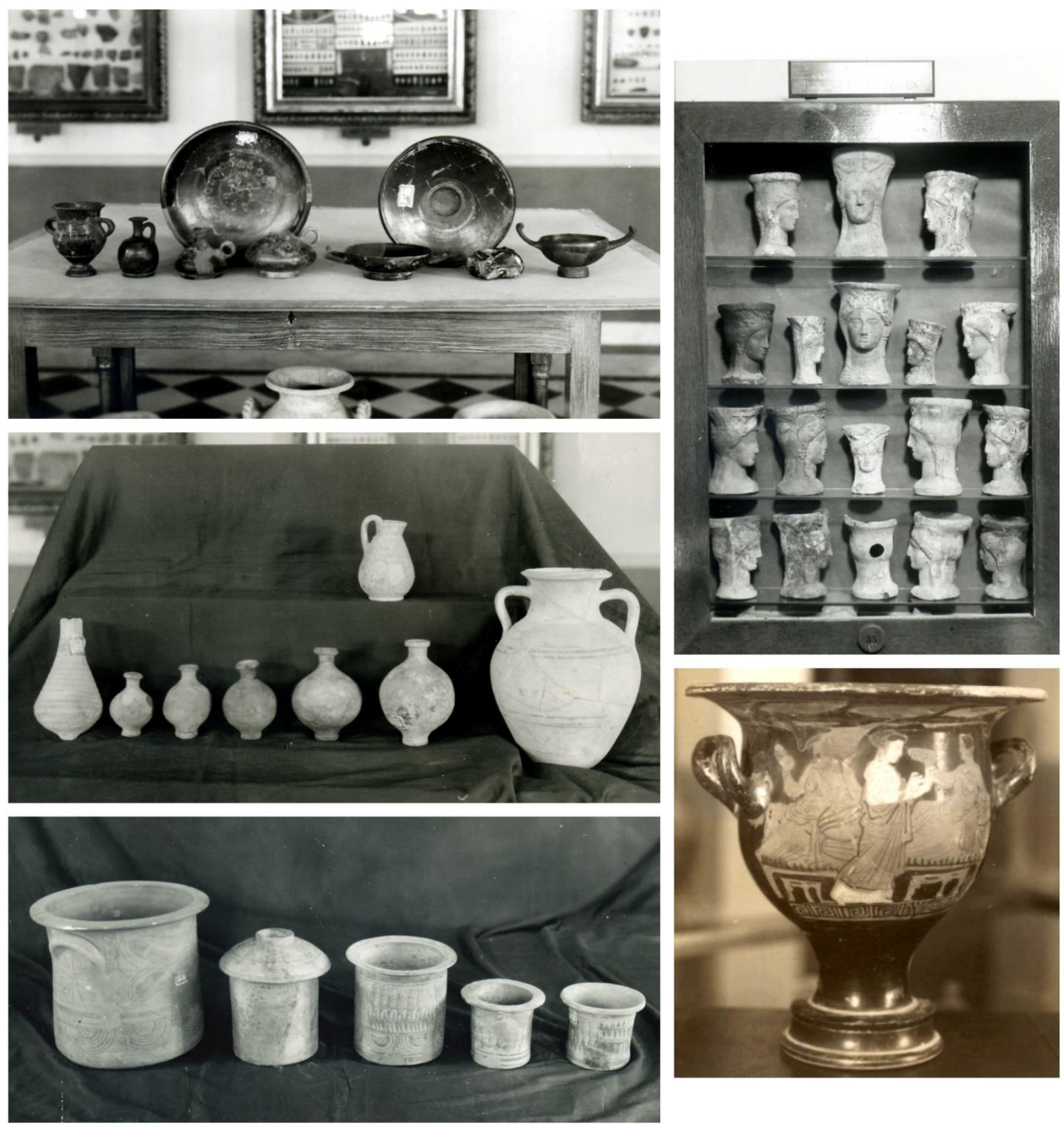

Fig. 18. Fotografías realizadas en el antiguo Museo Arqueológico Provincial de Alicante sobre varios montajes de materiales y vitrinas de la exposición, años 30 (fotos Archivo Gráfico MARQ). 

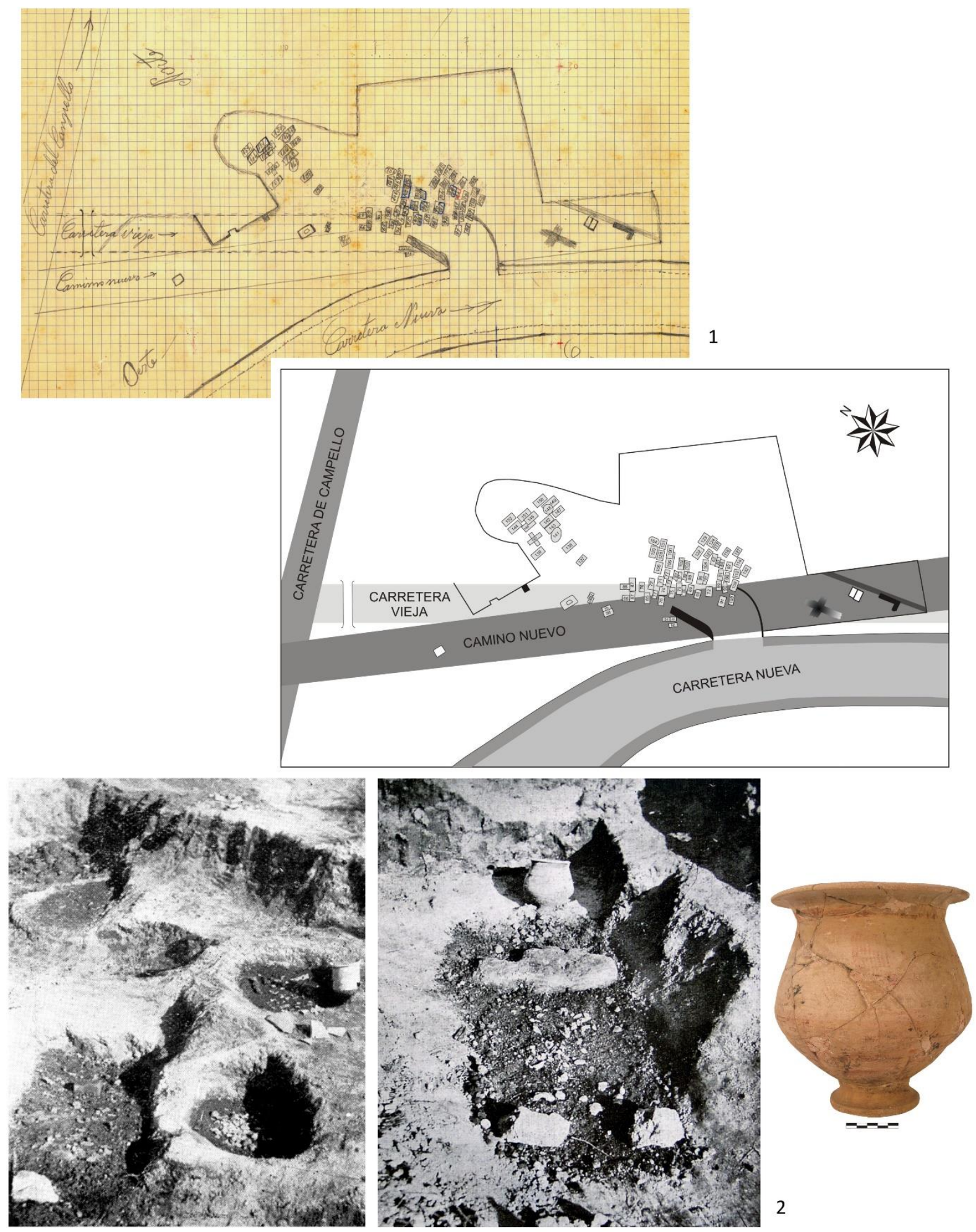

Fig. 19. 1. Croquis original de las excavaciones de l'Albufereta (foto Archivo Gráfico MARQ) y digitalización del documento (Verdú 2015: fig. 2.5). 2. Fotografía de diversos depósitos funerarios de la necrópolis (Lafuente 1957: lám. VII) y de una fosa con urna cineraria (Lafuente 1944: fig. 16), hoy identificada (foto Archivo Gráfico MARQ). 

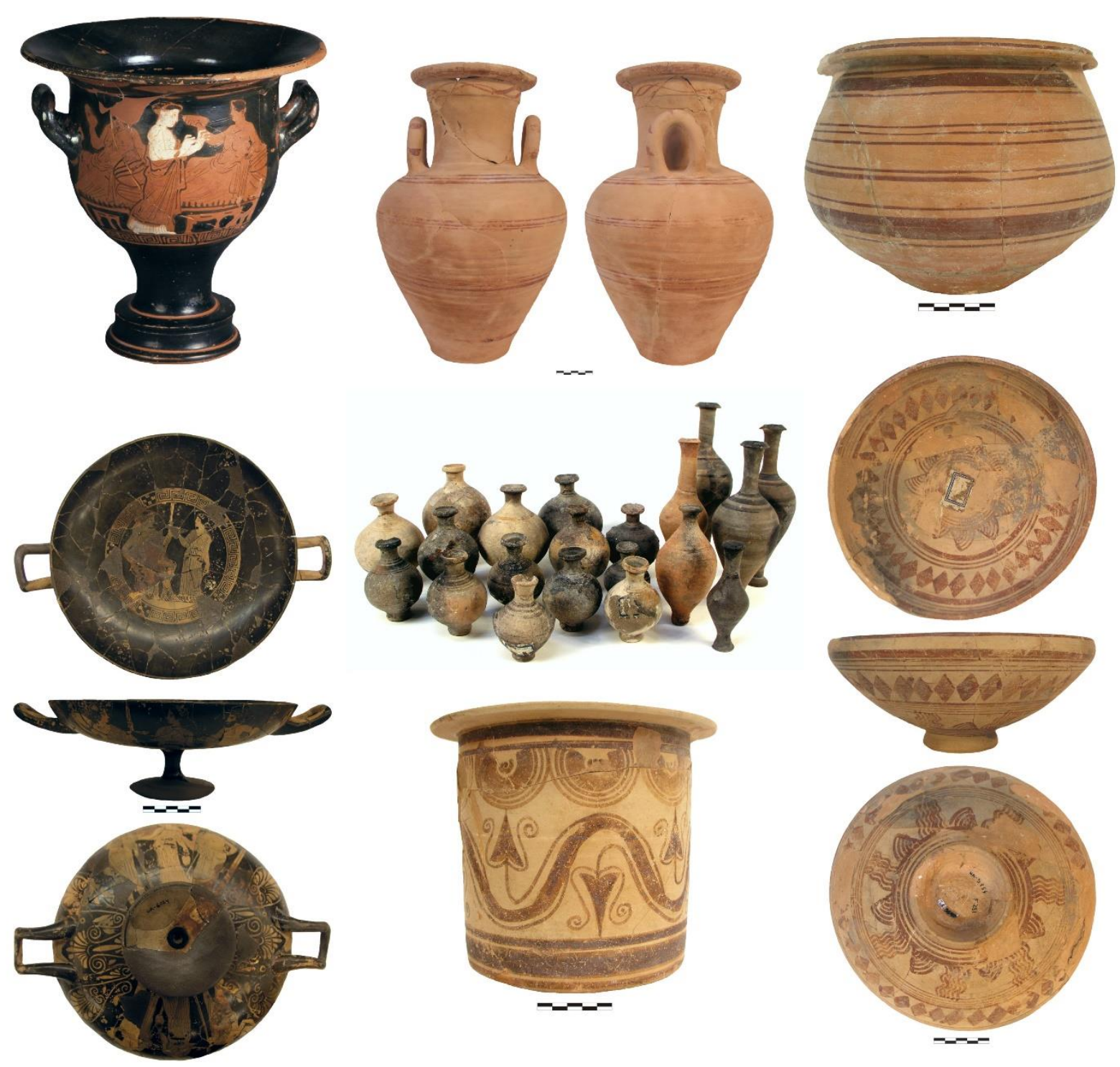

Fig. 20. Selección de materiales cerámicos recuperados en la necrópolis de l’Albufereta (fotos Archivo Gráfico MARQ).

A partir de la documentación antigua y de la moderna bibliografía se presenta, a modo de hipótesis, la reconstrucción de un monumento funerario tipo 'pilar-estela', así como la policromía que debió revestir buena parte de la nutrida colección de objetos de terracota registrados, entre los cuales los denominados 'pebeteros en forma de cabeza femenina' constituyen una de las señas de identidad del yacimiento (Moratalla y Verdú 2007: 340 ss.; Sala y Verdú 2014; Verdú 2005a: 61-63; 2015, 246 ss.). Por otro lado, frente a la relativa escasez de armas cabe citar la aparición de algunos utensilios metálicos de trabajo, así como de fragmentos de 'braserillos' y pasarriendas de bronce, cuentas de pasta vítrea, monedas púnicas y restos carbonizados de red de pesca (Fig. 21). Se trata de elementos revestidos de un especial significado en el contexto de la necrópolis. 


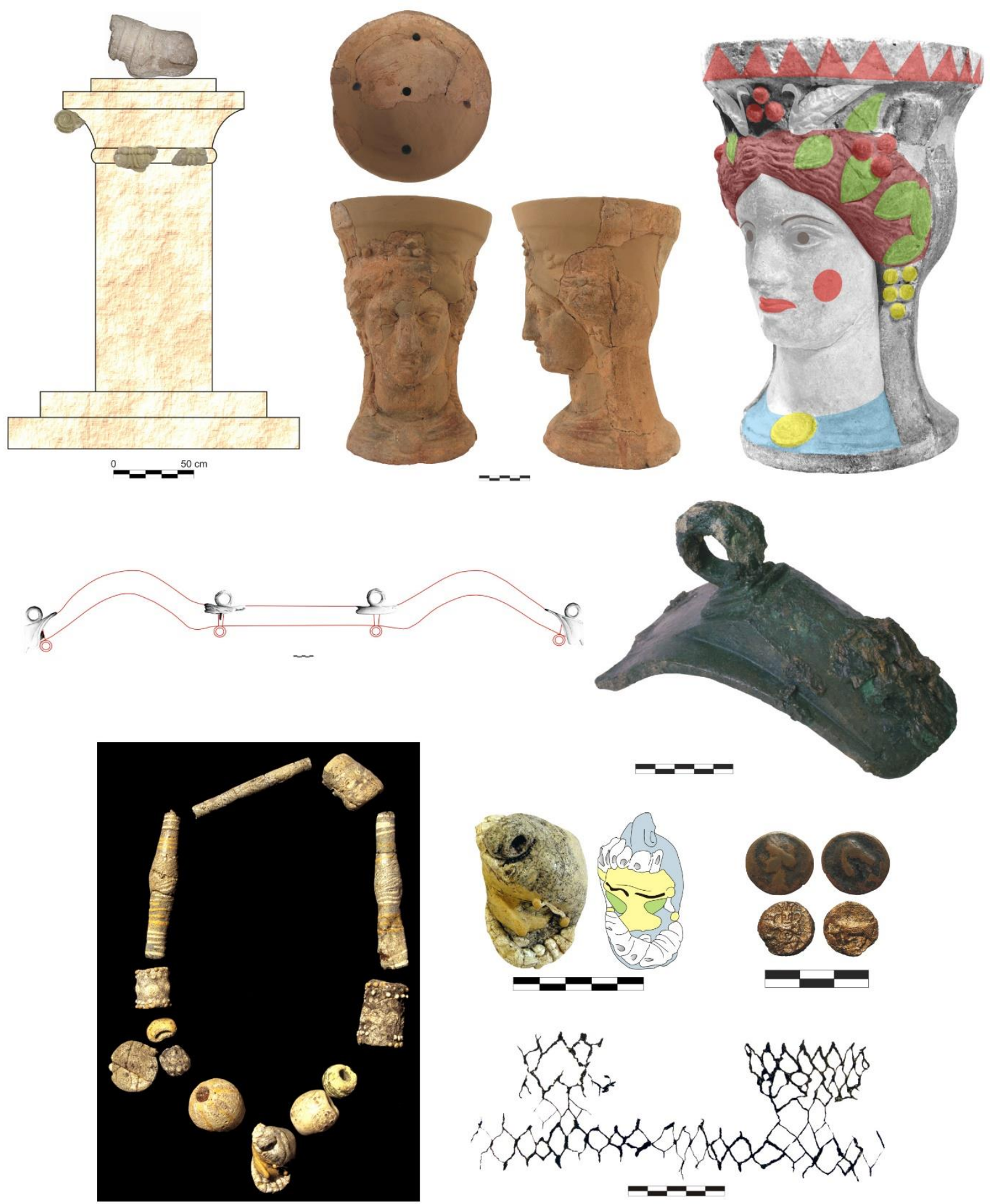

Fig. 21. Otros objetos procedentes de l'Albufereta: reconstrucción de un monumento tipo 'pilar-estela', pebetero en forma de cabeza femenina y propuesta de recreación de su policromía, esquema de colocación de las abrazaderas de yugo de bronce, collar de cuentas de pasta vítrea y colgante en forma de 'máscara demoníaca', monedas púnicas y restos de red de pesca carbonizada (fotos Archivo Gráfico MARQ). 
El análisis del registro material ha permitido efectuar finalmente un estudio comparativo orientado a determinar ciertas cuestiones relativas al género y riqueza de los ajuares funerarios de l'Albufereta (Verdú 2015: 423 ss.), ambos asuntos tratados, sin embargo, con ciertas reservas. Asimismo, se ha procurado corregir y proponer cronologías más precisas para buena parte de las estructuras para las que existen datos aprovechables (Fig. 22). De este modo, hoy sabemos que la necrópolis arrancaría a inicios del siglo IV a.C., manteniendo un ritmo más o menos regular de deposiciones hasta fines o inicios de la centuria siguiente, momento en el que se produciría un considerable incremento en el número de enterramientos hasta alcanzar sus años finales, en clara conexión con los acontecimientos derivados de la $2^{\text {a }}$ Guerra Púnica en las costas alicantinas y, en concreto, con la derrota de los Barca y la destrucción del Tossal de Manises, como han atestiguado las excavaciones recientes ${ }^{8}$.
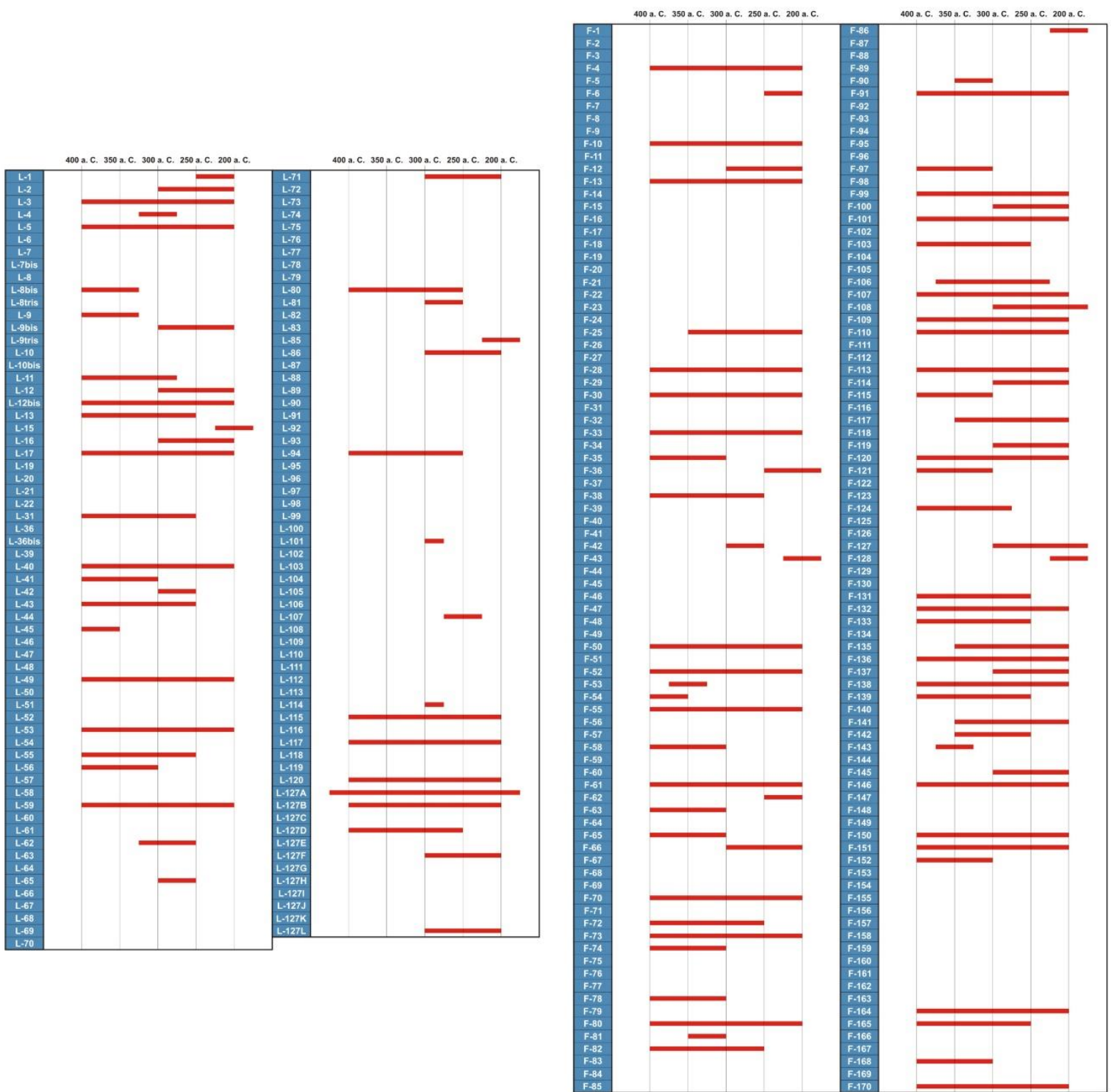

Fig. 22. Propuesta de cronología para las estructuras funerarias de la necrópolis de l'Albufereta (Verdú 2015: cuadros 5.1 y 5.2).

${ }^{8}$ Véanse al respecto Olcina 2009; Olcina, Guilabert y Tendero 2010; Olcina y Pérez 1998, entre otras obras. 
El empuje urbanístico transformaría para siempre el paisaje de l'Albufereta, salvándose de la destrucción el Tossal de Manises gracias a la obtención en 1961 de la Declaración de Monumento Histórico-Artístico Nacional (Rosser 2015: 305 ss.) y a una intensa actividad de concienciación ciudadana (Abad 1984: 36; Llobregat 1990: 96). Mientras tanto, la necrópolis sucumbía al paso del tiempo, perdurando su memoria a través de los objetos exhibidos primero en las vitrinas del Museo Arqueológico Provincial y hoy en las modernas instalaciones del MARQ. Su recuerdo pervive además gracias a las publicaciones y a la obra inédita de sus descubridores, cuya labor fue fundamental para conocer y convertir a este yacimiento en todo un referente bibliográfico (Verdú 2005a: 102 ss.).

\section{Bibliografía}

Abad Casal, L. (1984), Los orígenes de la ciudad de Alicante, Alicante. Instituto de Estudios Juan Gil-Albert. Alcalá-Zamora Díaz-Berrio, L. (2003), La necrópolis ibérica de Pozo Moro, Madrid. Bibliotheca Archaeologica Hispana 23.

Belda Domínguez, J. (1929), Excavaciones en el "Monte de la Barcella» término de Torremanzanas (Alicante). Memoria de los trabajos y hallazgos arqueológicos en las excavaciones practicadas en 1928, Madrid. Junta Superior de Excavaciones y Antigüedades 100.

Belda Domínguez, J. (1931), Excavaciones en el "Monte de la Barcella» término de Torremanzanas (Alicante). Memoria de los trabajos y hallazgos arqueológicos en las excavaciones practicadas en 1929, Madrid. Junta Superior de Excavaciones y Antigüedades 112.

Belda Domínguez, J. (1947), Algunos restos del antiguo culto a la diosa religioso-funeraria. // Congreso Arqueológico del Sudeste Español (Albacete, 1946). Albacete: 236-259.

Blánquez Pérez, J. J. (1986-87), Notas acerca de una revisión de la necrópolis ibérica de la Hoya de Santa Ana (Chinchilla, Albacete). Cuadernos de Prehistoria y Arqueología de la Universidad Autónoma de Madrid 13-14: 9-27.

Bonet Rosado, H. (1999), 'El Servicio de Investigación Prehistórica de Valencia: de Isidro Ballester a Domingo Fletcher' en J. Blánquez y L. Roldán (eds), La Cultura Ibérica a través de la fotografía de principios de siglo. Un homenaje a la memoria. Madrid. Universidad Autónoma de Madrid: 117123.

Box Amorós, M. (1987), Humedales y áreas lacustres de la provincia de Alicante, Alicante. Instituto de Estudios Juan Gil-Albert.

Cavanilles Palop, A. J. (1797), Observaciones sobre la Historia Natural, Geografía, Agricultura, Población y Frutos del Reyno de Valencia II, Madrid.

De Pedro Michó, M. J. (2006), 'Isidro Ballester Tormo i la creació del Servei d'Investigació Prehistòrica', Arqueologia en blanc i negre. La labor del SIP 1927-1950. València. Diputació de València: 47-66.

Enguix Alemany, R. (1973), Aproximación a una historia de la investigación de la cultura ibérica. Papeles del Laboratorio de Arqueología de Valencia 9: 19-28.

Figueras Pacheco, F. (1932), Acra Leuca. La ciudad de Amílcar, Alicante. Imprenta Lucentum. Ensayos de Geografía Antigua.

Figueras Pacheco, F. (1934), Excavaciones en la Isla del Campello (Alicante) 1931-1933, Madrid. Junta Superior del Tesoro Artístico 132.

Figueras Pacheco, F. (1946), El grupo escultórico de Alicante. Archivo Español de Arqueología 19: 309333.

Figueras Pacheco, F. (1956), La necrópolis iberopúnica de la Albufereta de Alicante, Valencia. Diputación de Valencia. Estudios Ibéricos 4.

Figueras Pacheco, F. (1971), Relación de hallazgos en el Tosal de Manises (Alicante). 1933-1935, Alicante. Publicaciones del fondo editorial del Excmo. Ayuntamiento de Alicante. Serie maior XIII.

Fletcher Valls, D. (1949), Defensa del iberismo. Anales del Centro de Cultura Valenciana 24: 168-187. 
García Cano, J. M. y Page del Pozo, V. (1990), La necrópolis ibérica de Archena. Revisión de los materiales y nuevos hallazgos. Verdolay 2: 109-147.

Gil Sánchez, F., Aldeguer Jover, F., Álvarez Antón, R. y Martínez Rodríguez, M. (1984), Alicante, 1934, Alicante. Banco de Alicante.

Lafuente Vidal, J. (1929), La necrópolis ibérica de El Molar (provincia de Alicante). Boletín de la Real Academia de la Historia 94: 617-632.

Lafuente Vidal, J. (1932), Alicante en la Antigüedad, Alicante.

Lafuente Vidal, J. (1934), Excavaciones en La Albufereta de Alicante (Antigua Lucentum), Madrid. Junta Superior del Tesoro Artístico. Sección de Excavaciones 126.

Lafuente Vidal, J. (1944), Algunos datos concretos de la provincia de Alicante sobre el problema cronológico de la cerámica ibérica. Archivo Español de Arqueología 18: 68-87.

Lafuente Vidal, J. (1957), Alicante en la Edad Antigua. Segunda edición aumentada, Alicante. Gráficas Gutenberg.

Lafuente Vidal, J. (1959), Museo Arqueológico Provincial de Alicante. Catálogo-guía, Alicante. Instituto de Estudios Alicantinos XII.

López Azorín, F. (1999), 'Los trabajos arqueológicos del Padre Lasalde' en J. Blánquez y L. Roldán (eds), La Cultura Ibérica a través de la fotografía de principios de siglo. Un homenaje a la memoria. Madrid. Universidad Autónoma de Madrid: 209-214.

Llobregat Conesa, E. (1990), 'Alicante ibérico' en F. Moreno (dir), Historia de Alicante, I. Alicante. Patronato Municipal para la conmemoración del Quinto Centenario de la Ciudad de Alicante: 29117.

Martínez Leal, J. (1990), 'La II República (1931-1936)' en F. Moreno (dir), Historia de Alicante, II. Alicante. Patronato Municipal para la conmemoración del Quinto Centenario de la Ciudad de Alicante: 641660.

Martínez Morellá, V. (1970), In memoriam: José Belda Domínguez. Revista del Instituto de Estudios Alicantinos 3: 33-45.

Monraval Sapiña, J. M. (1992), La necrópolis ibérica de El Molar (San Fulgencio-Guardamar del Segura, Alicante), Alicante. Catálogo de los fondos del Museo Arqueológico V.

Moratalla Jávega, J. y Verdú Parra, E. (2007), 'Pebeteros con forma de cabeza femenina de la Contestania ibérica' en M. C. Marín y F. Horn (coords), Imagen y culto en la Iberia prerromana: los pebeteros en forma de cabeza femenina, Spal Monografías IX. Sevilla. Universidad de Sevilla: 339-366.

Moreno Sáez, F. (1990a), 'La ciudad en el primer tercio del siglo XX' en F. Moreno (dir), Historia de Alicante, II. Alicante. Patronato Municipal para la conmemoración del Quinto Centenario de la Ciudad de Alicante: 601-620.

Moreno Sáez, F. (1990b), 'La cultura en el siglo XX' en F. Moreno (dir), Historia de Alicante, II. Alicante. Patronato Municipal para la conmemoración del Quinto Centenario de la Ciudad de Alicante: 781800.

Moreno Sáez, F. (2014), La Edad de Oro de la cultura alicantina. Canelobre 63: 97-107.

Moreno Sáez, F. y Mateo Martínez, C. (dirs) (1991), Memoria gráfica de la ciudad de Alicante, Alicante. Patronato Municipal para la conmemoración del Quinto Centenario de la Ciudad de Alicante.

Olcina Doménech, M. H. (2001), 'Las primeras excavaciones en Lucentum (El Tossal de Manises, Alicante)' en J. Blánquez y L. Roldán (eds), La Cultura Ibérica a través de la fotografía de principios de siglo. El litoral mediterráneo. Madrid. Universidad Autónoma de Madrid: 109-117.

Olcina Doménech, M. H. (2009), 'Evolución histórica y urbana' en M. Olcina (ed), Lucentum (Tossal de Manises, Alicante). Arqueología e Historia. Alicante. Museo Arqueológico de Alicante-MARQ: 3363. 
Olcina Doménech, M. H. y Pérez Jiménez, R. (1998), La ciudad ibero-romana de Lucentum (El Tossal de Manises, Alicante). Introducción a la investigación del yacimiento arqueológico y su recuperación como espacio público, Alicante. Museo Arqueológico de Alicante.

Olcina Doménech, M. H., Martínez Carmona, A. y Sala Sellés, F. (2009), La Illeta dels Banyets (El Campello, Alicante). Épocas Ibérica y Romana, I. Historia de la investigación y síntesis de las intervenciones recientes (2000-2003), Alicante. Museo Arqueológico de Alicante-MARQ. Serie Mayor 7.

Olcina Doménech, M. H., Guilabert Mas, A. y Tendero Porras, E. (2010), 'Lectura púnica del Tossal de Manises (Alicante)' en E. Ferrer (coord), Los púnicos de Iberia: proyectos, revisiones, síntesis. Mainake 32 (1): 127-137.

Olcina Doménech, M. H. y Soler Díaz, J. A. (2007), En el 75 aniversario del Museo Arqueológico de Alicante: diez apuntes sobre su historia. MARQ. Arqueología y Museos 2: 133-153.

Oliver Foix, A. J. (2014), La necrópolis ibérica de la Solivella: Nuevas visiones, nuevas propuestas. Cuadernos de Prehistoria y Arqueología de la Universidad Autónoma de Madrid 40: 67-79.

Peña Ligero, Á. (2003), La necrópolis ibérica de El Molar (San Fulgencio-Alicante). Revisión de las excavaciones realizadas en 1928 y 1929, Villena. Fundación Municipal José Ma Soler (Villena).

Peña Ligero, Á. (2005), 'La necrópolis ibérica del Molar (San Fulgencio, Alicante). Revisión de las excavaciones realizadas en 1928 y 1929' en L. Abad, F. Sala e I. Grau (eds), La Contestania Ibérica, treinta años después. Alicante. Publicaciones de la Universidad de Alicante: 369-384.

Quesada Sanz, F. (2001), 'Las primeras excavaciones en la necrópolis ibérica de El Cabecico del Tesoro (Verdolay, Murcia)' en J. Blánquez y L. Roldán (eds), La Cultura Ibérica a través de la fotografía de principios de siglo. El litoral mediterráneo. Madrid. Caja de Ahorros del Mediterráneo-Universidad Autónoma de Madrid: 61-69.

Ramos Pérez, V. (1970), Francisco Figueras Pacheco (1890-1960), Alicante. Ayuntamiento de Alicante.

Ramos Pérez, V. (1992), Breve historia del Ateneo de Alicante, Alicante. Ateneo Literario, Científico y Artístico.

Roca de Togores Muñoz, C. (2006), Joaquín de Rojas. Primer director del Museo Arqueológico Provincial de Alicante. MARQ. Arqueología y Museos 1: 157-168.

Rosser Limiñana, P. (2013), Arqueología del poblamiento de un territorio del Mediterráneo occidental (Alicante, España) desde época tardía a la primera ocupación islámica. Un espacio activo sin ciudad: de villas a aldeas. Tesis doctoral inédita, Alicante.

Rosser Limiñana, P. (2015), Historias y arqueólogos en Alicante. Historiografía arqueológica de los siglos $X I X$ y $X X$, Alicante. Instituto Alicantino de Cultura Juan Gil-Albert.

Rouillard, P. (1999), 'Arthur Engel, Pierre Paris y los primeros pasos en los estudios ibéricos' en J. Blánquez y L. Roldán (eds), La Cultura Ibérica a través de la fotografía de principios de siglo. Un homenaje a la memoria. Madrid. Universidad Autónoma de Madrid: 25-32.

Rovira i Port, J. (2001), 'Bosch Gimpera y la creación del Museo Arqueológico de Barcelona' en J. Blánquez y L. Roldán (eds), La Cultura Ibérica a través de la fotografía de principios de siglo. El litoral mediterráneo. Madrid. Caja de Ahorros del Mediterráneo-Universidad Autónoma de Madrid: 209219.

Rubio Gomis, F. (1986), La necrópolis ibérica de La Albufereta de Alicante (Valencia, España), Valencia. Academia de Cultura Valenciana. Sección de Prehistoria y Arqueología. Serie Arqueológica 11.

Ruiz Rodríguez, A., Sánchez Vizcaíno, A. y Bellón Ruiz, J. P. (2006), Los archivos de la arqueología ibérica: una arqueología para dos Españas, Jaén. Universidad de Jaén.

Sala Sellés, F. y Verdú Parra, E. (2014), 'Pebeteros en forma de cabeza femenina en la Contestania. Estado de la cuestión y perspectivas de estudio' en M. C. Marín y A. M. Jiménez (coords), Imagen y culto en la Iberia prerromana II: nuevas lecturas sobre los pebeteros en forma de cabeza femenina, Spal Monografías XVIII. Sevilla. Universidad de Sevilla: 19-34. 
Sanmartí-Grego, E. (1999), 'Bosch Gimpera y la Escuela Catalana de Estudios Ibéricos' en J. Blánquez y L. Roldán (eds), La Cultura Ibérica a través de la fotografía de principios de siglo. Un homenaje a la memoria. Madrid. Universidad Autónoma de Madrid: 109-112.

Soler Díaz, J. (2000), El Museo Provincial de Alicante como proyecto centenario. Canelobre 41-42: 35-46.

Soler Díaz, J. (2001), 'Síntesis de la historia del Museo Arqueológico Provincial de Alicante. Una crónica en seis actos' en J. Blánquez y L. Roldán (eds), La Cultura Ibérica a través de la fotografía de principios de siglo. El litoral mediterráneo. Madrid. Caja de Ahorros del Mediterráneo-Universidad Autónoma de Madrid: 83-91.

Soler Díaz, J. A. y Olcina Doménech, M. H. (2001), 'Los legados fundacionales y otros legados de piezas de Arqueología', Legados del MARQ. Alicante. Museo Arqueológico de Alicante-MARQ: 10-15.

Valenciano Prieto, M. C. (2000), El Llano de la Consolación (Montealegre del Castillo, Albacete). Revisión crítica de una necrópolis ibérica del Sureste de la Meseta, Albacete. Instituto de Estudios Albacetenses.

Verdú Parra, E. (2005a), Francisco Figueras Pacheco y las excavaciones en la necrópolis ibérica de La Albufereta de Alicante (1934-1936), Alicante. Museo Arqueológico de Alicante-MARQ. Serie Mayor 4.

Verdú Parra, E. (2005b), 'Las excavaciones arqueológicas en la necrópolis de la Albufereta. La metodología de campo en una excavación antigua' en L. Abad, F. Sala e I. Grau (eds), La Contestania ibérica, treinta años después. Alicante. Publicaciones de la Universidad de Alicante: 357-368.

Verdú Parra, E. (2015), La necrópolis ibérica de l'Albufereta (Alacant). Ritos y usos funerarios en un contexto de interacción cultural, Alicante. Museo Arqueológico de Alicante-MARQ. Serie Mayor 11.

\section{WebgrafíA}

http://www.alicante.es/sites/default/files/documentos /documentos/pla-dalacant-i-voltants-alcatlenginyer-m.miralles-1794/plano-ingeniero-m.miralles.pdf

http://www.alicantevivo.org/2007/04/el-padre-belda.html

http://www.alicantevivo.org/2007/09/alicante-en-el-recuerdo-la-albufereta.html

http://www.alicantevivo.org/2009/07/entrevista-postuma-d-francisco-figueras.html

http://www.alicantevivo.org/2009/11/la-cultura-en-el-recuerdo-francisco.html 


\title{
De la exhumación de las estructuras a los estudios arquitectónicos. Nuevas aportaciones historiográficas a la edilicia de Carteia
}

\author{
Alberto Romero Molero
}

Universidad Isabel I

\section{Introducción. La ciudad de Carteia}

La importancia de la ciudad de Carteia es motivada tanto por una situación geopolítica excepcional en el estrecho de Gibraltar como por un dilatado proceso histórico (Fig. 1), materializado en construcciones heterogéneas de diversa cronología (Roldán et alii 2006). Los orígenes de la ciudad se rastrean en la fundación de la factoría fenicia del Cerro del Prado a mediados del s. VII a.C., con su posterior traslado al actual emplazamiento a mediados del s. IV a.C. Durante la época romana, la ciudad experimentó un notable desarrollo urbanístico, tal y como se constata a partir de los restos arqueológicos exhumados. Tras una progresiva decadencia durante el Bajo Imperio y en época tardoantigua, este dilatado proceso histórico continuaría hasta la caída de la fortaleza meriní de Hisn Qartayanna a manos cristianas en el s. XIV de nuestra era.

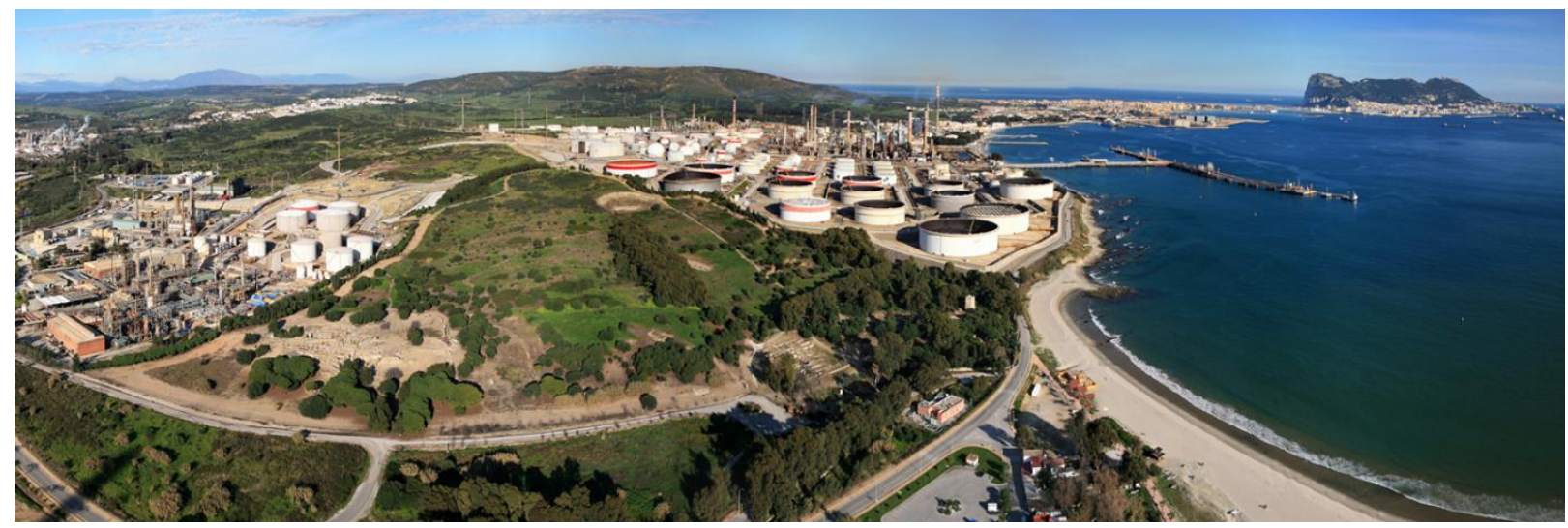

Fig. 1. Vista aérea de la ciudad de Carteia (San Roque, Cádiz). C Paisajes Aéreos S.L. Foto J.C. Guzmán Espresati (2007).

La situación de la ciudad al fondo de la Bahía de Algeciras y en la boca del estuario que en la Antigüedad configuraba la desembocadura del río Guadarranque, suponía el control estratégico del estrecho de Gibraltar, punto nodal de la geografía antigua, señalado en el imaginario mítico griego como las Columnas de Hércules (Jiménez Vialás 2009; Blánquez et alii 2012). Su posición geográfica explica la continua implicación de la urbe en los sucesivos conflictos que afectaron a la zona con las distintas potencias decididas a dominar el Mediterráneo y el control de la salida al Atlántico. Esta situación privilegiada geopolítica y estratégica- determinó, sin duda, un papel fundamental en el transcurso de la invasión musulmana, como excelente referencia para los nuevos conquistadores provenientes del otro lado del Estrecho. 
Aparte de su posible identificación desde época antigua con Tartessos $^{1}$, que alude a que ya entonces era considerada como una fundación de una gran antiguiedad, las fuentes ${ }^{2}$ destacaron el hecho de que Carteia fue la primera colonia latina fuera de Italia y describieron la riqueza piscícola de la zona y el desarrollo de las pesquerías del entorno de la ciudad.

\section{Historia de las investigaciones en la ciudad: de los años 50 a la actualidad}

Tres han sido los equipos de arqueólogos que excavaron en Carteia en la segunda mitad del pasado siglo XX: Santa-Olalla, Woods y Presedo (Roldán y Blánquez 2011a). Las intervenciones de Julio Martínez Santa-Olalla en los años cincuenta favorecieron que la comunidad científica española tomara conciencia de su importancia pues, de hecho, salvo pequeños intervalos, Carteia no dejaría ya de excavarse hasta prácticamente nuestros días (Roldán y Blánquez 2011b; 2012).

Las excavaciones por él acometidas estuvieron caracterizadas por dos aspectos fundamentales: por un lado, la diversidad en cuanto a los lugares intervenidos dentro de la ciudad: muralla, termas, teatro, factoría de salazón y necrópolis y, por otro, acorde con los criterios de su época, pero mantenidos durante décadas posteriores, por buscar siempre construcciones de carácter monumental. Sin embargo, lamentablemente, en cuanto a publicaciones, tan sólo llegó a redactar una recopilación de las fuentes textuales clásicas referidas a la ciudad, así como sus referencias en la historiografía moderna.

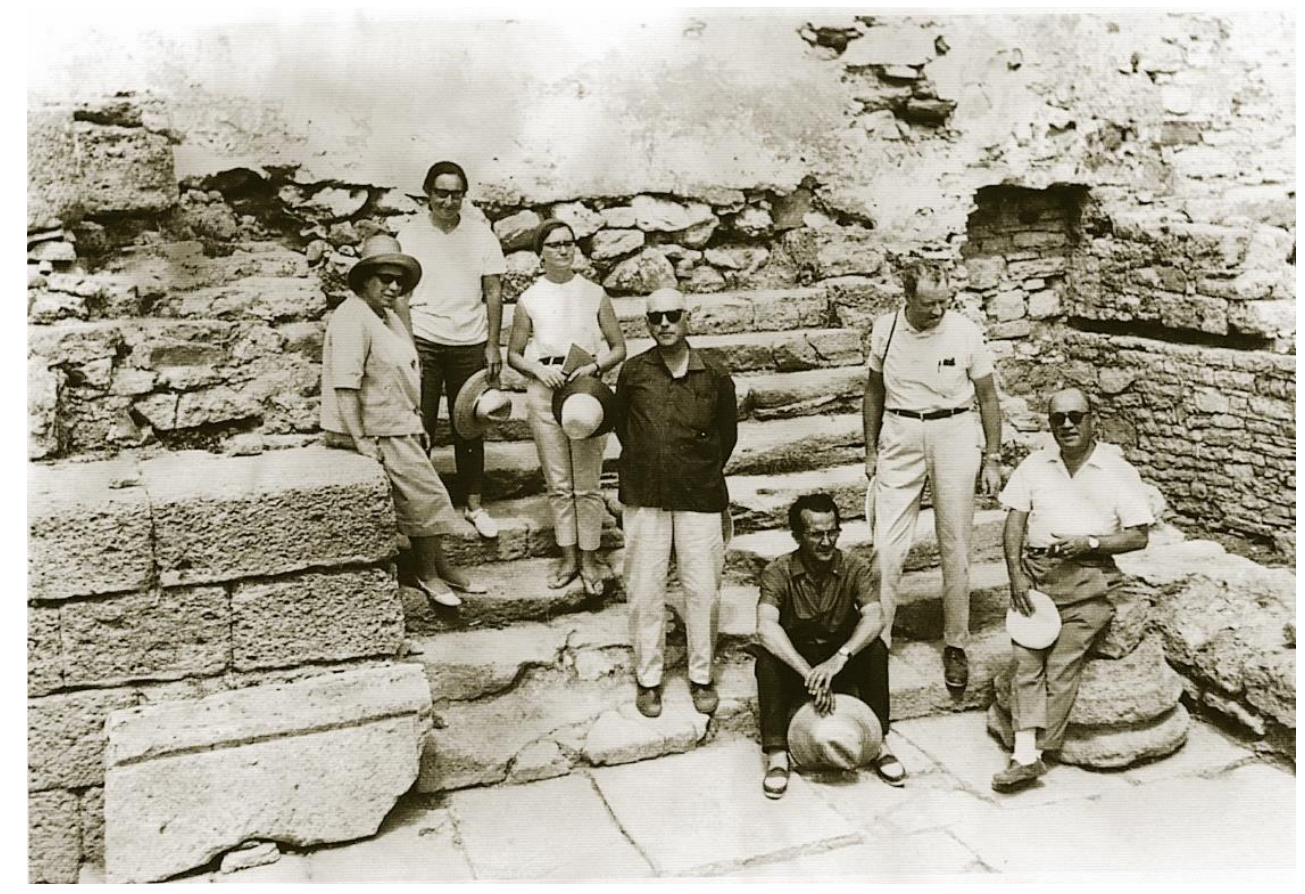

Figura 2. Visita de A. García y Bellido a Carteia durante los trabajos de D.E. Woods (1966). @ Familia
Collantes de Terán. Gentileza de Ma Belén Deamos.

Una segunda etapa en las investigaciones arqueológicas en Carteia fue protagonizada por Daniel Woods, Francisco Collantes de Terán y Concepción Fernández-Chicarro en los años sesenta (Fig. 2), con la subvención de la Bryant Foundation, motivada ésta por corroborar -o desechar definitivamente- la tradicional identificación de Carteia con la ciudad de Tartessos a la que anteriormente aludíamos (Roldan 2011a). Aquellos trabajos supusieron una mejor planificación en la investigación de Carteia, pues

\footnotetext{
${ }^{1}$ Véase para profundizar Jiménez Vialás 2009; Presedo et alii 1982: 12 y ss.; Roldán et alii 1998: 32; Woods 1969.

${ }^{2}$ Sobre el tema de las menciones a Carteia en las fuentes clásicas véase Roldán et alii 2006: 25-29. Otras síntesis en: López 1994; Presedo et alii 1982; Santa-Olalla 1953 en Roldán et alii 1998: 83-96; Woods et alii 1967.
} 
estuvieron ya orientados a obtener una visión general y más ordenada de la misma. Ello se tradujo en la realización de 21 cortes estratigráficos distribuidos por las cerca de 27 hectáreas intramuros, así como la actuación en nuevas zonas (Woods et alii 1967).

Tras una nueva interrupción de casi tres años, en 1971, el por entonces Catedrático de Historia Antigua de la Universidad de Sevilla, Francisco Presedo Velo, inició un nuevo periodo de excavaciones en Carteia hasta mediados de los años ochenta (Roldán 2011b). Entre 1971 y 1985 se acometieron excavaciones en grandes áreas, si bien centradas como hasta entonces en los edificios de claro carácter monumental. Fue así, cuando salieron a la luz sucesivas estructuras del posible 'foro'; la planta completa del templo, ya interpretada por el anterior equipo de investigadores como un capitolio; una nueva necrópolis de época tardoantigua ubicada delante de la escalinata del templo; o la domus de atrio muy próxima al mismo. De

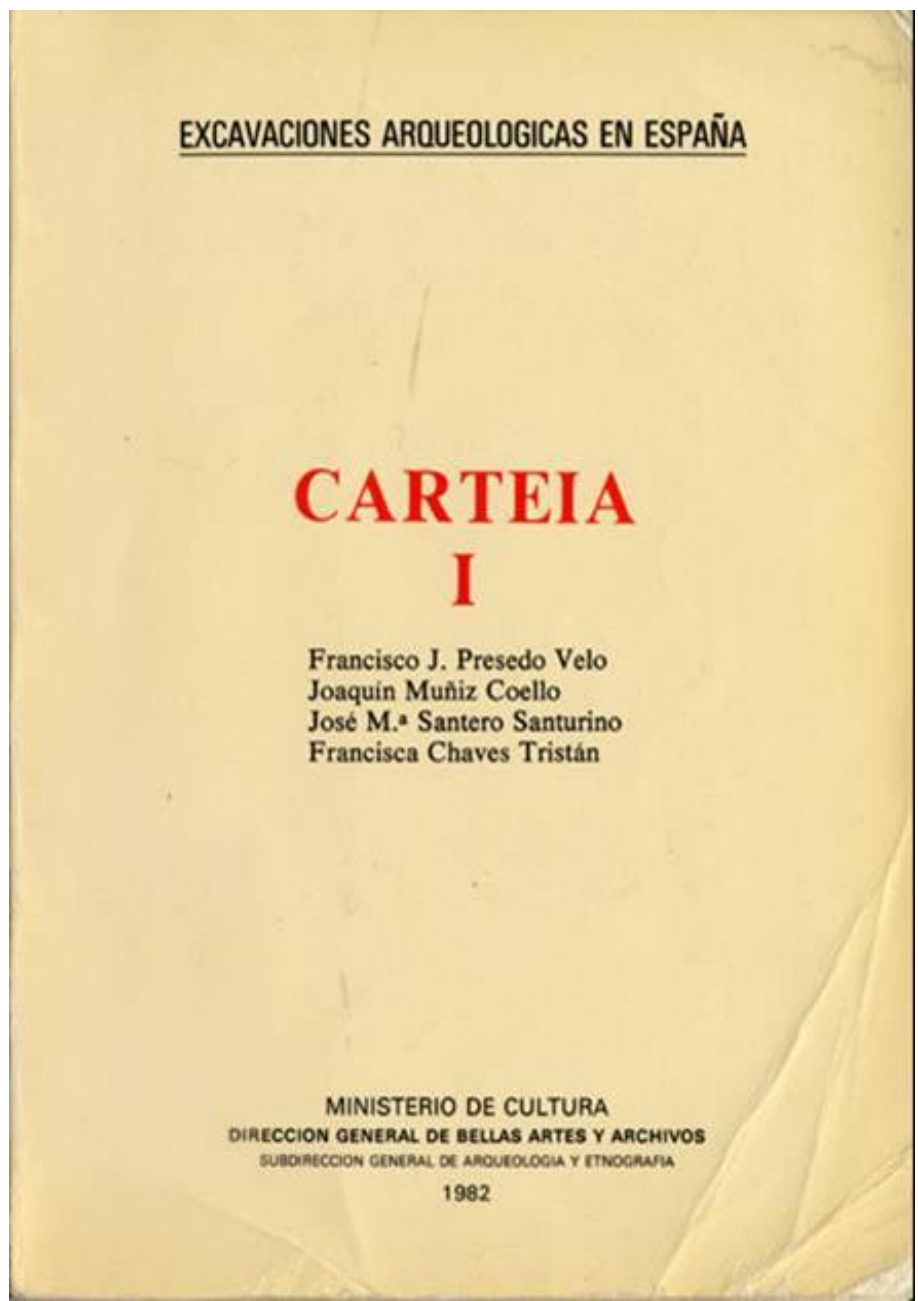

Fig. 3. Portada de Carteia I de F. Presedo et alii (1982). forma paralela también se hicieron trabajos puntuales en el edificio termal, en el posible macellum y en otros sectores de la muralla romana, en aquella ocasión al norte de la ciudad. Como en periodos anteriores, la mayor limitación de todos aquellos años de trabajo fue la falta de proporcionalidad -en cuanto a publicaciones- de los resultados obtenidos. Tan sólo contamos con una primera Memoria de Excavación (Presedo et alii 1982) (Fig. 3), así como algunos artículos interesantes, pero obligadamente reducidos.

En el año 1994, se inició una nueva fase en las investigaciones arqueológicas en Carteia dirigida esta vez por un equipo de profesores de la Universidad Autónoma de Madrid, bajo la denominación de Proyecto Carteia. Ello ha supuesto un nuevo punto de inflexión dentro de los trabajos propiamente arqueológicos, tanto en cuestiones metodológicas como en objetivos, al abarcar ya hoy, no sólo el estudio de su urbe sino también su entorno o espacio periurbano. Esta nueva investigación sistemática se ha llevado a cabo en dos sexenios: el primero entre 1994 y 1999 (Fase I) y, el segundo, entre 2006 y 2012 (Fase II), que fue prorrogado hasta 2013. Se buscó también obtener actualizadas secuencias estratigráficas destinadas a ordenar cronológicamente el conjunto de edificios hasta la fecha excavados: un templo; una necrópolis junto al mismo; un posible macellum, una domus y numerosos muros, algunos de los cuales, por sus características constructivas y disposición ya en ladera, apuntaban la presencia de la antigua ciudad púnica sepultada bajo la posterior romana.

El nuevo Proyecto Carteia está centrado no tanto en investigar nuevas zonas sino en mejorar el conocimiento de lo hasta entonces excavado por anteriores equipos y que hasta el presente había permanecido inédito. Por ello, todo el primer sexenio de investigación permitió acometer por primera vez una adecuada lectura 'arqueoarquitectónica' de las estructuras que emergían en toda la meseta del cortijo 
del Rocadillo, tradicionalmente conocida como 'área del foro'. Los resultados obtenidos en aquellos seis primeros años, además de diversas publicaciones especializadas, quedaron condensados en la correspondiente Memoria de Excavaciones (Roldán et alii 2006). Pero, de forma paralela, se acometió la publicación de tres libros que bien podemos caracterizarlos como de 'alta divulgación': Carteia I, Carteia II y Carteia III (Roldán et alii 1998; 2003; Roldán y Blánquez 2011a).

\section{El grabado de Carter. Un extraordinario documento para los estudios arquitectónicos de la ciudad}

En el caso de la ciudad de Carteia, la cartografía, los dibujos y los grabados aportan una valiosa información que nos permite reconstruir el aspecto del paisaje en los siglos pasados, comprobar el estado de conservación de los restos arqueológicos e, incluso, documentar estructuras arqueológicas desconocidas. En el caso del ámbito carteiense, se trata de una línea de investigación desarrollada por la Dra. Helena Jiménez Vialás, quien además de ser un tema abordado dentro de su tesis doctoral (Jiménez Vialás 2017), tiene su reflejo en la publicación monográfica sobre la colección cartográfica del Ayuntamiento de San Roque (Cádiz), ámbito territorial actual al que se circunscribe el yacimiento arqueológico (Jiménez Vialás 2012) (Fig. 4).

En este sentido, es obligado señalar el conocido grabado de Carter, el cual constituye la primera imagen pictórica conocida de la ciudad de Carteia (Jiménez Vialás 2012, 154 y

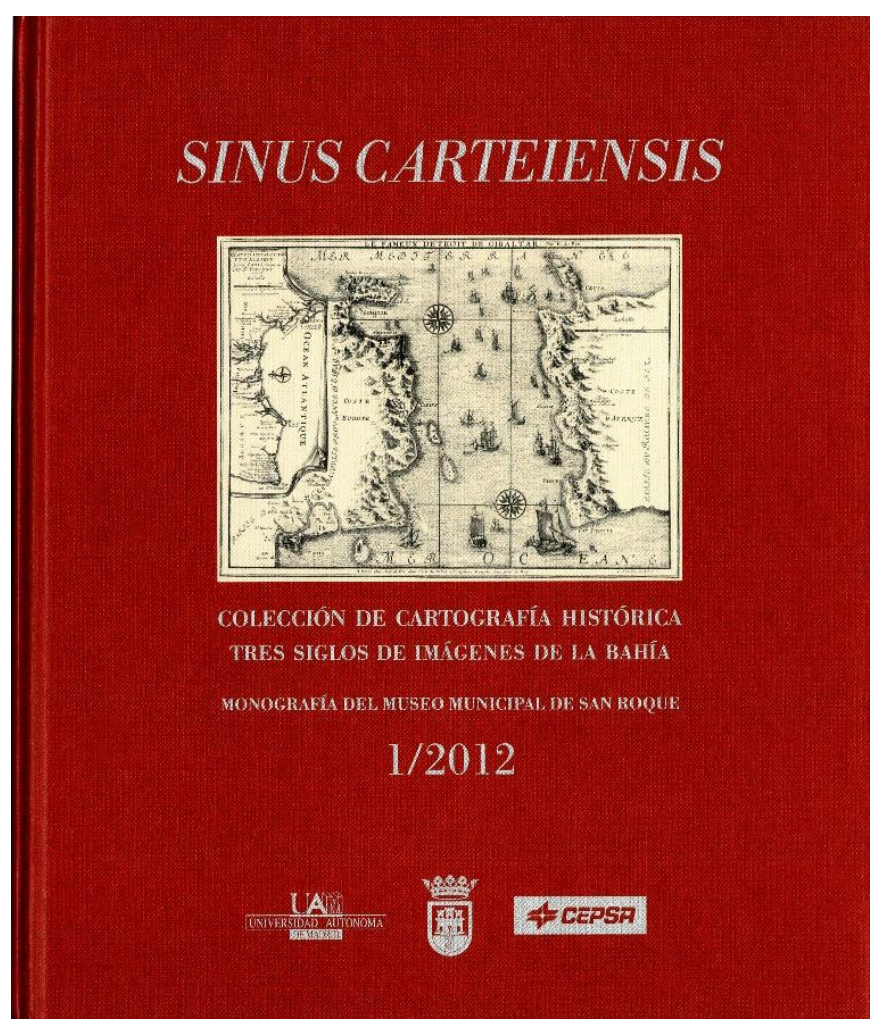

Fig. 4. Portada de Sinus carteiensis: Colección de cartografía histórica. Tres siglos de imágenes de la Bahía de H. Jiménez Vialás (2012).

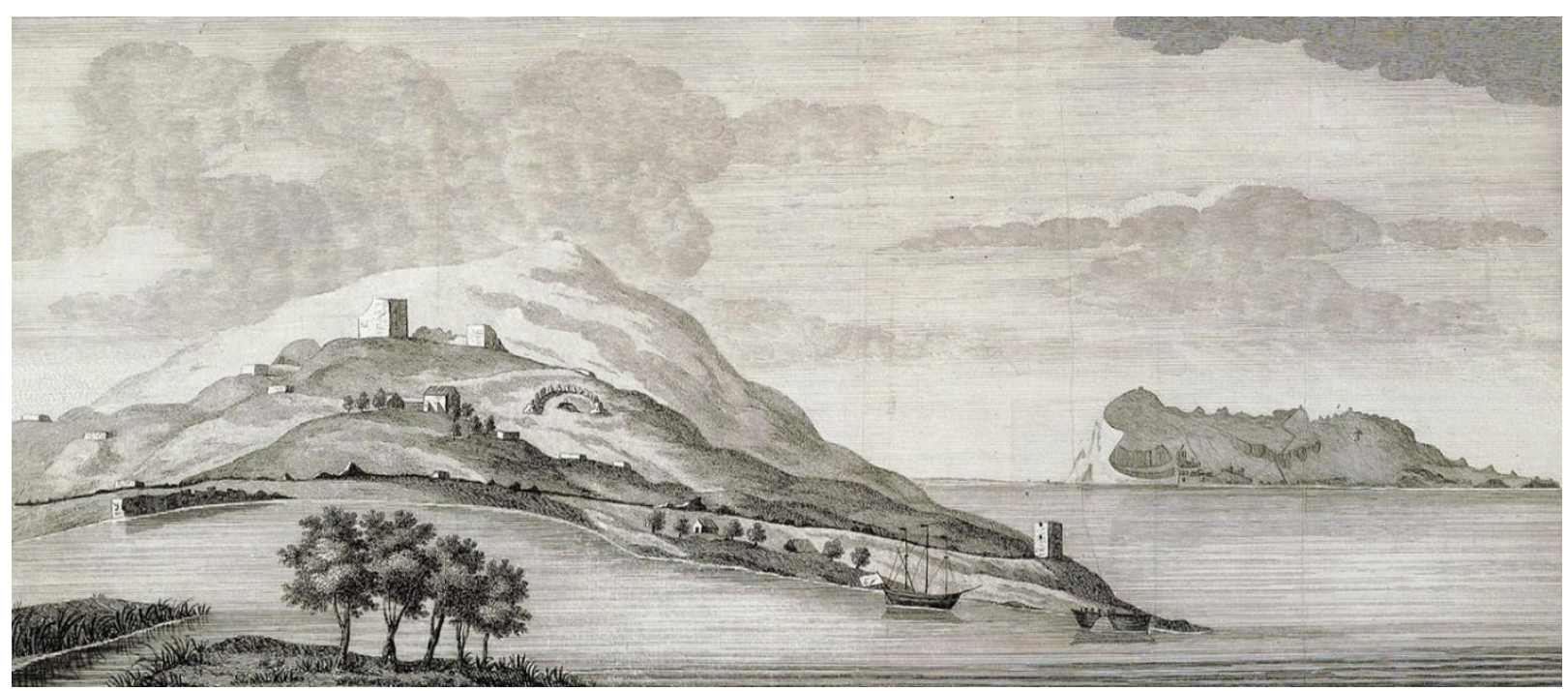

Fig. 5. West View of the Ruins of Carteia and its River, with a Prospect of the Rock of Gibraltar (1771). (c) Biblioteca Nacional de España, no inv. 89407. 
ss.). La vista West View of the Ruins of Carteia and its River, with a Prospect of the Rock of Gibraltar (Fig. 5) fue realizada en 1711 aunque se editaría años después como ilustración en Londres del A journey from Gibraltar to Malaga; with a view of that Garrison and its Environs, en dos volúmenes (1777). El grabado está acompañado, además, de una cuidada descripción de la ciudad como subcapítulo dedicado a Carteia dentro del capítulo IV Algeziras del libro I del primer volumen (páginas 60-143), conservado hoy en la Biblioteca Nacional ( ${ }^{\circ}$ inv. 89407).

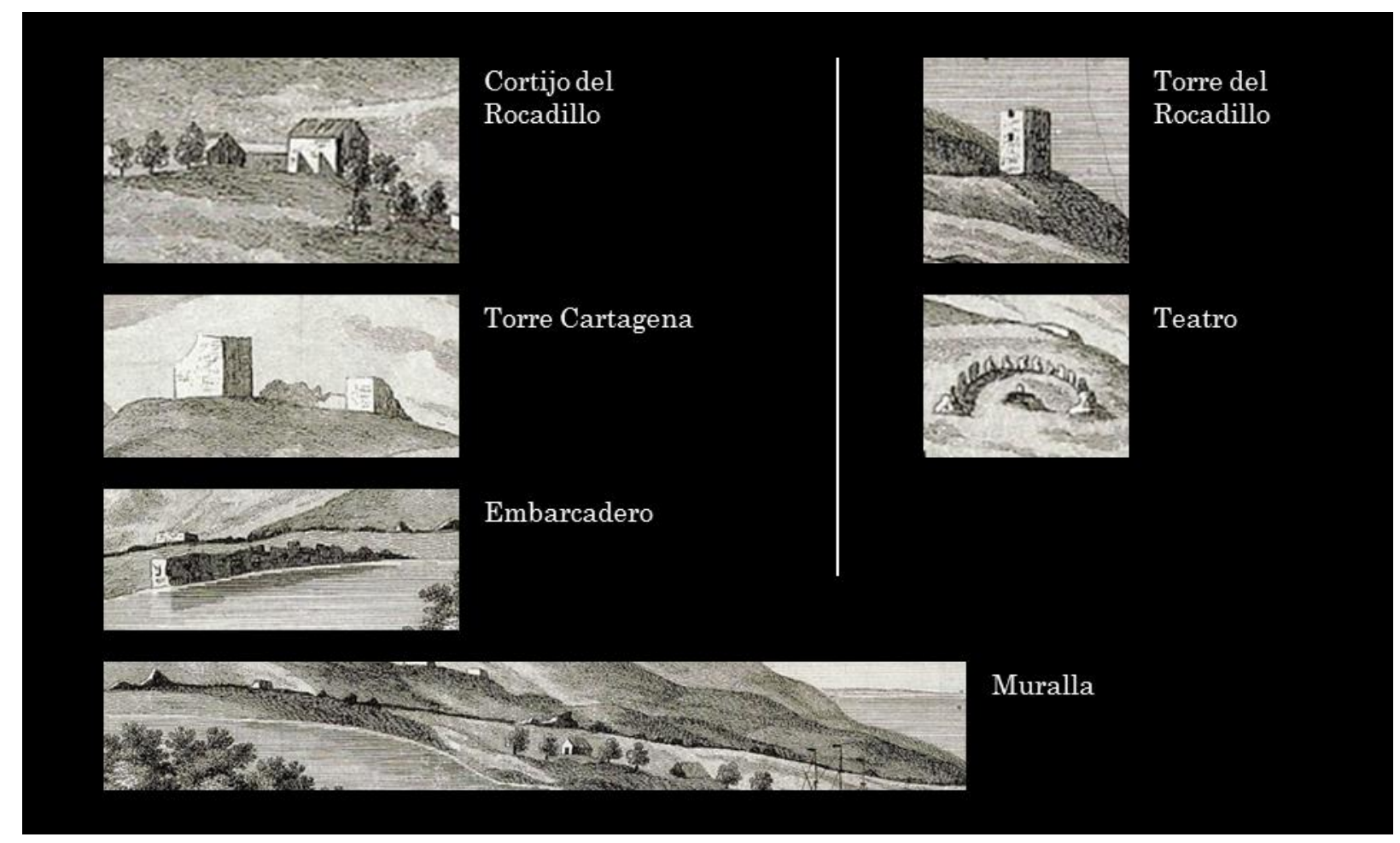

Fig. 6. West View of the Ruins of Carteia and its River, with a Prospect of the Rock of Gibraltar (1771) (detalle de las construcciones). (c) Biblioteca Nacional de España, no inv. 89407.

Este valioso documento constituye una vista idealizada del paisaje, aunque nos permite aproximarnos a los restos arqueológicos visibles entonces de la ciudad antigua (Fig. 6). Dicha idealización es perceptible con la sobredimensión de la Sierra Carbonera con su torre al fondo, el adelantamiento de la desembocadura del río Guadarranque, que se adentra de forma exagerada hacia el mar, y la sobreelevación de la fortaleza meriní de Hisn Qartayana o Torre Cartagena, que alcanza unas dimensiones muy superiores a las reales, aunque en aquel momento conservaría un alzado mayor que el actual.

El autor exageró aspectos reales con el ánimo de hacerlos suficientemente visibles o bellos en el dibujo. Dichos restos representados en esta panorámica son la torre del Rocadillo, la muralla, el embarcadero, el cortijo del Rocadillo, el teatro y la fortaleza meriní de Torre Cartagena. Las ocho casillas distribuidas dentro del perímetro de la ciudad podrían corresponder a chozas de pastores como hipótesis. Respecto a la muralla romana, está perfectamente representada en su trazado occidental, destacando dos posibles bastiones, lo que nos hace pensar que dicha construcción era visible en superficie.

\section{El teatro de Carteia}

Ponemos ahora nuestra atención en el teatro, tomando como punto de partida el grabado de Carter, el cual aparece representado de forma excepcional como un semicírculo formado por una serie de pilares -los restos del opus caementicium que sostenían la estructura del edificio- y un elemento informe en el centro, 
seguramente atribuibles a los restos de la antigua scaena. Esta construcción fue considerada por Carter como un teatro, si bien en muy mal estado de conservación, tal y como señala:

'El teatro de Carteia se encuentra en tal estado de ruina, en su totalidad, lo que serviría para adivinar su antigua belleza y magnificencia, tan totalmente destruida, que no sería digno de nuestra menor atención, sino por la satisfacción de los amantes de la Antigüedad sienten contemplando incluso sus más destruidos restos: sólo los cimientos de un orden de arcos están en pie, algunos de ocho o diez pies de altura, otros al nivel del suelo. Estos arcos están invadidos por matorrales, sólo se pueden distinguir seis u ocho de las gradas superiores (...)' (Carter 1777: 106-107).

En la actualidad, el teatro constituye uno de los más importantes edificios de la ciudad (Roldán 2015 con bibliografía). Citado en la historiografía moderna desde el siglo XVI por viajeros y eruditos, éstos aludían a sus restos identificándolo, de forma común, como un anfiteatro o señalando su deficitario estado de conservación. Contamos además de la representación de Carter con otras en grabados, como uno anónimo de la segunda mitad del s. XVIII o un primer mapa realizado por W. Faden en 1781 donde se constata de forma esquemática su planimetría. Se representa en todos los casos tanto su ubicación como su planta, con parte de las estructuras de la summa cavea, las cuales son identificadas de forma común como costillas o 'almenillas' (Fig. 7).

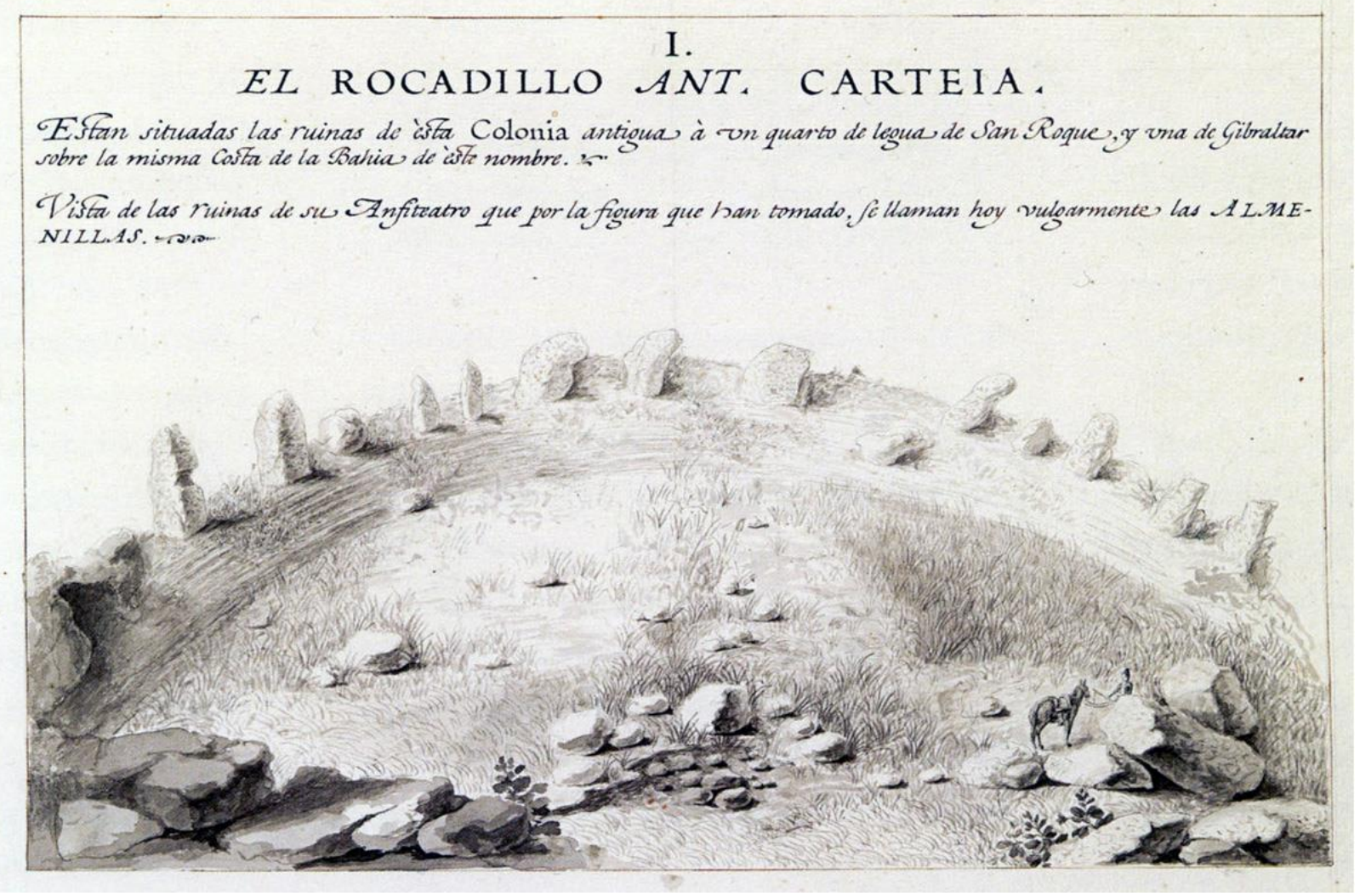

Fig. 7. Vista del 'anfiteatro' de Carteia con sus 'almenillas'. Anónimo, siglo XVIII, colección particular.

Las intervenciones arqueológicas de Julio Martínez Santa-Olalla a mediados del pasado siglo XX supusieron un cambio muy importante para Carteia en general y su teatro en particular. Dichos trabajos se focalizaron en una intensa limpieza de los muros que eran visibles en superficie (Fig. 8). Ya en los años ochenta, esta vez de la mano del profesor Presedo, el teatro fue objeto de nuevas limpiezas en la cávea y de la excavación de la scaena cuyos resultados podemos conocer gracias al diario de excavación inédito, 
hoy depositado junto con toda la documentación de aquellas campañas, en el Centro Documental de Arqueología y Patrimonio - el CeDAP- de la Universidad Autónoma de Madrid para su estudio.

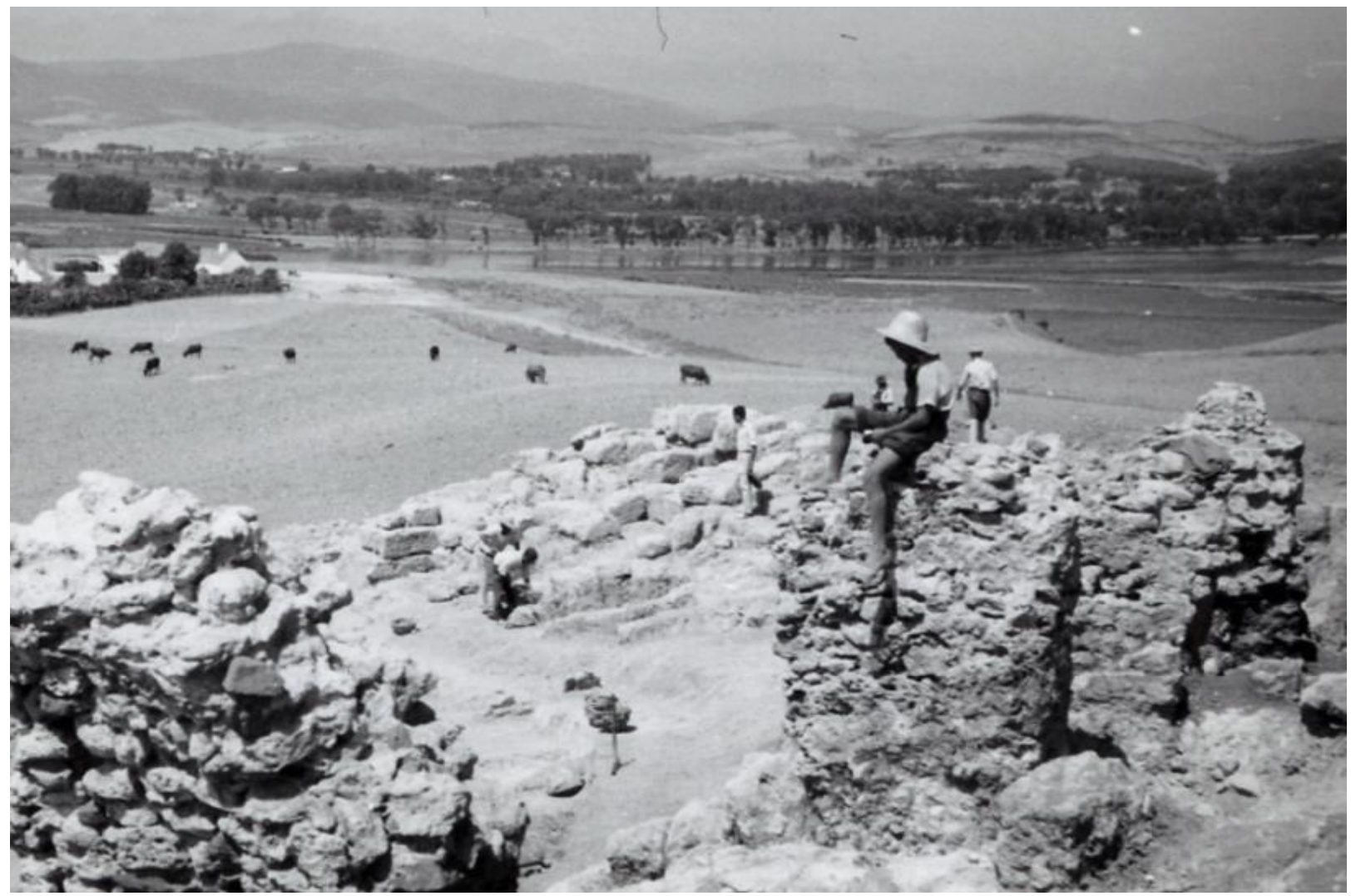

Fig. 8. Vista de las excavaciones de Santa-Olalla en el teatro de Carteia. () Museo Arqueológico Nacional, Legado J. Martínez Santa-Olalla no inv. 1973-58-FF-10562(18).

Tras estas excavaciones inéditas, el primer estudio llevado a cabo en el teatro de Carteia fue acometido por la Dra. Lourdes Roldán en 1992 en el marco de su tesis doctoral. Supuso un inicial acercamiento al análisis de sus técnicas y características constructivas y conllevó la primera planimetría científica del edificio. Dos años después se inició un proyecto de investigación sistemática de la Junta de Andalucía (Fase I del Proyecto Carteia, 1994-1999) de la Universidad Autónoma de Madrid y, dentro del mismo, se acometió un nuevo análisis del teatro, así como la excavación en 1995 de uno de los cortes realizados por Presedo en el postscaenium. De forma paralela, comenzó la búsqueda de la potencial documentación de antiguas excavaciones que han dado satisfactoria respuesta con la localización de una parte significativa del archivo fotográfico de Julio Martínez Santa-Olalla, así como la cesión en 2014 al CeDAP del Legado Documental Familia Presedo, en proceso de estudio en la actualidad.

Dicho edificio forma parte del ámbito de estudio del Proyecto de Investigación I+D+i dirigido por la Dra. Lourdes Roldán para el estudio de las técnicas constructivas de la arquitectura romana que hemos llevado a cabo hasta 2015 y que continúa en la actualidad de la mano de un nuevo proyecto de investigación, continuación del anterior. Dichos trabajos se centran en el análisis de sus técnicas constructivas y una pormenorizada lectura de sus paramentos acorde con las metodologías propias de la Arqueología de la Arquitectura. Gracias a ellos ha sido posible establecer una cronología relativa del edificio con, al menos, dos fases constructivas y concretar, con bastante precisión, tanto su sistema constructivo como sus dimensiones completas con cerca de $80 \mathrm{~m}$. de diámetro de la cávea. 


\section{La muralla romana}

Como una de las excepcionalidades que brinda la documentación dedicada a Carteia, en un momento tan temprano como inicios del siglo XIX, contamos ya con el primer plano verdaderamente arqueológico de la ciudad. En 1816, la revista gibraltareña The Gentleman 's Magazine and Historical Chronicle publicaba un breve artículo 'Account of antient Carteia, and its Remains' firmado por un tal Calpensis y que incluía un interesante plano (Jiménez Vialás 2011) (Fig. 9). Además de informarnos sobre las excavaciones que un grupo de militares ingleses llevaron a cabo en la ciudad durante la Guerra de la Independencia, este valioso documento muestra perfectamente el trazado de la muralla, tal y como podemos verlo en la fotografía aérea de los años cincuenta y como ha sido en parte documentado por medio de prospecciones.

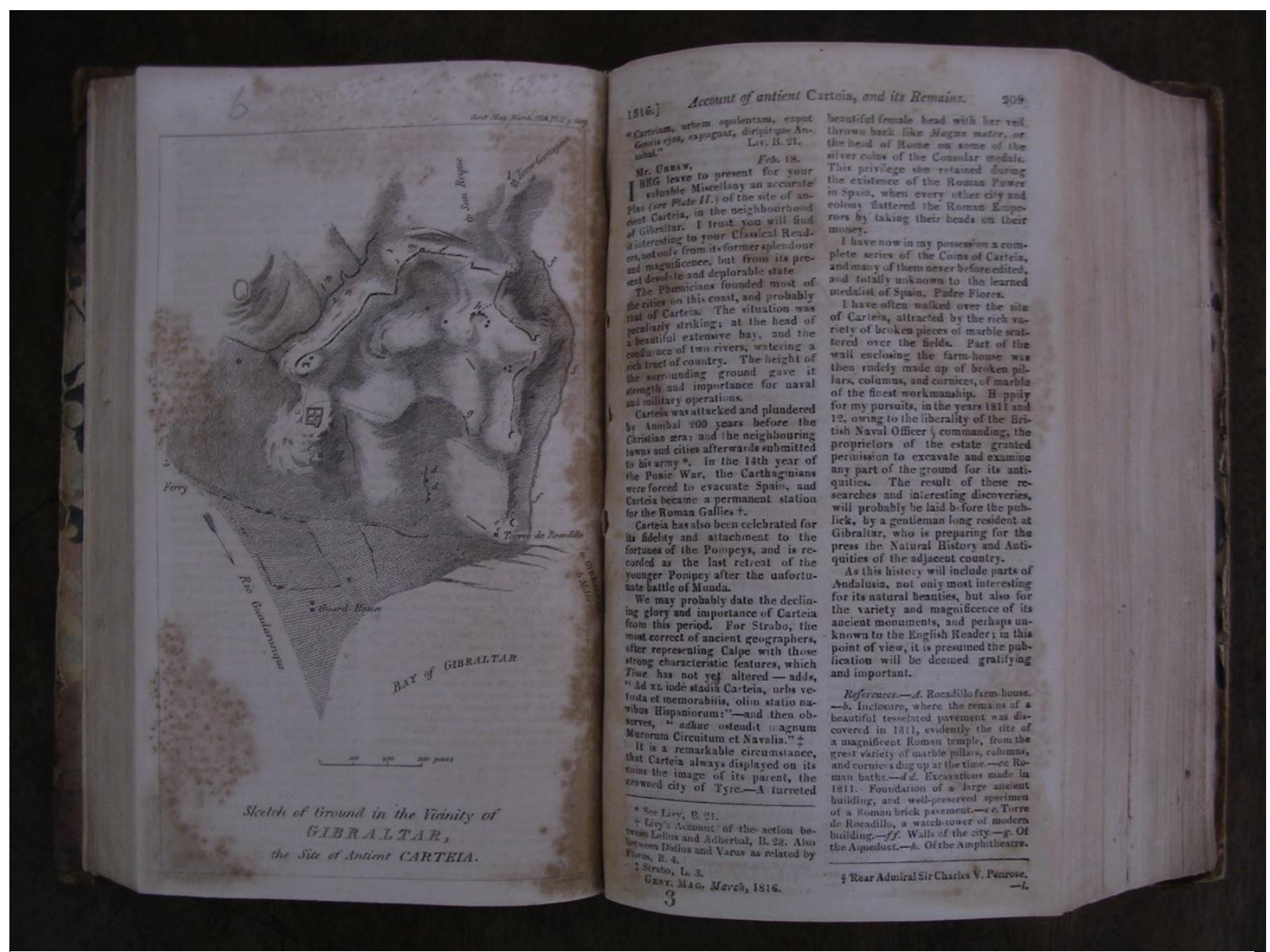

Fig. 9. Sketch of Ground in the Vicinity of Gibraltar, the site of antient Carteia. (C) Gibraltar Garrison Library, The Gentleman's Magazine LXXXVI (1816).

El autor representó los lados norte y sur, con sus vaguadas o posibles fosos, pero en el lado que da al río, salvo por algunas líneas que podrían insinuarla, no señaló resto alguno. Este hecho nos pone sobre la pista de que, ya a inicios del s. XIX, la estructura que Carter sí había documentado en esta parte estaba totalmente arrasada. En el s. XX, con anterioridad al inicio de las intervenciones arqueológicas sistemáticas en Carteia, algunos autores que visitaron la ciudad hicieron mención a la existencia de restos visibles de la muralla que permitían reconstruir gran parte de su trazado. Thouvenot en su obra sobre la Bética afirmaba que 'se le puede seguir todavía en gran parte de su trazado, ya que forma un talud cubierto de zarzas en medio de los campos’ (Thouvenot 1940: 386).

El equipo de Woods se atuvo a la propuesta de Manuel Pellicer en 1964, quien realizó un plano de la ciudad de Carteia (Fig. 10) con el ánimo de delimitar el área arqueológica intramuros, para salvaguardar 
el yacimiento por la inminente construcción de la refinería CEPSA en los años 60, la cual rodea el yacimiento arqueológico. En el mismo, la muralla presentaba al menos seis torreones de planta rectangular, dispuestos a intervalos irregulares. La existencia de estos torreones ha sido posible constatar, únicamente, en la zona noreste, la parte más alta de la ciudad. Esta planimetría, aunque sumaria, ha sido durante mucho tiempo la única global del yacimiento disponible por parte de los investigadores.

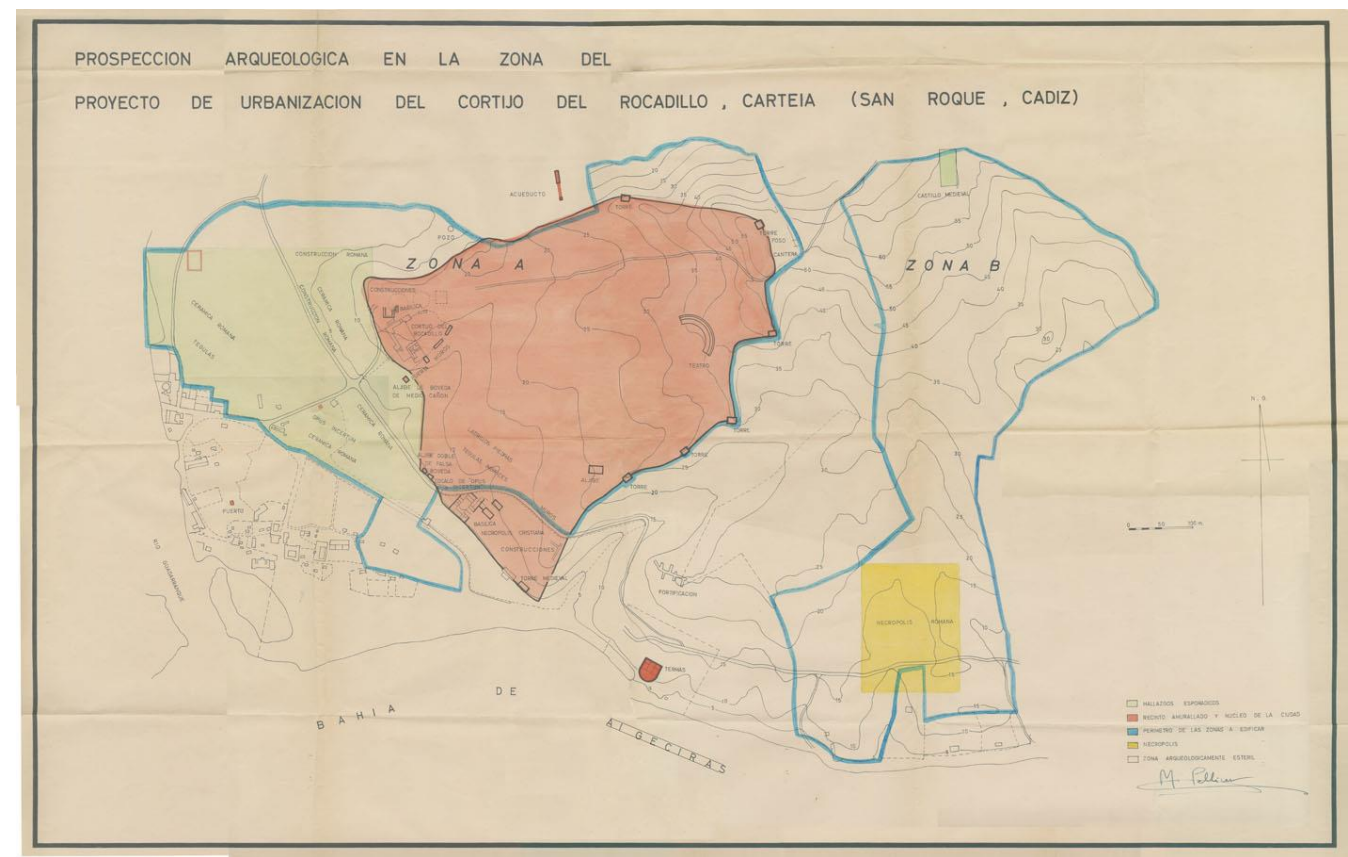

Fig. 10. Plano de la ciudad de Carteia y área periurbana (1965). ( Museo Arqueológico Nacional. Informe de M. Pellicer, no inv. 1973-58-FF-10316(2).

Los trabajos del nuevo grupo de investigadores se centraron fundamentalmente en la zona que en aquel entonces ocupaba el cortijo del Rocadillo, si bien se realizaron otros cortes diseminados por todo el yacimiento, hasta el punto de incluir algunos en la parte más al norte del mismo, concretamente el denominado como corte IV. Esta 'calicata' se ubicaba en una zona adosada a la muralla, parcialmente caída, y por la parte interior del recinto urbano. En el mismo, se documentaron cuatro metros de lienzo murario, constituido por bloques de piedra arenisca, no siempre regulares, cuya técnica no es romana, sino de época anterior, junto con material romano y cerámica ibérica tardía, tal y como se refleja en la pertinente publicación.

En lo referido a la cinta muraria, Presedo llevó a cabo una pequeña campaña de excavación y limpieza de la misma por la parte este y sur, en el tramo que se conserva bajo la torre del Rocadillo. Descubrió solamente algunas hiladas de piedra, comprobando que la muralla estaba caída hacia el exterior, y documentó la existencia de un bastión. Entre los materiales hallados abundaba la sigillata hispanica, junto con fragmentos de cerámica vidriada, lo que permitía ratificar una cronología romana en este punto de la cerca (Presedo et alii 1982: 62-63).

Posteriormente, se realizaron diversos trabajos, como los de la profesora Roldán, relativos al estudio de las técnicas constructivas para su tesis doctoral en los años 90 y publicados en Monografías de Arquitectura Romana, donde se analizaban diversos puntos de la muralla (Roldán 1992: 39 y ss.). Ya más recientemente, se ha procedido a una puntual intervención arqueológica en el bastión meridional que aludía Presedo y que ha suscitado nuevos planteamientos sobre el origen púnico del mismo (Cobos y Mata 2011). 
Proyecto Carteia, Fase II. Plano simplificado de la ciudad de Carteia (San Roque, Cádiz)

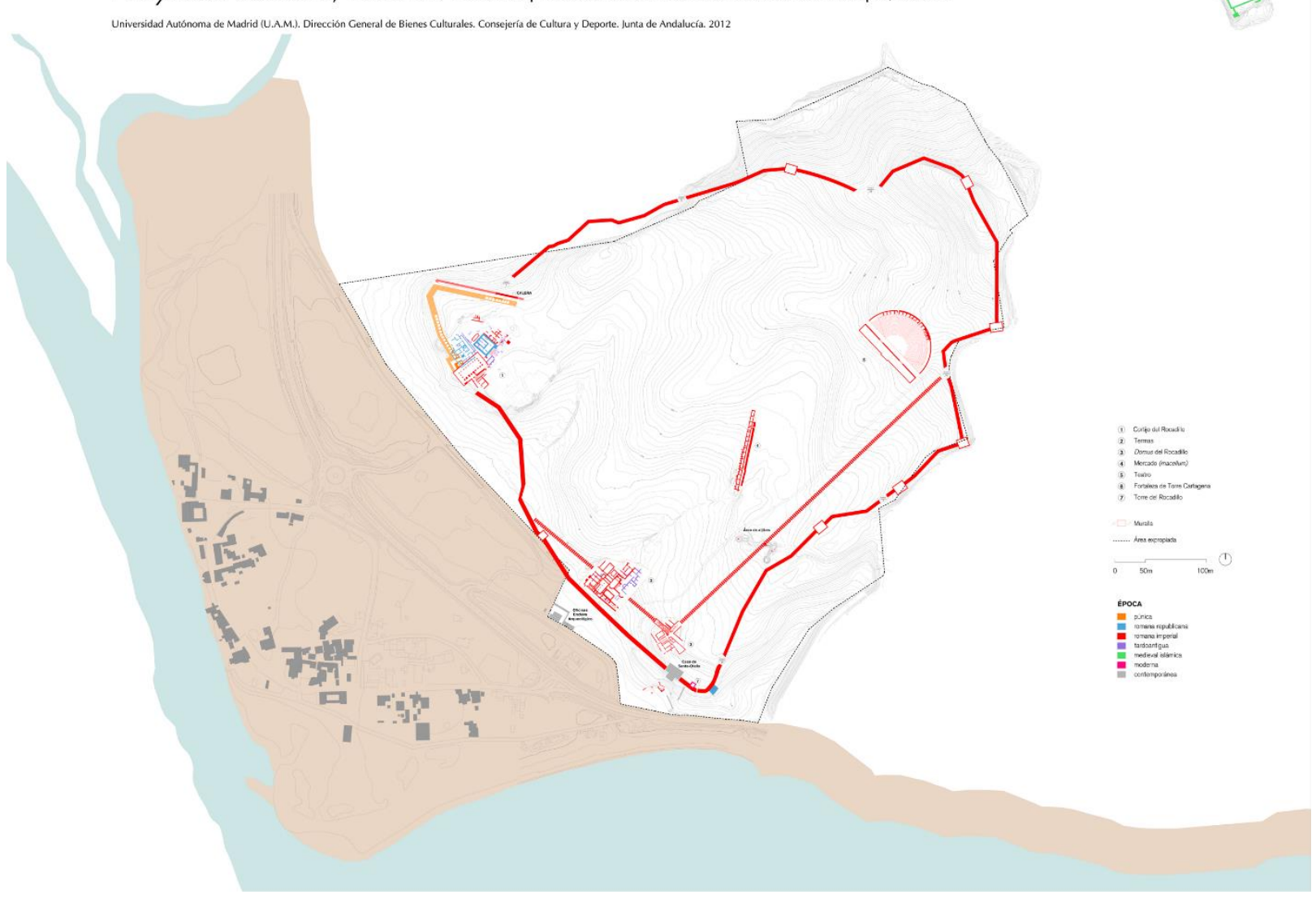

Fig. 11. Trazado hipotético de la muralla romana de Carteia (2012). (C Proyecto Carteia de la UAM.

Actualmente, la mayor parte del recorrido de la muralla permanece sepultado bajo los sedimentos y la propia maleza, a excepción de la zona meridional, y dos puntos en la zona norte y noreste (Fig. 11). Pese a ello sí es reconocible en toda su extensión, adoptando forma de polígono levemente alargado, adecuándose a las curvas de nivel y siguiendo pequeñas lomas.

\subsection{Algunas reflexiones sobre la muralla romana de la ciudad}

Una vez llegados a este punto de la disertación es necesario valorar los datos que disponemos. Pese a que éstos no son muy abundantes y la mayor parte proceden de excavaciones antiguas y documentación cartográfica, permiten dibujar grosso modo el panorama general de la muralla romana de Carteia. La primera cuestión que uno se plantea es la cronología de la misma, ya que los datos aportados por el estudio de técnicas constructivas no resulta determinante para apuntar, de forma precisa, el periodo de construcción de la misma. Esta carencia debe ser solventada mediante el conocimiento estratigráfico de la misma, de acuerdo con los actuales criterios metodológicos. Recientes trabajos del Proyecto Carteia han permitido profundizar en el conocimiento de la muralla púnica y romana al oeste del cortijo del Rocadillo, cuyos resultados alumbrarán con seguridad esta laguna en la investigación.

Sobre la construcción de murallas romanas en suelo hispano se establecen tres periodos. En primer lugar, la época de las acciones militares encaminadas a la conquista y pacificación de la Península Ibérica; posteriormente, con las incursiones de los mauri del Norte de África durante el reinado de Marco Aurelio; por último, la resistencia de las ciudades contra los ataques de las tribus germánicas (Hauschild 1994: 223). ¿Cuál de estas etapas podría estar relacionada con la construcción de la muralla romana de Carteia? Con los datos que disponemos en este momento, parece lo más prudente inclinarnos a pensar como 
hipótesis la primera etapa, por tanto, al transcurso de las diversas acciones bélicas de la primera fase, donde con probabilidad jugó un papel muy importante la guerra civil entre César y Pompeyo. No obstante, y debido al dilatado proceso histórico de la ciudad, es lógico pensar en diferentes refacciones, lo que puede llegar a enmascarar la imagen inicial de la construcción.

Por otro lado, la construcción del recinto amurallado no suponía -como es lógico- la construcción íntegra de todo el espacio intramuros, con lo que queda delimitado el pomerium. En Pompeya, este hecho ha sido constatado recientemente en novedosos estudios, donde el desarrollo urbano estaría condicionado por la construcción previa de la cerca (Pesando y Guidobaldi 2006: 17 y ss.). Un argumento más sobre la datación de la muralla en esta fase final de la República o inicios del Principado lo encontramos en la tradicionalmente conocida como 'villa del Rocadillo' y que hoy, con un criterio más estricto, es citada en la bibliografía como la 'domus del Rocadillo', dado el carácter urbano de la misma. Excavada por el profesor Presedo, no conserva la totalidad de su planta, la cual parece que se asienta sobre el trazado de la muralla romana. El estudio detallado de las técnicas constructivas de esta domus parece situar su cronología en la remodelación augustea de la ciudad, entre finales del siglo I a.C. y principios del siglo I d.C. (Roldán et alii 2003: 267). Esta casuística se repite en otros centros urbanos, como en el caso de Pompeya, donde algunos edificios de carácter privado se asientan directamente sobre la cinta muraria. Este hecho, podría señalarnos que en esta fase -periodo augusteo- se constataría el trazado de la muralla en este punto, en la zona sureste y, por tanto, próximo a la zona de la torre del Rocadillo y el bastión meridional.

Respecto al trazado de la muralla romana, se ha podido cotejar por el grupo de investigación actual que en el plano realizado por Pellicer existen puntos donde el recorrido es distinto, condicionado fundamentalmente por la topografía. Tras haber mantenido conversaciones con el propio Pellicer, éste nos confirmó que en algunos puntos tuvo que delimitar el recinto -aun no observando los restos- debido a la construcción de la refinería en el entorno, lo que justifica estas pequeñas modificaciones. En cuanto a las puertas de acceso a la ciudad, éstas no han sido excavadas, pero la propia topografía, así como los restos que afloran en algunos puntos, parecen indicar su posición. De forma paralela, sí se han documentado necrópolis, situadas -como es habitual- en los ejes de acceso a la ciudad, como es en el acceso este, con la necrópolis de El Gallo y, al oeste, con otra recientemente excavada más recientemente (Gestoso y López 2009).

Por todo lo aquí expuesto, queda evidenciada la importancia de la muralla objeto de nuestro análisis, la cual constituye un elemento fundamental para el estudio del desarrollo urbano de la ciudad de Carteia. Para un conocimiento más exhaustivo, es necesario acometer nuevas excavaciones de cara a poder valorar, en detalle, la problemática de la muralla romana, la cual carece de secuencias estratigráficas realizadas con criterios metodológicos actuales y de este modo precisar su cronología.

\section{Conclusiones finales}

Lamentablemente, las investigaciones arqueológicas acometidas desde mediados del siglo XX en la ciudad de Carteia no han tenido una repercusión bibliográfica acorde con los edificios exhumados, tales como las termas, el teatro, el macellum o la domus de atrio, aunque sí se han estudiado otros como el templo republicano, la muralla púnica o la probable basílica en los últimos años. Desde el año 1994, el denominado Proyecto Carteia de la Universidad Autónoma de Madrid, ha modificado los tradicionales planteamientos de investigación acordes con los criterios actuales de la investigación arqueológica, lo que ha permitido una relectura de los datos disponibles hasta la fecha. A través de la documentación disponible -mucha de ella inédita a día de hoy- de los diferentes Legados pertenecientes a los equipos de investigación de Carteia -fundamentalmente Santa-Olalla, Woods y Presedo-, u otras fuentes de conocimiento como son los grabados, dibujos y la cartografía disponible, nos permite evaluar tanto su importancia como sus aportaciones a los estudios arquitectónicos que acometemos actualmente en la ciudad, dentro de los planteamientos de la Arqueología de la Arquitectura. 


\section{BiBLIOGRAFÍA}

Blánquez Pérez, J., Jiménez Vialás, H. y Roldán Gómez, L. (2012), ‘Paisaje arqueológico - paisaje simbólico. Carteia y las Columnas de Hércules, una lectura comparada' en F. Prados, I. García y G. Bernard (eds), Confines. El extremo del mundo durante la Antigüedad. Publicaciones de la Universidad de Alicante, Alicante: 227-269.

Carter, F. (1777), A journey from Gibraltar to Malaga; with a view of that Garrison and its Environs; a Particular Account of the Towns in the Hoya of Malaga; the ancient and Natural History of those Cities, of the Coast between them, and of the Mountains of Ronda, 2 vols., T. Cadell, London.

Cobos Rodríguez, L.M. y Mata Almonte, E. (2011), El proceso constructivo de la torre meridional de Carteia (San Roque, Cádiz). Almoraima 39: 115-126.

Hauschild, T. (1994), 'Murallas de 'Hispania' en el contexto de las fortificaciones del área occidental del Imperio Romano' en La ciutat en el món romá = La ciudad en el mundo romano, XIV Congreso Internacional de Arqueología Clásica, Tarragona, 5-11 septiembre de 1993: 223-238.

Jiménez Vialás, H. (2009), Acerca de la búsqueda de Tartessos y su identificación en Carteia. Una revisión historiográfica. Almoraima 38, 11-25.

Jiménez Vialás, H. (2011), 'La cartografía antigua del Campo de Gibraltar: el ejemplo de Carteia' en L. Roldán y J. Blánquez (eds), Carteia III. Memorial. Universidad Autónoma de Madrid, CEPSA y Junta de Andalucía: 277-307.

Jiménez Vialás, H. (2012), La colección de cartografía histórica. Tres siglos de imágenes de la bahía de Algeciras. Monografía del Museo Municipal de San Roque, Sinus Carteiensis 1/2012, Universidad Autónoma de Madrid, Ayto. de San Roque, CEPSA, Madrid.

Jiménez Vialás, H. (2017), Carteia y Traducta. Ciudades y territorio en la orilla norte del Estrecho de Gibraltar (VII a.C. - III d.C.). Col-lecció Instrumenta 57, Publicacions i Edicions Universitat de Barcelona, Barcelona.

López Gil, E. (1994), Las fuentes antiguas sobre Carteia. Almoraima 12: 55-64.

Gestoso Morote, D. y López Rodríguez, J.I. (2009), La necrópolis altoimperial de Carteia y el mundo funerario romano. CEPSA, Astarté-Estudio de Arqueología, S.L.L., Málaga.

Pesando, F. y Guidobaldi, M.P. (2006), Pompei, Oplontis, Ercolano, Stabiae, Guide Archeologiche Laterza, Bari.

Presedo Velo, F., Muñiz, J., Santero, J.M. y Chaves, F. (1982), Carteia I. Excavaciones Arqueológicas en España 120, Madrid.

Roldán Gómez, L. (1992), Técnicas constructivas romanas en Carteia (San Roque, Cádiz). Monografías de Arquitectura Romana 1, Madrid.

Roldán Gómez, L. (2011a), 'Las excavaciones en Carteia en los años 60: Woods, Collantes de Terán y Fernández-Chicarro y de Dios (1963-1967)' en L. Roldán y J. Blánquez (eds), Carteia III. Memorial, Consejería de Cultura de la Junta de Andalucía, Universidad Autónoma, CEPSA, Madrid: 209-228.

Roldán Gómez, L. (2011b), 'Las excavaciones de Francisco Presedo en Carteia (1970-1986). Una primera aproximación historiográfica’ en L. Roldán y J. Blánquez (eds), Carteia III. Memorial. Universidad Autónoma de Madrid, Junta de Andalucía, Madrid: 235-249.

Roldán Gómez, L. (2015), 'El teatro augusteo de Carteia (San Roque, Cádiz). Nueva documentación arqueológica' en J. López (ed), Tarraco Bienal. Actes 2os Congrés Internacional D ‘Arqueologia $i$ Món Antic. August i les províncies occidentales. 2000 aniversari de la mort d’August, vol. 2. Fundació Privada Mútua Catalana, Tarragona: 95-101.

Roldán Gómez, L. y Blánquez Pérez, J. (eds) (2011a), Carteia III, Memorial, Universidad Autónoma de Madrid y Junta de Andalucía, Madrid. 
Roldán Gómez, L. y Blánquez Pérez, J. (2011b), 'Las excavaciones en Carteia en la década de los años 50: Julio Martínez Santa-Olalla (1953-1961)' en L. Roldán y J. Blánquez (eds), Carteia III. Memorial. Universidad Autónoma de Madrid y Junta de Andalucía, Madrid: 121-144.

Roldán Gómez, L. y Blánquez Pérez, J. (eds) (2012), Julio Martínez Santa-Olalla y el descubrimiento arqueológico de Carteia (1953-1961), Universidad Autónoma de Madrid.

Roldán Gómez, L., Bendala Galán, M., Blánquez Pérez, J. y Martínez Lillo, S. (eds) (1998), Carteia. Consejería de Cultura de la Junta de Andalucía, Madrid.

Roldán Gómez, L., Bendala Galán, M., Blánquez Pérez, J., Martínez Lillo, S. y Bernal Casasola, D. (2003), Carteia II. Consejería de Cultura de la Junta de Andalucía, Madrid.

Roldán Gómez, L., Bendala Galán, M., Blánquez Pérez, J. y Martínez Lillo, S. (eds) (2006), Estudio históricoarqueológico de la ciudad de Carteia (San Roque, Cádiz). 1994-1999. Arqueología Monografías 24 (2 vols.), Madrid.

Thouvenot, R. (1940), Essai sur la province romaine de Betique, Bibliothèque des Écoles Françaises d'Athènes et de Rome 149. De Boccard, Paris.

Woods, D.E. (1969), 'Carteia and Tartessos', Tartessos, V Symposium de Prehistoria Peninsular. Barcelona: 251-256.

Woods, D.E., Collantes de Terán y Delorme, F. y Fernández-Chicarro y De Dios, C. (1967), Carteia. Excavaciones Arqueológicas en España 58, Madrid. 


\title{
La Rota protohistórica como ejemplo de la evolución del concepto de Tarteso
}

\author{
Álvaro Gómez Peña ${ }^{1}$ \\ Universidad de Sevilla
}

\section{Introducción}

La relación entre el área geográfica de la actual villa de Rota y el período tartésico ha sido hasta hace pocas décadas un tema de especial relevancia dentro de los estudios sobre esta cultura (Fig. 1). El eje principal del debate se ha centrado desde el primer momento en la existencia o inexistencia de un brazo del Guadalquivir actualmente desaparecido que habría generado una isla entre él y la actual desembocadura. En ella habría estado ubicada la legendaria capital de Tarteso. La tradición literaria cuenta con numerosas muestras de interés por este asunto desde época grecorromana. Los textos de autores como Dionisio Periegeta, recogido en los comentarios sobre éste de Eustacio de Tesalónica (Eust. Coment. a D. P. 337), Avieno (Auien. OM, 284-290), Estrabón (Str. III, 1, 9; III, 2, 11) y Plinio (Plinio II, 3, 11) entre otros, fueron la base sobre la que se sustentaron las más variadas hipótesis sobre su exacta localización. Rota, por su situación a escasos kilómetros del delta del Guadalquivir, centró desde el primer momento la atención de algunos de los historiadores que más eco han tenido en la historiografía tartésica. En las siguientes páginas se recogen algunos de estos ejemplos a la vez que se hace hincapié en la instrumentalización de Tarteso dentro de cada respectivo período.

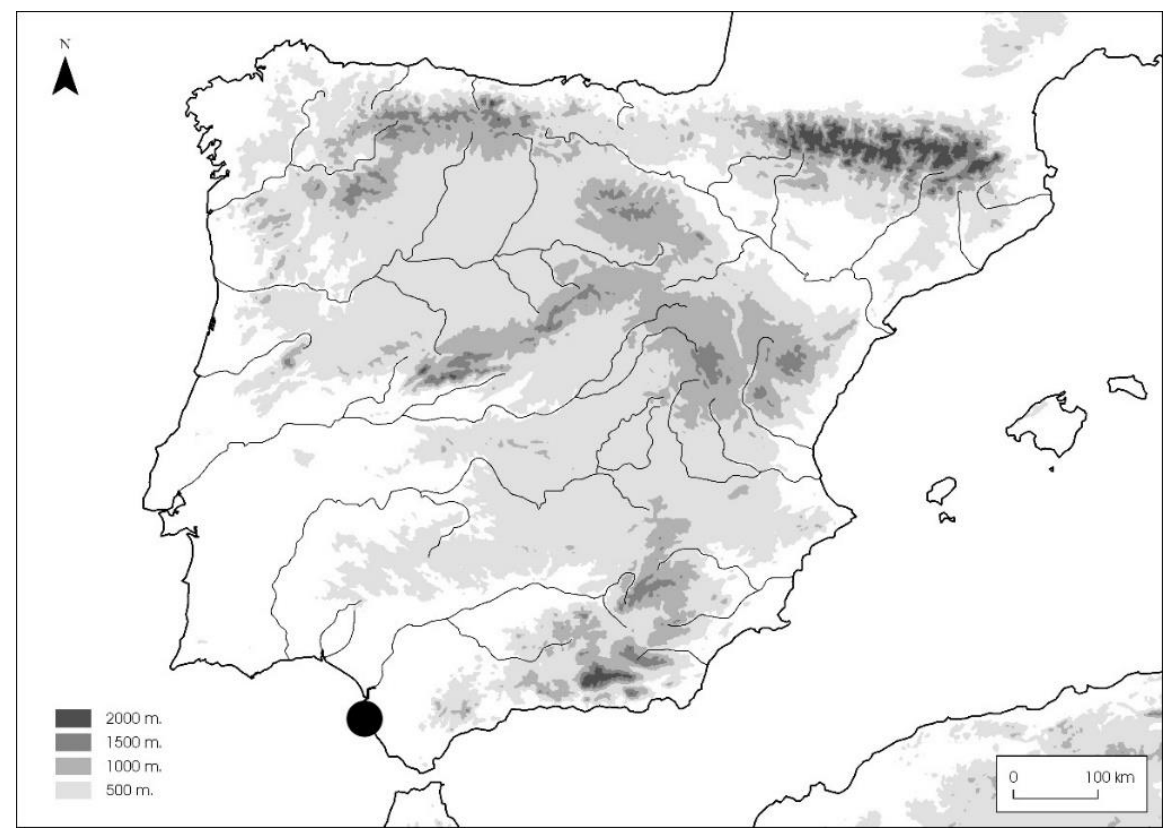

Fig. 1. Ubicación geográfica de Rota (Cádiz, España) (elaboración propia).

\section{S. XVI: Tarteso como instrumento de ensalzamiento de la monarquía}

Tras las menciones grecolatinas, el estudio de Tarteso fue un tema de escasísimo interés durante la Edad

\footnotetext{
${ }^{1}$ Profesor Sustituto Interino del Departamento de Prehistoria y Arqueología de la Universidad de Sevilla. Miembro del Grupo de Investigación 'Tellus. Prehistoria y Arqueología en el sur de Iberia' (HUM-949).
} 
Media. No fue hasta el siglo XVI cuando se le volvió a prestar atención nuevamente. Propio de esta época fue entre los cronistas un afán de unidad, derivado de una etapa de formación nacional heredera de la política de los Reyes Católicos (Álvarez 2005: 25-26; Wulff 2002: 128), y un exaltado amor a la patria y al pasado nacional, hecho que se reflejó en las crónicas e historias generales. Estos compendios tenían como objetivos, entre otros, generar una exaltación y sentimiento de unidad de las diversas comunidades peninsulares a través de su pasado y poner de relieve que dicho logro se había conseguido gracias al papel de la monarquía hispana. En ambos casos, se recurría a vincular genealógicamente a la realeza española con diversos personajes y temas bíblicos, tal y como siglos antes había ocurrido por ejemplo con la utilización de antepasados míticos dentro del mundo griego (Bernabé 2008: 74). En palabras de Florián de Ocampo, cronista de Carlos V, se trataba de 'presentar una España primitiva digna de la majestad de la España contemporánea’ (Mora 1998: 19-20).

La primera referencia, y una de las principales, fue la del propio Florián de Ocampo, quien rescató del olvido las hipótesis de los clásicos en su obra Los cinco libros primeros de la cronica general de España. En ella, creada para demostrar la gran antigüedad de la monarquía española, al tratar la cuestión tartésica situó la desembocadura del brazo perdido del río en la villa roteña, guiado por la existencia de un pequeño arroyo denominado Salado entre los términos municipales de Rota y El Puerto de Santa María:

'De estos dos braços en el vno mas Oriẽtal en este nuestro siglo presente,ya va de todo punto consumido :porque las aguas que solia lleuar,han trastornado todas enel otro braço :dado que sus muestras y la madre de su corriente parezcan oy dia claras çerca de la villa de Rota,y en otros pasos de aquella tierra'

(de Ocampo 1543 [1553]: Libro I, Cap. IX, fol. XXXI v.).

La enorme influencia de F. de Ocampo se hizo notar a las pocas décadas sobre Agustín de Horozco, primero criado del rey y posteriormente almojarife afincado en Cádiz desde 1578 hasta el fin de sus días. Horozco, en su Historia de la ciudad de Cádiz, y tras consultar la obra de F. de Ocampo(de Horozco 1598 [1845]: 8), hacía suya la misma idea del afamado cronista:

'Ya queda dicho que la villa de Rota dista de Cádiz como dos leguas y media a la parte del poniente, en aquella parte que dicen estaba el cabo Cronion, que tambien se dixo cabo de Saturno.

Son estas dos leguas i media (que ay de Cádiz a Rota) navegando por el mar i la bahia.

Ninguna muestra de población antigua ay en esta villa, ni aun de la madre i vertiente al mar entre esta villa i el Puerto de Santa Maria, trayendo su corriente dende mas arriba de la villa de Lebrixa, en la parte que son las Orcadas, dividiéndose Guadalquivir en dos brazos: este que llamaban oriental, i el que entra por Sanlucar, occidental, haciendo isla todo lo que avia entre estas dos corrientes i brazos, en cuyo sitio se cuenta aver avido i que pasaron muchas cosas los del Puerto de Menesteo, i los de Tartesia, con varias gentes que acudian a la estacion de un famoso templo que aquí veneraban'

(de Horozco 1598 [1845]: 280-281).

En la misma línea hay que incluir a Bernardo José Aldrete, gramático español, quien, citando como fuente a Ptolomeo, y haciendo notar con voz en tercera persona que no presenció las posibles huellas de la antigua desembocadura del Guadalquivir, escribió lo siguiente en su Del origen y principio de la lengua castellana ò roma[n]ce que oi se vsa en España:

'Las dos bocas del rio por donde entra en la mar pone Tolomeo, i del vnbraço, que a quedado en seco recogendo se el rio al otro, dicen que se veen las señales junto ala villa de Rota'

(Aldrete 1606: 352).

Caso muy similar fue el de Martín de Roa, anticuario español perteneciente a la Compañía de Jesús desde 1578 y rector de los colegios de la Compañía de Jerez de la Frontera, Sevilla, Málaga, Écija y Córdoba, quien siguiendo a los anteriores también recogió en su obra Santos Honorio, Eutichio, Estevan : patronos de Xerez de la Frontera en 1617 la existencia de dos brazos desembocando en la bahía gaditana y no 
descartaba la posibilidad de que uno de ellos lo hiciese en Rota:

\begin{abstract}
'Strabõ en el libro tercero de su Cosmografía, situando por orden los lugares de Andaluzia,de Cadiz passa al Puerto:del Puerto a Asta, i jũto a ella las marismas. I declarado mas adelanteel lugar de su asiento,dize: Ad æstuaria autem Asta, in quam Turditani conventiunt; sitam supra navale isulæ stadýs sumí centum, non multo pluribus. Cae la ciudad de Asta (adõde acuden los Turditanos)házialos esteros,o marismas:i estápuesta sobre la estala de los nauios de la Isla,distante della cien estadios quando mucho, o no muchos mas. Esta isla hazian los dos braços de Guadalquivir, en cuyo medio estuvo(como dizen)la famosa ciudad de Tarteso,que dio nonbre a toda esta region,i al rio Betis,en cuyo braço Oriental estava el puerto donde se abrigauã los navios que venian de contratacion a los lugares de su comarca,distãte de Asta tres leguas: la distancia justa qne ai de Xerez a San Lucar unico,i solo puerto conocido en el rio Guadalquivir.I quando fuesse assi(como piensan los naturales) que el braço mas Oriental deste rio entrasse por la villa de Rota en el mar, por la q llaman ahora Madre vieja del Rio; i alli uviesse estado el puerto de los navios, tanbien está de Xerez la misma distancia de las tres leguas.I aũ quando se alargasse alguno a pẽsar que ninguno de los braços del Betis formasse puerto a los navios,sino alguna caleta,o marisma de las q avia,i se muestrã por aquella ribera desde Rota a San Lucar (espacio q dize mui al justo con los ciẽ estadios,o mas,que señala Strabon a lo ancho de la Isla por la marina ,del un braço al otro del Guadalquivir)digo que Xerez tãto dista de toda aquella ribera como de Rota,i S. Lucar.Por donde parece mas cierto, que no pudo estar Asta en la Mesa,q dista de la mar porestas partes, o muchos mas,o mucho menos de las tres leguas que pone Strabon. Quanto mas que ni en escritos,ni en tradición ai memoria de otro puerto en el Betis, que el de San Lucar; ni lo pudo aver en las marismas,que solamẽte podiã navergarse con barcos, como lo escribe tanbien este Autor'
\end{abstract}

(de Roa 1617: Fol. 11r./v.-Fol. 12r.).

Todos estos ejemplos evidencian que, a partir de las lecturas de los autores clásicos, en el siglo XVI se fue consolidando la creencia en la existencia de una isla en la desembocadura del Guadalquivir en la que se habría ubicado la legendaria capital de Tarteso. Dentro de esta tendencia, los principales investigadores de la época trataron de situarla en la localidad roteña.

\title{
3. S. XVII: Tarteso como instrumento de prestigio de las localidades
}

Los textos escritos en el tránsito entre los siglos XVI y XVII muestran un cambio de escala en lo que concierne al interés por Tarteso. Si en el siglo XVI los autores se habían preocupado más por los intentos de completar Historias Generales de España, en el XVII se centró más el interés en el desarrollo de las historias locales. En éstas, el tema de los orígenes y de la antigüedad de villas, pueblos y ciudades se muestra como un asunto de especial relevancia, debido probablemente a la preocupación de la sociedad barroca por los valores aristocráticos de la alcurnia y el abolengo. Las ciudades y villas andaluzas, carentes de tradiciones de un Medievo cristiano, generaron todo un arsenal de gloriosos fundadores, preferentemente prerromanos, y mártires inauguradores de la fe cristiana. En este contexto, el tema de Tarteso gozó de un auge y una popularidad considerables (Álvarez 2005: 32-33; Wulff 2002: 129). El caso de M. de Roa responde a este proceso, quien aparte de escribir Santos Honorio, Eutichio, Estevan: patronos de Xerez de la Frontera, también compuso escritos sobre Málaga y Écija.

El anteriormente comentado afán de unidad y exaltación religiosa, unido al desarrollo de las historias locales, encontró en la Biblia un pretexto para continuar teniendo éxito en el ambiente de los siglos XVI y XVII. Si ya los historiadores clásicos apuntaban a que Tarteso podría haber estado situado en estas tierras, los cronistas de estas centurias apuntaron la idea de que el Tarsis bíblico fuera el mismo que el Tarteso de aquéllos. ${ }^{2}$ La asociación Tarteso-Tarsis incrementó exponencialmente la importancia del asunto en la erudición española. La imagen de Tarteso es ya en el siglo XVII lo suficientemente evocadora y potente como para convertirse en piedra angular de los debates históricos sobre las primacías de las sedes episcopales de Cádiz, Jerez y Sevilla y, en general, para todo historiador local y tratadista que se interesó

\footnotetext{
2 Jaime Alvar (2000: 41) expone el caso de la losa sepulcral inscrita hallada en Murviedro (Sagunto) a finales del siglo XVI y atribuida a Adorinam, un recaudador de impuestos de Salomón, que demostraba 'inequívocamente' la autenticidad de la llegada de las naves de Tarsis a Tarteso en España.
} 
por los orígenes de su patria chica. Inmerso en el proceso global de auge de la historia local en este siglo, se produce un fenómeno específico en las historias locales de las ciudades de la Baja Andalucía, las cuales recurren a identificar a Tarteso con las diversas localidades del mediodía peninsular (Álvarez 2005: 34; Beltrán Martínez 1969: 75-78; Pellicer 1976: 229-230).

La villa de Rota no iba a ser menos en este particular. La moda de identificación de la ciudad de Tarteso con modernas localidades de la Baja Andalucía coincide con la aparición de varios estudios anticuarios de notable corrección erudita que sobresalen entre el abigarrado panorama historiográfico de la época (Álvarez 2005: 34-35). Es el caso del anteriormente citado B. J. Aldrete, autor de Del origen, y principio de la lengua castellana (Aldrete 1606). También lo es el de Rodrigo Caro, anticuario utrerano que fue nombrado letrado de cámara del arzobispo de Sevilla, Pedro Vaca de Castro y Quiñónez, quien le envió como visitador general a recorrer las parroquias y monasterios de fuera de la ciudad de Sevilla pertenecientes a la diócesis. Debido a esta serie de viajes pudo escribir Antigüedades y Principado de la ciudad de Sevilla (Caro 1634), obra basada en el conocimiento directo de las ruinas y monumentos descritos y en su notable colección de monedas y epígrafes recogidos. Así lo hace notar en dicha obra enorgulleciéndose de haber visitado "personalmente los lugares de que escrivo [...]. Verá el lector en esta parte quanto importa, que los ojos registren lo que ha de escribir la pluma' (Caro 1634: prólogo al libro III). A propósito de Rota, esto fue lo que dejó escrito:

'Parecen por todo el mar vecino a Rota, y Chipiona, grandes peñascos, y es peligrosissimo para los navegátes.
En todo el sitio, que ocupava esta isla, y ciudad, y como una legua la mar adentro se descubren tal vez edificios
cubiertos del mar en sus crecientes, y alli junto un gran peñasco, en el qual està una cavidad muy grande, que
llaman vulgarmente la cuba de Rota, por su forma; y porque; quando quiere llover mucho, suena en aquella
parte un zumbido, o tronido sordo, el qual se oye en mas de quinze leguas la tierra adentro, de la misma
manera que alli; que no porque Rota está mas vecina, se oye este zumbido o tronido de otra manera. La causa
del clara cosa es, que es el espiritu, o ayre del mar impelido, y sacudido en aquella parte, como una bozina:
si ya no es, que el agua del mar con extraordinario movimiento passa por la estrechura de aquella cueva, y de
la manera, que quando se vazia un cantaro de agua, causa ruido en la angostura de la boca, encontrandose con
el ayre; afsi ni mas, ni menos suceda alli rimbombar el mar, encontrandose juntos el agua, que sale, y el
viento, que entra en parte estrecha. Ello es cosa, que muchas vezes la hemos oydo: y si tiene otras causas, que
las dichas, los Filosophos raciocinando las diran mejor; que yo he dicho mi sentimiento. Esta villa de Rota, que como dicho es, pensamos, que puede ser parte de la isla antigua de Tartesso, està oy en una peninsula, cercandola el mar por todas partes, sino es por la entrada del Septentrion: tendrà de presente setecientos vecinos, ay en ella una buena Iglesia parrochial con ricos ornamentos, y renta bastante, un Convento de frayles Descalços de la Merced: es del Estado de Arcos'

(Caro 1634: fol. 128).

Como se acaba de exponer, R. Caro participa de la opinión de que Rota se encontraba en el terreno que había pertenecido a la antigua isla tartésica. A renglón seguido indica que una legua mar adentro se observaban restos de estructuras - ¿acaso relacionadas por él con el período tartésico?-. No obstante, no existen huellas arqueológicas visibles en la zona indicada por Caro. En cambio, sí que se conoce desde hace siglos la construcción de diversos corrales de pesca, siendo éstos los únicos muros que asoman entre las mareas a dicha distancia de la costa. Este tipo de estructuras podrían definirse como recintos generalmente construidos con piedras y estacas clavadas y entrelazadas con ramaje que actúan de sistema de pesca pasiva al quedarse atrapados en ellos los peces cuando baja la marea por debajo de su altura (fig. 2). A este respecto, algunos datos tanto arqueológicos como textuales avalan la existencia de corrales de pesca como mínimo desde época romana en las costas gaditanas (Florido 2012: 70-71; Lagóstena 2007: 109-110). El testimonio más significativo es, sin duda, el realizado a propósito del tratado sobre la cría de peces de Columela, agrónomo gaditano del siglo I d.C., en su obra De los trabajos del campo (VIII, 17, 6-11). En ella explica cómo construir estanques para peces en zonas rocosas costeras practicando:

'[...] se cava una piscina poco profunda, hasta los dos pies, en la parte de la costa que nunca deja en seco el reflujo del mar. Luego, en los bordes se clavan rejas espesas que sobresalgan siempre por encima del agua, 
incluso cuando suba la marea. Seguidamente, se construyen delante unos diques en forma de círculo, de manera que rodeen y cobijen el espacio ocupado por el estanque y, al mismo tiempo, sobrepasen su nivel; de este modo, la impetuosidad del mar se quiebra contra la barrera de la escollera [...]. Convendrá, no obstante, que el dique esté cortado acá y allá en algunos puntos por pasajes pequeños y estrechos a la manera del curso del Meandro, los cuales dejan pasar el agua del mar, pero sin oleaje, por mucha que sea la furia de la tempestad'

(Holgado (tr.) 1988: 196).

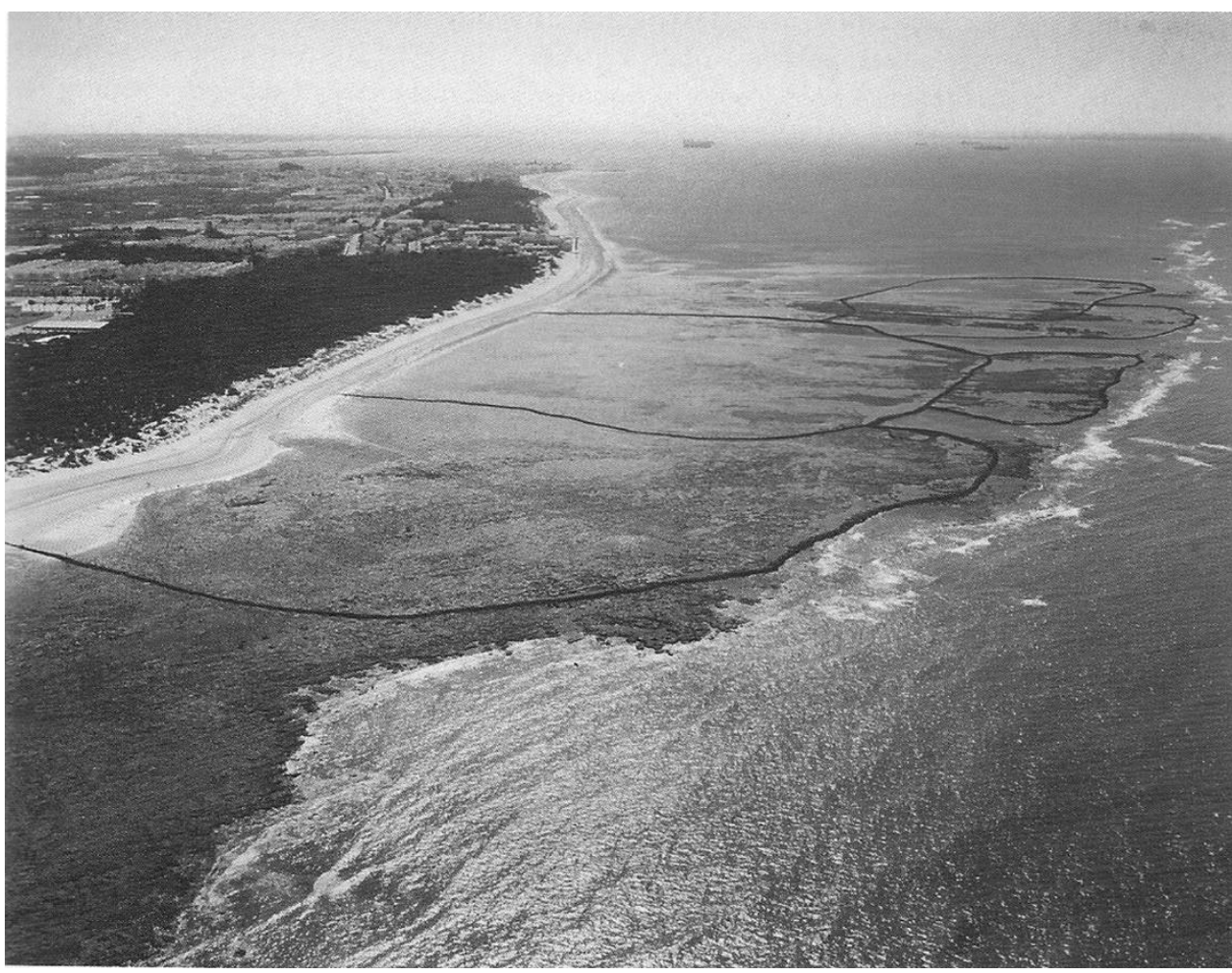

Fig. 2. Estado actual de los corrales de pesca roteños (Arias 2005).

Escasas décadas después de que R. Caro diera su opinión sobre los vestigios de la zona, dentro de la línea localista antes comentada hay que destacar la importante figura de Fr. Pedro San Cecilio, cronista de la roteña Orden de la Merced y definidor de la provincia de Andalucía. Sobre la protohistoria de la localidad afirmaba lo siguiente:

'Es la villa de Rota vna de las primitiuas poblaciones de España, contemporanea por lo menos de la celebrada Cadiz, y consiguientemente fundada por los primitiuos Españoles De no auerlo sido por ellos, no se puede negar fue fundacion de Fenices, muy en los principios de su mañosa entrada a apoderarse desta Prouincia, por gozar se su opulencia.

[...] Los Fenices la llamaron Guadir, que es lo mismo que cerca, ò vallado, como refiere el mismo Plinio. Los Griegos le dieron nombre de Eritia ò Eritréa, segũ afirma Herodoto. Los Tyrios (como se vè en el referido Rufo Festo Auieno) la apellidaron Tartesso: y este parece auer sido su segundo nombre, y mas vsual en la antiguedad, tomado del rio que la cercaua, llamado aísi en aquellos siglos.

[...] Pero dexada la Torre de Capion, boluamos al oráculo de Menesteo, en cuya demanda caminamos dende el principio del parágrafo precedẽte. No dudamos ser este la villa de Rota,lugar dende su principio ilustre,y grande, aunque los tiempos han hecho en él la suerte que en otros que antiguamente lo fuerõ mucho, y oy por marauilla se conocen sus sitios Pudole venir el nõbre de Eritia, ò Eritréa,que en otro tiempo tuuo aquella isla, dado por los Tyrios, como Plinio afirma,ò por los Griegos, como Herodoto quiere. 
[...] Lo mucho que della pudieramos decir, sacado de Autores antigos, y clásicos, remitimos a vn graue, y diligente moderno que lo acumuló todo, si bien habló con incertidumbre en muchas cosas, y parece confunde con el puerto de Menesto este Oraculo suyo de que tratamos, no considerando la claridad cõ que Estrabon diuidió a vno de otro en nõbre, y sitio; pues coloca al Oráculo entre las dos bocas de Guadalquiuir, y al Puerto fuera dellas, entre la mas Oriental de ambas, y el rio Guadalete, donde está, y siempre ha estado el Puerto, oy de santa María, antiguamente de Menesteo, ò Gaditano. Toda la grandeza, y opulencia de la antigua Tartesso, despues Oráculo de Menesteo, y oy villa de Rota. [...] Llamòse este lugar Oráculo de Menesteo,por auer este famoso Capitan Griego edificado alli Templo a alguno de sus falsos dioses, para ofrecerle sacrificios, y oraciones; ò por auerle dado los suyos alli sepultura, y dedicado alguna ara,ó delubro,tratándolo como a deidad,por sus insignes hechos,y gran sabiduría.

[...] Indica también la opulencia de la antigua, y celebrada ciudad de Tartesso, el muelle que oy en esta villa perseuera, a quien no han podido arruinar las injurias de tan larga carrera de siglos, ni los horribles, y casi constantes golpes con que el mar le combate'

(San Cecilio 1669: Lib. 2º Cap. 32, párr. XI: 497-504).

P. San Cecilio identifica Rota primero con Tarteso y posteriormente en el tiempo con el Oráculo de Menesteo, así como adscribe una serie de topónimos a la localidad dejando ver su confusión al entender que fenicios y tirios eran realidades culturales diferentes; a la profusión de topónimos hay que sumar la existencia de un muelle del que desgraciadamente no ofrece detalles para poder intentar realizar una aproximación interpretativa. Acerca de éste, el historiador Agustín de Horozco decía:

'[...] hácese una ensenada i razonable portezuelo en la parte que mira a Cádiz, que le fuera muy provechoso al lugar si no ovieran dexado perder un buen muelle de piedra, que le hacia abrigo hácia el vendaval, el qual se va ya casi desbaratando todo, i por eso perdiéndose el portezuelo'

(de Horozco 1598 [1845]: 281).

Es propio de los autores localistas de la Andalucía de los siglos XVII y XVIII la asunción de la defensa de las tradiciones de sus patrias chicas al ser ellos referentes intelectuales de las mismas, en un contexto en el que no faltaban las rivalidades con poblaciones vecinas ni las creencias populares visibles en ocasiones en los escritos oficiales. Siendo en su mayoría eclesiásticos, tenía para ellos una trascendencia fundamental el hecho de que el descrédito de los cronicones hubiese dejado al descubierto una desconcertante falta de mártires antiguos y la endeblez de los argumentos que podían esgrimirse en defensa de una temprana cristianización de la católica España. Por ello, la historiografía local de la época pretende siempre, en primer lugar, conseguir la identificación o reducción de un topónimo antiguo con la propia localidad. Segundo, revelar la antigüedad de su fundación. Y tercero, situar los inicios del cristianismo local en unas fechas que permitan suponer la existencia de mártires y argumente la pretensión de dignidades eclesiásticas. Todo ello fiel reflejo de una escala de valores transferida desde el campo del honor familiar: antigüedad, nobleza y cristianismo viejo (Guinea 1995: 124-126).

\section{SS. XVIII-XIX: Entre el Tarteso autóctono como instrumento anticuarista y el Tarteso fenicio como instrumento de la llustración}

Hasta el momento, la imagen que se había venido ofreciendo de Tarteso era eminentemente localista, y las glorias pasadas con las que vincular a monarcas y poblaciones se entendían desde esta perspectiva continuista. Sin embargo, a partir del siglo XVIII se perciben cambios en la imagen que de Tarteso y de los fenicios se tenía con respecto a los siglos anteriores, ya que durante un tiempo se valoró positivamente a éstos. Así pues, los orígenes y la esencia de Tarteso se empezó a poner en relación directa con la presencia de los colonos orientales.

Estoy de acuerdo con M. Álvarez en que estos cambios responden a dos razones: a una utilización de las fuentes antiguas mucho más ajustada y crítica y, sobre todo, a la proyección al pasado de los valores del ideario ilustrado (Álvarez 2005: 36-38). Usando las palabras del propio M. Álvarez, 'la aplicación de los 
valores de la Ilustración a la labor de reconstrucción de la Historia de España da como fruto la primera revisión global del modelo gestado en el siglo XVI y, muy especialmente, un importante cambio en el tratamiento de la cuestión de Tarteso, merced a la nueva y positiva valoración de los fenicios, ahora protagonistas destacados de la Historia Antigua de la nación' (Álvarez 2005: 38). Sin embargo, esos cambios que de la imagen de Tarteso se empiezan a tener durante el siglo XVIII, no anularon la visión que hasta el momento se venía teniendo desde los siglos anteriores.

Puede hablarse por tanto, de dos tendencias coetáneas. Por una parte, una línea de interpretación copartícipe con las ideas ilustradas, asociada a nuevos grupos de pensamiento y a nuevas perspectivas, rehusando la utilización de falsificaciones barrocas y depurando el criticismo, con un nuevo estilo marcadamente ordenado y racional, defensora del positivismo. Y por otra, una línea opuesta a dichos planteamientos que continúa con la tendencia tradicional de los siglos XVI-XVII, que seguía basándose en los ideales de esencialismo desde la Antigüedad, virtuosismo filonobiliario y que veía con buenos ojos a los godos por ser éstos quienes dieran unidad cristiana, territorial y monárquica entroncada con la monarquía castellano leonesa, auspiciada por sectores sociales opuestos a los cambios (Beltrán Fortes 1993: 118 y 122; Wulff 1995: 136-139).

Ya durante el siglo XIX, los estudios se centraron especialmente en la Historia de las instituciones, en la que se observa la esencia de la historia civil de la nación, cuyos verdaderos orígenes de España han de hallarse en el momento en que se establecen sus instituciones políticas características, hecho ubicable en la España visigoda. La Antigüedad pierde protagonismo en la medida en que, dentro del esquema evolutivo de la Historia de España, cambia el interés de los representantes de la historiografía liberal, centrándose en las instituciones y la legislación española (Álvarez 2005: 48). Este cambio encuentra sus bases en dos elementos que se sacralizan en la época y que resultan claves para entender todo esto. El primero es el concepto de 'progreso'. Mientras que las sociedades preindustriales sitúan la utopía en el pasado, las industriales lo hacen en el futuro. En las primeras, el tiempo cíclico de las cosechas y la concepción del poder Real basado en la voluntad divina van unidos en la inmensa mayor parte de los casos a la idea de un orden fundacional creado que ha de ser mantenido. El segundo es la idea de nación. En el mundo del siglo XIX se tiende a pensar que los países, ahora naciones, tienen una realidad independiente de quienes les gobiernen, y la pertenencia a una comunidad no requiere necesariamente el intermedio de un rey, debido, entre otras cosas, a que la soberanía nacional acaba siendo considerada como igual o superior al poder de éste. Se es miembro de una 'nación', de un cuerpo colectivo para el que se hace necesario inventar y definir una entidad, unos rasgos culturales e, incluso, con frecuencia una lengua (Wulff 2002: 121-122). Este es el contexto que explica la actitud de la historiografía liberal española de los dos primeros tercios del XIX respecto de la Historia más antigua.

\section{S. XX: Del Tarteso de la tradición literaria al Tarteso arqueológico}

Desde el siglo XVI y hasta fines del siglo XIX, la problemática relacionada con la protohistoria de las tierras de la actual villa de Rota se había articulado en torno a las fuentes escritas. La arqueología no había sido utilizada como elemento dialéctico en esta cuestión, ni desde concepciones artísticas ni como herramienta para intentar contrastar lo que los textos antiguos reflejaban. Es en este contexto en el que aparece la revulsiva figura de George Bonsor, quien influye decisivamente en hacer resurgir la problemática tartésica desde nuevos parámetros. En sus investigaciones se unió a Adolf Schulten, personaje clave para comprender la historiografía tartésica de las primeras décadas del siglo XX. G. Bonsor, en su obra Las colonias agrícolas prerromanas del Valle del Guadalquivir, dice que Tarteso fue una ciudad fundada por los sidonios en su expansión, influido sin duda como comenta M. Álvarez (2005: 65) por autores británicos como G. Rawlinson. Esto es lo que comentaba G. Bonsor a propósito de Rota:

'Hacia el interior de esta isla, formada por los brazos del Betis, había una ciudad llamada Tartesos que desde los tiempos de los fenicios, habría dado nombre a toda esta isla, al río, e, incluso, a toda la región.

[...] Habría pues que buscar las pruebas del emplazamiento de la primitiva colonia sidonia -Tarshish en la 


\section{Álvaro Gómez PeÑa}

Biblia- entre Rota y Chipiona, sobre el mismo borde del mar o, aún más probablemente, sobre la parte opuesta de la isla bañada por el primitivo brazo del río. He visitado en repetidas ocasiones estos parajes, mas están de tal manera invadidos por la arena del mar que no sería posible proseguir las prospecciones sino por medio de excavaciones profundas y costosas'

(Bonsor 1899 [1997]: 10).

A finales del siglo XIX y comienzos del XX, frente a la vinculación de los orígenes fenicios de Tarteso del período precedente, se prefirió asignar a la cultura tartésica un marcado carácter griego al calor del filohelenismo y del antisemitismo de la época. En esta línea filohelénica se manifestó Juan Carandell en su Datos para la geografia física y humana del litoral atlántico de la provincia de Cádiz y estudio de una población típica: Rota:

'Filiación griega de la Villa de Rota

La denominación de la localidad que nos ocupa guarda no pocas analogías con los nombres de otras españolas: Rosas y San Pedro de Roda, en la costa del Ampurdán (provincia de Gerona); Roda, en el Vallés (Barcelona).

De ahí á los Rodios (pobladores de aquel litoral mediterráneo) y á Rhodas, griegos, no hay más que un paso.

Lingüísticamente por un lado y arqueológicamente por otro, Rota tiene abolengo griego. Existe un trozo de muralla junto al mar, en la playa de la Costilla, de factura exactamente idéntica á la de la ciudad griega de Emporion (hoy Ampurias), en el litoral del golfo de Rosas (Gerona).

Una campaña sistemática de excavaciones en el subsuelo del casco antiguo de Rota, sería por demás instructiva y seguramente confirmaría el origen de la villa, colonia gemela de Gades, hoy Cádiz, ya que de la importancia estratégica de Rota hay testimonios reiterados en el transcurso de la historia patria, tan llena de episodios guerreros en tierra y en mar'

(Carandell 1925: 35).

La vinculación griega propuesta por J. Carandell se basa en el parecido toponímico y en la similitud de la muralla. En cuanto al topónimo Rota, Alfonso Franco (2004: 18) vincula el actual nombre de Rota con el musulmán de Rabita Ruta, cuya población se asentó en la zona como un lugar de ribat donde se retiraban los ascetas. Por su parte, con respecto a la muralla, ante la falta de datos para poder contrastar el origen griego de dicho lienzo, sería oportuna la realización de actividades arqueológicas en la zona del paseo y puerto marítimos de la localidad para comprobar esta hipótesis.

Curiosamente, en clara sintonía con esta noticia filohelénica, en la Real Academia de la Historia se hace constar con fecha de 16 de octubre de 1931 la denuncia de un particular bajo el pseudónimo de M. E. Apliofe $\mathrm{e}^{3}$ manifestando que en las obras de prolongación del muelle de la Villa de Rota se estaba poniendo en peligro uno de los pocos monumentos pelásgicos y se apuntaba la necesidad de realizar excavaciones científicas antes de que fuera demasiado tarde (Maier y Salas 2000: 127, CACA/9/7949/101).

En poco más de veinte años el estudio de Tarteso sufrió un abismo en cuanto a la estrategia investigadora. A. Schulten, en el período de entreguerras, reaccionó contra el evolucionismo de fines del siglo XIX y se decantó por la nueva corriente difusionista. A ello le unió el ideal y práctica de arqueología romántica a imitación de Henry Schliemann y su descubrimiento de Troya siguiendo al pie de la letra la Ilíada de Homero. A. Schulten, con la Ora Marítima de Avieno en la mano, situó a la ciudad de Tarteso en el coto de Doñana (Schulten 1922), como así lo creyera también Bonsor (1922). Ambos excavaron juntos sin encontrar la que consideraban capital de un rico imperio occidental. Sin embargo, esta decepción no provocó una negativa entre los intelectuales de la época sobre la existencia de la capital tartésica, sino que

${ }^{3}$ Sobre M. E. Apliofe hay que indicar que, a pesar de no conocerse su identidad, se sabe de la existencia de un M. E. Apliofe que escribía para Pictorial Review, como así lo demuestran los anuncios de la hemeroteca digital de ABC con fecha de $05 / 01 / 1916$ (p. 2) y 14/08/1916 (p. 2). Sobre si ambos eran la misma persona y la procedencia del nombre no es posible decir nada. 
abrió un nuevo campo de estudio, el de la paleogeografía como método para comprobar la existencia de la isla en la que se ubicaba Tarteso y los núcleos de habitación nombrados en las fuentes antiguas.

Fue entonces cuando saltaron a un primer plano las teorías sobre el brazo perdido del Guadalquivir de las que hablaban los cronistas y anticuarios de la Edad Moderna, surgiendo casi tantas hipótesis como estudiosos (vid. Abad 1975: 48-51 y nota 74; Barbadillo 1945: 42-45; Chic 1979: 7-11): $1^{\circ}$ Los dos brazos del río eran los que actualmente forman las islas llamadas Mayor y Menor. Esta era la opinión sustentada por Adolfo de Castro (1858 [1982]: 9). $2^{\circ}$ El brazo meridional o izquierdo es el actual cauce del Guadalquivir. El desaparecido iba por donde se encuentra hoy el coto de Doñana. Lo infructífero de las investigaciones de A. Schulten y G. Bonsor entre 1923 y 1925 aumentó las dudas sobre ella, si bien no la hicieron desaparecer. $3^{\circ}$ Los dos brazos eran las actuales desembocaduras del Guadalquivir y Guadalete, ríos que entonces se comunicarían. Esta teoría fue desechada por Juan Gavala quien en sus estudios sobre la geología de esta comarca opinaba que entre ambos ríos se levanta una barrera de la edad terciaria, por lo que las aguas de aquéllos nunca pudieron haberse comunicado (Gavala 1959). $4^{\circ} \mathrm{El}$ brazo desaparecido del Guadalquivir era el de la izquierda, mientras que el derecho lo era el actual. El poco éxito de A. Schulten y G. Bonsor en sus excavaciones dio alientos a la suposición de que el brazo desaparecido era el oriental. Uno de sus mayores exponentes fue José Chocomeli, para quien el cauce iba a salir hasta el arroyo Salado de Rota. La obra de J. Chocomeli, en la que defiende la tesis "Mesa de Asta = capital de Tartessos / Astaroth = puerto de Mesa de Asta", ha de ser entendida dentro de una corriente historiográfica filológica en la que se parte de un pasado patriótico esencialista en el que Tarteso, al margen de la idea de A. Schulten (1924 [2006]) sobre su origen fenicio, era entendido como un Imperio esplendoroso con el que conectaba el patriotismo español franquista y la naturaleza intrínseca de tartésicos y españoles como una misma identidad y un mismo ser sociohistórico (Díaz-Andreu 1993: 76).

A ello se unía la ausencia de datos arqueológicos que hicieran tangible la realidad pasada de Tarteso. En cuanto a la desembocadura por esta villa, el enorme peso de la tradición literaria jugaba a su favor. Según J. Chocomeli:

'[...] el brazo oriental del Guadalquivir puede asegurarse, sin ningún género de duda, que desaguaba por las inmediaciones de Rota, al este de la población. El testimonio más atrasado que da a conocer tal desembocadura lo hemos encontrado en Florian de Ocampo'

(Chocomeli 1940: 44).

Por su parte, la teoría de Pedro Barbadillo (1951: 39-40) coincide con la de J. Chocomeli en la segunda parte del trazado del cauce, es decir, en la identificación con el arroyo Salado de Rota. Basándose también en la tradición de que el desaparecido cauce fue por el del arroyo Salado, aduce que el nombre de éste indica que antaño fue más que un río un estero, o más propiamente un brazo de mar y que sus aguas dejaron allí la sal que depositaron. Apoyando esta idea, comenta que en el verano de 1950, para la nueva construcción de la plaza del Cabildo de Sanlúcar de Barrameda, se emplearon en su pavimentado cantos rodados que se traían de la playa de Chipiona, y habiéndose agotado en ella comenzaron a traerse de Rota, aguas arriba del cauce del arroyo Salado, sin que, para P. Barbadillo, la poca longitud de éste y su poco caudal actual explique la formación y existencia de aquellos cantos redondeados iguales a los que hay en la desembocadura de la boca subsistente del Guadalquivir. Salvo pequeñas discrepancias, la tradición de que el brazo desaparecido iba por Rota ya se ha visto que es una constante. Por mi parte, considero que la ausencia de investigaciones arqueológicas y paleogeográficas no deben de hacer admitir ni rechazar estas hipótesis según soplen los vientos que hacen interpretar las investigaciones de cada época en tanto en cuanto no se estudie la zona roteña.

Dentro de la tradición filológica que imperó hasta el siglo XX, también tuvo su espacio el estudio de los topónimos. Como se acaba de ver, J. Chocomeli propuso que el termino tartésico de la actual Rota fuera Astaroth $=$ puerto de Mesa de Asta. El origen de dicho término se encuentra en la obra Historia de Cádiz 
y su Provincia desde los remotos tiempos hasta 1814 de Adolfo de Castro, alcalde de Cádiz y gobernador de Cádiz y Huelva entre otros cargos, quien al hablar del término de Jerez de la Frontera decía lo siguiente:

'Sobre el nombre de esta población [Mesa de Asta] diré brevemente mi parecer. No creo que tenga origen en la voz Hasta, como quieren algunos. Imaginando varias veces en cual pudo ser, no tuve por inverosímil que la voz Asta se dijera por corrupción de Astaroth, á causa de haber fundado esta ciudad los fenicios y adorar en ella la divinidad Astarte, como diosa de los bosques, luna, reina del cielo, Venus Siria y esposa de Adonis ó Juno según otros'

(de Castro 1858: 7).

Este fragmento es utilizado por Adolfo de Castro para apuntar que si el origen del término Asta es fenicio, denominaría en cualquier caso a Mesa de Asta (Jerez de la Frontera) y no a Rota. Es más, no tiene claro cuál puede ser el origen de Asta e hipotetiza con posibles derivaciones en función de si el término es prelatino o latino, diciendo al respecto:

'Pero si orígen es mas moderno, Asta se llamó por corrupcion de Aestua (los esteros ó las marismas). En la media y baja latinidad se convirtió la voz Aestuaria (plural) en Astaria (singular)'

(de Castro 1858: 7).

Así pues, el propio Chocomeli da por cierto el topónimo Astaroth del que hemos hablado ya anteriormente:

'Este Asta-roth (de Asta -rojthos) es el nombre tartesio de Rota, puerto de Asta [...]. Se justifica por haber existido en un peñasco o islote frente a ella una gran cavidad llamada la cuba de Rota, donde el viento y las olas producían en ciertas circunstancias un fragor o trueno prolongado que "se oye en más de quince leguas tierra adentro" según detalla Caro'

(Chocomeli 1940: 39-40).

J. Chocomeli, siguiendo un grupo probablemente de origen onomatopéyico que toma del Dictionnaire étymologique de la langue grecque de Émile Boissacq, considera que Asta significa 'ciudad' y roth, como corrupción de rojthos, significaría 'fragor de las olas que entrechocan', 'rugido (de olas)', 'lanzar el estertor', 'romperse contra las rocas (mar)', de ahí que la considere el puerto marítimo de Asta. Mientras que A. de Castro hacía derivar el término de la diosa Astarté. Ambas derivaciones nos parecen totalmente inconsistentes dado que no existen datos para afirmar que tal topónimo existiera.

La escasez de elementos arqueológicos vinculados a Tarteso y a los fenicios en el suroeste peninsular, y la confusión acerca de los mismos, propiciaron que tanto en los siglos precedentes como en la primera mitad del s. XX se intentase ubicar a la supuesta capital en diferentes pueblos de la zona, en este caso utilizando las referencias geográficas de los textos clásicos. No obstante, como se comentó anteriormente al principio, los intentos paleogeográficos por acercarse a la realidad pasada de las tierras de la actual Villa de Rota no han sido los únicos llevados a cabo para estudiar el espacio y el tiempo protohistóricos, sino que desde la arqueología también se llevaron a cabo trabajos en la misma dirección. Así, las excavaciones llevadas a cabo por jesuitas en las playas de Rota cercanas al Puerto de Santa María, dieron entre la zona de Fuenterrabía y el arroyo Salado con varias tumbas de atribución fenicia para unos (Montero 1953) y púnica para otros (Barbadillo 1951: 61). ${ }^{4}$ Desde unos años antes a las intervenciones arqueológicas de 1948 se venían conociendo noticias de hallazgos puntuales de piedras rectangulares, monedas con dos peces en sus caras y una vasija de tipo medio llena de monedas.

El padre Lacave encontró cuatro tumbas con los cuerpos en el interior, así como una moneda a su juicio fenicia por los atunes que tenía dibujados y un trozo de piedra que mostraba el grabado de otros dos más.

\footnotetext{
${ }^{4}$ La distinción entre ambos términos no debe de entenderse como una diferencia cronológica según el uso dado generalmente a ambos términos en la bibliografía actual, sino a la proveniencia oriental de los allí enterrados, dando Montero un uso demasiado amplio cronológicamente e inapropiado desde nuestra actual distinción.
} 
Las sepulturas presentaban tipo rectangular, siendo más anchas por la parte de la cabeza $(70 \mathrm{~cm})$ que por la de los pies $(50$ ó $60 \mathrm{~cm}$ ) construidas con piedras bastante regulares. Estas piedras o sillares también cubrían al cadáver o el hueco. La profundidad de cada fosa era de $1.50 \mathrm{~m}$ a $2 \mathrm{~m}$. Las cuatro independientes, y algo distantes unas de otras, contenían sus respectivos esqueletos orientados con los pies hacia el este y la cabeza hacia occidente. Para llegar al esqueleto era necesario después de levantar las piedras sacar gran cantidad de tierra. El padre Lacave llegó a señalar dos capas superpuestas al esqueleto. A la primera de tierra, seguía una de cal o mezcla más consistente y al fin otra de tierra. Los huesos casi fosilizados y el cráneo lleno de tierra. En ninguna de las tumbas se encontró objeto o adorno alguno. Tampoco se vieron restos de vestiduras y faltaba todo indicio de haber existido ataúd de madera. De todo esto, el padre Lacave concluyó lo siguiente: $1^{\circ}$ Tumbas o sepulturas fenicias dada su orientación y construcción en sillares. $2^{\circ}$ Objetos de cerámica encontrados en el talud cercano deben ser restos de las antiguas casas o habitaciones fenicias que estarían separados de la necrópolis. $3^{\circ}$ Por la variedad de monedas concluye que debieron existir un poblado fenicio y otro púnico o cartaginés.

Oída y anotada la relación del padre Lacave, una comisión en la que se encontraba César Pemán marchó a la Puntilla del Salado para comprobar y analizar lo realizado. Cerciorados del descubrimiento, se hicieron las convenientes diligencias para adquirir el terreno y se prohibió todo trabajo en aquel paraje. Así, el terreno pasó a poder del Estado y éste se reservó el excavar y proseguir las investigaciones. Sin embargo, el dinero no dio para más.

En el verano de 1952, varios padres, alarmados por la paulatina destrucción que de las sepulturas estaba realizando el mar, decidieron establecer la localización de las sepulturas ya existentes y encontraron una quinta tumba orientada en la misma dirección. Las dimensiones del sepulcro eran similares a las antes descubiertas, así como la profundidad. Pero en esta ocasión la mano izquierda del esqueleto apareció apoyada sobre el pecho. Además, la piedra correspondiente al pecho apareció con una oquedad; en el talud cercano se encontró gran cantidad de trozos de cerámica y algunos pequeños cristales tornasolados. Con los trozos se llegó a prefigurar un ánfora de ascendiente fenicio-cartaginés en opinión de los excavadores.

A finales de 1953, los padres volvieron a pasar por la misma zona observando nuevamente los daños que causó el mar al estado original de las sepulturas tras su excavación. Y en julio de ese mismo año decidieron reunirse para intentar salvar los restos que iban quedando. Antes de julio recibieron una excursión de los estudiantes de segundo y tercer curso de Filosofia y Letras de la Universidad de Sevilla bajo la dirección de Juan de Mata Carriazo promovido por el padre Delgado. J. M. Carriazo, al igual que hiciera P. Barbadillo en su obra Alrededor de Tartessos (Barbadillo 1951: 61), confirmó la existencia de restos fenicios y cartagineses y la necesidad de delimitar un muro de una posible casa o de separación entre la necrópolis y el poblado. Tras varios días de labor, se encontraron escasos sillares sin continuidad constructiva, a lo que se sumó la incapacidad de continuar excavando. Los datos aportados podrían relacionarse con los conocidos conjuntos de tumbas púnicas de sillares aparecidos en zonas cercanas a Rota, como en la Playa de Santa María del Mar en Cádiz, o en Chipiona (Perdigones 1991: 221-232).

Durante el franquismo se produce el tránsito más claro hacia la arqueología profesional, rechazándose cada vez más la participación de quienes no se formaron profesionalmente como arqueólogos. Todavía en los años cuarenta y cincuenta son frecuentes los sacerdotes, ingenieros y médicos que se dedican a la arqueología -caso del padre Lacave y sus compañeros-.$^{5}$ Pero a partir de los setenta estas incorporaciones empezaron a disminuir. Todo ello se pone claramente en relación con el progresivo corporativismo de los profesionales y con la creciente sofisticación y tecnificación de la arqueología a partir de los años sesenta y setenta (Díaz-Andreu 1995: 34).

\footnotetext{
${ }^{5}$ De esta idea participa J. Beltrán Fortes (2009: 195-196) al escribir que: 'En los años 1940-1941 se completó la red de Comisarios Provinciales e Insulares que controlaron buena parte de la práctica arqueológica española hasta el año 1955, con una extracción heterogénea, pero en todo caso alejados generalmente de lo que podría denominarse como arqueólogos profesionales (de las Universidades y Museos Arqueológicos)'.
} 
Es a partir de los años 60' del siglo XX cuando el interés por la protohistoria en la Villa de Rota desaparece por completo hasta hace escasos años. Por una parte, considero que la paulatina falta de interés por la paleodesembocadura del Guadalquivir y por las conclusiones llevadas a cabo por J. Gavala (1959). Por otra, por la importancia tomada por otros centros próximos como Mesas de Asta (Jerez de la Frontera), Gadir (Cádiz) o el Poblado de Doña Blanca (El Puerto de Santa María) entre otros, que sumados a los hallazgos de El Carambolo (Camas), Setefilla (Lora del Río), Carmo (Carmona) y Cabezo de San Pedro (Huelva) empezaron a llenar de referencias el vacío arqueológico que hasta entonces se venía arrastrando.

Con todas estas intervenciones y la falta de evidencias sobre la legendaria capital de Tarteso, el interés por su búsqueda fue poco a poco desinflándose. A la par, empezó a haber un fuerte interés por los aspectos socioeconómicos de su cultura. El caso concreto de la Bahía de Cádiz es muy significativo, pues los yacimientos de Mesa de Asta, Doña Blanca o Gadir entre otros, han sido integrados dentro de un círculo comercial liderado por este último y coincidente con los actuales límites geográficos de la Bahía, dentro de este marco de referencia que algunos han dado en llamar Liga púnica-gaditana (Arteaga 1994). En ella habría que incluir los escasos restos localizados en Rota que han llegado hasta nuestros días. Mientras tanto, la Rota protohistórica, como tantos otros municipios, duerme el sueño de los justos.

\section{BiBLIOGRAFÍA}

Abad, L. (1975), El Guadalquivir, vía fluvial romana, Sevilla. Diputación Provincial de Sevilla.

Aldrete, B. J. (1606), Del origen y principio de la lengua castellana ò roma[n]ce que oi se vsa en España, Roma.

Alvar, J. (2000), 'Fuentes literarias sobre Tartessos' en C. Aranegui (ed), Argantonio, rey de Tartessos. Valencia. Fundación El Monte: 37-67.

Álvarez, M. (2005), Tarteso. La construcción de un mito en la historiografía española, Málaga. Diputación de Málaga.

Arias, A. M. (2005), El monumento natural de Andalucía. Corrales de Rota, Rota. Junta de Andalucía y Fundación Zoilo Ruiz Mateos.

Arteaga, O. (1994), 'La Liga púnica gaditana. Aproximación a una visión histórica occidental, para su contrastación con el desarrollo de la hegemonía cartaginesa en el mundo mediterráneo', VIII Jornadas de Arqueología Fenicio-Púnica: 23-57.

Barbadillo, P. (1945), Historia de Sanlúcar, Cádiz.

Barbadillo, P. (1951), Alrededor de Tartessos: los descubrimientos de la Algaida, Sanlúcar de Barrameda. Ayuntamiento de Sanlúcar de Barrameda.

Beltrán Fortes, J. (1993), 'Entre la erudición y el coleccionismo: anticuarios andaluces de los siglos XVI al XVIII' en F. Gascó y J. Beltrán (eds), La Antigüedad como argumento. Historiografía de arqueología e historia antigua en Andalucía. Sevilla. Consejería de Cultura de la Junta de Andalucía: 105-124.

Beltrán Fortes, J. (2009), 'En la otra orilla. La Arqueología española frontera a la del norte de Marruecos: algunas notas', En la orilla africana del Círculo del Estrecho. Historiografía y proyectos actuales: 185-205.

Beltrán Martínez, A. (1969), 'Tartessos en la historiografía española anterior a Schulten' en Tartessos y sus problemas. Vo Symposium internacional de Prehistoria Peninsular. Barcelona. Universidad de Barcelona: 75-78.

Bernabé, A. (2008), Dioses, héroes y orígenes del mundo. Lecturas de mitología, Madrid. Abada Editores. Bonsor, G. (1899 [1997]), Las colonias agrícolas prerromanas del Valle del Guadalquivir, Sevilla.

Bonsor, G. (1922 [1989]). El Coto de Doña Ana (una visita arqueológica). Clásicos de la Arqueología de Huelva 2: 9-36.

Carandell, J. (1925), Datos para la geografía física y humana del litoral atlántico de la provincia de Cádiz y estudio de una población típica, Rota, Madrid.

Caro, R. (1634), Antigüedades y Principado de Sevilla y Chorografía de su Convento Jurídico, o antigua 
chancillería, Sevilla. Andrés Grande.

Chic, G. 1979. Gades y la desembocadura del Guadalquivir. Gades 3: 7-23.

Chocomeli, J. (1940), En busca de Tartessos, Valencia. Semana Gráfica.

de Castro, A. (1858 [1982]), Historia de Cádiz y su Provincia desde los remotos tiempos hasta 1814, Cádiz.

Diputación Provincial de Cádiz.

de Horozco, A. (1598 [1845]), Historia de la ciudad de Cádiz, Cádiz. Manuel Bosch.

de Ocampo, F. (1543 [1553]), Los cinco libros primeros de la cronica general de España, Medina del Campo.

de Roa, M. (1617), Santos Honorio, Eutichio, Estevan: patronos de Xerez de la Frontera, Sevilla.

Díaz-Andreu, M. 1993. Theory and ideology in archaeology: Spanish archaeology under the Franco regime. Antiquity 67: 74-82.

Díaz-Andreu, M. y Mora, G. (1995), Arqueología y política: el desarrollo de la arqueología española en su contexto histórico. Trabajos de Prehistoria 52 (1): 25-38.

Florido, D. (2012), 'Corrales, una técnica de pesca tradicional en Andalucía', en D. Bernal (coord.), Pescar con arte: fenicios y romanos en el origen de los aparejos andaluces, Cádiz. Universidad de Cádiz: 65-94.

Franco, A. (2004), Rota en la Edad Media, Rota. Fundación Zoilo Ruiz-Mateos.

Gavala, J. (1959), La geología de la costa y bahía de Cádiz y el poema "Ora Marítima» de Avieno, Madrid.

Guinea, P. (1995), 'Tergiversaciones en la historiografía local andaluza del siglo XVIII sobre la Antigüedad y la Arqueología' en F. Gascó y J. Beltrán (eds), La Antigüedad como argumento II: Historiografía de arqueología e historia antigua en Andalucía. Sevilla: 121-133.

Holgado, A. (tr.) (1988), De los trabajos del campo. Lucio Junio Moderato Columela, Madrid. Siglo XXI.

Lagóstena, L. (2007), 'Columela, De re rustica VIII, 16-17: Una fuente para el conocimiento de la piscicultura en Baetica' en L. Lagóstena, D. Bernal y A. Arévalo (eds), Actas del Congreso Internacional CETARIAE. Salsas y salazones de pescado en Occidente durante la Antigüedad. Oxford. Archaeopress: 109-115.

Maier, J. y Salas, J. (2000), Comisión de Antigüedades de la Real Academia de la Historia. Andalucía: catálogo e índices, Madrid. Real Academia de la Historia.

Montero, M. (1953), 'Excavaciones en la Puntilla del Salado (Cádiz)'. Seminario de Estudios de Arte y Arqueología XX: 185-195.

Mora, G. (1998), La arqueología clásica española en el siglo XVIII: historias de mármol, Madrid. CSIC.

Pellicer, M. (1976), Historiografía tartésica. Habis 7: 229-240.

Perdigones, L. (1991), 'La necrópolis fenicio-púnica de Cádiz (Siglos VI al IV aC.)', IV Jornadas de Arqueología Fenicia-Púnica: 221-232.

San Cecilio, P. (1669), Annales de la Orden de Descalzos de Ntra. Sra. de la Merced, $1 \underline{a}$ parte, Barcelona. Schulten, A. (1922), Tartessos, Hamburg. Ein Beitrag zu ältesten Geschichte des Westens.

Schulten, A. (1924 [2006]), Tartessos. Contribución a la historia más antigua de Occidente, Córdoba. Almuzara.

Wulff, F. (1995), 'Historiografía ilustrada en España e Historia Antigua. De los orígenes al ocaso' en F. Gascó y J. Beltrán (eds), La Antigüedad como argumento II: Historiografía de arqueología e historia antigua en Andalucía. Sevilla: 135-152.

Wulff, F. (2002), 'La Antigüedad en España en el siglo XIX: seis Historias de España' en M. Belén y J. Beltrán (eds), Arqueología fin de siglo. La arqueología española de la segunda mitad del siglo XIX (I⿳彑口冋 Reunión Andaluza de Historiografía Arqueológica). Sevilla. Universidad de Sevilla: 119-155. 


\title{
La Arqueología en Córdoba en la década de 1950. Un recorrido historiográfico a través de sus protagonistas
}

\author{
Francisco José Rueda Olmo \\ Universidad de Sevilla
}

\section{Introducción}

A pesar de los esfuerzos encaminados a la recuperación y conservación del patrimonio que realizaron numerosas personas e instituciones locales, lo cierto es que durante el siglo XIX y buena parte del XX el legado patrimonial de Córdoba no recibió toda la atención que merecía. Sin embargo, esta situación de desidia y despreocupación generalizadas inició un cambio de rumbo de forma rápida a partir de 1951, con la llegada a la alcaldía de la ciudad de Antonio Cruz Conde (1951-1962). Consciente de su fecunda historia y del papel que los monumentos jugaban en el prestigio de las urbes modernas, las actuaciones del nuevo alcalde en materia de patrimonio estuvieron encaminadas al "embellecimiento" de Córdoba. Para ello se procedió, por ejemplo, a la recuperación y restauración de edificios tan simbólicos como el Alcázar de los Reyes Cristianos o la Torre de la Calahorra. Asimismo, se produjeron en aquellos años notables hallazgos arqueológicos como consecuencia del incremento de las obras de construcción y de la aplicación de un nuevo plan urbanístico, siendo quizás los más destacables los restos del templo romano de la calle Claudio Marcelo (descubiertos como consecuencia de la ampliación de las Casas Consistoriales) o los mosaicos romanos hallados bajo el antiguo mercado de abastos situado en la Plaza de la Corredera ${ }^{1}$. Este proceso de restauración de monumentos antiguos y medievales, junto con la instalación de un nuevo alumbrado y un servicio moderno de abastecimiento de aguas, dotó a la ciudad de una imagen muy diferente de la que había tenido hasta entonces. Este hecho puede apreciarse claramente en las fotografías de la época, en las que podemos percibir los cambios sufridos por la ciudad a través de un análisis comparativo entre el material fotográfico anterior a la década de 1950 y el realizado con posterioridad a dicho periodo.

Las obras de restauración de los monumentos recuperados bajo el mandato de Cruz Conde fueron llevadas a cabo por arquitectos de renombre, como Félix Hernández, Víctor Escribano o José Rebollo. Sólo el templo romano de la calle Claudio Marcelo y los baños del Alcázar califal fueron sometidos a un estudio mediante metodología arqueológica. El encargado del estudio del templo romano, tras la fase inicial emprendida por Samuel de los Santos Gener, fue el eminente arqueólogo clásico Antonio García y Bellido. A éste se deberá la correcta identificación e interpretación del templo.

Así pues, el legado patrimonial que Antonio Cruz Conde dejó a Córdoba ha servido, a título personal, para que éste sea considerado uno de los mejores alcaldes que ha habido hasta la fecha en la ciudad. Sin embargo, las actuaciones sobre los elementos patrimoniales no fueron continuadas de forma dinámica tras su cese del cargo. Habría que esperar prácticamente hasta los últimos años del siglo XX para que estos edificios volvieran a ser objeto de estudio, esta vez mediante una metodología más moderna y bajo otras perspectivas, que ha ayudado a conocer mejor no sólo su devenir concreto, sino también la propia fisonomía de la ciudad histórica.

\section{El hallazgo del templo romano de la calle Claudio Marcelo}

La importancia que ostentó durante época romana la ciudad de Corduba es sobradamente conocida. A su condición de colonia Patricia se suma su papel como capital de la Bética (Vaquerizo; Garriguet; Murillo 2011: 19). Además, la ciudad siguió gozando de buena salud después de la caída del imperio romano de

\footnotetext{
${ }^{1}$ No solo hubo hallazgos casuales, pues el propio Cruz Conde fomentó la excavación de los baños califales situados en el Campo Santo de los Mártires.
} 
Occidente, siendo muestra de ello el estado de autonomía que mantuvo entre el 550 y el 572 d.C. respecto al Imperio romano de Oriente, así como a la dominación visigoda (Wickham 2009: 88). Con la conquista árabe, en el 711, Córdoba volverá a desempeñar un papel de importancia en el mundo occidental, primero con el emirato (756), y más tarde con el califato (929). Todo este largo y fructífero desarrollo histórico ha motivado que Córdoba posea un registro estratigráfico continuado dentro de un amplio espacio cronológico, al igual que otras ciudades españolas de similar entidad. Sin embargo, como consecuencia de esa ocupación continuada el patrimonio arqueológico romano de Córdoba apenas es visible hoy día, al contrario de lo que ocurre en otras grandes urbes hispanas, como por ejemplo Mérida o Tarragona. De todos los vestigios de la colonia Patricia conocidos en la actualidad, el templo romano de la calle Claudio Marcelo constituye uno de los más significativos, tanto por su relevancia como por su investigación ${ }^{2}$.

Aunque el descubrimiento, en su conjunto, de los restos materiales pertenecientes a este edificio religioso de época romana se produjo a partir de los trabajos arqueológicos de 1951, lo cierto es que ya desde el siglo XVI se venían produciendo una serie de hallazgos casuales. Muestra de ello es que en aquella época la zona adyacente a la actual calle Capitulares era conocida como "Los Marmolejos", constituyéndose como una de las principales canteras para la obtención de materiales romanos (Santos Gener 1955: 121; Murillo et alii 2003: 54). En 1574 el corregidor de la ciudad, Don Pedro Zapata de Cisneros, efectuó la compra de las casas adosadas a la muralla con el objetivo de utilizar dichos terrenos para la construcción de las nuevas Casas Consistoriales, siendo constantes los hallazgos romanos a partir de entonces (Murillo et alii 2003: 55). Sin embargo, el inicio de las obras no se produjo hasta 1594, según constaba en la lápida conmemorativa fijada sobre el balcón principal ${ }^{4}$. También fue en esta época, y a merced de Ambrosio de de Morales, cuando quedó establecida la idea de que dichos restos arquitectónicos pertenecían al anfiteatro, donde sufrieron martirio San Acisclo y Santa Eugenia ${ }^{5}$ (Murillo et alii 2003: 55).

En 1731, al construirse la escalera principal de las Casas Consistoriales, se descubrieron importantes restos arqueológicos, entre ellos unos 'muros y puertas' que según Santos Gener (1955: 124) servirían de comunicación entre la basílica del Pretor y la entrada del anfiteatro. En 1877, con motivo de las obras de ampliación de las oficinas del Ayuntamiento en un solar lindante a este, y que anteriormente había pertenecido al Conde de Hornachuelos, se descubrió un 'caballo de una estatua colosal de bronce" ${ }^{6}$ (Santos Gener 1950: 140; 1955: 125; Garriguet 2007: 304), que no fue extraída debido a la negación de los propietarios del inmueble por temor a un hundimiento (Santos Gener 1950: 140-141). A este respecto, cabría destacar el hallazgo en la Puerta de Osario de una inscripción perteneciente a una estatua ecuestre dedicada a un flamen imperial de la Bética $^{7}$ (Santos Gener 1950: nota 5), que podría guardar relación con una estatua similar a la anteriormente comentada, y que estaría en perfecta consonancia con las afirmaciones de Garriguet sobre la ubicación de esta (vid nota 6).

Iulio M(arci)f(ilio) Q(uinti) nep(oti)/ Gal(eria) Gallo/ Mummianotrib(uno)/militumcoh(ortis) maritimae/ IIviro c(olonorum) c(oloniae) P(atriciae) flamini/ divor(um) Aug(ustorum) provinc(iae)/

\footnotetext{
${ }^{2}$ A este respecto, por ejemplo, véanse los trabajos de J.L. Jiménez (1990, 1991, 1996, 1999, 2004 y 2011).

${ }^{3}$ Conocida así a causa de los pilares de un Vía Crucis que los frailes de San Pablo mandaron poner en ella (Santos Gener 1955: 122).

${ }^{4}$ Reinando el Rey Don Felipe el Segundo de este nombre y siendo Corregidor de Córdoba Don Pedro Çapata de Cisneros comenzóse esta obra en el año 1594.

${ }^{5}$ Esta interpretación sobre la ubicación del anfiteatro, sostenida entre otras cosas por la ubicación extramuros de los restos, se mantuvo hasta mediados del siglo XX, apareciendo dicho edifico en los croquis realizados por Samuel de los Santos Gener (Santos Gener 1950: 143; 1955: 120).

${ }^{6}$ A partir de las referencias literarias de Santos Gener y del conocimiento de la topografía urbana de Córdoba en el s. XIX, Garriguet sitúa la zona del hallazgo entre el tempo y el pórtico septentrional, es decir, en el espacio ocupado por la plaza que rodeaba el templo (Garriguet 2007: 304).

${ }^{7}$ CIL II. 2224 = ILS 6905.
} 


\section{Baeticae/ huic ordo c(olonorum) c(oloniae) P(atriciae) statuam/ equestremdecrevit/ AeliaFlavianauxor/ honorem suamimpensam/ remisit}

'A Julio Gallo Mummiano, hijo de Marco, nieto de Quinto, de la tribu Galeria, tribuno militar de la cohorte marítima, duovir de los colonos de colonia Patricia, flamen de los divinos Augustos en la provincia Bética, para éste el ordo de los colonos de la colonia Patricia decretó una estatua ecuestre. Su mujer AeliaFlaviana, recibió el honor, asumió sus gastos'.

Con el cambio de siglo los hallazgos arqueológicos se siguieron produciendo, y en 1916 salió a la luz una hilada de basas de columnas en el cruce entre las calles Claudio Marcelo y María Cristina, todo ello como consecuencia de la apertura del segundo tramo de la calle Claudio Marcelo ${ }^{8}$ (Santos Gener 1950: 138; 1955: 126; Murillo et alii 2003: 57). En 1920 se procedió a la construcción de los sótanos para las oficinas de arbitrios, lo que propició el descubrimiento de nuevas piezas, entre ellas un capitel (Santos Gener 1950: 140). Seis años más tarde se localizó una columna frente a la esquina de la calle Alfonso XIII con Alfaros, no pudiendo ser extraída debido a su tamaño (Santos Gener 1950: 140; Murillo et alii 2003: 57). Ya en 1940, al edificarse la Farmacia y la Biblioteca Municipales en la esquina de la actual calle Capitulares con la Plaza del Salvador, aparecieron numerosos sillares, arquitrabes y basas, además de un lienzo de la 'muralla romana" ${ }^{9}$ (Santos Gener 1950: 140; Murillo et alii 2003; 57).

En 1951 se procedió al derribo de las Casas Consistoriales para la ampliación del Ayuntamiento, quedando al descubierto nuevos restos arqueológicos, todo ello como consecuencia de la construcción de los sótanos (Santos Gener 1955: 121). Se iniciaron entonces una serie de trabajos arqueológicos, cuyo objetivo era el de esclarecer la tipología del edificio al que pertenecían los diferentes restos arquitectónicos, así como su cronología (Santos Gener 1955: 129). Al frente de dichos trabajos se situó Samuel de los Santos Gener (Fig. 1), director del Museo Arqueológico, quien contó con la ayuda del arquitecto municipal Félix Hernández (Fig. 2). La zona objeto de la intervención poseía unas dimensiones de 25 x $8 \mathrm{~m}$ y de 3,50 $\mathrm{m}$ de profundidad, donde se hallaron una serie de sillares de piedra caliza, dos basas de mármol blanco, dos piezas de moldura y pequeños fragmentos de capitel. (Santos Gener 1955: 126-128). Durante el curso de los trabajos arqueológicos se llegaron a extraerse seis capiteles de orden corintio realizados en mármol, varias basas del mismo material, pero de orden jónico, fragmentos de fuste y de arquitrabe (Santos Gener 1955: 129-135).

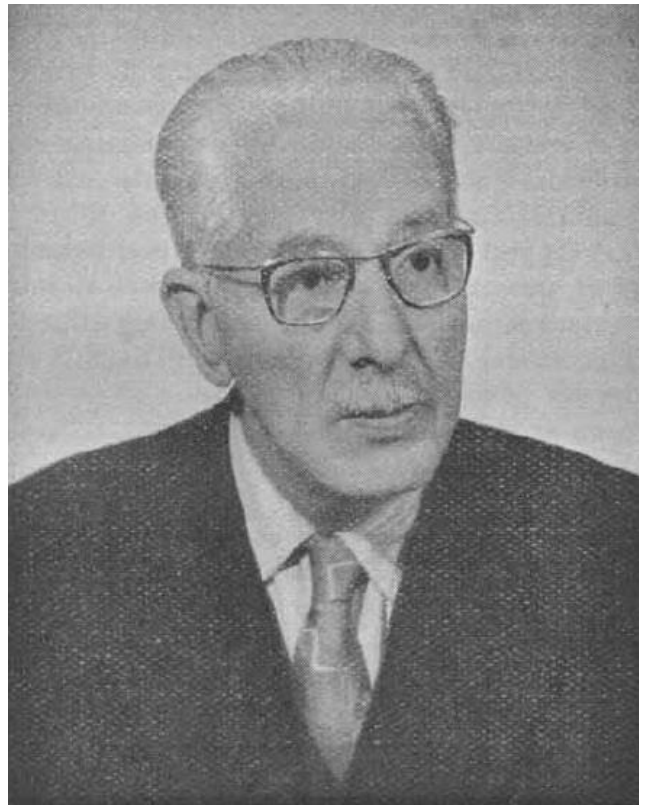

Fig. 1. Samuel de los Santos Gener.

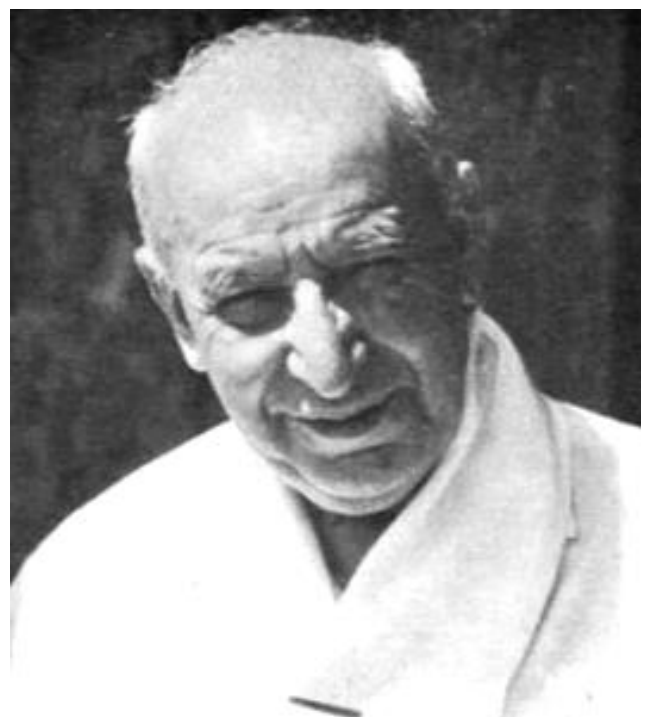

Fig. 2. Félix Hernández hacia 1970.

\footnotetext{
${ }^{8}$ En 1878 se procedió al derribo de la muralla de la calle Capitulares (antigua calle Calvo Sotelo) con motivo de la apertura de la nueva calle Claudio Marcelo (Murillo et alii 2003: 56).

${ }^{9}$ Se confundió el muro de contención de la plataforma sobre la cual se situaba el templo con la muralla romana, situada 40 m más al Oeste (Murillo et alii 2003: nota 8).
} 
Pero las labores arqueológicas desarrolladas durante este tiempo no ayudaron a determinar de forma clara la tipología del edificio, mucho menos su cronología. Respecto a su tipología, Santos Gener descartó la hipótesis de que los restos arquitectónicos pertenecieran al pretorio o al foro (Santos Gener 1950: 154). De este modo, se decantó por interpretar dichos restos como los pertenecientes a un templo o una basílica (Santos Gener 1950: 154). Debido a la tipología helenística de los capiteles (corintios), le atribuyó una cronología augustea (Santos Gener 1950: 154), aunque sin demasiada autoridad, ya que también establecía la hipótesis de que se tratase de un edificio de época republicana que, tras ser destruido durante la toma de la ciudad por César, fuese reconstruido por orden del emperador Nerva en el 97 a.C. (Santos Gener 1950: 159; 1955: 141).

En 1958, Antonio Cruz Conde solicitó la ayuda del arqueólogo Antonio García y Bellido para poder arrojar luz sobre los interrogantes que rodeaban a los restos hallados junto al Ayuntamiento. Además, el alcalde también le hizo saber su deseo de urbanizar todo el entorno con la construcción de un 'Parque Arqueológico' (García y Bellido 1961: 371-372). Así pues, García y Bellido, con la ayuda de Félix Hernández, comenzó realizando un análisis exhaustivo de todas las piezas marmóreas tras el cual llegó a la conclusión de que todos aquellos restos arquitectónicos pertenecían a un templo romano, el cual se encontraba precedido por un altar o ara (García y Bellido 1961: 373) que se situaba dentro de un edículo a nivel de suelo, de forma cuadrangular y abierto al cielo (García y Bellido 1961: 374). Debido a sus dimensiones, García y Bellido estableció un paralelismo entre este edificio y la Maison Carrée de Nimes, que posteriormente serviría a Felix Hernández para reconstruir parte del templo. Se trataba, pues, de un templo hexástilo de $9 \mathrm{~m}$ de altura, sobre un podium de 3,5 m de alto, con columnas de mármol blanco, fustes estriados y capiteles corintios (Fig. 3) (García y Bellido 1961: 374).

El siguiente paso consistía en dotar a dicho edificio de una cronología, para lo que se procedió a la realización de seis catas arqueológicas ${ }^{10}$ (Tabla 1). Estas catas aportaron una cronología en torno al último cuarto del s. I d.C., además de una modificación del terreno para la construcción de la plaza que rodeaba el templo (García y Bellido 1961: 374). Teniendo en cuenta la época, así como el rol que desempeñaba Corduba como caput de la Bética, García y Bellido afirmó que el templo romano de la Calle Claudio Marcelo estaba destinado al culto imperial (García y Bellido 1961: 375).

Mientras tanto, Félix Hernández, basándose en la Maison Carrée de Nimes, procedió a la reconstrucción de las estructuras descubiertas, realizando la anastilosis de las columnas del pronaos y de la primera columna del lado norte de la cella. Además, Don Félix pudo calcular la cota desde la que se alzarían las columnas, gracias a los restos de la escalera, del altar y del pavimento original. Para la reconstrucción se utilizaron nuevos materiales y hormigón para las columnas. De las once que se encuentran reconstruidas solo tres están hoy en día coronadas por capiteles originales (Jiménez 1991: 121).

En comparación con el resto de edificios recuperados bajo el mandato de Cruz Conde, el templo romano de la c/ Claudio Marcelo fue el único, junto con los baños del Alcázar, que se sometió a un estudio arqueológico. De este modo, las aportaciones más significativas de García y Bellido fueron la identificación del templo como tal y el intento de establecer una cronología para su construcción. Además, también fue consciente de la dificultad que suponía no haber hallado ningún tipo de inscripción, por lo que no se pudo confirmar a quién estaba dedicado el templo, una problemática que persiste hoy en día. Sin embargo, las posteriores intervenciones arqueológicas demostraron que el templo era un elemento más de un complejo aún mayor.

\footnotetext{
${ }^{10}$ Respecto a estas catas, así como al material cerámico extraído de ellas, vid García y Bellido 1970.
} 


\begin{tabular}{|c|c|c|c|}
\hline & LOCALIZACIÓN & DESCRIPCIÓN & MATERIAL \\
\hline CATA I & $\begin{array}{l}\text { Zona de la escalinata de } \\
\text { acceso al templo. }\end{array}$ & $\begin{array}{l}\text { Se halló una cámara } \\
\text { rectangular rellena de } \\
\text { material de acarreo, } \\
\text { sobre la cual se } \\
\text { construiría } \\
\text { posteriormente la grada. }\end{array}$ & $\begin{array}{l}\text { Se descubrieron restos } \\
\text { materiales cerámicos de } \\
\text { vidrio y una plaquita de } \\
\text { hueso representando a } \\
\text { un león. }\end{array}$ \\
\hline CATA II & $\begin{array}{l}\text { Bajo el piso superior del } \\
\text { podium. }\end{array}$ & $\begin{array}{l}\text { Esta segunda cata } \\
\text { proporcionó hasta cinco } \\
\text { niveles. La parte interior } \\
\text { de la cella quedó sin } \\
\text { excavar, ya que el ala } \\
\text { occidental ral del } \\
\text { Ayuntamiento cortaba } \\
\text { los cimientos del templo } \\
\text { por el muro de entrada a } \\
\text { aquélla. }\end{array}$ & $\begin{array}{l}\text { Teja, ánforas, estuco, } \\
\text { cerámica } \\
\text { cerámica } \\
\text { sigillata. }\end{array}$ \\
\hline CATA III & $\begin{array}{l}\text { Al norte del altar, cerca } \\
\text { de una pequeña zona } \\
\text { donde se había } \\
\text { localizado un pavimento } \\
\text { primitivo en buen estado } \\
\text { de conservación. }\end{array}$ & $\begin{array}{l}\text { Se practicó un corte } \\
\text { vertical en el cual se } \\
\text { distinguieron de nuevo } \\
\text { cinco niveles. }\end{array}$ & $\begin{array}{l}\text { Tan solo se encontró } \\
\text { material en el quinto } \\
\text { nivel, que contenía } \\
\text { esquirlas de los bloques } \\
\text { de sillares. }\end{array}$ \\
\hline CATA IV & $\begin{array}{l}\text { Lado noroeste del } \\
\text { templo. }\end{array}$ & $\begin{array}{l}\text { Contenía parte del suelo } \\
\text { original que unía el altar } \\
\text { con la escalinata de } \\
\text { acceso al templo. El } \\
\text { corte vertical efectuado } \\
\text { manifestó hasta ocho } \\
\text { niveles estratigráficos, } \\
\text { de los cuales los dos } \\
\text { últimos no llegaron a } \\
\text { excavarse }\end{array}$ & $\begin{array}{l}\text { Se descubrió un bordillo } \\
\text { compuesto por sillares, } \\
\text { además de restos } \\
\text { cerámicos y fragmentos } \\
\text { de vidrio y estuco. }\end{array}$ \\
\hline CATA V & Al pie del altar. & $\begin{array}{|lccr|}\text { Fue la más } & \text { profunda, } \\
\text { con } 4,80 & \mathrm{~m} & \text { de } \\
\text { profundidad. } & & \\
\end{array}$ & \\
\hline CATA VI & Al sur del altar. & $\begin{array}{l}\text { El suelo original estaba } \\
\text { bien conservado a pesar } \\
\text { de la falta del } \\
\text { pavimento. La capa de } \\
\text { relleno sobre la cual se } \\
\text { extendió el hormigón } \\
\text { proporcionó materiales } \\
\text { anteriores a la } \\
\text { construcción del templo. } \\
\text { Además, el margen de } \\
\text { excavación no era muy } \\
\text { amplio, debido al al } \\
\text { peligro de derrumbe, por } \\
\text { lo que hubo que usar } \\
\text { puntales para sostener el } \\
\text { pavimento original }\end{array}$ & $\begin{array}{l}\text { De esta cata se pudieron } \\
\text { extraer fragmentos de } \\
\text { cerámica indígena y } \\
\text { terrasigillata, ánforas y } \\
\text { vidrio, además de una } \\
\text { fíbula anular de bronce. }\end{array}$ \\
\hline
\end{tabular}

Tabla1. Relación de catas practicadas por Antonio García y Bellido (Rueda 2015-2016: 156) 


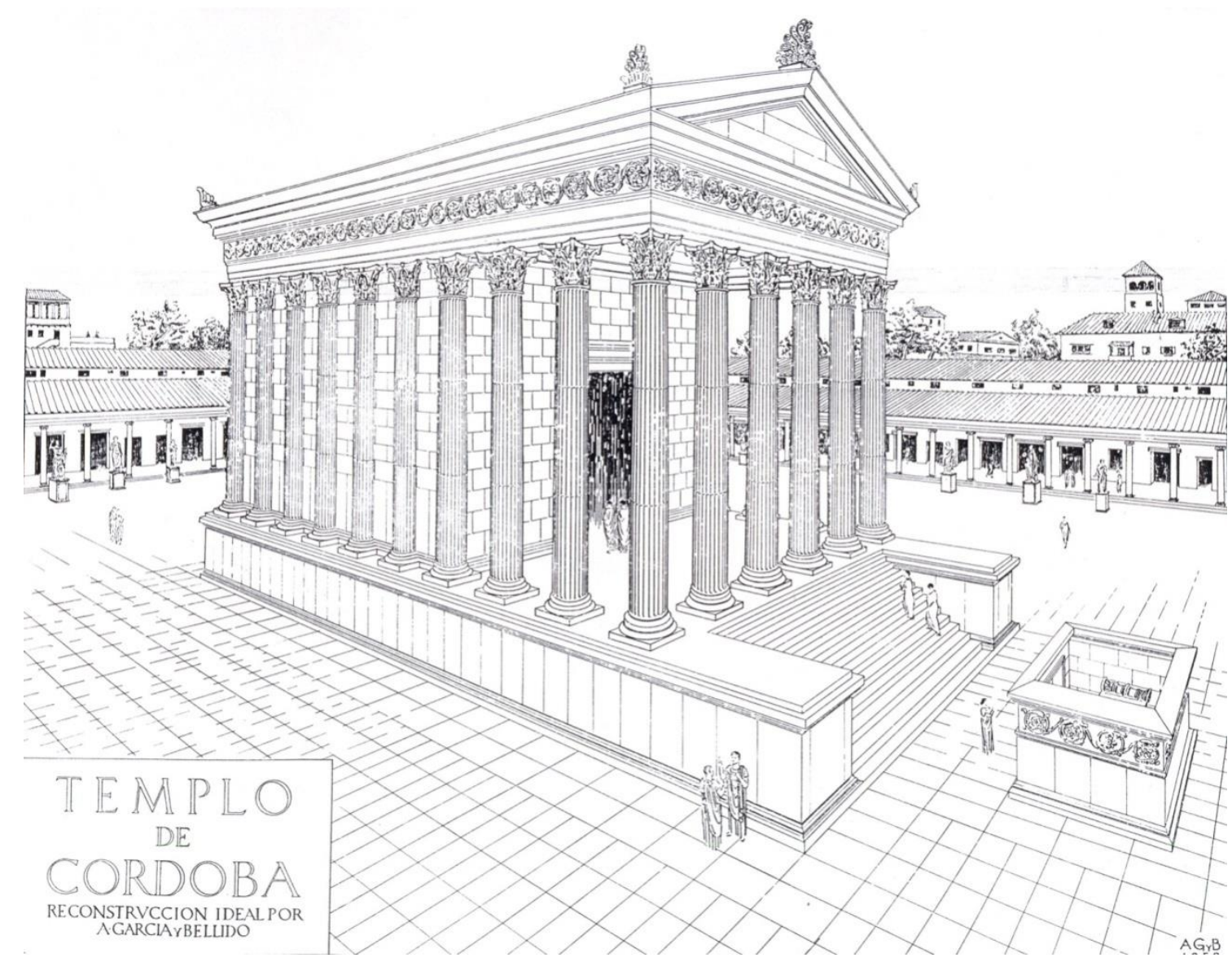

Fig. 3. Reconstrucción del templo romano de la calle Claudio Marcelo según Antonio García y Bellido (1961: 214).

Las intervenciones arqueológicas en el solar del templo de la c/ Claudio Marcelo se reanudaron tras más de veinte años ${ }^{11}$ en los que no se llevó a cabo ninguna actividad de carácter científico. Las excavaciones fueron retomadas por J.L Jiménez, cuyos trabajos, llevados a cabo entre 1985 y 1987, se centraron en la cella del templo. La documentación de este espacio había resultado sumamente difícil en los años cincuenta, ya que sobre aquél se encontraba superpuesto un edificio municipal. La excavación y documentación de la cella era de vital importancia, tanto desde el punto de vista arquitectónico como cronológico. Por un lado, la excavación dejaba al descubierto la planta ${ }^{12}$ del edificio, mientras que por otro el material recuperado de la zanja de cimentación podía aportar datos para su datación.

Sin lugar a dudas, la falta total de inscripciones ha dificultado tanto el establecimiento de una cronología precisa como la interpretación y el conocimiento de la dedicación del propio templo. Así pues, para otorgar una cronología al edificio se ha tenido que recurrir hasta el momento al análisis estilístico (elementos de decoración arquitectónica a veces difíciles de fechar con precisión) y cerámico. En este sentido la cerámica localizada en los rellenos de la cella permitió a J.L. Jiménez situar la construcción del templo a partir del

\footnotetext{
${ }^{11}$ Estos trabajos estuvieron encaminados, sobre todo, a la recopilación de la documentación sobre las excavaciones realizadas por parte de Santos Gener y García y Bellido. También se procedió al traslado al Museo Arqueológico de algunas piezas arquitectónicas.

${ }^{12}$ La planta del templo mide más de $32 \times 16 \mathrm{~m}$, con un pódium de 3,5 m de altura. También se pudo documentar la utilización masiva del opus quadratum (Garriguet 2007: 302).
} 
principado de Claudio (Jiménez 1996: 132-133). No obstante, su situación en el espacio urbano ${ }^{13}$, así como sus similitudes arquitectónicas con la Maison Carrée de Nimes, llevaron a J.L. Jiménez a interpretarlo como un templo de culto imperial, posiblemente dedicado a la dinastía flavia (Jiménez 1991: 128). Las excavaciones de los años ochenta constataron también que el edificio se encontraba extramuros $^{14}$, algo que anteriormente había sido fruto de debate entre los investigadores. En el periodo comprendido entre 1994 y 1995 se hicieron algunos sondeos en el entorno del templo romano, esta vez también de la mano de J.L. Jiménez, aunque con la ayuda de técnicos de la GMU ${ }^{15}$. Los trabajos se centraron en la parte posterior ${ }^{16}$ del edificio, y sus objetivos consistían en localizar los restos del pórtico occidental ${ }^{17}$, así como documentar mejor un muro de sillería descubierto en 1987 que se encontraba cerca de la pars postica (Garriguet 2007: 302).

Las intervenciones arqueológicas se prolongaron durante los años noventa a cargo de la GMU y la Universidad de Córdoba, esta vez al este del templo, en el Huerto del Convento de San Pablo-manzana de Orive y en el callejón del Galápago. Los resultados obtenidos consistieron en restos pertenecientes a un circo $^{18}$ y a una plaza (situada entre éste y el templo) dispuestos a cotas más bajas que las del templo. De esta manera, tenemos un complejo monumental en terrazas de concepción unitaria (Garriguet 2007: 302) que se sitúa prácticamente en paralelo con la Vía Augusta.

Las últimas excavaciones realizadas hasta el momento en el templo han tenido lugar entre los años 2001 y el 2003 y en ellas se ha intervenido el espacio situado delante de las anterides. Los resultados, además de confirmar la cronología julio-claudia avanzada para el inicio de las obras, han dado lugar al hallazgo de una serie de elementos escultóricos entre los que destacan la mitad posterior de una cabeza masculina, un fragmento con launas de una estatua masculina thoracata y un posible fragmento de manto militar (paludamentum) (Garriguet 2007: 311-312) ${ }^{19}$. Además, las excavaciones también permitieron documentar los restos de un vicus de origen tardorrepublicano / augusteo, localizado en el espacio extramuros, que se extendía desde la calle Capitulares y la Plaza de la Corredera hacia el sur. Parte de las casas de este vicus habrían sido derruidas para dar paso a la construcción del templo y su entorno, manteniéndose intacta otra parte del mismo que perduraría hasta el s. III d.C.

\section{Los mosaicos romanos de la plaza de la corredera}

En 1959, el Ayuntamiento de Córdoba procedió a la demolición del mercado de abastos situado en la plaza de la Corredera con el fin de devolverle a Córdoba uno de sus monumentos más ilustres; la citada plaza de tipo castellano. Dicho mercado había sido inaugurado en 1896 y su construcción había sido emprendida por el industrial José Sánchez Peña y el francés Louis Louhnoux. Ambos tenían una concesión administrativa del espacio que ocupaba el mercado, y que expiraba en 1956 (Solano 2007: 47). A la llegada de Antonio Cruz Conde a la alcaldía de Córdoba, este anunció que tenía intención de derribar el mercado

\footnotetext{
${ }^{13}$ El templo se encuentra cercano a la 'Puerta de Roma', que a su vez conecta con la Vía Augusta (Carmona; Courault 2011: 212).

${ }^{14}$ Los trabajos de J.L. Jiménez demostraron que, para la construcción del templo se procedió al derrumbe de una parte de lienzo de la muralla, quedando ésta interrumpido por el templo.

${ }^{15}$ Gerencia Municipal de Urbanismo del Excmo. Ayuntamiento de Córdoba.

${ }^{16}$ Esta zona se encontraba situada en un solar recayente de la C/ M ${ }^{a}$ Cristina (Garriguet 2007: 302).

${ }^{17}$ Los restos del pórtico norte se encuentran integrados en el Ayuntamiento desde 1986, mientras que los de la parte meridional fueron hallados en 1989 en la esquina de las calles Claudio Marcelo y Diario Córdoba (Garriguet 2007: 302).

${ }^{18}$ Del circo solo se conocen muros de sustentación de un sector del graderío septentrional y varias cloacas. Su uso se interrumpió a finales del s. II d.C. por razones desconocidas (Vaquerizo; Garriguet; Murillo 2011: 25).

${ }^{19}$ Sin embargo, estos hallazgos escultóricos, junto con los de los años cincuenta, no fueron los únicos de los que tenemos constancia. En 1877 se produjo el hallazgo de un caballo perteneciente a una estatua colosal de bronce, el cual no pudo extraerse debido a que se encontraba bajo un muro medianero. Garriguet sitúa esta escultura en un espacio comprendido entre el templo y el pórtico septentrional, todo ello atendiendo a los croquis y referencias literarias de Santos Gener, así como al conocimiento de la topografía urbana de la Córdoba del s. XX.
} 
en el plazo de un año. No obstante, el derribo total del edificio no se produciría hasta 1959, como se ha indicado.

Unos años antes, en 1951, el Ayuntamiento había aprobado la pavimentación de las cuatro calles que rodeaban el mercado. Sin embargo, antes de llevar a cabo el derrumbe del edificio debía resolverse el problema de la ubicación de los negocios que aquél acogía. La solución a este problema se llevó a cabo en septiembre de 1955 con la instalación de un mercado subterráneo en los sótanos del mercado central, que anteriormente eran utilizados como almacén para las mercancías (Solano 2007: 45-46). En 1957 se produjo la ampliación de este espacio subterráneo, todo ello para dotar a los trabajadores de las mejores instalaciones posibles. En 1958 la empresa CEPANSA se hizo cargo del derribo del mercado de abastos, para lo cual realizó un pago al Ayuntamiento de 900.000 pesetas por el aprovechamiento de los materiales (Solano 2007: 47) ${ }^{20}$.

Como consecuencia de la adaptación de este espacio subterráneo, así como de su ampliación, tuvo lugar en 1958 el hallazgo de doce mosaicos romanos ${ }^{21}$. Los trabajadores comunicaron tal hecho al arquitecto municipal, Víctor Escribano Ucelay, quien aconsejó su extracción. Por fortuna, Antonio García y Bellido se encontraba en la ciudad con motivo de los trabajos arqueológicos llevados a cabo en el templo romano. García y Bellido analizó en profundidad uno de estos mosaicos, que fechó hacia mediados del siglo III d.C., concretamente el que tiene representado en su parte central dos figuras entrelazadas identificadas como Eros y Psique (Fig. 4), y disponiendo en los ángulos de alegorías de las cuatro estaciones (Solano 2007: 48-49).

Estos mosaicos pertenecían a una gran domus romana con peristilo, cuyo pavimento estaba formado por un mosaico en blanco y negro, de tema marino, que rodeaba la fuente central. El mosaico de Polifemo y Galatea (Fig. 5), posiblemente el más interesante de todos, se encontraba decorando el triclinio. A esta misma casa debieron pertenecer los mosaicos de Medusa y Océano. Para Antonio García y Bellido, el mosaico de Eros y Psique, así como el geométrico de mayores dimensiones, pertenecerían a una casa contigua. Lo cierto es que no se puede decir mucho más de esta domus, pues los mosaicos no fueron extraídos por profesionales y, por consiguiente, no se logró documentar ningún material a parte de los ya citados mosaicos (Blázquez 1981: 13).

El siguiente paso tras la extracción y restauración de los mosaicos fue establecer su ubicación. Dio la casualidad de que las obras de la plaza de la Corredera se llevaban en paralelo a las de restauración del Alcázar de los Reyes Cristianos. El Alcázar contaba con un Salón de Audiencias y con una capilla adosada a uno de sus muros. Además, este espacio disponía también de una escalera que comunicaba con un patio, todo ello correspondiente al periodo en el que el edificio perteneció a la Inquisición. Estos espacios fueron abiertos y aprovechados para la ubicación de un nuevo Salón en el cual acabaron colocándose, como decoración parietal, ocho de los doce mosaicos descubiertos ${ }^{22}$.

Nos disponemos ahora a ofrecer algunos datos más significativos acerca de aquellos mosaicos que, debido a su decoración, representan los más interesantes de todo el conjunto.

\footnotetext{
${ }^{20}$ Se aprovecharon todos los materiales excepto las losas, que serán reutilizadas para la pavimentación de la plaza.

${ }^{21}$ Datados entre los siglos II y III d.C.

${ }^{22}$ A partir de ese momento y hasta la fecha se conoce a esta estancia como "Salón de los Mosaicos".
} 


\subsection{Eros y Psique}

Localización actual: Salón de los Mosaicos del Alcázar de los Reyes Cristianos.

Dimensiones: 4'40 x 3’47 m.

Cronología: ss. III-IV.

Descripción: La pareja, de aspecto aniñado e identificada como Eros y Psique, aparece volando $\mathrm{y}$ fundiéndose en un abrazo. Esta imagen de la apoteosis del amor fue muy popular en época romana, reproduciéndose en mosaicos, pinturas, relieves y grupos escultóricos (Mañas 2011: 165).

\subsection{Océano}

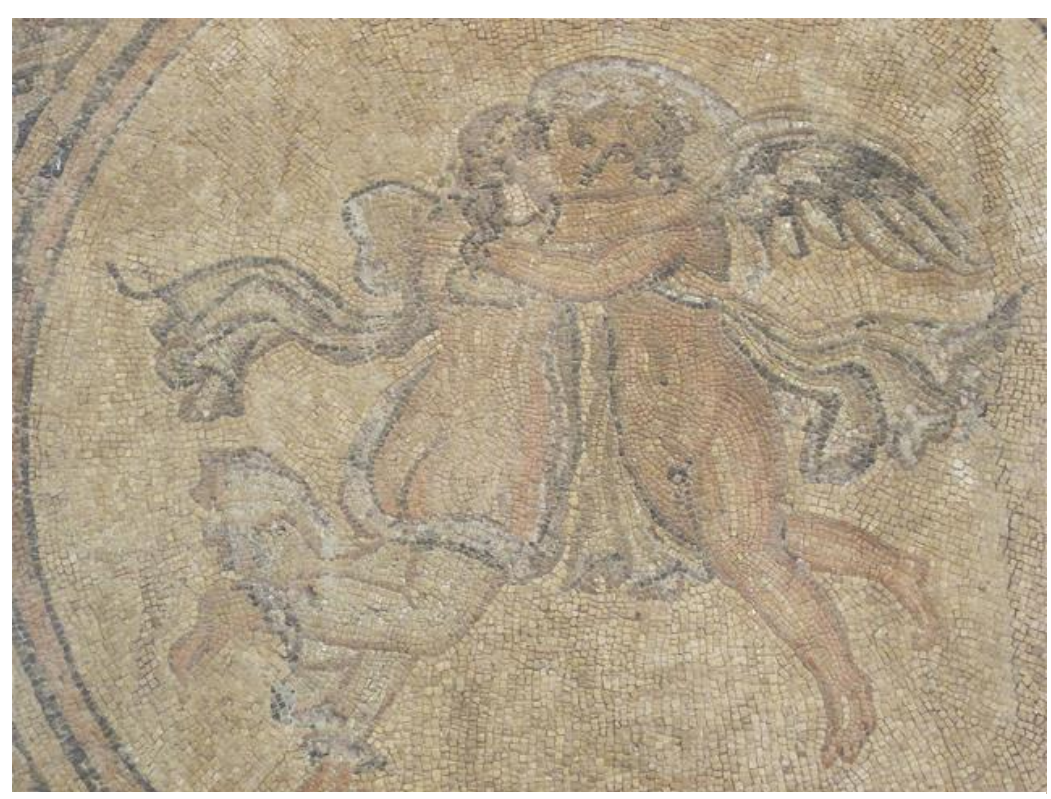

Fig. 4. Mosaico de Eros y Psique (Neira 2011: 283).

Localización actual: Sala de recepciones del Alcázar de los Reyes Cristianos.

Dimensiones: 90 x $97 \mathrm{~cm}$.

Cronología: $2^{\mathrm{a}}$ mitad del siglo III.

Descripción: Océano sigue el modelo convencional del arte romano. Representado con un rostro barbado coronado por unas pinzas de crustáceo. La barba y el bigote semejan algas de las que emergen delfines. La nariz es ancha y la expresión del rostro melancólica. Los colores utilizados para este mosaico son el amarillo, el negro, el blanco, el rojo y el ocre. Las teselas de pasta vítrea poseen las gamas del verde y del azul, presentes en la barba de Océano y en los delfines. El fondo de la composición es de color blanco (Blázquez 1981: 22).

\subsection{Medusa}

Localización actual: Salón de los Mosaicos del Alcázar de los Reyes Cristianos.

Dimensiones: 2'60 x 2'55 m.

Cronología: Siglo III.

Descripción: La cabeza de Medusa aparece representada en el medallón central de un gran mosaico. Este medallón está inscrito dentro de un octágono, el cual, se encuentra rodeado de rombos y rectángulos, estos últimos encerrando una decoración de nudos sobre fondo blanco (Blázquez 1981: 21).

\subsection{Thyasos marino}

\section{Localización actual: ?}

Dimensiones: 7’65 x 4’25 m.

Cronología: Siglo II.

Descripción: Se trata de un mosaico confeccionado en blanco y negro, el cual se encontraba muy deteriorado en el momento de su hallazgo. El tema es la fauna marina, tanto la real como la mitológica, pues junto a los peces encontramos un gigantesco ketos con cabeza de lobo y las fauces abiertas. Según la 
interpretación de García y Bellido la fauna iría huyendo de los monstruos marinos, que amenazan con cazarla. En cuanto a su localización dentro de la domus, este se encontraría rodeando un impluvium (Blázquez 1981: 19-20).

\subsection{Actor trágico}

Localización actual: Salón de los Mosaicos del Alcázar de los Reyes Cristianos.

Dimensiones: 1'57 x 1'42 m.

Cronología: ss. II-III.

Descripción: Este mosaico representa a un actor trágico, con la máscara colocada sobre el rostro y en actitud de declamar. Se dirige hacia la derecha empuñando un callado (rhabdos) y en posición inclinada, indicio de que representaría a Edipo, según García y Bellido. El personaje viste una túnica corta y un manto, y en el fondo aparece representada una tienda o skene. Se trata de una composición con una gran riqueza cromática, con teselas de pasta vítrea de diferentes matices de rojo, azul, verde y amarillo, que se utilizaron en el rostro, en la máscara de teatro y en los pliegues del vestido sobre el pecho (Blázquez 1981: 18).

\subsection{Polifemo y Galatea}

Localización actual: Salón de los Mosaicos del Alcázar de los Reyes Cristianos.

Dimensiones: 4'10 x 5'10 m en conjunto. El emblema central mide 1'82 m de lado.

\section{Cronología: siglo III.}

Descripción: En el emblema están representados el cíclope Polifemo y la ninfa Galatea, ambos sentados sobre un fondo de paisaje. A la izquierda se encuentra Galatea, sentada sobre el lomo de un Ketos. Aunque con el torso desnudo, lleva un manto que le cubre las piernas, además de un collar, un brazalete y una pulsera. Frente a ella se encuentra Polifemo, el cual también se encuentra en posición sedente. Aparece representado como un pastor, con cayado y un caramillo. Aunque este es de mayores proporciones que su acompañante, no deja de formar una composición simétrica con la figura de la ninfa (Blanco Freijeiro 1959: 174-175; Blázquez 1981: 13-14; Mañas 2011: 165). Es un mosaico único ${ }^{23}$, ya que el tema que se representa no es frecuente en la

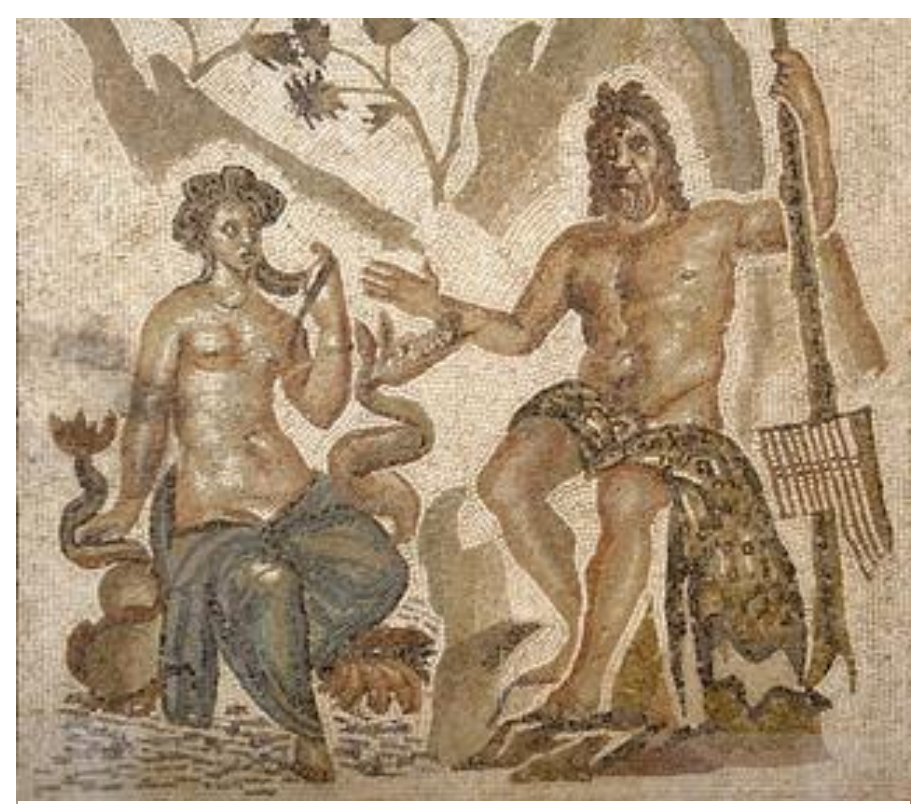

Fig. 5. Mosaico de Polifemo y Galatea (Neira 2011: 284). pintura ni en el mosaico romano.

\section{El sarcófago romano del Alcázar de los Reyes Cristianos}

En 1958 el Ayuntamiento de Córdoba llevaba a cabo una serie de obras de urbanización al norte de la ciudad, concretamente en la zona del Brillante. Como consecuencia de estas, el 5 julio de ese mismo año

${ }^{23}$ Es posible que el dominus al que perteneciese el mosaico fuese una persona culta, conocedora del tema representado a través de la literatura (Neira 2011: 284). 
se produjo el hallazgo de un magnífico sarcófago de mármol con espléndidos relieves presentes en tres de sus $\operatorname{lados}^{24}$ (Fig. 6). Fue hallado a una profundidad de 3'50 m, sin su cubierta y con el interior relleno de tierra (García y Bellido 1958: 237; 1959: 12), por lo que en algún momento el cuerpo del difunto fue exhumado. El sarcófago apareció en la huerta de San Rafael, cerca de la carretera del Brillante, que coincidiría con una vía de la ciudad romana que se dirigía hacia la sierra y en la que se disponía una necrópolis. La existencia de esta no solo se debe a la localización de dicha vía y al hallazgo del propio sarcófago, sino también a la aparición de una serie de inscripciones funerarias como consecuencia de los trabajos de saneamiento llevados a cabo durante el transcurso de las obras (García y Bellido 1959: 7).

En cuanto a la decoración del sarcófago, éste presenta una parte central dividida en tres partes o escenas. La parte central está conformada por la representación de una puerta de dos hojas, una de ellas ligeramente entreabierta, que representaría la entrada al Hades. Los pomos de las puertas están sujetos por las fauces de dos leones, localizados en la parte inferior, mientras que la superior está ocupada por la representación de dos cabezas de carnero, lo que podría indicar una alusión al culto a Amón o a Dionisos en un sentido escatológico (García y Bellido 1958: 237; 1959: 16).

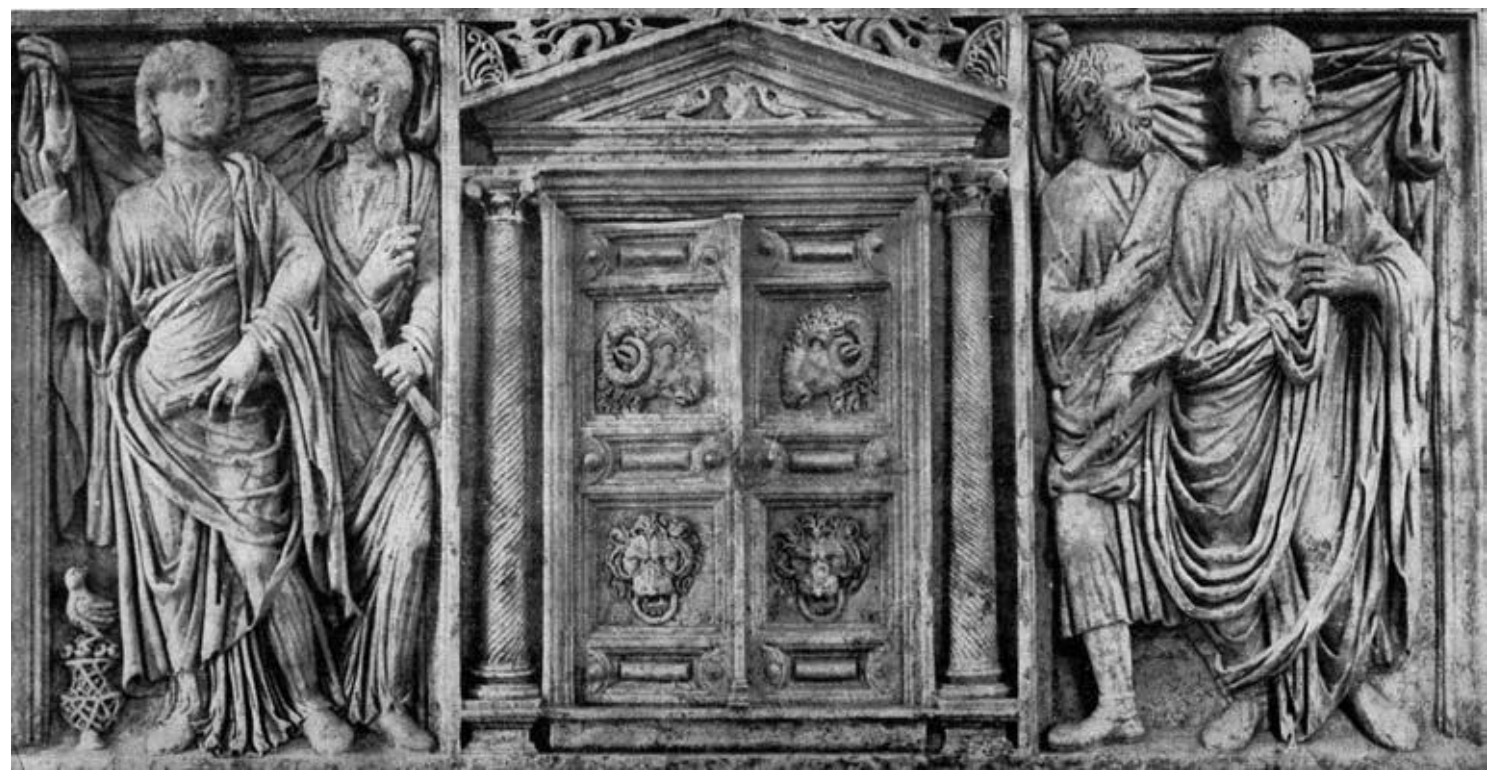

Fig. 6. Relieve de la cara principal del sarcófago romano hallado en la zona del Brillante (Córdoba) (García y Bellido 1958: 237).

A la derecha de esta parte central encontramos dos figuras masculinas que representarían al difunto, con toga y un volumen en la mano, y a su maestro el filósofo, el cual le ayudaría en el tránsito de esta vida a la otra. En la parte izquierda se puede observar una pareja femenina en posición similar, la cual sería una representación de la esposa del difunto y de su maestra. Los laterales están decorados por figuras de caballos alados, representando a Pegaso, en clara alusión al vuelo del alma (García y Bellido 1958: 238).

El marco cronológico correspondiente a la elaboración de la pieza quedaría encuadrado en el primer tercio del siglo III d.C. Esta datación ha sido posible establecerla gracias a las particularidades técnicas y al tocado de sus personajes. Así, el peinado del filósofo y el de los carneros y leones nos trasladarían a finales de época flavia. Sin embargo, es la elaboración del peinado femenino el que nos aporta un mayor ajuste cronológico, pues éste coincidiría con el representado en una serie de monedas en las que aparecen los retratos de tres emperatrices: Julio Aquilina Severa (segunda esposa de Heliogábalo), Annia Faustina

${ }^{24}$ Antonio García y Bellido publicó en 1959 un extenso artículo en el que analizaba al detalle el sarcófago romano de Córdoba. Dicho artículo ha servido como base para la realización de este apartado. 
(tercera mujer del mismo) y Orbiana (esposa de Aljandro Severo). De este modo, podría ajustarse la fecha de elaboración entre el 225 y el 235 d.C. (García y Bellido 1958: 238; 1959: 32-33).

En referencia al taller, este sarcófago habría procedido de la misma ciudad de Roma, donde los numerosos talleres monopolizaban el mercado de este tipo. Es obvio que, por la decoración del mismo, así como por las fechas en que se lleva a cabo su decoración, su propietario debió ser alguien potentado cuyas creencias religiosas se encontrarían cercanas a la teología escatológica del mundo romano. Posteriormente a su descubrimiento, el sarcófago fue llevado al Alcázar de los Reyes Cristianos por orden municipal, donde permanece hoy en día.

\section{La (re) excavación de los baños del Alcázar}

Hacia 1961, el Ayuntamiento de Córdoba llevaba a cabo una serie de obras en los jardines del Alcázar de los Reyes Cristianos con el fin de construir la glorieta de Julio César. A causa de dichas obras se produjo el hallazgo de una serie de restos constructivos, los cuales habrían pertenecido a una edificación de época de Abderramán III. Este hallazgo proporcionó numerosas piezas del ataurique que ostentó el edificio, además de varios fragmentos de basas, fustes y capiteles labrados en mármol. Todos ellos fueron clasificados por Manuel Ocaña, Félix Hernández y Manuel Salcines López ${ }^{25}$ (Ocaña 1984: 139). Fue precisamente a raíz de este hecho cuando se gestionó la idea de volver a excavar los Baños del Alcázar, tal y como nos cuenta Manuel Ocaña (1984: 139):

'Una tarde, mientras cruzábamos el Campo Santo de los Mártires después de haber pasado varias horas dedicados a dicho trabajo, don Félix nos expuso lo conveniente que sería para el mejor conocimiento del alcázar del califato el disponer de un sector del mismo, que sirviese de segura base de partida para la realización de futuras excavaciones, y lo fácil que resultaría conseguirlo, si se rescatase del subsuelo de dicho Campo el baño que, a mediados del año 1903, apareció incidentemente...'

En efecto, en 1903, al plantar unos árboles en el Campo Santo de los Martires, aparecieron unas bóvedas correspondientes a los Baños del Alcázar. Su investigación estuvo a cargo de Rafael Ramírez de Arellano, quien excavó gran parte de su perímetro. Sin embargo, la Junta de Sanidad obligó a soterrar los hallazgos, pues los hacía responsables de unos brotes epidémicos (Marfil 2004: 53).

De este modo, Ocaña y Salcines se dispusieron a localizar el lugar exacto donde aparecieron los baños, preguntando a múltiples eruditos locales que, por su avanzada edad, quizás fueron testigos de los hallazgos acaecidos en 1903. Pero lamentablemente, los testimonios obtenidos no les permitieron cumplir su objetivo, por lo que hubo que recurrir al ingenio. Así, Manuel Ocaña recurrió al jardinero municipal para averiguar qué zona de los jardines absorbía el agua de riego con mayor rapidez, indicio de que bajo tierra existía algo que actuaba como drenaje. Tras delimitar este sector, se propuso un proyecto de excavación consistente en la realización de ocho catas, el cual fue gratamente acogido y apoyado por el alcalde de la ciudad, Antonio Cruz Conde (Ocaña 1984: 140). Así pues, el trabajo se organizó en dos jornadas; una para la localización de los restos y otra para su excavación. El objetivo fue cumplido y se lograron excavar las bóvedas aparecidas en 1903, las cuales fueron objeto de visita por parte de Cruz Conde (Fig. 7).

De esta excavación, lo más interesante fue el hallazgo de una serie de fabulosos restos de yesería decorados con motivos florales correspondientes al periodo taifa, almorávide y almohade (Ocaña 1984: 141) aparecidos en un salón adyacente a los baños, y que fueron estudiados y analizados por Manuel Ocaña. Un grupo de estos se diferenciaba de los demás por poseer una ornamentación floral que respondía a un módulo casi tan pequeño como el que usaron los artesanos califales en trabajos de eboraria. Para Ocaña esto se explicaría debido a que tras la fitna hubo una caída de la demanda de productos de lujo, entre ellos el marfil, lo que provocó que los artesanos se vieran forzados a dedicarse a otras variantes del tallado,

${ }^{25}$ Oficina Municipal de Turismo. 
entre la que se encontraba el yeso. Un segundo grupo de yesos ofrecía una decoración floral cuyos motivos se asemejaban a los del primer grupo, aunque respondiendo a un módulo algo mayor (Ocaña 1984: 144).

Ocaña dató esta ornamentación como correspondiente al periodo almohade, entre el 1160 y el 1171, a raíz de los datos suministrados por el cronista IbnSahid al-Salà (Ocaña 1990: 101). Con motivo del hallazgo de estas yeserías, Ocaña trató de descubrir la diferencia entre la palma digitada almorávide y la almohade, concluyendo que en la primera los grupos de foliolos separados por los aretes cuentan con un número de dígitos que varía en función del capricho del tallista, mientras que en la segunda se representan siempre en grupos de dos y al anillo se le configura con traza cúfica, de manera que dada uno de ellos, junto con el par de foliolos inmediatos, conforman un motivo epigráfico repetitivo: la raíz árabe whd (wahada), esencia del movimiento almohade (Ocaña 1990: 103; Navarro y Jiménez, 2005: 275).

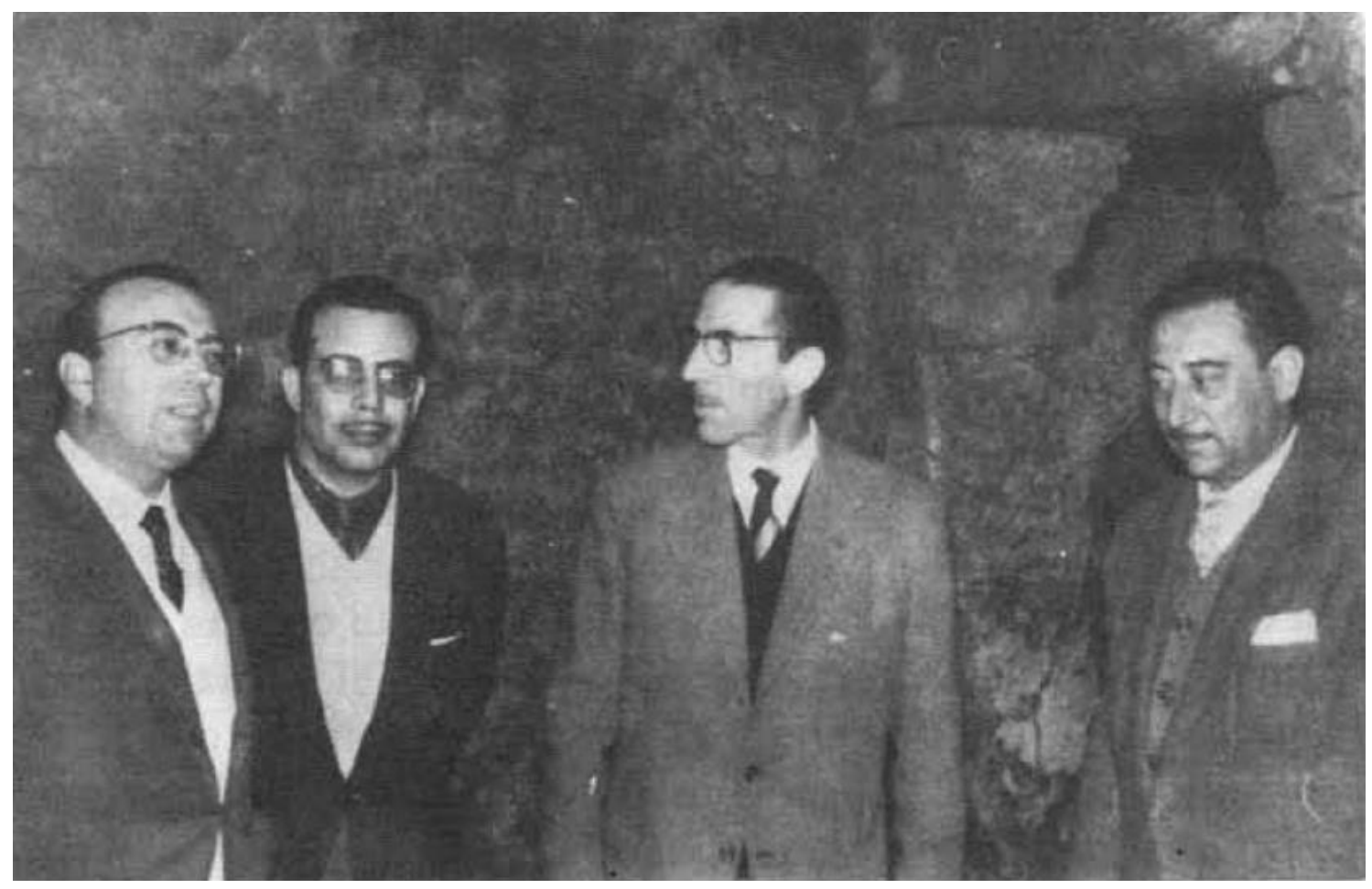

Fig. 7. Visita del alcalde de Córdoba, Antonio Cruz Conde (centro), a los Baños del Alcázar el 18 de diciembre de 1961. A su derecha, Manuel Ocaña (Ocaña 1984: 141).

Las excavaciones prosiguieron durante el siguiente año bajo la dirección técnica de Félix Hernández y la participación de un grupo de estudiantes del Servicio Universitario de Trabajo (Fig. 8), documentándose una estancia de época califal a juzgar por los restos de cerámica (Castejón 1961-1962: 241-242). Dicha estancia estaría relacionada con el baño de época califal, un Hammam prototípico compuesto por un pórtico, un vestuario (Bayt al-Maslaj), una sala fría (Bayt al-Barid), una sala templada (Bayt al-Wastany), una sala caliente (Bayt al-Sajum), un horno y una caldera (Marfil 2004: 59).

Los trabajos arqueológicos en esta zona continuaron entre 1963 y 1964, siendo el hallazgo más interesante el de una estancia o salón de cronología almohade, en el que se documentaron determinados restos ornamentales que habrían pertenecido a una arquería (Castejón 1964-1965: 164). Por tanto, y atendiendo a sus características arquitectónicas, se trataría de un baño de época almohade (ss. XI-XIII) que estaría conectado al baño califal por medio de un salón porticado, desde cuyo pórtico se accedería a un salón de recepciones construido durante la taifa de Sevilla (s. XI) a juzgar por los restos de yesería (Marfil 2004: 62-63). 
Estos baños seguirán en uso hasta 1328, año en que el rey Alfonso XI de Castilla arrasa y nivela todo este sector para la construcción del denominado "Campillo del Rey", justo delante del Alcázar Nuevo (Castejón 1961-1962: 241).

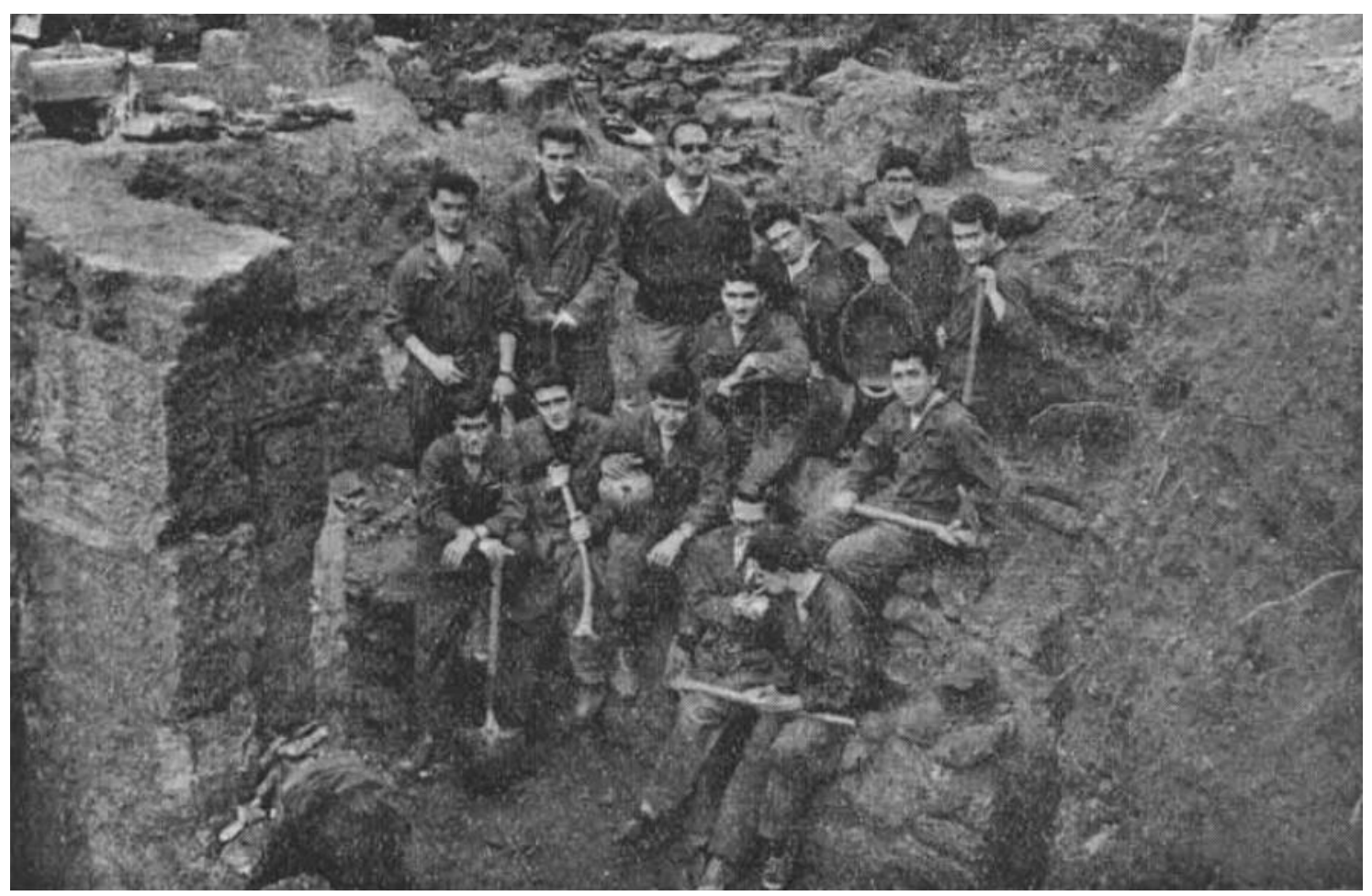

Fig. 8. Grupo de estudiantes del Servicio Universitario de Trabajo en las excavaciones de los Baños del Alcázar (Castejón 1961-1962: 241).

\section{La búsqueda de la Rauda}

A mediados de 1962 se iniciaron una serie de trabajos arqueológicos en los Jardines del Palacio Episcopal con el fin de descubrir la rauda ( rawda), es decir, el panteón de la dinastía Omeya en al-Andalus, el cual constituye uno de los escasos casos en los que se permite la inhumación dentro del recinto de la medina. De este modo, dieron comienzo los trabajos, autorizados por la Dirección General de Bellas Artes en 13 de junio de 1962. Estos estuvieron bajo la dirección de Rafael Castejón, Delegado Provincial del Servicio Nacional de Excavaciones Arqueológicas ${ }^{26}$, quien contó con la colaboración del arquitecto de la sexta zona, Félix Hernández.

Así pues, se procedió a la realización de una cata de 4 x 4 m en los citados jardines, obteniendo como resultado el hallazgo de dos pilares de sección rectangular realizados con sillares dispuestos a soga y tizón (Castejón 1961-1962: 247; Montejo 2006: 239). Dichos pilares poseían una altura de 1'3 y 0’88 m respectivamente, con unas dimensiones de 1 x 1'24 m de lado, y de 1'14 x 1'38 m en su parte inferior. $\mathrm{Su}$ zócalo estaba revestido y pintado en rojo, con una franja del mismo color en su parte inferior. El espacio que había entre estos dos pilares era de 3'66 (Castejón 1961-1962: 248; Momtejo 2006: 240). Por su parte, el pavimento sobre el que se posicionaban estos pilares se encontraba a una profundidad de $2^{\prime} 50 \mathrm{~m}$, siendo descrito de la siguiente manera por Rafael Castejón (1961-1962: 248):

${ }^{26}$ Debemos recordar que en 1955 la Comisaría General de Excavaciones Arqueológicas fue sustituida por el Servicio Nacional de Excavaciones Arqueológicas (Decreto de 2 de diciembre de 1955 por el que se reorganiza el Servicio Nacional de Excavaciones Arqueológicas, $\mathrm{BOE} \mathrm{n}^{\circ} 2$ de 2 de enero de 1956). 
'El piso original es de hormigón homogéneo de cal, pintado en rojo y hacia mediodía está la galería interior, toda ella pintada de rojo el suelo de hormigón calcáreo. Se descubrió esta galería en una anchura a partir de pilastras de 2'90, y todo su borde opuesto aparecía roto a partir de una línea paralela a la de pilastras, señalando acaso la línea de muro interior... El espacio entre pilastras tiene hacia norte una faja de mármol blanco de unos $45 \mathrm{~cm}$, que indica el escalón hacia el hueco del patio'.

Para Rafael Castejón (1961-1962: 248-249) esta galería mencionada habría estado cubierta por 'fuertes entablamentos', pues no se halló ninguna dovela que hubiese pertenecido a algún arco. Además, también se rescataron abundantes clavos de unos $40 \mathrm{~cm}$ de longitud. A causa de todo ello se decidió buscar la línea de pilares al exterior de los jardines del Palacio Episcopal, en el Campo Santo de los Mártires, obteniendo resultados negativos al encontrarse 'a nivel análogo al de las pilastras, una irregular construcción, ovalada, como pozo de noria, horno de cal o cosa parecida, inclasificable desde cualquier punto de vista, que ha vuelto a ser soterrada, porque entraba bajo la tapia de cerramiento del jardín episcopal y podía ser causa de ruina' (Castejón 1961-1962: 249; 1963: 233).

Obviamente, el objetivo principal de la excavación no fue cumplido ${ }^{27}$, puesto que no se logró documentar ningún tipo de enterramiento. Como consecuencia del resultado negativo de la excavación, Castejón propuso dirigir la búsqueda de la tumba de los califas 'más a mediodía, en línea paralela a la presunta fachada sur del Alcázar, a cuyo lugar se refieren las más precisas citas de los cronistas islámicos’ (Castejón 1961-1962: 251; 1963: 233).

\section{Recuperación de monumentos}

\subsection{El Alcázar de los Reyes Cristianos}

El lugar donde se ubica hoy en día el Alcázar de los Reyes Cristianos ya había sido ocupado en época romana y visigoda. Sin embargo, fue durante la etapa islámica cuando la zona suroccidental de la ciudad alcanzó mayor importancia, convirtiéndose en el centro político, económico y religioso. Aquí se construyó el Alcázar omeya, y más tarde, en época almohade, la Alcazaba (vid. Murillo et alii 2011).

Cuando Córdoba fue conquistada en 1236 por Fernando III el Santo (1217-1252), éste repartió los terrenos del antiguo Alcázar omeya, reservándose una parte para él mismo y cediendo el resto al obispo Lope de Fitero $^{28}$, a algunos nobles y a la Orden de Calatrava (Garriguet y Montejo 1998: 347). En documentos de tiempos de Alfonso X el Sabio (1252-1284) se alude a unas 'Casas Reales del Alcázar' y a la denominada Capilla de San Eustaquio. Esto podría indicar la existencia de un Alcázar Cristiano anterior al que edificara Alfonso XI (1312-1350) en 1328 (Garriguet y Montejo 1998: 347). Tal idea ha provocado división entre los investigadores que defienden esta teoría y los que afirman que la erección del Alcázar de los Reyes Cristianos corresponde realmente a Alfonso XI.

Entre los que defienden la hipótesis de un alcázar previo al de 1328 se encuentran M. Muñoz Vázquez y R. Gómez Ramos (Garriguet y Montejo, 1998: 347-348), mientras que V. Escribano alegaba que la Torre de los Leones no pertenecería a época de Alfonso X, según él debido a la pobreza que padeció la ciudad durante la segunda mitad del s. XIII (Escribano 1972: 52 y 57). Nieto Cumplido y Luca de Tena afirman que el alcázar islámico conquistado por Fernando III estuvo en uso hasta 1328. En esta misma línea se sitúa M.T. Laguna, aludiendo a principios estilísticos (Garriguet y Montejo 1998: 349).

${ }^{27}$ Para A. J. Montejo (2006: 241) el error de partida en los planteamientos de Rafael Castejón reside en su localización del límite meridional del Alcázar, propuesto en su artículo de 1929 'Córdoba Califal', publicado en el Boletín de la Real Academia de Córdoba.

${ }^{28}$ La parte del palacio Califal que otrora fuese el 'Aula Regia' visigoda, actualmente el Palacio Episcopal (Escribano 1972: 28). 
Un documento fechado en 1313 demuestra la ocupación que, desde este año, y hasta 1328, hicieron los monjes agustinos del Alcázar del Rey (Garriguet y Montejo 1998: 349). En 1328 Alfonso XI ${ }^{29}$ les donó a estos monjes unas casas en la Collación de Santa Marina a cambio de dicho terreno. A partir de entonces, el Alcázar de los Reyes Cristianos pasó a ser la residencia de los reyes de Castilla debido a su importante papel estratégico en las sucesivas campañas militares contra el reino Nazarí de Granada (Garriguet y Montejo 1998: 350).

De esta manera, su espacio estaba dedicado a residencia real, siendo Isabel I de Castilla el último monarca en ocuparlo (Solano 2007: 38). En efecto, durante parte de la campaña de Granada la reina estuvo alojada en este recinto. Aquí recibió además en audiencia al genovés destinado a cambiar el rumbo de la historia con el descubrimiento del Nuevo Mundo, Cristóbal Colón. Sin embargo, en el año 1482 el Alcázar fue cedido a la Inquisición, abandonando de esta manera sus funciones reales (Solano 2007: 38). Este hecho marca la configuración arquitectónica de la fortaleza, ya que la Inquisición realizó una serie de reformas para poder adaptar este espacio a sus necesidades. De todas las reformas acometidas, la más significativa fue, quizás, la construcción de múltiples celdas y calabozos para albergar a los reos (Solano 2007: 37), algo que condicionará en un futuro la investigación arqueológica. En el siglo XX el espacio que otrora fuese residencia de reyes era una prisión militar. Es a partir de aquí cuando el gobierno de Antonio Cruz Conde emprende una serie de acciones, que muchos catalogarían de verdadera lucha, para devolver al Alcázar su gloria pasada.

El proyecto de recuperación del Alcázar de Córdoba comienza en 1951, cuando Córdoba entra a formar parte del grupo de ciudades que mantuvieron alguna relación con Isabel la Católica. Como es lógico, el edifico histórico que mejor representaba esta relación entre la ciudad y la citada reina era el Alcázar. Así pues, Cruz Conde mandó elaborar un proyecto de reconstrucción y restauración que contó con el apoyo de la Real Academia de Córdoba. Sin embargo, el camino se presentaba arduo, pues no estaba exento de problemas (Solano 2007: 36).

La primera dificultad con la que se encontró el alcalde fue nada más y nada menos que hacer frente al ejército, pues en este periodo el Alcázar pertenecía a dicha institución, ya que había sido utilizado como prisión militar. Esto significaba que para poder hacer uso del recinto se necesitaba primero la aprobación del gobernador militar de la provincia, el general Castejón. Pero Cruz Conde y Castejón habían tenido una serie de discrepancias en relación a la cesión por parte del Ayuntamiento de unos sillones para un desfile militar en la Victoria. El desencuentro llegó hasta tal punto que, mediante la elaboración y difusión de una carta, Castejón acusó al alcalde de deslealtad hacia 'el Ejército salvador de la Patria'. A esto, el alcalde contestó con contundencia mediante la redacción de otra carta, dando además cuenta de la situación a los Jefes de Cuerpo, quienes se disculparon por la actitud del general Castejón. Esto facilitó la intervención en el Alcázar, aunque la misma no estuvo exenta de dificultades, tal y como expresa el propio alcalde en sus memorias: 'De resultas, el Alcázar hubo que tomarlo como acción de guerra. Primero un torreón, después otro y así pieza por pieza, según conseguíamos que fuesen desalojando la documentación de los juzgados militares y algún material, municiones, etc., todo inservible’ (Primo Jurado 2005: 50).

Así, en primer lugar, se procedió al derribo de los edificios adosados a la fachada norte, parte de los cuales habían sido destinados para albergar mendigos (Solano 2007: 36). El siguiente objetivo fue encontrar las puertas originales, ya que la mayoría de puertas y accesos habían sido tapiados para poder albergar celdas y otras estancias. De esta manera se pudo dar con la puerta principal, la cual se encontraba en la fachada sur. Pero, sin lugar a dudas, el hallazgo más importante, junto con el de los baños (vid Santos Gener 1954:

\footnotetext{
${ }^{29}$ Samuel de los Santos Gener argumentó la hipótesis de que Alfonso XI aprovechó la capilla de San Eustaquio, construida por Alfonso X el Sabio, para la construcción del Alcázar, hipótesis apoyada por Manuel Gómez Moreno. Esta capilla se había situado con anterioridad en el llamado Alcázar Viejo, sin embargo, no se han encontrado restos arqueológicos ni en el Corral de los Ballesteros ni en lo que en su día fue el convento de los Basilios (Orti Belmonte 1966: 87).
} 
587), fue el de la puerta que se encontraba bajo la torre de los Leones, datada hacia finales del reinado de Alfonso XI (Escribano 1972: 58), con una bóveda de crucería y arcos transversales al eje que arrancan desde unos capiteles con motivos vegetales. Samuel de los Santos Gener (1954: 582) la describía de la siguiente manera:

'Al pie de la Torre del León se descubrió, en 1952, una puerta de entrada, con ojiva perfilada por una moldura de media caña, y sillares figurados sobre estucos con pintura blanca las juntas y con rojo los sillares; sirve esta puerta de acceso al Alcázar por el Campo Santo de los Mártires y por los jardines, y está abovedada como si fuese la cripta de la capilla que existe en la misma torre sobre ella'.

Aunque en 1953 se produce el hallazgo de los baños mudéjares y la visita de Franco consigue acelerar el proceso de obras, lo cierto es que éstas se verán paralizadas por falta de recursos (Solano 2007: 37). Además, surgía un nuevo problema que giraba en torno a la ocupación de los jardines, entonces utilizados como huertas. Estos terrenos estaban en manos privadas, pero la cuestión no era tanto la propiedad como su finalidad. En dichos terrenos el Ministerio de Educación Nacional había previsto la construcción de un campo de deportes para el Instituto de Enseñanza Media, lo que dificultaba en gran medida el proyecto del Ayuntamiento. Dada la situación, Cruz Conde pidió la ayuda del ex Director General de Turismo, quien se puso en contacto con el ministro de Gobernación, Blas Pérez, el cual ordenó que se paralizasen las obras del campo de deportes (Primo Jurado 2005: 25-53).

En 1954 se reanudaron las obras y el Ministerio de Educación Nacional aprobó un proyecto, redactado por Félix Hernández, en el que se proponía la restauración de algunos lienzos de muralla. Un año más tarde el Consejo de Ministros cedió los jardines al Ayuntamiento, aunque a cambio éste tuvo que cederle al Instituto de Enseñanza Media el espacio dedicado al Parque Municipal (Solano 2007: 37-38). En 1956 se procedió a la actuación sobre los jardines (Fig. 9 y 10), los cuales permitieron abrir la comunicación con el patio morisco que se había descubierto. Para la reconstrucción de los jardines se contó con la ayuda de Prieto Moreno, arquitecto conservador de la Alhambra de Granada, quién llevó a cabo su diseño (Solano 2007: 39).

En 1957 la atención se centró en el patio morisco (Fig. 11 y 12), aunque también hubo una serie de actuaciones encaminadas a mejorar la imagen del Alcázar (Solano 2007: 39):

- Acometida de agua.

— Pavimentación con mármol blanco.

— Reparación de estanques.

— Construcción de fuentes.

— Reforma de las fachadas este y sur.

— Construcción de almenas en la muralla oeste.

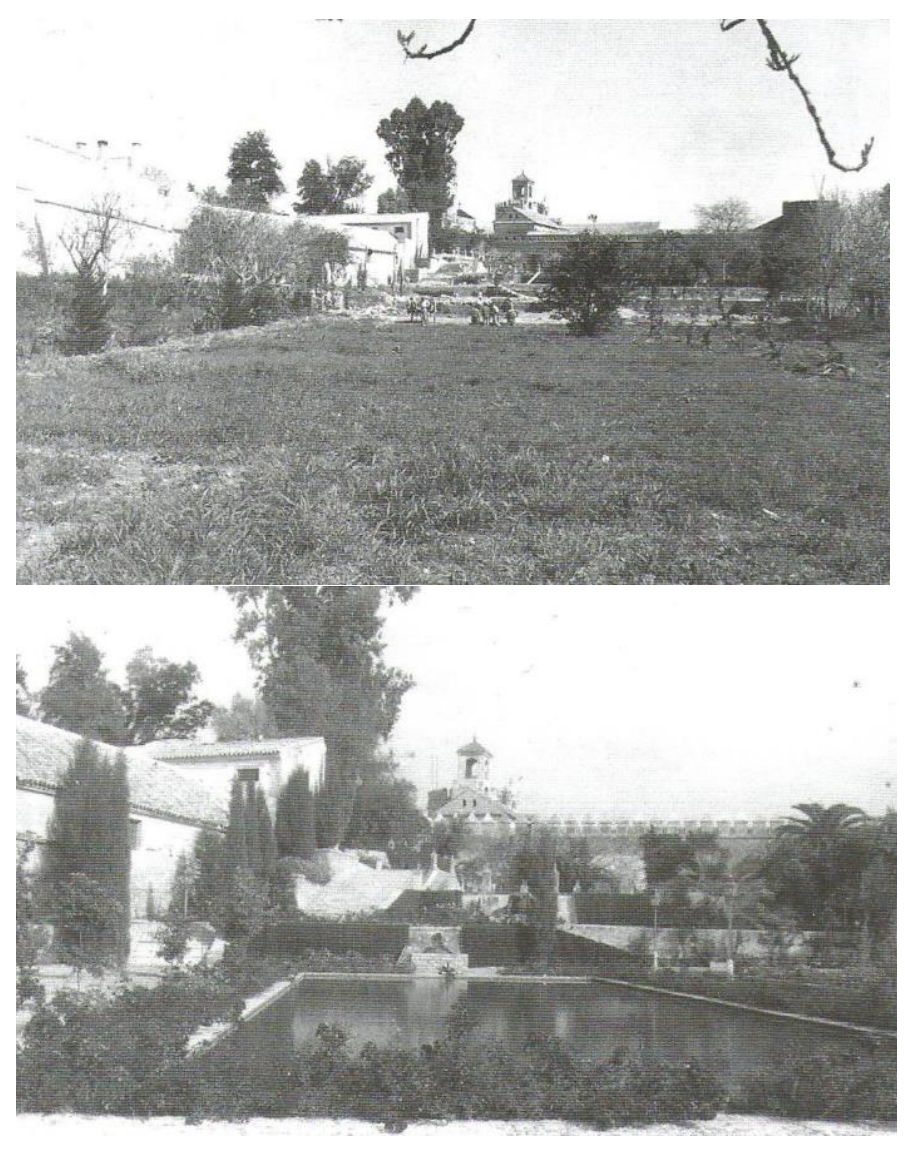

Fig. 9 y 10. Transformación de los jardines del Alcázar tras las labores de puesta en valor (Solano 2007). 
En julio del mismo año la Comisión Provincial de Monumentos realiza una visita a Córdoba, coincidiendo con el descubrimiento de un salón circular aparecido bajo la torre de la Inquisición. El 26 de octubre de 1958 Jesús Rubio, ministro de Educación, inaugura la primera fase de la restauración, y finalmente, en 1960, el Alcázar abre sus puertas al público (Solano 2007: 39).

De este modo, se recuperaba uno de los monumentos más ilustres de la ciudad de Córdoba. Sin embargo, dicha recuperación del Alcázar de Córdoba tan solo estuvo sujeta a cánones arquitectónicos y estilísticos, en muchos casos infundados $y$ sin rigor científico. Habrá que esperar hasta los años noventa y principios del s. XXI para que el Alcázar de los Reyes Cristianos sea sometido a diferentes estudios arqueológicos, cuyos objetivos serán la identificación de las diferentes fases constructivas.

Respecto a las intervenciones arqueológicas llevadas a cabo en el Alcázar de los Reyes Cristianos con posterioridad a la época de Cruz Conde debemos destacar, en primer lugar, las de los años 1993-1994, enmarcadas

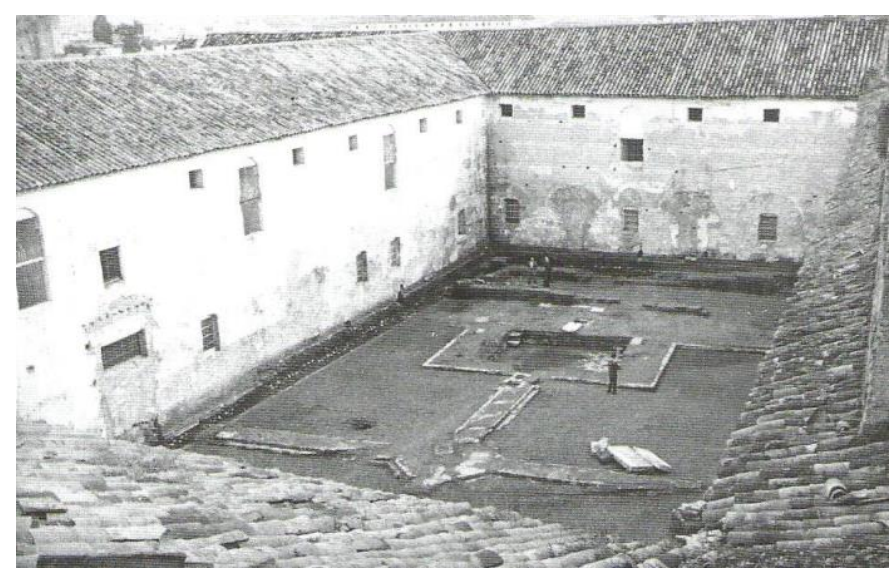
en un proyecto de restauración de sus lienzos,

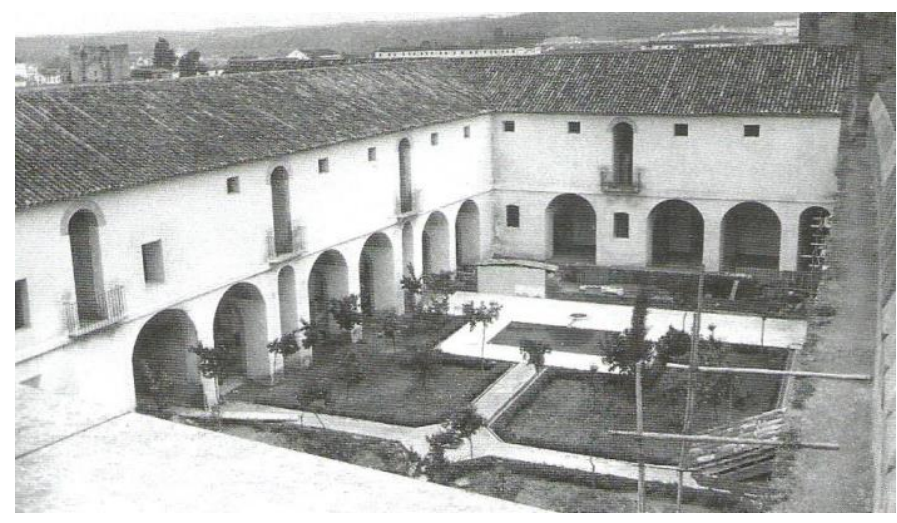

Fig. 11 y 12. El patio morisco antes y después de su restauración (Solano 2007). torres y cubiertas ${ }^{30}$. Los trabajos de campo consistieron entonces en la realización de seis cortes distribuidos fundamentalmente por la periferia del edificio, de acuerdo con los objetivos del proyecto de restauración del mismo. Pero fue en el corte 9, localizado en el interior del Alcázar, concretamente en el denominado 'Patio de Mujeres', donde se obtuvieron los resultados más importantes. Se documentaron dos tramos de la muralla meridional de la ciudad hispanomusulmana y bajomedieval. En la zanja Oeste, realizada por V. Escribano en 1968, se produjo la identificación de dos lienzos de muralla, que J.A. Garriguet y A. J. Montejo los han interpretado como correspondientes las murallas romana y andalusí (Garriguet y Montejo 1998: 353).

Por otro lado, debe hacerse referencia también a los trabajos arqueológicos y de restauración llevados a cabo en la Muralla de la Huerta del Alcázar ${ }^{31}$. En el año 2000 se procedió a la realización de los primeros cortes $^{32}$. El objetivo de los mismos era documentar la potencia y las características de la cimentación del perímetro defensivo, además de detectar las diferentes fases constructivas y su cronología (Murillo et alii 2011: 185). Entre los años 2002 y 2004 se procedió a la excavación de otros cuatro cortes localizados en

\footnotetext{
${ }^{30}$ Estas excavaciones estuvieron a cargo de miembros del Área de Arqueología (J.A. Garriguet y A.J. Montejo) de la Universidad de Córdoba y bajo la dirección de D. Vaquerizo.

${ }^{31}$ Estos trabajos estuvieron enmarcados dentro de los proyectos de la Escuela Taller 'Murallas de Córdoba' (19982000), "Murallas de Córdoba II” (2001-2003) y "Murallas de Córdoba III" (2003-2005), promovidas por la Gerencia Municipal de Urbanismo (GMU) en colaboración con el INEM y el Fondo Social Europeo (Murillo et alii 2011: 185).

${ }^{32}$ Los primeros Cortes (excepto el $\mathrm{n}^{\circ} 1$ ) se localizan extramuros (2, 3, 4 y 12), en el lienzo meridional (Murillo et alii 2011: 185).
} 
la cara norte de la muralla y entre 2004 y 2006 se practicaron nuevos sondeos. También se procedió al control de las obras de restauración de la Torre octogonal (Murillo et alii 2011: 185). A partir de dichas intervenciones, se ha podido constatar una secuencia histórica que abarca desde época emiral ${ }^{33}$ hasta el periodo contemporáneo. Esta zona de la ciudad será clave a partir del s. VI debido a la ubicación de los centros de poder político y religioso procediéndose a la construcción de un nuevo recinto sobre el frente amurallado $^{34}$.

En las excavaciones arqueológicas llevadas a cabo entre 1999 y 2002 por parte de la Gerencia Municipal de Urbanismo se detectó un malecón ${ }^{35}$. Como resultado de los análisis de los materiales cerámicos asociados al relleno se ha establecido una cronología para el dique en torno a la primera mitad del s. IX (León Muñoz, León Pastor y Murillo 2008: 271-272). Gracias a dichas intervenciones sabemos que este arrecife es la restauración y reedificación del antiguo dique romano (Murillo et alii 2011: 221).

También, durante este periodo, se llevaron a cabo una serie de obras en la zona comprendida entre la muralla meridional de la ciudad y el río ${ }^{36}$. Este espacio, denominado al-Hassá ${ }^{37}$, estaría destinado a la celebración de actos públicos de administración de justicia o paradas militares. Esto provocaría que en un determinado momento de época emiral se dotase a este espacio de un pavimento enlosado y de edificios públicos (Murillo et alii 2011: 218). Así pues, y atendiendo a los resultados obtenidos, cabe preguntarse si el al-Hassá se encontraba fuera o dentro del recinto amurallado, y si el Alcázar estaba frontero con el lienzo meridional de la muralla.

Pero será con el Califato Almohade (s. XII) cuando se produzca la verdadera transformación de esta zona de la ciudad, refortificando el ángulo suroriental de la Medina mediante la construcción de una gran Alcazaba, que estaba configurada por cuatro recintos (Murillo et alii 2011: 22-223).

Todos los procesos de fortificación que sufrió esta zona de la ciudad desde la tardoantigüedad estuvieron encaminados al control del río, el puente y las murallas. Por esa razón, las labores defensivas también se trasladaron hasta la cabecera del puente.

\subsection{La torre de la Calahorra}

La denominada Torre de la Calahorra constituye hoy en día uno de los elementos patrimoniales más significativos de la ciudad de Córdoba. Sin embargo, las sucesivas reformas de las que ha sido objeto a lo largo de la historia, debido a su valor estratégico, han provocado que resulte sumamente complicado establecer una secuencia cronológica respecto a su construcción. Además, el edificio ha quedado ensombrecido por la orilla norte del río, donde se ubicaba el poder político y religioso, siendo el ángulo suroccidental el que ha sufrido mayores reformas en materia de fortificación.

\footnotetext{
${ }^{33}$ Sin embargo, en intervenciones arqueológicas próximas a la zona sí que se han detectado fases correspondientes al periodo romano. Quizá, el hallazgo más interesante sea el de una infraestructura romana relacionada con una escalinata en la Puerta del Puente, documentada en las excavaciones de 1999, y junto a la que también se documentó una plaza porticada. Esta plaza estaría relacionada con las áreas dedicadas a la producción y almacenamiento del aceite, y que se encontraban ubicadas en el sector frontero con el río (Murillo et alii 2011: 215).

${ }^{34}$ De esta fortaleza tan solo se ha documentado su cierre oriental. Dicho recinto es similar al Castellum del recinto amurallado de Barcino (León Muñoz, León Pastor y Murillo 2008: 269).

${ }^{35}$ Muro de más de $3 \mathrm{~m}$ de anchura, realizado en sillería atizonada en su fachada externa y un remedo de opus africanum en su parámetro interno (León Muñoz, León Pastor y Murillo 2008: 271-272).

${ }^{36}$ Se trata de un espacio que oscila entre los 15 y $20 \mathrm{~m}$ de anchura.

${ }^{37}$ Sobre el al-Hassá Castejón (1929) interpretó erróneamente este espacio como una "azotea o explanada amplia que se extendía delante del Alcázar hasta la muralla, por lo que dominaba el río y el arrecife". García Gómez (1965) apoya esta interpretación, afirmando que el arrecife, la explanada (al-Hassá) y el Alcázar no se encontraban al mismo nivel. Por otro lado, Torres Balbás (1957) profundiza en su descripción y en la referencia a las fuentes literarias (Murillo et alii 2011: 218).
} 
Llama la atención que, a pesar de las numerosas descripciones que tenemos del puente mayor de Córdoba, ninguna de ellas haga referencia a una puerta de acceso en la orilla sur del río (León 2003: 398). Las descripciones del puente, junto con sus restauraciones, se suceden con cierta frecuencia a partir de la conquista de Córdoba por las tropas musulmanas. En este contexto, la restauración más antigua de la que tenemos constancia se sitúa entre los años 719 y 720 . La reparación del puente se lleva a cabo mediante la utilización de ladrillo y piedra de la muralla.

En sus descripciones sobre el puente de la ciudad, al-Idrisi no menciona ninguna estructura fortificada en la cabecera del mismo. Esto ha dado pie a que algunos investigadores de principios del s. XX estableciesen la teoría de la inexistencia de un edificio defensivo a mediados del s. XII. Pero la carencia de referencias textuales acerca de la Calahorra puede ser consecuencia de que ésta se constituyese como un elemento integrado dentro de la propia estructura del puente (León 2003: 399).

La referencia textual más antigua en relación a esta fortificación data de 1236. La existencia de esta fortaleza del puente (castrumquoderat in ipso ponte) obstaculizó el paso de las tropas castellanas, por lo que Fernando III (1217-1252) mandó construir balsas para cruzar el río ${ }^{38}$ (León 2003: 399-400). Tras la batalla del Campo de la Verdad, en 1368, Enrique II de Trastámara (1366-1379) emprende una serie de reformas en el edificio que reflejan grosso modo la imagen actual de la Calahorra: una construcción cerrada y exenta, de planta cruciforme de tres brazos y dotada de dos torres circulares en los ángulos (León 2003: 393).

Con el paso del tiempo, la Calahorra perdió sus funciones originales, siendo destinada para multitud de usos, entre los que destacan; prisión para la nobleza, polvorín, colegio para niñas y, finalmente, casa cuartel de la Guardia Civil (Fig. 13). Así pues, Antonio Cruz Conde se dispuso a rehabilitar la torre para poder devolverle su aspecto original, pues el que presentaba a los inicios de su restauración distaba mucho de su estado inicial (Solano 2007: 41).

De este modo, el Ayuntamiento emprendió las gestiones necesarias para poder emprender el proyecto. Indudablemente, estas gestiones debían contar con el permiso de la Guardia Civil, ya que ésta tenía un cuartel dentro de la torre. Dichas gestiones resultaron ser bastantes llevaderas, pues, al contrario de lo ocurrido con el Alcázar de los Reyes Cristianos, la Guardia Civil se prestó dispuesta a colaborar con el Ayuntamiento para facilitar el proceso de recuperación de la Calahorra (Primo Jurado 2005: 43). Por consiguiente, la torre fue cedida al Ayuntamiento, mientras que éste procedía en 1952 al arrendamiento de seis casas en el Campo de la Verdad para las familias de los guardias pudiesen tener un alojamiento provisional (Solano 2007: 41).

Mediante el derrumbe de tabiques y cielos rasos la torre fue volviendo poco a poco a su estado original, dejando ver partes de su arquitectura que habían permanecido ocultas hasta ese momento (Fig. 14). En 1952 se propuso que la Calahorra albergase una exposición con motivo del quinto centenario del nacimiento de Don Gonzalo Fernández de Córdoba, el Gran Capitán (Primo Jurado 2005: 43). Este hecho provocó que las obras se acelerasen, ya que Franco acudiría al acto, en el cual se celebraría un desfile militar. Las obras de restauración fueron dirigidas por el arquitecto Víctor Escribano, quién contó con la aprobación de Félix Hernández (Solano 2007: 41).

\footnotetext{
${ }^{38}$ Parece improbable que una simple puerta de acceso pudiese contener a un ejército. Recientes investigaciones arqueológicas han demostrado que en el entorno de la Calahorra existía un recinto amurallado de época almohade.
} 
El 29 de abril de 1953 Franco inauguró la citada exposición sobre el Gran Capitán, que contó con la colaboración del Museo del Ejército y del Archivo de Simancas (Primo Jurado 2005: 43). En 1954, una vez finalizada aquella, el Ayuntamiento procedió a instalar en la Calahorra el Museo Histórico de la Ciudad. En junio de 1955 se produjo la visita de los reyes de Jordania, y en 1956 el edificio fue abierto al público, aunque todavía quedaban algunas actuaciones por finalizar (Solano 2007: 41-42).

Además de estas funciones, la torre de la Calahorra fue usada por el Ayuntamiento para albergar recepciones, tal y como menciona el propio Cruz Conde en sus memorias (Primo Jurado 2005):

'En diversas ocasiones utilicé la torre de la Calahorra para ofrecer en ella comidas a personalidades y huéspedes ilustres. La primera ocasión fue a los reyes de Jordania, Hussein y Dina. El Ayuntamiento carecía de todo lo necesario, pero de casa de mis padres y de algunos amigos llevé vajilla, candelabros, fuentes, etc., hasta que posteriormente el Ayuntamiento adquirió una vajilla Bidasoa y cubertería con el escudo de Córdoba, así como cristalería y cuanto era preciso para ofrecer estos homenajes con la dignidad propia de la ciudad'.
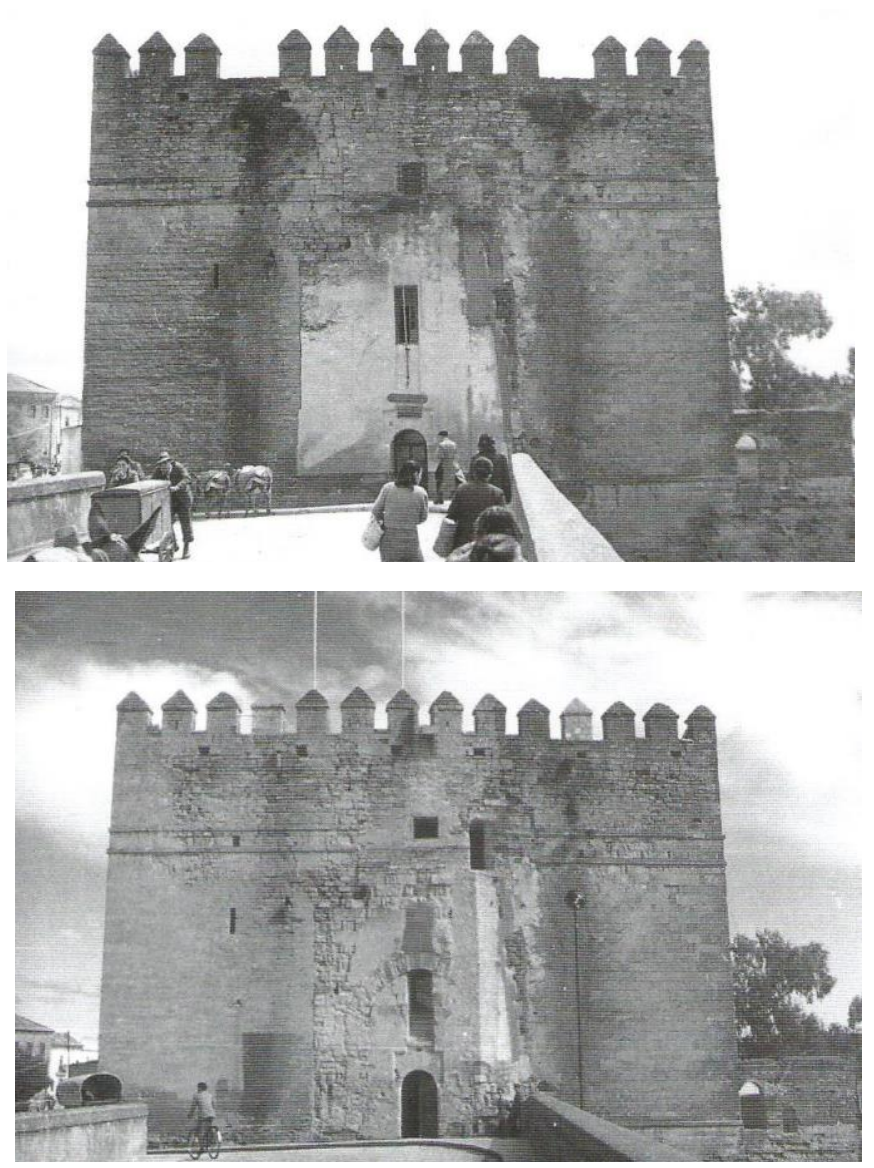

Fig. 13 y 14. La torre de la Calahorra después de su restauración (Solano 2007).

La recuperación de este elemento del patrimonio arquitectónico cordobés por parte de Cruz Conde significó un paso más en su labor por dotar a la ciudad de una imagen moderna, a la vez que recuperaba aquellos monumentos que fueron testigos del ilustre pasado de Córdoba. Además, la restauración de la torre sentó las bases para posteriores investigaciones, en las que el estudio del edificio no se llevaría de forma aislada, sino en relación con la orilla norte del río y el ángulo suroccidental de la ciudad.

En 1987 el Ayuntamiento de Córdoba cedió administrativamente la torre de la Calahorra a la fundación Roger Garaudy para albergar en ella el Museo Vivo de Al-Andalus, constituyéndose de este modo como un recinto museístico de tres plantas.

Grosso modo, la imagen que refleja hoy día este monumento es el resultado de las reformas emprendidas en 1369 por Enrique II Trastámara con posterioridad a la batalla del Campo de la Verdad. Sin embargo, hoy día sabemos que esta fortificación tuvo su origen en época califal (vid León 2003).

En la fachada principal se puede apreciar a simple vista tres grandes cuerpos, que constituyen dos torres unidas por un arco. El lado oeste presenta un paramento de sillería de calcarenita dispuesto a soga y tizón ${ }^{39}$, trabados con mortero de cal. La torre oriental presenta una planta rectangular y, al igual que la del lado oeste, fue construida con sillarejos de calcarenita trabados con mortero de cal (León 2003: 396). Pero es la parte central de esta fachada, que constituiría la primitiva puerta islámica de entrada al puente, la que

${ }^{39}$ Dos tizones y una soga (León 2003: 396). 
ha sido objeto de un estudio más intenso, pues ha sido en ella donde se han detectado los materiales de época califal.

Esta parte se encuentra orientada perpendicularmente al eje del puente, siendo la zona que ha sufrido las mayores reformas de todo el conjunto. Posee un gran arco de herradura, cegado, en el que se abren dos puertas a distintas alturas. Es precisamente en esta zona, revestida por parches de ladrillo, sillería y mortero, donde encontramos los elementos más antiguos de la obra original, que a su vez han servido como base para establecer una cronología califal a la primera construcción defensiva del puente (León 2003: 396). De este modo, y a pesar de las múltiples reformas que ha sufrido este complejo defensivo, aún pueden hacerse perceptibles aquellos materiales integrados en la posterior obra cristiana.

Los restos de la puerta islámica original se concentran, por tanto, en la fachada principal. Con los datos obtenidos se han podido establecer las medidas y características de dicha estructura. Se trataría de una torre islámica, de planta rectangular, cuyo eje estaría alineado con el puente romano. La anchura del edificio sería de 7,97 m. Las dos torres laterales que sustentan el arco tienen una anchura de 2,06 m, la oriental, y de 1,99 la occidental ${ }^{40}$. La altura de la parte central es de 10 m (León 2003: 400-402).

La erección del edificio islámico se realizó mediante sillería de calcarenita. Este tipo de roca se ha utililizado desde época romana por su facilidad a la hora de labrar los bloques. Sin embargo, la blandura de este material supone también un mayor deterioro debido a la erosión, por lo que las estructuras debieron de estar enlucidas en cal (León 2003: 410). Como ya se ha comentado, la forma en la que se disponen los sillares es a soga y tizón, encontrando la misma técnica en complejos civiles (Madinat al-Zahra), militares (Alcazaba de Almería) y religiosos (Mezquita aljama de Córdoba) ${ }^{41}$.

Pero es el estudio del arco, ubicado en la fachada principal, el que proporciona mayor número de datos a la hora de establecer el marco cronológico de la torre. Tenemos un vano cegado ${ }^{42}$ con una anchura de 4 $\mathrm{m}$, rematado por un arco de herradura en el que aún puede distinguirse su trazado. De este arco solo se conservan elementos de la rosca en su costado oriental (León 2003: 402) ${ }^{43}$, pero gracias a su restauración en la década de los cincuenta sabemos que se trata de un arco de herradura, característico de época califal. De dicho arco no se conserva la mitad oeste ni tampoco el alfiz ${ }^{44}$, si es que lo tuvo. Respecto a las dovelas, éstas presentan una anchura de entre 20 y $25 \mathrm{~cm}$.

Este arco posee dos características particulares respecto a los cánones de la arquitectura califal: 1) La desviación en la orientación del eje de las dovelas próximas a la clave. 2) La ausencia de peralte en el trasdós del arco, cuyo grosor disminuye desde la base hacia la clave (León 2003: 408).

Con base en las crónicas que aluden a las innovaciones defensivas introducidas por Abderramán III en las puertas de Córdoba en el año 914, se ha planteado la hipótesis de que pudo existir otra puerta en la fachada meridional, la cual estaría dotada de un arco similar. Esta fórmula de puente fortificado habría sido frecuente durante la época de Almanzor, encontrando algunos ejemplos susceptibles de ser sometidos a

\footnotetext{
${ }^{40}$ De las dos torres, la occidental es en la que peor se ha conservado la fábrica original como consecuencia de los añadidos en épocas posteriores.

${ }^{41}$ Esta disposición de los sillares a modo de soga y tizón puede contemplarse en el muro oriental (soga y dos tizones) gracias al material fotográfico, ya que las labores de restauración emprendidas en esta zona a lo largo del s. XX han tapado los sillares (León 2003: 414).

${ }^{42} \mathrm{El}$ cerramiento del arco se produjo en el s. XIV, transformando la puerta islámica en un castillo cerrado y exento. Como consecuencia de ello, la nueva fortaleza presentaba una entrada en altura a la que se accedía mediante un puente levadizo (León 2003: 403).

${ }^{43} \mathrm{El}$ análisis de esta zona resulta complicado como consecuencia de las obras de reparación, las cuales se efectuaron mediante el parcheado con ladrillo, mampostería y cemento (León 2003: 402).

${ }^{44}$ El alfiz era un recurso puramente decorativo, detectado en la arquitectura califal, siendo prueba de ello aquellas puertas ubicadas en la fachada oriental de la Mezquita aljama que no fueron objeto de restauración por parte de Velázquez Bosco (León 2003: 406).
} 
un análisis comparativo. Uno de ellos sería el puente de Alcántara en Toledo, cuyas fortificaciones conocemos gracias a un grabado de Anton Van den Wyngaeerde del año 1563 (León 2003: 419). Del mismo modo, también tenemos constancia de un grabado de la ciudad de Écija de 1567 firmado por Hoefnagle (León 2003: 420) en el que se puede apreciar la puerta fortificada de acceso mandada construir allí por Almanzor a finales del s. $\mathrm{X}^{45}$, después de que Abderramán III demoliese el primitivo viaducto en el 914 para sofocar una revuelta de los ecijanos.

En la zona ocupada por la Calahorra se detectó en el año 2001 un recinto amurallado de planta rectangular que ocupaba casi una hectárea de terreno ${ }^{46}$. La técnica constructiva resultaba idéntica a la empleada en el recinto occidental de la Alcazaba que, junto con el material cerámico recuperado de la zanja de cimentación (vid. Salinas, Martín y León 2009) permitió fechar esta fortificación hacia el último tercio del s. XII (León y Blanco 2010: 712).

\subsection{Las murallas de la Avenida del Corregidor}

El perímetro amurallado de la ciudad de Córdoba tiene su origen en la fundación romana de Claudio Marcelo, hacia la primera mitad del siglo II a.C. (Vaquerizo, Garriguet y Murillo 2011: 11). Más tarde, en época augustea, el recinto amurallado se ampliará hasta los márgenes del río (Ibid. 19). Durante la tardoantigüedad y el periodo islámico el trazado de la muralla corresponderá en gran medida al de época clásica, siendo el ángulo suroccidental la zona más importante desde el punto de vista político y religioso (vid. Murillo et alii 2011). Sin embargo, en el s. XI se produce la fortificación del arrabal de la Axerquía, cuyo perímetro llegó a superar al de la propia Medina (León y Blanco 2010: 702). Ya en el s. XV las murallas serán fruto de una leve reforma, hasta que en el s. XIX, como consecuencia de la pérdida de sus funciones militares, se produce el derribo de lienzos, torres y puertas (Murillo et alii 2011: 227). En los años cincuenta del s. XX, a iniciativa de Antonio Cruz Conde, las murallas occidentales de la Avda. del Corregidor serán objeto de reconstrucción.

En 1952 se aprobó el proyecto mediante el cual se iniciaba la restauración del tramo que iba desde la Puerta de Sevilla hasta el nuevo puente de San Rafael en el marco de la apertura de las Avenidas del Conde de Vallellano y del Corregidor. Este proyecto fue redactado por el arquitecto Carlos Sáenz de Santamaría, quién contó con la ayuda del Ingeniero Municipal Carlos Font de Riego. Dicho proyecto contemplaba también la creación de una zona ajardinada, así como el traslado de una antigua puerta que servía de acceso al Alcázar. En la memoria presentada se aludía a la necesidad de crear un talud para nivelar el firme de la carretera $^{47}$. Estas obras de urbanización y embellecimiento finalizarían en 1953. Hasta este momento no se hace referencia a la restauración de ningún lienzo, por lo que es posible que existiese un proyecto paralelo no localizado, o también, que se actuase sin proyecto, tal y como indica en su estudio Eduardo Redondo (Redondo 2013: 55).

En marzo de 1954 finalizó la construcción del foso, así como de la barbacana, y en el verano de ese mismo año también se terminaron la avenida y la reconstrucción de la muralla. Por otro lado, los trabajos de ajardinamiento se encontraban en un proceso muy avanzado. Recientemente se ha sostenido la hipótesis de que fue Félix Hernández quien inició la restauración de los lienzos más cercanos al río, hasta la torre cuadrangular más septentrional (Redondo 2013: 59). En 1955 la actuación se centró en la puerta de Sevilla y en la torre albarrana unida a la muralla mediante dos arcos de herradura (Solano 2007: 43) ${ }^{48}$. Las obras

\footnotetext{
45 "Y construyó también un puente sobre el río Istiyya, río que es el Shamil. Y él allanó los caminos difíciles y los barrancos abruptos" (Arjona 182: 195).

${ }^{46}$ Estas intervenciones se desarrollaron dentro del marco del convenio entre la Gerencia Municipal de Urbanismo y la Universidad de Córdoba (León; Blanco 2010: 711).

${ }^{47}$ Esta medida provocó que la muralla se situase en una cota inferior a la de la vía. Por este motivo también se propuso la adecuación, el saneamiento y la construcción de los accesos a estos terraplenes. También se planteó la creación de un paseo en la parte inferior, que conectaría con el foso que circundaba el antemuro (Redondo 2013: 55).

${ }^{48}$ Hoy día solo es perceptible uno de esos arcos de herradura, ya que el segundo fue tapiado.
} 
de reconstrucción fueron dirigidas por el arquitecto José Rebollo, quien inició un proceso de sustitución de aquellos sillares que se encontraban en mal estado. Rebollo también presentó un proyecto para la construcción de un puente que permitiese cruzar el foso y acceder al Cuartel de Sementales. Durante dichas obras se produjo el descubrimiento del foso y del antemuro del sector de la puerta de Sevilla, ya que las edificaciones se encontraban superpuestas a éstos. En 1956 se inició un nuevo proyecto que comprendía la restauración del lienzo 1, en el cual Félix Hernández se encargaría de la reconstrucción de la torre hexagonal que enlaza éste con el número 2. Así pues, los últimos trabajos de restauración en la Avenida del Corregidor se centraron en recuperar el acceso y entorno de la puerta de Sevilla. Hernández se encargó de la restauración de la puerta y de la torre, mientras que Rebollo acometió la urbanización y el embellecimiento del espacio colindante (Redondo 2013: 62).

La restauración de las murallas afectó al acceso del antiguo barrio del Alcázar, ya que los accesos eran mucho más limitados que antes, algo que ocasionó el disgusto de algunos vecinos. A pesar de ello, el proyecto siguió hacia delante y en 1957 se procedió a la pavimentación de esta entrada. Como ya se ha comentado, junto a la reconstrucción de la muralla y de las puertas, también se inició un proceso de embellecimiento de toda esta zona con la creación de jardines, fuentes, etc. Así, en la puerta de Sevilla se instaló la tumba romana descubierta años antes por Enrique Romero de Torres y Samuel de los Santos Gener en la calle Antonio Maura. Dicha tumba, de carácter hipogeo, habría contado con un remate de tipología indeterminada, además de un recinto pavimentado con grandes losas al exterior (Ruiz 2005: 81$82)^{49}$. El descubrimiento y traslado de dicha tumba viene recogido en las memorias de Antonio Cruz Conde: 'Al construir la Avenida de Vallellano, se descubrió una tumba romana que dejamos in situ, entre los jardines y colocamos otra, hallada en el camino de Almodóvar, como elemento decorativo en los alrededores de la Puerta de Sevilla' (Primo Jurado 2005: 189).

En 1958 se produjo el derribo de una parte de la muralla que arrancaba desde la puerta de Almodóvar, debido principalmente a la acción de los propietarios de las casas adosadas a la muralla en su parte interior, pues ésta había sido objeto de apertura de entradas y ventanas. Ese mismo año finalizaron los trabajos de restauración de las murallas de la Avenida del Corregidor y de la puerta de Sevilla. Prueba de ello es la aprobación de un presupuesto para la instalación de un alumbrado en la avenida del mismo nombre (Redondo 2013: 66).

Tras la finalización en la Avenida del Corregidor, las obras de restauración se trasladaron al espacio que discurre entre la puerta de Almodóvar y el Campo Santo de los Mártires. Sin embargo, el proceso de restauración de este tramo de la muralla resultó bastante lento debido a la falta de recursos. Ya en 1960 el proyecto recibió una ayuda económica por parte de Antonio Gallego, director general de Bellas Artes. De este modo, en 1961 el Ayuntamiento aprobó el presupuesto para la reconstrucción de la muralla que comprendía el tramo anteriormente mencionado (Solano 2007: 44).

A principios de época imperial, durante el periodo augusteo, el perímetro amurallado de Corduba se extendió hasta los márgenes del río Baetis (Guadalquivir) (Ventura 2011: 38). Además, se procedió a la reparación de las murallas republicanas, que habían sufrido daños como consecuencia del asedio de César tras la batalla de Munda (45 a.C.). Así pues, este nuevo perímetro constaba de $1.700 \mathrm{~m}$, y junto a la anterior superficie urbana, conformaba 79 hectáreas (Escudero et alii 1999: 204). Es posible que el sistema muralla-agger se repita en esta nueva ampliación, pues en el lienzo occidental se detectó material arquitectónico tardorrepublicano, reutilizado posiblemente en el paramento interno del muro que sostendría dicho agger (Ibid.).

\footnotetext{
${ }^{49}$ Tradicionalmente, la necrópolis occidental romana había sido considerada de condición plebeya, pero esta teoría queda hoy día desfasada a raíz del descubrimiento de esta tumba y de los mausoleos de Puerta de Gallegos (Ruiz 2005: 81-82).
} 


\begin{tabular}{|c|c|c|}
\hline \multicolumn{3}{|c|}{ PROCESO DE RESTAURACIÓN DE LAS MURALLAS } \\
\hline FECHA & HITO & ACTOR PRINCIPAL \\
\hline Marzo de 1952 & \begin{tabular}{|c|}
$\begin{array}{c}\text { Aprobación del desmonte de la Puerta } \\
\text { de los Sacos }\end{array}$ \\
\end{tabular} & $\begin{array}{l}\text { Félix Hernández (Arquitecto } \\
\text { Conservador de la Sexta Zona) }\end{array}$ \\
\hline 4 de junio de 1952 & $\begin{array}{c}\text { Aprobación del proyecto de apertura } \\
\text { de la Avda. del Conde de Vallellano y } \\
\text { del Corregidor }\end{array}$ & $\begin{array}{c}\text { Carlos Sáenz de Santa María } \\
\text { (Arquitecto del Ensanche) y Carlos } \\
\text { Font de Riego (Ingeniero Municipal) }\end{array}$ \\
\hline \multirow[t]{2}{*}{$\begin{array}{l}\text { Septiembre de } 1954 \text { - } \\
\text { enero de } 1954\end{array}$} & $\begin{array}{l}\text { Obras de ajardinamiento y } \\
\text { urbanización de la Avda. del } \\
\text { Corregidor }\end{array}$ & $\begin{array}{l}\text { Carlos Sáenz de Santa María } \\
\text { (Arquitecto del Ensanche) }\end{array}$ \\
\hline & $\begin{array}{l}\text { Restauración de los lienzos } 3,4 \text { y } 5 \text { de } \\
\text { las torres cuadrangulares } 1,2 \text { y } 3 \text { de la } \\
\text { muralla de la Avda. del Corregidor }\end{array}$ & $\begin{array}{l}\text { Félix Hernández (Arquitecto } \\
\text { Conservador de la Sexta Zona) }\end{array}$ \\
\hline Junio de 1954-1955 & $\begin{array}{l}\text { Aprobación del presupuesto para la } \\
\text { continuación de las obras de } \\
\text { restauración en el lienzo } 2 \text { de la } \\
\text { muralla de la Avda. del Corregidor }\end{array}$ & José Rebollo (Arquitecto Municipal) \\
\hline 1955 & $\begin{array}{c}\text { Construcción ex novo del puente sobre } \\
\text { el foso para la salida del Cuartel de } \\
\text { Sementales (lienzo 3) }\end{array}$ & José Rebollo (Arquitecto Municipal) \\
\hline Abril de 1955 & $\begin{array}{l}\text { Liberación de aguas negras del foso } \\
\text { por el que discurre el Arroyo del Moro }\end{array}$ & \\
\hline Septiembre de 1955 & $\begin{array}{c}\text { Instalación del alumbrado artístico en } \\
\text { los tramos restaurados de la muralla de } \\
\text { la Avda. del Corregidor }\end{array}$ & \\
\hline \multirow[t]{4}{*}{$1955-1958$} & $\begin{array}{l}\text { Restauración de la torre hexagonal de } \\
\text { la muralla de la Avda. del Corregidor }\end{array}$ & $\begin{array}{c}\text { Félix Hernández (Arquitecto } \\
\text { Conservador de la Sexta Zona) }\end{array}$ \\
\hline & Restauración de la Puerta de Sevilla & $\begin{array}{l}\text { Félix Hernández (Arquitecto } \\
\text { Conservador de la Sexta Zona) }\end{array}$ \\
\hline & \multirow{2}{*}{$\begin{array}{c}\text { Restauración de la torre albarrana de } \\
\text { la Puerta de Sevilla }\end{array}$} & Dirección facultativa: Félix Hernández \\
\hline & & Dirección técnica: José Rebollo \\
\hline \multirow[t]{2}{*}{$1956-1958$} & $\begin{array}{c}\text { Restauración del lienzo } 1 \text { de la muralla } \\
\text { de la Avda. del Corregidor }\end{array}$ & José Rebollo (Arquitecto Municipal) \\
\hline & $\begin{array}{c}\text { Urbanización del entorno de la Puerta } \\
\text { de Sevilla }\end{array}$ & José Rebollo (Arquitecto Municipal) \\
\hline
\end{tabular}

Tabla 2. Proceso completo de restauración de las murallas de la Avenida del Corregidor durante el mandato de Antonio Cruz Conde (tomada de Redondo 2013: 123-124). 
En esta nueva ampliación se documentaron, directa o indirectamente, cinco puertas de acceso ${ }^{50}$, de las cuales dos se situaron en el tramo occidental de la muralla. La primera es la Puerta de Almodóvar (vid. Márquez 1998: 192-193), cuya datación para este periodo ha sido posible gracias al registro estratigráfico y al hallazgo de un capitel de pilastra monumental, fechable en época augustea temprana. La segunda es la Puerta de Sevilla, que a pesar de no haber podido ser documentada para época augustea, sí lo ha sido para época visigoda (Arjona 1982: 14). Esta puerta sería necesaria para el acceso desde la ciudad al puerto fluvial. A comienzos de época imperial se inicia también un proceso de monumentalización de las puertas republicanas. En este sentido, el entorno de la Puerta de Gallegos fue objeto de dicho proceso mediante la edificación de dos mausoleos (Escudero et alii 1999: 205).

En época emiral y califal el perímetro amurallado de la Medina coincide grosso modo con el de época clásica, al que habría que sumarle la fortificación del arrabal de la Axerquía en el s. XII, en época almorávide (León y Blanco 2010: 704). En 1935 Manuel Ocaña estableció la ubicación de sus puertas, que posteriormente fueron documentadas arqueológicamente (Escudero et alii 1999: 208). De este modo, para el lienzo occidental, se ha identificado la llamada Puerta de Amir en las inmediaciones de la Puerta de Gallegos, documentándose una necrópolis islámica, excavada en 1993 (Escudero et alii 1999: 208). También se ha establecido el emplazamiento hipotético de la Bab al-Attarin entre la entrada a la calle Caballerizas Reales y una torre existente más al sur (Garriguet y Montejo 1998: 330). Durante el periodo islámico tiene lugar la construcción del Alcázar omeya en este sector de la ciudad, y posteriormente el de la Alcazaba almohade.

Durante la Baja Edad Media podemos detectar dos espacios urbanos, por un lado, la Villa, que comprendía el espacio de la antigua Medina, y por el otro la Axerquía. Centrándonos en el recinto que encerraba la Villa, localizamos dos puertas de acceso en el apéndice suroeste. La primera sería la Puerta de los Sacos, localizada en la esquina suroeste de la muralla meridional del a Huerta del Alcázar, mientras que la segunda la constituye la Puerta de Sevilla, construida en la segunda mitad del s. XIV, y junto a la que se sitúa una torre unida a la muralla a través de dos $\operatorname{arcos}^{51}$ (Escudero et alii 1999: 215).

En la parte occidental destacan de nuevo la Puerta de Almodóvar ${ }^{52}$ y la Puerta de Gallegos, las cuales poseían torres albarranas, aunque solo se ha podido documentar la de la segunda ${ }^{53}$, que se derribó en 1825 . Esta puerta se habría visto afectada por una serie de reformas durante época bajomedieval, centrándose las mismas en la parte superior, en la que se insertaron las armas de Castilla y los escudos de la ciudad de Córdoba. Fue reconstruida tras el terremoto de 1755, hasta que finalmente desapareció en el s. XIX (Escudero et alii 1999: 219).

En los últimos años del siglo pasado las murallas occidentales presentaban un cierto nivel de deterioro, por lo que a través del programa de las Escuelas Taller 'Murallas de Córdoba' se llevó a cabo una serie de actuaciones encaminadas a la reparación de pavimentos, mobiliario urbano, cercamientos y ajardinamientos, así como la limpieza de paramentos. Uno de los puntos de la muralla occidental que recibió mayor atención fue la Puerta de Sevilla, con el fin frenar el proceso de deterioro que estaba sufriendo. Se procedió a la retirada de los añadidos para poder acceder de este modo a la fábrica original, instalando un sistema de impermeabilización. Posteriormente se procedió a la reparación de los sillares afectados por el agua y al cierre de la torre respecto a la azotea con la que se comunicaba (Redondo 2013:

\footnotetext{
${ }^{50}$ En el tramo Sur se documenta la Puerta del Puente, mientras que en la esquina suroriental tenemos la Puerta de Pescadería y otra no documentada en época medieval, situada en la parte oriental, y cuya situación se ha establecido mediante la documentación d una calzada romana (Escudero et alii 1999: 205).

${ }^{51}$ Es posible que se tratase de una torre albarrana, a la que posteriormente se le añadiría un segundo arco.

${ }^{52}$ Su nombre se estableció después de la conquista cristiana, ya que su camino conducía a esta localidad (Escudero et alii 1999: 215).

${ }^{53}$ La cimentación de la torre albarrana de Puerta de Gallegos se documentó mediante la Intervención Arqueológica de Urgencia (I.A.U.) a raíz de las obras de construcción de un aparcamiento subterráneo en la Avda. de la Victoria (Escudero et alii 1999: 219).
} 
104-105). Si bien es cierto que la actual imagen de las murallas occidentales de Córdoba corresponde a la reconstrucción idealizada de los años cincuenta, también lo es que dicha reconstrucción ayudó a que estos tramos de muralla perviviesen hasta hoy en día, permitiendo del mismo modo que se puedan llevar a cabo investigaciones referentes al perímetro amurallado de la ciudad.

\section{Conclusiones}

Los proyectos de recuperación y puesta en valor de distintos monumentos antiguos y medievales de Córdoba llevados a cabo durante los años cincuenta del siglo XX contribuyeron en buena medida a remodelar y modernizar la imagen de la ciudad. En la mayoría de los casos estos proyectos, hasta cierto punto ambiciosos para la época, fueron acompañados de un estudio histórico-artístico, generalmente elaborado por los mismos arquitectos encargados de la restauración de los edificios. El mejor ejemplo de ello quizás sea el Alcázar de los Reyes Cristianos, acerca del cual el arquitecto municipal Víctor Escribano Ucelay publicó una monografía bastantes años después de su intervención en el mismo (vid. Escribano 1972). Dichos proyectos no contemplaron la contribución que la Arqueología era capaz de reportar al conocimiento de aquellos emblemas del patrimonio cordobés (algo que tampoco era de extrañar del todo en aquella época).

Sin embargo, una interesante excepción a esta regla la constituye el templo romano de la calle Claudio Marcelo, debido lógicamente a que sus restos no se hallaban emergentes, sino que aparecieron de manera casual bajo unas dependencias municipales anexas a las Casas Consistoriales. En esta ocasión su estudio corrió a cargo del reputado arqueólogo Antonio García y Bellido, si bien la excavación del citado templo la había iniciado Samuel de los Santos Gener, quien contó con el apoyo del arquitecto Félix Hernández. Con sus trabajos sobre el templo cordobés García y Bellido sentó las bases de su conocimiento, que no ha dejado de incrementarse con los años gracias a las sucesivas intervenciones arqueológicas llevadas a cabo en su solar o su entorno. Del mismo modo, con su empeño por reivindicar y recuperar el pasado romano de Córdoba a través de estos vestigios, Cruz Conde se ha convertido en el modelo a seguir de los actuales responsables municipales, que están llevando a su culmen la puesta en valor del edificio.

Ha sido en las últimas décadas del siglo XX y a principios del XXI cuando las investigaciones arqueológicas de estos elementos han adquirido especial protagonismo, por encima o al menos a la par que las labores de restauración arquitectónica, produciéndose por tanto un giro metodológico respecto a la época de Cruz Conde. Las excavaciones han aportado nuevos datos que han ayudado a situar estos monumentos dentro de un marco cronológico y espacial más preciso. Así, uno de los mayores logros de la arqueología cordobesa en los últimos años ha sido el poder establecer una relación entre dichos elementos y su entorno urbano, entendiéndolos a la vez como hitos de diferentes épocas de ese gran yacimiento único que es Córdoba. Esta propuesta adquiere un gran valor si tenemos en cuenta la ocupación continuada de dicha ciudad desde época prerromana.

Pero el estudio de la época de Antonio Cruz Conde nos aporta una conclusión, en cierto modo, desoladora, y que debemos tomar como referencia a la hora de embarcarnos en los actuales proyectos de protección y difusión del patrimonio. Ésta es, que a pesar de contar con el apoyo del gobierno municipal y de un grupo selecto de académicos e intelectuales, las medidas en materia de patrimonio que se ejecuten tan solo tendrán una pervivencia a corto o medio plazo, ya que para que su efecto tenga una repercusión a largo plazo (que es lo deseable), el patrimonio histórico-arqueológico debe de estar respaldado por una amplia mayoría de la sociedad, puesto que es en ella donde reside la tarea última de salvaguarda y protección.

Esto queda especialmente reflejado con posterioridad a 1962, año en el que Cruz Conde abandona la alcaldía de la ciudad. A partir de entonces nos encontramos con un periodo prolongado en el que la insensibilidad social en materia de patrimonio, y sobre todo la absoluta falta indiferencia del Ayuntamiento, así como su mermado conocimiento en la materia, llevaron a Córdoba a sufrir una de las etapas más oscuras en lo que a la arqueología se refiere, quedando patente en hechos tan relevantes como el levantamiento de la Avda. Gran Capitán para la construcción de unos aparcamientos subterráneos, o el 
internacionalmente conocido caso de Cercadillas, cuyos restos arqueológicos fueron sacados a la luz a principios de los 90 como consecuencia de la construcción de la línea de AVE que unía Córdoba con Sevilla.

\section{BiBLIOGRAFía}

Arjona, A. (1982), Anales de Córdoba Musulmana (711-1008). Monte de Piedad y Caja de Ahorros de Córdoba.

Blanco Freijeiro, A. (1959). Polifemo y Galatea. Archivo Español de Arqueología 32: 174-177.

Blázquez J. M. (1981), Mosaicos romanos de Córdoba, Jaén y Málaga, Corpus de Mosaicos de España, III, Madrid. CSIC.

Carmona, S y Courault, C. (2011), 'Las murallas, como límite' en Baena, M.D; Márquez, C; Vaquerizo, D (eds.), Córdoba, Reflejo de Roma, Diputación Provincial de Córdoba: 209-212.

Castejón, R. (1929), Córdoba Califal. Boletín de la Real Academia de Córdoba 25: 256-339.

Castejón, R. (1961-1962), Excavaciones en el Alcázar de los Califas. AL-MULK 2: 240-253.

Castejón, R. (1963), Excavaciones en Córdoba para localizar las tumbas de los califas. Noticiario Arqueológico Hispánico 7: 229-235.

Castejón, R. (1964-1965), Las excavaciones en el Alcázar de Córdoba. AL-MULK 4: 163-165.

Escribano, V. (1972), Estudio histórico artístico el Alcázar de los Reyes Cristianos de Córdoba. Monte de Piedad y Caja de Ahorros de Córdoba.

Escudero, J. et alii (1999), 'Las murallas de Córdoba (el proceso constructivo de los recintos desde la fundación romana hasta la Baja Edad Media)' en García Verdugo, F y Acosta, F (Coord.), Córdoba en la Historia. La construcción de la Urbe. Ayuntamiento de Córdoba: 201-224.

García y Bellido, A. (1958), El sarcófago romano del Brillante (Córdoba). Zephyrus 9: 237-241.

García Y Bellido, A. (1959), El sarcófago romano de Córdoba. Archivo Español de Arqueología 32, no 99100: 3-37.

García y Bellido, A. (1961), Crónica de Arte y Arqueología. El templo romano de Córdoba. Boletín de la Real Academia de Córdoba 81: 213-217.

García y Bellido, A. (1970), Los hallazgos cerámicos del área del templo de la calle Claudio Marcelo en Córdoba, Madrid. CSIC.

Garriguet, J.A. (2007), 'La decoración escultórica del templo romano de las calles Claudio MarceloCapitulares y su entorno (Córdoba). Revisión y novedades' en Nogales, T y González, J (eds.), Culto Imperial: política y poder, Mérida. L’Erma di Brestschneider: 301-321.

Garriguet, J.A. y Montejo, A.J. (1998), 'El Alcázar de los Reyes Cristianos de Córdoba' Actas del I Congreso de Castellología Ibérica, Aguilar de Campo. Diputación Provincial de Palencia: 345-364.

Jiménez, J.L. (1990), Arquitectura religiosa romana en Corduba-Colonia Patricia: panorama y perspectivas. Anas 2/3: 77-86.

Jiménez, J.L. (1991), El templo romano de la calle Claudio Marcelo en Córdoba. Cuadernos de arquitectura romana 1: 119-132.

Jiménez, J.L. (1996), 'El templo romano de la calle Claudio Marcelo en Córdoba: aspectos cronológicos, urbanísticos y funcionales' en León, P (Ed.), Colonia Patricia Corduba: una reflexión arqueológica, Sevilla. Consejería de Cultura de la Junta de Andalucía: 29-153.

Jiménez, J.L. (2004), 'El templo romano de Córdoba' en Blázquez, J y Pérez, M (eds.), Antonio García y Bellido y su legado a la Arqueología Española (1903-1972), Madrid. Miscelánea: 159-171.

Jiménez, J.L y Ruiz, M.D. (1999), 'La contribución del templo de la calle Claudio Marcelo al conocimiento de la fisonomía urbana de Colonia Patricia Corduba' en García, F y Acosta, F (Coord.), Córdoba en la Historia. La construcción de la Urbe. Ayuntamiento de Córdoba: 217-220.

Jiménez, J.L. y Gutiérrez, M.I. (2011), 'El templo de la calle Claudio Marcelo' en Baena, M.D; Márquez, C; Vaquerizo, D (eds.), Córdoba reflejo de Roma, Diputación Provincial de Córdoba: 221-224. 
León, A. (2003), La Calahorra, o el puente fortificado de Córdoba en época califal. Anales de Arqueología Cordobesa 13-14: 391-425.

León Muñoz, A., León Pastor, E yMurillo, J.F. (2008), 'El Guadalquivir y las fortificaciones urbanas de Córdoba', Actas del 4o Congreso Internacional sobre fortificaciones. Las fortificaciones y el mar. Alcalá de Guadaíra: 261-290.

León, A. y Blanco, R. (2010), 'La fitna y sus consecuencias. La revitalización urbana de Córdoba en época almohade' en Vaquerizo, D; Murillo, J.F. (eds.), El Anfiteatro Romano de Córdoba y su entorno urbano. Análisis Arqueológico (ss. I-XIII). Monografías de Arqueología Cordobesa 19 Vol. I-II. Universidad de Córdoba: 699-726

Mañas, I. (2011), 'Mosaicos en Colonia Patricia Corduba' en Baena, M.D; Márquez, C; Vaquerizo, D. (eds.), Córdoba reflejo de Roma. Diputación Provincial de Córdoba: 156-169.

Marfil, P. (2004), 'Los baños del Alcázar Califal de Córdoba. Resultados de la intervención arqueológica desarrollada en el año 2000' en Gómez Navarro, S (Coord.), El agua a través de la historia, Córdoba. Asociación Arte Arqueología e Historia: 51-75.

Márquez, C. (1998), La decoración arquitectónica de Colonia Patricia. Una aproximación a la arquitectura y urbanismo de la Córdoba romana. Universidad de Córdoba. Obra Social y Cultural de CajaSur.

Montejo, A. (2006), La rauda del Alcázar de Córdoba. Anales de Arqueología Cordobesa 17: 237-256.

Murillo, J.F. et alii (2003), El templo de la C/ Claudio Marcelo (Córdoba). Aproximación al foro provincial de la Bética. Romula 2: 53-88.

Murillo, J.F. et alii (2011), Investigaciones Arqueológicas en la Muralla de la Huerta del Alcázar. Anejos de Anales de Arqueología Cordobesa 2: 183-230.

Navarro, J; Jiménez, P. (2005), 'La yesería en época almohade' en Cressier, P; Fierro, M; Molina, L (eds.), Los almohades: problemas y perspectivas, vol. 1, Madrid. CSIC: 249-303.

Neira, L. (2011), 'El mito extramuros' en Baena, M.D; Márquez, C; Vaquerizo, D (eds.), Córdoba, Reflejo de Roma, Diputación Provincial de Córdoba: 278-280.

Ocaña, M. (1984), El origen de la yesería andalusí a juzgar por un hallazgo olvidado. Boletín de la Real Academia de Córdoba 106: 139-147.

Ocaña, M. (1990), Panorámica sobre el arte almohade en España. Cuadernos de la Alhambra 26: 91-112.

Orti Belmonte, M.A. (1966), Córdoba monumental, artística e histórica. Diputación Provincial de Córdoba.

Primo Jurado, J.J. (2005), Antonio Cruz Conde y Córdoba. Memoria de una gestión pública (1951-1967). Ayuntamiento de Córdoba.

Redondo, E. (2013), La restauración de las murallas de Córdoba y el proceso de construcción de la nueva fachada urbana en los años cincuenta del s. XX, León, A (Dir.) Trabajo Fin de Máster en Arqueología y Patrimonio. Ciencia y profesión, Universidad de Córdoba. Inédito.

Rueda, F.J. (2015-2016), El templo romano de Córdoba. Una revisión historiográfica en torno a su investigación, interpretación y puesta en valor. Arte, Arqueología e Historia 22: 151-162.

Ruiz, A.B. (2005), La via sepulchralis occidental: un ejemplo de monumentalización funeraria en Colonia Patricia. Anales de Arqueología Cordobesa 16: 79-104.

Salinas, E; Martín, I; León, A. (2009), 'Los contextos cerámicos almohades en el recinto fortificado de la Calahorra', Actas del VIII Congreso Internacional de Cerámica Medieval, Ciudad Real: 1035-1040.

Santos Gener, S. (1950), Corduba Marcelli aedificium. Boletín de la Real Academia de Córdoba 21: 135162.

Santos Gener, S. (1954), Notas para la historia del Alcázar Nuevo de los Reyes Cristianos de Córdoba. Revista de Archivos, Bibliotecas y Museos 60.2: 579-594.

Santos Gener, S. (1955), Memoria de las excavaciones del Plan Nacional, realizadas en Córdoba (19481950). Madrid.

Solano, F. (2007), La Córdoba de Antonio Cruz Conde. El alcalde que cambió la ciudad, Córdoba. Almuzara 
Vaquerizo, D; Garriguet, J.A; Murillo, J.F. (2011), 'Novedades de arqueología en Corduba, Colonia Patricia' en González, J y Pavón, P (eds.), Colonias de César y Augusto, Roma. L’Erma di Bretschneider: 9-46.

Ventura, A. (2011), 'Caracterización de la Córdoba romana, de sus funciones, fundadores y funciones' en Baena, M.D; Márquez, C; Vaquerizo, D. (eds.), Córdoba, Reflejo de Roma. Diputación Provincial de Córdoba: 28-40.

Wickham, C. (2009), Una historia nueva de la Alta Edad Media. Europa y el mundo mediterráneo, 400800 , Barcelona. Crítica. 


\title{
El estudio de la cerámica numantina durante el primer tercio del siglo XX
}

\author{
Álvaro Sánchez Climent \\ Universidad Complutense de Madrid
}

\section{Introducción: las primeras excavaciones en Numancia}

A pesar de que fue a finales del siglo XIX cuando comenzaron las primeras intervenciones en la ciudad de Numancia, existía desde tiempos muy remotos un cierto interés por parte de algunos eruditos e historiadores en localizar geográficamente las ciudades que se nombraban en las fuentes clásicas. Una de estas ciudades, por supuesto, fue Numancia, en la cual, en un primer momento, no hubo un cierto consenso en su ubicación geográfica o a qué pueblo pertenecía.

A partir del siglo XVIII, algunos autores como Florian de Ocampo o el Padre Flórez no dudaron de la atribución soriana de Numancia. De hecho, a Juan de Loperráez le debemos el primer plano documentado de Numancia y sus ruinas visibles y que publicó en su obra Descripción histórica del obispado de Osma en 1788. Pese a estas primeras publicaciones sobre Numancia y sus restos arqueológicos, no fue hasta el siglo XIX cuando se realizaron las primeras excavaciones en la ciudad.

La primera excavación arqueológica de la que se tiene constancia se llevó a cabo en 1803 auspiciada por el ayuntamiento de Soria y la Sociedad Económica Numantina en un intento por buscar las inscripciones que permitieran relacionar la lengua de los numantinos con la vasca. Si bien, pese a estos primeros trabajos, no fue hasta mediados del siglo XIX cuando encontremos un verdadero trabajo de excavación dirigido por E. Saavedra entre los años 1861 y 1867.

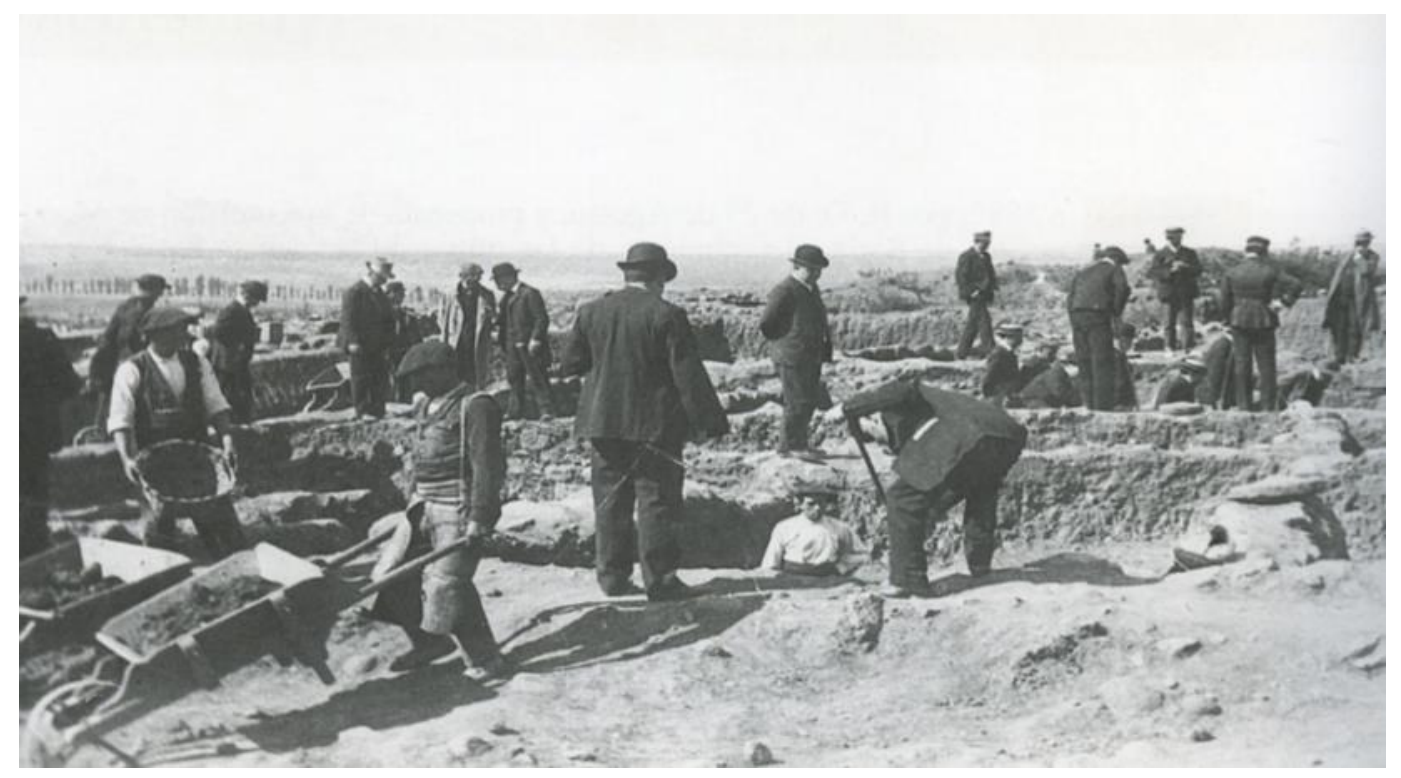

Fig. 1. Excavaciones practicadas en el cerro de La Muela (Garray, Soria) durante la Comisión de Excavaciones Arqueológicas (1906-1923). Fuente: www.numanciasoria.es

En 1882 el yacimiento arqueológico fue declarado Monumento Nacional. No obstante, las excavaciones arqueológicas no se retomarían hasta años más tarde de la mano de A. Schulten (1870-1960) que, bajo el patrocinio del Káiser Guillermo II, realizó diversas excavaciones durante el año 1905. Sin embargo, una 
opinión enfrentada a la excavación por parte de extranjeros provocó que en 1906 se constituyera la Comisión de Excavaciones Arqueológicas (Fig.1). Pese a todo, Schulten, como protegido de Saavedra, continuó con las excavaciones, si bien fuera de la ciudad, excavando los campamentos romanos y el cerco de Escipión entre los años 1906 y 1912. Al autor alemán le debemos su serie en cuatro volúmenes titulada Numantia (1914-1931).

Como ya hemos comentado, en 1906, paralelamente a los trabajos de Schulten, se organiza una Comisión de Excavaciones Arqueológicas auspiciada por la Real Academia de la Historia y dirigida en un primer momento por E. Saavedra (1829-1912) hasta su muerte. A partir de este momento J. R. Mélida (18561933) se puso al frente de la Comisión de Excavaciones, enfocando todos sus esfuerzos en la excavación de la ciudad, dejando al descubierto unas 11 hectáreas, teniendo lugar, a partir de este momento, las primeras publicaciones sobre las estructuras habitacionales de la ciudad, así como también una serie de publicaciones recogiendo algunas notas sobre cerámica numantina haciendo alusión a la tecnología y exponiendo abundante material fotográfico de la cultura material. Fue, por lo tanto, a partir de este momento cuando comenzaron a aparecer las primeras publicaciones sobre la cerámica de Numancia. Durante estos años se fundaría, además, el Museo Numantino en la localidad de Soria con el objetivo de recoger y estudiar los restos arqueológicos hallados en la ciudad.

\section{El estudio de la cerámica numantina: de origen micénico a la primera tipología}

Una de las primeras publicaciones a la que haremos referencia es la publicación de H. Breuil (1877-1961) y J. Cabré (1882-1947) Sur l'origine de quelques motifs ornamenteaux de la céramique peinte d'Aragon, publicada en la Bulletin hispanique, 13 (3) en 1911. Dichos autores, de sobra conocidos, fueron dos de los grandes arqueólogos y prehistoriadores de su tiempo. Breuil es bien conocido por una incesante labor investigadora en el estudio del arte rupestre nacional. Además del estudio del arte rupestre de la cámara de los polícromos de Altamira, fue uno de los primeros en describir los motivos esquemáticos de los abrigos de pintura rupestre de Peña Escrita y Chorrera de los Batanes (Fuencaliente, Ciudad Real) y la cueva de Santimamiñe (Vizcaya, P. Vasco), entre otros.

Por su parte, Juan Cabré, originario de Calaceite (Teruel), fue también uno de los grandes arqueólogos del momento, ejerció su trabajo en diversas necrópolis de incineración como las necrópolis de La Osera (Ávila) y la de Altillo del Cerropozo (Guadalajara), siendo también documentalista en varias excavaciones del marqués de Cerralbo como, por ejemplo, la necrópolis celtibérica de Navafría (Clares, Guadalajara), entre otras.

Estos primeros trabajos relacionados con la cerámica de Numancia no se centraron en cuestiones tipológicas y/o tecnológicas, sino que en estos primeros momentos los estudios se relacionaron mayoritariamente en las ornamentaciones de los vasos. No es de extrañar que estos primeros estudios se centraran principalmente en los motivos decorativos, pues estos arqueólogos dedicaron gran parte de sus estudios al arte rupestre, siendo el principal campo de investigación de H. Breuil. Cabré, por su parte, aunque centró gran parte de sus esfuerzos en la excavación de necrópolis de incineración, sí que realizó algún estudio posterior sobre arte rupestre como el de la cueva de los Casares (Riba de Salices, Guadalajara) (Cabré Aguiló 1934a, 1934b, 1935 y 1940; Cabré Aguiló y Cabré Herreros 1936).

La teoría imperante por aquel entonces en relación a las decoraciones de los vasos cerámicos era el de establecer un origen micénico para dichas ornamentaciones, teorías auspiciadas por P. Paris (1859-1931) a partir de su Essai sur l'art et l'industrie d'Espagne primitive I-II (1903-1904). ${ }^{1}$ En dicho ensayo Paris analiza diversas cerámicas arqueológicas procedentes de varios yacimientos de la Península Ibérica como,

\footnotetext{
1 'En ce qui concern la technique de la painture, dabord que les decorateurs de nos vases n'ont aucune époque connu le secret du vernis quil donne à la céramique de l'age d'or Gréce (...) les potiers ibères doivent étre mis cela su la mème rang que les Phéniciens, les Chypriotes, les Carthaginois et les Grees archaïques, depuis les Mycéniens jusqu'au VI siècle', (Paris 1903-1904: 111).
} 
por ejemplo, los vasos ibéricos del Cerro de los Santos (Montealegre del Castillo, Albacete), así como de otros yacimientos arqueológicos del sureste peninsular. Teoría que, por otra parte, pese a carecer de base científica suficiente, causó fortuna. Si bien, algunos autores se mostraron reacios a aceptarla.

Volviendo a la obra de Breuil y Cabré, ambos abordaron una evolución de los motivos pintados de los vasos numantinos a partir de la abstracción y esquematización de los caballos, estableciendo una evolución cronológica desde los motivos más naturalistas hasta los más esquemáticos (Fig. 2). Para ello se basan en el análisis de tres tipos de motivos decorativos: los caballos de perfil, que evolucionarían a los espirales, los caballos de frente que darían lugar a la representación de motivos triangulares y, por último, los 'petit chevaux' o caballitos alternos que pasarían a ser a los motivos de tipo serpentiforme o meandros (Breuil y Cabré 1911: 255 y ss.)

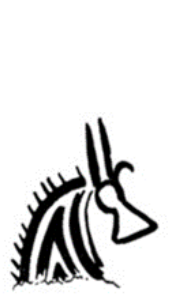

Fig. 2, $\mathrm{n}^{\circ}$,

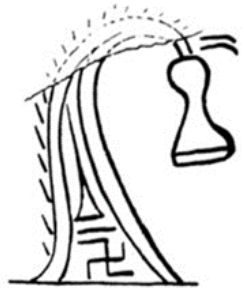

Fig. 2, $\mathrm{n}^{\circ}$,

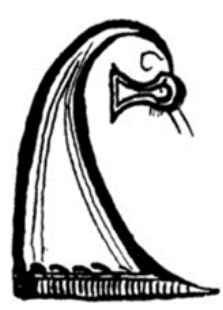

Fig. 2, n०3.

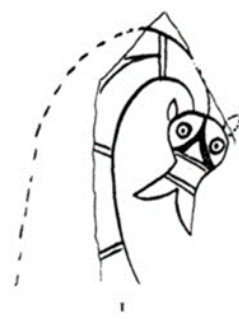

B
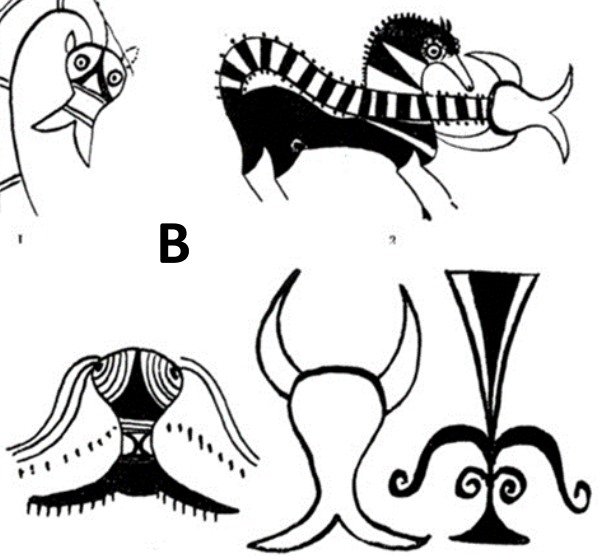

Fig. 2. Motivos de caballo (y su evolución) en los vasos numantinos según Breuil y Cabré (1911: 255). A: estilización de los caballos de perfil. B: estilización de los caballos de frente.

Una de las revistas que más interés alcanzó durante esta etapa, fue la revista de la Sociedad de Amigos del Arte, denominada Arte español, y que tuvo una larga trayectoria entre los años 1912 y 1969, año este último de cese de publicación. La revista reúne trabajos relacionados con la arquitectura, cerámica, escultura, pintura, exposiciones, etc. En un principio la revista comenzó teniendo carácter trimestral, no obstante, a partir de 1942 pasa a ser cuatrimestral. Es interesante destacar que entre los años 1932 y 1936 la revista pasó a denominarse Revista española de arte. Si bien tuvo un parón con motivo de la Guerra Civil entre 1936 y 1939, en 1941 retomó su publicación hasta 1969, cuyo último ejemplar fue el tomo 26, volumen 19-20, número 3. Del primer tercio del siglo XX, solamente podemos destacar dos publicaciones relacionadas con la cerámica de Numancia, ambas de 1913: La estilización del caballo en la cerámica de Numancia de A. Rioja de Pablo y La cerámica numantina de J.R. Mélida.

J.R. Mélida, nacido en Madrid en 1856, junto con Cabré y Breuil, también fue otro de los grandes arqueólogos de su tiempo. Director del Museo Arqueológico Nacional entre 1916 y 1930, dirigió campañas de excavación en Mérida y, como hemos hecho referencia anteriormente, en Numancia. Si bien inicialmente las primeras publicaciones mostraban un cierto interés por las ornamentaciones de los vasos, es decir, al estudio decorativo de los mismos y al intentar establecer el origen de las cerámicas y una secuenciación cronológica, Mélida, si bien hace referencia también a la riqueza decorativa de los vasos, en dicha publicación se centró en cuestiones más tecnológicas. Dicho autor no hace una clasificación tipológica de las cerámicas al uso, aunque habla de las formas y de la tecnología de los vasos. Distinguió entre tres modelos de cerámica en función de la manufactura: las cerámicas 'negras' que las consideraba como las más primitivas, pues solamente estaban decoradas con motivos de rayas y círculos incisos (al contrario de la riqueza pictórica de la cerámica pintada); en segundo lugar las 'lisas', sin decorar, y, en 
tercer lugar, las 'rojas' que se caracterizaban por ser más abundantes y profundamente decoradas, incidiendo en la gran variedad de las formas y en su gran riqueza iconográfica. No obstante, al no tratarse de una publicación de gran extensión, no se detiene demasiado en las características de las cerámicas, si bien es consciente de su peculiaridad y de su calidad, pues 'el barro no solamente sirvió para la fabricación de las vasijas, sino que suplió la falta de escasez de otras materias primas para la confección de utensilios varios, y hasta armas' (Mélida 1913: 216).

El segundo artículo al que haremos referencia versa sobre la estilización del caballo en los vasos cerámicos numantinos de A. Rioja de Pablo. Se trata de un breve artículo muy continuista con respecto a la obra de Breuil y Cabré, artículo que, por cierto, cita equivocadamente, pues el autor hace referencia a la Revue hispanique, revista parisina vinculada al hispanismo y publicada entre los años 1894 y 1933, y que rivalizó con la Bulletin hispanique de la Universidad de Burdeos, revista esta última donde fue publicada la obra de Breuil y Cabré, y que hemos visto en párrafos anteriores. El autor de este artículo, básicamente, repite las mismas ideas de Breuil y Cabré haciendo referencia a la estilización del caballo en los vasos cerámicos, los cuales los caballos de perfil darían lugar a los motivos en forma de espiral, mientras que los caballos de frente evolucionarían a los motivos metopados triangulares. La gran abstracción de los caballitos daría lugar a la aparición de los meandros o serpentiformes siendo para Rioja de Pablo 'ideas para representar una serie de caballos de carreras' (Rioja de Pablo 1913: 215). No obstante, la gran aportación de este autor es la negativa a aceptar las teorías del momento que consideraban al arte de los vasos decorativos ibéricos como micénicos, como ya hemos visto anteriormente: 'de la comentada influencia del arte Micenario en la civilización ibérica, particularmente en la cerámica de este pueblo, tan universalmente admitida, sin que se conozca a alguien que se atreva á (sic) discutirla, mi insignificante personalidad tiene sus pequeñas dudas (...)' (Ibídem: 212). Para demostrar su negativa a aceptar las teorías sobre el origen micénico de los motivos decorativos, aportó una serie de láminas confeccionadas por él mismo de algunos de los motivos presentes en los vasos cerámicos. Al igual que Breuil y Cabré, este autor refleja la evolución cronológica de los motivos decorativos de la cerámica numantina a partir de la estilización de los caballos.

En un primer momento tuvimos dudas sobre la autoría de este artículo, pues no es una personalidad conocida dentro de los estudios prehistóricos de este primer tercio del siglo XX. Tras buscar información sobre dicho autor, descubrimos que se trataba de Aurelio Pérez Rioja de Pablo (1888-1949), fotógrafo soriano, cuyo trabajo se centró principalmente en el reflejo de la sociedad rural soriana a través de la fotografía. ${ }^{2}$ Alejado, por lo tanto, de la arqueología, mostró gran interés por la obra de H. Breuil y J. Cabré y por la cerámica de Numancia hasta el punto de mostrar sus preocupaciones por el origen del arte decorativo de los vasos numantinos (Fig. 3).

Poco después de la publicación de estos autores, en 1914, y como consecuencia del trabajo publicado por Breuil y Cabré en la revista Bulletin hispanique, P. Paris, del que ya hemos hecho mención anteriormente, publicó La céramique de Numance en la revista Revue de l'art ancien et moderne, número 36 (1914-1919) y que fue una clara respuesta a las interpretaciones de ambos autores.

P. Paris, arqueólogo e hispanista francés, fue miembro del Instituto de Francia. Realizó una incesante labor en diversos yacimientos arqueológicos del sureste peninsular y contribuyó a la fundación de la Bulletin hispanique. Fue también director de la Casa Velázquez de Madrid en 1928 y fue protagonista de, quizás, una de las anécdotas más conocidas, pues fue el impulsor de la venta de la Dama de Elche al Museo del Louvre, París. Como ya hemos comentado, este artículo fue una más que dura respuesta a la publicación de Breuil y Cabré de 1911, pues realizó duras críticas a ambos calificando su obra de una singular y

\footnotetext{
${ }^{2}$ Para más información sobre Rioja de Pablo, vid. Pérez Frías, T. (2011), Aurelio Pérez Rioja de Pablo: artista fotógrafo (1888-1949), Soria. Diputación Provincial de Soria.
} 
forzada adivinación sus interpretaciones. ${ }^{3}$ Exalta la gran belleza de los vasos numantinos, defendiendo, como ya explicábamos anteriormente, sus teorías sobre el origen micénico de las cerámicas ibéricas.
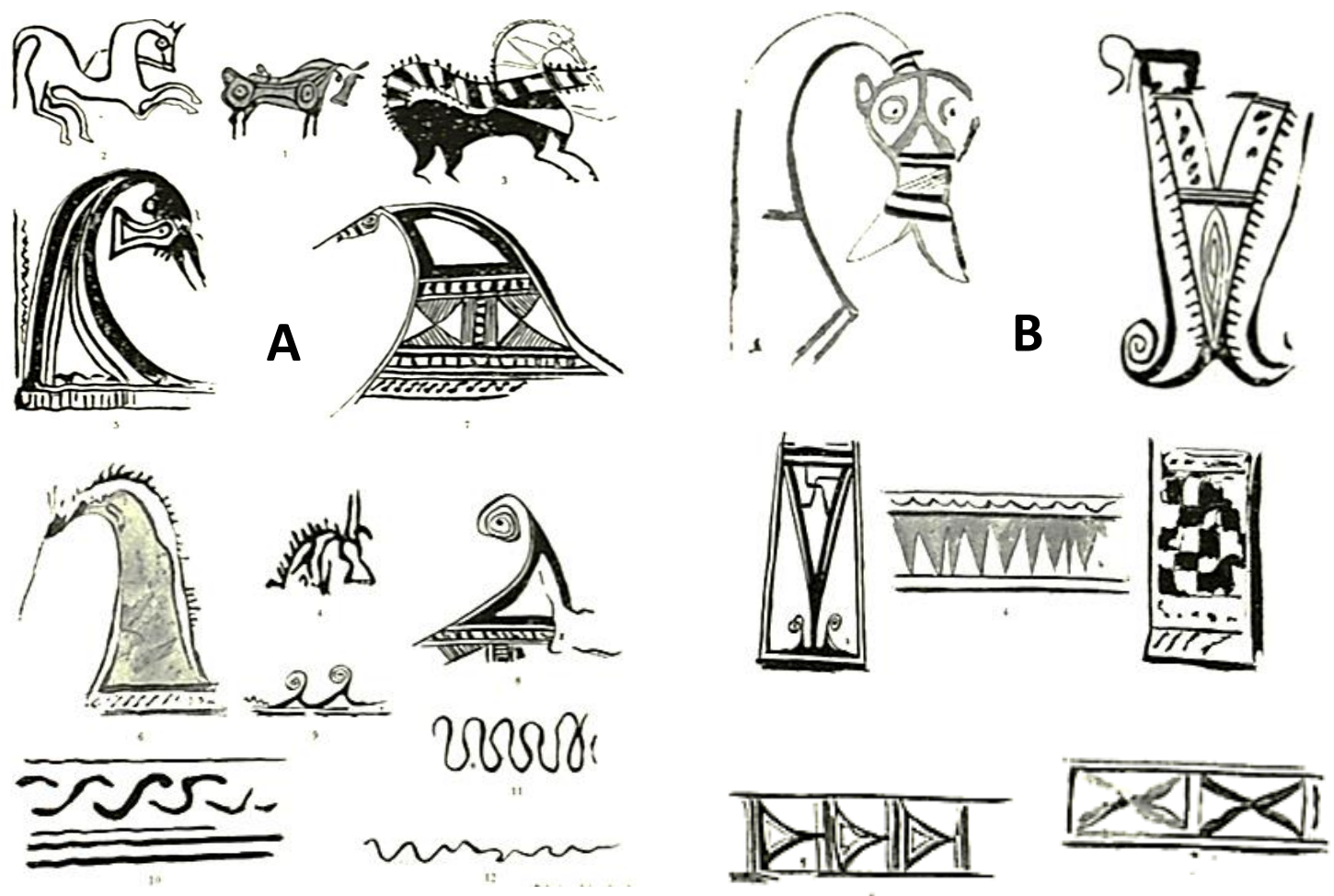

Fig. 3. Prótomos de caballo y su estilización. Rioja de Pablo (1913: 213). A: caballos de perfil que darían lugar a espirales. B: caballos de frente que darían lugar a motivos triangulares.

A partir de 1915 entra en escena otro autor, procedente del ámbito académico, y que influyó de manera decisiva en los estudios arqueológicos posteriores. P. Bosch Gimpera (1891-1974), considerado como una de las figuras que más ha influido en los estudios de la Prehistoria hispana, fue uno de los grandes catalizadores de las tesis invasionistas siguiendo la misma estela iniciada por Schulten años antes. De formación filológica clásica, no fue hasta su estancia en Alemania cuando mostró gran interés por la Arqueología y la Prehistoria, doctorándose con la tesis dirigida por Mélida y defendida en 1913 bajo el título El problema de la cerámica ibérica (cuya revisión la realizó a mediados de los años 50 desde el exilio con la obra Todavía el problema de la cerámica ibérica) a partir del debate suscitado por Paris sobre el origen micénico de las producciones cerámicas de la Edad del Hierro en la Península Ibérica.

En dicho trabajo Bosch Gimpera habla de la cerámica ibérica en su conjunto haciendo especial mención a la cerámica procedente de lo que actualmente se considera la Celtiberia nuclear y sus extensiones: la 'región aragonesa y sus extensiones' focalizada principalmente en el valle medio e inferior del Ebro y la 'región castellana' dividiendo ésta última en dos sectores claramente diferenciados, uno meridional correspondiente a las zonas bajas surorientales de la provincia de Soria, en la comarca del Alto Jalón

\footnotetext{
${ }^{3}$ M. Le abbé Breuil, don ton connaît l'ingénieuse subtilité à éclaircir les mystères des peintures et gravures prehistoriques, a expliqué les processus de la stylisation numantine de la tête et del l'encolure du cheval vues de profil, puis de face, et ses explications sont définitives. (...). Il faut la force de divination singulière de l'abbé Breuil pour retrouver (...) (Paris 1914-1919: 12 y ss.).
} 
internándose hacía la provincia de Guadalajara y la serranía conquense y uno septentrional, con la provincia de Soria como núcleo principal, incluyendo Palencia junto a los 'despoblados', es decir, restos de poblaciones antiguas de las provincias de Segovia, Ávila, Salamanca y León. En dicho trabajo habla sobre la gran riqueza ornamental y tipológica de los vasos numantinos. Una de las grandes aportaciones de Bosch Gimpera en relación a esta cerámica es su cronología, pues para dicho autor la afinidad tipológica con algunos materiales arqueológicos procedentes de las necrópolis excavadas por Cerralbo podría tener continuidad en el oppidum. Si bien, no propone una fecha de origen para la cerámica numantina, su final parece estar muy claro: año 133 a.C., fecha de conquista de la ciudad por las huestes romanas.

En 1918 aparece en escena la publicación de E. Pottier (1855-1934) que no publicó un artículo muy extenso, ni tampoco exclusivo de la cerámica de Numancia, Le problème de la céramique ibérique en la Journal des Savants, número 16. No obstante, es interesante destacar esta publicación porque dicho autor propuso el abandono del origen micénico para la cerámica ibérica: 'creo que se debería renunciar a la idea de una supervivencia micénica en la decoración de los recipientes' 4 y que supone una dura crítica a las teorías de P. Paris. Esta reinterpretación la basa a partir de diversas excavaciones que se estaban realizando en las ciudades de Numancia y Ampurias, y cuya estratigrafía impedía la asociación de las cerámicas ibéricas a las cerámicas de influencia micénica, planteando, por lo tanto, influencias egeas para este arte figurativo a partir de las colonizaciones de los pueblos del Mediterráneo Oriental, poniendo énfasis en la capacidad de las poblaciones indígenas en la creación de su arte ornamental propio como consecuencia de esas influencias mediterráneas.
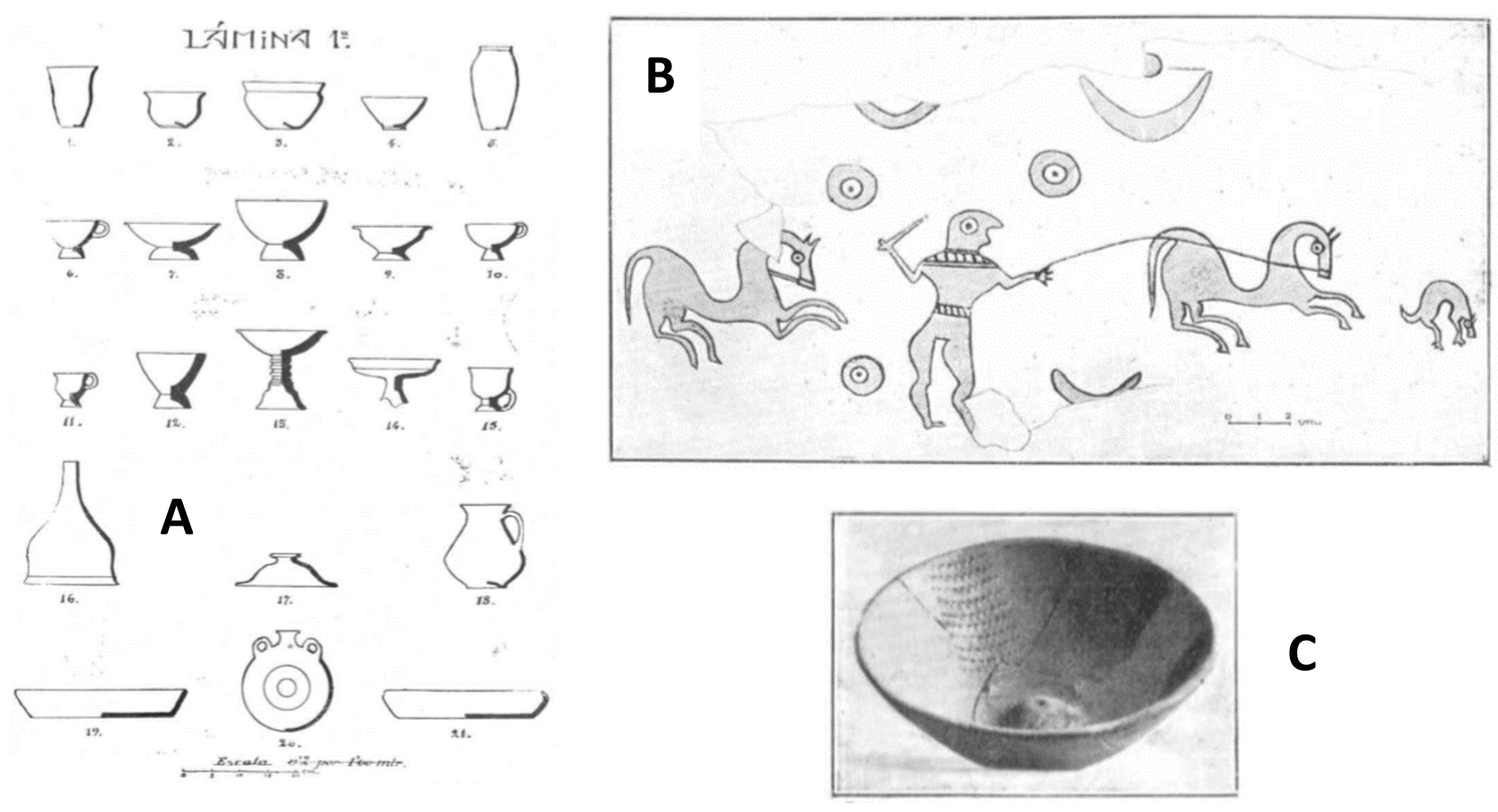

Fig. 4. Algunas láminas presentes en la obra de Taracena (1924). A: lámina 1 de su clasificación tipológica. B: Motivos decorativos de un vaso con decoración polícroma. C: fotografía de un cuenco para rallar.

Desde que Mélida fue el responsable de la Comisión de Excavaciones Arqueológicas a partir de 1912, publicó varios trabajos sobre los resultados obtenidos en las diversas campañas de excavación: las memorias de excavaciones de Numancia (1912 y 1915), parte de las cuales las publicó con B. Taracena

${ }^{4}(\ldots)$ je crois devoir abandonner cette idée d'une survivance mycénienne dans le décor des vases. (Pottier 1918: 283). 
(1917-1923). Quizás, las más interesantes en relación al tema que nos ocupa son la Cronología de las antigüedades anterromanas (1916), donde hace referencia a la amplia cronología de Numancia que podría extenderse desde el Neolítico con la aparición de hachas pulimentadas, hasta la conquista de la ciudad en el 133 a.C., y la Excursión a Numancia pasando por Soria (1922), exponiendo en esta última una revisión concienzuda sobre la historia de Numancia y su arqueología, siendo minuciosamente descriptivo con cada una de las estancias del oppidum celtibérico, así como los campamentos romanos que sitiaron la ciudad durante dos décadas. Además, recoge la descripción de algunos monumentos de Soria y de los materiales expuestos en el Museo Numantino, fundado algunos años antes de esta publicación. En el capítulo donde describe las diversas estancias y colecciones del Museo Numantino, dedica un pequeño epígrafe a las industrias ibéricas (Mélida 1922: 253 y ss.) en el que habla sobre diversos hallazgos numantinos, mostrando especial interés en la cerámica y en el 'arte ibérico' sobre la calidad decorativa y cromática de los motivos plasmados en los vasos numantinos, junto con otros representantes del arte celtibérico como, por ejemplo, la coroplastia. Dicho autor distingue, además, diferentes tipos cerámicos en función de la manufactura y la calidad de la pasta, en consonancia con su publicación de 1913, pero con mayor extensión y detalle. Distinguió principalmente dos tipos de cerámica en función de su fabricación: cerámica a mano y cerámica a torno, esta última con dos modelos claramente diferenciados: la roja, muy abundante, de muy buena calidad y profundamente decorada; y la blanca, cerámica de pasta más fina y menos decorada en la que hace referencia a algunas formas cerámicas como las tinajas, queseras, jarras, etc. destacó además los jarros de tipo oinochoe, y unos recipientes de morfología cilíndrica que él mismo denominó como jarra bock debido a su semejanza con las jarras alemanas de cerveza o humpen, y cuya terminología, para ese tipo de recipientes, se ha mantenido hasta nuestros días, un tipo de cerámica que él mismo consideró como exclusivo de Numancia; si bien excavaciones posteriores en ciudades celtibéricas como Segontia Lanka y Castilterreño de Izana revelaron que esta forma cerámica no era exclusiva del oppidum, aunque sí a un área de influencia numantina.

A pesar de que estas primeras publicaciones ya mostraron un gran interés y fascinación por la peculiaridad de la cerámica peninsular, y en especial por la cerámica de Numancia, no fue hasta la publicación de la memoria de Tesis Doctoral de B. Taracena (1895-1951) La cerámica ibérica de Numancia (1924) cuando asistimos al primer monográfico dedicado exclusivamente a la cerámica de esta ciudad, acudiendo, por lo tanto, a un verdadero interés tipológico por esta cerámica más allá de cuestiones puramente ornamentales y/o tecnológicas. La obra de Taracena se considera como una de las primeras tipologías propiamente dichas, es decir, una de las primeras sistematizaciones en tablas tipológicas de las formas cerámicas de un yacimiento celtibérico. Taracena sigue mostrando interés por la tecnología y los motivos decorativos, pero ahora se ordenan las formas cerámicas en tablas 'poniéndolas a contribución para clasificar cronológicamente la interesantísima cerámica de esta ciudad' (Taracena 1924: 12), considerando la producción cerámica de esta ciudad con un gran interés científico 'que ha producido hallazgos más numerosos e interesantes para el estudio de la cerámica de nuestros antepasados de los últimos siglos antes de J.C.' (Ibídem: 1). Pese a que esta obra constituye, por lo tanto, la primera ordenación sistematizada de la cerámica celtibérica (Fig. 4) y estuvo focalizada a un yacimiento en particular, la obra de Taracena supuso un auténtico referente para futuras investigaciones en este yacimiento y en otros, siendo, además, el culmen en la investigación en la cerámica de Numancia durante este periodo. La labor arqueológica de Taracena es de sobra conocida, pues realizó un incesante trabajo en diversos yacimientos arqueológicos en Soria (además de otras provincias), pues soriano era de nacimiento, excavando diversas necrópolis celtibéricas como las de Monteagudo de las Vicarías, La Mercadera, Almaluez, etc. Y en algunos poblados como, por ejemplo, Segontia Lanka, Castilterreño de Izana y los Castillejos de Ocenilla, entre otros. También fue director del Museo Arqueológico Nacional desde 1939 hasta su fallecimiento en febrero de 1951.

El monográfico de Taracena se divide en cuatro apartados: técnicas de fabricación, forma de los vasos, decoración y cronología. Divide las cerámicas en dos grupos a lo largo de varias tablas de clasificación y láminas en función de su técnica de fabricación: las cerámicas de fuego reductor y las cerámicas de pasta clara, es decir, de cocción oxidante, siendo estas últimas las que mayor variedad tipológica y decorativa 
presentan. Estas cerámicas de pasta clara, a priori las más interesantes, las divide en dos grupos en función del color de la misma: las cerámicas de pasta roja y los vasos de tonalidad 'gris blancuzca'. En cuanto a los motivos decorativos de esta cerámica gris; destacan los vasos de decoración polícroma caracterizados con decoraciones de mayor naturalismo y diversas tonalidades, abarcando desde las más amarillentas hasta las rojizas y negras. La tipología de los motivos es muy variada, destacando las decoraciones de zoomorfos (caballos, aves, peces, etc.). Posteriormente, se encontrarían los vasos de pasta roja sin decoraciones y, por último, los vasos rojos con motivos abstractos monocromos, estos últimos básicamente compuestos a base de geométricos, siendo este último el grupo más variado y rico de la cerámica numantina.

En cuanto a la cronología de los vasos, quizás uno de los aspectos más interesantes de la obra de Taracena, dicho autor fue tajante al respecto al establecer paralelismos tipológicos con cerámicas del Mediterráneo Oriental en los motivos decorativos y relacionándolas con las cerámicas procedentes de algunos yacimientos arqueológicos del área mediterránea como Emporiae y Massalia, planteando, por lo tanto, un origen indígena para este tipo de cerámicas (en consonancia con otros autores contemporáneos) y bañadas de una fuerte influencia en el desarrollo artístico procedente del Mediterráneo Oriental y patente en otros yacimientos celtibéricos, como en el caso de la necrópolis de Arcóbriga, proporcionando un lapso cronológico que abarcaría desde las primeras cerámicas polícromas de pasta grisácea y motivos decorativos más naturalistas, hasta las cerámicas de pasta roja con decoraciones monocromas y con mayor presencia de geométricos y motivos abstractos, siendo estas últimas las contemporáneas a la presencia romana en Celtiberia y que se encontrarían en los niveles de incendio proponiendo como fecha segura el 133 a.C., momento final de la conquista de la ciudad.

\section{El final de una etapa y el comienzo de otra}

Con la obra de Taracena podemos poner punto y final al estudio de la cerámica de Numancia para este primer tercio del siglo XX. Tras la obra de Taracena y el final de la Comisión de Excavaciones Arqueológicas en 1923, solamente se llevaron a cabo algunas actuaciones de poca importancia y muy esporádicas. Habrá que esperar hasta los años 60, fuera de nuestro ámbito cronológico propuesto, cuando se lleven a cabo una serie de cortes estratigráficos realizados por F. Wattenberg (1923-1967) y que proporcionaron interesantes datos sobre las fases de ocupación de la ciudad. De la mano del autor vallisoletano de origen alemán podemos destacar su publicación Las cerámicas indígenas de Numancia (1963), realizando una nueva clasificación tipológica tomando como base la ordenación de Taracena. Sin embargo, la gran aportación de este autor fue la ordenación cronológica de las cerámicas, pues la realizó de manera inversa a la propuesta por el investigador soriano. De esta manera, para Wattenberg, las cerámicas polícromas con motivos más naturalistas serían una evolución de las cerámicas monocromas de motivos abstractos. Esta reordenación cronológica a la inversa fue criticada debido a una falta de solidez en su propuesta, pese a ello fue empleada hasta su reinterpretación reciente (Jimeno et alii. 2012), no obstante, esto ya es otra historia.

\section{Bibliografía}

Bosch Gimepera, P. (1915), El problema de la cerámica ibérica, Madrid. Comisión de Investigaciones Paleontológicas y Prehistóricas, vol. 7.

Breuil, H. y Cabré, J. (1911), Sur I'origine de quelques motifs ornementaux de la céramique peinte d'Aragon. Bulletin Hispanique 13 (3): 253-269.

Cabré, J. (1934a), La cueva de Los Casares. Anales de la Asociación Española para el progreso de las Ciencias, año 1, no 4. Madrid. En Cabré, J. (1998), Investigaciones en las cuevas de los Casares y de la Hoz (1934-1941). Juan Cabré Aguiló (con la colaboración de María Encarnación Cabré Herreros). Sigüenza. Rayuela: 29-37.

Cabré, J. (1934b), La cueva de los Casares y de la Hoz. Archivo Español de Arte y Arqueología 30: 225254. 
Cabré, J. (1935), Cave Art of some 30000 years ago: A wonderful discovery in Spain. The illustrated London News, n. 5014. London. Illustrated London News.

Cabré, J. (1940), Figuras antropomorfas en la cueva de los Casares (Guadalajara). Archivo Español de Arqueología 14: 81-96.

Cabré, J. y Cabré, M.E. (1936), La cueva de los Casares, Riba de Saelices, Guadalajara (España). XVI Congrèes International d'Anthropologie et d'Archéologie Préhistoriques. Bruxelles, 1-8 Septembre 1935. Bruxelles. Imprimerie Médicale et Scientifique: 402-416.

Jimeno, A.; Chaín, A.; Quintero, S.; Liceras, R. y Santos, A. (2012), Interpretación estratigráfica de Numancia y ordenación cronológica de sus cerámicas. Complutum, 23 (1): 203-218.

Loperráez, J.B. (1788), Descripción histórica del obispado de Osma. Tomo II. Madrid.

Mélida, J.R. (1913), La cerámica numantina. Arte español: Revista de la Sociedad de Amigos del Arte 2 (5): 216-219.

Mélida, J.R. (1912 y 1915), Memoria de excavaciones de Numancia, Madrid. Junta Superior de Excavaciones y Antigüedades.

Mélida, J.R. (1916), Cronología de las antigüedades ibéricas anterromanas. Madrid.

Mélida, J.R. y Taracena, B. (1917-1923), Memoria de excavaciones de Numancia. Madrid. Junta Superior de Excavaciones y Antigüedades.

Paris, P. (1903-1904), Essai sur l'art et l'industrie d'Espagne primitive. l et II. Paris. Ernest Leroux.

Paris, P. (1914-1919), La céramique de Numance. La revue de l'art ancien et moderne. Tomo XXXVI, Julliet-Décembre, 1914: 5-16.

Pérez Frías, T. (2011), Aurelio Pérez Rioja de Pablo: artista fotógrafo (1888-1949), Soria. Diputación Provincial de Soria.

Pérez Rioja de Pablo, A. (1913), La estilización del caballo en la cerámica de Numancia. Arte español: Revista de la Sociedad de Amigos del Arte 2 (5): 212-215.

Pottier, E. (1918), Le problème de la céramique ibérique. Journal des savants, 16 anée NovembreDécembre 1918: 281-294.

Schulten, A. (1914, 1927, 1929 y 1931), Numantia. Die ergebnisse der ausgrabungen. 1905-1912. 4 volúmenes. München. I: Die Keltiber und ihre kriege mit Rom (1914); II: Die stadt Numantia (1931); III: Die lager des Scipio (1927); IV: Die lager bei Renieblas (1929).

Taracena, B. (1924), La cerámica ibérica de Numancia. Madrid. Biblioteca de Coleccionismo.

Wattenberg, F. (1963), Las cerámicas indígenas de Numancia. Madrid. Consejo Superior de Investigaciones Científicas (CSIC). 